



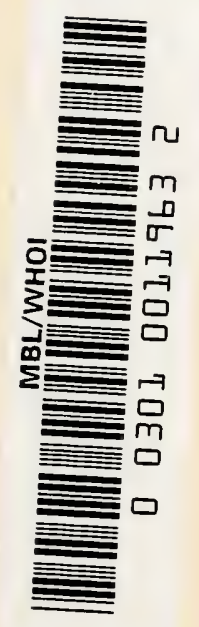







\title{
AN INTRODUCTION TO B IOPHYSICS
}

BY

DAVID BURNS, M.A., D.Sc.

GRIEVE LECTURER ON PHYSIOLOGICAL, CHEMISTRY IN THE UNIVERSITY OF GLASGOW

WITH A FOREWORD BY

D. NOEL PATON, M.D., LL.D., F.R.S. REGIUS PROFESSOR OF PHYSIOLOGY AND DIRECTOR OF THE PHYSIOLOGICAL INSTITUTE, UNIVERSITY OF GLASGOW

With Eighty=five Illustrations

\author{
NEIV YORK \\ THE MACMILLAN COMPANY' \\ I92 I \\ All rights reserved
}




\section{TO}

L. R. V. M. 


\section{PREFATORY NO'TE}

Thus book makes no pretensions to be a eomplete or even a systematie survey of Biophysics. Its object is partly to be explanatory. Current medical publications are full of terms culled from physico-chemieal and physical terminology; the clinician of to-day clothes his idcas in words unknown to his brethren of yesterday; his phrascology, at least, is physieal.

Apart from and beyond a mere explanation of physico-chemical terms, an attempt has been made in the following pages to present physiologieal phenomena from a purely physical standpoint. The problems of life, and vertebrate life in particular, have been viewed through a physicist's eycs. This does not necessarily imply that the matter of the book is permeated with mechanistie philosophy. We are all, more or less, amateur philosophers, but we would be pool scientists indeed if our "views "were permitted to colour our facts. Phenomena, as they appear to-day, are set out for the critical examination of the student. "He will have all the facts and eireumstances fully mobilised, standing up side by side before him like an awkward squad, and there is nothing more awkward than some facts that have to stand out squarely in the daylight! And he inquires into their ancestry, makes them hold out their tongues, and pokes them once or twice in the ribs, to make sure that they are lively and robust faets capable of making a good fight for their lives. He never likes to see one thing too large... lest he sees something else too small; but will have everything in true proportion." (David Grayson.)

It is a grcat pleasure to me, on reading over the final proofs, to notice how generously my mastcrs and collcagues have eome to my aid. Quite apart from the direet help given me by Professors Noël Paton and E. P. Cathcart, who contribute the opcning and closing chapters of the theoretical part of the book, I have reccived daily cncouragement from them in my task, for which $I$ cxpress my sincere gratitude. If this effort to make plain the 
essentials of Biophysies is in any way sueeessful it is due to the truly seientifie atmosphere of the Institute of Physiology which they govern and inspire.

I beg to reeord my obligation to Dr. Shanks for the eare he has devoted to the ehapter on the eye; to Dr. Morris for reading the first three seetions of the book in slip-proof ; to Dr. Watt, Leeturer on Psyehology in this Institute, for reading the chapters on Reeeptors and for his suggestions thereon; to Dr. Wishart, because, by reading many of the proofs and by eheeking mathematieal matter, he has saved me from many a fault and blunder.

My debts to previous authors are many and I eannot own them all. Diseerning readers will see, for example, the ideas of my old teaeher, Professor Soddy, mirrored in eertain of the earlier ehapters; Professor Thompson's Growth and Form is the basis of part of Chapters XVI., XXIV. and XXXIV.; McKendriek, Gray, Wrightson, Keith, and Watt are the sourees from which mueh of Chaps. XIX. and XXIX. have been drawn. A book of this nature eould not be written without eonstant reference to the Principles of General Physiology. If my Introduction but serves to turn some student to the great book of Professor Bayliss, to meet the master mind, it will have sueeeeded.

I am under obligation to the authors and publishers of several books from which illustrations have been borrowed.

To Professor Noël Paton and Messrs. Green for permission to use eight figures from the Essentials of Human Physiology (viz. Figs. 25, 27, 58, 59, 69, 72, 73 and 85) ; to Professor Starling and Messrs. Churehill for the following figures from Principles of Human Physiology: 1, 5, 8, 16, 35-41, 43, 45, 50, 70, 74, 75, 80 and 83 ; to Mr. Crowther for Fig. 21 from Molecular Physics, and to Mr. Emil Hatsehek for Figs. 7, 9 and 10 taken from An Introduction to the Physics and Chemistry of Colloids, both books from Messrs. Churehill.

To Professor Cushny for leave to reproduce the ideal diagram of a Malpighian eorpusele (Fig. 28) from his monograph on The Secretion of Urine (Messrs. Longmans, Green and Co.); to Professor Soddy and "The Eleetrieian" Publishing Co., for the diagram of the gold-leaf eleetroseope (Fig. 22) from Radioactivity.

To Dr. Bradford for allowing me to reproduce, from the Biochemical Journal, his photograph of adsorptive stratifieation (Fig. 11) and to Professor Roaf for the $p \mathrm{I}-\mathrm{C}_{\mathrm{r}}$ graph reprodueed from the Proceedings of the Physiologieal Soeiety (Fig. 84). 
To Messrs. the Cambridge and Paul Seientifie Instrument Co. for the figures ilhustrating the electro-eardiograph (Figs. 61-67); to Messis. Hawksley for those of the viseosimeter (Figs. 77 and 82) and to Messrs. Gallenkamp for Figs, 2 and 3 of the bomb calorimeter.

The remaining forty illustrations were drawn by Dr. G. M. Wishart, Assistant in the Department of Chemieal Physiology, and by Mr. John Waters, a student of medieine here. To their skill and eare $\mathrm{I}$ owe mueh.

I am greatly obliged to Mr. A. V. Steen, B.Se., one of our demonstrators, for reading all the proofs. The freedom of the matter from certain errors is the result of his painstaking efforts.

Finally, I desire to record my gratitude to my publishers for their patience and eourtesy during the prolonged period of publication and to the printers for the care they have taken and the eonsideration shown when my ignoranee made large demands on their time and patience.

Institute of Pifysiology,

University of Glasgow. 



\section{CON'TEN'TS}

Introductiox. By Professor I). Nuël I'aton, M.D., LL.D., F.R.S. - $\quad$ xi

\section{PART I. SYSTEMATIC}

SECTION I. ENERGETICS

CIAP.

I. LAWS OF ENERGY - - $\quad$ - $\quad$ - $\quad$ - $\quad$ - 1

II. The Storage of Energy - $\quad$ - $\quad$ - $\quad$ - $\quad$ - 13

III. Liberation of Energy-(1) Calorimetry - - - - 21

IV. Liberation of Energy-(2) The Animal as a Machine - 32

V. Liberation of Energy-(3) Energy of Substance in Solution. Osmotic Pressure - $\quad$ - $\quad$ - $\quad$ - $\quad 36$

Vi. Liberation of Energy-(4) Surface Tension - - - 46

SECTION II. CELLULAR MECHANICS

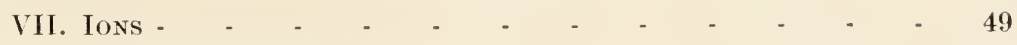

VIII. Disperse SYStems - $-\quad$ - $\quad$ - $\quad$ - $\quad$ - 65

IX. Enzrues - - $\quad$ - $\quad$ - $\quad$ - $\quad$ - $\quad$ - $\quad$ - $\quad$ - 91

X. Membranes - $\quad$ - $\quad$ - $\quad$ - $\quad$ - $\quad$ - $\quad-107$

XI. Radio-activity - - - $\quad$ - $\quad$ - $\quad-\quad-\quad$ - 117

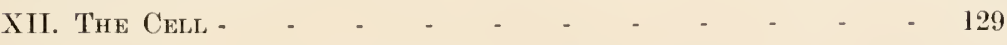

SECTION III. CELL COMMUNITIES

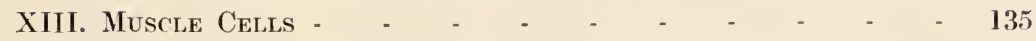

XiV. Manufacturing Cells - $\quad$ - $\quad$ - $\quad$ - $\quad$ - $\quad$ - 148

XV. Eliminating Cells - - - - - - $\quad$ - $\quad-\quad-\quad-155$

XVI. Connective Tissue Cellis - - - - - - - $\quad-166$

XViI. Intelligence Service-Nerve Cells - - - - - $\quad 182$

XViII. Outposts of the Intelligence Service-General Receptors 191

XiX. Outposts of the Intelligence Service-Ear - - $\quad 200$

XX. Outposts of the Intelligence Service-Eye - - - 215 
CHAP.

SECTION IV. TRANSPORT

XXI. Inland Transport-The Blood - - - - - - - 229

XXiI. Inland Transport-Respiratory Function of Blood - 246

XXiII. Inland Transport-Loading UP - - - - $\quad 258$

XXIV. Inland Transport-Circulation - - - - - $\quad 274$

XXV. Inland Transport-Electrocardiggram - - - - 295

XXVi. Overseas Transport-External Respiration - - $\quad 301$

XXVII. Overseas Transport-Alimentary Canal - - - $\quad 313$

XXVIII. Overseas Transport-Locomotion - - - - - 320

XXIX. Overseas Transport-Voice - - - - - - 325

SECTION V. THE ANIMAL AS A WHOLE

XXX. The Preservation of Neutrality - - - - - - 331

XXXi. The Regulation of Temperature - $\quad$ - $\quad$ - $\quad$ - 336

XXXII. Tropisms - - - - - - - - - - $\quad$ - 354

XXXiII. AdAPTATION - $-\quad$ - $\quad$ - $\quad$ - $\quad$ - $\quad$ - 360

XXXIV. Growth - $\quad$ - $\quad$ - $\quad$ - $\quad$ - $\quad$ - $\quad$ - 363

XXXV. Development - - - - - - - - - 377

XXXVi. Death and Dissolution - $\quad$ - $\quad$ - $\quad$ - 388

XXXVII. EFficiencY - - - - - - - - - - 391

PART II. ILLUSTRATIVE EXPERIMENTS - - 398

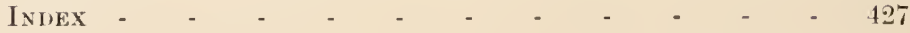




\section{IN'TRODUC'TION}

\section{By Professor D. Noël Paton, M.D., LL.D., F.R.S.}

ON looking baek over a forty years' assoeiation with physiology nothing is more striking than the influenee which the applieation of physies has exereised upon the progress of the seienees.

I well remember that, as long ago as 1878 , my first teaeher began his leetures on the Institutes of Medieine by defining physiology as the applieation of physies and ehemistry to the study of the body in aetion.

But at that time the possibility of applying these seienees was limited. In the first plaee, their development, and especially the development of physies, was not suffieiently advaneed. The dissociation of atoms into ions was hardly recognised, the signifieanee of Graham's colloids was not appreeiated, and the phenomena of surface tension had hardly been applied to molecular physies. In the seeond plaee, physiologists were then generally men trained for medieine whose edueation in physies and ehemistry had been extremely limited. Of eourse, there were notable exeeptions-e.g. Helmholtz and du Bois Reymond.

These older physiologists had to be eontent with reeording phenomena rather than with explaining them, and they loved to ehronicle their observations in high-sounding Greek names. Can one ever forget the sense of profound knowledge which one enjoyed as a junior student in mastering sueh terms as "delomorphous" and "adelomorphous" as deseriptive of the eells of the stomach? The so-ealled chemieal physiologists were perhaps the worst offenders. For, having isolated, or thought they had isolated, some eonstituent of the body of quite unknown ehemieal eonstitution, they promptly gave it a name with no eonneetion with its ehenieal nature, and these names have generally continued in use, to the confusion of generations of students. In the present age of "hormones" and "vitamines" one wonders how far the tendeney has been eradieated. 
It was the "what happens?" which interested these older workers: "Why it happens?" was generally beyond them, and vague theories of some peeuliar and special vital action took the place of actual demonstration.

Undoubtedly the association of physiology with the more exaet seience of physics, based as it is so largely upon mathematics, has had an enormous effect in getting rid of this habit of vague theorising and has materially helped to clarify minds "debauched with the so-called scienee of biology" as Tait, in the early eighties, was wont to describe our mental condition.

It has also stimulated the critical faeulty, which insists upon a elear proof and demonstration as a basis of eonclusions.

It is much to be regretted that even at the present time the importance of a mathematical training, so essential for the study of physies, is not generally reeognised, and that it is still possible to take a higher degree in seienee without this necessary preparation.

It has been through the co-operation of physics and chemistry that the solution of many of the problems of life have been reached, and as the possibility of reaehing these solutions has become more generally recognised, the spirit of scientifie euriosity - the desire to know, which is the basis of all scientifie workhas been stimulated; although probably in the future as in the past, humanity will still be divided into the enormously large elass of those who have no real desire to understand the workings of nature and the very snall class of those who have the spirit of euriosity, who do desire to know. These alone are the seientists, although many seicnce graduates belong to the major class.

With or without any wider diffusion of the spirit of curiosity, the development of the critieal faculty and the better training of the younger workers in physics and chemistry has brought physiology nearer to the position of an exact seience, and with this, its value as a training for students of medicine has greatly inereased. The doctor, in making a diagnosis, has not merely to observe and record what has happened, but he must ascertain why it has happened. His problems are the same in nature and his methods are the same as those of the physiologist, and thus physiology has regained its position as the Institutes of Medieine.

The doctor of the past considered that he had made a diagnosis when he was able to give his patient's disease a name. 'The physician of the future will eare less and less for such names. He will simply be eoncerned with the solution of the questions- 
"What is abnormal?" "Why is it abnormal?" Perhaps it is wiser not to enquire too euriously into the position of the physician of the present.

The development of physiology on the lines indicated has also made possible the growth of the seienees of experimental pathology, of experimental medicine and of pharnacology ; and the lnowledge of disease and of its treatment has thus been put upon a sounder basis.

All this has followed the adoption of physies and chemistry as the guides of the physiologists.

In the present volume, Dr. Burns attempts to show the part which physies has eome to play in the solution of the problems of physiology. A science of bio-physies has evolved in the same way as that of bio-ehemistry. Perhaps some attempt should have been made in the title to indicate that it is the problems of the physiology of vertebrates rather than the basie problems of life generally which are dealt with.

The book is intended for students of human physiology, although it eannot fail to interest all workers in biology.

It demonstrates what a very large number of the characteristie reactions of living matter may be explained in terms of ordinary physical processes, and it thus shows the reduction which is taking place in the number of phenomena which some are still content to explain as due to a mysterious vital aetion instead of simply confessing that they are yet not understood.

As the application of physies and chemistry to physiology is extended, it is safe to prediet that fewer and fewer of these vital manifestations will remain unexplained.

The origin of living matter, its increase and dispersion all over the globe, its marvellous and cndless developments and evolutions, and its reactions with its surroundings may all be explained in terms of physies and chemistry. But consciousness and its association with living things will ever remain the mystery it has been and is. 



\section{BIOPHYSICS}

\section{PART I. SYSTEMATIC \\ SECTION I.: ENERGETICS}

\section{CHAPTER I}

\section{LAWS OF ENERGY}

"The history of man is dominated by and refleets the amount of
available energy."

Brophysics deals with the application of physical and physicochemical laws to the actions of living things. It is neeessary at the outset to have a clcar understanding of what is meant by a natural law, or principle of nature. A law in scicnee is a different eoncept from a law in philology or in jurisprudence. Repeated obscrvation of a rceurring phenomenon leads to the conclusion that there is a natural and unalterable sequenee of events. This is summarised in a law. Newton's Law, for instance, epitomises the eonclusions of a large series of observations, viz. that objects frce to do so always fall towards the earth. A natural law, then, is not a principle governing the action of nature, but a generalisation drawn from observation of the phenomena, stating, in short, how these phenomena have always been known to act in the eireumstanees. If the obscrvations are eorreet, the law is true and, in like eireumstances, will always hold. If at any time a reliable observation were made that seemingly went against the law, scientists would not doubt the validity of the law, but would carcfully examine the concomitant eiremustances to see in what point they differed from those defined in the law. The problem before us is to determine whether laws deduced from the study of non-living matter may be applied to the elucidation of biological phenomena. Physical B. B. 
seienee is the most fundamental of the experimental scienees and, so far as is known, its laws are applieable to all non-living mattcr. Bioehemists have attempted to break down the wall of partition which has becn reared by eommon eonsent between the chemical constitution of living and non-living. They have been partially sueeessful in that they have been able to build up eertain typieal produets of life from non-living material. No one, horvever, has, as yet, either analysed or synthesised living matter. The finest chemieal teehnique available eannot be employed without injury to the tissue studied. In spite of this drawbaek, the seicnee of nutrition may be elassed as exaet. Mathematieal formulæ may be employed to cxpress results, and chenical response to a definite stimulus may be predieted.

Life has been eompared to a flame. The Aneients looked on fire as a living thing, and is their view not, to some extent, justifiable? The eontinual ringing of the ehanges-of form, of eolour, or of position-by the flickering flames of our house fires draws the eye. Constantly, alterations are going on. No flame is still for any length of time. All is seemingly unordered and uneontrolled change. Yet down to the most minute movement all is governed by physieo-ehemieal laws. Every flieker can be aeeounted for, and eould be reeorded as due to pressure of liberated gas, pressure and direetion of draught, temperature of fire, etc. Fire-mysterious and all-powerful gift of the gods-has yielded to the prying endeavours of the seientist, and ean be harnessed and employed in the serviee of man.

Similarly, while not eommitting oneself to a vitalistie or to a mechanistie eoneeption of life, one may study, with eonsiderable profit, the various physieal phenomena exhibited by living matter. Examination of even the simplest form of life is suffieient to show that a eharaeteristie phenomenon is ehange. No living thing is absolutely still. It is undergoing ehange in one way or another. It may alter its position relatively to its environment; it may alter in its parts; it may grow ; it may undergo alterations in internal (atomie or moleeular) strueture. The physieochemieal processes indieated by these ehanges or initiated by them are studied under the term metabolism (Gr. met $a=$ ehange). Metabolism may eonsist in a building up of matter, anabolism $(\mathrm{Gr}$. an $a=\mathrm{up})$ or in the reverse proeess, a breaking down of matter, eatabolism (Gr. kata=down). If anabolism is greater than catabolism, the organism grows ; if the two proeesses balance, the organism exists. The predominanee of eatabolism leads to 
disintegration. Complete immobility denotes death. Change indieates the utilisation of energy, which obviously must have eome from some souree outside the organism. "The meehanistie notion of life, the representation of the body as primarily and fundamentally a machine, is often bitterly and not very intelligently opposed. We are told that the maeline-the seientists' initation of life -is not merely a purely inanimate meehanism. In its cumning combination of valves and regulators it has a brain, part of the brain of its designer. The partial likeness is that of the machine to the man, of the limited imitation to the original, not the other way about, whieh is true enough. But let us bear in mind onc essential and undeniable fact. Machine or man, inanimate mechanism with the mechanieal imitation of a brain, or brain eontrolling an animate mechanism, what of the power? The power to live, the power to do work is not in the brain nor in the body, not in the valves nor the moving parts. 'The power, whether of life or of meehanism, is external. This is the real ground of analogy" (Soddy). We must determine the sourec of this energy, study its laws, see how it is made available for living matter, and then sec how it operates in living matter.

Energy is the underlying cause of all changes in matter. This does not seem a very satisfactory definition but, so far, it is the only one possible. It is a very striking fact that the two fundamentals of our external world, matter and energy, have for us no existence apart from their effect on us. We cannot prove that there are sueh things exeept in so far as they manifest themselves, matter by being changed, and energy by producing ehanges, which in turn alter our sensation-complex.

There can be no change of any sort without free energy. Energy exhibits itself in many forms-heat, light, movement of matter, electricity, radio-aetivity, etc.

In 1798, Count Rumford, who was engaged in boring eannon, showed that movement-or kinetic-energy could be transformed into heat. Later, Joule demonstrated the equivalence of these two forms of energy. 427 kilogrammetres of work always produec (under standard conditions) one Calorie of heat. Conversely, heat may be transformed into meehanieal movement. Indeed, any form of encrgy may be converted into any other form of energy. (Radio-active matter cvolves energy which manifests itself in various forms, yct all attempts to ehange other forms of energy into radio-active energy or even to influence the rate of transformation have failed. Chap. XI.) 
TABLE I.

Mechanical Equivalent of Heat.

UNITS.

\begin{tabular}{|c|c|c|c|c|c|}
\hline $\begin{array}{l}\text { Tempera- } \\
\text { ture. }\end{array}$ & Time. & Mass. & Length. & Force. & $\begin{array}{l}\text { Equiva- } \\
\text { lent. }\end{array}$ \\
\hline $1^{\circ} \mathrm{C}$ & Second & Gram & Centimetre & Dyne at $15^{\circ} \mathrm{C}$. & $4 \cdot 2 \times 10^{7}$ \\
\hline $1^{\circ} \mathrm{C}$ & , & ," & ", & $\begin{array}{l}15^{\circ} \mathrm{C} \text {. at lat. of } \\
\text { Greenwich }\end{array}$ & 42700 \\
\hline $1^{\circ} \mathrm{F}$ & , & Pound & Foot & $\begin{array}{l}\text { Poundal at } 59^{\circ} \mathrm{F} \text {. } \\
\text { Wt. of a pound at }\end{array}$ & $2504 \cdot 7$ \\
\hline $1^{\circ} \mathrm{F}$ & $"$ & ," & $"$ & $\begin{array}{l}59^{\circ} \mathrm{F} \text {. at lat. of } \\
\text { Greenwich }\end{array}$ & $778 \cdot 1$ \\
\hline $1^{\circ} \mathrm{C}$ & $"$ & ", & ", & $\begin{array}{l}\text { Wt. of a pound at } \\
15^{\circ} \mathrm{C} \text {. }\end{array}$ & $1400 \cdot 6$ \\
\hline
\end{tabular}

To convert to ergs : Calories $\times 4 \cdot 2 \times 10^{7}=$ ergs.

From observation it is found :

(1) That one form of energy may be transformed into any other form.

(2) That when any quantity of energy in any one form disappears, an exactly equal quantity of another form of energy makes its appearance.

Energy like matter is therefore indestructible (Law I.).

Every substance possesses a certain amount of energy. 'This is ealled its internal or intrinsic energy. Further, every group of substances has associated with it a certain definite amount of energy as long as it remains unehanged. When any change takes place in the group, or in any member of the group, there is usually a corresponding change in its total energy, either an increase, due to the reception of energy from its environment, or a deerease due to an evolution of energy. Put into other words, each of the new substances will have its own eharacteristic intrinsic energy, and the new group will, in general, have a different total energy-content from that of the original group.

E.g. Cane sugar $+\mathrm{O}_{2} \longrightarrow \mathrm{CO}_{2}+\mathrm{H}_{2} \mathrm{O}+$ heat energy.

\section{Corollaries of the First Law.}

The following two deductions are of biologieal interest:

1. The total energy of a system in a given state is for the system 
in question a definite eharaeteristic of that state, and it is totally independent of how the system reaehed that state.

The energy that would be liberated by the fall of a kilogram, e.g. of lead, from a height of 300 metres would be the same no matter how the kilogram was first elevated to the point from which it was dropped. For instance :

(a) It might be lifted bodily and vertically.

(b) It might be lifted bodily and up an inclined plane.

(c) It might be lifted bodily and rapidly.

(d) It might be lifted bodily and with infinite slowness.

(e) Or it might be lifted in small pieces, say 1 milligram, at a time.

( $f$ ) It might be lifted as a series of chemical compounds weighing more than 1 kilogram as salts of lead and reduced to metallic lead before dropping.

(g) Or it might be dug out from the top of a hill, 300 metres high, and transported horizontally by aeroplane.

The essential conditions are that it weighs 1 kilo. and that it falls 300 metres, cosmic influences being constant.

Similarly, ghueose has the same energy-eontent no matter how it has been prepared provided the measurement is earried out under similar conditions, e.g. glueose may be synthesised from simple substanees ; it may be prepared by the natural or artifieial hydrolysis of more eomplex earbohydrates, or it may be derived from sueh substanees as proteins, fats, etc.

2. When a system changes from one state to another, the alteration of total energy whieh aeeompanies that ehange is altogether independent of the proeess by whieh the change is brought about.

The examples given above, if reversed, will aet as examples of this corollary. The rate and angle of fall arc not determining factors in the liberation of energy, nor does the way in which the energy of glucose is liberated have any effect on the total amount set free.

These two corollaries, as we shall see later, make it possible to construet a balanee sheet of the energy intake and output of the organism.

Degraded Energy (Law II.).

When a substanee or group of substances is ehanged into a substance or group of substanees with a smaller energy-eontent, the energy thus liberated is, in theory, available for work. In practiee, it is found that all this surplus energy eannot be recovered as work. No system is absolutely isolated, and though the total eosmieal energy may be eonstant its distribution and its state may alter. Some of the freed energy is always eonverted into heat, part of which is dilfused among surrounding objeets 
and is thus lost, as far as work is coneerned. The quantity of cnergy is not deereased, but its dispersion is so great that in quality it has not suffieient potential gradient to be of use. As an example of dispersion of energy, consider a stone dropped into an infinitely large lake. As the radius of the series of eoneentric ripples inereases the wave-height deereases, till at infinite radius the wave height will be infinitely small. The wave energy has been so spread that it may be disregarded.

The second law is usually worded, "The entropy of an isolated system tends to inerease." Entropy is a function which, while theoretically of great value as indieating the direction in which chemical or other processes take place, eannot be direetly measured. Further, one never has, in Biology, to deal with an isolated system. The diffieulty as well as the great interest of our seience depends on the elose interrelation and eo-ordination of all the systems in it. A simple expression of the law, and one suited to our purpose would be, "Every change takes place at the eost of a certain amount of available energy." 'The amount of energy "degraded" during a transformation from one form of energy to another may be taken as an inverse index of the effieieney of the transforming mechanism.

\section{States of Energy.}

A substanee may be endowed with kinetic energy, or with potential energy, or with both. Kinetic energy is direetly available for work, potential energy requires the use of some kinetic energy to liberate it. The energy of a substance may be in the motion of the substance itself or in the motion of the ultimate particles composing it. This kinetic energy and its value depend on the mass of the substanee and the rate at which it moves or at which its particles vibrate.

Potential energy, on the other hand, is said to be possible to a substance in virtue of its eonfiguration, i.e. position, composition, history, etc. A quantity of energy that may be measured is stored up (or rendered passive in some way), and this same quantity is theoretically reeoverable in a measurable form. It may not be apparent hozo energy is stored up, but it may be demonstrated that it is stored and is reeoverable. The simplest example is the application of force to a perfectly elastie system. On removal of the foree the system will return of itself to its original configuration, and an amount of work will be done by it, in returning, exactly equivalent to the amount of the foree of 
distortion. The hackneyed example of energy storage is, of course, our eoal supply.

Energy in the potential state, as long as it remains potential, is useless. It eannot be transformed into any other form of energy without altering its state, and its state eannot be altered without the employment of kinetic energy. This point is biologieally important.

1. A weight hanging from a string has potential energy according to its mass and its distance from the eentre of the earth, ete.

2. An explosive has potential energy depending on its ehemieal eomposition and physieal state.

3. Petrol, eoal, or any other fuel has similar energy bound in it.

4. A sleeping man may be said to have potential energy. Now, in order to get work out of these quieseent bodies, all that is neeessary is the applieation of a suitable stimulus, i.e. a small quantity of free kinetie energy. $\boldsymbol{E} . g$.

(1) The resistanee that prevents the weight from falling must be overeome, i.e. the string severed.

(2) The explosive must be fired or detonated.

(3) The fuel must reach ignition temperature.

(4) The sleeper must be awaked.

In 1882 Hehmoltz introduced the terins "free" and "bound" to denote respectively that part of the kinetie energy of a system free or available for eonversion to work, and that part not free or not available for this purpose. Later writers, realising that potential energy as such was not available for work, widened the connotation of "bound" to inelude this dormant energy. As a matter of logieal definition, only potential energy is really bound. That which is bound ean be freed by cutting the bonds. i.e. by doing an amount of work which bears no relation to the amount of energy bound, but depends on the nature of the bonds. Dissipated or degraded energy is not in any true sense bound. It is not free to do work, i.e. it is not available. To render it available an amount of energy would have to be expended on its environment at least equal to the amount of energy rendered available.

A weight resting on the ground may be considered as representing a body having degraded energy. Its energy potential is the same as its environment. No work could be got from it without the previous expenditure of work on it. If a certain amount of work were done in raising it from the ground, then the same amount of work would be recovered on letting it fall to the ground (taking into account the mechanical equivalent of the degraded heat). On the other hand, a weight resting on a ledge 
above the ground may perform work in falling if sufficient free energy be applied to tip it over. The quantity of work done in tipping over the weight bears no relation whatever to the amount of energy liberated in falling.

The following seheme may help to make the matter clear :

Total Energy of the Universe

(1) $\downarrow$

Available for work,

i.e. Free Kinetic Energy
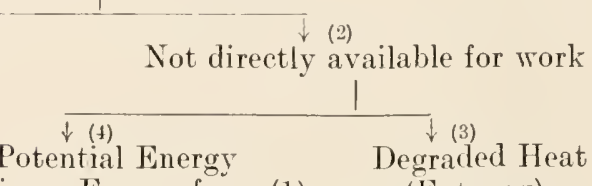

(Entropy)

Totally unavailable

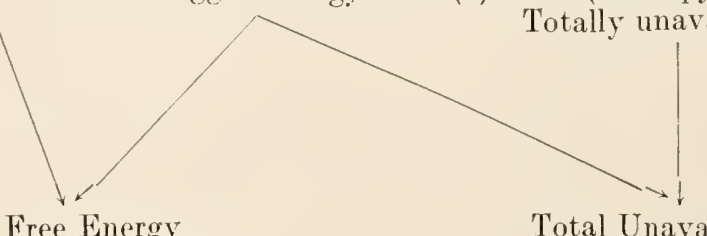

Free Energy

Total Available Energy

Energy

(3) Called "bound" energy by Helmholtz in 1882.

$(3+4)$ Called "bound " energy by later workers.

(4) Called "bound" energy by Physicists.

One of the most important problems in biology is the means by which potential energy is translated into work and the meehanism by which this translation is eontrolled.

"The struggle for existence is the struggle for free energy " (Boltzmann).

Of potential energy there is an abundant supply. Some of it, e.g. eoal, requires the employment of only small quantities of free energy to render it immediately available for work, while other varieties, e.g. radio-aetive minerals, have their energy bound in sueh a way that it is evolved with exeessive slowness. Uranium eontains the same amount of energy as 250,000 times its weight of eoal (or more), but little more than $\frac{1}{10,000,000,000}$ part of this is given out in a year (Chap. XI.). To enable mankind to avail himself of this kind of energy, some means will have to be devised for speeding up and eontrolling the output. As Professor Soddy puts it: "Primitive man froze on the site of what are now eoal mines, and starved within sound of the waterfalls that are now working to provide our food. The energy was there, the knowledge to utilise it was not. So while we are 
leading eramped lives and fighting among ourselves, whether in peace or war, for a modicum of the means of existence, science tells us that, in the commonest materials that make up the framework of the world, there is energy of a magnitude of which we have no experience, and the means of livelihood of which we have no standard. The energy is there. The knowledge that ean utilise it is not-not yet." In a similar way, the nations had diffieulty in proeuring rations of sufficient energy-content during the later days of the war, while all around them were abundant supplies, but no method existed by which their energy could be made available.

\section{Physiological availability.}

'This introduces a further point. The energy-content of ecllulose is much the same as that of stareh, yet as a source of energy for man the former substance is useless, while the latter is perhaps his main source of energy supply. An inorganie example may make this clearer. Two lakes may be exactly similar exeept that one has an outlet, while the other is surrounded by impassable mountains. The water power, i.e. the stored energy of the former, is utilisable, while the latter could not be tapped without arduous engineering labours. The energy-eontents of the radio-elements (atomic energy) of ecllulose (as human food) and of the undrained lake are said to be non-utilisable. Future scientists may diseover low to draw upon this surplus energy supply.

\section{Inertia.}

The seeond law of energeties lends itself to the deduction that the cause of all action (change) is the tendency of energy to attain the same uniform degree of intensity as its environment. Further, the degradation of energy follows the line of least resistance. This is known as the "Law of Least Action" or the "Principle of Le Chatelier." It is a law common to all seienees, and is considered by some to be a universal principle. Physicists tell us that bodies remain in a state of rest or of uniform motion in a straight line unless energy be imparted to them to overcome their incrtia. Inertia is the resistance to ehange possessed by everything, living and non-living.

One may take a step further and qualify the law by stating that the nature of the change indueed by an alteration in any factor which influences the system will depend on what will, in 
the eireumstances, give relief from strain with the least possible expenditure of energy. When a state of strain is made more or less permanent, the organism readjusts itself to meet the strain. That is, the easiest eourse is not to remove the eause of strain, but to make such an alteration in itself as shall render the external elange innoeuous. This is the principle underlying the theory of adaptability. A tree arranges its branches so as to offer least resistance to the prevailing wind. Other examples might be drawn from the seiences of physiology, economics, psyehology and ethies.

Physiology. The introduction of an irritating substanee into the alimentary eanal eauses vomiting to remove the eause of irritation, i.e. to relieve strain. Some less exhausting means of relieving strain has to be taken to meet the more or less continuous administration of poison. The eells of the organism so alter as to be immune from such irritation. Mithridates is said to have qualified for the throne of Pontus by the ingestion of all sorts of poisons in his youth.

Economics. The law of supply and demand, rates of exehange, ete., are merely restatements of this prineiple of least aetion.

Psychology and Ethics. The unjust judge met the early appeals of the widow with a firm refusal. His mind was relieved, his ease settled. Beeause of her very importunity, persistent strain was set up which had to be relieved by reopening the ease and giving a just deeision.

Enough has been said to show the possibilities of this deduetion from the seeond law of energeties. The thorough-going meehanist states that this law of least aetion is the prineiple governing the aetion of living as well as dead matter.

All aetion, it is said, is a response to stimulus, and is sueh as will most permanently and with "least action" relieve the state of strain. The meehanist denies any eause of action but this. What has been taken for the effeet of will or instinet is in reality the effect of light, of gravity, of frietion, of ehemical foree, or of some other known or knowable external foree. In short, some alteration in an external faetor has brought about an instability in the physieo-ehemical equilibrium of the object or of the organism, and thus a shift in the equilibrium will take place in such a direction as to deerease the magnitude of the alteration which woukd otherwise oeeur. The animal, human or otherwise, is but a machine, working aceording to physico-ehemieal prineiples, 
reaeting blindly and quantitatively to every ehanee foree whieh plays on it. While, to a eertain extent, we may regard this as true, we must, nevertheless, draw a sharp distinetion between those aetions whieh may be regarded as pertaining to organie life and those whieh pertain to conseious life dominated by personality. Plants and animals may be governed by this law of equilibrium, and every one of their aetions may be regarded as a blind response to stimuli, just as the swing of a galvanometer needle is. Man, in so far as he is an animal, may also be eonsidered a blind agent. Is there not, however, something superadded-not to interfere or even to govern, but to earry out a function of its own? For example, there are no grounds for dealing with volition merely as a eomplex ehemieal equation or as a problem in moleeular physies, resulting merely from physieal or ehemieal ehanges in the body or environment. Suppose a man meets another man in the street who suddenly strikes him. The injured man has several eourses open to him :

1. He may hit baek.

2. He may run away.

3. He may feteh a polieeman, and so on.

The aetion taken depends on several faetors :

1. The previous history of the two men.

2. The relative sizes of the two men.

3. The nature of the speetators.

4. The nearness of the polieeman.

5. The real business of the injured man, whether pressing, ete.

6. The personality of the injured man.

Knowing the man one may prediet his aetion in a eertain ease, and one may probably be right, but it is only a probability - not a eertainty. While the eause of volition is still unknown and eannot but be regarded as mysterious, there is nothing to hinder researeh into the meehanism whereby the Will eauses its dicta to beeome acta.

To summarise, the physieal neeessities of man have beeome a problem of energy pure and simple. The faet that man is living seareely makes the problem more eomplieated than one arising out of the fuel demands of an inorganie maehine. So mueh work has to be done, so mueh energy must be provided.

Energy is indestruetible, and in itself is only valuable in its eonversion from what may be ealled higher to lower forms. This 
transformation involves the loss of some available energy. A eertain amount finds its way into the great oeean (or "sink") of heat energy of nearly uniform temperature. The attainment of this dead level is the final goal of all energy whether it is utilised or not. 


\section{CHAP'TER II}

\section{THE STORAGE OF ENERGY}

"The energy available for each man is his income. Stored energy is a
legacy deposited in Nature's bank."

ALL life processes demand for their eontinuation and maintenance a continuous supply of energy. In metabolism, as far as matter is coneerned, there is a closed cycle. Animals feed on plants, and plants feed on the produets of animal metabolism and disintegration. The net result is practically nil. Energy, however, must be supplied from outside. The one essential physical factor that makes the process possible is the supply of energy as sunlight to the plant.

The ultimate sourec of all the energy upon whieh existence on this planct depends is the sun. (One need not here enter on the interesting question of how the sum evolves energy ; sec Soddy, Matter and Energy, Chap. X.) As far as we know, the higher forms of life are unable directly to use, either heat or light as sourees of bodily energy. Some of the lower forms of animal life may have this power; plants certainly have. As we shall see later, light energy may act as the trigger, setting free potential energy and causing work to be done.

All living matter may be divided into two distinct classes: (a) that subsisting upon the materials which they take from the earth and the air, and $(b)$ that dependent upon other organisms either living or dead. Examination shows that the main chemical difference between these two elasses is that the former contains a green pigment called ehlorophyll as a regular functioning constituent, whilc the latter does not. It is evident that ehlorophyll is correlated with the state of independence that is typical of plant life.

\section{Chlorophyll.}

(Revise : Physies of light, especially that of absorption spectra, page 71 ; chemistry of chlorophyll and its relation to xantho- 
phyll, erythrophyll, etiolin and carotin ; botany of green plants, distribution of chlorophyll in leaves; variegation in leaves; and structure of ehloroplasts) (see Fig. 1).

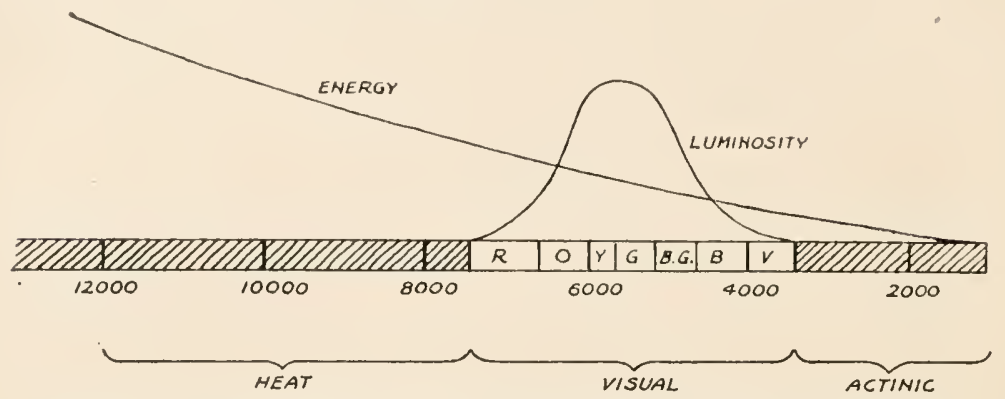

FiG. 1.-Curves showing relative energy and luminosity of different regions of the spectrum. (Abney.) The wave-lengths are given in Angström units. An Angström unit (A.U.) $=$ one ten millionth of a millimetre $=0^{\circ} 1 \mu \mu$.

\section{Absorption Spectrum of Chlorophyll.}

An optical property of primary importanee in a substanee is its differential absorption of light. The wave motion of the cther, which constitutes white light, is very complex, consisting not only of transverse vibrations in every planc, but of waves of different lengths associated together. Now each wave length produces a definite eolour-sensation in the optieal reeeiving mechanism. The shortest wave length optically perceptible to man is $4 / 10,000 \mathrm{~mm}$. (violet), the longest $7 / 10,000 \mathrm{~mm}$. (red). Bctween thesc cxtremes there are blue rays $470 \mu \mu$, green $510 \mu \mu$, and orangc $620 \mu \mu$. (These arc average figures, e.g. the various lengths classed under orange vary from 595 to $645 \mu \mu[\mu \mu=$ $1 / 1,000,000 \mathrm{~mm}$.].) Beyond these visible rays exist both shorter (ultra-violet) and longer (infra-red) rays. From physics one learns that the ultimatc constituents of matter exist, not in a statc of rest, but in a state of ordered motion. That is, the cleetrons (or other ultimate complex, see colloids, p. 75 , and radiant cnergy, p. 117) vibrate with a definite periodicity dependent on the intrinsic cnergy of the system to which they belong. From the study of the emission speetra of gases, a relationship may be dedueed between the period of vibration of a particle and the position of the light bands cmitted by the elcment in gaseous form. Conversely, if one views the absorption speetra of that gaseous clement, blaek bands will be found in place of the light emission bands. To takc a concretc example, if a substance when emitting light produced rays eonsisting for the most part of waves $680 \mu \mu$ long, the colour of the light evolved would be 
red. The substanee, if viewed through a spectroseope, either when undergoing combustion or in the gaseous state, would produce a dark band in the red section of the spectrum. Further, light falling on a coloured substance is not completely absorbed. A red substanee refleets red light and absorbs the other rays. Only light eorresponding to the speetral bands is absorbed. Grotthus proved that no effect could be produced by light unless it was absorbed. He showed that red iron-thiocyanate was bleached by exposure to green light, yellow chloride of gold and blue starch-iodine complex by blue and yellow light respectively.

1. A mere glance at the absorption spectrum of the green leaf is sufficient to show that the light best absorbed is that having a wave length less than $500 \mu \mu$, the amount absorbed becoming greater as the wave length beeomes shorter, i.e. the ehloroplasts absorb the actinic rays (violet and a small amount of the ultraviolet rays). There is also a well-marked absorption band in the red portion of the spectrum between 665 and $685 \mu \mu$. The figure for the maximal energy of solar radiation is given by S. P. Langley as 650 to $666 \mu \mu$ for high sun, so that the green leaf is able to $(a)$ utilise the aetinic rays, and $(b)$ absorb light of that wave length (red) which is emitted by the sun in greatest amount. The pigments of the chloroplast do not utilise greenyellow light, nor do they absorb the heat (infra-red) rays at all.

2. Consider next the physical (and chemical) ehanges brought about by the absorption of light. Although this is the primary problem in Biology and has attraeted many investigators, it remains unsolved. Researeh has made it more apparent that the meehanism for converting solar radiation into bound energy is not so simple as was at first thought. Certain facts, however, have been brought to light.

(1) Matter is assimilated. Elements taken from the environment are built into organic compounds. Boysen-Jensen has shown that in July the aceumulation of matter (dried) may reaeh 16.5 per cent. of the total dry weight of the plant. A large proportion of this matter can be shown to be carbohydrate by a very simple experiment. It is only necessary to screen a portion of a leaf from the light, leaving a certain portion exposed, and then observe any differences between the normal and the darkened portions. If a leaf, like sunflower or fuehsia, is ehosen and previously kept overnight in the dark, exposure to light for 15 minutes is suffieient, and one hour is more than ample for our purpose. The leaf is then bleached with warm alcohol, and 
iodine is applied. The part exposed to light will appear blucblack-rich in starch, while the sereened portion is starch free. It has been shown that during the day the stareh eontent of leaves may rise to $6 \cdot 44$ per cent. of the dry leaf weight. At night the stareh value may drop as low as 0.38 per eent. Timiriazeff has devised a very neat experiment which demonstrates that stareh formation is greatest where there is greatest absorption of light. Living hydrangea leaves, previously deprived of stareh by retention in the dark, have then projected on them a solar spectrum for 5 or 6 hours. The leaf is decolorised and treated with iodine, and then the absorption bands of the chloroplast pigment complex are found mapped out in blue, showing that starch has been formed only where light has been absorbed. Other carbohydrates are also found. Cane sugar is formed and can be detected before starch can be found, and it is generally present in greater amounts, $7 \cdot 63$ per eent. to $2 \cdot 63$ per cent. of the dried-leaf weight. Other sugars are present in small variable quantities.

(2) It seems that $\mathrm{CO}_{2}$ is absorbed beyond the needs of respiration, and that $\mathrm{O}_{2}$ is evolved. Engelmann has provided in a striking manner a demonstration of the faet that the maximum evolution of oxygen takes place where there is the maximum absorption of light and, as stated above, the maximum formation of stareh. He placed a filament of eladophora in water, to which he added some motile bacteria having an avidity for oxygen. On the thread of alga he projected a minute solar speetrum and kept it under the mieroseope. It was seen that the baeteria gathered just at those places (red and violet) where light was absorbed.

Kniep and Minder have determined the earbon assimilation, and they find it direetly proportional to the amount of energy absorbed as light. Further, Willstatter and Stoll have estimated

(a) The $\mathrm{CO}_{2}$ taken up by a leaf area in the dark, i.e. respiratory $\mathrm{CO}_{2}$.

(b) The $\mathrm{CO}_{2}$ absorbed in light of a definite intensity.

(b) $-(a)=$ assimilated $\mathrm{CO}_{2}$.

(c) The $\mathrm{O}_{2}$ evolved in the dark - respiratory $\mathrm{O}_{2}$.

(d) The $\mathrm{O}_{2}$ evolved in the light - total $\mathrm{O}_{2}$.

(d) $-(c)=$ non-respiratory $\mathrm{O}_{2}$.

(e) $\frac{(b)-(a)}{(d)-(c)}=\frac{\mathrm{CO}_{2}}{\mathrm{O}_{2}}=$ assimilation coeffieient.

(Cf. respiratory quotient, see Chap. III.). 
They find that under all eonditions of light the assimilation coefficient is 1 . From this it may be inferred that $\mathrm{C}$ not $\mathrm{CO}_{2}$ is being built into the leaf. In short, the chloroplast aets as a machine for converting $\mathrm{CO}_{2}$ into $\mathrm{C}$ and $\mathrm{O}_{2}$ which is evolved. The carbon then unites with water to form some simple sugar, which one is not known. The final product is stareh. The process may be represented by the equation :

$$
x \mathrm{H}_{2} \mathrm{O}+x \mathrm{CO}_{2}+\text { light energy }=\mathrm{C}_{x} \mathrm{H}_{2 x} \mathrm{O}_{x}+x \mathrm{O}_{2} .
$$

It has been proved that the first step is the formation of formaldehyde, i.e. $x=1$.

$$
\mathrm{H}_{2} \mathrm{O}+\mathrm{CO}_{2}+112,090 \text { gram cals }(?) \rightleftharpoons \mathrm{O}_{2}+\mathrm{CH}_{2} \mathrm{O}
$$

(formaldehyde).

Formaldehyde is injurious to plant tissues, and it is rapidly transformed into other products.

If $x=2$ then the formaldehyde would condense to form glycollie aldehyde-a diose.

$$
\mathrm{CH}_{2} \mathrm{O}+\mathrm{CH}_{2} \mathrm{O}+\text { energy } \rightleftharpoons \mathrm{C}_{2} \mathrm{H}_{4} \mathrm{O}_{2} .
$$

Similarly, glueose could be formed.

$$
\mathrm{C}_{2} \mathrm{H}_{4} \mathrm{O}_{2}+\mathrm{C}_{2} \mathrm{H}_{4} \mathrm{O}_{2}+\mathrm{C}_{2} \mathrm{H}_{4} \mathrm{O}_{2}+\text { energy } \rightleftharpoons \mathrm{C}_{6} \mathrm{H}_{12} \mathrm{O}_{6} \text {. }
$$

Two molecules of glueose combine to form maltose.

$$
\begin{aligned}
\mathrm{C}_{6} \mathrm{H}_{12} \mathrm{O}_{6} & +\mathrm{C}_{6} \mathrm{H}_{12} \mathrm{O}_{6}+3300 \text { gram-calorics } \\
& \rightleftharpoons \mathrm{C}_{12} \mathrm{H}_{22} \mathrm{O}_{11}+\mathrm{H}_{2} \mathrm{O} .
\end{aligned}
$$

(v) The gums or dextrins are composed of condensed molccules of maltose, $e . g$.

$$
\mathrm{C}_{12} \mathrm{H}_{22} \mathrm{O}_{11}+\mathrm{C}_{12} \mathrm{H}_{22} \mathrm{O}_{11}+\mathrm{H}_{2} \mathrm{O}+\text { energy } \Rightarrow \mathrm{C}_{24} \mathrm{H}_{46} \mathrm{O}_{23},
$$

and so on.

(3) The encrgy value of $\mathrm{CO}_{2}$ is $2 \cdot 1$ eals. per gram, that of $\mathrm{H}_{2} \mathrm{O}$ is $6 \cdot 5$, while stareh has a value of 4191 gram cals. It is evident, thcreforc, that in some way the plant has converted a certain amount of kinetic energy into potential energy. Now, as the formula for starch is uncertain, let us consider the amount of energy required to form glucose from $\mathrm{CO}_{2}$ and $\mathrm{H}_{2} \mathrm{O}$. Carbon dioxide and water are fully oxidised. Theoretically, they may be considered as undergoing a process of reduction before combining to form the aldehyde, but as the encrgy evolved during reduction would be balanced by the energy absorbed during formation, we may limit our problem to the total energy change according to the two equations given above, viz. (i) and (iii). 
From (i) we sec that a gram-molecule of formaldehyde has an energy-content approximating 112,300 gram calories. 'This store of encrgy is derived from the constituents $\mathrm{H}_{2} \mathrm{O}$ ( 117 gram eals.), $\mathrm{CO}_{2}(92 \cdot 4$ gram cals.), and from absorbed sunlight $(\mathbf{1 1 2 , 0 9 0 \cdot 6}$ gram cals.).

With the formation of formaldchyde, practically all the energy necessary for the formation of carbohydrates has been absorbed. As we shall learn later (Chap. V.), osmotic energy is a function of concentration. 'Thereforc, when six molecules of formaldehyde are condensed to one molecule of glucose, a corresponding amount of osmotic encrgy is liberated, and this may be utilised in part in endowing the glucose with the shightly higher content of chemical energy which it possesses over that of the formaldehyde. Sunlight here acts as a catalyst (Chap. IX.).

As we have seen, all the light falling on the leaf is not utilised - even all the light absorbed is not stored. Some energy is required for direct domestic use, e.g. transpiration. It has been calculated that about 10 per ecnt. of the incident light is absorbed by the chloroplast pigments. In an experiment by Brown and Escombe it was found that a total amount of incident light, which, if converted into heat units would correspond to 0.041 cal. per sq.cm. per minute, caused the decomposition of 0.00034 c.cm. of $\mathrm{CO}_{2}$ per sq.cm. per minute. In the conversion of $1 \mathrm{c.cm}$. of $\mathrm{CO}_{2}$ into glucose 5.02 gram cals, are stored. Therefore, in building $0.00034 \mathrm{c.cm}$. of $\mathrm{CO}_{2}$ into sugar the amount of energy rendered potential would be

$0.00034 \times 5 \cdot 02=0 \cdot 0017$ gram cals. per $\mathrm{cm}$. per minute.

As that is about 4 per cent. of the total incident radiation, the efficiency of the chloroplast under maximal conditions is somewhere about 40 per cent. When the process is reversed and carbohydrate split up with the assimilation of oxygen and the evolution of carbon-dioxide, this energy is again set free. It may be freed in such a way that a certain proportion of it appears as light. This light has, according to Trautz, the same wave length as the originally absorbed light. Of course, in general, the cnergy will be evolved in a form more suitable for utilisation than this (sce Chaps. on Osmosis, Surface Tension, etc.).

Fats are stored up also in the plant. Very little research has been done on the synthesis of fats in the plants. Whether the plant can form these compounds directly or whether they are only synthesised from carbohydrate is not known. That they 
ean be formed from earbohydrates is known, and Leathes states that this aetion is exothermie, several moleenles of simple sugar going to the formation of one (larger) moleeule of fat, having, of course, a higher ealorie value. The fat is almost exclusively found in the fruit.

Ineidentally, energy is bound in the formation of proteins. This energy comes indirectly from the sun. Atmospherie nitrogen is fixed in a form available for plant use by eertain bacteria. Eaeh gram of nitrogen so fixed earries with it a eonsiderable quantity of energy which is obtained from the oxidative decomposition of $100 \mathrm{mg}$. mannitol, the parent aleohol of the carbohydrate, mannose.

To conclude, the plant acts as a transformer of kinetic into potential energy by the formation of carbohydrates, fats, proteins (the so-called proximate principles of food) and a few other substances of minor importance as storehouses of energy.

Having regard to the faet that free energy is of vital inportance, and that the potential encrgy of the foodstuffs is readily rendered available, one would eonsider it a profitable study to determine the exaet mechanism of this eonversion. So far, study of pure ehlorophyll has led to negative results. Kremann and Sehnidlersehitseh have reeently shown that pure ehlorophyll, in aleohol, absorbed the same amount of $\mathrm{CO}_{2}$ as the aleohol itself, and it made no differenee whether the solution were exposed to light or kept in the dark. The absorption spectrum of neither ehlorophyll $a$ nor ehlorophyll $b$ nor elılorophyll $a+b$ is similar to the spectrum of the living green leaf. Knowledge is ineomplete both of the ehemical nature of the various eonstituents of the ehloroplast and of the distribution and physieal state of the eomponents of this heterogeneous system. The pigments are assoeiated with a eolloid eomplex and the absorption of $\mathrm{CO}_{2}$ with alterations in the eleetrieal state.

To sum up, man obtains the energy neeessary for his maintenance and for the performance of physieal work from the disruption of proteins, earbohydrates and fats, synthesised in the first instance by green plants which trap and store solar energy. Historically and until quite reeently, the energy of sunlight, apart from an insignifieant amount drawn from the tides, was the sole income of energy available for the world. Mankind still maintains himself solely on the energy derived from the sun through the intermediary of plant and animal metabolism, but he derives lis energy for work to an inereasing extent from 
a legaey of potential energy laid by in former times. He has devised detachable limbs (machines and tools) able to utilise the encrgy of eoal, petrol, ete., of which he eould not avail himself without their aid. This made possible an enormous inerease in the world's work-work done no longer by human beings and beasts of burden, but by inanimate machines using the energy of fire, electrieity, ete. To-day, a single maehine does the work of an army of men. In this way he eonserves present-day solar energy and lives on the banked ineome of past ages. Some time in the future he may learn how to synthesise food from inorganic eonistituents by the use of any form of available energy. Then and only then will he be able to dispense with plant life. Steps in this direction have been made. Moore and Webster have synthesised formaldehyde by exposing an aqueous solution of $\mathrm{CO}_{2}$ to ultra-violet light (Chap. XI.) in the presence of inorganie colloids (Chap. VIII.). They have also shown that dilute solutions of nitrates exposed to ultra-violet rays are eonverted into nitrites with an absorption of energy. One gram molecule of nitrite formed from nitrate transforms about 10,000 gram-ealories of radiant energy into the potential state - a strong endothermie reaction. This is similar to the ehange taking place in the plant in the formation of nitrogen eompounds-the first stage in protein anabolism. 


\section{CHAPTER III}

\section{LIBERATION OF ENERGY}

\section{(1) CALORIMETRY}

"From the use of materials arise physical results, such as work, heat and electricity, which we can express in heat units. This is the power derived from metabolism."

VoIT.

The next matter for eonsideration is the method of measuring the potential energy of foodstuffs and eomparing the value so found with the aetual amount of energy liberated in the organism. It should then be apparent whether living matter in its various energy-ehanges obeys the laws of energeties. For purposes of measurement, it is eustomary in biology to eonvert all forms of energy into that of heat. This is seientifieally correet, as heat is the "lowest grade" of energy, and all other forms of energy (ordered motion) may be degraded to unordered motion (heat); and it is not possible eompletely to eonvert any form of energy into any other form of energy but heat. In any sueh eonversion, as we have seen, there is always a eertain loss as heat. The unit of heat adopted in biology is the large ealorie-that is, 1000 times the amount of heat required to raise one gram of pure water from $15^{\circ}$ to $16^{\circ} \mathrm{C}$. This value is almost the same as that required to raise one kilogram of water $1^{\circ} \mathrm{C}$.

Just as a eountry must have a standard eoin of the realm-pound or dollar-in whieh its assets may be eomputed, so must there be a standard unit for the eomputation of energy. The bank-teller totals up his day's transaetions in $\mathfrak{E}$ s. d., no matter how various are the forms in whieh he has reeeived or parted with the money. Cash, notes, eheques, deposit receipts, ete., all appear on his final balance-sheet under one denomination. Similarly, all energy transaetions ean be summed up and balaneed as so many ealories reeeived, so many ealories expended. Further, the faet that not a single sovereign may have erossed the eounter, 
does not hinder the banker from entering $£$ sterling in his books. So ealories may be the units employed, although heat may not necessarily enter the reaetion.

\section{A. Measurement of energy-value (E.V.) of foods by ultimate analysis.}

The energy of a pure ehemieal eompound may be ealeulated from its ehemieal formula. The amount of heat evolved when $\mathrm{C}^{\mathrm{C}}$ is oxidised to $\mathrm{CO}_{2}$ and when $2 \mathrm{H}$ is eombined with $\mathrm{O}$ to form water has been determined. The equations of these two reaetions eould therefore be written :

$$
\begin{aligned}
\mathrm{C}+\overline{\mathrm{O}_{2}} & =\mathrm{CO}_{2}+94 \cdot 31 \text { eals. } \\
2 \mathrm{H}_{2}+\overline{\mathrm{O}}_{2} & =2 \mathrm{H}_{2} \mathrm{O}+117 \cdot 4 \text { eals. }
\end{aligned}
$$

(A horizontal line above the formula of a substance in a thermo-chemical equation indicates that the substance is in the gaseous state, the absence of any line indicates the liquid state, while a line below the formula indicates the solid state. The suffix aq is intended to convey the idea that the substance is in solution in such a large volume of water that the addition of more water would not produce any appreciable effect-that is, the substance is so dilute that its heat of dilution on the further addition of water would be negligible.)

One must note that any alteration of gaseous volume or of any other physical characteristie of any of the reaeting units would, by utilising some energy as positive or negative work, produce an alteration in the amount of heat evolved. Welter enuneiated a rule whereby one might arrive at an approximate value of the heat of oxidation of a eompound eontaining oxygen as well as earbon and hydrogen. Aeeording to this rule the oxygen is subtracted from the molecular formula with as much hydrogen as would serve to eonvert it eompletely into water, the heat of oxidation of the earbon and hydrogen in the residue then gives a rough value of the heat of oxidation in the whole eompound. For example :

A fat, tripalmitin, has the following formula $\mathrm{C}_{51} \mathrm{H}_{98} \mathrm{O}_{6}$ Deduct intramoleeular water - $\quad-\quad \mathrm{H}_{12} \mathrm{O}_{6}$

$$
\text { Leaving for oxidation - } \quad-\quad-\quad-\overline{\mathrm{C}}_{51} \mathrm{H}_{56}
$$

$$
\begin{aligned}
\mathrm{C}_{51} \mathrm{H}_{86}+145 \mathrm{O}_{2} & =51 \mathrm{CO}_{2}+43 \mathrm{H}_{2} \mathrm{O} \\
& =51 \times 94 \cdot 31+43 \times 58 \cdot 7 \\
& =7333.9 \text { eals. }
\end{aligned}
$$

That is, a gram moleeule ( 806 grams) of tripalmitin in being eompletely oxidised to $\mathrm{CO}_{2}+\mathrm{H}_{2} \mathrm{O}$ would liberate 7333.9 eals. of heat. Similarly, the energy stored in the form of earbohydrate may be ealeulated. A diffieulty, however, oeeurs with proteins. 
In the ease of earbohydrates and fats the end-products are those of complete oxidation, but in the ease of proteins, the final results of metabolism are not substanees of the lowest

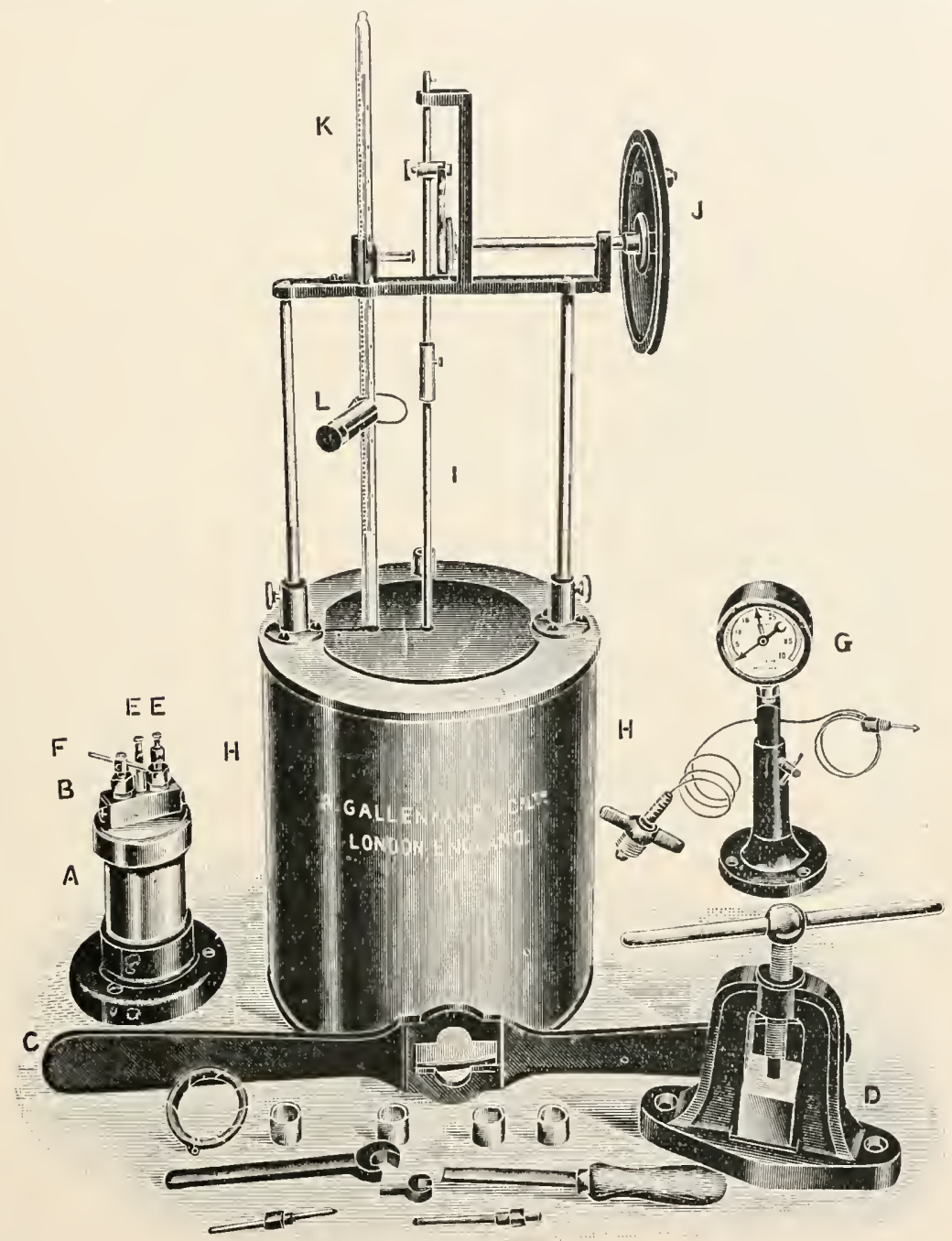

Fra, 2,-Bertholot-Nahler Bomb Calorimeter.

A. Bomb or autoclave (see Fig. 3).

H. Insnlating vessel.

(i. Manometer on stand with mions to fix to oxygen eslinder and to bomb (at S, Fig. 3).

D. A steel mould for making pellets from the material to be burned.

energy content, i.e. protein is not completely oxidised. Further, these protein end-products are eliminated in solution, and this requires some correction. Finally, to obtain the correct content 
of the foodstuff of $\mathrm{C}, \mathrm{H}$ and $\mathrm{O}$ requires a complieated ehemieal teehnique. 'This method of ealeulating energy-value is little used in biology. Pure substanees are seldom used as food material, exeept in eertain kinds of experiments.

\section{B. Measurement of E.V. of foods by calorimetric combustion.}

The prineiple underlying this method is the combustion of a known amount of the matcrial in an apparatus so devised that

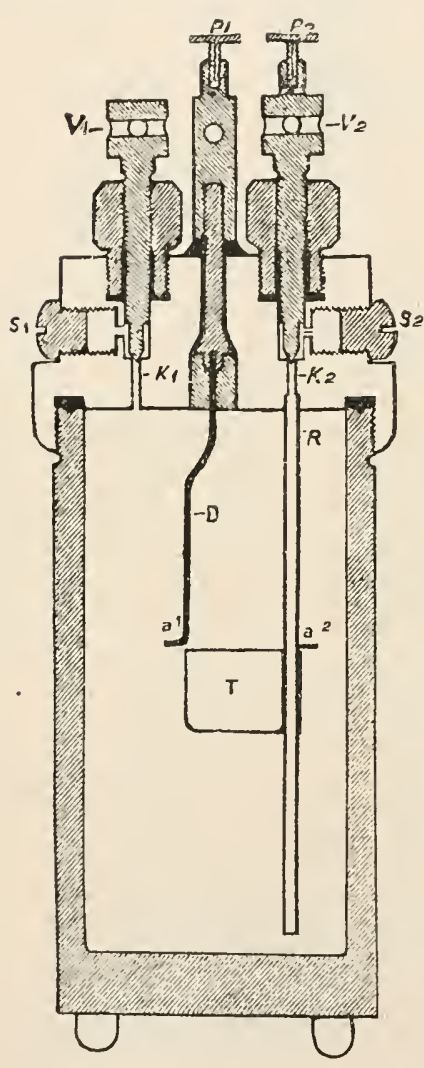

FIG. 3.-Section through a Kroeker bomb (see text). practically all the heat evolved is absorbed by a known amount of water and by the apparatus itself (which is of known heat eapacity). Some form of bomb calorimeter is now universally employed for this purpose. The instrument (Fig. 2) consists of three main parts.

1. The bomb itself is eonstrueted of steel, nickel-plated, with a cover to be serewed on firmly against a lead washer. Its eapacity is about 300 e.es. Through the eover the entranee and exit gas channels pass; $K 2$ with its continuation platinum tube, $R$, is for the introduetion of oxygen, and $K 1$ for the withdrawal of the gaseous products of eombustion. Both ehannels are elosed by means of the serew spindles $V_{1}$ and $V^{\prime} 2$, running in stuffing boxes. $S_{1}$ and $S 2$ are serews to stop the lateral communieation with $K \mathbf{K}$ and $K 2$. Into these may be serewed niekel-plated tubes. Through the eentre of the eover passes a strong platinum wire, $D$, and this, as well as $R$, is fitted with short pegs, $a^{1}, a^{2}$, on which hangs the erueible T. A short collar, just above these pegs, is for the attachment of the ignition wire. $P 1$ and $P 2$ are two small serew-elamps for attaching to the electric wires for ignition (Fig. 3).

2. The insulating ehamber is a double-walled eopper vessel of about 11 litres eapacity, and the space between the walls is to be filled with water at room temperature. It is lined with 
white enamel, and eontains within it, but insulated from it by a thin cbonite stand, 3 . the bright niekel-plated water holder.

Besides this it is neeessary to have a stirring deviee, a thermometer to read to $1 / 100^{\circ} \mathrm{C}$., and a means whereby oxygen at 15-20 atmospheres pressure ean be put into the bomb.

\section{Calibration.}

Certain values have got to be determined before the apparatus ean be employed.

\section{Calorie Value of Match.}

In order to eonvert energy from the potential to the free state, we have already seen that some free energy must be addedthe material must be ignited. Various forms of mateh are employed. Some workers prefer to suspend a dried eotton thread of known weight from a platinum wire eonnecting $D$ and $R$. The thread dips into the erucible $T$, and touches or is embedded in the material to be burned. On eompletion of an eleetrie eireuit through $P 1$ and $P 2$ the platinum wire glows and sets off the eellulose mateh, whieh in turn eauses the foodstuff to ignite. Others prefer to weigh out a pieee of iron wire, 5-6 ems. long and $0 \cdot 1 \mathrm{~mm}$. thiek, and put it in plaee of both the platinum wire and the cotton thread. In any ease, the amount of heat evolved in the ignition process has to be determined earefully, and dedueted from the heat evolved, in a eomplete estimation or in the determination of the water equivalent.

\section{Water Equivalent.}

The apparatus itself-vessels, thermometer, stirrer-is heated along with the water it eontains. Its water equivalent, i.e. the quantity of water which has the same heat eapacity as the apparatus, must be determined and added to the quantity of water aetually employed in the experiment. Several methods exist for this determination. The most exaet, and at the same time the most eonvenient, is to burn in the ealorimeter a weighed quantity of a substance whose ealorie value is known with absolute eertainty, and ascertain the resultant ehange in the temperature of the water. The water equivalent is:

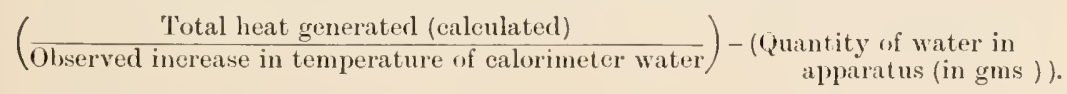

\section{Calibration of Thermometer.}

The thermometer has to be ealibrated, and a correction applied for this. 


\section{Cooling Constant.}

Another eorrection to be made in the final ealeulation is that of the cooling eonstant of the apparatus. The ehief souree of error in ealorinetrie experiments lies in heat exchange with extermal objects by eonduction and radiation. To reduee this error to a minimum $(a)$ the ehemical action must go on as fast as possible, henee the use of oxygen under pressure; $(b)$ the temperature of the ealorimeter water is kept as nearly as possible at the same value as the temperature of the room. We have already stated how the grosser errors of eonduction and radiation are avoided by the strueture of the insulating chamber. In spite of this there is a eertain loss, which is measured as part of the regular routine of an experiment and is allowed for.

In order to ealeulate the energy of any material one must know what the end-products of the eombustion are. We have seen that $\mathrm{C}$ and II are always under these eireumstanees eompletely oxichised to $\mathrm{CO}_{2}$ and $\mathrm{H}_{2} \mathrm{O}$, which undergo little or no further energy ehanges. $\mathrm{S}$ and $\mathrm{N}$, on the other hand, are eonverted into sulphurie and nitrie oxides, whieh in turn dissolve in and eombine with water forming $\mathrm{H}_{2} \mathrm{SO}_{4}$ and $\mathrm{HNO}_{3}$. A eorrection has to be applied for their heats of solution and combination. For very fine work, eorrections may be applied for the latent heat of evaporation of water and for the heat of solution of $\mathrm{CO}_{2}$.

Determinations of the energy-value of the proximate prineiples of food have shown that only minute differenees exist between the various members of any elass. For example, one gram of cach of the following earbohydrates has the aceompanying value in ealories :

\section{TABLE II.}

$\begin{array}{llll}\text { Stareh } & =4 \cdot 191 & \text { large ealories. } \\ \text { Cane Sugar } & =3 \cdot 955 & . & , \\ \text { Maltose } & =3 \cdot 94 & . & , \\ \text { Milk Sugar (Laetose) } & =3 \cdot 95 & , & , \\ \text { Glueose } & =3 \cdot 74 & ., & , \\ \text { Fruit Sugar (Fruetose) } & =3 \cdot 75 & , & ,\end{array}$

Average values have therefore been adopted and aceepted as standard. E.g.

$\begin{array}{lllllll}\text { Carbohydrate } & - & - & - & - & 4 \cdot 1 & \text { Calories. } \\ \text { Fat - } & - & - & - & - & 9 \cdot 3 & , \\ \text { Protein - } & - & - & - & - & 5 \cdot 3 \quad,\end{array}$


Of course, the diseerning student will understand that, except in rare and restrieted feeding experiments which have a special end in view, pure carbohydrate, fat and protein are not exhibited. Determinations are made of the energy-value of aetual foods. This gives opportunity for the display of some ingenuity on the part of the investigator, since some of the commoner articles of diet do not readily lend themselves to combustion and are not easily dried. Nevertheless, extended experiments are being condueted by physiologists, in which, as part of the routine, the total energy-value of the daily diet is determined.

The energy-value of the diet does not represent the energy used by the organism.

(a) Some energy-earrying substanees eannot be digested, and therefore are exereted unchanged in chemical composition and energy eontent, e.g. cellulose.

(b) Other constituents of the diet may undergo some chemical alteration, but may be exereted not fully deprived of their energy.

(i) Proteins are not eompletely oxidised in the body. 'Their end-products are urea and allied substances.

Beeause of the difference in the end-products there is a physiological calorie value for proteins different from their purely physical value. Rubner determined this physiological value by dedueting from the absolute value, the heat value of nitrogenous end-products in facees and urine with their heats of solution. He arrived at the figure 4.015 . The acecpted average value is $4 \cdot 1$ calories per gram of protein.

(ii) Certain substances are exereted in eombination with protein disintegration produets, e.g. hippuric acid.

(c) Certain substanees or their disintegration products seem to be necessary constituents of faeces, e.g. fats (see Chap. XXVII.).

The energy-value of all cxereta must therefore be deducted from the energy intake before an energy balance can be struek.

\section{Measurement of the E.V. of foods by animal calorimetry (a) direct, (b) indirect.}

It is obvious as a direct deduction from the first law of energeties that if this law holds in living as well as in non-living matterenergy transformations, the same amount of encrgy should be evolved from the utilisation of food inside as well as outside the body, provided always that the physical state and chemical end-products are the same in cach ease. If an animal could be put inside a ealorimeter and given a definite amount of food, 
the heat evolved should, providing our hypothesis is true, be exaetly the same as would be cvolved in direct food calorinctry. Eaeh gram of carbohydratc should produce $4 \cdot 1$ cals., and so on. This can be put to the test in eitlıcr of two ways. The first is known as direct (animal) calorimetry, and consists in accurately measuring the heat evolved by the animal under investigation. The sccond or indirect method is based on a knowledge of the amount of heat evolved per litre of the respiratory gases and per gram of urinary nitrogen.

(a) The direct method was first employed by Crawford (1779). His ealorimeter, in principle, consisted of a doublc-walled box with a known amount of water betwcen the walls. The animal was plaeed in the inner box for a definite time and the increase in tempcrature of the water noted at the end of the experiment. The mcthod is, of course, primitive, and the veriest tyro in physics could suggest quite a host of sourees of error, but on this crude instrument are based those fincr implements of rescareh which, in the hands of Benedict and his colleagues, have contributed so much to the knowledge of nutrition. Crawford found that for every 100 ozs. of oxygen used during the combustion of carbon in his ealorimeter, the tempcrature of the watcr was raised $1.93^{\circ} \mathrm{F}$. A live guinea pig consuming the same amount of oxygen produced an inerease of $1 \cdot 73^{\circ} \mathrm{F}$. This seemed sufficient evidence for him to conclude that, in each case, the heat produced was due to the conversion of pure air into fixed, or, as we should now say, to the combination of $\mathrm{C}$ and $\mathrm{O}_{2}$.

A year later, Lavoisier and Laplace published the result of cxperiments which confirmed Crawford's results, and made firm the prineiple of indircet calorimetry. They determined the amount of ice melted by the eombustion of a weighed amount of carbon (a candlc) and the volume of the $\mathrm{CO}_{2}$ evolved. A similar experiment was then tried with a guinca pig. They found that for equal volumes of $\mathrm{CO}_{2}$ formed, the candle yielded $25 \cdot 4$ eals. as against the guinca pig's $31 \cdot 8$. The experiment is bristling with crrors, many of whieh the authors realised. For instance, the respiratory and calorimetric deterninations were not, as by Crawford, made simultaneously, and obviously thermal conditions were not the same. As we shall see later, cold raises the $\mathrm{CO}_{2}$ output. If allowance is made for this and for other minor crrors, the figures for eandle and animal come close enough to justify the conclusion that the processcs are similar, and that the source of heat in both is the combination of $\mathrm{C}$ and $\mathrm{O}_{2}$. 
The various sourees of error due to faulty tcchnique have bcen gradually climinated, and the resultant ealorimeters that bear the names of Atwater, Rosa, and Benediet and that of Williams produee results that are suffieient to convince cven the most sceptieal of honest observers that the oxidation of assimilated foodstuffs in the living body produces the same evolution of energy as they would if burned in the bomb calorimeter, provided the end-products are identical.

The dircet method is not of such general use as the indirect. Study of the papers from the Carnegie Institute of Washington or of those from Corncll University makes clear the complexity of the maehine and the intrieaey of its manipulation. The cost, except for the smallest Williams' boxes, is prohibitive. The apparatus ean be mueh simplified if the direct estimation of the energy-ehanges is omitted and the observer eonfines himself to measuring the respiratory gases and the urinary output.

(b) Indirect. As we have seen, the basis of this method also was laid by Crawford. It depends upon the following cstablished faets :

(I) The quantity of energy liberated depends on the chemical composition of the food used.

(II) The quantity of oxygen absorbed depends also on the ehemical composition of the food used; therefore,

(III) There must be some relation between the energy evolved and the quantity of oxygen absorbed.

(IV) The three proximate prineiples of food differ markedly in chemical eomposition. (a) Proteins contain nitrogen, which is eliminated almost entirely in the urine. (b) Carbohydrates and fats differ widely in their proportion of $\mathrm{O}$ to $\mathrm{C}$.

(V) If a determination were made of the amount of heat and the amount of $\mathrm{C}$ and $\mathrm{O}_{2}$ which corresponds to each gram of urmary nitrogen, one eould, from the nitrogen exereted, caleulate the heat liberated from the protein of the dict. (1 gram of urinary nitrogen $=\mathbf{2 6 . 5 1}$ cals.) Having deducted the protein $\mathrm{O}_{2}$ from the total $\mathrm{O}_{2}$ absorbed and the protein $\mathrm{CO}_{2}$ from the total $\mathrm{CO}_{2}$ climinated, onc arrives at the figures corresponding to the non-protein $\mathrm{O}_{2}$ and $\mathrm{CO}_{2}$ respectivcly.

(VI) Now, as we have said, carbohydrates differ from fats in their respective eontents of $\mathrm{C}$ and $\mathrm{O}_{2}$. Carbohydrates have the general formula $x\left(\mathrm{CH}_{2} \mathrm{O}\right)$, while fats eontain less $\mathrm{O}_{2}$ compared with thcir content of oxidisable matter, e.g. $x\left(\mathrm{C}_{9} \mathrm{H}_{12} \mathrm{O}\right)$. Therefore, when carbohydrates alone are uscd, the ratio of the volume 
of $\mathrm{CO}_{2}$ eliminated to the volume of $\mathrm{O}$ absorbed will be 1 , as may be deduced from the equation :

$$
\begin{aligned}
\mathrm{C}\left(\mathrm{H}_{2} \mathrm{O}\right)+\mathrm{O}_{2} & =\mathrm{CO}_{2}+\mathrm{H}_{2} \mathrm{O} \\
1 \mathrm{vol} & =1 \mathrm{vol}
\end{aligned} \quad \mathrm{R} . \mathrm{Q}=\frac{\mathrm{Vol} \mathrm{CO}}{\mathrm{Vol} \mathrm{O}_{2}}=1=1 .
$$

Fats arc eompounds of the trihydric alcohol, glyeerol, with organic aeids of the aliphatie (fatty) homologous series. The simplest fatty acid is formie, H.COOI. The higher aeids are built up by sueeessive additions of $\mathrm{CH}_{2}$.

TABILE III.

Saturated Series. $\mathrm{C}_{n} \mathrm{H}_{2 n} \mathrm{O}_{2}$.

E.g.

II.COOH - formic acid $\mathrm{CH}_{2} \cdot \mathrm{HCOOH}$-aectie aeid

$\mathrm{CH}_{2} \mathrm{O}_{2}$

$\mathrm{C}_{2} \mathrm{H}_{4} \mathrm{O}_{2}$

$\mathrm{CH}_{2} \cdot \mathrm{CH}_{2} \cdot \mathrm{HCOOH}$ - propionie aeid $\mathrm{C}_{3} \mathrm{H}_{6} \mathrm{O}_{2}$ $\mathrm{CH}_{2} \cdot \mathrm{CH}_{2} \cdot \mathrm{CH}_{2} \cdot \mathrm{ICOOH}$ - butyrie acid $\mathrm{C}_{4} \mathrm{H}_{8} \mathrm{O}_{2}$

(CII $)_{15} \cdot \mathrm{HCOOH}$ palmitic aeid $\mathrm{C}_{16} \mathrm{H}_{32} \mathrm{O}_{2}$

$\left(\mathrm{CH}_{2}\right)_{16} \cdot \mathrm{HCOOH}$ - margarie acid $\mathrm{C}_{17} \mathrm{H}_{34} \mathrm{O}_{2}$

$\left(\mathrm{CH}_{2}\right)_{17} \cdot \mathrm{HCOOH}$ - stearie aeid $\quad \mathrm{C}_{18} \mathrm{H}_{36} \mathrm{O}_{2}$

Unsaturated Series. $\mathrm{C}_{n} \mathrm{II}_{2 n-2} \mathrm{O}_{2}$ oleie aeid $\quad \mathrm{C}_{18} \mathrm{H}_{31} \mathrm{O}_{2}$

A glanee at this list will make it elear that the amount of oxygen does not inerease although the $\mathrm{C}$ and $\mathrm{II}$ are increased. This paueity of oxygen eontent is more marked in the fats than in the fatty aeids.

$$
\begin{array}{ccc}
\text { Palmitic Acid } & \text { Glycerol } & \text { Palmitin } \\
\mathrm{C}_{15} \mathrm{II}_{31} \mathrm{COOH} & \mathrm{HO} \\
\mathrm{C}_{15} \mathrm{H}_{31} \mathrm{COOH} & \mathrm{H} \mathrm{O}-\mathrm{C}_{3} \mathrm{I}_{5}=\mathrm{C}_{51} \mathrm{H}_{98} \mathrm{O}_{6}+3 \mathrm{H}_{2} \mathrm{O} \\
\mathrm{C}_{15} \mathrm{H}_{31} \mathrm{COOH} & \mathrm{HO} \\
\mathrm{C}_{51} \mathrm{H}_{98} \mathrm{O}_{6}+145 \mathrm{O}=51 \mathrm{CO}_{2}+49 \mathrm{H}_{2} \mathrm{O} . \\
\text { Now ratio }= \\
\text { Vol CO } \mathrm{CO}_{2}=\frac{51}{72 \cdot 5}=0 \cdot 70 .
\end{array}
$$

That is, ratio for carbohydrates is 1 .

$$
\text { " } " \text { (Zuts : }, 0 \cdot 7 \text { (eirea) }
$$

(VII) Values for a non-protein ratio lying between 0.7 and 1 denote the utilisation by the body of a mixture of fats and earbo- 
hydrates; the eloser the ratio eomes to unity the more earbohydrates are being oxidised, and vice versî.

(VIII) Now, knowing the proportion of carbohydrate and fat in the dict, one may calculate the amount of energy set free from the two following figures:

(a) If earbohydrate alone is used each litre of $\mathrm{O}_{2}=5 \cdot 047$ eals.

(b) If fat , , , , , , , $=4 \cdot 686$ cals.

Intermediate values may be obtained by interpolation. The results obtained by indirect calorimctry are within 2 per cent. of results from the respiration calorimeter.

In a series of twenty-two different experiments with a dog, Murlin and Lusk obtained the following results :

Indirect calorimetry - $\quad$ - $\quad$ - 2244 cals.

Direct,$" \quad$ - $\quad-\quad 2230$,

Difference - $\quad$ - $\quad$ - $\quad 14$,

Pereentage - - - - 0.6 , 


\title{
CHAPTER IV
}

\section{LIBERATION OF ENERGY}

\author{
(2) THE ANIMAL AS MACHINE
}

"The living and the dead, things animate and inanimate, we dwellers in this world, and this world wherein we lwell, are bound alike by physieal and mathematical law."

Thompson.

WE have just seen that:

(1) Some of the radiant energy of the sun is stored by plant ageney, and is ingested by the animal as food; and (2) the sum total of the energy taken in by the organism in this way ean be aceounted for. 'There is neither gain nor loss of energy in the living animal : the physieal law of eonservation of energy holds good.

We must eonsider the physies underlying the liberation of this energy. Does it follow any of the methods well known to us ? Can we eompare the foodstuffs to fuel and the body to a heat engine? In other words, what intermediate stage, if any, does the potential energy of, say, stareh, reach before beeoming apparent as animal energy? The physiological text-books are so full of referenees to eombustion, fuel value, burning of foodstuffs, that it is natural for the student to look upon the life proeesses as somewhat similar to those of a steam engine. In spite of this it ean be definitely said that the animal body bears little resemblanee to any form of heat engine. The intermediate stage between potential and free energy is not the wasteful one of heat. In order that heat may be eonverted into work there must be a eertain allowanee for "spillage." There must also be a certain gradient of potential. In other words, unless there is a eertain minimum differenee in temperature between the souree of heat and the sink (or heat condenser), the maehine will not work. (Prineiple of Carnot.) In 1824 Carnot determined, theoretically, the pereentage of heat that any heat engine eould eonvert into work. A theoretieally perfeet engine, working 
between the absolute temperatures $T_{1}$ and $T_{2}$, takes up $Q$ cals. from a heat reservoir at the temperature $T_{1}$ and transforms the part $W$ into work, then

$$
W=Q \frac{T_{1}-T_{2}}{T_{1}} \text { (Carnot's Equation). }
$$

Evidently the fraction $\frac{T_{1}-T_{2}}{T_{1}}$ is that part of the $Q$ units of heat whieh represents the amount of energy made available for work. That is, even under unattainably perfect conditions no more heat than $\frac{T_{1}-T_{2}}{T_{1}}$ of the amount given can be converted into work. This equation gives the efficiency of the heat engine.

The most efficient steam enginc yet constructed-a Nordbeg air compressor of 1000 h.p.--converts $25 \mathrm{pcr}$ cent. of the heat energy it recives into work. Most steam engines are only 8 to 10 per eent. cfficient, i.c. only 8 tons out of every 100 tons of perfect fucl burned have their energy eonverted into work.

\section{TABLE IV.}

\section{Comparative Thermal Efficiencies.}

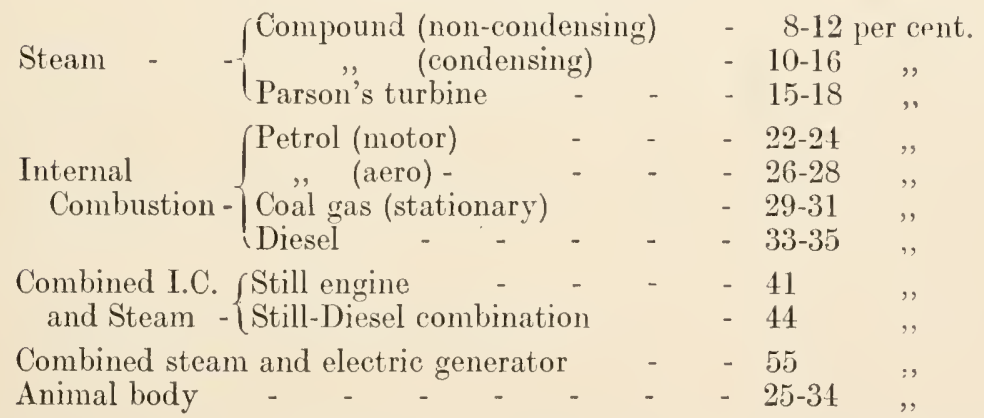

If one werc to eonsider the animal as a heat engine, then it must operate between two temperatures. Onc of these temperatures we know, viz. body tempcrature, which is $38^{\circ} \mathrm{C}$. or $273+38=311^{\circ}$ absolute. This is the condenser or "sink" tempcraturc. The other temperature, that of eombustion, must be higher. How mueh higher may be calculated from the equation above.

or transposing

$$
\text { Efficiency }=\frac{T_{1}-T_{2}}{T_{1}}=E,
$$

$$
T_{1}=T_{2} / I-E
$$

B. B. 
Suppose we take a low figure for animal effieieney, say 20 per eent. Then, substituting, we find that

$$
T_{1}=\frac{311}{1-0 \cdot 2}=\frac{311}{0 \cdot 8}=389^{\circ} \text { absolute or } 116^{\circ} \mathrm{C} \text {. }
$$

That is to say, in order to have an efficieney of 20 per eent. with a condenser temperature of $38^{\circ}$, the temperature of the heat souree would need to be $116^{\circ} \mathrm{C}$. Experienee teaches that the produetion of any such temperature in any tissue would eause death. Lethal temperature is somewhere about $47^{\circ} \mathrm{C}$. However the animal may transform bound encrgy into free, it does not do so by eonversion to heat as one of the stages.

It is not definitely known how the living organism is able to make use of the ehemieal energy of the foodstuffs. Analogy with familiar non-living machines breaks down here. An eleetrie battery is able to transform ehenical energy into kinetic energy without the middleman heat, the go-between in this ease being certain unknown but ordered atomie movements. Observation shows elearly that musele at least is not similar to an eleetric motor. Similarly, one ean dispose of all other forms of energytransformation used in machines to get work from bound energy.

To attempt to gain an insight into the workings of the living organism one must go back to elementary prineiples, and study the machine itself. 'The history of the foodstuffs after ingestion must be followed, and any ehanges they undergo must be noted. The processes of digestion, absorption and assimilation will be noted later. Meanwhile, we want to know what, in general, happens to all foods used as sourees of energy. Have they, in the main, a eommon history ? Of one point at least we may be sure, and that has been dealt with at some length in the preeeding ehapter, namely, that liberation of energy in the animal and oxidation are invariably eoncomitants. Thus the amount of oxidation may be taken as a measure of the cnergy transformation.

Again, it has been definitely proved that all encrgy changes and all vital oxidations take place $i n$ the living eell. Physiological ehemists, while unable to arrive at a definite conelusion as to the eomposition of the cell, are at one with the histologists in stating that the cell material is of the nature of a solution. Cell protoplasm eonsists of over 75 per cent. of water acting as the solvent for eertain crystalloids and as the dispersion medium for various eolloids. The cell eomes into intimate contact with other eclls, and all eell eontents are not of the same ehemical eomposition 
nor in the same physieal state. There will, therefore, arise differenees in surface tension and may be differences in osmotic pressure. It will, therefore, be profitable for us to examine the energetics of simple solutions; then of colloid eomplexes; and finally to apply any relevant knowledge so gained to aseertained facts regarding ecll bchaviour.

We must not forget that our aim in this digression (to solutiondynamies) is to elucidate the processes by which the potential cnergy of foods is rendered kinetic. 


\section{CIIAP'TER $V$}

\section{LIBERATION OF WNERGY}

\section{(3) ENERGY OF SUBSTANCE IN SOLUTION}

"The problem of achieving perpetual motion eontrary to the second law" (of thermodymanies) " is that of bringing order and dircetion once more into the chaotic rush of the molecules, to marshal and drill the mob so that once more they can act tugcther to produce a common effect." SobDr.

\section{Osmotic Pressure.}

'The first process that affeets food is that of digestion. Digestion is merely the breaking down of the material supplied so that it ean pass through the absorbing medium in solution. It follows (from this statement and from the physieal state of the living cell) that all energy manifested by an animal eomes from substanees in solution. No material is of any use for energy purposes unless it is soluble, and until it is rendered soluble it eannot be absorbed and utilised.

That is, the available energy of a cell may be divided into :

(1) 'The potential energy inherent in the various substanees that compose it.

(2) The kinctie energy these substanees have beeause they are in solution.

These two statements together imply that the mere solution of a substance may so alter the state of that substanee that energy is set free. (Cf. heat evolved on diluting eoneentrated $\mathrm{H}_{2} \mathrm{SO}_{4 \cdot}$ ) Further, it may be inferred from this that the physieal conditions which determine the eharaeter and behaviour of living eclls depend on the eomposition of the latter and on their cntironment.

Far-reaehing dieta sueh as these eannot be aeeepted without question. First of all, has the solution of a substance any effeet on its energy content? Does sugar, for instanee, lose some of its energy-eontent when dissolved in tea? Does the bound 
energy so liberated appear as kinetie energy without the intermediation of heat, electrieity, ete.?

When a solid goes into solution it at onee loses the properties eharaeteristic of the solid state. Its particles beeome mobile, and all the properties dependent on regular molecular arrangement disappear. Thus the solid may be optieally aetive or doubly refraeting, and the solution quite void of these properties.

The passage of the substance into solution bears some resemblanee to its passage into the liquid state. A doubly-refracting erystal almost invariably loses its double refraction when it melts; and most substances which are optieally aetive in the solid state are inactive when fused.

The substance might eoneeivably have passed into the gaseous state. Physieal ehemists are agreed that this is the most probable course. They find that for dilute solutions, at any rate, the simple gas laws hold good.

In order to explain and correlate these gas laws and the phenomena of solution, evaporation, ete.. the Kinetic Theory of the strueture of matter has been formulated. The views that have been held regarding the eonstitution of solutions have been very varied, and sinee Thermodynamies is too general in its method of treatment to yicld a eomplete answer to the problem, hypotheses, guided and tested by experiment, are aeepted. The following theory was first propounded by van't Hoff in 1885, and it lias been improved by later physieists. It allows the Seeond Law of Energeties to be applied with conspicuous ease and elearness to the theoretieal investigation of the quantitative relations between the properties of solutions. Matter is regarded as an aggregation of particles (moleeules), each of which is perfeetly elastie and strueturally independent. Between them there exist spaces.

Two opposite forees are at work on molecules.

(1) A Cohesive Force. Newton's Law states that every portion of matter attracts every other portion of matter. The stress between them depends on the mass of the partieles and the distanee between them. Stress $=\frac{m_{1} \times m_{2}}{d^{2}}$ where $m_{1}$ and $m_{2}$ are the masses of the particles and $d$ the distance between them.

(2) A Repellent Force (Real Kinetie Energy $=\frac{1}{2} m v^{2}$ ). Every molecule is free to vibrate in a straight line within the limits of the intermolecular spaces. In a solid these spaces are small, 
and therefore the attractive forees are predominant. If a greater kinetic energy be given to the moleeules by means of heat, for instanee, their path will be inereased at a rate corresponding to the eoeffieicnt of expansion. At a point, the repellent foree will exactly balance the attraetive force, that is, $\frac{1}{d^{2}}=\frac{v^{2}}{2}$. The substanee then assumes the liquid state, gravity alone determining the arrangement of the molecules.

If the temperature of the liquid be raised. some of the moleeules will have sufficient velocity to burst through the surfaee layer and become free gas moleeules. If these gas moleeules move away unhindered, other moleeules from the liquid will take their place, and the liquid will evaporate. If, however, the liquid is kept in a elosed space, the gas moleeules which leave its surface will be able to procecd no farther than the walls of this space, and rebounding from these must eventually return in the direction of the liquid. Some will strike the surfaee of the liquid and will be retained by it. But the molecules still eontinue as before to lcave the surface of the liquid, so that, at onc and the same time, there are molecules entering and leaving the liquid. When the pressure of the molecules leaving the surfaee of the liquid balanees the gaseous pressure above it, a stationary state will be reached, i.e. the same number of moleeules will be freed from the liquid as arc being absorbed by it. That pressure is the Vapour Pressure of the substance. (Cf. tension of gas in solution.)

In addition to the Kinetic Theory of gases, one must assume the statement generally known as the Hypothesis of Avogadro: "Equal volumes of different gases, at the same temperature and pressure, contain the same number of molecules." This proposition has been adopted as a working hypothesis, and as sueh has stood the test of time. It is, in faet, a necessary supplement to the Atomie 'Theory.

The laws governing the physieal behaviour of gases are simple statements correlating pressure, volume and temperature.

(1) Boyle's Lawo. The volume of a given mass of gas varies inversely as the pressure on it, if the temperature of the gas remains constant.

$$
\operatorname{I} \sim \frac{1}{P}
$$

(2) Charles' or Gay Lussac's Larc. 'The volume of a given mass 
of any gas varies directly as the absolute temperature if the pressurc remains constant.

$$
V_{T}=V_{0}(1+a T) .
$$

(3) The pressure of a given mass of any gas varies directly as the absolute temperature, provided the volume of the gas remains constant.

$$
P_{T}=P_{0}(1+a T) .
$$

Any one of these laws may be dedueed from the other two. The whole may be summed up in the formula

$$
P I^{r}=R T,
$$

where $R$ is a constant varying only with the unit of energy used.

\section{TABLE V.}

UNIT OF ENERGY.

Gram-Centimetre -

Joule (Volt-Coulomb) -

Volt-Faraday - -

Litre-atmosphere - - $\quad$ - 0.08207.

Gram-calorie - $\quad$ - $\quad$ - 1.985.
VALUE OF $R$.

- 84,760 .

- $8 \cdot 315$.

- $0.8613 \times 10^{4}$.

The thermal equation with the gram calorie as unit is the one most often cmployed in Biophysics, and is generally taken as 2. That is, the gas equation assumes the approximate form

$$
P V=2 T \text {. }
$$

What is the pressure of a gas? The gas only manifests its kinetic energy by alteration in its pressurc or its volume. As has already been stated, the molecules of a gas are free to move in a straight line till they collide with another molecule or with the walls of the containing vessel. The particle will then rebound in its line of approach with a velocity equal to its orginal velocity, but, of course, with the opposite sign.

The pressure of a gas is due to the bombardment of the walls of the containing vessels by the molecules.

For unit volume, $\frac{2}{3}$ of the total kinetic energy of the gas is responsible for the pressure of that gas. Another conelusion that may be drawn from the kinetic theory of gases is that the velocity of a gaseous particle is inversely proportional to its mass. 
This brings us to the study of gaseous diffusion. Before entering on this subject it is necessary to keep in mind Dalton's Law of Partial Pressures, whieh may be stated as follows: In a mixture of gases eaeh gas exerts the same pressure as it would exert if it were alone present in the volume oeeupied by the mixture. The pressure of each gas is ealled its partial pressure. In other words, if several gases are brought together, eaeh of them will be distributed through the whole space as if the other gases were entirely absent.

Gaseous diffusion takes place, and as a result there ensues a perfectly uniform mixture of the gases no matter what their

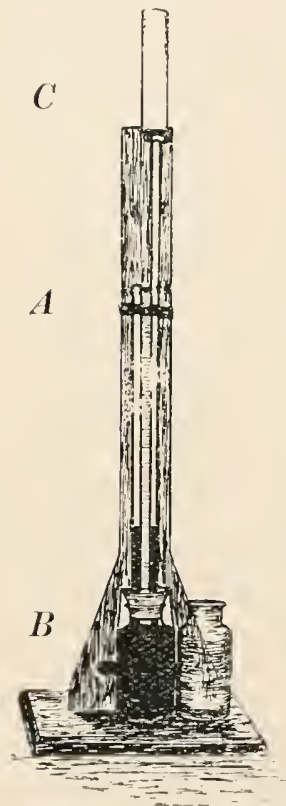

FIG. 4.--simple diffusio meter. original proportions were, and irrespeetive of the masses of their respective moleeules. This diffusion takes plaee independent of gravity. A heavy gas will diffuse upwards into a lighter one.

Now, suppose we separate the two gases, $A$ and $B$, by a thin porous septum such as a plug of plaster of Paris. It was observed by Graham that the pressure of the gases did not remain the same on both sides of the membrane. The pressure was greatest on the side of the heavier gas. The moleeules of lighter gas $B$ would bombard the septum far oftener than those of the heavier gas $A$, and therefore there would be a greater ehance of some of them hitting the pores and getting through and so raising the pressure in $A$.

That this is so may be very easily demonstrated by a simple picee of apparatus (Fig. 4). $C$ is an unglazed earthenware cell sueh as is usually employed to hold the zine rod in a Leelanehé battery. Into its mouth is fixed a rubber stopper carrying a glass tube, the lower end of which passes just through one of the holes in a similar rubber stopper of the bottle $B$. The glass tube $A$ passes right through the other hole of this stopper and goes to the foot of $B . \quad B$ is filled with eoloured water. Both stoppers must be thoroughly air-tight. If now a widle-mouthed bottle eontaining coal gas is inverted so as to enelose $C$, the eoloured fluid will rise in $A$ showing inerease in pressure in $C$. If the gas used were heavier than air, negative diffusion would take plaee, 
and pressure in $A$ would fall. This demonstrates the eonversion of unordered moleeular motion into ordered hydraulie motion eapable of doing work.

The relative veloeities of diffusion of any two gases even through a thin porous septum are inversely proportional to the square roots of their densities.

This does not hold if the septum is not very thin, for then the veloeity is deereased by the impaet of the moleeules on the inside surface of the pores.

Graham further found that it was possible to procure semipermeable membranes - that is, a membrane which would allow free passage to one gas but not to another. What will happen in such a ease? Suppose $B$ ean pass freely through the septum while $A$ eannot. Both gases are at 1 atmos. pressure. Then $B$ will diffuse through the membrane, and fill up the next spaee as if $A$ were not there, i.e. there will finally be $\frac{1}{2}$ atmos. of $B$ on both sides. The total pressure on $A$ will be $1 \frac{1}{2}$ atmos. The exeess of pressure is due to the gas $A$, which eannot pass through the septum. So that by taking the difference of pressure on the two sides of a semi-permeable membrane, we obtain the partial pressure of the gas to whieh the membrane is impermeable. (See Respiration, Chap. XXIII.)

An attempt may now be made to apply these laws (whieh are only absolutely true for perfect gases) to solutions-in the first instanee to simple solutions only.

$$
P V^{r}=R T=2 / 3\left(\frac{1}{2} n m v^{2}\right) .
$$

All these symbols seem applicable to a substance in solution exeept $P$. What is the pressure of a solute? This may be determined in a way similar to the determination of gaseous pressure. If an osmometer be fitted up (Part II. p. 398) with a solution of sugar inside and water outside, in a short time the fluid inside will increase in volume and will rise in the osmometer tube developing a hydrostatic pressure. To what is this pressure due? Obviously water (and pressure) will be transferred from a point where its pressure is high to a point where its pressure is low. In some way or other the presence of sugar (or other solute) has lowered the pressure of the water. Can this be explained by referenee to the kinetic energy ? Reasoning baekwards, it may be argued that the sugar aets as a drag upon the water moleeules-that is, the bombardment of the membrane becomes unbalanced. The pure solvent is able to exert a greater 
pressure than the solution. When, then, will the pressure inside beeome equal to the pressure outside-that is, when will the hydrostatic pressure developed beeome great enough to balanee the reduction of pressure to the solute? Experiment has shown that the maximal rise of hydrostatie pressure is reached when its value is equal to the differenee in vapour pressures between the solvent and the solution. Vapour pressure, as we have seen. depends on the kinetie energy of the moleenles in a liquid. Experiment has further shown that for simple dilute solutions the magnitude of the osmotic pressure depends on the molecular weight of the substance dissolved, the amount of substance in the solute per unit volume and on the temperature of the solution. That is, osmotie pressure is eontrolled by just those faetors which eontrol gaseous pressure. Suppose the gram-moleeular weight of the (undissoeiated) substanee to be taken as $m$ grams, dissolved in $V$ litres of water, at the absolute temperature $T$. The coneentration, i.e. the number of mols. $(n)$ per litre would be $\frac{n}{r}$.

Now, we may eonsider that dilute solutions obey the gas laws, and therefore

$$
P V=R T \text { or } P=\frac{R T}{V} .
$$

We have seen that $\frac{2}{3}$ of the kinetic energy of a gas is manifested as gaseous pressure, and so we may state that

$$
P=\frac{2}{3} \frac{\frac{1}{2} n m v^{2}}{V} \text {. }
$$

That is, osmotie pressure is equivalent to $\frac{2}{3}$ of the total kinetie energy of the partieles in solution. Put in another way, it might be stated that in a simple solution the osmotic pressure of a substance would bc numcrically equal to the gaseous pressure which the substance would exert were it a gas occupying the same volume as the solution.

Now we have seen that the variables conneeted with gaseous pressure are $T$ and $V$. As, aceording to Avogadro's hypothesis, equal volumes of gases under equal $T$ and $P$ contain the same number of moleeules, we may state that, if $T$ is kept eonstant, $P$ varies as the number of moleeules. De V ries (1884) found that one gram-molecule of sugar dissolved in water to make up a litre, has at $0^{\circ} \mathrm{C}$. an osmotic pressure of $22 \cdot 4$ atmos. (Praetically all gases at $0^{\circ} \mathrm{C}$. and $760 \mathrm{~mm}$. pressure have a gram 
moleeular volume of $\mathbf{2 2 . 4}$ litres, or conversely at $0^{\circ} \mathrm{C}$. it would require a pressure of $22 \cdot 4$ atmos. to reduee a gram moleeular volume to one litre.) De Vries, Pfeffer, and others have shown that this is true not only for sugar, but for all simple (undissociated) solutions. Van't Hoff (1887) pointed out that the osmotie pressure of simple solutions is the same quantitatively as gas pressure. We have already pointed out that vapour pressure is a funetion of moleeular activity, and may be taken as an index of the kinetie energy of the liquid. The kinetic energy again varies with the temperature of the liquid system. It follows that vapour pressure caries directly with temperature. We have seen that the putting of a substanee into solution lowers the vapour pressure of the solvent and, therefore, lowers its heat eontent. This ean be dedueed from the seeond law of energeties. From what has been said regarding the lowering of vapour pressure, which always oeeurs when one substanee is dissolved in another, it may be inferred that the boiling point of a liquid is always raised when a substanee is dissolved in it. (These only apply to instanees where the V.P. of the solute is negligible.) A very volatile substanee, ether, for instanee, would raise the V.P. and lower the B.P.

Correlated with these two sequelae of solution is the lowering of the freezing point. (Part II.)

The magnitudes of the osmotie pressure, lowering of the vapour pressure and freezing point, and raising of the boiling point depend in general on $\frac{n}{V}$, the number of partieles in solution per unit volume. Beeause these magnitudes are all interrelated and are interdependent they have been named the colligative properties of a solution. They are definite physieal quantities quite independent of semi-permeable membranes, ete. The membranes make osmotic pressure apparent.

Osmotie pressure is of eonsiderable magnitude. We have seen that a gram-moleeular solution has an osmotie pressure of 22.4 atmos., i.e. 330 lbs. per sq. inel. The ordinary dilute laboratory reagents develop a pressure of about 50 atmos. In a plant, root pressure has been estimated at about 60 feet of water.

If, however, one were to tabulate the osmotie pressure of gram-moleeular solutions of all substanees, one would find that solutions eould be divided into three great elasses aecording to pressure. 
1. O.P. Approximately

$22 \cdot 4$ atmos.

2. O.P. Decidedly greater than $\mathbf{2 2 \cdot 4}$,

3. O.P. " less , $22 \cdot 4$,

The first class have becn termed simple (undissociated) solutions. According to the kinetic theory the second and third classes have a larger or smaller number of particles in solution than theory warrants.

Class 2. Wherc have the cxtra particles come from? Has the moleculc divided? If onc compares the osmotic pressure of cane sugar and sodium chloride in gram-molecular solution, one finds them (roughly) as $1: 2$. How can this be explained ? In 1887 Arhennius propounded his dissociation theory, which has sinee becn proved, amplified and universally accepted. According to this theory, some of the molecules of ccrtain salts when dissolved in water split up or dissociate into their constituent ions. An ion is an atom or a sub-molecular group charged with electricity and attached to eertain water molecules.

For example,

$$
\begin{aligned}
\mathrm{NaCl} \text { (solid) }+\mathrm{aq} & =\mathrm{cat}-\text { ion }+\mathrm{an}-\text { ion } \\
& =\mathrm{Na}+\mathrm{Cl} \\
& =\left(\mathrm{Na}\left(\mathrm{H}_{2} \mathrm{O}\right) x\right)+\left(\mathrm{Cl}\left(\mathrm{H}_{2} \mathrm{O}\right) y\right) .
\end{aligned}
$$

It is the presence of these ions which gives a solution the power of conducting electricity, and so any substance which dissociates, i.e. becomes ionised on going into solution, is said to be an electrolyte.

All salts may therefore be elassed as

Electrolytes, Class 2.

Non-Electrolytes, Class 1 and Class 3.

It is worthy of note that electrical conductivity is not a property cither of the solvent or of the solute, but of the solution.

Pure distilled water is a non-clectrolyte.

Pure dry hydrochloric acid is a non-clectrolytc.

But an aqueous solution of hydrochloric acid is a very good clectrolyte. All eleetrolytes are not dissociated to the same extent. A salt of cither a strong acid or a strong base requires the addition of comparatively little water completely to convert all its molecules into ions. On the other hand, a weak acid or base is difficult to dissociate.

If the gram-moleeular weight of an clectrolyte be dissolved in a litre of water a certain fraction of the molecules will split into ions. This fraction is the degree of ionisation of the electrolyte 
at this concentration. The degree of ionisation may be determined by estimating the amount of resistance of the solution to a small electric current (conductivity method), or it may be approximatcly calculated from the lowering of the freezing point. (For univalent strong electrolytes at concentrations not cxceeding $0 \cdot 1$ molar, Noyes and Falk consider that the percentage error is in most cases between 1 and 4.)

One may note in passing that the ions of many clectrolytes possess the property of uniting with other ions, or even with non-clectrolytes in solution, to form complex ions. For example, ions cannot normally remain free in aqucous solution, but bccome hydrated. A hydrated ion is sometimes termed an ionic micelle.

In solutions of the third class, the O.P. and other colligative properties point to a reduction in the number of particles in solution. A clubbing of molecules has taken place. Bccause the substances that compose this group have a somewhat gluey consistency, Graham called them colloids (Gr. ко́ $\lambda \lambda_{\eta}=$ glue). The physics of colloidal complexes will be dcalt with in a separate chapter. Hcre we mercly wish to draw attention to their low osmotic pressure. Colloid substances may be converted into noncolloid or crystalloid derivatives, and so liberate energy, e.g. starch, a colloid having practieally no O.P. may be readily hydrolysed to maltose, which is a crystalloid-non-electrolytc, having a molal O.P. Glucose, which has a molal O.P., may be stored in the liver as glycogen-a eolloid, which again readily undergoes hydrolysis to glucose. (See Chap. VIII., Colloids.) 


\title{
CHAPTER VI
}

\section{THE LIBERATION OF ENERGY}

\author{
(4) SURFACE ENERGY
}

"This Phaenomenon proeeds from a propriety whieh belongs to all kinds of fluid Bodies more or less, and is eaused by the Ineongruity of the Ambient and ineluded Fluid, which so aets and modulates each other, that they acquire, as neer as is possible, a spherical or globular form."

НоOKE, 166.5.

(See also Chap. XIII. Muscular Contraction; XIV. and XV. Secretion and Excretion; XVI. Nerve Conduction; XXVI. Respiration.)

\section{A. Pure Liquids.}

Two forces act on molccules :

(a) A repellent force-kinetic, revealed in osmotic pressure, vapour tension, etc.

(b) A cohcsion or attractive forcc-Newton's "Gravity."

"Every particle attracts every other particle with a force inverscly proportional to the square of the distance betwecn them." This gives rise within the liquid to intrinsic pressure, whose magnitude we have no dircet means of measuring, and whose cnergy we cannot utilise. Why? Bccause the various tractative forces acting on each and every moleculc within the liquid ncutralise one another. The attractions, except on the surface layer, arc uniform and cancel out. Consider a single internal molecule. The tractative forces acting on it may be resolved into four components acting cyclically at right angles to onc another. It is obvious that these forecs are paired. That at twelve o'clock is equal to and opposite to that at six, and therefore ineffective. Similarly, the eastwards pull at thrce o'clock is neutralised by the westwards pull at ninc. In the surface layer, mattcrs are different. One component, that is the forec pulling downward at 6 o'clock, has no opposing force at 12 to stabilisc the molecule. There is, thcrefore, a state of strain 
in the surface area. This statc of strain is called the surfaee tension of the fluid, and by release of this strain work may be donc. That there is apparently an elastic skin over fluids at their junction with air is casily demonstrated. (Physicists call the junction of a fluid with any other substance an interface. They write of fluid-air, fluid-gas, fluid-fluid interfaces.) At a water-air interface substances heavier than water can be supported. A clean ncedle floats on water. Water-bcetles, etc., move freely on the surfacc. Resistanec to deformation is greater on the surfaee than in the body of the liquid (cf. Searle's torsion balance).

How can this energy be utilised? How can S.'T. be either raised or lowered? Whatever alters intrinsic pressure will, of course, alter surface tension. The magnitude of the intrinsic pressure depcnds inversely on the kinetic energy of the molecules. The less the kinetic encrgy the less the mean frec path of the molceules, and the less the distanee between the molecules. Intrinsic pressurc varies as $\frac{1}{d^{2}}$. This variation of S.T. with K.E. does not concern the biologist, as alterations in K.E. imply alterations of tempcrature, and we have seen that only slight alterations in temperaturc are compatible with life.

It is possible to alter surface tension without altering intrinsic pressure by altering the electric charge on the surface layer. According to the Helmholtz-Lippmann theory, at any surface therc are two clectrical layers equal in amount but opposite in sign.

1. On the surfaec molecules of the fluid.

2. On the immediate external layer of the surrounding medium -air, glass, ete.

Therefore, any alteration in the amount of the charge on the liquid layer will produce an altcration in the surface tension. If the charge on the surface is inereased, the K.E. of the molecules (i.e. repulsion of like signs) will be inereased, " $d$ " will be increased and S.T. will be diminished. Conversely, an incrcase in S.T. is brought about by decreasing the cleetrical charge. The S.T. cannot, of course, be inercased beyond that which the superfieial layer: would have in the absence of any charge or double laycr. This alteration may be brought about directly or indirectly.

I. Directly. Lippmann's eapillary electrometcr. If a capillary tube be taken and a drop of mercury placed in it, the mercury will run down and some will gather as a drop at the tip. If now the tip of the capillary be immersed in dilute $\mathrm{H}_{2} \mathrm{SO}_{4}$, the $\mathrm{Hg}$ 
will become + and the $\mathrm{H}_{2} \mathrm{SO}_{4}$ surface layer -. The S.'T. deereases and some $\mathrm{Hg}$ will drop out. Alteration in this eharge by connecting the $\mathrm{Hg}$ to a negative electrode will produce an inerease of S.T. and an upward movement of the mereury. The amount of movement depends on the differenee of potential existing between the $\mathrm{Hg}$ and the $\mathrm{H}_{2} \mathrm{SO}_{4}$. and may be used as a means of measuring small differences of potential (see Fig. 5).

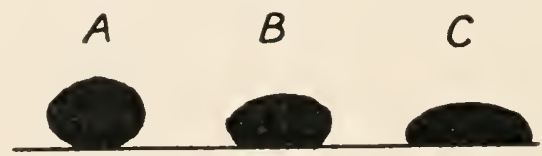

Fis. - Form assumed by mercury globules nuler different electrical states. $b$ is a mereury globule immersed in dilute $\mathrm{H}_{2} \mathrm{SO}_{4}$. It assumes a more spherical form $A$ when conneeted with the negative pole of a battery, while conneetion to the positive pole reduces surface tension as shown at $C$.

II. Indirectly. Effeet of solutes. Substanees which when fluid have a lower surface tension than water, lower surface tension when dissolved in water, and vice versâ. Why this happens is not known. A plausible explanation is that of ionisation; but if ionisation is the eause, why should weak organie acidsonly slightly dissociated-have great lowering power, while strongly dissoeiated inorganie salts have very little effect? Very few substanees raise S.T., and that only to a very slight extent. Most organic substanees lower S.'T. markedly, e.g. addition of butyric aeid to water to make a 1 per eent. solution lowers S.T. from 75 to 35 dynes.

A solid-liquid interfaee has always a lower S.T. than either a liquid-liquid or a liquid-air interface. That is why water rises in a capillary tube.

It is obvious, therefore, that means exist for readily lowering S.T. and so setting free energy.

\section{B. Solutions.}

The addition of a solute makes some alteration in the intrinsie pressure of a fluid and neeessitates a redistribution of energy. Solutes are not universally dispersed throughout a solution. "The eoneentration throughout a fluid tends to be so adjusted as to reduee the energy at every point in it to a minimum" (GibbsThomson Prineiple). Solutes that lower surfaee tension are more concentrated at the surface, while those raising the surface tension are found in smallest amounts at the surface. This may be dedueed from the seeond Law of Energeties. (See Part II. for demonstration of S.T. and for methods of estimation : adsorption will be treated in Chap. VIII., Colloids.) 


\title{
SECTION II.: CELLULAR MECHANICS
}

\section{CHAP'TER VII}

\author{
IONISATION
}

IONS-THE WORKMEN OF THE CELL

\begin{abstract}
"Many things move me to suspeet that everything [natural as well as meehanival] depends upon certain forees, in virtue of Whieh the partieles of bodies, through forees not yet understood, are either impelled together.... or are repelled and reecle from one another."

Newtov.
\end{abstract}

'Tirs subject has becn alluded to in eonnection with abnormal osmotic pressures (Chap. V. p. 44). where it was pointed out that elcetrolytes, on going into solution, were more or less dissociated into their eonstituent ions. The extent to which an electrolyte is thus dissociated determincs whether it is a strong or a weak electrolyte. Inorganic acids and bases and their salts arc almost completely dissociated in solution, the dissociation increasing with dilution until, of eourse, eompletc dissociation is reached. Organic acids and bases, as a rule, are dissociated with difficulty, complete dissociation being reached only at great dilutions. There are exceptions, some organie bases arc just as well ionised as the strongest inorganic bases. Guanidin salts, for instance, have dissociation values lying between sodium and barium salts. Salts formed of a weakly dissoeiated acid and a strongly dissociated base or of a weak base and a strong aeid have dissoeiation values intermediate to those of their eonstituents.

There arc two outstanding points of interest about ions.

1. Ions are always eleetrically charged. The "metal" ion having a positive and the "acid" ion a negative eharge. (The former, in Faraday's terminology, is called a cation and the latter an anion.)

2. Ions are never frce, but are always hydrated. 
1. Electrical Charge. It is obvious that if two clectrodes from a source of supply be dipped into a solution containing ions, that in virtue of their charge the anions (negative ions) will be attracted towards the anode (positive electrode) and the eations (positive ions) will be drawn towards the eathode (negative electrode). Such a solution will therefore conduct electricity, and further, its efficiency as a conductor will depend on the number of ions present, i.e. on the dissociation of the solute.

This provides the basis on which the method for estimating the coneentration of ions has been devised. In doing this the electrical resistance, in ohms, is measured. Conductivity is the reciproeal of resistance (Part II. p. 415).

Relative Speed. Another factor must be taken into account. We have seen that ions do not all move at the same rate. The rate depends on the atomic weight of the ions, the degree of hydration and the influence of other ions. (Ions by their electric charge influence one another.) Under similar conditions, each ion moves at a eonstant rate.

That the rate is slow is shown by passing an electrie current through a solution eontaining coloured ions at one electrode and noting the time they take to reach a similar concentration at the other eleetrode. Kohlrauseh determined the relative speed of ions at $18^{\circ} \mathrm{C}$. and for a constant potential gradient found as follows :

TABLE VI.

\begin{tabular}{|c|c|c|c|c|c|}
\hline \multicolumn{3}{|c|}{ Cationg + } & \multicolumn{3}{|c|}{ AnIONS - } \\
\hline Ion. & Atomic Wt. & Relative spreed. & Ion. & Atomic Wt. & Relative Speed. \\
\hline $\mathrm{H}$ & 1 & 318 & $\mathrm{OH}$ & 17 & 174 \\
\hline K & 39 & $64 \cdot 6$ & $\frac{1}{2} \mathrm{SO}_{4}$ & 48 & 68 \\
\hline $\mathrm{NH}_{4}$ & 18 & $61 \cdot 4$ & $\mathrm{Br}$ & 80 & 67 \\
\hline$\frac{1}{2} \mathrm{Ba}$ & $68 \cdot 5$ & 55 & I & 127 & $66 \cdot 5$ \\
\hline$\frac{1}{2} \mathrm{Sr}$ & $43 \cdot 7$ & 51 & $\mathrm{Cl}$ & $35 \cdot 5$ & $65 \cdot 5$ \\
\hline$\frac{1}{2} \mathrm{Ca}$ & 20 & 51 & ${ }_{2}^{1} \mathrm{C}_{2} \mathrm{O}_{4}$ & 44 & 63 \\
\hline$\frac{1}{2} \mathrm{Mg}$ & 12 & 45 & $\mathrm{CH}_{3} \breve{C O O}^{\circ}$ & 59 & $33 \cdot 7$ \\
\hline $\mathrm{Na}$ & 23 & $43 \cdot 5$ & & & \\
\hline $\mathrm{Li}$ & 7 & $33 \cdot 4$ & & & \\
\hline
\end{tabular}

Bredig has pointed out that with organic ions the longer the earbon chain, the less the speed. The decrease in speed is, however, comparatively slight.

2. Hydration. Consideration of the numerical values of the relative ionic rates gives a means for ealculating the hydration of the various ions. It may be taken for granted that the speed 
of ions apart from hydration is proportional to their mass, e.g. potassium and chlorine have approximately similar atomic weights and similar speeds. Any variation from this proportion is usually attributed to the different hydration of the ions. It is gencrally conceded that, as stated above, all ions are hydrated. 'Therefore potassium and chlorine must be hydrated to almost the same extent. Bousficld has shown that 9 water molecules are attached to both ions of potassium chloride when completely dissociated. Now, as the speed of $K$ to $C$ is as $\begin{gathered}6+6 \\ 39\end{gathered} \frac{65 \cdot 5}{35 \cdot 5}$, i.e. as $16: 19$, almost as $4: 5$, it may be considered that $\mathrm{K}$ has 4 and $\mathrm{Cl} 5$ water molecules per ion.

In the group of alkali metals tabulated above it will be seen that the lightest metal, lithium, fumishes the most sluggish ion of the three, and, conversely, the most mobile ion is that of the heaviest metal, potassium, sodium being intermediate both in atomic weight and in speed. 'This is supposed to mean that lithium is more heavily hydrated than sodium, and sodium nore than potassium. The number of molecules of water combined with their chlorides when completely dissociated is respectively, 21, 13 and 9 . If the 5 molecules of water which form an envelope for the chlor-ion, be subtracted from the total, lithium is found to be hydiated to the extent of $\mathbf{1 6}$ and sodium to 8 molecules.

\section{Effect of Temperature.}

Increase in temperature according to the kinctic theory and laws of energy will increase the speed of ions, provided of course that dissociation is complete. Partially dissociated salts are more completely ionised by increase in temperature. For equal increment of temperature, different ions increase in speed according to their degree of hydration. The more highly hydrated the ion, the greater is its temperature co-eflicient. 'This is explicable on the hypothesis that a rise of temperature will favour the disruption of hydrate-complexes and decrease the size of the ion, and so reduce the frictional resistance to its passage through the fluid.

When dealing with surface tension (p. 47), the Helmholtzian double layer or surface elcetrical charge was mentioned. This may now be attributed to the different ionic specds. Whichever of the two ions has the greater mobility will get into the surface layer and of course will carry its charge with it. This will cause the mobilisation on the immediately opposite "side" of the surface of an equal and opposite charge. As has been said above, 
this gives rise to a difference of electrical potential, which may explain some of the anomalies of diffusion through living animal membranes.

Of course there exists an enormous electrostatie attraetion between ions of opposite sign. The introduction of other eleetrolytes into a solution may therefore alter not only the rate of migration of the original ions but the nature of the surface charge. The addition of $\mathrm{HCl}$ to a solution of $\mathrm{KCl}$ would increase the diffusion potential that would be produced at the boundary between solutions of $\mathrm{KCl}$ at different concentrations; the more IICl present, the greater the diffusion potential.

'This is due of course to the relatively greater speed of the hydrogen ion. The $K$ ions move at about the same speed as the $\mathrm{Cl}$ ions, while the $\mathrm{H}$ ions move about five times as fast. The boundary surface previously charged negatively with a low E.M.F. would take on a positive eharge with a higher E.M.F.

It is imperative to note that unless the electrostatic force mutually exerted between anion and cation is overcome, these ions though separated will never be far apart.

In ordinary solutions the "metal" ion, no matter what its relative speed, cannot be separated from its "acid" ion by mere

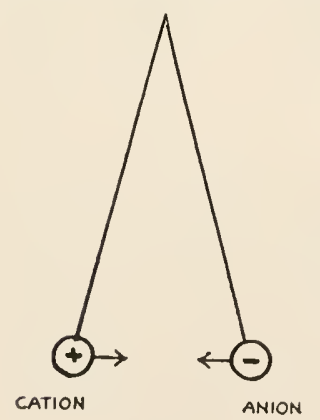

FIG. 6.-Model of anion and cation. Two pith balls suspended by silk threads attract one another if carrying opposite charges. When the charges are of the same sign, the balls diverge, i.e. repel one another.

\section{(The higher} diffusion. The disturbance of electrieal equilibrium caused by the introduction of electrodes into the solution will produce a separation of the salt into metal and aeid.

Now, if there exist equal and opposite eharges on an- and cat-ions, tending to draw them together, why, in the first instance, did they separate, and what keeps them apart? This brings us to the discussion of the dielectric constant. 'T'o put a name on a thing or on a process does not explain it. Neither is it sufficient to say that the dielectric constant or specific inductive capacity of any medium is a measure of the capaeity of that medium to act as a dielectric (nonconducting) substance of an electric condenser. The higher the value of the constant, the greater is the value of the condenser.

If two pith balls (Fig. 6) are hung by a dry silk thread and given equal and opposite charges of clectricity, they may be regarded as representing ion-hydrates. 
There is a eonstant relation between the eharge of a body and its eleetrie potential. This ratio is ealled the capaeity of the body as a eonduetor, and depends on the nature of the medium separating the two eharged bodies. The tendeney of two oppositely charged bodies to eome together is altered by altering the dielectrie or medium separating them. Air is taken as the standard dieleetrie, and all other dielectric eonstants are referred to that of air as unity. From the aceonpanying table it will be seen that water has a high dieleetrie eonstant.

TABLE VII.

$$
\begin{aligned}
& \text { Air }=1 \cdot 0 \\
& \mathrm{C}^{\circ} \mathrm{O}_{2}=1 \cdot 0004 \\
& \mathrm{H}=0.9997
\end{aligned}
$$

\begin{tabular}{|c|c|}
\hline Water & $=81 \cdot 7$ \\
\hline Alcohol & $=25 \cdot 0$ \\
\hline Formaldehyde & $=84 \cdot 0$ \\
\hline Acetic Acid & $=6 \cdot 46$ \\
\hline HCN (liquid) & $=95$ \\
\hline Vaseline & \\
\hline $\begin{array}{l}\text { Turpentine } \\
\text { Benzine }\end{array}$ & $=2$ \\
\hline $\begin{array}{l}\text { Paraffin } \\
\text { Liquid Fat }\end{array}$ & \\
\hline
\end{tabular}

(The determination of the dieleetrie eonstant of different substanees is of interest from its bearing on Maxwell's eleetromagnetic theory of light. 'The dielectrie constant of a substanee in the ease of light of long wave-length is the same as its refraetive index squared.)

Aeeording to the electron theory, an atom is eomposed of eleetrons. Eleetrons are all similar, and are supposed to be not sensible matter, but the smallest possible unit of negative eleetrieity Atoms of different substanees owe their different qualities to the varying number of eleetrons they contain and to the diversity of their eombination. These eleetrons are supposed to exereise an obstrueting influenee on the passage of an electric eharge due to their tendeney to move in the direetion opposite to the dircetion of the eurrent. The larger the number of the eleetrons, therefore, the greater the obstruetion and the greater the value of the dieleetrie eonstant. Water has a high dieleetric eonstant, and so onee the moleeule has beeome dissoeiated. the resultant ions may approach very near to one another without eombining. In short, the dielectrie eonstant is a measure of the insulating eapaeity of the substanee. The addition of solutes alters the value of the dieleetrie eonstant of the solvent.

The atoms in a molecule are held together by very strong 
electrostatic forces. A very large amount of energy must therefore be expended in separating these atoms. Energy is also expended in removing one of the valence electrons from each eation. 'This energy is supplied by the energy of combination of the electronegative molecules of the solvent (heats of dilution and hydration) and by the heat of combination of the anions with the freed valence electrons. It is thus that Sir J. J. Thomson explains the charges of the ions. The ionising porcer of a solvent seems to be some function of its dielectric constant. On the other hand, the degree of ionisation of a salt secms to be due to the electronic structure of its constituent atoms. The whole subject is bristling with difficultics and so far cxplanations can only be regarded as reasoned guesses.

\section{Water.}

The solutions dealt with above have all been aqueous. Solutions in water as the solvent were early recognised as the most important. According to the old Grcek philosophers water was "the beginning of all things." Thales said, "All things have their origin in water and return unto the same." The importanec of water as a solvent was generally recognised early in the seventeenth century. Aqueous solutions are fundamental for all biological phenomena. The physical propertics of water are in general extreme - their numcrical expressions are cither extremely large or extremely small, and usually the former. Its specific heat and its diclectric constant are the highest of any of the more common liquids. Therefore, water should have a very high ionising power as a solvent.

One has been accustomed to look upon water as a simple inert substance, of the chemical formula $\mathrm{H} . \mathrm{OH}$ and with a molecular weight of 18. Physical chemists have proved that this conception does not account for all the properties of water. Lewis and also Langnuir, from thermodynamical principles and also from the study of the colligative properties (see p. 43) of water, have constructed diagrams of the molecule of water. Discussion of this work is somewhat without the bounds of this book.

In recent years it has been amply demonstrated that a triatomic molecule could not possess the properties of water. For instance, it is composed of gases with extremcly low frcezing and boiling points. Oxygen boils at $-181^{\circ}$, while the figure for hydrogen is $-253^{\circ} \mathrm{C}$. From comparison with compounds of known composition, ice should form at $-150^{\circ}$ and the tempera- 
ture of steam should be $-100^{\circ} \mathrm{C}$. The inference from this is that the moleeule of water is bigger than $\mathrm{H}_{2} \mathrm{O}$. Each simple moleeule or hydrol is supposed to combine with another hydrol so as to form a dihydrol or three hydrols may polymerise to trihydrol, and so on. Water, as we know it, eonsists of a mixture of these various hydrols. The relative amount of each kind is determined $(a)$ by the temperature of the fluid, and $(b)$ by the substanees present in solution or, in a less degree, in suspension.

(a) Temperature controls the kinetie energy of the moleeules and so the size of the intra-moleeular spaees. Increase of temperature, therefore, by inereasing the kinetie energy will eause a disruption of polyhydrol into its simpler eonstituents. Decrease of temperature has the reverse effeet. Theoretically, there is the gas $\mathrm{H}_{2} \mathrm{O}$ and the solid $\left(\mathrm{H}_{2} \mathrm{O}\right)_{3}$, and between these extrcmes the liquid $\left(a\left(\mathbf{H}_{2} \mathrm{O}\right)+b\left(\mathbf{H}_{2} \mathrm{O}\right)_{2}+c\left(\mathbf{H}_{2} \mathrm{O}\right)_{3}^{\circ}\right), a, \quad b$ and $c$ being eonstants dependent on the temperature. At each temperature there is equilibrium between the amounts of the various hydrols. The temperature of water has thus an importanee in deeiding its physical and chemieal properties, and therefore, in all reactions involving water, temperature should be stated.

(b) As has been pointed out above, there is a eertain equilibrium composition of water at each temperature. This equilibrium is disturbed by the presence of a solute, especially if it is dissoeiated. Hydrol is abstracted to hydrate the ions or molecules of the solute and a rearrangement of equilibrium takes place.

\section{Ionisation Constant.}

Absolutely purc water is almost, but not quite a non-electrolyte. As absolutely pure water has not yet been prepared, this is a deduction from the behaviour of water under certain eireumstanees.

Water is ionised aceording to the equation

$$
\mathrm{H}_{2} \mathrm{O} \rightleftharpoons \mathrm{H}^{+}+\mathrm{OH}^{-} \text {. }
$$

According to Guldberg and Waage's Law of Mass Action (p. 61), the product of the eoneentrations of the reacting substances, $\mathrm{H}^{+}$and $\mathrm{OH}^{-}$, bears a direct relationship to the mass of the resultant substanee $\mathrm{H}_{2} \mathrm{O}$.

That is

$$
\frac{\left[\mathrm{H}^{+}\right] \times[\mathrm{OH}]^{-}}{\left[\mathrm{H}_{2} \mathrm{O}\right]}=\text { constant } \mathrm{K}_{\boldsymbol{w}} \text {, }
$$

where $\left[\mathrm{H}^{+}\right]=$the fraction of the total water which is dissociated into hydrogen ions. 
$\left[\mathrm{OH}^{-}\right]-$the fraction of the total water whieh is dissociated into hydroxyl ions

and $\left[\mathrm{H}_{2} \mathrm{O}\right]=$ the fraction of the total water which is left undissociated.

Stated in words, the product of the concentration of hydrogen ions and hydroxyl ions is always equal to a constant quantity $\boldsymbol{K}_{m}$, The value of $K_{w}$, the ionisation constant of zoter, depends only on the temperature.

$$
\begin{aligned}
\text { At } \quad 0^{\circ} \mathrm{C} . & K_{w}=\frac{1}{10,000,000,000,000,000} \\
\text { At } 23^{\circ} \mathrm{C} . & K_{w}=\frac{1}{100,000,000,000,000} \cdots \\
\text { At } 40^{\circ} \mathrm{C} . & K_{w}=\frac{28}{100,000,000,000,000} \cdots \\
\text { At } 100^{\circ} \mathrm{C} . & K_{w}=\frac{48}{100,000,000,000,000} \cdots
\end{aligned}
$$

To save writing those cumbrous fraetions, the index notation is used. 'Thus fraetion

$$
\begin{aligned}
& (1) \text { is }=0.01 \times 10^{-14}=C_{w} \text { at } 0^{\circ} \mathrm{C} \text {. } \\
& (2) \text { is }=1 \times 10^{-14}=C_{w} \text { at } 23^{\circ} \mathrm{C} \text {. } \\
& (3) \text { is }=28 \times 10^{-14}=C_{w} \text { at } 40^{\circ} \mathrm{C} \text {. } \\
& (4) \text { is }=48 \times 10^{-14}=C_{w} \text { at } 100^{\circ} \mathrm{C} \text {. }
\end{aligned}
$$

Now, as the quantity of water dissoeiated is so very small compared with the total quantity of water, it is clearly legitimate to put $\left[\mathrm{H}_{2} \mathrm{O}\right]=1$ in the mass aetion equation, whieh now beeomes :

$$
\left[\mathrm{H}^{+}\right] \times\left[\mathrm{OH}^{-}\right]=\boldsymbol{K}_{w} \text {. }
$$

It is obvious that $\mathrm{H}^{+}$and $\mathrm{OH}^{-}$are produced in equal amounts, and therefore

$$
\left[\mathrm{H}^{+}\right]=\left[\mathrm{OH}^{-}\right]=\sqrt{ } \boldsymbol{K}_{w} \text {. }
$$

Between $22^{\circ}$ and $23^{\circ} \mathrm{C}$. water has a dissociation constant with which it is convenient to work, and measurements of hydrogen ion eoneentrations are usually made at this temperature or referred to this temperature;

$$
\begin{aligned}
& \text { i.e. at } 23^{\circ} \mathrm{C} ., K_{w}=10^{-14} ; \\
& \therefore\left[\mathrm{II}^{+}\right] \times\left[\mathrm{OH}^{-}\right]=10^{-14} .
\end{aligned}
$$

$\left[\mathrm{H}^{+}\right]$is therefore equal to $\sqrt{10^{-14}}=10^{-7}$,

$$
\text { and }\left[\mathrm{OH}^{-}\right] \quad, \quad, \quad, \quad \sqrt{10^{-14}}=10^{-7} \text {. }
$$

It is usual to write $\mathrm{II}^{\bullet}$ for $\mathrm{II}^{+}$and $\mathrm{OH}^{\prime}$ for $\mathrm{OH}^{-}$. 
Still further to shorten the symbols, Sørensen suggested the use of the logarithm to denote the hydrogen ion eoneentration. Instead of writing $10^{-7}$ one may write merely the positive index 7 , keeping the rest of the formula in mind. This is ealled the $p_{\mathrm{H}}$, $p$ denoting the index to the base 10 , and $\mathrm{H}$, of eourse, showing that hydrogen ions are under eonsideration. 'That is, in neutral water' at about $23^{\circ} \mathrm{C}$.

or

$$
\begin{aligned}
& p_{\mathrm{H}}=p_{\mathrm{OH}}=7, \\
& C_{\mathrm{H}}=C_{\mathrm{OH}}=10^{-7} .
\end{aligned}
$$

In words, neutral water has a hydrogen ion concentration of $\%$

Appended is a list of values of $P_{\mathrm{H}_{2} \mathrm{O}}$ for various temperatures, ealeulated thermodynamieally.

TABLE VIII.

\begin{tabular}{r|r|r|r}
\hline $\mathrm{T}$. & $p \mathrm{H}_{2} \mathrm{O}$. & $\mathrm{T}$. & $p$ \\
18 & $16 \cdot 04$ & 31 & $13 \cdot 70$ \\
19 & $14 \cdot 14$ & 32 & $13 \cdot 67$ \\
20 & $14 \cdot 11$ & 33 & $13 \cdot 64$ \\
21 & $14 \cdot 07$ & 34 & $13 \cdot 61$ \\
22 & $14 \cdot 04$ & 35 & $13 \cdot 58$ \\
23 & $14 \cdot 01$ & 36 & $13 \cdot 56$ \\
24 & $13 \cdot 96$ & 37 & $13 \cdot 53$ \\
25 & $13 \cdot 93$ & 38 & $13 \cdot 51$ \\
26 & $13 \cdot 89$ & 39 & $15 \cdot 47$ \\
27 & $13 \cdot 86$ & 40 & $13 \cdot 45$ \\
28 & $13 \cdot 83$ & 50 & $13 \cdot 34$ \\
29 & $13 \cdot 80$ & 75 & $12 \cdot 77$ \\
30 & $13 \cdot 76$ & 100 & $12 \cdot 31$ \\
\hline
\end{tabular}

Some people prefer a more eumbrous but nevertheless a more comprehensible method of reeording ionic eoneentrations. In Sørensen's method it is rather diffieult to see at a glanee the relative eoneentrations of ions at two temperatures. As the temperature deereases, dissoeiation inereases, but the negative exponent or $p_{\mathrm{H}_{2} \mathrm{O}}$ deereases. At $18^{\circ}$, for example, the $p_{\mathrm{H}}$ is $7 \cdot 3$, and at $23^{\circ}$ it is 7.0 , Put in this way, one does not readily grasp the fact that the $p_{\mathrm{H}}$ at $23^{\circ}$ is double the $p_{\mathrm{H}}$ at $18^{\circ}$. If, however, the negative exponent be kept a whole number and the fraetion be put as a multiplier, the relation is seen at onee, e.g.

$$
\begin{aligned}
& 18^{\circ} p_{\mathrm{H}}=7 \cdot 3=0.5 \times 10^{-7}=C_{\mathrm{H}}, \\
& 23^{\circ} p_{\mathrm{H}}=7 \cdot 0=1 \quad \times 10^{-7}=C_{\mathrm{H}} .
\end{aligned}
$$


The conversion of one expression into the other is simple.

For example: To convert $p_{\mathrm{H}} 7 \cdot 6$ to other notation

$$
\begin{gathered}
p_{\mathrm{H}} 7 \cdot 6=10^{-7 \cdot 6}=10^{-7.0} \times 10^{-0.6}=0 \cdot 25 \times 10^{-7}, \\
\text { antilog of }-0 \cdot 6=0 \cdot 25 .
\end{gathered}
$$

Conversely we find the short expression for

or

$$
\begin{aligned}
C_{11} 5 \times 10^{-6} & =\log 5+\log 10^{-6} \\
& =\cdot 6990+(-6 \cdot 0000) \\
& =5 \cdot 3=P_{\mathrm{HI}}, \\
5 \times 10^{-6} & =10^{\cdot 699} \times 10^{-6}=10^{-5 \cdot 3}=p_{\mathrm{H}} 5 \cdot 3 .
\end{aligned}
$$

(Graph for conversion from one notation to other, Part II. p. 424.)

\section{Reaction.}

It is very important to be able to ascertain with great exactness, the true acidity or alkalinity of physiological media. It is not sufficient to state that a certain fluid is acid to litmus, etc. Litmus, for one thing, is not nearly sensitive enough to indicate the minute changes in reaction which alone are of physiological value. The whole activity, of the mammal at any rate, is regulated by reaction. Alterations in acidity are the causative factor in the regulation of respiration, the activity of muscle, the excitability of nerve, and play an important part in regulating secretion and excretion. Physical and chemical means are employed to keep the healthy body within a narrow range of reaction, about the neutral point. Any marked deviation from this is pathological, and is the result of pathological (or experimental) conditions. As we shall see later, the neutrality of the organism is an equilibrium, any disturbance of which will produce change, and, moreover, any change in the organism will tend to disturb this equilibrium (Chap. XXX.).

Examination of a number of acids shows that when they dissociate in water they disturb the balance existing between the concentrations of $\mathrm{H}^{+}$and $\mathrm{OH}^{-}$ions.

For example :

$$
\begin{array}{ll}
\mathrm{HCl} & =\mathrm{H}^{+}+\mathrm{Cl}^{-} \\
\mathrm{HNO}_{3} & =\mathrm{H}^{+}+\mathrm{NO}_{3}^{-} \\
\mathrm{H}_{2} \mathrm{SO}_{4} & =\mathrm{H}^{+}+\mathrm{HSO}_{4}^{-} \\
\mathrm{CH}_{3} \mathrm{COOH} & =\mathrm{H}^{+}+\mathrm{CH}_{3} \mathrm{COO}^{-}
\end{array}
$$


In each case the aeid produees $\mathbf{H}^{+}$ions. Now, as $[\mathrm{H}] \times[\mathrm{OH}]$ is a eonstant, the result of this inerease of $\mathrm{H}^{+}$ions nust eause a dcerease in the eonecntrations of $\mathrm{OH}^{-}$ions.

In the same way, examination of the behaviour of alkalies shows also a disturbance of the ratio of $\left[\mathrm{H}^{+}\right]$to $\left[\mathrm{OH}^{-}\right]$.

For example :

$$
\begin{aligned}
& \mathrm{NaOH}=\mathrm{Na}^{+}+\mathrm{OH}^{-} \\
& \mathrm{NH}_{3} \mathrm{OH}=\mathrm{NH}_{3}{ }^{+}+\mathrm{OH}^{-} .
\end{aligned}
$$

The concentration of $\mathrm{OH}^{-}$ions is increased.

In water the eoncentrations of $\mathrm{H}$ and $\mathrm{OH}$ are equal. Thesc faets lead to the following definitions :

(a) Any substanee whieh when dissolved in water yields $\mathbf{H}^{+}$ as one of the dircet produets of its ionisation is an acid.

(b) Any substance whieh when dissolved in water yields $\mathbf{O H}^{-}$ as one of the direct products of its ionisation is a base.

(c) Any substance whieh on ionisation yields at least one positive ion other than $\mathrm{H}^{+}$and at least onc negative ion other than $\mathrm{OH}^{-}$is a salt.

(d) If, in addition to the positive and negative ions mentioned in $(c)$, the salt yields an $\mathrm{H}^{+}$ion it is ealled an acid salt.

E.g.

$$
\begin{aligned}
& \mathrm{KHSO}_{4}=\mathrm{K}^{+} \quad+\mathrm{SO}_{4}^{--}+\mathrm{H}^{+} \\
& \mathrm{NaHPO}{ }_{4}=2 \mathrm{Na}^{+}+\mathrm{PO}_{4}^{--}+\mathrm{H}^{+} \\
& \mathrm{COOH} \\
& \mathrm{COONH}_{4}=\mathrm{NH}_{4}^{+}+(\mathrm{COO})_{2}+\mathrm{H}^{+}
\end{aligned}
$$

(e) If, in addition to the positive and negative ions mentioned in $(c)$, the salt yields an $\mathbf{O H}$-ion, it is ealled a basic salt.

$$
\text { E.g. } \begin{aligned}
\mathrm{Fe}(\mathrm{OH})_{2} \mathrm{Cl} & =\mathrm{Fe}^{+++}+\mathrm{Cl}^{-}+2 \mathrm{OH}^{-}, \\
\mathrm{CH}_{2} \cdot \mathrm{NH} \cdot \mathrm{OH} \cdot \mathrm{COOK} & =\mathrm{K}^{+}+\mathrm{CH}_{2} \mathrm{NH}_{3} \mathrm{COO}^{-}+\mathrm{OH}^{-} \text {. }
\end{aligned}
$$

(f) Substanees whieh produee both $\mathrm{H}^{*}$ and $\mathrm{OH}^{\prime}$ ions on dissoeiation are ealled amphoteric eleetrolytes or ampholytes. 'They must evidently have two ionisation constants, $K_{\mathrm{H}}$ and $\boldsymbol{K}_{\mathrm{OH}}$. It is obvious that acidity depends on the preponderanee of hydrogen ions over hydroxyl ions, and conversely, alkalinity is due to the presenee of hydroxyl ions in exeess of hydrogen ions. Neutrality is an equilibrium between $\mathrm{H}^{\circ}$ and $\mathrm{OH}^{\prime}$.

This neutral point oceurs in water at $23^{\circ} \mathrm{C}$. when the eoneentration of hydrogen ions is $1 \times 10^{-7}$, i.e. $p_{\mathrm{H}}=7$. If the concentration is greater than this, e.g. $1 \times 10^{-5}$, or $p_{\mathrm{H}}=5$, then the 
concentration of $\mathrm{OH}^{\prime}$ must be correspondingly decreased according to the equation,

or

$$
\begin{aligned}
& {\left[\mathrm{H}^{+}\right]\left[\mathrm{OH}^{-}\right]=10^{-14}} \\
& {\left[\mathrm{OH}^{-}\right]=\begin{array}{l}
10^{-14} \\
\left(\mathrm{H}^{+}\right)
\end{array}=10^{-14(-5)}=10^{-9} .}
\end{aligned}
$$

A $p_{\mathrm{H}}$ of 5 will be accompanicd by a $p_{\mathrm{OH}}$ of 9 . This will be an acid solution.

Converscly, if the concentration of hydroxyl ions is increased there is a corresponding decrease in hydrogen ions. E.g.

$$
\text { if } p_{\mathrm{OH}}=3, \text { then }\left(\mathrm{H}^{+}\right)=\frac{10^{-14}}{10^{-3}}=10^{-11}=p_{\mathrm{H}} \text { of } 11,
$$

an alkaline solution.

Reaction may, therefore, be expressed in terms of $p_{\mathrm{H}}$ or of $p_{\mathrm{OH}}$. Generally the former is used, and alkalinity is expressed as decrease of acidity. The quality as well as the nature of the reaction is expressed by the $p_{\mathrm{H}}$. The greater the concentration of hydrogen ions, the greater is the degree of acidity and the smaller the degrce of alkalinity.

It is rather confusing for the beginner, but he must note:

(1) that as acidity incrcases, the exponcnt or $p$ figure decreases ;

(2) that as the figures are logarithms, multiplication is done by addition and division by subtraction ;

(3) that this docs not give a measure of the amount of acid present, but of its strength. The $p_{\mathrm{H}}$ is not an index of quantity but of intensity. It gives the number of $H$ ions per litre, but of course says nothing of how many litres or c.c. of acid are prescnt.

The strength of an acid (or alkali) may be expressed as normal or as a fraction of normal. A normal solution contains in onc litre, the gram-equivalent weight of the substance. A normal solution of acid, for instance, has in each litre one gram of hydrogen capable of forming hydrogen ions. If the acid is completely dissociatcd, i.e. if it is a "strong" acid, it will contain one gram of hydrogen as $\mathrm{H}^{+}$. The strength of acid commonly used for laboratory purposes is $1 / 10$ of normal $=\frac{N}{10}$. The hydrogen ion concentration of such a solution would be $1 / 10$ gram per litre $=\left(\mathrm{H}^{+}\right)$of $1 \times 10^{-1}$ or $p_{\mathrm{H}}$ of 1 and $p_{\mathrm{OH}}$ of 13 .

Watcr of $p_{\mathrm{II}}=p_{\mathrm{OH}}=7$ is thus, at $23^{\circ} \mathrm{C}$., $\mathrm{N} / 10,000,000$ acid and $\mathrm{N} / 10,000,000$ alkaline. If the acid added to water is not completely dissociated (i.e. a weak acid), then, of course, the degree of dissociation must be taken into account. A decinormal solution of 
acetic acid, for instanee, at $23^{\circ}$ is dissociated $1 \cdot 36$ per cent. Therefore its $\left(\mathrm{HI}^{+}\right)$would be equal to $\frac{1 \cdot 36}{100} \times 10^{-1}=1 \cdot 36 \times 10^{-3}$ or $p_{\mathrm{H}}$ of
$2 \cdot 86$.

Normal solutions of aeid are all equal as regards the amount of alkali they ean neutralise. 1 c.c. of any N/10 aeid is exaetly neutralised by 1 e.e. of any N/10 alkali. That is, they have the same titratable aeidity. They differ in their eoneentration of hydrogen ions.

As we have seen

$$
\begin{aligned}
& \frac{\mathrm{N}}{10} \mathrm{HCl} \text { in water at } 23^{\circ}=p_{\mathrm{H}} 1 \text { or } C_{\mathrm{H}}=1 \times 10^{-1}, \\
& \frac{\mathrm{N}}{10} \mathrm{CH}_{3} \mathrm{COOH} \quad, \quad=p_{\mathrm{H}} 2 \cdot 86 \text { or } C_{\mathrm{H}}=1 \cdot 36 \times 10^{-3} .
\end{aligned}
$$

That is, hydroehlorie aeid, under the above eonditions, has

$$
10^{-1} \div 10^{-2.86}=73 \cdot 5
$$

times the amount of hydrogen ions per litre that aeetic aeid has. $\mathrm{N} / 10 \mathrm{Hydroehloric}$ aeid at $23^{\circ} \mathrm{C}$. is therefore 73.5 times as strong as $\mathrm{N} / 10$ aeetie aeid.

\section{Salts.}

It is very seldom that aeids, weak or strong, oecur alonc or diluted with water in physiologieal fluids. Salts are always present. In $(d)$ and $(e)$ are mentioned two elasses of salts whieh alter the $[\mathrm{H}]$ of water when dissolved in it. They do so directly in virtue of their possession of an additional $\mathrm{H}^{*}$ or $\mathrm{OH}^{\prime}$ ion.

Other salts cause alterations in aeidity by upsetting the balanee between $\mathrm{II}^{\circ}$ and $\mathrm{OH}^{\prime}$ in water. 'Their aetion is indirect.

(1) The salt of a strong aeid and a strong base, e.g. $\mathrm{NaCl}$, eauses little or no ehange in $[\mathbf{H}]$.

(2) If one of the eonstituents of a salt be weak, ehanges oecur.

(a) If the salt $\mathrm{BA}$ of the strong base $\mathrm{B} . \mathrm{OH}$ and the weak aeid $\mathrm{HA}^{-}$be dissolved in water it forms $\mathrm{BA}=\mathrm{B}^{+} \mathrm{A}^{-}$. But owing to the ionisation of the solvent there are present $\mathrm{H}^{+}$and $\mathrm{OH}^{-}$ions and a seeond change takes plaee, $\mathrm{H}^{+}$and $\mathrm{A}^{-}$ions are present. Aeeording to the law of mass action

$$
\frac{\left[\mathrm{H}^{\bullet}\right] \times\left[\mathrm{A}^{\prime}\right]}{[\mathrm{HA}]}=K_{\mathrm{HA}} \quad \text { or } \quad \mathrm{H}^{\bullet}+\mathrm{A}^{\prime} \leftrightharpoons \mathrm{HA} .
$$

As no $\mathrm{HA}$ is present to balance the reaetion, $\mathrm{H}^{*}$ will eombine with $\mathrm{A}^{\prime}$ to form $\mathrm{HA}$ until the point of equitibrium for that dilution has been reaehed. The removal of hydrogen ions from the 
solution by this reaction, however, disturbs the equilibrium between $\mathrm{H}^{\circ}$ and $\mathrm{OH}^{\prime}$ and some more water must ionise to maintain the product $[\mathrm{H}] \times[\mathrm{OH}]$ eonstant.

Summarising these reactions as follows :

$$
\mathrm{A}^{\prime}+\mathrm{H}_{2} \mathrm{O}=\mathrm{HA}+\mathrm{OH}^{\prime}
$$

the net result is the liberation of $\mathrm{OH}$ ions. The addition of a salt of a strong base and a weak acid is to make the solution alkatine, i.e. to reduee the hydrogen ion eonecntration. This is a faet of great physiologieal importanee, as most of the salts of the body are eomposed of organic acids eombined with the strong bases sodium and potassium.

$\mathrm{KCN}$, a powerful poison, dissociates as follows :

$$
\left.\begin{array}{l}
\mathrm{KCN}=\mathrm{K}^{+}+\mathrm{CN}^{-} \\
\mathrm{H}_{2} \mathrm{O}=\mathrm{H}^{+}+\mathrm{OH}^{-}
\end{array}\right\}=\mathrm{HCN}+\mathrm{K}^{+}+\mathrm{OH}^{-} .
$$

'This eauses an alkalinity equal to that of potassium hydrate. The alkalinity of solutions of sodium earbonate is due to the reactions,

$$
\begin{array}{ll}
\mathrm{Na}_{2} \mathrm{CO}_{3} & =2 \mathrm{Na}^{+}+\mathrm{CO}_{3}^{-} \\
\mathrm{H}_{2} \mathrm{O} & =\mathrm{H}^{+}+\mathrm{OH}^{-} \\
\mathrm{CO}_{3}{ }^{-}+\mathrm{H}_{2} \mathrm{O} & =\mathrm{HCO}_{3}^{-}+\mathrm{OH}^{-} \\
\mathrm{HCO}_{3}{ }^{-}+\mathrm{H}_{2} \mathrm{O} & =\mathrm{H}_{2} \mathrm{CO}_{3}+\mathrm{OH}^{-} \\
\mathrm{H}_{2} \mathrm{CO}_{3} & \leftrightharpoons \mathrm{H}_{2} \mathrm{O}+\mathrm{CO}_{2}
\end{array}
$$

If the $\mathrm{CO}_{2}$ is allowed to eseape, the last reaetion will only ecase when all the $\mathrm{H}_{2} \mathrm{CO}_{3}$ has been deeomposed. The total result is an increase in $[\mathrm{OH}]$ and, therefore, of alkalinity.

(b) In the ease of a weak base eombined with a strong aeid, the solutions become aeid, as the following equations denote.

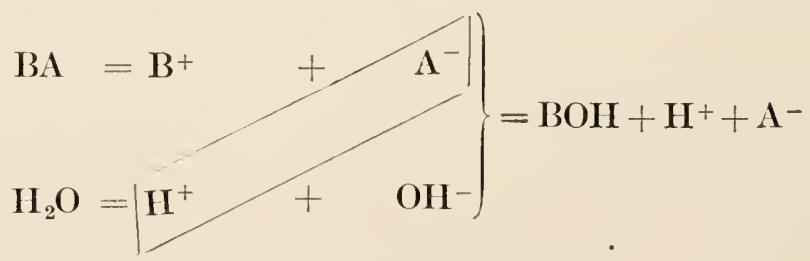

and $\mathrm{HA}$ is a strong aeid and $\mathrm{BOH}$ a weak base.

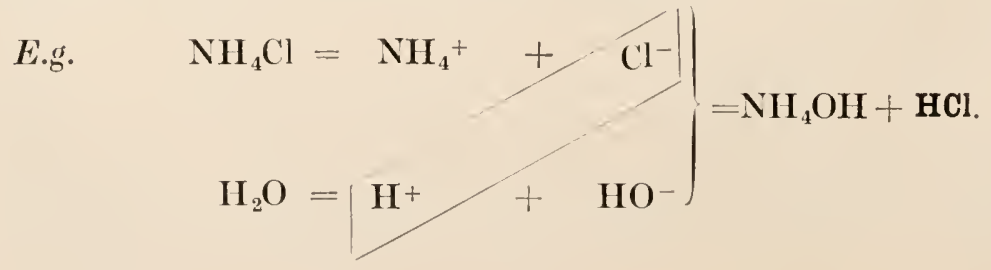


(3) When both the eonstituents are weak the solution will remain neutral, if aeid and base are of equal strength, if the aeid be the stronger, the solution will be aeid, and eonversely an alkaline solution will be produeed if the base be stronger than the aeid. E.g.

$$
\mathrm{CH}_{3} \mathrm{COONII}_{4}+\mathrm{II}_{2} \mathrm{O}=\mathrm{NH}_{4} \mathrm{OH}+\mathrm{CII}_{3} \mathrm{COOH} \text {. }
$$

'This solution will be ahmost neutral, beeause the degrees of ionisation of ammonium hydrate and aeetie aeid are ahmost identical.

\section{Effect of Temperature.}

The effeet of temperature on the dissoeiation of water has been dealt with above (p. 56 and Table VIII.). Inerease in temperature eauses a very large inerease in the amount of water ionised. An inerease in temperature of $1^{\circ} \mathrm{C}$, say from $38^{\circ}$ to $39^{\circ}$, eauses the $[\mathrm{H}] \times[\mathrm{OH}]$ to rise from $10^{-\mathbf{1 3 . 5}}$ to $10^{-13.47}$, an inerease of about 20 per cent. Strong eleetrolytes have a low temperature eoeffieient of dissoeiation. It is, therefore, obvious that inerease of temperature will affeet salts aeeording to the dissoeiation eonstant of the aeids and bases eomposing them.

(a) Both strong, temperature of little effeet.

(b) Weak aeid +strong base. Inerease of temperature eauses the degree of dissoeiation of aeid to inerease. Aeid ions combine with hydrogen ions from $\mathrm{H}_{2} \mathrm{O}$ and liberate $\mathbf{O H}^{-}$.

(c) Strong aeid and weak base. Inerease of temperature eauses the degree of dissociation of base to inerease. Base ions eombine with hydroxyl ions from the $\mathrm{H}_{2} \mathrm{O}$ and liberate $\mathbf{H}^{+}$.

(d) Both weak. The result of any inerease in temperature is to inerease the dissoeiation of the weaker at a greater rate than the stronger with correspondingly slight ehanges in $[\mathrm{H}]$ and $[\mathrm{OH}]$.

It will be seen that apart from the aetion of temperature on the dissoeiation of water itself, in $(b)$ inereased alkalinity and in $(c)$ inereased aeidity result from inerease in temperature. This aetion is slight, however, eompared to the aetion of temperature on the weakest salt known, water.

The effeet of alterations of temperature on a salt solution where one of the eonstituents of the salt is weak is the eombined effeet of

$$
\begin{aligned}
& \text { I. the alteration in } \mathbf{K}_{\mathrm{H}_{2} \mathrm{O}} \text {; } \\
& \text { II. the alteration in } \mathbf{K}_{\text {Salt }} \text {. }
\end{aligned}
$$

In brief, the inereased aeidity or alkalinity produeed by inerease of temperature is greater (theoretieally) than eould have been 
produeed from increased disscciation of the salt. The signifieanee of this will be seen later.

At present the point under eonsideration is the meehanism for converting the potential encrgy of the food-stuffs into the kinetie energy exhibited by protoplasm. Enough has been said to indieate

(1) That shight alterations in hydrogen ion eoneentration may produce large alterations in surface tension (Chap. VI.).

(2) That shight alterations in hydrogen ion eoncentration may produee large alterations in the degree of dissoeiation of salts.

(3) That the degree of dissociation of salts, acids and bases governs the value of surface tension and osmotie pressure. The next ehapter deals with the inactivation of these factors. 


\section{CHAP'TER VIII}

\section{DISPERSE SYS'TEIIS}

\section{COLLOIDS-THE RESERVOHRS OF ENERGY}

"The properties of colloidal solutions ean be most efliciently inquired into by applieation, as far as possible, of the sance views and methods as those generally applied to true solutions." S/RENSEN.

In Chapter $V$. eolloids were mentioned as a series of substanees which when dissolved in water have a lower osmotic pressure than would be expected from their molecular weight. The reason for this, deduced from the colligative properties of their solutions, is that in water they form aggregates or colloidal partieles of extramolecular size.

The effect of this is enormously to increase the effective surface of the solvent. Therefore the phenomena of surface tension and surface adsorption will be marked.

The appended table makes elear the enormity of the inerease in effective surface that takes place when a sphere is divided into a large number of small shot and these are, in turn. divided into partieles of eolloidal size.

TABLE IX.

InCREASE IN SURFACE OF A SPIERE WHEN ITS RADIUS IS Decimally Divided.

\begin{tabular}{|c|c|c|}
\hline Length of Radius. & $\begin{array}{l}\text { Number of } \\
\text { splueres. }\end{array}$ & Total Surfuce. \\
\hline 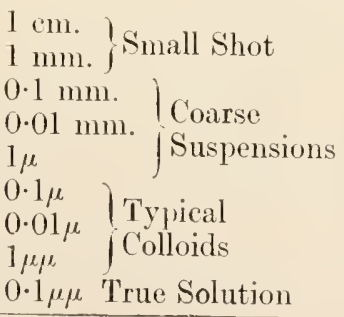 & $\begin{array}{l}1 \\
10^{3} \\
10^{6} \\
10^{9} \\
10^{12} \\
10^{15} \\
10^{18} \\
10^{21} \\
10^{24}\end{array}$ & $\begin{array}{cc}12 \cdot 6 \mathrm{sq} \cdot \mathrm{cm} . \\
126 & , \\
1260 & \text { ", } \\
1 \cdot 26 \text { sq. } & \text { metres } \\
12 \cdot 6 & \text { ", } \\
126 & \text { ", } \\
1260 & \text { ", } \\
12,600 & \text { ", } \\
126,000 & \text { ", }\end{array}$ \\
\hline
\end{tabular}


This table shows how a molecular solution of particles of $0 \cdot 1 \mu \mu$ radius which has no effective surface acquires an effective surface of 12,600 square metres when the particles are inereased in size sufficiently to give them an effective surface, i.e. to bring them into the colloidal realm. These figures demonstrate the extraordinary adsorbing surface of a small amount of matter highly dispersed. In connection with the theory of surface tension Wo. Ostwald has introduced the term specific surface to denote the ratio of surface to volume or $S / V$. In a sphere $S=4 \pi r^{2}$ and $V=\frac{4}{3} r^{3}:$ therefore $\frac{S}{V}=\frac{3}{r}$. It has been found in physical chemistry that adsorption to a surface becomes an important factor when the specific surface reaches a value of about 10,000. It has also been noticed that when the specific surface becomes greater than $6 \times 10^{7}$ or thereby, i.e. when the material is so finely subdivided that it is in molecular solution, adsorption phenomena cannot be detected.

Further, it has been demonstrated that colloids, as a rule, carry a definite charge, some positive some negative. 'The sign of the charge depends both on the nature of the colloid and on the nature of the medium in which it is.

(1) As eolloids have extremely low osmotie pressures they are a suitable medium for the storage of potential energy. Carbohydrates may be stored as starch or glycogen, both colloids, and changed readily into maltose or glucose, which are crystalloids.

(2) The salts adsorbed by a colloid are so rendered osmotically inactive, but may be set free again by alteration of the colloidal electric charge.

(3) Some eolloids imbibe water and eompress it. A hydrated gel (jelly) has therefore a store of hydraulic pressure within it. Gels may thus be regarded as the great reservoirs of energy in the body (Part II.).

A great deal has been done to elucidate the nature of colloids. A full discussion of that work is out of place here, but a brief account of the results may be acceptable.

Protoplasm may be considered as a watery solution of crystalloids and colloids. The division is due to Graham, the pioneer in colloidal research. As the result of a large series of investigations on the rates of diffusion of various substances in water, he was led to divide all substances into two classes, e.g. Crystalloids, which have a high rate of diffusion and which crystallise from 
saturated solutions, and Colloids, which diffuse very slowly and in general have a glucy consistency. "They appear," he writes, "like different worlds of matter, and give occasion to a corresponding division of chemical science." He noticed that crystalloids passed through animal membranes while colloids did not.

That is, if a mixture of colloids and crystalloids were put into a simple dialysing drum (such as described in Part II. p. 406). immersed in rumning water, after a time most of the crystalloidal material would have been dialysed out of the mixture, while the colloidal matter would still remain in the drum. The dialyser furmishes a method for the separation of crystalloids.

It has now been proved that matter may exist either in a crystalloidal or in a colloidal state, and that by suitable means a colloid may be crystallised and so pass through a membrane previously impermeable to it. The converse process may also take place.

The solvent is sometimes the factor on which depends the state of the solute. The alkali salts of the higher fatty acidsstearic, palmitic, oleic-form a true molecular solution in alcohol, but with water they act as colloids. On the other hand, sodium chloride, a typical water-soluble crystalloid, assumes the colloidal state in benzol.

Von Weimarn and others have prepared colloidal solutions of over two hundred substances usually considered as crystalloids. By proper manipulation, almost any solid ean be dispersed through a liquid cither as a crystalloid or as a colloid. Consequently, one now speaks of the colloidal state rather than of certain substances as bcing colloids.

The difference between a crystalloidal and a colloidal solution depends, in the main, on the size of the particle in the fluid.

'There is some difficulty in expressing the relationship between the colloid and the fluid in which it is. It is not in true solution, but is suspended and dispersed throughout the medium. The colloid may, therefore, be called the dispersed substance or dispersate and the fluid the dispersing medium or dispersant.

The application of the "Plase Rule" (of W. Gibbs) has helped to clcar up several difficulties in physiological physics, and some writers have adopted terminology suitable for use when this rule is discussed. It is sufficient here to say that the dispersed phase is the substance which is suspended or distributed throughont the continuous phase. In nearly every case the former is the colloid and the latter the fluid. 
As an illustration, attention may be drawn to a disperse system having two phases and only one eomponent, e.g. A fine mist of liquid water suspended in water vapour.

'The dispersed, internal or non-eontinuous phase is eomposed of the droplets of water ; the eontinuous or external phase, or dispersion medium, is the water vapour. 'The stability of this dispersion depends on two faetors, (a) the temperature of and (b) the diameter of the droplets. (Suel a system is ealled divariant.) The smaller the droplets, the greater is the ratio of surfaee to mass and the higher is the vapour pressure. All the droplets will not be of the same size, and therefore the larger droplets will tend to beeome larger still at the expense of the smaller ones. 'The system is, on this account, said to be metastable.

Disperse systems may be elassified aceording to the nature of the contaet surfaee between the phases. 'Taking the three states of matter, solid, liquid and gaseous, five different kinds of contaet surface can be produeed, as is indieated in the following table, in which are also given examples of the various disperse systems.

TABLE X.

\begin{tabular}{|c|c|c|c|c|}
\hline Class. & Contact Surfacc. & $\begin{array}{l}\text { bispersed } \\
\text { Phase. }\end{array}$ & $\begin{array}{c}\text { Continuous } \\
\text { Phase. }\end{array}$ & Examples. \\
\hline I. & Gas-Jiquid & $\begin{array}{l}\text { Gas } \\
\text { Liquid }\end{array}$ & $\begin{array}{l}\text { Liquid } \\
\text { Gas }\end{array}$ & $\begin{array}{l}\text { Foam, Suds, Lather. } \\
\text { Mist, Spray. }\end{array}$ \\
\hline II. & Gas-Solid & $\begin{array}{l}\text { Gas } \\
\text { Solid }\end{array}$ & $\begin{array}{l}\text { Solid } \\
\text { Gas }\end{array}$ & $\begin{array}{l}\text { Hydrogen in platinum, lava, } \\
\text { meringues. } \\
\text { Smoke, dust and some fumes. }\end{array}$ \\
\hline III. & $\begin{array}{l}\text { Liquid-Liquid } \\
\text { (Emulsoids) }\end{array}$ & Liquid & Liquid & $\begin{array}{l}\text { Milk (fat in water), } \\
\text { Lymph, egg white (raw). }\end{array}$ \\
\hline IV. & $\begin{array}{l}\text { Liquid-Solid } \\
\text { Suspensoids }\end{array}$ & $\begin{array}{l}\text { Liquid } \\
\text { Solid }\end{array}$ & $\begin{array}{l}\text { Solid } \\
\text { Liquid }\end{array}$ & $\begin{array}{l}\text { Rock inclusions. } \\
\text { Colloidal metals, etc. }\end{array}$ \\
\hline V. & Solid-Solir & Solid & Solid & Ruby Glass (Gold in Glass). \\
\hline
\end{tabular}

('lass III. (Emulsoid) is of the most importanee in biology, but C'lass IV. (Suspensoid) has been most studied and is of eonsiderable industrial value. Colloids met with in nature are all dispersed in water, having salts in solution. They might therefore be classified aceording to their degree of dispersion. The degree of dispersion of a phase is the ratio of total surface to volume, or 
the surface exposed to each c.c. of the dispersed phase. There would be a continuous series of systems ranging from a nondispersed two-phase system on the one hand to a homogeneous mixture of an ionised salt in water, i.e. a true solution. Colloids may thus be regarded as intermediate in this series, $e$.g. Gold coin in water, gold dust suspended in water, very fine gold dust suspended in water, range of eolloidal gold in water (( $/$ sigmondy), solution of gold salt (undissociated) and, finally, completely dissociated gold salt in aqueous solution.

Physiological colloids differ from this metallic series in one respect at least. They dissolve in water and they also imbibe water. A solution of albumin. for instance, eannot be regarded as a solid dispersed throughout a liquid, but is a strong solution of albumin dispersed throughout a weaker solution.

This state is not peculiar to natural organic colloids, but, as has been amply demonstrated by Von Weimarn. can be obtained from such materials as $\mathrm{NaCl}, \mathrm{Al}(\mathrm{OH})_{3}$ and silver salts. He has enunciated a postulate called the law of corresponding states, which is as follows: "The degree of dispersion and the general physical appearance of precipitates are always the same irrespective of the chemical nature of the precipitates provided that the precipitation takes place under corresponding conditions." Working with substances as widely apart in their chemical nature as the various salts of aluminium, barium, silver, sodium and many others, Von Weimarn has prepared preeipitates with almost any desired degree of dispersion ranging in each instance, all the way from coarse and obviously crystalline precipitates, to gelatinous preeipitates and thick transparent jellies.

Colloidal matter may be further divided into two groups. White of egg is an emulsoid colloid. In its ordinary state, as obtained from the egg, it ean be dissolved in water to form a clear solution. Boiling the solution causes coagulation of the egg white. It eomes out of solution in the form of a white solid, insoluble in water. Those colloids which form solutions like egg white are called sols. Aceording to the medium in which they were dispersed they were termed by Graham, hydrosols, alcosols, glyeerosols, ete. These colloids whieh assume a semi-solid form like coagulated egg white are called gels. In a gel the more liquid phase is dispersed through the less liquid phase.

An examination of the optical properties of these various disperse systems makes it clear that there is a regular gradation in the size of the particles dispersed, which passes from the easily visible 
suspension to the invisible solute. If the size of a particle is decreased below $200 \mu \mu$, it cannot be seen even by the most powerful microseope made, or that could ever be made. The particle is ultra-microscopic because its diameter is less than half the wave-length of light. But, just as a beam of sunlight renders visible innumerable specks of dust floating in the air, so light may be diffracted by ultra-microseopie particles above a certain diameter.

\section{Faraday-Tyndall Phenomenon.}

When a strong beam of light is sent through a rectangular cell eontaining pure water, the beam may be rendered visible before and after its passage through the water, but no cone of light is seen in the water itself when viewed at right angles to the direction of the light and against a dark background. If now a colloid be dispersed through the water, light will be diffracted from the particles in the water and the beam will appear in the solution as a diffuse cone of light. 'This diffracted light is plane polarised (p. 102), and is always produced when light passes through any medium eontaining particles whose dianetcr is small in comparison with the wave-length of light.

White light is composed of waves of different lengths varying from $760 \mu \mu$ to $450 \mu \mu$. When white light is scattered from a surface instead of being reflected as in a mirror, it gives rise to the sensation of white. Ice, in mass, does not appear white because light is not seattered from its surface. If the ice is powdered, light is scattered from the powdered surfaees and the whole appears white. Crystallised copper sulphatc appears blue, but the light seattered from the surfaees of the finely powdered erystals is white. 'The white eolour of the lily or of white hair is not due to the presence of a white pigment, but to the scattering of light from the surfaees of innumerable minute air bubbles embedded in the tissue. From this it follows that particles of different sizes will seatter light of different wave-lengths. In short, the colour of the seattered light may serve as an indication of the size of the particle, provided the difference in the index of diffraction between the dispersoid and the dispersant be kept constant.

'The blue eolour of the sky is explained by eonsidering that the fine particles of dust, globules of water, etc., suspended in the atmosphere causc lateral diffusion of light of short wave-length giving a blue eolour, while the red rays are transmitted direct, 
produeing the gorgeous sunset eolours (see Speetroseope, Chap. II.). In one of Tyndall's experimental verifieations of this theory he passed light through a tube eontaining a mixture of gases (butyl nitrate in air and hydrochlorie aeid in air), which gradually combined to form a dust-like suspended precipitate. At first the particles were exeeedingly small and the eolour seen from the side of the tube was a delieate tint of blue. As the partieles inereased in size the blue beeame more intense, "until at length a whitish tinge mingled with the pure azure, announeing that the partieles were now no longer of that infinitesimal size, which seatters only the shortest waves."

'The eolour of some samples of stained glass is eaused not by an even distribution of the pigment or stain throughout the glass, but by the dispersion of fine metallie partieles. Water of suffieient depth appears blue due to the presence of tiny suspended partieles. If larger partieles are present, some light of longer wave-length, e.g. yellow, is diffracted and the colour becomes green. The water of the Rhone as it leaves Lake Geneva is intensely blue, while the Rhine at Strassburg is green. 'The Rhine eontains about 70 per eent. more ealeium earbonate in suspension than the Rhone.

Tyndall observed that the blue of the eye has a similar origin to the bluc of the sky, the sea, and the Rhone, viz. seattering of light from small suspended partieles. The uvea, the dark pigmented layer at the back of the iris, prevents the reflection of light and prevents the eolour of the blood in the vessels behind it from beeoming apparent. In an albino this pigment is absent and the eye appears pink. The eolour of blue eyes is due to finely suspended unpigmented eolloid partieles in the iris. 'The various eolour stages between the blue and the grey eye arise from differenees in the mean size of the dispersoid partieles - the finer the partieles, the more intense the blue. Except with people who have very black eyes, the pigment on the posterior surface of the iris does not develop at birth. That is, most babies are born with deep blue eyes. As they beeome older the colloidal partieles become larger and the blue beeomes less intense. Further, the uveal pigment may develop and the colour ehange from blue to hazel, brown or black. 'The reverse ehange never takes place (Baneroft).

Colour may be due, as we saw in Chapter II., to the reflection of non-absorbed light. Complete absorption of light gives rise to the sensation of black. A perfeet reflecting surface would be, of eourse, invisible. If follows that partieles of different sizes 
will "select" light of certain wave-length for absorption, and, as a consequence, colour may result from " selective" absorption, reflection or diffraction.

In the following table. from Ostwald is given the rclationship between size of particle and colour $(a)$ from light absorbed, and (b) from light transmitted.

TABLE XI.

Correspondng Absorbed and Subjective Colours.

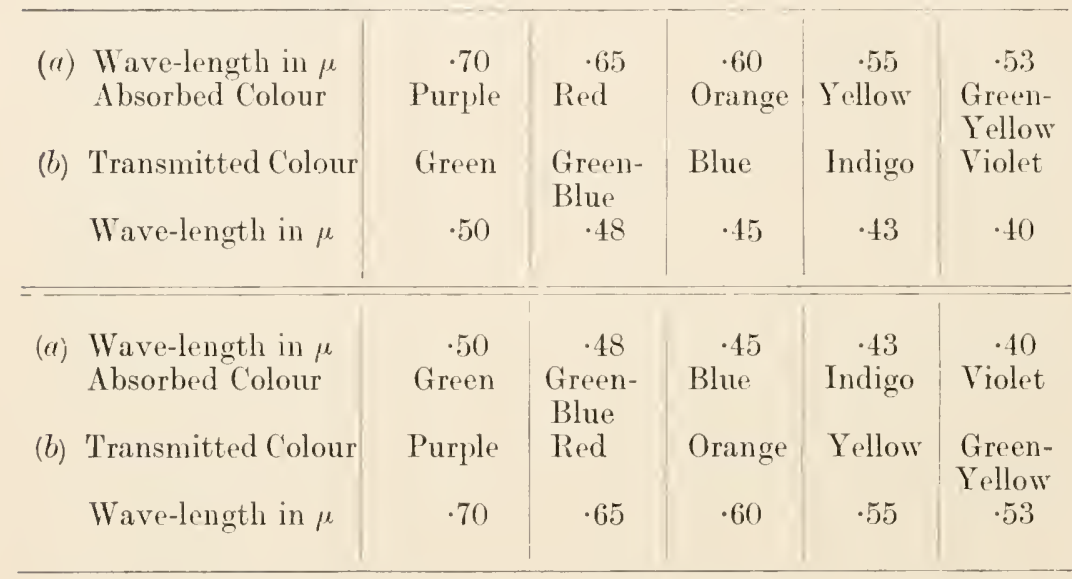

One must, however, take into aecount the other optical components, e.g. refractive index of medium. The absorbed colour given above does not neessarily indicate the eolour of light scattered by the particles.

As the particle becomes smaller, the colour alters to light of longer wave-length, e.g. from blue or green. through various shades of ycllow and orange to red. If the suspended particles are very fine, blue light is, as we have noted above, seattered laterally, while red light is transmitted. Such a system will appear red by transmitted light and blue by refleeted light (e.g. skim-milk, tobacco smoke and colloidal gold). A very interesting series of coloured plates to illustrate this will be found at the end of Zsigmondy's monograph. It has also been shown that, as the particles decrease in size, the absorption bands in the spectrum of the solution shift towards the ultraviolet (Ostwald).

The amplitude of vibration of a particle is a function of its mass, temperature being kept constant. As the mass alters so will the period of vibration. According to Wood, metallie particles, if highly dispersed, owe their colour not to ordinary 
reflection, diffraction, interference, ete., but to optical resonance. Resonance is the production of vibrations in a borly by the periodic application of a stimulus which has the same period as the natural period of the body. The vibrations of a tuning fork may be transmitted through the air and cause to vibrate another tuning fork of the same pitch. Since the resonator owes the cnergy necessary to set it into vibration to the stimulating body it follows that the stimulating body must lose energy to the resonator. The particles in colloidal solution are supposed to be vibrating with the same frequency as light of a certain wave-length. Consequently, they will reccive energy from the light which will tend to increase their amplitude of vibration. The kinetic energy of the solution will tend to increase, but any increase in kinetic energy would mean increase in tempcrature and a slight altcration in frequency. This opens up the possibility of considcrable cnergy changes in comparatively short times.

What effect will be produced when the rates of vibration are nearly but not quite the same? If two pendulum-controlled clocks which are keeping nearly the same time when on separate stands are placed on the same stand they will keep time exactly. Both pendulums transmit vibrations to the stand, and so to one another. The faster pendulum exerts a periodic force on the slower pendulum and is itself slowed by the loss of energy. In the same way the slower pendulum tends to cause forced vibrations in the stand and so influence the faster pendulum. Finally the two pendulums (and stand) vibrate at periods exactly the same. Is it possible that light may cause forced vibrations of colloidal particles?

Certain investigators have claimed that the Brownian movement may attain an increased velocity because of incident light. Exncr found that exposure to light of a suitable wave-length had a positive accelerating effect. Compared with the movement as a wholc the alteration brought about by incident light is negligible.

Onc effect of optical resonance is the production of surface colours. When light of a certain wave-length is strongly absorbed by particles, they may also reflect that light "selectively." For instance, magenta crystals (aniline colour) transmit red but reflect green. If the particle is made small enough it will scatter the light that it previously transmitted, and will transmit, of course. the light that is not scattered. This is readily carried out with indigo. In mass, this colloidal dye absorbs red and transmits bluc. It reflects red. If a fine suspension is made it scatters blue, i.e. appears blue when observed laterally to the plane of incidence of light. By transmitted light it is red, i.e. appears red when looked at against the light. 
The ultra-microscope is, in principle, just a means of vicwing the Tyndall cone through a microseope. A powerful beam of light is thrown horizontally through a small body of fluid plaecd under a microscope set vertically. The only light entering the

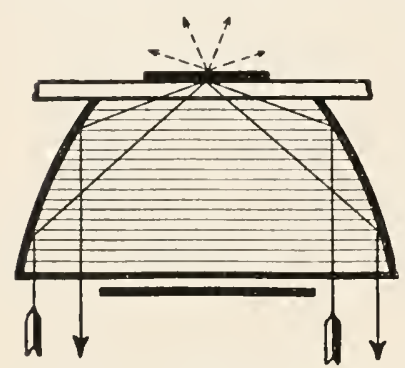

FIG. 7.- - Diagrammatic section through a paraboloid condenser to show the direction taken by the rays of light. (Hatsehek.) objeetive is that diffracted from the particles present in and optieally different from the fluid (Fig. 7). The apparent image bears no relation to the actual size of the particle, but depends on the intensity of the light, and on the indiees of refraction of the partiele and the dispersant. Nevertheless, by making ecrtain assumptions. the size of the partieles may be caleulated.

Particles visible under the ordinary microseope are ealled mierons. Smaller particles are termed sub-microns, if they are rendered apparent by the ultramicroscope; if not, they are amierons. The smallest partiele of gold obscrved by Zsigmondy, using bright sunlight illumination, was $1.0 \mu \mu$ in diametcr. Bearing in mind the large difference in index of refraetion between gold and water, this may be eonsidered as the smallest partiele ever observed. The following table (from Zsigmondy) shows the limits of size of the various classes of particles :

\section{TABLE XII.}

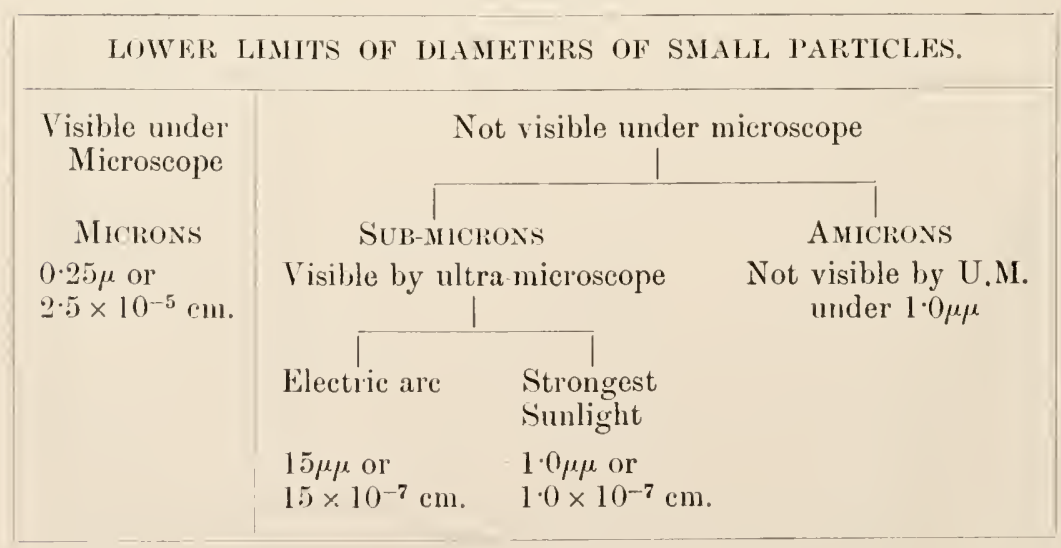

$\mu$ equals $10^{-3} \mathrm{nmm} .=10^{-4} \mathrm{~cm} ., \mu \mu=10^{-7} \mathrm{~cm}$. 
Evidence tending in the same direction and towards the same limits of size is afforded by experinents initiated by the classical series of ultrafiltrations of Bechhold. Membranes of known permeability are prepared, i.e. the diameter of the pores is known. and the colloidal solution is filtered through these by pressure. $A$ series of filters is tried till one is obtained which has the smallest pores which will allow the colloid to pass through. Obviously the particles must be smaller than the pores, and probably, though not necessarily, they are larger than the next filter in the series. The sizes of particles obtained in this way are in reasonable agreement with the values obtained from ultramieroscopic ealculations.

The little dots of light seen under the ultramicroscope are not at rest. 'They dart about hither and thither in a seemingly inexplicable way. According to the kinetic theory of matter, a fluid was assumed to be made up of molecules in a state of very rapid motion and having a mean free path intermediate between that of a solid and that of a gas. The colloidal particles in the liquid are hustled into motion by continuous collision with the rapidly moving molecules of the liquid. If the particles have a natural period of vibration which is a multiple of that of the water molecules their amplitude of vibration will be inereased (e.g. by suitably timing blows on a pendulum its excursion can be inereased to a considerable extent. Each blow need be very slight).

This motion of the particles, while a very striking feature in the field of vision of the ultramicroscope, is not elaracteristic of colloidal solutions. Particles sufficiently small to be influenced by the high velocity bombardment of the molecules or ions of the solvent may still be well within the limits of visibility under an ordinary microscope. This movement owes its name to its discoverer Brown, a botanist, who described the peculiar oseillation of pollen grains suspended in water in 1827. 'This Brownian movement may be seen by means of an ordinary microseope in a solution of the water-colour gamboge especially when the diaphragm of the mieroscope is almost elosed. The rate of movement is independent of the chemical nature of the particles, but depends on three factors, viz. (a) the size of the particle, $(b)$ the temperature, and $(c)$ the viscosity of the dispcrsion medium. 'The rate is increased by decrease in the mass of the particle, by increase in temperature or by decrease in the viscosity of the medium. The movement persists, never changing, once equilibrium has set in, for all time. It has been observed in granitc and in other 
rocks in small pockets of liquid, which they must have oceluded for millions of years. But equilibrium must first be reached.

Direct observation of the absolute motion of the particles is very difficult, although differences in motion are easily perceptible. This difficulty has been overeome by the application of the cinematograph to the microscope. $\perp$ glance at Fig. 8, obtained in this way, shows that a particle oscillates apparently in a haphazard fashion about a certain mean position during a short interval of time. Any alteration in the kinetic energy of the dispersing medium. of course, produces altcrations in the mean velocity of the particles-e.g. increase of temperature increases

A.
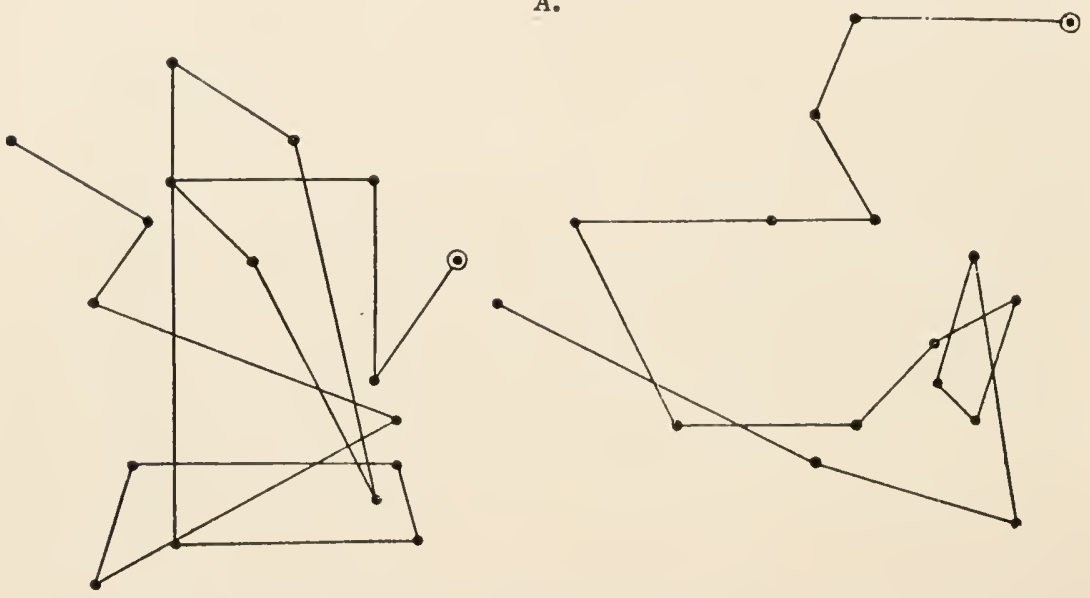

Fig, 8.-Movements of two particles of india-rubher latex in colloidal solution, recorded by cinematograph and ultra-microscope. (Henri.)

velocity. The velocity may also be modified by alterations in the hydration of the particles. Ramsay considers that the particles in pure water do not touch one another at any time, each particle being surromnded by a liquid layer. This layer is destroyed by the addition of salts, which thus eause negative acceleration.

To use a somewhat homely illustration, the colloidal particle may be likened to a morsel of bait dropped into the water of a river estuary. The moment that it reaches the water it is pushed to and fro by a multitude of hungry small fish. The veloeity and amplitude of the oscillatory movements of the bait depend principally on the size of the bait and on the energy with whieh it is attacked. 
If a colloidal solution or a fine suspension of gamboge or mastie be kept undisturbed at constant temperature for some time, Perrin found that there was a distribution of the colloidal partieles under the influenee of gravity. At the bottom of the container will be found a denser distribution than at the higher levels. This is exactly similar to the decrease in the density of the atmosphere with height above sea level, and Einstein argued that the

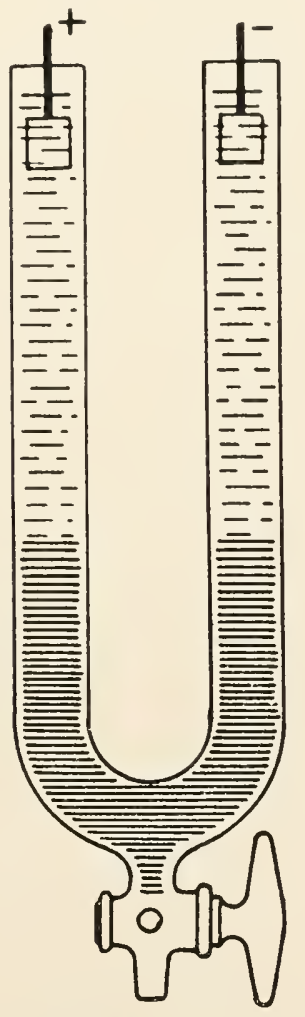

FIa. 9.- Ipparatus for demonstating cataphoresis. The deeply shaded lower portion of the $U$-tuhe is filled witil a colloidal sol, the urper part with ordinary distilled water. On the passage of an elcetric current the colloin rises towarts the electrode of opposite sign to the sol. (Hatschek.)

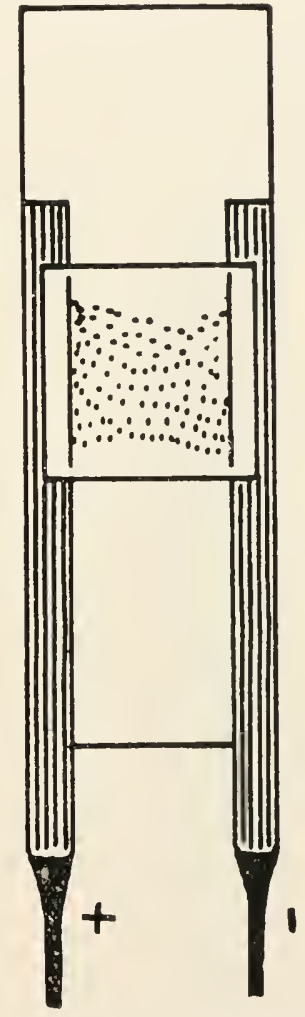

Fic. 10.-A Imaratus for ultramicroscojie observation of the movements of colloids in an electric field (see Part 1I.). (IIatschek.)

distribution of suspended particles with height should follow the law which governs the density of the atmosphere with height. Perrin proved by experiment that this was true. In one experiment with mastic at four different levels $12 \mu$ apart he found 116 , 146,170 and 200 particles per unit. For the same levels the follow- 
ing values were calculated: 119, 142, 169, 201. This and numerous other experiments confirm quantitatively the theory that the Brownian movement is the result of molecular impacts. After this adjustment of eoneentration to level has been reached, no other change scems to take place. To this cause may be attributed a share at least of the responsibility for the stability of colloidal solutions.

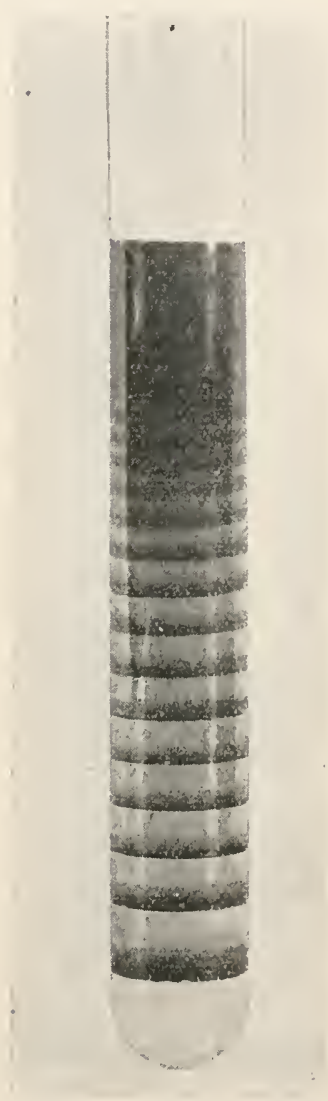

FIG. 11--Adsorptive stratification of silver bichromate in an agar gel. (Bradford, Biochemical Journal.)

The electrical properties of a colloidal dispersion may have much to do with the permanence of the suspension. Each colloidal particle earries a definite charge scemingly dependent on the hydrogen ion concentration of the dispersing medium. The colloid gencrally has a greater conductance than the intermicellar liquid itself. This is due to the unequal adsorption of ions of electrolytes present in the dispersion medium and in some instances by ionisation of the colloid itself. By virtue of this charge the particles of the disperse phase will act like ions and will migrate through the solution to any point of opposite charge. This electrieal migration is called cataphoresis (Figs. 9 and 10).

\section{Diffusion of Electrolytes.}

Cataphoresis should not be eonfused with the electrieal diffusion of eleetrolytes into gels. 'That dissolved substances diffuse into or out of gels was a fact familiar to Graham. The rate of diffusion may be altered by the addition of certain substanees to the gel. A gel, after treatment with sodium sulphate, glueose, alcohol, glyecrol, etc. (dehydrating agents), offers considerable resistance to the diffusion of electrolytes. Urea, iodides, and chlorides, on the other hand, cause acceleration of the rate of diffusion. These added substances cause altcration in the relative amounts of water held by dispersoid and dispersant and so produce alterations in the more liquid phase. The degree of continuity of liquidity is a causative factor in the velocity of diffusion. 


\section{Liesegang Phenomenon.}

If a gel eontains a substance in solution and a seeond substanee eapable of reacting with the first is allowed to diffuse into the gel, the product of the reaction is deposited in strata separated by elear intervals (Part II.). In Fig. 11 is illustrated a test tube filled with 1 per eent. agar gel eontaining potassium biehromate. On top of this was placed a solution of silver nitrate. It is obvious that the silver biehromate formed is deposited in strata separated by elear agar. No satisfactory explanation of this phenomenon has been offered (Part II. p. 413).

\section{Electrical Diffusion.}

The rate at which electrolytes diffuse into gels may be inereased by the passage of an eleetric eurrent. This method is sometimes employed in the administration of drugs, - so ealled ionie medication. "Metal"-ions (eations) are earried into the tissues from the positive eleetrode of any eurrent-supply deviee, while " aeid "-ions (anions) are driven in from the negative electrode (see Chap. $\mathbf{X}$. and Part II. p. 413).

\section{Coagulation of Gels and Precipitation of Sols.}

If a eolloid has a positive charge when in a liquid of high $\mathrm{H}^{+}$ eoneentration and has a negative charge when the $\mathrm{H}^{+}$is low, an intermediate point (isoelectric point) ean be reaehed when the eolloidal partieles has either no eharge or, which eomes to the same thing, half of them with + and the rest - . In such a ease the eolloid would lose its electrical stability. Positive and negative particles would eoalesee to form aggregates too large to exhibit Brownian movement and the colloid would separate into diserete phases.

This coagulation may be brought about by adding $(a)$ acids or alkalies, $(b)$ suitable electrolytes or $(c)$ eolloids of opposite sign. The eoagulation of suspensoids (Class IV. eolloids) by the above means is easily earried out and is a reversible process. On washing out the adsorbed preeipitant the dispersoid is re-established. Emulsoids (Class III.), on the other hand, are more stable than suspensoids. They usually need the addition of a large quantity of the coagulating substance and the resulting eoagulum is frequently irreversible. This may be due to alteration in the eontinuous phase. We have seen that an emulsoid is a diphasie system where the eontinuous phase is more or less a eontinuation of the disperse phase. If a substance $\boldsymbol{A}$ is dispersed in water to 
form an emulsoid what really results is a dispersion of a solution of water in $A$, throughout a solution of $A$ in water. The stability of such a system will depend in great measure on the viseosity of the intermicellar liquid. The viscosity depends on the concentration of the more viscous $A$ in the less viscous water. The range of viscosity making for stability will be bounded on the one hand by a eertain minimum and on the other hand by a certain maximum eoneentration of water in the continuous phase.

\section{Protective action of Emulsoids.}

Many emulsoids when added in comparatively minute quantities to suspensoids prevent the coagulation of the suspensoids by eleetrolytes. As a matter of fact, eaeh emulsoid which exhibits this property has a characteristie protective power which may be used as a definite factor for the identification of the colloid. The suspensoid generally used in the test is colloidal gold. Zsigmondy, who devised the method, defines the "gold number" as the number of milligrams of an emulsoid which are just sufficient to prevent 10 c.e. of a bright red gold sol (prepared under certain specified conditions) from changing into violet or shades of violet after the addition of 1 c.c. of 10 per eent. sodium cliloride solution (Part II.).

He divides colloids into four classes aceording to their "gold number," viz. :

TABLE XIII.

\begin{tabular}{|c|c|c|}
\hline Class. & Gold Numbcr. & Examples. \\
\hline $\begin{array}{l}\text { I. } \\
\text { II. } \\
\text { III. } \\
\text { IV. }\end{array}$ & $\begin{array}{l}0.005-0.1 \mathrm{mg} . \\
0 \cdot 1 \quad-10 \mathrm{mg} \text {. } \\
10 \quad-500 \mathrm{mg} . \\
\text { Inactive - }\end{array}$ & $\begin{array}{l}\text { Gelatin, caseinogen, animal glue. } \\
\text { Crystalline egg albumin, gum acacia. } \\
\text { Dextrin, starch. } \\
\text { Mucin, silicic acid. }\end{array}$ \\
\hline
\end{tabular}

The general opinion seems to be that the emulsoid forms a pelliele round each suspensoid particle and prerents coagulation, cither (1) beeause, as we have seen, emulsoids are less sensitive to the precipitating action of clectrolytes and the compound particle is endowed with an emulsoid eoat; (2) because the electrolyte does not come in eontact with the suspensoid particle and does not neutralise its electrie eharge, or (3) merely by offering a material obstacle to the eoalescence of the particles.

The fluids of the body contain two colloidal substances of peculiar interest. Albumin and globulin are both emulsoids, 
but they differ physically in at least three respects summarised below.

\section{TABLE XIV.}

\begin{tabular}{l|c}
\multicolumn{1}{c|}{ Albumin. } & \multicolumn{1}{c}{ (ilobulin. } \\
\hline $\begin{array}{l}\text { Sol in water. } \\
\left.\text { (Sol in } 5 \text { per cent. } \mathrm{NaCl}_{\text {. }}\right)\end{array}$ & $\begin{array}{l}\text { Insol in water. } \\
\text { (Sol in } 5 \text { per cent. } \mathrm{NaCl} \text {.) }\end{array}$ \\
$\begin{array}{l}\text { Not pt. by } \frac{1}{2} \text { sat. }\left(\mathrm{NH}_{4}\right)_{2} \mathrm{SO}_{1} \\
\text { Protects suspensoids. }\end{array}$ & $\begin{array}{l}\text { Ppt. by } \frac{1}{2} \text { sat. }\left(\mathrm{NH}_{4}\right)_{2} \mathrm{SO}_{4} . \\
\text { P'pts. suspensoids. }\end{array}$
\end{tabular}

Albumin has a protective action on gold sol while globulin acts almost as if it were a suspensoid. The proportions of albumin and globulin in the various body fluids is practically invariable in health, but during the course of various diseases the balance is upset. If the globulin content is increased relatively to the albumin, then the body fluid will lose a portion of its protective power. In some cases the globulin is not increased, but carries an increased positive clectric charge. This increases its precipitating action. (Method given in Part II.)

Evaporation or dehydration, if it reduces the water content below the minimum, will cause coagulation. Conversely, dilution causes a disperse system to break up.

Heating and Cooling, which alter viscosity directly and also indirectly by altering the amount of water distributed between the two phases, also cause coagulation. Heating certain sols changes them into the more rigid gels. Various native proteins, for instance those of $\mathrm{cgg}$ white. serum, muscle, coagulate to a gel on heating to a temperature specific for each protein. This process is irreversible and takes place in the presence of electrolytes. On the other hand, gelatin forms a sol on heating and a gel on cooling - a reversible reaction which is profoundly modified by the presence of electrolytes.

Action of Radium. (See also Chap. XI.)

The intimate connection between coagulation and the charge carricd by the particles is shown by the action of the $\beta$ rays of radium. As these rays are negative charges of electricity, they should stabilise negative colloids by increasing their charge, and precipitate positive colloids by neutralising their charge. Hardy found that positively charged acid-globulin was reduced to a state of jelly in three minutes, while the particles of negatively charged alkaline-globulin were rendered more mobile by exposure to $\beta$ radiation. 
The behaviour of most organie gels is complieated not only by the presence of electrolytes, and by the fact that the eontent of the intermiecllar fluid in clcetrolytes may be rapidly altered, but also by the fact that the dispersed substance is a mixture of elosely related substanees. Thus agar-agar, a earbohydrate supcrfieially similar to the protcin-hydrate gelatin, consists of at least two substances $\alpha$ and $\beta$ agar-agar which are mutually convertible under eertain eonditions. Purified, a agar-agar is practieally insoluble in water. The $\beta$ form is very soluble in water. On warming some of the former with water it gradually passes into the soluble form and thus goes into solution. Insoluble $\alpha$ partieles may be dispersed in larger partieles of $\beta+$ water. They in turn form a true sol with water. Alteration of physical or chemical eonditions will therefore alter the relative coneentration of $\alpha$ and $\beta$. The $\beta$ colloid protects its $\alpha$ relative from eoagulation by thus forming a pelliele round it. Stareh-a pseudo-eolloid - is a mixture of several carbohydrates of high molecular weight, each of which is eapable of taking up a different quantity of water. (See under Emulsions.)

Of great physiologieal interest are soaps, the alkali salts of the fatty aeids. These soaps are found in the body wherever fats are found-in bilc, blood, facees, ear wax, sebum, ete., as well as in some pathological fatty seeretions. The soaps furnish a series in whieh the molecular weight regularly inereases. Step by stcp with this increase in molceular weight there is a regular gradation of the properties of the dispersoid from the true solution of the soaps of the lower fatty aeids to the eolloidal gels of the higher homologues. Still more important physiologically is the effect of altering the anion. Sodium, potassium, ammonium, caleium and magnesium soaps are found in physiologieal analyses and these differ from one another, especially in their power to hold water. Ammonium and potassium soaps are so hydrophilic that they do not solidify but form jellies (soft soap). Sodium soaps also hold a considerable amount of water, but only about $\frac{2}{5}$ of that held by "soft" soaps. So little water is held by the soaps of ealeium and magnesium that they do not form a sol to any appreeiable extent. The addition of alkali to a sodium soap greatly inereases its hydrophilie properties. Soap solutions may be broken up in various ways.

(a) The addition of an acid stronger than the fatty acid frees the fatty acids, e.g. $\mathrm{II}_{2} \mathrm{SO}_{4}+2 \mathrm{Na} \overline{\mathrm{A}}-\mathrm{Na}_{2} \mathrm{SO}_{4}+2 \mathrm{H} \overline{\mathrm{A}}$.

(b) On adding a powdered neutral salt to a soap solution the 
soap is "salted out" as a curdy mass. The salt reduces the hydrophilic powers of the soap and so reduces the stability of the dispersoid. 'This is a different phenomenon from the preeipitation of a colloid by electrolytes.

(c) On adding a soluble salt of ealcium or magnesium to a soap of ammonium, sodium or potassium a eurdy precipitate is produeed. This eurd is a ealcium or magnesium soap, which, as we have seen, has little or no affinity for water.

(d) Solvents of soaps added to a watcr-soap dispersoid lead to a partition of the soap between solvent and dispersion medium. The effect of the anaesthetics on soap sols is interesting. Alcohol brings about a rapid separation of soap and water, practieally all the soap dissolving in the alcohol. Chloroform has much the same effect, but the partition is not so complete. 'To get anything like a complete extraetion large anounts of ehloroform must be used. Ether has hardly any effeet.

Soaps have a powerful effeet in lowering surface tension, which effect is greatly increased by the aldition of small quantities of alkali (Shorter and Ellingworth). A stalagmometer reading of oil dropping into water was 65 drops. When 1 per cent. soap was added to the water the drops inereased to 260 (Hatsehek).

\section{Emulsions.}

Although, as far as is at present known, emulsions do not take a direct part in the energy exchanges of the body, and should therefore not be treated in this section; yet as they are so closely allied to the colloids, and are really never found unless mixed with eolloidal or semi-colloidal matter, it is eonvenient to deal with them now.

An emulsion may be regarded as an emulsoid with somewhat larger dispersed partieles (mierons). The term, as usually employed, has, however, a narrower eonnotation, the disperse phase being eonsidered as a fat or fat-like substanee distributed throughout water in such a way as to remain stable for an indefinite period. Oil and water are two immiscible liquids and no amount of meehanical mixing will induce them to form a permanent emulsion. It is true that after a prolonged beating of the two together a maximum of 2 per cent. of the oil may be taken up by the water, forming a stable dispersoid. Measurement of the partieles, however, demonstrates that they are of the order of sub-mierons, and thus a true colloidal system has been formed. An example of this is the condensed water of steam cngines, which contains lubrieating oil in suspension. 
Analyses of natural and artificial emulsions, like milk, bile, rubber, cod-liver-oil emulsion, ete, demonstrate the presenee of more than merely oil and water. A colloid or semi-colloid must be present.

TABLE XV.

\begin{tabular}{|c|c|c|c|c|}
\hline Emulsion. & Wisperse Plhase. & Continuous Pliase. & Colloids. & Crystalloids. \\
\hline Milk & $\begin{array}{l}\text { Oil } \\
3.8 \text { per cent. }\end{array}$ & $\begin{array}{l}\text { Water } \\
87 \text { per cent. }\end{array}$ & $\begin{array}{l}\text { Caseinogen } \\
\text { Albumin } \\
\text { Globulin } \\
3 \cdot 2 \text { per cent. }\end{array}$ & $\begin{array}{l}\text { Lactose and } \\
\quad \text { Salts } \\
\mathrm{Na}_{2} \mathrm{CO}_{3} \text {, etc. }\end{array}$ \\
\hline Bile & $\begin{array}{l}\text { Fats and } \\
\text { Lipoids } \\
5 \cdot 9\end{array}$ & $\begin{array}{l}\text { Water } \\
77 \cdot 5\end{array}$ & $\begin{array}{l}\text { Soap } 3 \cdot 2 \\
\text { Mucin } 0 \cdot 45\end{array}$ & \\
\hline Egg yolk & $\begin{array}{l}\text { Fat } \\
35 \cdot 3\end{array}$ & $\begin{array}{l}\text { Water } \\
47 \cdot 2\end{array}$ & $\begin{array}{l}\text { Protein } \\
15 \cdot 6\end{array}$ & \\
\hline Ear-wax & $\begin{array}{l}\text { Fat } \\
26\end{array}$ & $\begin{array}{l}\text { Water } \\
10\end{array}$ & $\begin{array}{l}\text { Potas. Soap } \\
52\end{array}$ & $\begin{array}{c}\text { Mostly organic, } \\
\text { little asl. }\end{array}$ \\
\hline Butternut & $\begin{array}{c}\text { Water } \\
4 \cdot 4\end{array}$ & $\begin{array}{l}\text { Fat } \\
55 \cdot 1\end{array}$ & $\begin{array}{l}\text { Protein } \\
23 \cdot 7\end{array}$ & \\
\hline $\begin{array}{l}\text { Human fatty } \\
\text { tissue. }\end{array}$ & $\begin{array}{l}\text { Water } \\
15\end{array}$ & $\begin{array}{l}\text { Fat } \\
82 \cdot 5\end{array}$ & $\begin{array}{l}\text { Protein } \\
2 \cdot 5\end{array}$ & \\
\hline Rubber latex & $\begin{array}{l}\text { Rubber } 20 \\
\text { and } \\
\text { Resin } 2\end{array}$ & $\begin{array}{l}\text { Water } \\
76 \cdot 2\end{array}$ & $\begin{array}{l}\text { Protein } \\
2 \cdot 8\end{array}$ & $\begin{array}{l}\text { Sugars, } \\
\mathrm{K} \text { and } \mathrm{Ca} \text {, etc. }\end{array}$ \\
\hline $\begin{array}{l}\text { Pharmaceu- } \\
\text { tical } \\
\text { Emulsions }\end{array}$ & $\begin{array}{l}\text { Oil } \\
50\end{array}$ & $\begin{array}{l}\text { Water } \\
50\end{array}$ & $\begin{array}{l}\text { Egg white } \\
\text { Gum arabic } \\
\text { Saponin }\end{array}$ & $\begin{array}{l}\text { Sugar } \\
\text { Phosphates } \\
\text { Carbonates }\end{array}$ \\
\hline $\begin{array}{l}\text { Lubricating } \\
\text { Emulsion }\end{array}$ & $\begin{array}{l}\text { Water } \\
1\end{array}$ & $\begin{array}{l}\text { Oil } \\
99\end{array}$ & $\begin{array}{l}\text { Soap } \\
1\end{array}$ & \\
\hline
\end{tabular}

If the generie term oil is used to denote any liquid that is not miseible with water, we may note that there are two entirely different types of emulsions, the one being drops of oil suspended in water and the other being drops of water suspended in oil (ef. emulsoid sol and gel). For example, milk belongs to the former and butter to the latter class. It is important to know 
under what conditions each of these types is formed. One might at first imagine that the governing faetor would be the relative amounts of oil in water, much water and little oil producing the oil-in-water type and exeess of oil over water producing the water-in-oil emulsion. 'This is not so. The nature of the emulsoidcolloid determines the type of the emulsion absolutely. The relative amounts of oil and water have nothing to do with it. 'T'o understand the signifieanee of this, one must examine the function of the eolloid.

Some means must be adopted onee the oil has been dispersed to (a) decrease the interfacial tension between the droplets and the dispersion medium so that the dispersed particles will not coalesee, $(b)$ eonfer on the droplets an electrical charge so as to cause mutual repulsion, and $(c)$ meehanieally keep the droplets separate. 'The presenee of an emulsoid seems to eonfer stability on an oil-water emulsion. 'Two theories to aeeount for this are of suffieient importance to warrant attention.

1. Most physical ehemists prefer the theory which postulates a third phase, namely, a thin layer of colloid or semi-eolloid separating the disperse from the continuous phase. This interfacial film reduces the surface tension on the film-water interface, eonfers a charge on the droplets by adsorption, and, by having the remainder of the eolloid as an outer phase, provides a medium sufficiently viseous to keep the droplets in suspension.

2. Reecntly Fiseher and Hooker have promulgated their theory of the action of the protective colloid. They eonsider that an emulsion may be triphasie but need not neeessarily be so. Their idea is that a diphasic system is all that is required for stability, e.g. oil and an emulsoid in water.

The nature of the enulsoid determines the type of emulsion produced. If the eolloid is one whieh is "wetted" by water (hydrosol or hydrogel), and is adsorbed by oil, it (or its solution) will form a film round the oil droplets and give an emulsion of oil in water. On the other hand, if the colloid is dispersed through oil and is adsorbed by water it will emulsify water in oil. Most emulsions are of the first type, oil-in-water.

The oil eannot be dispersed throughout a hydrated colloid until a certain lower limit of water eontent has been exeeeded, nor can it be divided permanently into a hydrated eolloid after an upper limit has been passed.

Emulsions are broken through the institution of conditions that are the reverse of those that make for their stabilisation. 
In other words, a colloid is a suitable emulsifying agent only when it holds a certain amount of water. That amount may vary between an upper and a lower limit. If at any time the water in the system oversteps either of the limits the cmulsion will lose its stability and will separate out. The emulsions hardest to break are those where the emulsifying agent is a carbohydrate like gum acacia, starch or dextrin. They hold their water of hydration with avidity. Salts, acick, or alkalies in moderate concentrations, alcohol, chloroform and ether have very little action on them. Milk, an oil in protein emulsion, is very diflicult to break. Dilution has little effect and fat solvents do not readily extract the fat. This is probably due to an adsorption effect in which the carbohydrate plays a part as yet unknown. The colloidal material comes to be coneentrated on the surface between the oil and the aqueous phase. T'hese protecting films drawn over the oil globules keep them from coaleseing even when brought close together and also form a membrane impermeable to fat solvents.

At this point the two theories secm to be on common ground. Neither of them can, however, give a satisfactory explanation of the stabilising effect of the presence of a small quantity of carbohydrate on oil-protein or oil-soap emulsion. The carbohydrate need not be a hydrophilic colloid itself. Cane sugar is an excellent stabiliser. Why are tissues less easily poisoned by anaestheties and other poisons when glyeogen is in the cells?

Similarly the colloid in a water-in-oil emulsion must be hydrated. Using soap as his stabiliser, Pickering emulsified 99 per cent. oil by volume in one volume of water. The resulting emulsion was a stiff jelly which could be eut with a knife and the eube so prepared would stand alone. These solid cubes when left standing in dry air seem to liquefy. The reason for this is that the soap film loses moisture by evaporation, cracks, and sets free the oil. The mass does not become liquid because of the adsorption of water but breause of the loss of water. Several of the heavy lubricating oils contain a considerable quantity of calcium soap. Now, calcium soaps are very insoluble in water but form colloidal solutions in oil, therefore, in these lubrieants the water is emulsified into the oil and a thick grease is formed. Rosin acts similarly to calcium soap and is used in the preparation of cheap brands of ready-made paints as an instrument for the emulsification of water in the linseed oil. As much as 80 per cent. water may be ahsorbed in this way. 
The hydrophilic properties of sodium and calcium soaps have already been mentioned. Their behaviour in cmulsion-making throws light on some peculiar problems in physiology. Locb and his co-workcrs found that certain marine organisms died when put into fresh water. This will not appcar surprising to the student who remembers the phenomena of endosmosis, $e$.g. plasmolysis, haemolysis, etc. That this explanation is not correct is shown by putting the organisms into solutions of sodium chloride or of calcium chloride having the same osmotic pressure as sea water. If, however, the organisms which would have becn killed by immersion in these isotonic solutions were placed in a solution having a definitc ratio between the amount of sodium and calcium present, life was maintained quitc normally. All protoplasm may be considered as an emulsion of lipoid material in a colloidal-crystalloidal complex. The presence of the sodium soap formed by interaction with the lipoids causes the formation of a lipoid-in-water emulsion while the calcium soaps cmulsify water-in-lipoid. The two types of emulsion thus formed are in equilibrium with an environment containing a definite $\mathrm{Na} / \mathrm{Ca}$ ratio, that of sea water. Alteration in this ratio upsets the balance between the two types of cmulsion and causes the cessation of growth and subscquently of life (see Nerve, Chap. XVII.).

The rigidity of tissue is to a large extent due to their emulsion character. We have up till now considered protoplasm as a liquid, arguing that it is so because it shows the phenomena of surface tension, because it allows the ready diffusion of crystalloids into and through it, and because it reacts chemically as a liquid. On the other hand, tissues, as we handle them, are more or less rigid, having elasticity and definitcness of form. Do Pickering's solid cmulsions and the $\mathrm{Na} / \mathrm{Ca}$ ratio not suggest a fairly plausible explanation of this double nature of protoplasm? The "softening" of tissues observed in various pathological states may be due to the breaking of the protoplasm-emulsion from any cause (Part II.).

Our food materials as well as our tissues are colloidal complexes. They are derived in part from the animal, in part from the vegetable kingdoms.

A. Animal foods may be classified as :

(1) Milk and its produets-cream, buttcr, and cheese.

(2) Flesh.

(3) Eggs.

(1) Milk is a fine emulsion of fat in a protein-colloidal solution. 
(a) The fat globules each seem to be enveloped by a covering of adsorbed protein.

(b) The chief protein in milk is caseinogen, a phospho-protein which exists in milk as a soluble caleimm compound. This compound is broken by the action of acid, and protein separates as a curd.

(c) 'The carbohydrate of milk, lactose, is split by various microorganisms, forming lactic acid. thus souring the milk and causing curdling.

Butter is simply the fat of the milk more or less completely separated from the other constituents and forming a water-in-oil emulsion. Whole, unchanged milk shows no tendency to form butter. To form butter the fat particles are concentrated at the surface by centrifugal action (or merely by allowing the cream to rise), and then by causing the cream to sour, the fat is freed from its emulsion with the colloidal matter. Since the hydrated colloids tend to collect in the surface layer between the fat globules and the dispersant aqueous phase of the cream, churning is performed to break these layers and hasten the coaleseence of the fat. "The combined efforts therefore bring about a progressive increase in the eoneentration of the oil with a decrease in the concentration of the hydrated colloid until the instability of the oil in hydrated colloid becomes so great as to 'break' and yickl the hydrated colloid-in-fat emulsion which we call butter" (Fischer and Hooker). That milk and cream are oil-in-water emulsions can be proved microseopically. They wet paper and are not greasy to the touch. Butter is a water-in-oil emulsion, feels greasy, oils paper, and microscopically appears as a fincly divided aqueous colloid phase in a continuous oil phase.

(2) Flesh. Under this head is included, not only the muscles of various animals, but such cellular organs as the liver, kidneys, thymus, ete. The colloidal nature of such tissues has already been dealt with (see effect of cooking, below).

(3) Eggs. The white of eggs is practically an albumin hydrosol containing some erystalloids, while the yolk is an emulsion of lipins (lecithin, etc.), in a hydrosol of protein (ordinary proteins, and vitellin, a phospho-protein).

\section{B. Vegetable Foods.}

In the food of man, vegetable foods play as important a part as animal products. Generally, their make up is that of a mixed hydrogel of protein, higher carbohydrates (and in the ease of 
oatmeal, maize, nuts, eertain legumes and vegetables), a fair proportion of fat. This gel is enelosed in a eapsule of ecllulosea higher earbohydrate which is very resistant to the aetion of the human digestive juices. The eapsule must be destroyed by previous treatment, e.g. milling, eooking, chewing, ete., before the eontents ean be utilised. Far and away the most important of our foodstuffs are derived from cereals. From 30 to 50 per eent. of the energy of an ordinary diet eomes from them. 'They are generally used as flour, baked into bread, or as meal made into porridge. Wheat flour is a eomplex gel powder eonsisting of about 10 per eent. protein, about 75 per eent. earbohydrate (starch and eellulose), and about 2 per eent. fat in the colloidal state. The individual particles eontain moleeularly dispersed salts, sugar, water, and adsorbed gases sueh as air and earbondioxide. Of the 10 per eent. of protein, gliadin forms about 4 per eent. and glutelin about 4 per eent. There is less than 1 per eent. of globulin $(0 \cdot 6$ per eent.) and albumin $(0 \cdot 3)$ present. The mixture of glutelin and gliadin is known as gluten. Gluten is insoluble in water or in dilute salt solutions, and therefore readily forms a disperse system with water ealled dough. Dough is a polydispersoid eomposed of the ghutelin (and other proteins) earbohydrates and erystalloids mentioned above bound together by colloidal gliadin. It is a viseous semi-liquid mass which, however, may be eut like a solid, and when torn exhibits a fibrous surface. The elastie properties of dough depend upon the proportion of electrolytes present, espeeially on the phosphates. When it is dried it ehanges into a gel and later beeomes brittle like glue. There is doubtless a elose eonnection between the viseosity of flour-water mixtures, and the stickiness, rising property, power of absorbing $\mathrm{CO}_{2}$ of the dough, hydration of the stareh and the porosity and volume of the resultant loaf.

The viseosity is found to inerease with the eonecntration of the flour and also to beeome greater for some time after mixing. This is doubtless due to the slow swelling of the stareh and abbumin. If eoneentrated solutions are suddenly diluted the viseosity is too great at first, but gradually approaches a normal value. This is probably eaused by a slow inerease in the dispersion, beeause when the larger particles are removed by means of filter paper normal results are obtained.

Cooking. While many reactions oceur in eooking, the ehanges that are of paramount importanee are of a colloidal nature. Dough, for instanee, undergoes a marked alteration in its physieal 
characters during the baking proeess. The proteins are coagulated (gel formation) and the degree of dispersion of the starch is increased. Adsorbed gases are set free and the bread "rises." Further alterations take plaee in the loaf after it is removed from the oven.

The physieal nature of flesh is profoundly altered by subjection to cooking. In roasting, grilling, boiling, or frying, the meat is exposed directly to heat. The proteins in the outer layers are immediately eoagulated, thus forming a more or less impermeable covering which prevents the eseape of the meat juiees, leaving the centre portion of the flesh only slightly altered ehemieally, but with all sols eonverted into hydrogels. On the other hand, if the meat is immersed in eold water and boiled much of the protein-sol and practically all the salts and extractives are dissolved out and form soup. In this soup the protein-sol is coagulated as the temperature rises, and on eooling it is adsorbed to the surface and often is removed with the fats as a seum. The remaining meat undergoes eoagulation, but is flavourless. Stewing is a modifieation of boiling, but the extractives, salts and soluble proteins, are served as gravy. 


\title{
CHAP'TER IX
}

\author{
EN/TMIES
}

THE TOOLS OF THE CELL

\begin{abstract}
"Instances of Magic; .... By which I mean those wherein the material or efficient cause is scanty and small as compared with the work or effect produced; so that even when they are eommon, they seem like niracles, some at first sight, others even after attentive eonsideration." BACON.
\end{abstract}

'Tre living cell is a factory where, without any great display of cncrgy, work is carried on which, outside the body, could only be done by the use of strenuous processes. In the cell arc prepared secrctions which act on insoluble raw material, rendering it soluble and so fit for transit to the cell and passage into it. Within the cell, these prepared materials undergo further change; some are used as sources of energy; from others, the ecll builds up complex tissue; others again are altered somewhat and stored for future use. 'The cell manufactures from the material supplied, various substances such as are required, it may be by distant cells which are so occupied by some special process that they are unable to perform the particular synthesis. The by-products of manufacture are rendered harmless by processes possible, as yet, only in the cell. Some cells, as indicated above, have a specialised function. 'To a certain extent, all the cells of a nulticellular organism are specialised. They are divided into communities, each engaged on some special work and requiring special raw material. Some of these communities, however, engage to a certain extent in general manufacturc. 'They are almost, though not quite, self-supporting. The white cells of blood, for instance, are really uniccllular organisms. Other communities are ahmost entirely dependent on imports for their sustcnance. Norve cells, for example, form the means for intercommunication betwcen cell-communitics. Their general metabolism is peculiar.

Contrast the quiet, conomical, and neat living-factories with the places where things are made outside the body. Our manu- 
facturing cities are not spotless nor are our processes there cconomical. Smoke, sound, and slag-heaps are universal accompaniments of a manufacturing community. Most of the processes earried on in the cell have not becn reprodueed in the laboratory. Fischer, the finest physiological chemist of this or any century, has failed to synthesise the simplest protein. Fat and carbohydrates are interconvertible in vivo but not in vitro. True, steps have been taken towards the building up of a protein. Polypeptides-compounds containing eighteen amino acidshave been the crown of Fischer's efforts, but at what a cost of material, time, and energy. It las been well said that laboratory processes are just a roundabout way to the sink.

How does nature accomplish her work? What tools does she use? How does she harness her power?

Nature employs eatalytic methods. A catalyst is defined as a substance which, while not entering into the final product of the reaction, alters its rate and in some cases alters the point of equilibrium. A model may make this clcarer. A sheet of glass may be inclined at such an angle that a body placed at its upper end just slips slowly to the foot. The momentum of the sliding body may be insufficient to carry it to the foot of the glass plate, and motion may thus stop midway down the plane. If a small quantity of oil be placed either on the glass or on the bottom of the weight, it will slide rapidly to the foot of the plane. The oil remains unchanged. No energy has passed from the oil to the wcight, and yet the rate of falling and the point of equilibrium have been altered. The lubricant may be taken as representing a catalyst. Some one has said that a catalyst, like a tip to a waiter, accelerates a reaction that otherwise would proceed with infinite slowness. It takes no part in the main reaction, is adsorbed to the reacting body, and may be recovered intact at the end of the reaction by destruction of the substratc.

Catalysts are of very many kinds, and the mechanism of their action is so varied and so little understood that few, if any, general principles can be enunciated. They may be classificd according to the means they adopt to influcnce a reaction.

1. Contact agents. Many reactions seem to be accelerated by the adsorption of the reacting substance on the surface of the catalyst, e.g. cffect of colloidal catalysts.

Colloids, as we have seen, are characterised by the development of surface. If we take a sphere of metal which just fits into a eubical box, and divide that sphere into smaller spheres of uniform 
size, the same mass of metal may be paeked into the box regardless of the size of the spheres, provided they are uniform in size. Mass and total effective volume are not altered, but surface is inereased. The surface of a sphere is $4 \pi r^{2}$. If the original sphere be divided into 100 small shot, then the new surface would be $100 \times 4 \pi r_{1}{ }^{2}$ where $r_{1}=$ radius of small shot. Now $r_{1}=\sqrt{13}=4 \cdot 64$, i.e. the surfaee would be inereased over four and a half times. If the subdivision were earried still further till there were $10^{30}$ small shot, then the total adsorbing surfaee would be inereased $10,000,000,000$ times. The intensity of adsorption is ehiefly dependent on the area of adsorbing surfaee (ef. Table, p. IX.). In other words, eontaet eatalysis is indieated where the specifie surface of the catalyst eomes within the eolloidal range. Charcoal is used as an adsorbent in the clarifieation of sugar. A eubie metre of ehareoal eonsisting of particles $1 \mathrm{~mm}$. in diameter has a surface of about $600 \mathrm{sq}$. metres. If the partieles are redueed to eolloidal dimensions, say to $0 \cdot \mathbf{1} \mu$ diameter, then the adsorbing surfaee beeomes $60,000,000$ square metres.

2. Carriers. In some eases the eatalytie agent combines ehemieally with one of the reacting substanees to form an unstable intermediate compound. This, in turn, breaks up, regenerates the eatalyst, and liberates the reagent in the aetive atomic state-so ealled nascent. Many oxidations and reductions are brought about in this way.

3. Ionic Catalysts. Hydrogen and hydroxyl ions act as eatalysts for many reactions which oeeur in aqueous solution. The velocity of such a reaction in dilute solution is proportional to the eoneentration of the ions in question, provided the themodynamie environment remains constant. The ion probably acts as a earrier, forming an unstable perhydrate as intermediate product.

The great majority of vital eatalytic reaetions have, as eatalyst, an enzyme. Enzymes themselves cannot be deteeted or estimated. Their presence is made apparent by their action. By estimating the amount of the products of enzyme activity an idea of the rate of reaction may be gained. Nany attempts have been made to isolate and purify ecrtain cnzymes and, though eomplete suecess has not been granted to any investigator, mueh has been learned of their nature and of the conditions neeessary for enzyme action.

(a) Enzymes are colloidal. They ean readily be separated from crystalloids by dialysis or ultrafiltration. Chemically, they resemble their substrate or are so elosely assoeiated with their 
substrate that existence apart is impossible. It may be that the colloidal character of enzymes is the secret of their action. At any rate an artificial oxidising enzyme has been prepared by mixing a suspensoid - fincly divided manganese, with an cmulsoid gum acacia. The adsorption complex so formed, if suitable crystalloids were present, reacted as an artificial "laceasc."

(b) Enzymes retain their activity only over a very well-defined range of temperature. It is common knowledge that physiological proeesses take place most readily at body tempcrature. Every biological laboratory is equipped with deviees for keeping incubators at a constant temperature-say, $37^{\circ}-40^{\circ} \mathrm{C}$. Before these appliances had been perfected, investigators in this realn had to kecp their experinental material on their person. The Abbé Spallanzani (1729-1799), in his classical work on digestion, carried his digest-tubes in small pockets in his armpits for several days. During the Great War, when seientifie work had to be carried out in all sorts of places, at least one physiologist, bereft of gas regulators, had to resort to this simple but efficicnt method of maintaining a fairly uniform tempcrature. In this way, reactions in which they play a part differ from those usually styled ehemical. The rate of most ehemical processes is doubled or trebled when the temperature is raised $10^{\circ} \mathrm{C}$. The enzymes follow this rulc only from $0^{\circ} \mathrm{C}$. to a temperature called their optimum temperature, above which the rate decreases rapidly. The optinum temperature of most enzymes lies between $30^{\circ}$ and $40^{\circ} \mathrm{C}$. The decrease in rate of reaction when the temperature is allowed to go over $40^{\circ} \mathrm{C}$. is probably due to coagulation of the cnzyme. Increase in temperature causes altcrations in the physical state of colloidal matter. 'These altcrations, in viscosity, in eolour, and in eonductivity, all indicate an increase in the size of the colloidal particles, and consequently a deerease in thcir specific surface. 'The effective adsorbing surface is diminished. At the optinum temperature the increased chemical action duc to temperature more than balanees the decreased adsorbing surface. Beyond this tempcrature, the loss of surface becomes relatively important. If the temperature is raised till the specific surface is reduced, by coagulation, to a valuc below 10,000 , adsorbing power is totally lost, chemical action is stopped, and the enzyme is said to be dead.

In the appended figure (Fig. 12) curve 1 (dotted line) shows how, as the temperature increases, a purc chemical action is aecelerated. Curve 2 (dash line) represents the rate at which the 
effective surface is decreased by rising temperature. The process, it will be notieed, is not an instantaneous one, but proceeds with a definite velocity which increases very markedly somewhere about $30^{\circ} \mathrm{C}$. Curve 3 (firm line) is the graph of the rate of the same ehemical reaction as shown in (1), but earried out by enzyme action. 'This eurve may be drawn by plotting the differences of the ordinates of (1) and (2) on the same seale of temperatures.

(c) The hydrogen ion concentration of the medium in which the enzyme aets has much to do with its aetivity. Each enzyme is active only when the bathing fluid has a $p_{\mathrm{H}}$ of a certain range with an optimum $p_{\text {н }}$ at which the action proceeds at its best.

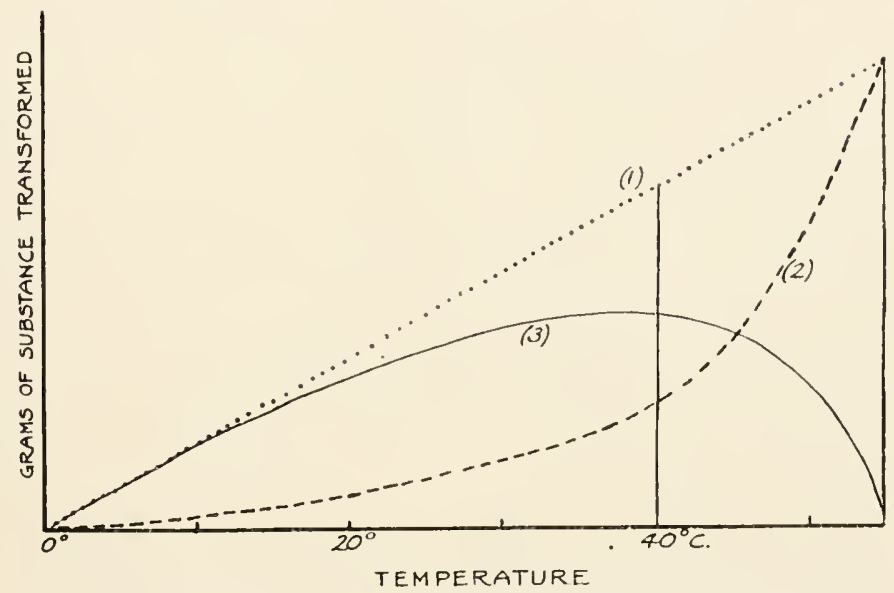

Fig. 12.-Graph to show how the effect of increase of temperature on the rate of enzyme action is the result of the interaction of two factors, (1) increased chcmical action and (2) increased destruction of enzyme.

The extraordinary sensitiveness of colloids to the $p_{n}$ has been mentioned.

(d) The crystalloid content of the substrate solution is peculiar for each enzyme. Certain salts are, of course, destructive. All salts which break up eolloidal eomplexes, inhibit or destroy enzyme action. Enzymes are "salted out" by the neutral salts that precipitate eolloids and may thus be separated.

(e) Anaesthetics have no effect on enzyme action.

Chloroform, thymol, ete., may therefore be used to keep experimental enzyme solutions free from bacteria.

To sum up, - the ranges of temperature, $p_{H}$, salt eontent, ete., all point to the colloidal nature of enzymes.

The material on which an enzyme acts is ealled its substrate, and each enzyme aets on a specific substrate and on no other. In 
many eases the name applied to the enzyme is derived from that of its substrate by altering the terminal syllable to-ase. Thus maltase acts on maltose.

$\begin{array}{ll}\text { Lactase aets on lactose } \\ \text { protease ,, } & \text { protein } \\ \text { aldehydase ,, } & \text { aldehyde } \\ \text { lipase ,, } & \text { lipin } \\ \text { peroxidase , } & \text { peroxide. }\end{array}$

Sometimes the funetion of the enzyme may be indieated by its name, viz. :
oxidase
oxidises (-peroxide + peroxidase)
eatalase
breaks down peroxides
invertase
inverts eane sugar.

The majority of enzymes of physiologieal importanee, however, have no aecepted systematic name. They are the ones first known and they were named to suit the faney of their diseoverer. Ptyalin (Gr. Pteuin-to spit) aets on stareh and should be ealled salivary amylase. Several others are in a similar position, e.g. Pepsin (Gr. Pepsis - digestion) = aeid or gastrie protease. 'Trypsin (Gr. Tribein-to rub-prepared by rubbing pancreas with sand and glyeerol) =alkaline or panereatic protease.

Some writers prefer to use names whieh point to the splitting power of the enzymes, e.g.

proteolytic or proteoclastie enzymes aet on proteins

amylolytie or amyloclastie ., ,, starehes

lipolytic or lipoelastic , , , fats.

On the other hand, hydrolytie enzymes produee their effeet by adding or subtraeting water.

Some enzymes aet in the eells while others are seereted by the eells and aet on a substrate outside the eell. The former, endoenzymes, lave been little studied. An active suspension of them may be prepared by grinding up tissue with sand and extracting with watery glyeerol. It is probable that all musele eells eontain enzymes which aet on protein-disintegration produets, either rebuilding proteins from amino aeids or breaking down these amino aeids. Similarly; the regeneration and the disintegration of earbohydrates and fats have been attributed to endo-enzymes. There are also speeial enzymes to earry out oxidations and reductions in the eell. 'The various stages in the production of uric aeid from nucleoprotein lave been studied exhaustively, and each stage has been shown to have its enzyme or series of enzymes. 
The ecto-enzymes are secreted in the various digestive juices and act on their substrates in some portion of the alimentary canal. They really act outside the body and have one function only-to break down the food into a state in which it can pass through the gut wall into the body.

Zymase Secretion. Some of these enzymes seem to be secreted ready for action. They themselves are in the active state, and the juice of which they form a part contains the necessary salts and has a suitable $P_{\mathrm{H}}$. The moment that the juice comes in contact with the substrate, digestion begins.

\section{Zymogen Secretion.}

Pseudo-activation. Others, however, enter the alimentary canal in an inactive state. Their inactivity is not due to the lack of a suitable medium, but to the form in which the enzyme appears, i.e. as a pro-enzyme or preeursor of the enzyme. An activator is required. For example, the active principle of gastric juice is secreted as pepsinogen which becomes active pepsin on coming into contact with a fluid of a certain $P_{\mathrm{H}}$. This is not a true activation. Acid does not so much activate pepsinogen as form a necessary concomitant for pepsin. That this is so may be demonstrated by neutralisation of the acid, with consequent loss of activity in the enzyme. On reacidifying digestive activity restarts. Acid and pepsin have been termed co-enzymes-a misleading term. True activation is irreversible. Once an enzyme has been rendered active its activity cammot be withdrawn or restored at will. As an example of true activation, the pancreatic enzyme trypsin may be taken. Pancreatic juice drawn from the duct contains trypsinogen. This precursor gives birth to active trypsin on coming into contact with enterokinase of the succus entericus. The meehanism of the change is unknown. Enterokinase is an enzyme whose sole function is to act on the zymogen form of trypsin. No other protease can be substituted. The rate of activation is peculiar and suggests autocatalysisi.e. it starts slowly at first and the rate rapidly increases with time. Vernon suggests that a third cnzyme, deuterase, aets as a middleman.

A simpler explanation might be found in the adjustment of equilibrium between two hydrophilic colloids with different crystalloid contents.

In order to explain the immunity from digestion of the living cells, anti-enzymes have been postulated. The stomach wall, for B. B. 
instanee, contains protein which is not digested by gastric protease as long as the blood supply is intact. Occhusion of the blood supply to any part leads to the formation of a gastric ulcer. Parasitic worms live in eontact with enzymes that would cause rapid digestion in the event of their death. Neither Cohnheim nor Bayliss is inclined to aceept the anti-enzyme idea as correct. (1) 'The latter has shown that the phenomenon can be explained without any such hypothesis-e.g. by the adsorption of the enzyme by another colloid. Agitation of a suspension of trypsin with charcoal results in a loss of digestive activity due to the adsorption of the enzyme by the chareoal. The chareoal here acts as an anti-cnzyme. (2) Enzymes as colloids are sensitive to any alteration in their environment. A shight alteration in salt content, colloid or water conecntration, or $P_{n}$ leads to alteration in their power of adsorbing or being adsorbed by thcir substrate.

\section{Specificity.}

Each enzyme acts on a specific substrate, and if the substratc is a mixture of optical isomers, one of these (and always the same one) will be scleeted for preferential treatment. Examples may make this clearer. If maltase be added under suitable conditions to the following disaccharides it will be found to act on one only -maltose.

TABLE XVI.

\begin{tabular}{|c|c|c|c|c|c|}
\hline \multicolumn{3}{|c|}{ Sugar. } & \multicolumn{2}{|l|}{ Componeuts. } & \multirow[t]{2}{*}{ split by. } \\
\hline Maltose & - & - & Glucose $u$ glucoside & - & \\
\hline Isomaltose & & - & Glucose $\beta$ glucoside & - & Emulsin. \\
\hline Centiobiose & & - & Glucose $\beta$ glucoside & - & Enuulsin. \\
\hline Cellobiose & & - & Glucose $\beta$ glucoside & - & Emulsin. \\
\hline Lactose & - & - & Glucose $\beta$ galactoside & - & Lactase (crude emulsin). \\
\hline Isolactose & - & - & Glucose galactoside & - & $?$ \\
\hline Melibiose & - & - & Glucose galactoside & - & Melibiase (crude emulsin) \\
\hline Trehalose & & - & Glucose + glucose - & - & Trehalase. \\
\hline Cane Sugar & & - & Glucose + fructose - & - & Invertase. \\
\hline Turanose & - & - & Glucose + fructose - & - & ? (not invertase). \\
\hline
\end{tabular}


Similarly, lactose and melibiose are both ghueose galactosides differing only in the hydroxyl of the glueose molecule united to the galactoside. As galaetosides, both are slowly hydrolysed by erude emulsin (known to be a mixture of at least three enzymes). Lactase is, however, without action on melibiose, and melibiase does not split milk sugar. Till further experimental work has been done attempted explanation of these faets is mere guesswork. Fiseher has suggested that the enzyme is to its substrate as a key is to its own particular loek. The evidence at present available does not altogether lend itself to this explanation. It looks as if a careful study of the alterations brought about in the eonfiguration of eolloids by shight modifieations of the surrounding eonditions might lead towards an aecptable explanation of speeificity. (Sce also Optical Activity, p. 101.)

Weight is given to this suggestion by examination of the synthesising power of enzymes. Since enzymes aecelerate reaetions that would take place without them and all reaetions are theoretically reversible, the synthesis of complex bodies from their eonstituents might be expeeted by the aid of the same enzyme as brought about the splitting of the eomplex to simple. 'Tliat is, a lipase should not only split a fat into fatty acid + glyeerol, but should regenerate fat from fatty aeid + glyeerol.

A reversible or balanced reaction is one in which, under definite conditions, there is a certain equilibrium point at whieh the amount of material being broken down is exactly balaneed by the amount being built up. For example, take a stoppered bottle half full of water. Two proeesses are going on simultaneously. (a) Liquid water is undergoing vaporisation and the gaseous hydrol is passing into the air, (b) Gaseous water particles are passing from the air into the water to form, say, dihydrol. When the air is saturated with humidity for that particular temperature, exaetly the same number of water moleeules will leave the water as enter it. Now alter the conditions, (1) open the bottle to a dry atmosphere, i.e. to unlimited air containing infinitely little moisture. 'The reaction will proeeed entirely in one directionevaporation. (2) If the bottle be opened to an air supersaturated with moisture, the reverse proeess, eondensation, will predominate.

The effeet of the removal of the maltose in increasing the speed of digestion of starch is shown very clearly in the following experiment by Lea, in which the course of the digestion of the starch was followed by the iodine reaction. In one case, the 
digestion was carricel on in a beaker, and in the other in a dialysing tube immersed in rumning water so that the maltose dialysed out.

TABLE XVII.

\begin{tabular}{c|l|l}
\hline Time (in mins.). & Dinlysed starch sulution. & \multicolumn{1}{c}{ Nut Dialysed. } \\
\hline 0 & Pure blue & T'ure blue \\
20 & Trace of violet & Tiolet \\
20 & Red with violet tinge & Red with violet \\
20 & Colourless & Very faint red \\
15 &, & Colourless \\
\hline
\end{tabular}

Eeto-cnzymes gencrally have a eatalytie function. 'The byproducts of their aetivity are removed as rapidly as they are formed. Many endo-enzymes have for the most part an anabolie activity. They are brought into eontact with simple eompounds and proeed to build them into more complex substanees. All cnzymes have both breaking-down and building-up funetions. The eonditions under which they work determine their function.

A peculiar phenomenon has been noted in this eonneetion, namely, that the substanee built up by an enzyme may not be quite the same as the eomplex substance originally broken down by it. Maltase, for example, splits maltose into molecules of glueose, but the substance formed by the aetion of maltase on glueose is not maltose but its $\beta$ form, isomaltose. On the other hand, isomaltose is split by emulsin into glueose, while emulsin causes two glueose moleeules to unite to form maltose. This is explained by supposing that the nature of the enzyme-substrate complex influences the rate of the reaetion. If $\mathbf{H C l}$ is used as (atalyst, the equilibrium point is reached with gheose, maltose, and isomaltose present in the same proportions, irrespective of the original proportions present in the substrate. The point of equilibrimm is ehanged by the enzyme. If maltase is used, the proportion of maltose is diminished, but if emulsin is the enzyme employed the point of equilibrium is shifted towards isomaltose. The whole subjeet requires re-examination from the point of view of eolloid chemistry, especially with regard to the influenee of $\boldsymbol{P}_{\mathrm{H}}$ on aetivity. 'The following table gives the optimum $\boldsymbol{P}_{\mathrm{H}}$ for eertain enzymes: 
TABLE XVIIT.

\begin{tabular}{|c|c|c|c|c|c|c|c|c|}
\hline Ptyalin & - & - & - & - & - & - & - & $6 \cdot 7$ \\
\hline Invertase & - & - & - & - & - & - & - & 4.5 \\
\hline Maltase a & cting on $\mathrm{m}$ & naltose & & - & - & - & - & $6 \cdot 6$ \\
\hline, & & nethyl & I-gluc & sside & & - & . & $6 \cdot 2$ \\
\hline Pancreati & c lipase & - & - & - & . & - & & $8 \cdot 0$ \\
\hline Pepsin on & proteins & - & - & - & . & - & - & $1 \cdot 5 \cdot 2 \cdot 5$ \\
\hline & (plastein & forma & ation) & - & & - & . & $1 \cdot 0$ \\
\hline Rennin & $-1 \quad-$ & - & - & - & & - & & $5 \cdot 7$ \\
\hline Trypsin o & n peptone & - & - & - & & - & & $7 \cdot 7$ \\
\hline & gelatin & - & - & - & & - & & $9 \cdot 7$ \\
\hline Erepsin & $-\quad-$ & - & - & - & & - & & $7 \cdot 8$ \\
\hline Urease (I & Decomp. of & f urea) & - & - & & - & & $8 \cdot 7$ \\
\hline,$\quad(S$ & yuth. , & & - & - & - & - & - & $7 \cdot 0$ \\
\hline
\end{tabular}

Much has been made of the fact that enzymes seem to be rather finical as to what compounds they will attack. Two compounds may exist side by side similar exeept in one respeet. They may differ in strueture as the right liand differs from the left. That is, the one compound is structurally a mirror image of the other. The enzyme selects one for attention and hardly looks at the other. If the enzyme is engaged in synthesis, it invariably builds right-handed sugars and left-handed leueine (an amino aeid). If engaged on demolition the enzyme will hydrolyse all or nearly all of the right-handed sugar before touching its mirror image, and similarly with leueine. IIow ean this be explained?

\section{Optical Activity.}

It is obvious that a paper-eutter or strip of metal ean pass through a book only in the plane of the pages, and may pass through a second book when both books are similarly placed or when one has been plaeed upside down, i.e. rotated on its eentral axis $A C$ by $180^{\circ}$. If, after passing through book one, the strip of metal is given a twist, then book two will have to be turned through a corresponding angle before the metal will slip through its pages. The rotation of book two may be taken as an index of the twisting of the plane of the netal strip. Various factors may modify this twisting:

(a) The nature of the metal. The same twisting foree would produce very different results in, say, eopper and stecl.

(b) The length of the strip exposed to the twisting foree. The longer the strip between $B 1$ and $B 2$ the greater will be the twisting, other conditions being equal. 
(c) Temperature. Inerease in temperature will inerease the twisting.

(d) Obviously the nature and strength of the distorting foree will modify the angle of rotation of the strip.

A polarimeter is a deviee in which these basal facts are applied to light. If a beam of light (at $A$ ) is made to take the place of the metal strip and for the books we substitute some optical arrangement which will allow light vibrating in one plane only to pass, then the eye (at $C$ ) would see a lighted field when $B 1$ and $B 2$ were in the same plane and only then. As we shall see presently, the plane in which polarised light vibrates may be twisted by the action of various crystals and of several substanees

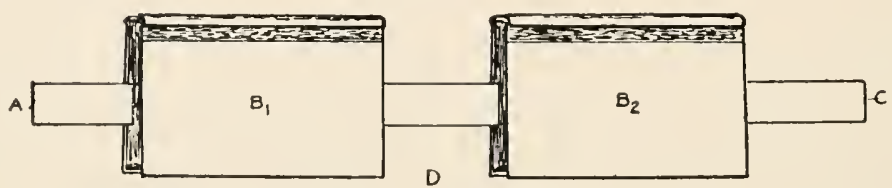

Fia. 13.- Model of polarimeter. $A=$ souree of light, $B_{1}=$ polariser, $D=$ point at which twisting force is applied, $B_{2}$ analyser, the amount of twisting at $\left.l\right)$ can be estimated from the angle through which $b_{2}$ has to be rotated to allow of the passage of the metal strip $A C, C=$ eyepiece.

in solution and when fused. The amount of the rotation depends on the factors enumerated above, viz. :

(a) The nature of the light. The angle of rotation depends on the wave length of the light; the shorter the wave length the greater the rotation.

(b) The length of beam exposed to the optically active material.

(c) Temperature as above.

(d) I. Nature of the optically active material : each such has a specifie rotatory power.

II. Strength of solution; double the eonecntration produees double the rotation.

The modification of a prism for produeing light vibrating in one plane was devised by Nicol and so bears his name. He made use of a property of Ieeland spar (ealcium earbonate), namely, its double refraction. Iceland spar erystallises in many forms, but they are all split most readily along eertain planes which are all inelined to each other at fixed angles, and by eleavage the erystals ean always be redueed to the rhombohedral form. If such a erystal of Ieeland spar be placed on a pieec of paper in the eentre of which a black dot has been made, on looking down through the erystal, two blaek dots will be seen. If now the erystal be rotated without lifting it from the paper, one dark spot will remain station- 
ary while the other will rotate round it as a centre. This phenomenon of double refraction may be demonstrated in another way. If a strong beam of light be allowed to fall on one of the faces of a crystal of Iceland spar and the transmitted light be received on a sereen, two spots of light will be seen, and if the erystal be rotated as before one spot will circle round the other. That is, the beam of light has been split into two rays of equal intensity. One ray, the stationary one, has travelled through the crystal just as it would pass through glass - obeying the ordinary laws of

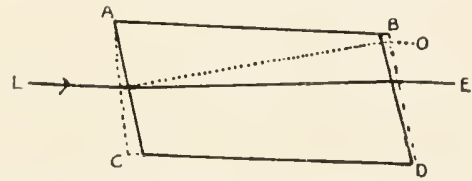

Fig, 14-Diagram of the paths of the ordinary and extraordinary rays of light through a rhombohedron of lceland spar. The light, falling on the face $1 C$ divides into two rays, both of which are polarised. The extraordinary ray $(E)$ is the lesser refracted ray : the ordinary ray $(O)$ is the more refracted ray.

refraction (Snell's Law). It is ealled the ordinary ray. 'The other ray is ealled the extraordinary ray, and it does not obey the ordinary law of refraetion. It is this ray whieh gives the movable image when the erystal is rotated. (Snell's Law states that the ratio of the sine of the angle of ineidence to the sine of the angle of refraction is eonstant, $\frac{\sin \alpha}{\sin \beta}=\mu$.

Both rays are plane polarised, but in planes at right angles to one another. Nicol's problem was to get rid of one of these rays

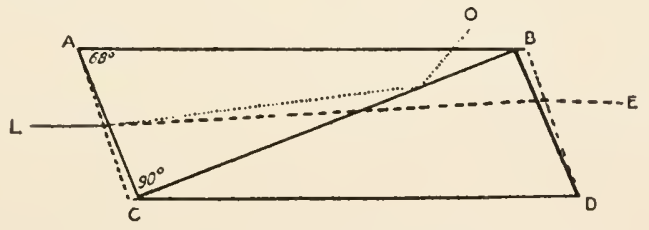

FIG. 15.-Diagram of refraction in a Nicol's prism.

so as to get light vibrating in one plane. The method he adopted is very ingenious. The angular separation between the ordinary and extraordinary rays is not very great, so that it is not possible to sereen off one of the rays unless a very thick erystal be employed.

A rhomb of Ieeland spar was eut in two by a plane $B C$ (Fig. 15) perpendieular to the prineipal plane for the faee $A B$. The eut surfaces were earefully polished and then ecmented in their original position by a thin film of Canada balsam. The index of refraetion of balsam $(1 \cdot 55)$ is intermediate between the minimum 
values for the ordinary ray $(1 \cdot 66)$ and the extraordinary ray $(1 \cdot 48)$. Therefore the ordinary ray falling on the surface $A C$ at an angle greater than the eritieal angle will be totally reflected, while the extraordinary ray will pass through the prism. This ray, as we have stated above, is plane polarised. To the mnaided eye it differs in no way from ordinary light, but, when viewed through a second Nicol's prism, its condition is reeognised by the fact that on rotating the prism the beam of light from the first prism alters in colour, passing through the various colours of the speetrum and returning again to white when the rotation has been earried through $180^{\circ}$. If monochromatic light has been used the field will be illuminated when the prineipal planes of the two prisms are parallel. On rotating the second prism through an angle of $90^{\circ}$ the ray is extinguished and

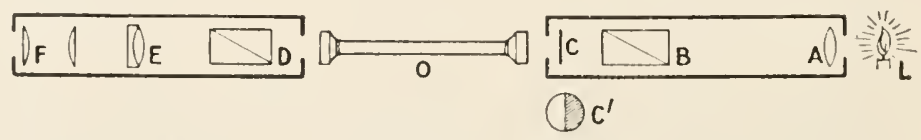

FIG. 16.-Diagram of Laurent Polarimeter. Monoeluromatic light from the source $L$ passes through the lens $A$ which renders the rays of liglit parallel, and then through the polariser $B$. $O$ is the observation tube containing the fluid under examination, while $D$ is the analysing Nicol prism. The field of view is observed through the telescope $E F$. At $C$, the circular opening of the tube carrying the polarising prism is lialf eovered by a thin quartiz plate (shown at $C^{\prime \prime}$ ), the thickness of which is such that the light in passing tluromgh the plate is altered in pliase by liali a wave-lengtl.

the prisms are said to be crossed. If the rotation be earried on to $180^{\circ}$ the planes are again parallel and again the field is bright, and so on. In two positions the planes are parallel and in two at right angles. The first prism is called the polariser, the second, by which alone we can recognise the polarisation of the light from 1, is called the analyser (Fig. 16). If now a plate of quartz cut with the faces perpendieular to the optic axis be placed between crossed Nicols, it will be found that some light passes through the analyser. That is, the quartz has rotated the plane of the light polarised by the first prism. By rotating the analyser a position can be found when all light is stopped. The amount of rotation of the analysing Nieol is a measure of the rotation of the plane of polarised light by quartz. A body which has this property of rotating the plane of polarised light is said to be optically active.

Some samples of quartz rotate the plane of polarisation in a elockwise or right-handed (or + ) direetion, other samples have a reverse (or -) direction of rotation. (The direction is taken as from the direction in which the light is travelling, not from the analysing eye.) A dextrorotatory piece of quartz superimposed 
on a similar lacvorotatory piece would be optically inactive. Physical examination of quartz erystals shows that $d$-erystals differ from l-erystals in one respect only, viz. : the position of their sceondary facets. The ordinary form of a quartz crystal is a six-sided prism topped by a six-sided pyramid. The alternate solid angles where two prism faces meet two pyramid faces is gencrally levelled off to form a small secondary face or facet. When the erystal is viewed with the pyramid upmost and these faects slope to the right, the specimen will rotate the plane of polarisation to the right, and vice versa when the facets incline to the left. The one erystal is a mirror image of the other, and is called its optical isomer.

If the erystal is symmetrical with no secondary facets then optical activity is impossible. Any perfect cube is an exact

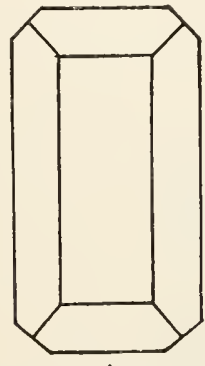

A

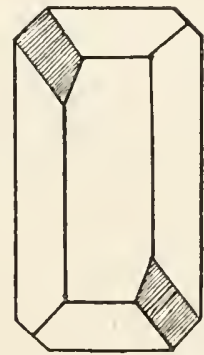

B

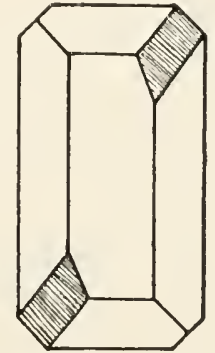

C

Fir. 17.--Crystals of Ammonium Hydrogen Halate. (a) Symmetrical crystal, optically inactive; (b) Asymmetrical crystal, dextrorotatory; (c) Asymmetrical crystal, laevorotatory. (Aiter van 't Hotf.)

duplicate of any other perfect eube. Such holohedral erystals ean be prepared. In Fig. 17, $A$ represents a lolohedral erystal of inactive anmonium hydrogen malate: $B$ represents a dextrorotatory crystal, while $C$ represents its mirror image, a lacvorotatory crystal of this salt.

Of amorphous bodies which are optically active, with the execption of one or two little known compounds of nitrogen, all are compounds of earbon in which one or more of the earbon atoms has its valencies satisfied by four different at oms or radicles. Such a earbon atom is termed asymmetric (Fig. 18).

Compounds containing asymmetric carbon atoms are a geometrical necessity and exist in proteins, earbohydrates and fats. Each momber of a pair of optical isomers is identically equal in every respect but one. As stated at the beginning of this seetion, enzymes preferentially act on one isomer. For example, those 
sugars which are dextrorotatory are more readily hydrolysed than their laevorotatory isomers. The mould penicillium glaucum destroys $l$-leucine and $d$-glutamie acid without having any extensive action on $d$-leueine or $l$-glutamic acid.

Fiseher showed that the proteoclastic enzyme, trypsin, aeted asymmetrically on synthetic polypeptides, e.g. inactive d.l.alanyl-lencine was digested in such a way that only the compound of $d$-alanine and $l$-leueine was hydrolysed, whereas the compound of $d$-alanine and $d$-leucine was undigested. That is. the natural

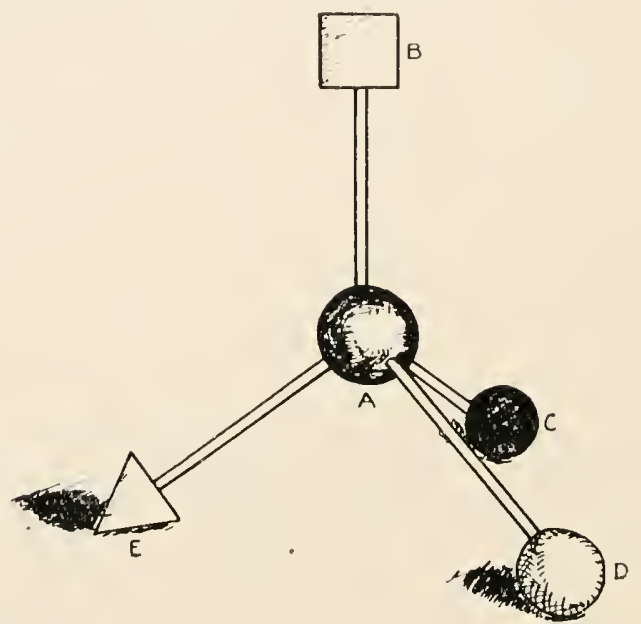

FIG. 18.--Diagram of a carbon atom $(A)$ having its valencies supplied with four different atoms $B, C, D, E$. The mirror image of this structure would be its optical isomer.

isomers were destroyed by the enzyme before the isomers not oecurring in nature were manifestly attacked.

Much research has been done to elueidate the reason for this preferential treatment, and some faneiful explanations have been put forward. The problem is a diffieult one and the bias of the enzyme at present inexplicable. One faet, however, may be of importanee for future development, viz. : if inactive reagents are used to destroy or produee eompounds having an asymmetric $C$ atom, then both isomers will be produeed or destroyed equally ; if, on the other hand, optieally aetive agents are employed, one isomer has preferential treatment. 


\title{
CHAP'TER X
}

\section{MEMBRANES (PLASMAHAU'T)}

\author{
THE IIOUSE OF THE CELT.
}

" The retention of an individuality by the eell must be determined by ehemieal and physieal differenees between this layer and the surrounding fluid."

StarLing.

Tre unit of life is the eell. It follows that all ehanges that affeet life take place in the eell. The metabolism of a eomplex organism is the sum of the ehanges of the eells that eompose it. It is therefore logieal to study unieellular animals with a view to the application of the knowledge so gained to the elueidation of the more intrieate problems of multicellular organisms.

We have seen that the eell consists of protoplasm, which may be regarded as a watery solution, eontaining all three elasses of solutes (i.e. eolloids, dissoeiated and non-dissoeiated erystalloids) and also substanees in suspension. Now it is elear, that as amoeba, for instanee, lives in water, some skin or pelliele is neeessary to prevent the protoplasm from suffering infinite dilution. Further, if osmotie pressure is to be eonverted into hydraulie pressure, a membrane is neeessary, as we have seen. In plants, growth is, in part, due to osmotie energy, and therefore plant eells must be bounded by a eell wall which will allow the passage of water, but not of, say, sugars. Nägeli, Pfeffer, De Vries and others have demonstrated the existenee of such a eell wall. If plant eells are immersed in a hypertonie salt solution, i.e. in a salt solution having a greater osmotie pressure than the osmotic pressure of the eell contents, then exosmosis will take plaee. Water will pass from the eell, eausing the eell substance to shrink. But the eell wall does not shrink and a spaee is left between the eontents and the eontainer, so rendering the latter apparent. This proeess is termed plasmolysis.

The eell wall differs eonsiderably from the eell eontents in ehemieal eomposition as well as in physieal state. It is a seeretion 
or exeretion from the cell. In plants, it gencrally eonsists of eellulose. Certain animals develop an cxoskelcton of the exereted salt of linc, of siliea or of chitin. These excreted membranes should not be confounded with the true cell membranc or plasmahaut. which term connotes the layer of cell protoplasm which. in animal and plant eells alike, lies between eell and environment. Only through this layer or membrane ean the cell be influeneed by changes in the surrounding medium.

The presence of a covering for animal eells cannot be proved in quite the same way. Anmal eell membranes are more elastie than those of plants. Microseopie examination shows generally a differenee in refractive index (page 103) round the border of cells. Free cells like red blood corpuseles may be submitted to experiments similar to the plasmolytic one detailed above. If corpuscles are put into a solution of lower osmotic pressure (hypotonie solution) than their eontents, they will swell up beeause of the passage inwards of water, i.e. endosmosis, and will probably burst. This is ealled haemolysis, and may be brought about in other ways, which are, however, all obviously methods for destroying a membrane (page 243). Artifieial membrancs may be made which act in a similar way to animal eell coverings. These experiments, together with the fact that it is quite impossible to conceive of energy changes taking place in naked protoplasm, are sufficient evidence of the need for cell membranes.

Iuch researeh and much speeulation has been published on the nature of these membranes. What conditions have they to fulfil? At least four qualities are essential :

(1) The membrane must prevent the outward passage of cell substance while allowing water to pass freely in and out.

(2) The membrane nust permit of the intake of nutrient material and of the output of undigested and nonutilised material.

(3) The waste produets of metabolism, gascous and liquid, must find a way out, while oxygen must find a way in.

(4) Finally, the membrane must be of such a nature as to allow of expansion. Mere elasticity will not answer this end. The membrane must be capable of almost instantaneous growth.

The animal cell membrane nust not be eonsidered as a box or container in which the eell protoplasm has been placed. It is not something apart from the eell like an eggshell. It is not even 
something made by the eell and deposited outside like the erustaeean shell. It is just as mueh part of the cell as the protoplasm itself. Unless this point is understood. diffieulties will be found in the study of alterations in permeability. The animal cell membrane must be considered as a part of the cell, having a similar metabolism to the interior of the eell and dying when the rest of the cell dies.

The exaet ehemical composition of animal cell membranes is not known, but modem researeh tends to show that it is similar to that of the eell as a whole. We are meantime more coneerned with their formation and structure. The fourth essential quality of a cell membrane mentioned above gives a elue as to the mode of its. origin.

\section{Formation.}

The only membrane that eould answer to this test, i.e. as eapable of instantaneous formation and expansion, is one formed by a Gibbs-Thomson deposition of solutes on the surfaces (see p. 48). That such a membrane ean be formed is readily demonstrable.

1. Brailsford Robertson's artificial amocba (Part II. p. 403) shows mobility and keeps intaet for some time.

2. Egg albumin solution forms a pellicle or eoat of great toughness, cf. meringues.

3. 'Traube's membranes, espeeially in the hands of Leduc (Part I1. p. 399), yield life-like growths.

Strietly speaking, a substanee which is adsorbed under certain eireumstances will be set free when the circumstanees are reversed. Many substanees, however, undergo alteration in physical state on adsorption. For example, in the formation of meringues, the egg white beeomes eoagulated and so becomes incapable of reentering the liquid state. Sueh an irreversible reaction is termed pseudo-adsorption.

Adsorption (including pseudo-adsorption) is, as we have seen in the last chapter, dependent on the ability of the adsorbed substance to lower surface tension. Now, from its very nature, surface tension has a negative temperature coefficient. Inerease of temperature lowers surface tension. It follows that increase of temperature will diminish the amount of material adsorbed, and, eonversely, a deerease in temperature will inerease the adsorbability of substanees in solution. Can we associate with this fact the varying thiekness of membranes aceording to their degree of exposure to cold? 


\section{Structure.}

In spite of many attempts to overthrow it, the most satisfaetory explanation of the structure of a cell membrane is the pore theory. The question as to whether the pores are like those of a sponge or like those of a honeyeomb is not of importance, for the membrane is of extreme thinness. It has been proved that the rate of passage of a fluid through an artificial membrane is the same as the rate of flow through capillary tubes. For our purpose, then, we may consider that cell membranes are composed of some of the eell material eoncentrated at the surface and admitting water, ete., through the spaées between the molceules or other eomplexes which compose this layer.

\section{Permeability.}

Artificial membranes may be prepared of any desired permeability (Part II. p. 405). A membranc which allows water to pass through and no solute is said to be semipermeable. A perfect semipermeable membrane has never been prepared, though Traube's copper ferroeyanide membranes are very nearly so.

If an animal membrane, such as a pig's bladder, be stretched across the end of a eylindrieal tube so as to form a drum-head, one has a simple dialysing membrane such as was employed by Graham in his elassieal researches. When this membraneeovered end is immersed in water, the liquid eannot rush into the dialysing vessel all at once, but slowly oozes through. A solution of sodium chloride passes in almost as rapidly as water alone. Sugar passes through the membrane slowly, while a stareh solution fails to penetrate at all.

A list of hydrated ions eould be drawn up in the order of their magnitude or, which comes to the same thing, in the order of their speed of migration. With certain apparent exceptions, which will be mentioned immediately, the ability to pass through a membrane is a function of the size (or speed) of a partiele in solution. By a earcful seleetion of membranes a mixed solution may be separated into its constituent solutes. In general, a membrane aets like a filter-paper made infinitely fine-so that ultramieroseopic partieles may be retained on the filter. Indeed, the proeess of separating substances in solution from one another has been termed "ultra-filtration."

A living membrane, however, alters in its permeability. It may at one time allow a solute to pass through and at another prevent its passage: or at times allow a comparatively large partiele to 
pass through while retaining smaller particles. It may also appear to "select" certain constituents of the surrounding fluid to pass in, seemingly quite irrespective of their size compared with their fellows. Again, the process of negative osmosis may take place through an animal membrane. That is, water may pass from the more concentrated side to the more dilute side. 'This flow of water takes place against osmotic pressure. Of course a cell is in close juxtaposition to several other cells, and therefore the composition, structure, and permeability of any one eell membrane may vary from place to place according to the nature of the interface. One interface may ke such as to allow free passage of solutes to which other interfaees may be semipermeable.

Alterations in permeability may be due to (1) alterations in the membrane or (2) alterations in the material presented to it.

(1) The membrane itself may undergo change in composition and permeability as the eell contents or the environment change in (a) composition, or in (b) physical state. The composition of the surface layer depends on the substances present in solution in the interior and on the nature of the interface. Any alteration in the chemical state of either of these phases will produce such an alteration at the surface as will alter permeability. The electrical double layer on the surface plays a considerable part in deciding the composition of the membrane. If a solute of opposite electrical sign to the membrane come within the electrieal sphere of attraction it will be adsorbed and will cither thicken the membrane or may occlude, wholly or partially, some of the interstices. In any case, adsorption will alter the permeability of the adsorbing surface. It may have a further effect. 'The adsorbed matcrial may cnter into combination, chenical or physical, with the membrane, producing a sccond alteration in permcability. It may cven cause a third alteration, by ultimately passing through the membrane and going into solution on the other side.

If the adsorbed material be an amphoteric colloid, then the electrical charge on the niembrane may be modified and so produce apparently abnormal osmosis. Collodion membranes, for instance, are practically indifferent as regards electrical charge. Water passes through these membranes into solutions of nonelectrolytes and of electrolytes more concentrated than $\frac{-4}{8}$ at a rate in accordance with the van t'Hoff theory of osmotic pressure, i.e. a lincar function of the concentration of the particles (colloidal 
aggregates, molecules or hydrated ions) in solution. 'Treatment of the membrane with an amphoteric colloid like gelatine or haemoglobin eauses an anomalous osmotic pressure. These colloids, as we have seen, form salts with either acids or bases. One may prepare, for instance, gelatine hydrochloride or sodium gelatinate. In the first instance, cationic gelatine has a + charge, while in the second ease it acts as an anion and so has a - eharge. The result of this is that when the membrane has a positive charge it will attraet water as if the water had a negative eharge, and viee zersa. That is, the rate at which water will pass through the membrane will depend on the intensity of the charge in the membrane, not on the sign of the charge.

(2) The material presented to the membrane may undergo changes :

(i) Its partieles may be inereased in size,

(a) by adsorption of other material,

(b) by eombining with similar particles.

(e) by hydration.

An inerease in size, if sufficiently great, will prevent passage where previously passage was free.

(ii) 'The eonverse may take place, i.e. the particles may be dissociated and so be able to pass through interstiees previously too narrow for them.

(iii) The electrical state of the material on either side of this membrane may undergo alterations. This is a general statement in which is ineluded the effect of hydrogen ion concentration on permeability. 'The diffusion of water through an indifferent membrane depends on two forees. (a) pure osmosis, (b) electrical osmosis eaused by the presence of electrolytes. The intensity of the electrieal forces depends on the nature of the eleetrolytes. Neutral salts of mono- or di-valent eations influenee the rate of diffusion as if they conferred a positive charge upon the water molecules. In other words, the molecules of the pure solvent are attracted by the eharge on the anions and repelled by the charge on the cations of the electrolyte, the attractive and repulsive forees obviously inereasing with the valency of the ion and diminishing inversely with the radius of the ion. Alkalies act in the same way. If, however, one eonsiders neutral and aeid salts of tri- or tetra-valent eations then one finds the reverse to be the ease. 'The water molecules aet as if they were negatively charged and so are attracted by the eations and repelled by the anions of the electrolyte. Aeids aet in this way and have a high eleetro- 
statie effect on aceount of the small ionic radius of the hydrogen ion. It is important to note that eertain salts of biological interest have a marker electrostatie value-very dilute solutions of oxalates, phosphates, and eitrates and of the tetra-valent ion $\mathrm{Fe}(\mathrm{CN})_{2}$ attract water violently. On the other hand, the effeet of the anion may be masked by the opposite clectrostatic effeet of the cation. As the valeney of the eation inereases, the attractive forec of the anion decreases. ('aleium ehloride, for instanec, has little more action than distilled water, beeause the calcium almost neutralises two positive charges on the two anionie charges (ef. Iydrophilic property of Ca, Chap. VIII.).

The value of this electrical foree has been determined by Loch in a very neat manner. Inside a collodion bag he plaeed an $\boldsymbol{M} / \mathbf{1} \mathbf{2 8}$ solution of $\mathrm{KCl}$ and outside the bag an $\boldsymbol{M} / \mathbf{6 4}$ solution of sugar. These solutions are approximately isotonic, i.e. movement of water through the membrane by osmotic forces is thus eliminated. If found that water did diffuse from the sugar solution to the KCl solution. 'This transport of water must be due to the cleetrieal pull of the $\mathrm{KCl}$. He then raised the concentration of the sugar outside the bag till its osmotie pressure just balanced the attractive forces of the $\mathrm{KCl}$. 'The sugar solution was now $M / 8$. Therefore the elcetrical forces which are at work eorrespond to an osmotic pressure which is the difference between the osmotic pressures of an $M / 8$ and an $M / 64$ solution of sugar $=\frac{7 M}{64}=\frac{7 \times 22 \cdot 4}{64}$ $=\mathbf{2}+4$ atmos. (approx.).

These clectrical forces also account for negative osmosis - the passage of water from a more to a less eoncentrated solution. As far back as 1835. Dutroehet observed that water diffused out of a pig's bladder filled with a dilute solution of oxalie aeid, into pure water. Early investigators tried to explain this on the assumption that there was a greater imbibition of water on the acid side of the membrane and a lesser on the side in contact with the pure water. In 1914 negative osmosis was observed taking place through a poreclain filter and, therefore, the imbibition theory becomes untenable. Loeb has shown that negative osmosis oceurs when neutral salts as well as aeids and alkalies in ecrtain well-defined concentrations are separated from water by a membrane capable of taking up cither a positive or a negative charge. At these concentrations the repelling aetion of the ion with the same sign of charge as that of water becomes greater than the attractive action of the ion with the opposite charge. 
The appended eurve (from Loeb) shows the effeet of coneentration on the attractive force of $\mathrm{Na}_{2} \mathrm{HPO}_{4}$ on water. Various coneentrations of this salt from $M / 8192$ to $M / 8$ werc put into collodion bags fitted with a manometer. 'The ordinates are the values for the rise in the level of the solution in the glass tube (after the first twenty minutes) which oecurred when the eollodion bags filled with different coneentrations of disodium phosphate were dipped

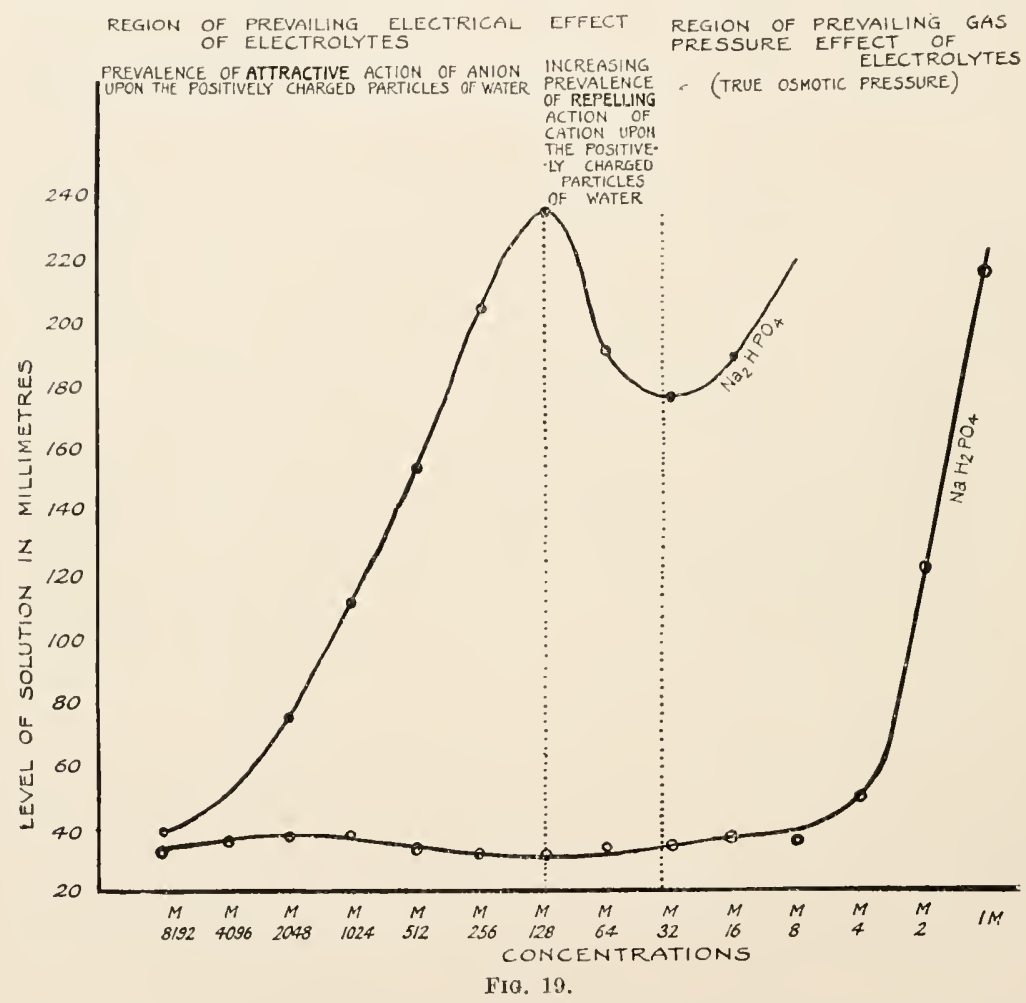

into beakers of distilled water. The abscissae are the logarithms of the concentrations of the phosphate solutions. This eurve shows clearly that at a very low eoncentration of the salt the rate of diffusion of water from pure solvent into the solution through the collodion membranc inereases rapidly with inereasing eoncentration, and that it reaches a maximum at a eomparatively low coneentration of the salt, viz. : M/128. This inercase in rate has becn shown to be due to the predominanee of the attractive action of the anion upon the positively charged hydrols. With an inercase in concentration beyond $M / 128$ the rate of diffusion 
falls abruptly to reaeh a minimum at a eoneentration of $M / 16$. This fall is eaused by the inereasing prevalenee of the repelling aetion of the eation on the positively eharged partieles of water. Further inerease in concentration eauses an inerease of rate of diffusion. This final passage of water into the solution is due to true osmotie pressure. At the concentrations zohere the rate of diffusion is decreased, i.e. where the curve falls $(\boldsymbol{M} / 256-\boldsymbol{M} / \mathbf{1 6}$ in the case of $\mathrm{Na}_{2} \mathrm{HPO}_{4}$ ) watcr passcs from the solution through the collodion membrane to the pure solvcnt. That is, negative osmosis takes plaee.

Negative osmosis is a partieular instanee of electrical osmosis.

In Part II. p. 399 will be found anode details of an experiment whieh shows that water ean be drawn through eertain eolloidal membranes by direet eleetrieal means. If the $p I I$ of the water is greater than 7 (i.e. aeidulated water) the attraetion is towards the anode, but if the $p I I$ is less than 7 , the water rises in the tube eontaining the eathode. To obtain this result, the membrane used must be of material eapable of eombining either with anions or with eations-e.g. proteins. Collodion does not form sueh eompounds and so eannot form a membrane suitable for experiments $\begin{aligned} & \text { single large pore to demonstrate electrical } \\ & \text { osmosis. }\end{aligned}$ on eleetrieal osmosis until it has adsorbed an amphoterie eolloid. In Fig. 20 is represented a gelatine-eollodion membrane in aeidulated water-i.e. in water with a slight exeess of hydrogen ions. The membrane adsorbs some of these exeess jons, interaets ehemieally with them to form gelatine hydroehloride and so aequires a positive eleetrieal eharge. The passage of a eurrent through the membrane and water depends on the earriage of the elarge by ions - in this ease $\mathrm{H}^{+}$and $\mathrm{OH}^{-}$. The negative ions are attraeted to the positively eharged membrane till the eharge on it is equalised. The positive ions attraeted by the negative potential pressure at the eathode, pass through the membrane, and raise the hydrostatie pressure on the eathodal side. It is 
obvious that the hydrogen ion concentration must inerease at the eathode and decrease at the anode. (Pole funding paper is blotting paper soaked in phenolphthalein-an indicator which while colourless in neutral solutions becomes red in distinetly alkaline solutions).

Water passes through the membrane in the reverse way when the solution on both sides of the membrane is alkaline. A dilute acid solution separated from a dilute alkaline solution of the same relative strength by an amphoteric nembrane will produce a passage of water from the anodal to the cathodal side due to the greater speed of the positive ion.

Polarisation. When a eurrent is passed between two elcetrodes inmersed in an aqueous solution, the potential differenee between the electrodes tends to decrease and will in time fall off altogether on aceount of the deposition of ions of the opposite sign on the surface of the clectrode. This polarisation of the electrode may be prevented by physical or chemical means (ef. various types of concentration cells). A similar ionic layer forms on membranes when a current is passed through them for some time (sce also Chap. XII., Polarisation Current).

Selective permeability of membranes has often becn notiecd in electrical transference experiments. The elassical experiments of Hittorff are now known to be, in some eases, vitiated by his use of ox-gut membranes to prevent eomnection eurrents. For instance, such membranes are much more permeable to $\mathrm{SO}_{4}$ ions than to Cu ions. A large crror is thus introduced into electrical diffusion :experiments with $\mathrm{CuSO}_{4}$ due to the adsorption of the copper ions on the substance of the membranc.

Till more is known of the physical state of the cell and its environment, definite statements camnot be made conecrning the causes of alterations in permeability of membranes. Phrases like "selective" adsorption should meanwhile be avoided, as they postulate intelligenee in the cell to "sclect." Although the unknown must be explained in terms of the known, the day is surcly past when it is necessary to assume a Maxwellian "demon" or a cellular intelligence. It is certainly not unscicntific to admit the possibility that the unknown is similar to the known or may be explained by analogy to known physical processes. 


\title{
CHAP'TER XI
}

\author{
RADIO-ACTIVITY
}

\author{
THE ATOAI IN DISSOLUTION \\ "From harmony, from heavenly harmony \\ This universal frame began; \\ When nature underneath a heap
}

Of jarring atoms lay." Dryos.

'TiE various manifestations of energy already dealt with have all been assoeiated with matter in the form of small aggregates (colloids), atoms, or ions (charged hydrated atoms). ('hemists onee defined the atom as the smallest non-divisible portion of matter. Neerlless to say, many scientists were content to be deeryed as old fashioned and refused to accept this opinion of the atom. My old teacher, Prof. Joln Ferguson, would allow no one to refer to atoms. He preferred the more cumbrous but exact term "Combining Proportions." Modern work has confirmed these opinions of the atom. Physicists are now interested in the strueture of the atom. No longer is it considered as nondivisible. No longer does it remain as fundamental. Of what then does the atom consist? Many and varied are the presentday theories of its structure, but in general most schemes are similar. It is supposed to consist of a number of smaller units, negative electrons, all moving rapidly and irregularly round a eentral positive eharge. A negative electron is nothing more than a unit charge of electrieity. 'The number of electrons in each ring is definite and may undergo alteration in definite quanta only.

(1) Not more than a eertain number of electrons ean continuc in stable motion in one ring. If more are added the system breaks up into two or more rings.

(2) If the orbital veloeity of the rings exeeds or falls below a ecrtain eritical value, the electrons are rearranged to ensure stability for that speer. 
A model may make this elearer. The outer particles may be represented by a number of exactly similar sewing-needles, magnetised simultaneously in a solenoid. They are floated vertieally in a small trough (Fig. 21), by having, say, their $N$ poles inserted each to the same depth in exactly similarly pieces of cork. The place of the positive eore is taken by a bar magnet set vertically, $N$ pole upwards, below the trough. It will be noticed that the needles arrange themselves in two rings. If ten

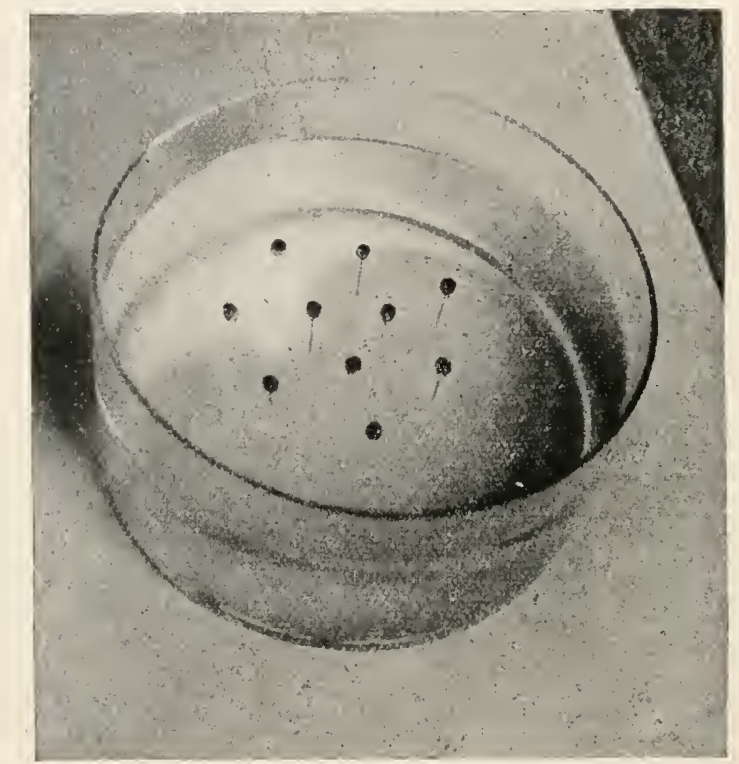

FIG. 21.-A “Model" Atom. (From Crowther's Molecular Physies.)

needles are floated, seven will be in the outer ring and three in the inner.

It has been found that the greatest number of magnets whieh we ean have in an empty ring is five. If a sixth is added, two rings are formed with five needles on the outside and one in the middle. The number which must be placed in the middle rapidly inereases with the number in the outer ring. The removal of one needle from the outer ring may eause a eomplete rearrangement of the needles, i.e. a new series of conecntrie cireles may be formed differing from the first series in the number of the component needles in each ring.

As we have mentioned, the electrons forming an atom are supposed to be in eonstant rapid and irregular motion. If for 
some reason the motion of an electron beeomes eentrifugal, then, if suffieient speed be developed, it will tend to fly off. The atom will be ruptured and a new atom will be formed.

TABLE XIX.

\begin{tabular}{|c|c|c|c|c|c|}
\hline \multirow{3}{*}{$\begin{array}{l}\text { Total number } \\
\text { of needles. }\end{array}$} & \multicolumn{5}{|c|}{ Number in each ring. } \\
\hline & \multirow{2}{*}{ Outer. } & \multicolumn{4}{|c|}{ Concentric inner rings. } \\
\hline & & (1) & (2) & (3) & (4) \\
\hline 5 & 5 & - & — & 一 & - \\
\hline 6 & 5 & 1 & - & - & 一 \\
\hline 10 & 7 & 3 & - & - & - \\
\hline 15 & 10 & 5 & - & - & - \\
\hline 30 & 15 & 10 & 5 & - & 一 \\
\hline 45 & 17 & 14 & 10 & 4 & - \\
\hline 51 & 18 & 15 & 11 & 6 & 1 \\
\hline
\end{tabular}

In 1878, Crookes found that the passage of an intermittent high-tension eurrent of eleetrieity through a tube from whieh air had been so thoroughly withdrawn that only about $10^{-7}$ of atmospheric pressure was present, produeed the so-ealled Kathode Rays. 'These rays originate at the kathode at right angles to its surface and proeeed in straight lines like light independent of the position of the anode. Whatever eomes in the path of the rays is eaused to fluoresee, e.g. the walls of the tube. They heat the object struek. By using a eoneave kathode, they may be foeussed on a piece of platinum which soon beeomes red hot, and may even be fused. Mechanical pressure is exerted by the rays. If direeted on to light vanes attached to an axle they may be made to turn little mills, or in the "railway tube" they drive a wheel along glass rails. 'The stream of rays is deflected by a magnet as if it were a stream of negatively charged partieles. In 1893, Lenard, following up Hertz's diseovery that metal was transparent to the kathode rays, made a small window of aluminium foil in the end of the vaeuum tube and so brought the kathode rays through the foil into the open air.

In 1895, Roentgen, repeating Lenard's work, aeeidentally diseovered the X-rays. He had eovered the vacuum tube with a black paper ease to shield the eyes from the kathode fluoreseenee, so that the effeet of the rays outside the tube might be more easily observed. He thus notieed that a barium-platinoeyanide sereen which happened to be near beeame fluoreseent whenever the tube was working though no visible rays could reach it. On plaeing 
his hand between the screen and the tube, he saw, for the first time, the now familiar sciagraph of the bones of the hand. The $\mathbf{X}$ - or Roentgen rays originate from the place where a kathode ray strikes, from the walls of the tube, in the first instanee, or in a focus tube from the piece of platinum (anti-kathode) upon which the kathode rays are focussed. They issue equally in all directions and travel in straight lines. For any tube, the power of penetration of the $\mathrm{X}$-rays is inversely proportional to the density of the substance penetrated. The higher the degree of exhaustion of the tube the greater the penetrating power of the rays produecd. In a "hard" tube the vacuum is so good that a very great differenee in potential between the electrodes is necessary to foree the discharge through. 'The kathode rays therefore attain a high velocity and the $\mathrm{X}$-rays they produce on impaet with the antikathode have a high penetrating power. On the other hand, if the tube is not well "exhausted," the X-rays cvolved are easily absorbed. Such a tube is termed "soft." Inlike the kathode rays they are not affected by the most powerful magnetie field. Like the kathode rays they excitc fluorescence, act on sensitised photographic plates and ionise gases, i.e. they make air, or other gas through which they pass end which under ordinary circumstanees are practically insulators, capable of conducting limited quantities of either positive or negative electricity.

Poincaré suggested that the production of X-rays might be an effect common to all fluorescence. In 1896, Becquerel, acting on this idea, examined some fluorescent salts of uranium. He found that the double sulphate of uranium and potassium exposed to sunlight could affect a sensitised plate even when the plate was protected by a layer of copper or aluminium foil. 'This metallic layer excluded the possibility of action by ultra-violet light or by ehemical vapours enitted by the salt. Further investigation showed that the phenomenon was exhibited by uranous salts which are not fluorescent as well as by the fluorescing uranic salts. Both are active in proportion to the amount of uranium they eontain. That is, the eontinuous emission of these rays is a specifie property of uranium now generally termed Radioactivity.

The characteristies of the radiation from uranium are very similar to those of the X-rays. They are found to consist of three very distinet types of rays, differentiated in the first instanee by their power of penetrating matter. 'They have been termed by Rutherford $\alpha, \beta$ and $\gamma$ rays. The $\alpha$ rays are particles of the gas 
helium expelled radially from the uranium with the colossal speed of 20.000 miles a second. They have so feeble a penetrating power that they are completely stopped by a single sheet of notepaper or by a few eentimetres of air. The a rays carry a positive charge, but are only slightly deviable by an intense magnetic field. The $\beta$ rays resemble the $X$-rays in penetrating power, and pass with ease through thin metal, glass, etc., but are nearly all stopped by a single eoin. Becquerel proved that the $\beta$ rays are identieal with the kathode rays, i.e. negative charges of electricity. Their superior penetrating power is duc to their enormously greater veloeity. The $\gamma$ rays are not deflected by magnetic fields. They resemble in all respects the $\mathrm{X}$-rays, but are far more penetrating than rays even from the hardest vacuum tube. They will readily pass through a pile of twelve eoins. Their nature is probably the same as that of X-rays, i.e. thin pulses in the ether.

'The power of ionising a gas which is a common charaeteristic of the radiations from radio-active matter is used as a means for measuring the intensity of radiation. The simplest apparatus for this purpose is a goid-leaf clectroseope. Fig. 22 represents the type of electroseope used by Soddy. It consists of a tin can with a movable bottom $E$ for the insertion of the substance to be tested. A paraflined rubber eork $I I$, is picreed in the centre by the metal wire $G$ which carries at its end a rod of fused quartz, $A$.

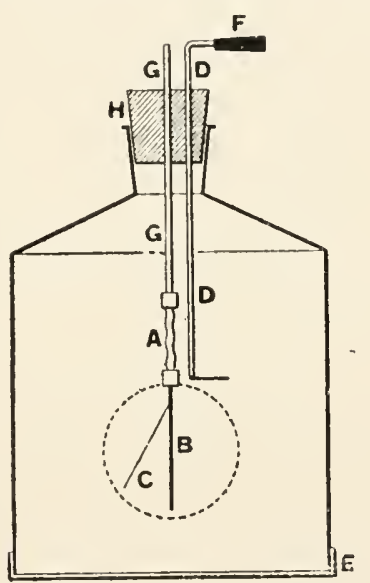

FIG. 2.2.- - seetion through goldleaf electroscope as used to determine the ionising lower of radioactive matter. See text. (From soddy's Ruliouctirity. Eleetrician Press.)

A thin brass strip, $B$, to which a single gold leaf, $C$, is attached is fastened to the lower end of the quartz rod. $F$ is a vulcanite handle by means of which the eharging rod $D$ ean be brought into eontact with $B$. The rate of collapse of the gold leaf may be observed by means of a reading microscope through a window in the can (dotted line).

In 1903, the Curies, who were cxamining the minerals eontaining uranium, discovered a new element, radium, in pitchblende. This very radio-active material was obtained pure in 1911. From a ton of pitehblende may be extracted about 200 mgrms. of radium chloride, which was responsible for over 80 per cent. of the radio-activity of the raw material. 
Subsequent investigations by the above workers, and prineipally by Rutherford, Soddy, and their collaborators, have shown that there are three series of radio-active elements. The appended ehart from Soddy shows the relationship between the members of the series and between two of the series themselves. This chart demonstrates to us the remarkable fact that the atom of the heavy clements at the head of each series are eontinuously and regularly undergoing disintegration. Matter and energy are being lost at a rate which, so far, eamnot be modified in any way.

Lately Campbell and Wood have diseovered that eertain of the elements of low atomic weight are also radio-active. One of these, potassium, is found universally and in abundant quantities in animal and vegetable cells. Potassium is a neeessary permanent constituent of every living eell. Of the 12-15 clements essential to life, it is the only one possessing distinet if minute radio-aetivity. 'The activity of potassium may readily be demonstrated by means of the gold-leaf electroseope. It is shown that $\beta$ rays are emitted. Potassium is 1000 times weaker than uranimm and $1,000,000,000$ times weaker than radium in the emission of $\beta$ rays.

As is well known, potassium is an absolutely necessary constituent of the fluid used for the perfusion of an organ. If a potassium-free Ringer's fluid is passed through a frog's heart, the heart will come to a standstill in about half an hour. 'The frog's peripheral vessels may be perfused with Ringer's fluid for hours without any sign of oedema. As soon as a potassium-free fluid is used, marked oedema begins, eausing the frog to swell and inerease in weight. Further, the frog's kidneys when perfused with 'Tyrodé's fluid or similar fluid eontaining glueose allows no glucose to pass out into the urine. If the potassium is omitted in making up the fluid, gheose at once eseapes into the urine. Ringer demonstrated, long before its radio-active nature was diseovered, that rubidium may be substituted for potassium in equimolecular amounts. He explained this by its similar chemieal nature. Similarly, eaesium, another of the lighter radio-aetive elements, may take the place of potassium in the perfusion fluid. No non-radio-active element has been found which is eapable of acting as a substitute for potassium. Further, Zwaardemaker was able to perform normal perfusions provided a substanee enitting $\beta$ rays was within effective distanee of the frog.

The last named worker and his eollaborators then set out to determine the amounts of the heavy radio-active clements necessary 
TABLE XX.

TABLE OF RADIO-ACTIVE DISINTEGRATION.*

I. MAIN SERIES.

A. Uranium, Radium and Artinium Series.

\begin{tabular}{|c|c|c|c|c|c|c|c|}
\hline \multicolumn{2}{|l|}{ Element. } & \multirow{2}{*}{$\begin{array}{c}\text { Atomic } \\
\text { Weight. } \\
238\end{array}$} & \multirow{2}{*}{$\frac{\text { Radiation. }}{\alpha}$} & \multicolumn{3}{|c|}{ Period of A verage Life. } & \multirow{2}{*}{$\begin{array}{l}\text { Chemical character } \\
\text { (Isotopic with). } \\
\text { Uranium. }\end{array}$} \\
\hline Uranium-I. & - & & & $8,000,000,00$ & 0 years & - & \\
\hline Uranium- $X^{1}$ & - & $2: 34$ & $\beta$ & 35.5 days & $-\quad \quad-$ & - & 'Thorium. \\
\hline Uranium- $\mathrm{X}^{2}$ & - & 234 & $\beta$ & $1 \cdot 65$ minutes & $3 \quad-$ & - & Eka-tantalum. \\
\hline Uranium-II. & - & 234 & $\alpha$ & $3,000,000$ ye & $\operatorname{ars}(?)$ & - & Uranium. \\
\hline lonium - & - & 230 & $\alpha$ & 100,000 year & $\mathrm{rs} \quad-$ & - & 'Thorium. \\
\hline Radium - & - & 226 & $\alpha$ & 2440 years & - & - & Radium. \\
\hline Ra. Emanation & - & 222 & $\alpha$ & $5 \cdot 55$ days & - & - & Emanation. \\
\hline Radiun-A. & - & 218 & $\alpha$ & 4.3 minutes & - & - & Polonium. \\
\hline Radium-B . & - & 214 & $\beta$ & 38.5 minute & - & - & Lead. \\
\hline Radium-C - & - & 214 & $\begin{array}{c}\beta \\
(99 \cdot 97 \%)\end{array}$ & $28 \cdot 1$ minute & - & - & Bismutl. \\
\hline Radium-C $\mathrm{C}^{\prime}$. & - & 214 & $\alpha$ & $1 / 1,000,000 \mathrm{t}$ & h sec. (?) & - & Polonium. \\
\hline Radium-D . & - & 210 & $\beta$ & 24 years & $-\quad=$ & - & Lead. \\
\hline Radium-E - & - & 210 & $\beta$ & $7 \cdot 2$ days & - & - & Bismuth. \\
\hline $\begin{array}{l}\text { Radium-F } \\
\text { (Polonium) }\end{array}$ & - & 210 & $\alpha$ & 196 days & - & - & Polonium. \\
\hline End Product & - & 206 & $1-$ & Infinitely lo & ng & & Lead. \\
\hline & & & B. Thoriu & M SERIES. & & & \\
\hline Thorium . & - & 232 & $\alpha$ & $25,000,000,0$ & 00 years & - & Thorium. \\
\hline Mesothorium -I. & - & 228 & $\beta$ & $9 \cdot 67$ years & $-\quad \cdot$ & - & Radium. \\
\hline Mesothorium-II. & - & 228 & $\beta$ & 8.9 hours & - & - & Actinium. \\
\hline Radiothorium & - & 228 & $\alpha$ & 2.75 years & - & - & Thorium. \\
\hline Thorium-X & - & 224 & $\alpha$ & $5 \cdot 25$ days & - & - & Radium. \\
\hline Th. Emanation & - & 220 & $\alpha$ & 78 seconds & - & - & Emanation. \\
\hline Thorium-A - & - & 216 & $\alpha$ & $0 \cdot 2$ second & - & - & Polonium. \\
\hline Thorium-B - & - & 212 & $\beta$ & $15 \cdot 4$ hours & - & - & Lead. \\
\hline Thorium-C - & - & 212 & $\beta(65 \%)$ & 87 minutes & $-\quad-$ & - & Bismuth. \\
\hline 'Thorium-C' & - & 212 & - & $\begin{array}{c}1 / 100,000,00 \\
\text { sec. (?) }\end{array}$ & 0,000 th & & Polonium. \\
\hline End Product & - & 208 & - & Infinitely los & ng $\quad-$ & - & Lead. \\
\hline
\end{tabular}

\section{BRANCH SERIES. (A.)}

(At either Uranium-I. or Uranium-II. the serics branches, and 8 per cent. of the total number of atoms disintegrating, follow the branch Actinium Series.)

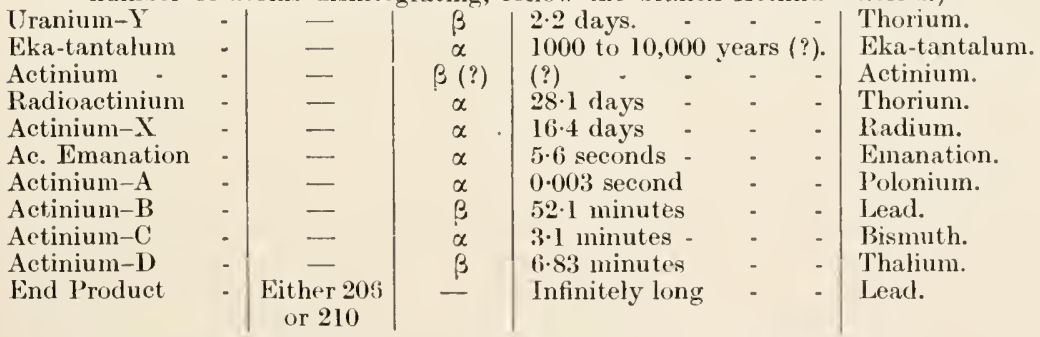

(At Radium-C, 0.03 per eent. of the atoms follow the branch series.)

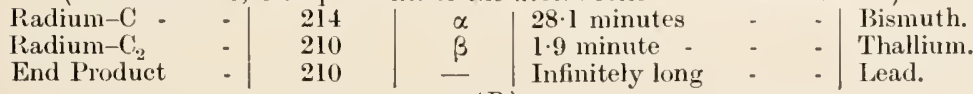
(B.)

(At Thoriun-C/35 per cent. of the atoms follow the branch series.)

Thorium-C -

\begin{tabular}{ll|l} 
Thorium-D - & - & 208
\end{tabular}

\begin{tabular}{ll|l} 
End Product & - & 208
\end{tabular}

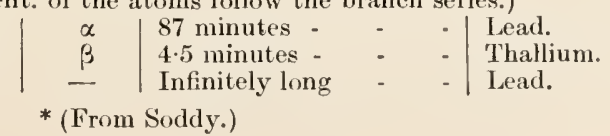


to replace potassium. These radio-elements, as we have seen, emit $\alpha$ rays in marked exeess of the $\beta$ rays neeessary for physiologieal purposes. They found that, as was to be expeeted, the $\alpha$ radiation eompletely masked the $\beta$ radiation. If means were taken to exelude the $\beta$ rays these $\alpha+\beta$ radiating salts aeted as exeellent substitutes for potassium. Radio-active substances may thus be elassified for biologieal purposes into two groups.

\section{TABLE XXI.}

I.

$\beta$ Radiating (negative).

Potassium.

Rubidium.

Caesium.
II.

a Radiating (positive).

Uranium.

Thorium.

Radium.

Ionium.

Lanthanum.

Cerium.

Niton (Emanation).

A heart beating with a fluid eontaining the appropriate quantity of any of Group I. may be switehed on to any other group) I. element in aequi-radio-active amounts. Similarly, the group II. elements are interehangeable. But direet transferenee from a I. fluid to a II. or vice versa at once produces eomplete stoppage. The two groups are antagonistic. If, however, the heart is washed eompletely free from one group with radio-aetive-free fluid it may without harm be perfused with a fluid eontaining one of the elements of the antagonistie group.

Fluoreseein and cosin adsorb the $\alpha$ and $\beta$ rays unequally. If one of these dyes be added to the perfusion fluid the amount of radio-aetive material present may be redueed appreeiably and still produee normal action. In summer, smaller quantities of radioaetive salts are needed than in winter. This is related to the lowered ealeim eontent in the frog's blood in winter.

To summarise, potassium is a neeessary eonstituent of all living matter because of its property of emitting negative eleetrons ( $\beta$ rays). It may be replaeed by other radio-active substanees in aequi-radio-aetive proportions provided these substanees are not otherwise toxie. How potassium aets in the living eell ean as yet be only a matter of surmise. Presumably the freed eleetron passing with great veloeity through erowds of ions, molecnles and eolloidal aggregates will have some effeet on them. It is known to have at least two effeets : 
(1) Because of its velocity, the $\beta$ ray accelerates the rate of migration of gaseous ions in a sinilar way to ultra-violet light of extremely short wave-lengtlı (below 2000 Angströn units). i.e. the ionised gas becomes an electrical conductor.

(2) On account of its unit negative charge, it has a disturbing effect on all systems in electrieal cquilibrium through which it passes.

Rutherford has recently shown that a particles (positively charged atoms of helium, atomic weight =4) may causc trivalent nitrogen (14) to disintegrate with the formation of monovalent hydrogen (1). He considers that the hydrogen ion is nothing more or less than a unit positive charge. Other atoms are spheres, composed as we have seen of a positive corc (probably an atom of hydrogen) surrounded by negative electrons. The negative electric charge is evenly distributed over the surface.

'The modern tendency is thus to postulate the sameness of all elementary matter. What we have becn accustomed to look upon as elements may merely be stages in the disintegration of more complex substances into their positive and negative units. When the disintegration takes place explosively and continuously the substance is considered as radioactive.

In the preceding portion of this chapter, ultra-violet rays, kathode rays, $\mathrm{X}$-rays and the $\alpha, \beta$, and $\gamma$ rays of radioactive natter have been mentioned as types of radiation. These various radiations differ from onc another in their cffects on living matter in degree rather than in kind. In general, the lower the velocity of the ray, the greater its physiological action, provided always that its velocity is sufficiently great to produce any physiological cffect. (A high velocity bullet cuts a clean hole in a piece of glass, while a spent bullet shatters the glass). 'The effect scems to depend more on the velocity of the ray than on its nature, e.g. a rays are material while the others are not, yet similar actions may be produced under proper conditions ('Wwardenaker's expts., l.c.). (A soft candle may be fired through a wooden target, cutting a hole just as if it were a hard-nosed bullet). 'The physiological cffect of any ray is proportional to its power to ionise air. $\beta$ rays have 60 times the ionising power of $\gamma$ rays, and experiment has shown that $\gamma$ rays require to operate for 60 mins. on living matter to have the same effect as onc minute's exposure to $\beta$ rays. That is, by varying the length of exposure, sinilar results may be obtaince from radiations having different ionising powers. If rays are classed according to their power to ionise 
air, then those having the greatest ionising effeet will have a toxie rather than a benefieial effect on living organisms, while, eonversely, the weaker rays will promote the funetion of the organism. The power of ionisation being equal, then generally a long exposure produces toxic effects and a brief exposure beneficial.

This latter effeet has induced experimentalists to study the effect of radium on plant growth. They have found that up to a eertain optimum point the rays of radium act as a positive stimulus. In early stages, root growth is stimulated, from which there is, as result, an increased growth of shoot. Infloreseence is generally fuller and is better coloured. Ultra-violet rays aeting for a brief period on sugar eane not only produee growth but produce an inerease in the pereentage of sugar. If, however, this optimum amount of radiation be overstepped, that is, if the plant is submitted to a longer exposure or to a greater eoneentration of rays, depression, culminating in eomplete arrest of physiologieal funetion, is produeed. Further exposure to the rays eauses death of tissue. The benefieial effeets of short exposures are not eonsidered sufficiently great to justify the employment of radio-aetive matter in hortieulture or agrieulture.

Similar results have been obtained by those who studied the effect of radiation on eggs and eells. For example, exposure of the fertilised eggs of arbacia to rays of radium, if short, eauses stimulation of the cell function. If the radium is applied during the approach of the germ muclei, then cell division is aecelerated. If the exposure is long, eell division is retarded. The effeet of radium is more marked during the metaphase than during either the prophase or the telophasc. Eggs are not so easily influeneed by radium emanations after the dividing stage is passed. 'In order to produee any effeet on the rate of growth of ascaris eggs about ten times the intensity of radium has to be applied as was effeetive during the dividing stage, or the length of exposure has to be increased tenfold. The $\beta$ and $\gamma$ rays seem to act on different parts of the egg. The nueleus, especially if it is undergoing mitosis, is influeneed by the $\gamma$ rays, while the $\beta$ radiation has most effect on eytoplasm. The fertilisation membrane of nereis is thiekened as a result of exposure to radium. The length of exposure being, in this ease at least, more effieacious than the intensity.

The physician is interested in radiant energy of this type because of its lethal influence on pathological growths and on bacteria. Ultra-violet rays, or lights like the Simpson Light, which emit a 
large proportion of ultra-violet rays, have been employed as germicides in surface wounds. The penetrating power of these rays is slight, and, therefore, they ean have little effect on decplying structures. Nevertheless their action on certain bacilli have been somewhat extensively studied. Typhoid bacilli are killed by exposure to rays of wave-length $2100-\mathbf{2 8 0 0}$ Ângström units. Bacilli vary in vulnerability, e.g. on exposure to light from a Cooper-Hewit (mereury vapour) lamp plaeed $12 \mathrm{~cm}$. above them, $b$ mucosus eapsulatus was killed in 20 sees., staphyloeoceus aureus in 90 sees., while 150 sees. elapsed before the death of $b$ subtilis. Lupus (tubereular ulceration), eareinoma and other morbid growths are oecasionally treated with ultra-violet light. It is worth while noting that normal cells equally may suffer through exposure to rays over 2800 Äu. Digestive enzymes are killed. Protection may be provided by passing the light through 1 per eent. solutions of gelatine-peptone, amino-benzoic acid, eystine, tyrosine and leucine. Tyrosine has especially good detoxifying action in alkaline solution. These solutions absorb rays of wavelength $2480-2710 \AA$. and so reduce the toxicity and bactericidal action of ultra-violet light.

Similarly, X-rays have a strong lethal aetion. Pioneers in radiography suffered from this action. There is no doubt as to the power of the $\mathrm{X}$-rays to kill $b$-typhosus suspended in water, or to inhibit the growth of tumours. But care has to be exereised in their application. For instanee, a number of mice were artificially immunised against a transplantable careinoma. Half of them were then exposed to the $\mathrm{X}$-rays. It was found that the miee so exposed had lost their inmunity and had been rendered suseeptible to careinoma while the controls were still immune. Animals which have been X-rayed repeatedly are generally more susceptible to eertain diseases than unexposed animals, e.g. monkeys more readily develop poliomyelitis after being exposed to the $\mathrm{X}$-rays.

The rays emitted by radio-active elements, especially radium, have been employed more extensively in the treatment of morbid cell growths than either ultra-violet light or X-rays. The eells are not killed outright but division of the nuclei is inhibited, eventually leading to death of the eell. The suecessful treatment of eaneer patients by radium is well known. The rays of radium are eapable of eausing definite regressive changes in deep seated tumours such as mediastinal lympho-sareoma, earcinoma of the lungs, and abdominal metastases of eareinoma of the testis. 
Several investigators have reporterl results to show that the growth-promoting substance in yeast may be partially inactivated by exposure to radium enanation. It is probable that the therapentic effect of radium treatment may be due to this destruction of the growth-promoting substanee. It has been known for long that radium rays have a destructive effect on colloidal solutions, due probably to a disturbance of their eleetrical state. Globulin and vitellin are coagulated and lecithin suspensions arc decomposed on exposure to the emanation from radium. That the action is electrical is borne out by the antagonism between $\alpha$ radiation and $\beta$ radiation. Either of them prevent bacterial growth in agar enltures, but the simultancous application of both kinds of rays is ineffective (cf. antagonism of eolloids, ete., p. 81). Of eourse, normal as well as pathologieal tissue may be damaged by exposure to radium. Fispeeially sensitive are the sexual cells. Spermatozoids of sea urchins are enfeebled and killed, as are also the gametes of the grasshopper by exposure to radium sufficiently weak to have no action on other cellular units of the testicles. The action is similar to exposure to cold. Radium causes an immediate decrease in the total number of white cells in the blood (Chap. XV.). This result is probably due to inhibition of the formation of the leucocytes rather than to the destruction of already formed eells. The greatest deerease oeeurs from $\frac{1}{2}$ to 6 hours after application of the radium. Within 24 hours a normal concentration of white eells may be observed.

By the operation of Le Chatelicr's principle (p. 9), matter exposed to radio-active elements should develop sone protective mechanism against the action of the rays. Becquerel noticed that $\beta$ rays changed yellow phosphorus into its red form, which is not acted on by the rays. We have already mentioned that the fertilisation membrane of nereis is thickened where exposed to radium. Some observers find that the presence of chlorophyll is protective. Others deny this. 


\section{CHAP'TER XII}

\section{THE CELL}

"Citizens of the state whieh the entire multicellular organism seems to be,"

WE have seen that foodstuffs are broken down into units sufficiently small to pass through the intestinal wall. Logically, we ought next to study the system by which these absorbed substanees are eonveyed to the eell. It is important to realise that until they are inside the cell they are useless. All energy changes take place in the living cell. It will, however, be eonvenient first to examine a ecll, note its imports and exports and study the various activities by virtue of which it is said to be alive.

In 1893. Schwann put forward the theory that animal tissues were an aggregation of large numbers of cells. Later work has justified this assumption. It is now generally held by biologists (1) that the earliest form of living matter was undifferentiated protoplasm, and that from this simple form of life there has been evolved, first the unieellular and then the polyecllular organism; and (2) that each individual life follows this evolutionary eourse, originating as a single cell and gradually gaining in complexity with age. In view of these two beliefs, the evolutionary hypothesis (phylogeny) and the developmental history (ontogeny), it is logical to subject a uniecllular organism to close examination in order that the various manifestations of life may be, at least, eatalogued.

Amoeba is a uniecllular animaleule which may be found in the stagnant water of almost any ditcl.. It is made of material differing so slightly from the medium in which it lives that it ean only be seen under the microseope after patient seareh. When seen it is found to be non-homogeneous. Apparently it eonsists of a greyish mass in which there are oeeasional granular aggregates, spaces containing water, spaees eontaining extraneous matter and a darker more compact mass, the nucleus. If the amoeba were 
cut in two the part which did not eontain the nucleus would only live for a short time, while the other part would functionate nomally. The nueleus is, therefore, necessary for life. Ultramieroscopic examination shows that the grey mass is a colloidal (emulsoid) solution in water. ('hemical analysis of dead amoeba confirms the ultramicroscopic examination. Water to the cxtent of about 75 per cent. acts as dispersion medium for a colloidal complex and as a solvent for eertain crystalloids. The colloid is an aggregate containing protein, fat and carbohydrate. The crystalloids are to some extent adsorbed on the surfaces of the colloidal mass and to some extent are in free solution. The elementary chemical composition conveys little information as to the properties of the complex. 'To say that protoplasm contains a certain percentage of carbon, hydrogen, oxygen, nitrogen, sulphur and phosphorus in a colloidal state, and potassium, calcium, sodium, chlorinc and phosphorus in solution is not of much use as a contribution to the study of life. It is just as preposterous to appraise the value of great pictures in terms of the chemical composition of the paints and pigments employed as to attach any great significance to the chemical elements of a dead eell. What is of great importanec is the physical state of the matter, just as the value of a painting lies in the physical juxtaposition of pigments, an artistic blending of eolour, light and shade, whereby the eye is pleased, so the life of a cell depends on the size, consistency, etc., of the colloid-crystalloid complex forming its protoplasm. "When," says Schäfer, "the chemist sueeceds in building up this complex it will, without doubt, be found to exhibit the phenomena which we are in the habit of associating with the term "life"." What are the phenomena commonly associated with the term "life," especially as manifested by a unicellular animal?

(a) Movement is the eommonest phenomenon indicative of life. Amocba moves. It extrudes footlike processes, pseudopodia (Gr. pscudio, false (=similar to), podes, foot), at one part and retraets them at another and so moves along. Similar amocboid movements are characteristic of the white cells or leueocytes (Gr. leukos, white) of the blood. Reeently, Goodrieh has carefully studied these movements of the leucoeytes. II produces eamera lueida drawings to show that the pseudopodia usually take up the form of expanded motile membranous folds when the living lcucoeytes are examined suspended frecly in the normal fluid which is their habitat. One of his drawings is reproduced in 
Fig. 23. Movements of a precisely similar character may be produced in substanees which are eertainly not alive, such as Brailsford Robertson's model amoeba made of eamphor, benzene and water (Pt. II.). These purely physico-chemieal reactions are produeed by alterations of the surface tension of the fluids under observation. Maeallum has shown (pp. 140 and 151), that alterations in surface tension oceur in living tissue during motion. Movement can, therefore, not be considered as a speeifieally vital phenomenon. Certain parts of the eell, e.g. the vaeuoles, show a rhythm in their movements. In polyeellular organisns, certain organs, $e$.g. the heart, pulsate. It is comparatively easy to produce rhythmical novement in matcrial which is not living. A globule

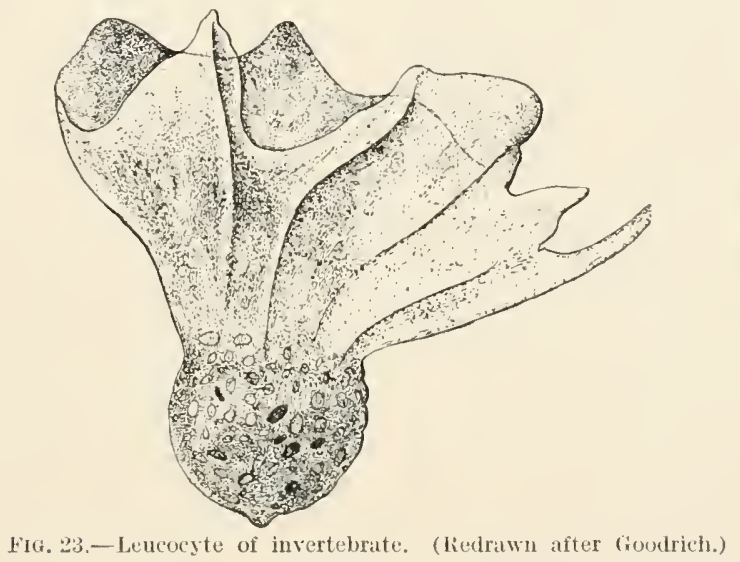

of mereury more than an ineh in diameter may be made to pulsate with perfect regularity for hours. (See Ostwald's "Physieal H(art," Pt. H.).

(b) Irritability is a general property of living matter. When amoeba is touehed, it withdraws its pseudopodia (barotaxis). It moves towards and over suitable food and moves away from quinine or from a lypertonie solution of erystalloids (negative ehemiotaxis). Hydrogen ions if not too concentrated exert positive chemiotaxis, while hydroxyl ions have a repellent efleet. This may explain galvanotaxis. Strong light repels while a moderate illumination attraets many lower organisms. Further, the more refrangible rays of light exert a negative phototaxis, while the less refrangible rays are positively attractive. If the swarm spores of eertain algae are plaeed in a tank with a eover, half of which is blue glass and half is red, and exposed to light, they will stream away from the blue and towards the red end of the 
box. Ultra-violet rays have a marked cffect on living organisms. 'They kill, e.g. the tuberele bacillus is killed by ultra-violet light and lupus is eured by projection of the Finsen are on the growth. Change of temperature may exert either a positive or a negative cffect, the aninalcule avoiding the abnormal. That is, too high or too low a temperature exerts negative thermotaxis. Nonliving matter shows irritability. We have seen how sensitive colloids are to slight alterations in their environment. 'They exhibit chemiotaxis and galvanotaxis very markedly. Even inorganic matter may respond to stimulation. Lillie has demonstrated this in the ease of iron. A piano wire which has becu dipped in concentrated nitrie acid and then suspended in dilute nitric acid will show changes if "stimulated" mechanically, chemically, or electrically. The irritability of living matter is, aceording to Verworn, of a specifie type and is thus indicative of life.

(c) Ingestion and excretion are phenomena exhibited by all living eells. Nutrient material is taken from the environment, prepared, used, and the non-utilisable rest is foreed out. Amoeba cngulfs food and forms a vacuole in which will be found food and water. Into this vacuole are seereted digestive enzymes which reduce the ingested material if possible from the colloidal to the erystalloidal state. It then passes into the protoplasm and the undigested residue is forcibly excreted by contraction of the vacuole. These processes all have their physico-chemical counterparts. A drop of chloroform will reject a picee of capillary glass tubing foreed into it. If the glass be eoated with shellac it will be drawn into the chloroform, the shellac dissolved from it and then the clean glass is expelled from the interior of the ehloroform to the surface.

(d) Growth is not a property characteristic of living matter. Ledue has taught us that by osmosis life-like forms may be produced which grow.

(e) Electric Phenomena. The electrical power generated by living matter has always been a subject of interest and of amazement. Quite apart from such animals as possess electrical organs, e.g. the electric ecl which can generate an E.MI.F. of scveral hundred volts, every living animal, in fact every living cell, produees electromotive forees. The ordinary potential differenees observed in living matter may seldom reach $0 \cdot 1$ volt, but everyone knows that if $n$ small units are eonneeted in series, the resultant voltage is $n$ times the voltage of the single unit. Dissection of an 
eleetrie organ shows that it is built up serially of large numbers of units. The cause of the potential differences in eells must be sought for in the "selective" permeability of the cell membranes, or in alterations of the content of the protoplasm in eleetrolytes.

(i) Differential permeability. Bayliss separated a eoneentrated from a dilute solution of the sodium salt, congo red, by a nembrane of parchment paper which is permeable to the sodium ion but not to the anion. He found that the dihute side became eleetro-positive on aceount of the preponderanee of eations on that side.

(ii) Differential permeability does not afford a suffieient explanation for all bioelectrie plicnomena. Even when the membrane is freely permeable to both ions of the salt and when the anion is the faster of the two, the dilute side of the parehment beeomes eleetropositive. This brings us again to the eharge on the membrane. Parelment has a negative charge in water, and in dilute solutions of neutral salts - so has baked clay, wood, bone, chareoal, natural gelatine, etc., and all these eause a positive eharge to develop on the dilute side. That is, the generation of a potential differenee is just the reverse of electrieal endosmose (Chap. X.). This may be eonfirmed by altering the eharge on the membrane. Gelatine may be indueed to take up a positive eharge. Mines found that when a dilute solution $\left(\begin{array}{l}\mathrm{N} \\ 80\end{array}\right)$ was separated by a gelatine membrane from a more eoneentrated $\left(\begin{array}{c}\mathbf{N} \\ \mathbf{S}\end{array}\right)$ solution of sodium elsloride, the dilute solution beeane electropositive. Gelatine is made positive by treatment with the ions of polyvalent metals. When an eleetropositive gelatine membrane was used, the dilute solution beeame negative.

(iii) A slight alteration in hydrogen ion coneentration oeeurring on one side of a membrane will cause the development of E.M.F. If two solutions, one of $p I I r$ and the other of $p I I \quad 8$ are separated by a membrane more permeable to $I^{+}$ions, an E.M.F. of about 30 millivolts may be obtained. The living cell has a $p H$ of about $7 \cdot 4$ and its E.M.F. is not usually greater than 30 millivolts.

\section{Polarisation current.}

In all chemieal proeesses, alterations in potential difference take place. The living eomplex, known as a eell, is a system in which chemieal transformations proeeed eontinually and, therefore, eleetromotive foree is being generated eontinuously. These eurrents may be demonstrated if speeial arrangements are made 
to prevent polarisation of the electrodes (Part II.). The electrodes which are used to lead the current from the cell (or group of cells) to the galvanometer are subject to polarisation as explained in Chap. X. The products of electrolytic decomposition of the cell substance are transported to the electrodes and accumulated there. The deposition of these products at the two poles, in course of time, alters the nature of the electrodes. The cathode, for instance, because of the accumulation of positive ions on it, becomes more and more anodal. 'This produces an electric tension that causes a current, the so-called polarisation-current, to flow in the opposite direction to the original one. As this current grows in strength it reduces the value of the tissue-current and after a short time eompletely obliterates it. (See also Muscle, Chap. XIII., and Nerve, ('hap. XVII.)

(f) Electrical effects are produced in living cells by suitable stimulation. If a cell is injured the injured part becomes electropositive to the rest. 'This phenomenon, apart from any other conditions, would be quite sufficient to justify the postulation of a cell membranc. Consider the cell as a mass of protoplasm in an envelope of matter which is permeable to the negative ion but not to the positive ion of a dissociated electrolyte. This will cause a difference of potential on the two sides of the membrane. Inside will be a preponderance of negative ions while outside will be an equal preponderance of positive ions. Current of Injury.If now we could connect the inside of the membrane with the outside, there would be a flow of current till the difference of potential had been equalised. Current would flow to the pierced. injured (or inside) part from the outside. That is, the injured part would be similar to the zine pole of a zinc-copper galvanic couple. 'There the flow of current is from the zine to the copper inside the battery. The zinc is therefore said to be electropositive. The current, however, flows from the copper to the zinc, outside the battery. The zinc is, therefore, said to form the negative pole. Current of action.-When alterations of tension or stress take place in a cell they are accompanied by alterations in electric potcntial. 'The part under stress becomes as if injured, i.e. electropositive or zincy to the normal or unstressed part. This may be due to an inerease in the permeability of the membrane at the stressed part, so that the positive ion gains access to the cell. The seat of stress does not, however, remain at its point of origin but passes as a wave of increased stress over the whole cell, followed immediately by an electropositive wave. 
SECTION III: CELL COMMUNITIES

\section{CIIAP'TER XIII}

\section{THE ARIYY WHEREWITH THE BODY WAGES WAR WITII NATURE-TIIE MUSCLE CELLS}

" Tho' born to fight,

Yet, mix'd and soften'd, in his work unite;"

Pope.

In the animal body there are various kinds of eell eommunities. There seems to be no doubt that originally eaeh eell was selfsupporting, and a small eell-eommunity, like a small village in a remote eorner of eivilisation, was able to perform all neeessary aetivities without the help of other communities. In a big complex eoneern like the mammalian body, however, each eell community has speeialised in some form of aetivity, and it has therefore to depend on other eommunities for ecrtain neeessities. No such eell is absolutely self-supporting. For the same reason we eannot validly consider any eell as typieal of all others. Each has its own particular duty to perform and is adapted to perform that particular duty most ceonomieally. It eould, if eireumstances compelling it arose, do other things usually left to other eells, but would perform these maceustomed duties elumsily and unceonomieally.

The dominant eell eommunities in the somatic body are those forming the museles. Their aetivity, to a great extent, regulates all other ehanges taking place in the body. They demand for their use the lion's share of the energy intake of the body. The bulk of the repair material in the food is earmarked for their use. They keep a firm hand on the transport system and soon eause a "speeding up" if supplies fall short of their needs, or if the byeproduets of their activity are not removed with sufficient rapidity. The system of inter-communieation between eell-eommunities 
(the nervous system) exists in large measure to suit the museles. In short, the muscles are the master-tissues of the soma. They are not a manufacturing community but are power users. In another sense the museles are the servants of the body. By means of them the body fights a war not merely of defence but of aggression against its environment. As civilisation has advaneed, man has found it eonvenient by means of tools and machines to add to his musele power. In this way, he has been able to harness and utilise power from sourees that could not have been tapped without the use of these maehines. Tools and machines are thus as it were extended and detaehable limbs.

Muscle is a transformer of potential energy into kinetic energy, and of eourse into heat. The souree of the energy is, as we have seen, the foodstuffs as broken down by enzymes, i.e. glucose, fat and deaminised amino acids. There seems to be no doubt as to the means by which the energy is ultimately liberated from these food units. In Chapter III. we saw that the intake of oxygen and the output of earbon dioxide was so intimately connected with the process of energy liberation that we eould calculate the amount of energy set free in an organ by measuring these gascs. That is, the basis of museular activity is oxidation, just as the basis of the activity of a steam engine is the oxidation of coal. In Chapter IV. there was a diseussion of this, and evidenee was produced proving that in all other details the oxidative process in muscle differs from that of coal. What then happens in muscle ? There seems to be three stages in the translation of potential energy of food into muscular work.

(1) Contraction. The musele shortens and thiekcns. During this phase oxygen is not neeessary. An excised frog muscle in nitrogen will give a maximal contraetion once every five minutes for over two hours before showing signs of fatigue. The output of earbon dioxide is not inereased over the amount evolved during rest. The heat evolved is negligible if the muscle is allowed to shorten under certain conditions. If it is made to contract isometrically i.e. against a spring that does not permit of its shortening, the energy developed, that would in ordinary eourse produce contraction, appears as heat. This heat is directly proportional to the length of the muscle fibres. Further, increase of temperature causes a decrease in the tension developed on stimulation, i.e. contraction has a negative temperature eoeffieient. A muscle at $0^{\circ} \mathrm{C}$. in an experiment of Bernstein's developed a tension of 375 grams. On raising the temperature 
to $18^{\circ} \mathrm{C}$. the maximal tension was found to be $205 \mathrm{~g}$. Surface cnergy is the only possible form of energy that could be associated with muscular eontraction which has a negative temperature coefficient.

In dealing with surface tension (Chap. VI.) it was pointed out that most physical and ehcmieal aetions are accelerated by increase of temperature, while surface energy is diminished as temperaturc rises.

A glance at Fig. 24 may make it clear how surfaee energy may be made to do work.

A wire frame is made, to one side of which is attached a silk thread. Over the whole area is a film of soap. The thread $M$

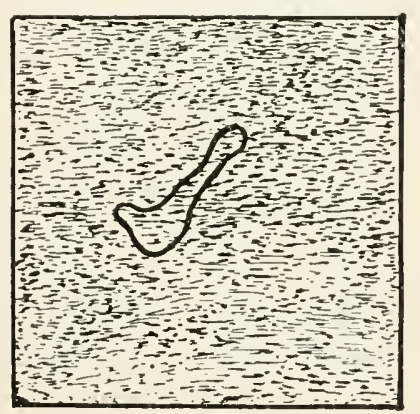

A

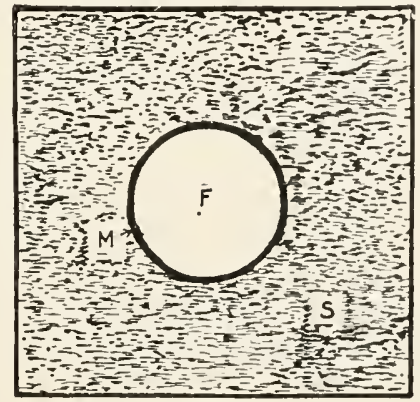

B

In $A$ there is a loop of fine silk floating in the film.

In $B$, the fitm enclosed by the loop has been broken. (After Van der Mensbrugglie.)

takcs up an indifferent position as shown in $(A)$ as the surface tension at the interface between $F^{\prime}$ and $S$ is exactly balaneed by the internal cnergy of $F=$ internal energy of $S$. If now the film is broken inside $\boldsymbol{F}$, say by prieking with a needle, $\boldsymbol{M}$ tends to become a circle. That is, the internal energy of $S$ is inereased rclatively to that of $F$. However it is brought about, the result is an inercase in the surface tension at the interface $\boldsymbol{F}-S$, i.e. the thread. It is of value to note that it is not nceessary for the film to be broken. Theoretically, all that is necessary is a difference in internal cnergies on the two effeetive sides of the thread, the lower internal energy being inside the loop. Further, no matter how slight the difference on the two sides of the thread the movement would be maximal.

Muscle consists of a number of long fibrillae immersed in sarcoplasm. The membrancs of the fibrillae may be represented by the thread mentioned above, the protoplasm of fibril and sareoplasm as the soap film. Anything which causes a differenee 
of surface tension at the interface between fibril and sareoplasm will cause the fibril to eontraet to its fullest extent. Of eourse the student will understand that the subjeet bristles with diffieulties, and the above explanation can only be taken as a very crude and ineomplete basis for further elaboration.

The only metabolite of museular contraction that stands on a very firm experimental foundation is lactie aeid. In the absenee of oxygen muscle beeomes aeid. If contraction takes plaee in the presenee of oxygen, lactie aeid does not appear. Laetie aeid formation in musele has been a veritable red herring drawn across the traek. The problem looks so simple with laetie aeid as an intermediate step in the oxidation of earbohydrates. The eareful investigations of Prof. A. V. Hill of Manehester have made it elcar that no sueh simple process is possible. First, the laetic acid is not a step in the oxidation of earbohydrates, and seeondly it is not oxidised itself to $\mathrm{CO}_{2}$ and $\mathrm{H}_{2} \mathrm{O}$ as was thought. It is not part of the fucl but is a neeessary part of the machine, moving to and fro like the piston of a gas engine. The arrival of the stimulus (free kinetie energy) is the trigger setting free lactie aeid from some physieo-ehemieal combination and so eausing an inerease in $\mathrm{II}$ ion eoneentration and eonsequently an inerease in tension at the surface of the fibril and sareoplasm. If this tension is not allowed to eause eontraetion, the energy of tension ean be eonverted, as we have seen, into heat. The amount of heat so obtained has been shown by Hill to be quantitatively equal to the amount of work derivable from the tension. That is, the efficiency of contraction is 100 per cent.

\section{(Mean maximum value $=91$ per eent.)}

(2) Restitution. This extraordinarily efficient first stage of museular aetivity where stored energy is eonverted into work

\section{TABLE XXII,}

Gaseous Exchange in M. Levator Labii Superioris of the Horäe Pep. gram of muscle per minute (Chauveau and Kaufmann).

\begin{tabular}{|c|c|c|c|c|}
\hline & \multicolumn{2}{|c|}{ REST. } & \multicolumn{2}{|c|}{ ACtivity. } \\
\hline & Oxygen ahsorbed. & $\mathrm{CO}_{2}$ given out. & Oxygen absorbed. & $\mathrm{CO}_{2}$ given out. \\
\hline $\begin{array}{l}1 \\
2 \\
3\end{array}$ & $\begin{array}{l}0.0032 \text { c.c. } \\
0.0079 \\
0.0028\end{array}$ & $\begin{array}{l}0.0019 \text { c.c. } \\
0.0058 \\
0.0026\end{array}$ & $\begin{array}{l}0.05+c . c . \\
0 \cdot 014 \\
0.010\end{array}$ & $\begin{array}{l}0.063 \text { c.c. } \\
0.018 \\
0.013\end{array}$ \\
\hline
\end{tabular}


must be followed by a stage in which energy is again stored for work. During this phase four things are evident, viz. :

I. Oxygen is neeessary.

II. Carbon-dioxide is evolved.

III. Laetie acid disappears.

IV. Heat is evolved.

Examination of table XXII. given above will make it elear to the student that I. and II. are different parts of the same reaction. Oxygen is used to oxidise some earbon eompound which is exereted as $\mathrm{CO}_{2}\left(+\mathrm{H}_{2} \mathrm{O}\right)$. If oxygen is not present we learn from the work of Fleteher and Hopkins that the lactie aeid set free during the eontraction phase is not removed. The amount of heat evolved has been very earefully estimated by Hill and others. They find that it is almost exactly equivalent to the tension developed in contraetion. If the tension be estimated in heat units and found to be $5 \times 10^{-6}$ eals. per gram-weight of tension per eentinctre of musele length, the heat evolved during the restitution phase would also be $5 \times 10^{-6}$ eals. per gram-weight. The work done in putting the musele baek into its precontraction state is equal to the tension developed during eontraction.

Two views are held regarding the mechanism of restitution. The eommoner idea is that laetie aeid is in musele as elsewhere an intermediate eompound in the oxidation of glueose. Glueose, we know, is stored in musele and this store is decreased during eontraction. The amount of heat liberated from glueose in the formation of lactie acid is very small, while the amount liberated when laetie aeid is itself oxidised to $\mathrm{CO}_{2}+\mathrm{H}_{2} \mathrm{O}$ is eonsiderable. 1 gram of laetic acid in oxidation sets free 3700 eals. These faets seem to fit in well to the following seheme. During eontraction laetie aeid is formed from gheose. For this, very little oxygen is required and very little $\mathrm{CO}_{2}$ is evolved. Practically no heat appears. During restitution the lactie acid is removed by oxidation and heat is evolved.

Neat though this theory is, it has been rendered untenable by the brilliant researehes of $\mathrm{A}$. V. Hill and $\mathrm{V}$. Weizsacker with their ingenious myothermie apparatus, and by Fleteher and Hopkins who devised a delicate means of estimating laetie acid. When 1 gram of lactie aeid disappears from musele, only 450 eals. instead of 3700 are produced. Obviously, only a small fraction of the laetie aeid is oxidised if any. Fleteher and Hopkins could not deteet any oxidation of lactic aeid. 
The lactic acid set frec in the contraction phase is, in the restitution phase, once more built up into the physico-chemical compound of which it was a part before the arrival of the stimulus provoked a contraction. As A. V. Hill has said, "The lactic acid is part of the machine and not part of the fucl." During contraction it is set free, during restitution it is built up again. To provide energy to build the lactic acid into its old place, i.e. to restore equivalence of internal energies between sarcoplasm and fibril, glucose has to be oxidised to $\mathrm{CO}_{2}$ and $\mathrm{H}_{2} \mathrm{O}$.

'There seems to be little doubt about the experimental evidence regarding the utilisation of glucose during restitution. The glucose stored in the muscle furnishes the main rescrvoir of cncrgy on which the muscles draw for carrying out this work. There is some evidence, not very clear it is true, suggesting that stored fat may also be ealled on to supply cnergy for muscle restitution. Either becausc carbohydrate is more readily mobilised or because it requires a lower tension of oxygen for disintegrative oxidation than fat or for both reasons, muscle utilises carbohydrate in preference to fat.

'The liberation of lactic acid in the first phase of muscular movement produces not only contraction but a whole series of physico-chemical changes which have got to be reversed during restitution. I. As a dissociable acid (Chap. VII.) it will produce an incrcase in $\mathrm{H}$ ions. II. This increase in $p H$ reacts on the colloids in suspension in the muscle, causing them to alter in clectrical charge (Chap. VIII.). III. This in turn scts free salts adsorbed to the colloidal surfaces and so produces an increase in osmotic pressure. IV. Further, the membranes will become polarised. V. From III. and IV. will result cndosmosis and the watcr content of muscle will increase.

Roaf has shown that there are definite alterations in II ion concentration associated with different stages of muscle contraction. Macalhm proved that activity caused an alteration in the concentration of salts in muscle, and Fletcher has demonstrated the increase in water content after exercisc.

What is the effect of temperature on the restitution phase? We have seen that the contraction phase has a negative temperature cocfficicnt. Theoretically, each of the five sequelac to the liberation of lactic acid as mentioncd in the preceding paragraph has a positive temperature coefficient. The building up of lactic acid into a complex would be accelcrated by temperature just like any other chemical reaction. 
That is

(I.) The dissoeiation of lactic aeid, the setting frce of $\mathbf{I}$ ions, is inercased in rate and cxtent by incrcasc in tempcrature (Chap. VII.).

(II.) No change known.

(III.) Temperature increase causes increase of salt de-adsorption.

(IV.) No change known.

(V.) Because of the increased dissociation of salts by the inerease in tempcrature and because of the increased kinetic encrgy of water sccking admission the rate of cndosmosis will increase with increase in tempcrature.

Thesc have all to be restored to precontraction statc, and therefore do not matcrially contribute to this part of the discussion. But the tempcrature coeflieient of contraction is negative, therefore all these reactions must fall within the phase of restitution. Experimentally it has bcen found that this phase increases in rate with temperature. ('The other effects of temperaturc on muscular contraetion will be dealt with later. Just now we are eoncerned with isolated muscle.) A moderate increasc of tempcrature thus inereases the removal of laetie acid and the restoration of potential cnergy to the muscles, while not appreciably lesscning their power to transform potential into kinetic energy, i.e. to eontraet. Further, it has becn shown by Lagrange that an increase in temperature inereases the efficiency of nusele. Lately, workers have aseribed this increased efficiency to the more rapid removal of laetic acid.

Now we have seen that:

(a) The restitution phase is accompanied by an inercase in the temperature of musele.

(b) The rate and efficiency of eontraction is reduced by inerease in temperature, and

(c) The rate and efficieney of restitution is inercased by increasc in tempcrature.

It therefore follows that there will be a tempcrature at which musele work (contraction and restitution) will be performed most efficiently. Further there will be an optimum speed at which work will be carried out. This speed will be regulated

(1) By the natural rhythm of eontraction of the muscledepending on the length of the eontractilc body (Fig. 25).

(2) By the optimum temperature, and

(3) By the amount of resistanec that has to be overeome in shortcning. (See also Chap. XXVIII.) 
The effieicney of this sceond phase of muscle work is less than that of the contraction phase, which we saw was 91 per eent.
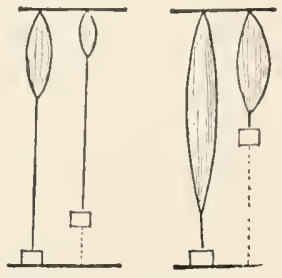

Fif. 25.-Intluence of the length of a muscle upon the work dome. A muscle one inch long (left-liand figure) in contracting to half its lengtli lifts a weight to hali an inch. A muscle of two inches, on the ofleer hand, is capable of lifting the weight to one inch.

(Noel Paton's Essentials of Human I'hysiology.)

Taken together they give a gross effieiency for a complete muscle twiteh as 50 per eent. But to this one might apply a correction to take into aceount the encrgy expended during musele rest.

(3) Rest. During complete inactivity, energy is used for maintaining the muscle in a state of preparedness for action, just as a nation has to spend money maintaining an army in peace time, so the muscle eell must always be ready for action. 'This is the third phase of museular lifeerroneously termed rest. As we shall see in the sequel, this phase is anything but restful. Again, just as in peace time, the eoordinating and integrating machine of empire, the Cabinct, kceps our standing army in a high state of effieieney, so the nervous system eonstantly sends impulses to the museles, kceping them ready for instant action. This state of resting readiness may be ealled the tone of muscle, and is, as indieated above, regulated in part by the nervous system (q.v.). During rest, energy is expended which if subtraeted from the total encrgy expended during restitution would raise the effieicney of that phase by about four per eent.

\section{TABLE XXIII.}

Oxygen used by Cat's Gastrocnemius M. (Verzìr, 1912).

\begin{tabular}{|c|c|c|c|}
\hline & & \multicolumn{2}{|c|}{ c.c. Oxygen used by musele. } \\
\hline & & per minute. & $\begin{array}{c}\text { per gram } \\
\text { per minute. }\end{array}$ \\
\hline Rest (Normal) & & $0 \cdot 050$ & $0 \cdot 003$ \\
\hline Contraction & & $0 \cdot 178$ & $0 \cdot 010$ \\
\hline Restitution & $\begin{array}{l}15 \text { sees. later } \\
11 \%, ", \\
11 \%,\end{array}$ & $\begin{array}{l}0 \cdot 336 \\
0 \cdot 208 \\
0 \cdot 154\end{array}$ & $\begin{array}{l}0 \cdot 020 \\
0 \cdot 012 \\
0 \cdot 009\end{array}$ \\
\hline Rest (Normal) & $146 \quad,, \quad$, & $0 \cdot 059$ & 0.0035 \\
\hline
\end{tabular}


The efficiency of museular contraction is found from the formula

$$
E_{g}=\frac{a}{b} \times 100,
$$

where $\quad a=$ actual work done (in cals.) per unit of time.

$b=$ total energy used (in cals.) , , , , ,

This gives the gross efficiency. The net efficiency is obtained by correcting for the encrgy expended during complete inactivity during a similar unit of time.

$$
\text { Net efficiency } \quad E_{n}=\frac{a}{b-c} \times 100,
$$

where $c=$ energy expended during inactivity (in cals.) per unit of timc.

As no extcrnal work is donc during inactivity it is difficult to assess the value of the efficiency of this phase.

The temperature co-efficient for a complete muscle cycle is $1 \cdot 8$, which means that the rate of the physico-chcmical reactions involved is almost doubled by an increase of $10^{\circ} \mathrm{C}$. As we have scen this rate is a compromise between the decrease in the rate of the physical reactions of the contraction phases and the increases in the physical and chemical reactions of the restitution phase.

\section{Character of the Electrical Variations in Muscle.}

The existence of elcetrical currents in tissues did not find direct proof until the year 1824 , when Nobili devised the galvanometer and showed that "natural currents" occur in the frog. Other investigators examined this current of rest and found that in a muscle removed from the body the current in the muscle passed from the ends to the middle and in the external (galvanometer) circuit from the middle to the ends. It has been conclusively proved that these "natural" currents are not natural at all but are an indication of injury to the muscle. Slight injury is unavoidable in the process of removing the muscle from the body-the less the preparation is injured the smaller is the current obtained from it. In other words, normal resting muscle is isoelectric and therefore currentless.

\section{Current of Injury or Demarcation Current.}

The injured part of a muscle is like the injured part of any ccll (p.134), "zincative" or electropositive to the uninjured part. That is, if non-polarisable clectrodes are led off from injured and non-injured parts to a current-detecting device, it will indicate 
a passage of current from the uninjured to the injured parts of the preparation through the galvanometer. Within the tissue, of course, the circuit will be completed by the passage of the current from injured to uninjured. This difference of clectromotive forec may be demonstrated without a galvanometer. If the nerve from an uninjured muscle be laid over an injured muscle in such a way that at one point it touches a cut portion, then, the undamaged muscle will contract every time the cireuit is completed by laying a second point of the nerve on an uninjured portion of the injured muscle.

This difference in E.M.F. persists as long as the injury. In a degenerating muscle its degenerating portion is clectropositive, galvanometrically negative or "zincative" to its normal portion. Naturally, the difference ceases when degeneration is complete. The whole mass is then isoclectric. The current is due, as has previously been explained (p. 1333), to physieo-chemical differenees at the junction of living and dying tissue. Dead tissuc gives no eurrent.

\section{Current of Action.}

Similar physico-chemical changes arc answerable for the wave of "negativity" which precedes the mechanical change in a contracting muscle. The part which is just about to contract is electropositive, or "zincative," to the rest. Consider for a moment a muscle, say $5 \mathrm{~cm}$. long. 'The preparation is supposed to be perfect and, therefore, there will be no demarcation current. If such a muscle be stimulated by a single induction shock at one end and two points A $3 \mathrm{~cm}$. and B $5 \mathrm{~cm}$. from the point of stimulation be led to an electrometer, then each stimulus will cause a wave of contraction to pass along the muscle, preceded by a wave of "negativity." That is, A will become "zincative" to the rest of the muscle-so that current would pass through a galvanometer from $\mathbf{B}$ to $\mathbf{A}$. A fraction of a second later, the disturbance will have passed on to B which will now be "zincative" to the rest, causing a current to pass through the galvanometer from $\mathbf{A}$ to $\mathbf{B}$. That is, $\mathbf{A}$ has first been electropositive and then electronegative to $\mathbf{B}$. Such a current is termed diphasic and is an indication of a propagated change.

A muscle nerve preparation may be used to demonstrate the presence of the current of action. If the sciatic nerve of a frog's gastrocnemius be placed on another gastrocnemius, the forner muscle may be made to contract by stimulating the nerve of 
the latter. The essential point about this preparation which is ealled the rheoscopic frog is that it actually proves the occurrence of a diphasic current in muscle in consequence of its activity. If the free nerve is stimulated by a tetanising eurrent both muscles go into tetanus. This secondary tetanus demonstrates that although the stimuli are bcing applied so rapidly that the contractions of the "battery" musele are fused, the diphasic nature of the excitatory process is still quite distinet and is indicated by the contraction of the "galvanometer" muscle.

The eurrent of action may be eonsidered as inclusive of the current of injury. Injury is stimulation. Thercfore, the current produeed by an injury confined to a small area should be weaker than that obtained by the excitation of the whole muscle. The E.MI.F. of the current of aetion of a sartorius is about 0.085 volts, while the demareation current may be about 0.053 volts.

An important piece of research work by A. V. Hill and W. Hartree has just been published. They devised instruments and methods enabling them to record photographically, not only the mechanical response of a muscle to a stimulus, but the heat produced at each phase of the mechanical response. Their apparatus was sensitive to $0 \cdot 000001^{\circ} \mathrm{C}$. One may summarise their main findings as follows :

(1) "The time relations of the heat production in the first few seconds after excitation are independent of the presence of oxygen." It has been stated above that the magnitude of the heat production was independent of the presence of oxygen. One may therefore consider that the energy required for the initial chemical changes caused by excitation does not arise from oxidation.

(2) A complete muscle twitch may be resolved into four phases.

Heat Production.

(a) Contraction - - - Initial rapid production diminishing gradually in rate as the stimulus proceeds.

(b) Maintenance of Contraction

(c) Relaxation

(d) Recovery
Small constant value ending shortly after stimulus ceases.

Relatively large evolution of heat, occurring rather suddenly during the later stages of relaxation.

A large but slow production of heat occurring in the presence of oxygen for some minutes after the contraction is over. 
(3) "The absolute amount of heat liberated in relaxation increases as the duration of the stimulus increases, up to a certain limit, after which it remains more or less constant."

(4) The heat developed during relaxation is derived from the mechanical potential energy liberated on excitation.

A close analogy is drawn by these workers, between the energy changes of muscle and of an accumulator.

(a) The energy of an accumulator-stored electrical energy-is liberated by the application of a "trigger," i.e. by completing the circuit between positive and negative poles. In the same way, the potential energy of muscle is liberated by the application of a stimulus. The chenical changes that accompany the evolution of energy from an accumulator do not involve oxidations-just as the initial processes of contraction in muscle do not.

(b) The amount of energy used in making electrical contact, e.g. depressing key, is very small and bears no relation to the amount of energy so liberated from the accumulator, as is the amount of energy required to stimulate a muscle fibre.

(c) If a suitable machine is in circuit, the energy set free from the accunfulator will manifest itself as "work" ; if not, it will be converted into heat.

(d) The moment the key is pressed the current starts in the electrical machine- say an electric motor. It passes round the coils of the armatures, and their soft iron cores develop attractive powers. The current, however, does not immediately rise to its full value owing to the self induction of the coils, nor do the soft iron cores become magnetised instantaneously under the influence of the magnetic field of the coil. Hence, the attraction exerted by the fixed poles on the armatures increases gradually up to a certain limit and then remains constant. These phenomena are similar to the development of mechanical response in a muscle.

(e) As long as the circulation is complete and the accumulator inexhausted, the inotor will rotate. Roughly speaking, the mechanical response and the length of stimulation are synchronous.

$(f)$ If the current is left on too long, the accumulator becomes polarised, the current falls off and the magnetic field consequently decreases. After a period of rest, the electromotive force of the storage element rises to its full value and the magnetic field is restored. This may be compared to muscular fatigue.

(g) On breaking the electrical circuit the magnetic field of the armature diminishes rapidly, though not instantaneously, to zero, and the motor slows down and stops. This process is analogous to relaxation.

(h) The current passing through the coils of the armatures and transforming them into magnets, endows them with (magnetic) potential energy which, as we have just seen, is, after a brief latent period converted into the kinetic energy of rotation. If the load on the motor is so great that revolution is prevented, then although tension is developed, no work is done. In the same way, muscle develops elastic potential energy on excitation which may result in the performance of external mechanical work if the muscle be allowed to shorten, but in an isometric contraction, shortening is prevented and no "work" is done. "The work actually performed depends in both cases on the conditions of loading."

(i) Heat production.

(i) Developmental. The electrical energy sent through the armature 
coils is converted partly into magnetic potential encrgy and partly into heat energy (Joule's heat) which is dissipated. The magnetic potential energy is converted partly into the kinctic form (rotation) and is partly dissipated as heat. The proportion of the incident energy which manifests itself as "free" and as "bound" depends on the length of time during which the current passes. A short cxcitation leads to the devclopment of power in preference to heat while the reverse is the result of a prolonged excitation. Similarly, with muscle-a single twitch develops very little initial heat while an increasing fraction of the potential energy appears as heat as the mechanical response is prolonged.

(ii) Maintenance. In order to maintain a constant magnetic field a constant current has to be maintained in the coils of the armatures. The coils heat up. This is analogous to a tetanic contraction.

(iii) Relaxation. The induced currents, set up in the coils and in the neighbouring conductors by breaking the circuit, are converted into heat, i.e. the evolution of heat continues until the whole of the magnetic encrgy of the field has been dissipated as heat. Similarly in the muscle when the stimulus ends, the heat production does not stop at once; it continues until all the elastic potential energy of the muscle has disappeared.

(iv) Recovery. None of the above processes require the immediate prescnce of oxygen. In order to restore the electrical system to its former level, i.e. to recharge the accumulator, some mechanism has to be employed to convert kinetic into electrical energy. The normal process implies oxidation-an engine is started, oxygen and fuel are consumed, a dynamo is driven and current produced. Similarly oxygen is necessary during the recovery phase of muscular contraction.

(v) Rest. Accumulators "run down" when not in use, and liberate a certain small amount of heat. To keep them in condition they must have periodical additions to their material and energy contents. This recharging involves heat production and oxidation. In the same way, muscle at rest (in the absence of oxygen) liberates heat (and lactic acid). In the presence of oxygen this liberation is made good by oxidation. That is, muscle normally is prevented from " rumning down" by " continuous recharging" with, of course, a steady evolution of heat.

The foregoing notes are taken materially and almost verbally from an article by Prof. A. V. Hill and W. Hartree in the Journal of Physiology, Vol. LIV., p. 84. The student will, of course, bear in mind that no theory of muscular contraction is implicd. A physical phenomenon which bears a very close resemblance to certain phases of the mechanical response of muscle to stimulation is given as suggestive of a type of mechanism. But, as has been said, "Resemblance is no proof analogies can never replace analysis." 


\section{CHAP'TER XIV}

\section{MANUFACTURING CELLS}

\footnotetext{
"For know, whatever was created needs

To be sustained and fed ; of elements

The grosser feeds the purer."
}

Milton.

IN the preceding chapter attention has been drawn to the muscles as cell communities which consume power but do not produce commodities for the usc of the body as a whole. Other cell groups, the glands, may be regarded as the industrial communitics manufacturing goods for use elscwherc. Others again are mere handlers of goods. These lattcr, the organs of absorption or excretion (negative absorption), do not as a rulc alter the chenical state of the material, raw or manufactured, that thcy handle. They accept delivery, repack in suitable containers it may be, and forward for transport.

The glands may be divided for convenience into two classes. First, those which by means of a duct, opening outside the body, secrete manufactured material. The glands of the alimentary tract and the skin glands (sweat and milk) belong to this class. The other class prepares material which itsclf is used by the body cells. They secrete into the blood stream. The former may be termed organs of extcrnal secretion, the latter organs of internal scerction, ductless glands or endocrinc organs.

- As far as is known the principle underlying the activities of all.glands is the same. Each manufactures some material which is stored up, and when wanted this material is washed out by a stream of water. That is, they all consist of a workshop and a dispatch department. These two functions are seemingly under different control and have to be studied scparately.

The work donc by a gland may be divided into threc phasesjust as we saw that muscle work could be so treatcd-viz. : (a) Activity,'(b) Restitution, (c) Rest or Maintenance. 
(a) Activity. The outsider may gauge the activity of a factory by studying its output, and so, mueh may be learned of a gland by noting how mueh it secretes and when. Some glands seerete continuously, others in spurts. With the former should be placed the endocrine organs, with the latter the digestive glands. Of eourse those which maintain a steady output may, under stress, greatly accelerate their rate of secretion, and of the latter class the salivary glands at least maintain normally a level of secretion which under a suitable stimulus is enormously increased.

There seems no doubt but that the industrial eell-group eonsists of four different parts or activities. (I.) The factory itself where the secretion is prepared. (II.) The store room where it is packed and kept in bulk. (III.) The dispateh department where it is first paeked small and ready for delivery and then (IV.) is sent out. Now when we speak of the activity of a gland we refer exclusively to this last function, viz., aetive secretion. What then regulates the rate of seeretion? Just those factors come into play which operate in our industrial world.

1. Stoek on hand and rate of output from workshop.

2. Effieiency of the dispatchers.

3. Demand for goods.

Normally, the store of goods on hand and the rate of manufacture do not materially influence the output. Of course, if the operatives are poorly nourished or badly supplied with raw material, then output will fall. Similarly, insufficiently fed or overworked dispatchers will perform their duties half-heartedly and output will be decreased, but as a rule this faetor does not come into play.

The decisive element controlling rate of output is the demand for goods. The store of goods is drawn upon and the faetory speeds up to replenish the store. If the stored material is sent out more rapidly than it can be replaced, then overtime has to be worked in the factory, and if persisted in, industrial fatigue is caused and total cessation of work is the final result.

These various conditions may be studied eonveniently by studying the intake of oxygen or output of $\mathrm{CO}_{2}$. In some instanees the intake of potential energy may be measured. From these it is found, as in muscle, that a very small proportion of the total $\mathrm{O}_{2}$ intake goes to the dispatch department. That is, the aetual setting free of the secretion does not require mueh encrgy (ef. muscle eontraction). 
(b) Restitution. Just as in muscular, so in glandular activity the great proportion of the oxygen used is associated with the phase of restitution. Encrgy is required for the building up of material to replace that lost during secretion.

(c) 'Then, as in muscle, the gland requires a certain amount of energy for domestic use. To keep its parts in repair and to preserve its identity, it requires a maintenance allowance. 'The following figure from Barcroft will help the student to realise the energy expended during these three phases in the activity of the salivary gland in the cat.

From the figure it will be seen that the maximal rate of seeretion occurs sometime before the maximal consumption of oxygen, and

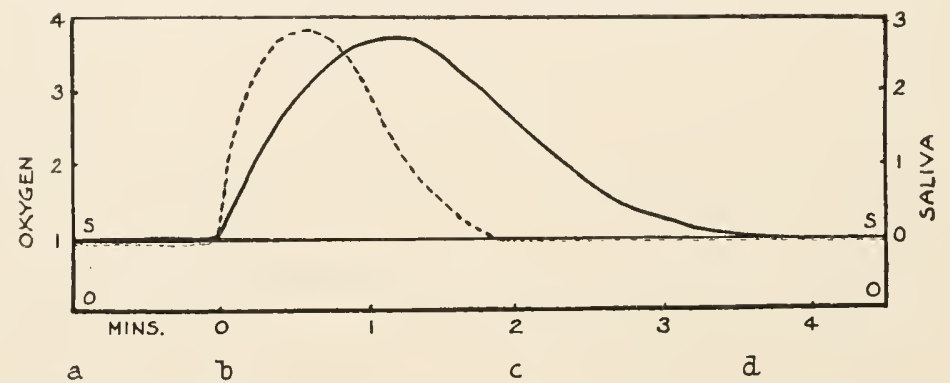

Fia. $26 .-$ Oxygen used by the salivary gland during rest, activity and restitution. From $a$ to $b$, the gland was not secreting, but was using a fairly constant amount of oxygen. From $b$ to $c$, the gland was active-secreting saliva at the rate denoted by the dotted line. From i to $d$, the gland was being restored to its pre-secretory state. $0-0=$ oxygen base line. The area, ooss, represents the basal or resting metabolism of the gland. Dark continuous line-oxygen consumption. $s-s=$ base line for saliva. Dotted line=saliva formed in c.e. per minute. (After Barcroft.)

that the inereased consumption of oxygen lasts for some time after the saliva has ceased to flow. Barcroft and his colleagues found that the length of this period of increased oxygen consumption depended upon the previous degree of activity of the gland as well as on its functional eapacity. In other words, if a previous inroad upon the store of material had not been made up, the factory cells would have to work at high pressure to keep pace with the demand. Work at high pressure is not economical. Each gram of secreted material is formed at an increased cost in oxygen and energy.

The energy required for secretion comes from the oxidation of ghueose. (Again compare with muscle.) For the dispatch of the material, little cxtra oxygen and little extra glucose is required. Asher and Karalov found that the restitution phase required the most energy. 'That is, the glucose content of the blood was markedly diminished in the post-secretory period. The amount 
of glueose used runs, as one would expect, parallel to the oxygen eonsumption.

The mechanism of seeretion has been provocative of much eontroversy. A regular pitched battle results when vitalists, neovitalists and mechanists diseuss the problem. What are the facts?

1. Mieroseopical examination of the gland shows that during inactivity the lumen (storehouse) beeomes filled with granules and the gland inereases in volume. When the gland is exeited to secretion, these granules disappear with the seereted fluid and the gland decreases in volume.

2. Water passes from the blood into the gland and out with the seeretion.

There seems to be no diffieulty in giving a plausible explanation of the second of these phenomena. The postulation of a semipermeable membrane is suffieient. The first fact presents difficulties.

(a) The osmotic pressure of the secretion is often greater than the osmotic pressure of the blood.

(b) The pressure in the duet against whieh the saliva may be seereted was found by Ludwig, in 1851, to be greater than that of the artery supplying the gland. Hill and Flack reeently estimated this differenee in pressure. They found that the pressure of secretion was as high as $240 \mathrm{~mm}$. $\mathrm{Hg}$. and the arterial pressure $130 \mathrm{~mm}$.

3. Macallum demonstrated alterations in surface tension during seeretory activity.

As mentioned in Chap. VI. this worker made use of the GibbsThompson distribution of salts to determine the relative values of surface tension in eells which had been killed and fixed almost instantaneously. He found, in the panereas for instance, that during rest there was an unequal distribution of potassium. but when the gland was stimulated to aetivity potassium salts were found equally distributed throughout it.

Theoretically, in an active gland there must be at least three different values for surface tension, viz. :

(1) Cell-lymph interface, i.e. on the outer face through which raw material and power enter.

(2) Cell-eell interface where the eell wall is in eontact with some of the other eells of the gland.

(3) Cell-lumen interface through which the secretion and the leaching out water pass. 
Now during activity he found that there was the densest condensation of potassium at (3), the cell-lumen interface, less potassium was found at the cell-cell interface and least at (1), the cell-lymph interface. According to the Gibbs-Thompson prineiple these results may be taken as an indieation.

(a) That during rest there is no marked differenee of surface tension at the gland interfaces, and

(b) That during activity a high tension develops at the surface between cell and lymph, a low tension between cell and lumen and that the cell-eell interface has a value intermediate.

4. It is well known that during glandular aetivity there is an increase in the rate at which blood enters the gland. In other words raw material and power are taken into the factory at an increased rate. The view was at one time held that the secretion was duc to this increased flow of blood. Barcroft's experiments have shown that this cannot be true, because

(a) The increase in the blood flow through the organ is initiated after the secretion begins and is continued for some time after secretion has ceased; and

(b) Vaso-dilatation may take place without secretion.

The increase in blood flow or vasodilatation is a consequenee of secretion and not the secretion a result of the vasodilatation. The actively secreting gland, as it were, sends out a call for oxygen, for power and for material. This call is in part met by this increase in the transport service (see Chap. XXIV.).

5. Alterations take place in electrical potential of one part of the gland to another. These have been studied prineipally by Bayliss and Bradford on the salivary gland and by Orbelli on the skin glands of the frog. The results vary somewhat with the means of investigation, but may be taken as indieating two things.

(a) 'The secretion of water, i.e. dispatch of secretion, is a different function of the gland or a function of a different meehanism in the gland from the elaboration of the true seeretory material. That is, we have to consider two phenomena, the preparation of matcrial and its flooding out of the eell by water. The former is accompanied by

(b) A large differenee of "potential between the cell-lymph interface and the cell-humcn interface, the latter by a small potential difference of the opposite sign from the former.

The cause of the former difference may be sought in the increased permeability (lowered surface tension) of the cell-lumen 
interface; allowing free passage to eat-ion and an-ion. That is, at this surface the electrieal potential reeorded will be that of the interior of the eell (ef. musele-eurrent of injury).

An explanation of the eurrent which flows during the elaboration of secretion is more diffieult. There seems no doubt that just before being earried out through the duet, the granules undergo some change. The large eolloidal partieles either break down into smaller particles or go into solution. Either of these actions is aceompanied by the setting free of adsorbed salts and alterations in the electrieal eharge.

6. These two proeesses, water seeretion and the elaboration of the organie seeretory material, seem to be eontrolled by different sets of nerves. Secretory nerves when stimulated eause the gland to be flooded with water, while "trophic" nerve fibres have to do with the elaboration of the granular material of the sceretion. (Heidenhain, 1868, and Babkin, 1913.) Both sets of fibres may go to the gland in the same nerve. It is interesting to note that acid and other irritants exeite secretory fibres only, while normal exeitants stimulate both secretory and trophic fibres.

Can we from these faets eonstruet a pieture of the meehanism of secretion?

(1) The formation of granules in the eell may be similar to the formation of stareh in the plant. Substances are thus put out of action. The colloidal granules not only have a low osmotic pressure but they adsorb erystalloids and so prevent endosmosis.

(2) On stimulation, these granules are broken down into smaller particles and water rushes in. It may be that stimulation of the gland follows the same course as in musele and produees aeid. This acid would interfere $(a)$ with the colloids present, especially with their power to hold water (imbibition) and salts (adsorption) and so bring about alterations in their size, electrieal charge and the osmotic pressure of their dispersion medium. (b) Acid has a direet aetion on the electrical eharge of any solution and, therefore, acts on its surface tension, lowering it. The only surface where this ean take place is between the eell and the lumen. The alkaline reserve of the blood is sufficient to keep the eell-lymph interface normal ; or rather supernormal, while the eell-interfaces obviously need not be considered.

(For a neat model of Mueoid seeretion due to M. Fischer, see Part II. p. 415.)

In short, the arrival of the appropriate stimulus causes the 
cell to draw on its storc of matcrial, alter the packing of the material and launch it into the duct on a current of water. The stimulus may be nervous or it may be a hormonc (chemical messenger) formed in another organ and transported to the gland by the blood.

Of the mechanism of these glands which secrete directly into the blood stream little is known. Scemingly the secretion is extruded from the cell and washed away by the blood itself. Their oxygen consumption has never been measured nor yet their utilisation of glucose.

Bayliss and Hill have shown that the salivary gland does not become heated during activity. From this we may deduce that all the additional energy set free during the course of activity is used in doing work (in elaborating the secretion and in setting it free, ctc.), and in maintaining to some extent the normal temperature of the body (cf. Muscle). Thus leaving alone the latter sink of energy we may consider a gland as 100 per cent. efficient and calculatc the work done from the oxygen intake or carbon dioxide output or from the diminution of sugar in the blood passing through it.

A considerable amount of work has been done in connection with the electrical changes which take place when a gland sccretcs. Bayliss and Bradford found that two kinds of changes occurred in the salivary gland. That associated with the secretion of water produced changes in the opposite dircetion from that associated with the output of the colloidal matter. The causes of this phenomenon are not yet certain but two "pointcrs" may be indicated. (1) The work of Locb and his colleagues has shown how the presence of colloidal matter may alter the sign of electrification of water (p. 111). (2) In accordance with the accepted theory of secretion, the onsct of true sccretion leads to an increase in the permcability of the cell membrane at one end. It is obvious that, at the more permeable end, we arc in electrical contact with the interior of the cell and so obtain the potential difference of the Helmholtz double layer between permeable and impermeable parts of the surface. During a nere secretion of water permeability is not supposed to undergo alteration. 


\section{CHAP'TER XV}

\section{THE ARIIY FOR HOME DEFENCE}

"Whatever uneertainty and variety may appear in the world, we remark, nevertheless, a eertain seeret concatenation and regular order at all times earried on by Providenee, which eauses everything to proceed in its eourse, and to follow the litw of its destiny."

Ia Rochefoucauld.

THERE are certain cells and certain cell-communitics whose function it is to guard the organism from the invasion of its cells by noxious substances and by predatory parasites.

1. Cells. The leucocytes or white cells of the blood are amoeboid in character and act as scavengers and dust cart combined. They absorb, kill and digest micro-organisms which have invaded the organism. They also ingest and digest effete tissues, such as the tail of the tadpole when the frog stage is reached. This is termed phagocytosis. Certain drugs, e.g. iodoform, are supposed to increase the amoeboid movenents of leucocytes and so increase their phagocytic power. This takes for granted that the bacteria, etc. are enclosed by the pscudopodial processes of the leucocyte. In the blood vessels it is very rare for leucocytes to be secn with extruded processes. They are found as spherical cells, and Ledingham has shown that when a leucocyte collides with a bacterium, ingestion, death, and digestion of the bacterium follows as a matter of course. They act just as we saw that anioeba acted, and phagocytosis is just the same as any amoeboid organism feeding. There secms no doubt but that they are subject to cheniotaxis like other amoebae-chemical lowering of surface tension applied unilatcrally. Exposure to an clectric ficld causes the leucocytes to move towards the cathode. Certain substances, so called opsonins, cause leucocytes to take up bacilli more readily. This is due, as Ledingham has pointed out, to the agglutination of the bacteria so that more are ingested at each encounter. The clumping of the bacteria by an opsonin follows the law of colloidal adsorption. It was once thought that the 
opsonin either stimulated the leucocyte or scnsitised the bacterium, making it more chemio-attractive to the destroyer (Fig. 23).

2. The kidneys are the great eliminating organs of the body. Each of them is built up of a number of long unbranched tubes closed at one end and, at the other, opening, along with several other similar tubules, into a common collecting tubulc. This in turn opens into the pelvis of the kidney. The production of urine goes on in these unbranched tubules, the collecting tubule serving apparently only as a conduit to the pelvis. The closed end of each tubule is invaginated within itself to form a Bowman's capsule, where its epithelium lies in close contact with the capillary tuft of blood vesscls - the whole end-structure being called a Malpighian corpuscle (see over, Fig. 28).

The kidney does not manufacture any of the constituents of its secretion except hippuric acid, but merely eliminates unchanged certain of the bodies brought to it by the blood.

It is not a mere filter, as the concentration of the constituents of the urine are vastly different from the concentrations of the same substances in the blood. There seems to be a threshold value for each and every substance in the blood which when exceeded is at once reduced to its normal value by the elimination of the excess by the kidney. It keeps the salt content of the blood steady; therefore, abnormal constituents will be eliminated in their entirety. Not only is there an alteration in the relative eoncentration of the various substances eliminated, but there is in general a concentration of solutes. This concentration of solutes necessitates the expenditure of energy.

The total energy used may be estimated, as in other glands, by the consumption of oxygen. When the kidney is at rest, that is, when little or no urine is being formed, very little oxygen is consumed. During activity the amount of oxygen used incrcases greatly. The following table taken from Barcroft and Brodie shows this :

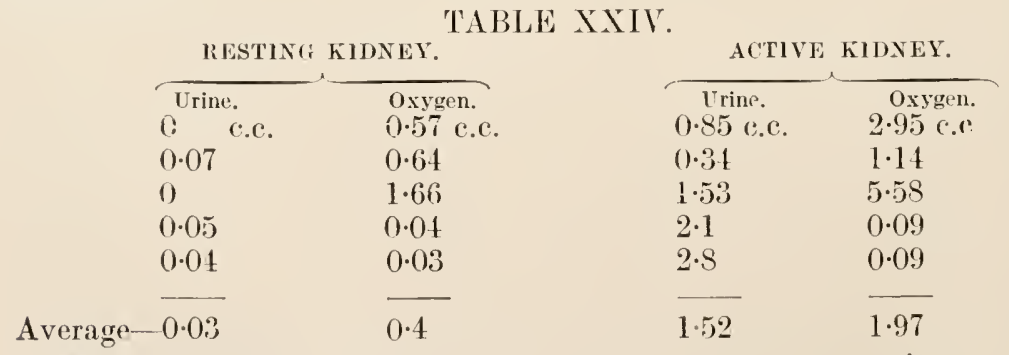

Work per minute $=320$ gram centimetres $=1650$ gram centimetres. 
During rest, the bulk of the oxygen eonsumed goes to the maintenanee of the kidney cells. On the average, the kidncy eells use about 0.04 c.e. of oxygen per gram per minutc and secretc about 0.003 c.e. of urine. During a period of inereased activity, the oxygen absorbed may rise to 0.28 c.c. per gram of kidney per minute. Each e.e. of normal urine costs about 1.05 c.c. of oxygen over and above what is required for cellular use.

The $\mathrm{CO}_{2}$ output varies very mueh even during rest and does not always increase in proportion to the oxygen absorbed. It may be that this metabolite is exereted by some other channel than the blood stream.

Attempts have been made to eorrelate the total energy exchange in the kidney with the work done, caleulated from the alteration in the osmotie eoncentration in the various urinary constituents. The minimum work done in the formation of a litre of urine may be ealeulated from the Hill-Donnan formula.

$$
\text { Work }=\mathrm{R} \cdot \mathrm{T} \cdot\left[\Sigma\left(C_{u} \log _{e} \frac{C_{u}}{C_{b}}\right)+\Sigma C_{b}-\Sigma C_{u}\right]
$$

where $\quad R=$ the gas eonstant, $T=$ absolute temperature,

$C_{b}=$ eoneentration in the blood of any eonstitucnt $a, b, c$, ete.

and $\quad C_{u}=$ its coneentration in the urine.

'T'his, of eourse, would only give the minimum work of the kidney, even if we knew the eoneentration and degrec of dissociation of each and every urinary eonstituent. It may be advisable to 'eall the student's attention to the faet that the energy used in effeeting any ehange is independent of the means by which that ehange is effeeted. The work done, ealeulated from the HillDonnan formula, is simply the minimum neeessary to eause the neeessary ehange in the moleeular eoneentration. It is independent of any process and commits one to no theory (see Chap. III.). Attention to this point will prevent many a ludicrous mistake.

Rhorer has caleulated the work done by the kidney in concentrating urea and sodium chloride, and from his figures Cushny considers that as the coneentration of urea eauses the eonsumption of about 0.7 eals., and similarly about 0.05 eals. are used in eoneentrating sodium chloride (per litre of urine), it would not be an overestimate to state that the produetion of a litre of urine entails the expenditure of at least 1.2 cals. This value, however, is but a fraction of the ehemical cnergy used as determined by the oxygen consumption. We have seen above that for eaeh volume 
of urine seereted, the kidney eonsumes about an equal volume of oxygen. Assuming that the oxygen all goes to the oxidation of gheose, then each eubie eentimetre of oxygen will eause the liberation of 0.05 eals. of energy from 0.015 grams of glueose. 'That is, the intake of energy for the output of about a litre of urine will be about 50 eals. There is thus a diserepaney between the total energy absorbed and the apparent work done. Meltzer and others aecount for this on the principle of the "factor of safety."

Maeallum dissents from this explanation. He adduees evidenee of a permanent low surface tension on the lumen-eell interface and aseribes the excess of energy used to the eontinuous maintenanee of this surfaee energy gradient. On the other hand the diffieulties to be overeome in measuring the fall in oxygen potential in the blood passing through the renal vessels are very great, and it may be that although the results are relatively aceurate their absolute values may be somewhat high. Bareroft and Brodie estimate that about $\frac{1}{10}$ of the total oxygen intake goes to the kidney.

These workers lave attempted, by means of estimations of the oxygen intake of the renal eells, to tell when the kidney aets as a passive filter and when the renal eells take an active part in secretion. During filtration, they say, no osmotic work is done, and therefore no energy is required and no oxygen used. Aetual renal aetivity will entail expenditure of energy and eonsumption of oxygen.

A solution made up so that in eomposition it approximated to blood minus the colloids was injeeted into a blood vessel of a eat. Immediately there was an inerease in the amount of urine seereted but no inerease in the amount of oxygen consumed-proof positive of the non-participation of the renal eells. Now let us see what has happened. 'The introduetion of the saline fluid eauses :

(1) A temporary increase in the volume of blood corresponding to the amount of the fluid injected.

(2) An increase in general blood pressure and therefore an inereased pressure in the renal arterioles.

(3) An inerease in the rate of the blood flow through the kidney vessels.

(4) A deerease in the eoneentration of the eorpuseles of the blood. This results in a decreased oxygen earrying power and a deercased viseosity.

(5) A dilution of the colloids of the blood. 
'The saline diuresis may have been caused by all or any of these eoneomitants. They may be eliminated one by one.

$(1,2$, and 3) Increased blood volume, pressure and flow may be considered together. Increase in pressure, ete., produced mechanically without altering the concentration of corpuseles or of colloids, certainly does produce an inereased flow of urine, the constituents of which have a concentration approximating to that produced after injection of Ringer's solution. Bareroft and Straube overcame this difficulty very ingeniously.

They previously removed a quantity of blood equal in volume to the Ringer they were about to inject, thus keeping the blood volume, etc., normal. The diuresis was produced as before, entailing no extra oxygen consumption.

(4) The addition of blood corpuscles to makc up the deficient concentration made no appreciable difference in the flow of urine.

(5) Knowlton introduced a colloid, gum acacia or gelatine into the perfusion fluid so that the colloidal osmotic pressure of the injected fluid was equal to that of the blood (25-30 $\mathrm{mm}$. of $\mathrm{Hg}$.). This prevented the onset of marked diuresis, gelatinc being morc efficicnt in this respect than gum acacia. Two causes may be ascribed to the lower efficiency of gum: $(a)$ its lower osmotic pressure (5 per cent. gum has an osmotic pressure of about $12 \mathrm{~mm}$. compared with 5 per cent. gelatine whose O.P. is $23 \mathrm{~mm}$. of $\mathrm{Hg}$. Bayliss recommends a 7 per ecnt. solution). (b) Gelatine has a certain water holding power which is altered by treatment with salts (sec Imbibition, Chap. VIII.).

The conclusion that one would draw from this series of experiments is that the passage of fluid and salts through the kidney by filtration is controlled by the concentration of colloids in the blood plasma.

Let us consider now a case where oxygen is consumed and, presumably, work done. Sodium sulphate is a diuretic. It is less diffusible than sodium chloride. A collodion membranc can be prepared which will allow the chloride and not the sulphate to pass through. Yet in the kidney the very reverse seems to take place. Sodium chloride acts very much like Ringer's solution, and though after a large injection of $\mathrm{NaCl}$ the chloride content of the urine rises, it does not materially alter the concentration of the other solutes. On the other hand, the injection of $\mathrm{Na}_{2} \mathrm{SO}_{4}$ is followed by the secretion of a urine almost cntirely a water solution of the sulphatc. Cushny has shown that, after the 
injeetion of a mixture of equal amounts of chloride and sulphate of sodium, more sulphate than ehloride is exereted, and while the chloride elimination falls to normal in about an hour, at the end of three hours the sulphate eontent of the urine is above the normal. These results point to the sulphate as having a direct aetion on the renal eells. It is known to be a eell irritant. 'The question now is, does the kidney use up more oxygen during a sulphate diuresis than during a Ringer diuresis ? Fig. 27, from Bareroft and Straube, shows that the oxygen used inereases as the amount of urine inereases. Therefore, one may say that the sulphate diuresis entails energy expenditure.

The various factors dealt with above as eoneomitants of saline diuresis may now be dealt with.

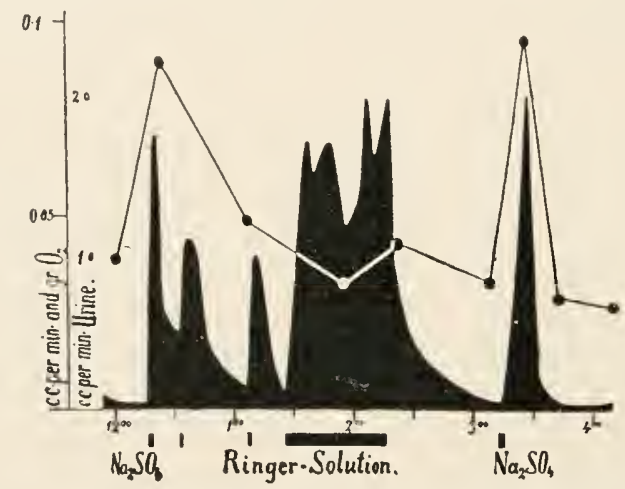

Fid. 27.-To show the relationship between the production of urine and the consumption of oxygen by the kidney under the intluence of Ringer-Solution and of sodium Sulphate. The black area indicates the amount of urine secreted, the thin line the consumption of oxygen. (Barcroft.)

1, 2, and 3. Increase in flow of blood, ete., do not play a part. Bainbridge and Evans showed that in a perfused living kidney, sulphate diuresis may oeeur without any inerease in volume. Gottlieb and Magnus are inelined to think from a study of kidney volume that eireulatory eonditions are less favourable for sulphates than for ehlorides.

4. The eorpuseular eoneentration of the blood has as little effeet under sulphate as under ehloride injection.

5. The introduction of a eolloid after a sulphate made little difference in the flow of urine, while it diminished it markedly after a ehloride injection (Ḱnowlton).

In short, filtration plays but a small part here. No doubt sulphates have a certain salt aetion but this is masked by their strong seeretory effeet. 
Next, one wants to eonsider what eells the sulphate stimulates. Cushny eaused one kidney to secrete against a pressure of $30 \mathrm{~mm}$. Hg., leaving the other kidney free. During the height of a $\mathrm{NaCl}+\mathrm{Na}_{2} \mathrm{SO}_{4}$ diuresis he found that for equal weights of urine the obstructed kidney produced a fluid eontaining less ehloride and more sulphate than the kidney with unobstrueted ureter. The result of one experiment is appended.

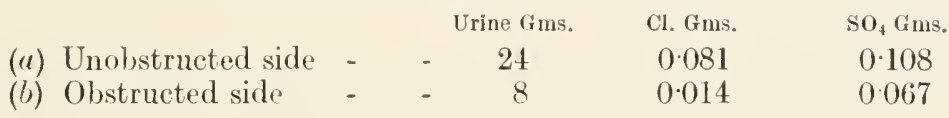

He supposed that the filtrate from Bowman's capsule must be of identieal eomposition in both kidneys, as both had the same blood supply. Therefore, some change must have taken place during the passage along the tubules. In one ease (obstruction) the fluid remained in eontact with the lining eells for a prolonged period, while on the other side free passage was allowed. Either sulphate must have been added to the fluid during its stay in the tubule or chloride and water absorbed. The two main modern theories of renal action differ on this point. The experiment is quoted at this stage to demonstrate that it is probable that sulphate stimulates the cells lining the tubule, and that their activity entails the eonsumption of oxygen and the expenditure of energy.

It is very diffieult to get reliable experimental results from the kidney. Its nature, blood supply and position do not lend themselves to surgical interference, and the student ought to be keenly eritical of results which are produced under uncontrolled abnormal conditions. Some facts, however, are obtainable and may be detailed here shortly.

1. Function. No one doubts that the kidney as a cell-eommunity has specialised in exeretion. Every eell in the body has the power of eliminating waste produets. Most of these substances find their way into the blood and those that are non-volatile are voided by the kidney cells.

\section{Structure.}

'The functioning parts seem to be strueturally, two, $(a)$ the capsules, and $(b)$ the tubules. Each eapsule is lined by flattened pavement cells supported by a delieate basenent membrane. The tubules are formed of eolumnar eells eontaining rows of granules running radially towards the lumen and beeoning finer as they reach the striated border of the eell-humen interface. 
3. Blood Supply. The artery supplying the kidney breaks up in the cortex into a large number of eapillaries, each of which forms a nodule or glomerulus invaginated in Bowman's eapsule. The eapillaries again eoalesee to form the efferent vessel, and this again breaks into a number of eapillaries entwining round the tubules. After this the blood leaves the kidney by way of the renal vein. That is, the blood is first supplied to the glomeruli and then to the tubules.

4. Blood Pressure and Secretion. If the blood pressure is lowered to between 40 and $30 \mathrm{~mm}$. Hg. secretion stops. Starling

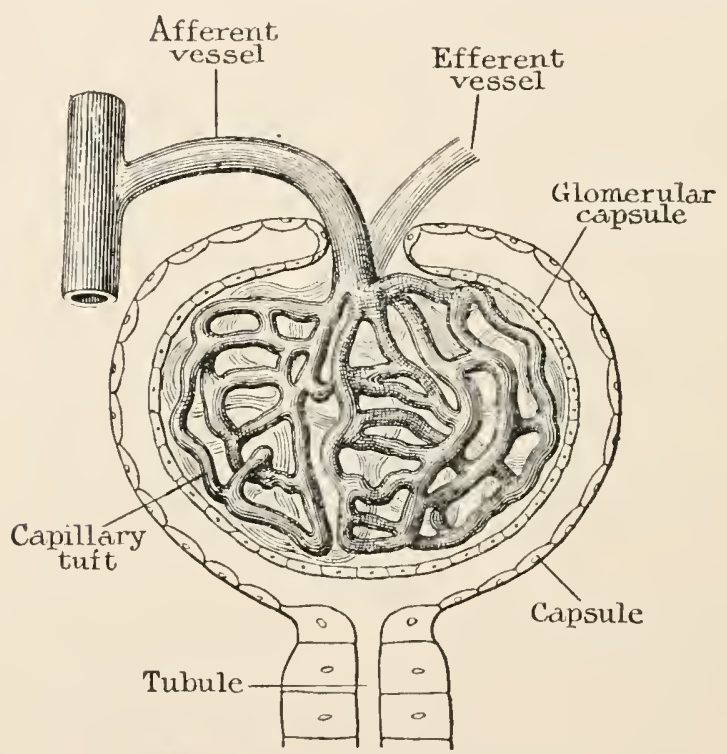

FIG, 28,--Diagram of Malpighian corpuscle. (From Cushny's Secretion of Urine.)

measured the osmotie pressure of plasma and found it to be about $30 \mathrm{~mm}$. Ig. It is generally inferred from this that unless the blood pressure be greater than the osmotie pressure of the plasma eolloids no seeretion will take plaee. Starling eonfirmed this by obstructing the ureter so that the Hydrostatie pressure therein was equal to $92 \mathrm{~mm}$. $\mathrm{Hg}$. when seeretion stopped. The blood pressure was 133 . That gives a filtration pressure of 133 minus the osmotie pull back of the colloids (30), i.e. 103, approximately equal to the pressure in the ureter.

It is only fair to point out that, though modern theorists are at one regarding the foreed filtration of eolloid free blood through the eapsule by means of glomerular pressure, i.e. heart work, 
arguments against the supposition may be found. For instance, the thin layer of epithelial cells is not strengthened in any way to stand a large filtration pressure. Again it is doubtful whether any such pressure exists in the glomeruli. Measurements are given of general arterial pressure, say in the earotid artery. The capillary pressure may be under th th of this.

Simple diffusion through a membrane impermeable to colloids will answer as well. Increase in blood flow instead of pressure regulates the amount of dialysate. Furthermore, it is generally stated that capsular fluid has the same composition as blood, less the colloids. No direct evidence of this has been produced. 'Theoretieally, it is not probable. Colloids have not only the power of holding salts by adsorption, but globulin especially holds water and sodium chloride in solution. This was proved by Milroy and Donegan, who showed that even when 250 c.c. of water per hour passed the outside of the collodion membrane, a solution of globulin (containing 0.15 per cent. nitrogen) in 0.15 per cent. sodium chloride, lost practically no salt in six hours. Any salt over the amount mentioned rapidly passes through the membrane.

5. 'The bone of contention between the two modern schools is the function of the tubule. One group holds that the tubular epithelium absorbs water and threshold salts (i.e. salts of use to the organism) from the fluid passing down the lumen. The other group holds that salts are excreted into the lumen by its lining cpithelium. Much of the evidence produced is of equal value to both sets of thinkers. Macallum's work, already mentioned, showing that a constant low surface tension was maintained at the cell-lumen interface rather weights the scales in favour of the second view. There is also no doubt that experiments where dyes, etc., are injected show that matter does pass, under these conditions, from tubular capillary through the tubular cells to the lumen of the convoluted tubulc. On the other hand, there is nothing to hinder the reverse process from taking place if need arises. Consider the cell as middleman between blood and secretion. Any abnormality in the blood would produce an alteration in the cell, which, if it could, would pass on the change to the secrction. Let us take a concrete example. Say there is a deficit in $\mathrm{NaCl}$ in the tubular capillary. As a result, because the cell NaCl-tension must be equal to the blood NaCl-tension. salt will pass from the cell to the blood. Similarly, if the dialysate or filtrate in the lumen has any $\mathrm{NaCl}$ at all, some of it will pass 
into the eell to make up the defieit. 'The experiments of Milroy and Donnegan, already referred to, eontain a series demonstrating the passing of $\mathrm{NaCl}$ from a watery solution to one eontaining a globulin.

Cushny's obstrueted ureter experiment referred to above may be interpreted in this light. Assuming, as he does, that the fluids eoming from both eapsules are identieal in both kidneys, then on the obstrueted side there is a fluid in prolonged eontact with the tubular epithelium, while on the other this fluid passes away more or less rapidly. Take for granted, for the sake of a standard, that the freely passed urine remains unaltered, that is, it is equal to the glomcrular filtrate on the obstrueted side-e.g. $24 \mathrm{gmis}$. water, $0.08 \mathrm{gms}$. $\mathrm{NaCl}$ and $0.11 \mathrm{gms}$. $\mathrm{Na}_{2} \mathrm{SO}_{4}$. Sodim ehloride is more diffusible than sulphate and readily penetrates eells, therefore the positive tension of $\mathrm{NaCl}$ in the tubule will eause some $\mathrm{NaCl}$ and water to enter the lining eells and so into the blood stream. The sulphate, not being so diffusible, will not so enter the cell. Thus the result would be a coneentration of the urine with a deerease in ehloride, i.e. with sulphate steady; ehloride would drop to a quarter $=0.02$ and water to a half $=12 \mathrm{gms}$. But no great energy need be expended here, only suffieient to evaporate urine to half its bulk. The water and salt so seereted into the blood stream would eause a further diuresis and so on. On the other hypothesis, viz. that the sulphate is to a great extent seereted by the tubule epithelium into the lumen, this diffieulty does not to the same extent arise.

In short, two factors may eome into play in the seeretion of urine, (a) the adjustment of the eell to alterations in its environment, and $(b)$ a meehanieal dialysis of water and erystalloids in solution through the capsule under suffieient pressure to wash the aetively seereted material through the colleeting tubule and on towards the pelvis of the kidney.

\section{Other Glands of Elimination.}

Of the physies of the other detoxifying glands, little or nothing is known. The largest of these is the liver, but beyond the isolation of enzymes, the physieo-ehemieal meehanism has not been to any great extent investigated.

The spleen is the burying-place of dead erythroeytes. It is a modified lymph gland where the blood eomes into intimate contact with the spleen eells or "pulp." In strueture it is a spongework of fibrous tissue, in a eapsule of the same material 
containing muscle fibres. 'These fibres contract and relax continuously, causing the whole organ to beat, like the heart, only much more slowly. The splecn contracts slowly about onec a minutc.

The intestine. Much wastc matter is excreted by the large intestine and here the physico-chcmical mechanism is more elearly indieated (see Chap. XXVII.).

Skin glands-sweat excretion will be considered under regulation of temperature (Chap. XXXI.), and climination by the lungs under 'Transport (Chap. XXIII.). 


\title{
CIIAP'TER XVI
}

\section{THE CIVIL ENGINEERS OF THE BODY}

\author{
CONNECTIVE TISSUE CEIAS
}

"Which doth neatly declare how nature Geometrizeth and observeth order in all things."

Sir Thouras Browne.

WE have just seen how increase in the size of an organism necessitates inerease in its complexity. Groups of simple naked eells held together only by a pelliele resulting from surface adsorption, would at the best form unwieldy organisms which would easily be distorted beyond their elastic limit and so destroyed. Some means of binding the eomponent eells together to form a body sufficiently rigid to withstand shoek and yet possessing suffieient mobility to seek its prey and avoid its enemies, is a logieal outeome of growth in size and in eomplexity. Moreover, if the animal is to have an effieient museular system under complete control and able to be employed under all environmental eonditions, some absolutely rigid systems of portable levers and fulerums must be presupposed.

The Vegetative Tissues are those which support, bind together and meehanieally proteet the other tissues of the body. They may be divided into two groups - the epithelial tissues which proteet surfaees, and the eonnective tissues which bind together and support the various organs of the body.

\section{Epithelium.}

The shape of the cells forming a protective layer or series of protective layers depends entirely on the resultant of the forees acting on them. We may take it for granted that here as well as with the single eell the ageney of surfaee energy is obviously of first importanee.

The theory underlying the phenomena associated with the manifestations of surface energy depends on the principle of Le Chatelier. Surface tension is proportional to the area of the surface of contact. It is also proportional 
to a coefficient which is specific for each pair of substances provided temperature is kept constant. It may be profoundly modified by the slightest alteration in one or more of the physical or chemical conditions of one or both of the phases forming the contact surface.

The form of a cell depends in great part on the magnitude of the surface forees brought to bear on it. If it is surrounded by exactly similar cells then it will tend to assume a more or less spherical form. This is exactly what onc finds in the centre of a mass of soap bubbles or in the middle laycrs of stratified squamous cpithelium. The cells are not absolutely spherical in shape, not only becausc the cclls in mass arc not absolutely similar but becausc the cells have to fit the space. No vacant spaces occur. Now, according to the principle of Le Chatclier, the surface cnergy will manifest itself by tending to reduce the area of contact. Mathematical proof has been given that the least possible arca of contact surface is attained when the partition walls meet together in groups of three, at equal angles, i.e. at angles of $120^{\circ}$.

The outer and inner layers differ markedly in shape from one another and from the middle layers. The outer layer is cxposed to air (skin) or to the free external fluids of the body (mouth and gullet) on the one side, but is in contact witl cells on all other sides. In addition, the outer surfacc is hable to undergo chenical changes-oxidations, etc., and physical changes-adsorption, etc. Thesc again affect tension. The result is that the outer layers are flattened and seale-like.

The inmost layer of cells is in eontact on one side with the structure on which the epithelium is laid and from which it takes its origin and its nourishment. These younger cells arc more or less clongated in shapc. Their form is governed by ccrtain forces in addition to those acting on the more central cclls. (a) It is obvious that the surface tension will be different at that surface where the cell is in eontact with a cell differing from itsclf in structurc and condition. 'These cells arc in contact on either side with similar cclls, but above, they press against fully grown spherical cclls, while below they form interfaces with the structure on which they lie and from which they derive their nourishment. (b) These deeper cells are in process of division, and, therefore, one must take into account the pressures of segmentation and of growth (cf. Plant Cells). (c) The outmost laycr, away from the nourishing fluids of the body, undergo keratinisation and resist the outwards push of young cells which are thus put under stress. Thesc various factors modify the shape of the deeper layers. 


\section{Connective Tissues.}

To appreeiate the significanee of the structure of the vegetative tissues, due attention must be direeted to their function. These tissues are eell eommunities with an important but little studied industry. They are the civil engineers of the body. 'The struetures they build are designed to stand stress and strain. Before eritically examining their handiwork let us study some elementary engineering problems, so that we may the better understand the phenomena of eell structures.

All the tissues of the body are more or less elastie. This property ineludes (a) ehange of form under the aetion of some foree and $(b)$ the return of the body to its original form when the deforming foree eeases to act.

The elasticity of connective tissues plays an important part in the body. (1) It is a permanent resistance to permanent distorting forees such as museular tension and gravity. The elasticity of the intervertebral dises, and of the ligamenta subflava, assists in maintaining the ereet posture of the body. (2) The form of tissues is preserved against distortion by temporary forees (Buffer action) and by intermittent forees. The elasticity of the costal eartilages and of the ribs restores the ehest wall to its original position when the inspiratory museles relax. (3) Intermittent movement is transformed into a eontinuous movement by transmission through an elastic medium (see cireulation). (4) Elastieity eeonomises muscular work by eoming into play in the intervals between sueeessive shocks (Marcy).

The amount of elasticity is determined by aseertaining the force necessary to ehange the form of the object to which the force is applied, and the perfection of the elastic action, by the quickness and accuraey with which the object returns to its former condition on release from the meehanical force. Thus, when a strong force is required to produee deformation of a body, that body is said to be highly elastic. On the other hand feeble elasticity is overeome by the applieation of a feeble force.

The foree which is applied to a body is termed by engineers the strain. The resistance to strain by a body necessitates the postulation of a stress within the body. Hooke (1660) stated that stress was directly proportional to strain. As a formula this is known as Young's Modulus,

$$
\frac{\text { stress }}{\text { strain }}=Y(\text { constant })=\frac{\text { load on specimen } \div \text { area of eross-section }}{\text { alteration in length } \div \text { original length }} \text {. }
$$


Let $P$ be the pull, $a$ the cross-sectional area, $l$ the length of the fibre, and $e$ the clongation produced; then :

$$
\frac{\text { stress }}{\text { strain }}=Y=\frac{P / a}{e / l}=\frac{P l}{e a} \quad \text { or } \quad e=\frac{P l}{Y a} \text {. }
$$

Wertheim gives the moduli of the following substances in grams weight per sq. cm.

TABLE XXV.

Bone - -
Tendon -
Nerve (
Muscle (resting)
Vein - -
Artery - -

$$
\begin{array}{r}
2304.1 \times 10^{6} \\
163.41 \times 10^{6} \\
18.89 \times 10^{6} \\
0.95 \times 10^{6} \\
0.87 \times 10^{6} \\
0.052 \times 10^{6}
\end{array}
$$

The above values are given in order of increasing "perfection" and decreasing "strength" of elasticity. The figure last given, that of arterial walls, may be taken as substantially that of elastic fibrous tissue.

Now strains may be applied in two ways. They may press or they may pull. A pressing or crushing force is called a thrust and a pulling or tearing foree is ealled a stretch.

The stress set up in the tissues is a function of the colloidal matter which we have seen gives rigidity to the tissucs. Water and aqueous solutions of erystalloids are praetieally incompressiblc, i.e. their volume elastieity is negligible. It is obvious that they camnot have any elastieity of shape. The dispersion of less than a gram of gelatine in a hundred eubic eentimetres of water cndows the solution with rigidity.

The cmulsoid gel has elastieity of shape, i.e. it returns to its original shape after the applieation of a strain by thrusting, stretehing or bending provided it has not been strained beyond the elastie limit.

A moment's thought will convince one that a quite different structure is required to meet strains of the stretching and of the thrusting varieties. (a) The material used in the building of struts to withstand thrust must have a high erushing limit, while that going to form ties requires high resistance to tearing In the following table drawn up by Sir Donald MacAlister, are given the approximate values of the crushing and tearing limits of some building materials. 


\section{TABLE XXVI.}

\section{AVERAGE STRENGTH OF MATERIALS}

(in kgs. per sq. $\mathrm{mm}$.).

\begin{tabular}{|c|c|c|c|c|c|}
\hline \multicolumn{2}{|l|}{ Material. } & & \multicolumn{2}{|c|}{ Crushing Strength. } & Tensile Strength. \\
\hline Sterl - - & - & - & - & 145 & 100 \\
\hline Wrought Iron & - & - & - & 20 & 40 \\
\hline Cast Iron - & - & - & - & 72 & 12 \\
\hline Wood (fibrous t & 1e) & - & - & 2 & 4 \\
\hline Bone - - & - & _ & - & $2-16$ & $9-12$ \\
\hline
\end{tabular}

A glance at this table is suffieient to show that a material whieh may make a very good strut may make a very poor tie, e.g. east iron. A further factor has to be taken into aeeount, viz. elasticity. In the following table, borrowed from "Growth and Form" by Prof. D'Arey Thompson, are given the loads whieh various fibres and various wires were found capable sustaining just at their elastic limit.

\section{TABLE XXVII.}

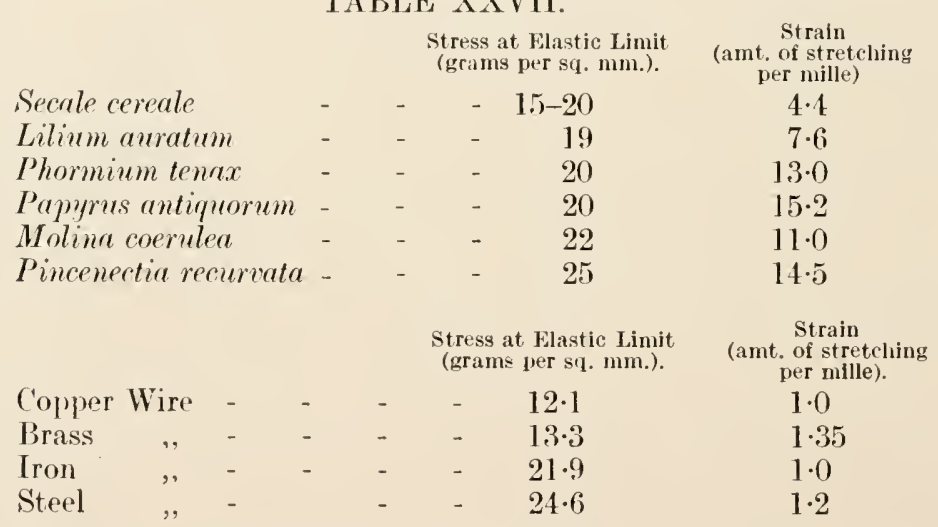

Comparison of these figures with those of the previous table will demonstrate the suitability of fibrous tissue to withstand a stretehing strain and yet retain a very high degree of elastieity.

The engineer plans his struetures to give the maximum strength with the minimum weight. Nature is equally eeonomical. Examination of the girders holding a roof will show that they are of two shapes. Those running from wall to wall having a crossseetion like the capital letter "I." This girder is a tie and has to withstand a stretching force. How has the engineer arrived at this form? Figure 29 represents a beam of square section. When such a beam is loaded midway between its supports it is slightly bent to give a concave upper surface. The upper 
surface is eompressed while the lower is stretehed. Therefore midway between the upper and lower surface lies a neutral zone or line of no stress and in its neighbourhood the material needs to have little strength. The girder maker can therefore quite safely eut away the eentre of his beam, leaving only the upper and the lower surfaces, and of eourse some eonneetion between them which may be almost as thin as he likes without destroying
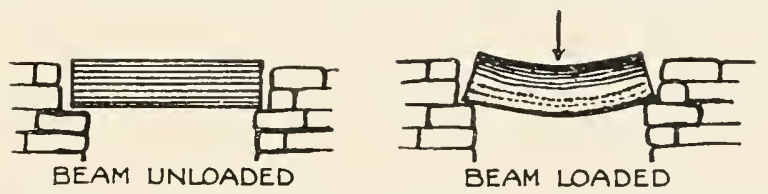

Fin. 29.-To show lines of compression (dark) and lines of tension (dotted) in a loaded rectangular beam. The clear space between the strut-lines and the tie lines indicates the neutral zone.

the strength. In other words, if the engincer can map out the lines of stress or directions of eompression and tension in the loaded strueture, all the manufaeturer has to do is to see that these lines lie in his material; all the rest may be eut away.

By means of the truss (Fig. 30) the simple girder beeomes a tie between two struts. The horizontal member of the truss undergoes tension only, while the sloping beams are eompressed.

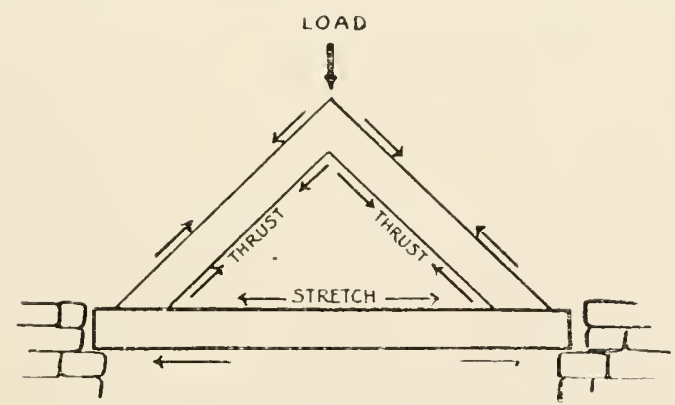

Fig. 30.-A simple triangular roof truss.

Such a strueture permits of the use of two kinds of materialmatter with a high tensile strength for the tie and matter able to bear up under eompression for the struts.

The two prineipal eonnective tissues are fibrous tissue and eartilage and their modifications. Fibrous tissue is the main binding medium of the body. It is derived from the mesoblast of the embryo. The cells of the mesoblast, which are typical spherical bodies lying close together, are gradually pushed apart by a clear transparent jelly-like exudant from the eells. 'They 
retain eonnection with one another by clongated proecsses giving the whole tissue the appearanec of an attenuated sponge filled with a gel. The eells apparently scercte a eolloid in a nonhydrated form which then swells up to form a gel by the imbibition of water. A model of this proeess may be made by adding water to a mixture of gum and oil (Part II.).

As development advances the eells of this mucoid tissue beeome longer and more spindle shaped (fibroblasts). The fibres arc of two elasses, differing from one another in ehemieal eonstitution as well as in physical properties.

(a) The white fibres are delieate transparent non-elastie fibres arranged in bundles whieh do not branch.

(b) The yellow fibres are highly refractile clastie fibres whieh braneh and anastomose with onc another. (Fecbly but perfeetly clastie.)

The difference in their physieal properties may be cxplained by their different chemieal constitution. The former are composed mainly of a non-elastie protein collagen which readily takes up water to form gelatine. The latter have in plaee of collagen another selero-protein elastin. Though difference in chemical constitution may explain difference in physical properties, it does not make any clearer how such a difference is brought about. If elastic and non-elastic fibres existed side by side in definite proportions one eould easily mimic the formation by the separation of two eolloids from a eolloidal matrix. But there is no such definite proportion. Some tissues, e.g. tendons, are almost cntirely eomposed of white fibres, while elastie fibres predominate in ligaments. In short, white fibrous tissuc is found where binding power alone is required, and where elastieity as well as strength is desirable, there one finds elastie fibrous tissue. The function of the tissue governs its form.

Just exactly how funetion governs form, one eannot at present say. There is no doubt that external physieal forces do affeet ehemieal aetions and internal physieal properties. Material under strain acts quite differently from the same matter unaeted on by any foree. An almost non-clastie bloek of rubber may bc endowed with considerable extensibility by being worked with. The optical properties of glass can be altered by submitting it to pressure. The clcetrieal eonduetivity of selenium depends on the amount of light falling on it. When more is known of the laws governing matter in the eolloidal state, then one may be able to give a elear answer to this problem. 
In certain situations peeuliar modifications of fibrous tissue are found :

(1) Endothelium consists of flattened eells forming a membrane. It differs from pavement epithelium by having the formed material (colloidal cxudate) between and not in the cells. Sueh endothelial layers line all the scrous cavities of the body and the lymphaties, blood vessels and heart. A structure similar to endothelium may be produced when an aqueous solution of, say, fatty aeid is added to a mixture of hydrated eolloids of high eonecntration. Under such eircumstanees the pressure of separation deforms the originally spherieal globules to form a beaded flattened honeyeomb.

(2) Fat cells. The experiments upon emulsoids detailed in Chapter VIII. throw light upon the appearanee of fat in the eells. There is scareely a tissue or fluid in the body that does not eontain fat in amounts in execss of the quantities that ean be dispersed in colloid-free water. Finely divided fat in eell protoplasm is comparable to an emulsion. It depends for its permanenee on the same faetors as maintain fat in a finely divided form in an aqueous dispersant, i.e. mainly on the presence, in the tissues, of hydrophilic eolloids. While the fat in the cells is not ordinarily visible or even demonstrable by microehemical methods, when an exeessive amount of fat is present it may be seen in the network of areolar fibrous tissue, especially round the smaller blood vessels. Little droplets of oil at first appear and these beeome larger, run together and coalesce, forming a single large globule, distending the cell and pushing to the sides the protoplasm as a sort of eapsule. Referenee to the chapter on emulsions will show that when the fat in an oil-in-colloid emulsion is inereased beyond a eertain amount, the nature of the emulsion is changed to colloid-in-oil. This latter emulsion differs from the former not only in the visibility of the fat, but in this respeet that the fat may be stained (black) by osmie aeid or (orange) by sudan III.

In starvation the fat gradually disappears from the cell leaving the hydrated eolloid, which also in time disappears and the cell resumes its shape.

Apart from aeting as a storehouse of energy, fatty tissue has important meehanical funetions. As we shall see later the layer of subeutaneous fat serves as an extra garment proteeting the wearer from the too rapid loss of heat (Chap. XXXI.). Then too, fatty fibrous tissue has a eonsiderable amount of resilienee, aeting as a buffer proteeting organs from external violenee. 
(3) Pigment cells. Fibrous tissue cells (and other cells) in certain parts of the body (e.g. eye) may contain a pigmentmelanin. How this pigment is formed and what exactly are its functions remain matters of conjecture. Chemically, mclanin is closely related with the melanoidins - dark pigments resulting from digestion of proteins with hot mineral acids. They scrve (a) as light filters-preventing the passage of light through the pigment cell. 'That is, the pigment absorbs encrgy. These pigmented areas are nearly ahways found in places exposed to light, and one may suppose that the incidence of strong light on fibrous tissue may causc the formation of melanin from the cell protein. Inorganic examples of the formation of light-absorbing chemical compounds by the absorption of light will occur to the student (cf. Silver Salts). (b) Their function is not only to protect the underlying tissue from the harmful action of radiant energy, but in many cases the pigment cells act as a transmitting station--receiving the light stimulus and transmitting it to the effectors. This dermatoptic function has becn studied and described by R. Dubois. Light falling on the pigment cells of the epithelium of the siphon of Pholas, a molhuse, causes a reflex retraction of the siphon. Observation under the microscope has shown that the pigment eclls in the skin of the frog contract when light falls on them. The pigments of the eye and their action in transmitting light stimuli will be dealt with in another chapter.

Two modifications of fibrous tissuc warrant separate treatment, i.e. cartilage and bone. In lower animals and during the foctal life of higher animals (as well as in certain situations in adult life) rigidity is given to the body by cartilage. The function of cartilage cells will be dealt with later under bone and lubrication. Here it is sufficient to note that the peculiarity of this tissue is the secretion of a homogeneous translucent gel which is tough and clastic. This chondro-mucoid material is a mixture of at least three colloids : ordinary protein, collagen and chondroitin. On decomposition this latter substance yiclds substances of a carbohydratc nature, glucosamine and glycuronic acid (cf. emulsions).

(4) The great supporting tissue of the body is calcified fibrous tissue or bone.

(i) Development. Bonc is formed by a deposition of calcium salts in white fibrous tissuc. Some bones which are more or less flat, e.g. vault of the skull and the scapula, are formed directly in fibrous tissuc. 'This is the so-called intra-membranous 
bone formation. The long bones are preformed in cartilage into which processes of fibrous tissue find their way and they in turn undergo calcification. All bone is developed from fibrous tissue. The cartilage merely plays the part of scaffolding and is all replaced by fibrous tissuc before ossifieation takes place.

TABLE XXVIII.

Relative Strength of the long Bones.

(MAN AGED 31.)

\begin{tabular}{|c|c|c|c|c|c|c|c|c|}
\hline \multirow{2}{*}{ Bene } & \multicolumn{2}{|c|}{$\begin{array}{l}\text { Crushing Strength } \\
\text { (in kg. jer sq. nmm.) }\end{array}$} & \multicolumn{2}{|c|}{$\begin{array}{l}\text { Bending } \\
\text { strengtll } \\
\text { (in kg.) }\end{array}$} & \multicolumn{2}{|c|}{$\begin{array}{l}\text { Shearing } \\
\text { Strength }\end{array}$} & \multirow{2}{*}{ Place of Rujture } & \multirow{2}{*}{$\begin{array}{l}\text { Torsiont } \\
\text { (in kg.) }\end{array}$} \\
\hline & $\begin{array}{l}\text { 1st appear- } \\
\text { ance of } \\
\text { breakdown }\end{array}$ & $\begin{array}{l}\text { Complete } \\
\text { crushing }\end{array}$ & Max. & Min. & MI:ax. & Min. & & \\
\hline Humerus & $8 \cdot 5$ & $\ldots$ & 300 & 120 & 505 & 250 & At ends & 40 \\
\hline Radius & $5 \cdot 3$ & - & 140 & 55 & 334 & 105 & In middle & 12 \\
\hline Ulna & $5 \cdot 5$ & - & 140 & 70 & 235 & 90 & Anywhere & 8 \\
\hline Femur & 13 & 29 & 475 & 230 & 810 & 400 & At the neck & 89 \\
\hline Tibia & $6 \cdot 0$ & 42 & 500 & 135 & 1060 & 450 & $\begin{array}{l}\text { At the lower } \\
\text { end }\end{array}$ & 48 \\
\hline Fibula & 3 & - & 55 & 21 & 61 & 20 & In the middle & 6 \\
\hline
\end{tabular}

* Torsion applied to the extremity of the bone with a leverage of $16 \mathrm{~cm}$. produced a spiral fracture with the forces given above. (Amar.)

Praetically nothing is known of the physical chemistry of bone formation. Microseopic investigation suggests to our mind a proeess similar to the formation of a honeycomb. The cells of fibrous tissue detailed to build bonc, i.e. ostcoblasts, sceretc matcrial containing a fair proportion of the phosphate and carbonate of calcium. It is known that the prescnec of a small quantity of a eolloidal eomplex alters the solubility of inorganie matter. For example, calcium phosphate is more soluble in an abbuminous hydrogel than in water. This effect is even more marked with ealcium earbonate. If we presume the presenee of the salts of lime in the fibrous tissue cells, then, by the principle of Willard Gibbs, they will be found in greatest eoneentration where the surface tension is lowest, that is at the ecll borders. Another factor may be brought into play, viz., alterations in the eolloidal matrix. Albumin is broken down in the body to proteoses and peptones. Now, cxperiment has shown that calcium salts dispersed in an albuminous hydrogel are thrown out of solution when proteoses and peptones appear in the gel. Further, ealeium phosphate is mueh more insoluble in proteose-peptone solution than the earbonate, whieh is only slightly affeeted by the 
ehange. It is significant that bone ash contains about 84 per cent. of the former and only $\boldsymbol{\gamma} \cdot 6$ per eent. of the latter salt.

One cannot say why cells in eertain situations should have this property of ossifieation. How far stresses and strains affect the process is unknown. This we do know, however, that the intemal structure of the bones undergoes alterations to suit alterations in the application of external forces.

(ii) Internal structure. In the earlier part of this chapter mention was made of lines of stress, and it was there stated that as long as sufficient strong material was present to inelude the course of these lines it was an obvious eeonomy to eut away as much as possible of the matter in which there were no stress lines. If these lines lie wholly in the struetural material, then the danger of rupture under shearing stress is eliminated. A shearing stress is a force which tends to cause one part of a structure to slide over another part. For example, a pile of coins compressed by a foree acting at right angles to the face of the coins effectively resists the compression. If, however, the force were to aet obliquely to the face of the topmost eoin, it would immediately cause the pile to slip asunder. In other words, a shearing stress is ineffective along the lines of maximum compression. The same can be demonstrated for lines of maximum tension. For all other lines, shearing stress has a definite value which is obviously at maximum at $45^{\circ}$, i.e. half way between the lines of tension and eompression. Prof. Culmann, an engineer from Zurich, happened to see some drawings by Prof. H. Meyer of the cancellous tissue of the femur and at once notieed how the trabeeulae of the bone coincided with the lines of stress. He gave his class of engineering students an outline of the femur and told them where the stresses fell. He asked them to draw the internal structure which would be necessary to meet these stresses. Fig. 31 shows the result. Alongside this figure is given a diagram of the Fairbairn craneone of the best weight-lifting meehanisms known. The similarity between the natural and the artificial structures is obvious. It will be notieed that the lines of the trabeeulae of the femur rum in two systems of curves. One system rums along the outer convex side of the shaft, curves downwards as it opens out with eoneavities downwards. The other system starts from the inner side of the shaft and rises spreading outwards with the coneavities upwards. These systems eorrespond to the two kinds of lines of stress present, e.g. tension and compression. The convex or outer side has to resist tension, while the inncr convex side, 
overhung by the loaded head, is the compression member. The head of the femur is a little more complieated than Fairbairn's erane, in that the load is applied on two points, i.e. on the head of the bone and on the great trochanter. This entails a division in the distribution of the stress lines eorresponding to the incidenee of the loads. In the eompact tissue of the shaft the tension and eompression lines run parallel. The lines of stress are elosest together at the point of greatest strain, i.e. in midshaft. This place has to be thickened to prevent the bone from snapping (a walking stiek pressed vertically against the floor breaks half-
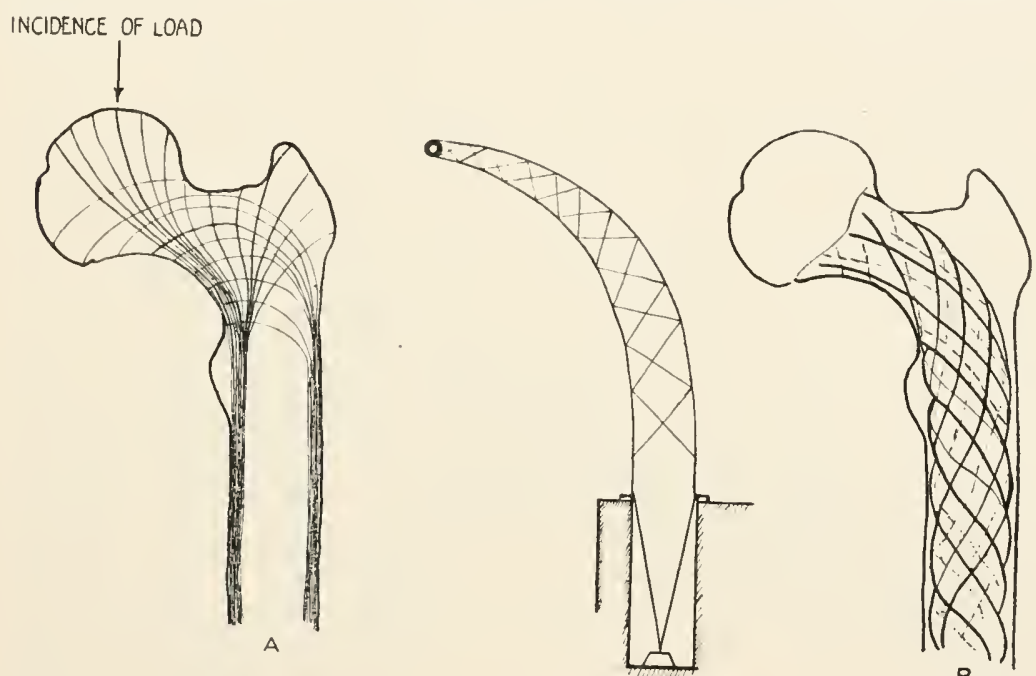

8

FIG. 31.- To show the stress lines in the head of the Femur, $A$, in section, and $r$, on the surface. The central diagram gives an idea of the location of the lines of stress in the head of a crane. (After Culmam, Meyer and Dixon.)

way up). The central portion of the shaft has to bear no strain, and therefore is hollow. It may be considered as a large mesh between the tension and compression lines. In the cancellous tissue the tension lines cross the eompression lines at right angles.

The same phenomenon may be seen in any bone whieh undergoes tension and compression. It is very noticeable in the human foot, especially in the heel bonc (calcaneus). It is roughly triangular, having three bearing surfaees. The upper surface is eompressed by the weight of the body applied from the ankle bone. Therefore, compression lines start from it and run downwards. The lower surface rests on the ground, i.e. has to bear an upward 
thrust, and so compression lines run upwards from this surface to meet the compression lines from the upper surface. The third or anterior surfaee is in eontact with the bones of the arch of the foot and transmits the ankle pressure forwards to them. This gives rise to a seeond system of eompression lines rumning obliquely forwards. These two systems correspond to the two beams in Fig. 30. Now the applieation of a load at the apex would eause the beams to diverge at their lower ends if they were not tied together by the girder. So tension lines must exist to prevent the fraeture of the bone between the two systems of eompression lines. These tension lines will be seen in Fig. 32

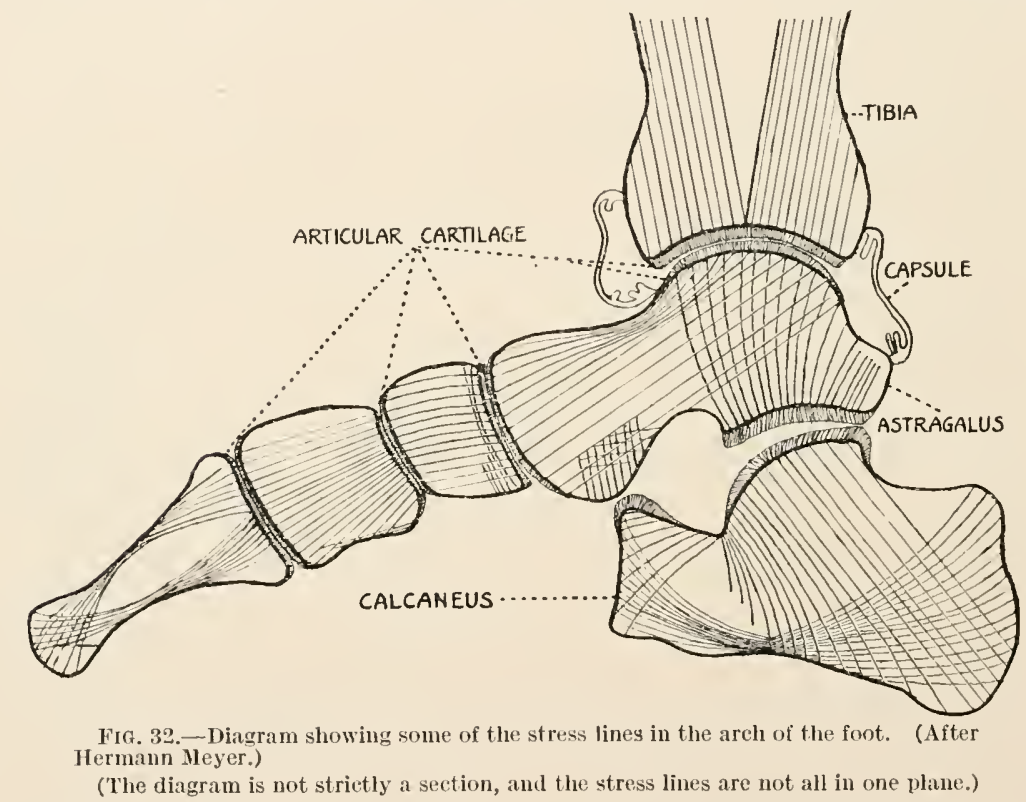

forming eurves with their coneavities upwards and orthogonal to the eompression lines. It will be noticed that these ties are closer together at the areh of the bone between the two struts, i.e. at the point where fraeture is most likely to take plaee. Just above this point no stress lines ean be seen, i.e. there is a neutral region. Examination of the bone makes elear the faet that in this neutral zone trabeeulae are almost entirely absent. Where there are no stress lines it would be a waste of material to build struts or ties. As Sir Donald MaeAlister puts it, "any mass of bone put there would not 'row its weight,' and it has been "turned out '." 
This internal strueture is altered to meet alterations in the ineidence of stress. For example, during the first twenty years of life when the body is growing and the bone lengthening, constant alterations in internal and external strueture have to be made. The unnecessary parts are decaleified and the fibrous tissue undergoes alteration. During this process some of the fibrous tissue eells beeome enlarged and multinueleated. Histologists eall these eells osteoclasts. The remaining fibrous eells afterwards beeome bone marrow. An adjustment to meet altered eonditions may be seen when a bone is broken and allowed to set badly, so that its parts hie somewhat out of their former positions. 'Tension and eompression lines do not now eoineide with the trabecular strueture. It has been shown by Wolff and others that in a few weeks, not only has an alteration taken plaee at the seat of fraeture but the entire trabecular system, right to the ends of the bone, has undergone remodelling to suit the new incidence of forces. More recent work on bone grafting has amply denonstrated the astonishing rapidity with which reconstruetion of the trabeeular meshwork takes plaee. One nust remember that in spite of its rigidity, bone is plastie. Physieal ehemists have proved that when an inorganie eonstituent separates as a definite phase from a eolloidal matrix, the new phase is at first liquid. We may, therefore, infer that the new trabeculae are more or less liquid when formed. The action of force upon them will tend to set them along the lines of that force, e.g. straws set along the direetion of the wind. They are practieally " earded" into position. There they are in equilibrium and will tend to "solidify" in that position.

(5) Lubrication. Certain eartilage eells have a peeuliar function, that of acting as a lubrieant between rubbing surfaees. One of the most worrying problems of the engineer is to prevent " heating up " of moving surfaees. This he attempts to do by interposing a fine uniform film of oil between surfaces where frietion is apt to take plaee. The partieles of the oil film aet as microseopie ball bearings over which the moving surfaees slide with the minimum of friction. The motor eyelist knows how essential it is to have the right amount of the right grade of oil in the right plaee. In spite of all preeautions however, "seizing" does take plaee. The film of oil is rubbed away just at the point where it is most required. Only one machine has, as yet, been designed whieh has a perfeet lubrieating system, and that is the animal body. In the body there are many rubbing surfaees. At joints, bone works against 
bone: tendons rum like Bowden wires in sheaths, and yet the healthy animal body moves noiselessly and without "heating up" or "scizing" at any speed.

(a) Joints. There are, eounting great and small, 230 joints in the human body varying in degrees of magnitude and importanee. The ends of the two opposed bones in a joint are eoated with a thin layer of eartilage. This eartilage, in the adult, is what is left of the seaffolding of bone. As we have seen, it is elastic and aets as a resilient buffer. The surfaee is always eovered, in health, with a film of synovial fluid.

This synovia is kept in place by being enelosed with the joint in a flaccid membrane or joint eapsule (Fig. 32). The synovial fluid results from the destruetion of the eartilage eells on the rubbing surface of the joint. In this way the supply of lubricant is absolutely automatic. The more the joint surfaees move on eaeh other, the greater is the destruetion of the cartilage eells and the more plentiful is the supply of synovia.

Two other points require our attention, (i) How is the supply of synovia kept up and (ii) what happens to the waste fluid. (i) The eartilage is constantly, like epithelium, growing. The young eells take their origin in the layer next to the bone and push their way up towards the outer surface of the artieular eartilage. Every cell destroyed to form synovia has its plaee taken by a eell from the layer below and so on. Growth and destruetion exactly balanee one another. (ii) The waste synovia is drained into the blood stream through eertain warty struetures whieh project into the creviees of the joints.

In ehronie rheumatism the eartilage cells fail to form synovia. 'The artieular eartilages beeome dry and leathery and the joints may be heard ereaking as they move. The underlying bone, stinulated by the unaeeustomed frietion, thickens and throws out gnarled proeesses. The supply of lubrieant has failed, and until someone diseovers just how eartilage ean be converted into synovia and what eontrols the process nothing ean be done to prevent "scizing" of the joints.

(b) Tendon sheaths. Museles are attached to bone by sinews or tendons and these eordy structures work in sheaths. 'The inner surfaee of the proteeting sheath as well as the outer surface of the tendon is endowed with a lubrieating substanee similar to that of the joints.

'There is one outstanding point of interest about the lubrieation system of the body and that is its nourishment. As far as is 
known all other cell communities draw the matcrial they require for maintenance and growth from the blood stream. As we shall sec in the sequel the red blood eorpusele performs the duty of oxygen carrier. No red corpuseles enter articular cartilage - the gristle in joints is pearly white. One can only suppose that the plasma which reaches the cells from the rich vaseular network on the surface of the underlying bone, earries dissolved in it sufficicnt oxygen to meet the needs of these lubricant-formers, as it earries sufficient protein, earbohydratc, cte., for their use.

The formation of cartilage and of synovia and of the relation of thesc two substances to bone and to fibrous tissue is a rich field for investigation. Certain eolloidal phenomena will oceur to the student as suggestive of an explanation, but absolutely no definite physico-chemical faets can be brought forward as acceptable cvidence. 


\title{
CHAP'TER XVII
}

\section{THE INTELLIGENCE SERVICE}

\author{
NERVE CELLS
}

\begin{abstract}
"The messengers that preserved a communication between the soul and the out ward members."

BERKELEY.
\end{abstract}

IT is obvious that in an organised eonglomeration of cell bodies like the animal body some means of rapid eommunieation must exist between one organ and another. Without it, rapid eoordinated movement by the body as a whole would be impossible. This work is accomplished by the nervous system. Two entirely different systems of rapid eommunication exist in the body. One runs to and from the body wall and has to do with the relation of the body to its environment. It belongs to the army of defenee and defianee. The other system of rapid eommunieation conveys messages to and from the industrial eommunities.

Embryologically, communication between an inland eell and the outer world is effeeted, in the first instance, by an ingrowth of the external epithelial eovering. That is, messages are passed on to the inmost eell by a file of eells, detailed for this service. These eells are, to begin with, all strueturally and funetionally alike (neuroblasts). Later, some few of them send out long processes towards the surface and towards the organ. These processes end in branching twig-like struetures called dendrites (Gr., a tree), through whieh they seem to be able to pass on stimuli to one another. The name synapse (Gr., a jumetion), is given to the juxtaposition of the dendrites from the proeesses of two nerve eells. The eell with its proeesses is ealled a neuron. (See Fig. 33.)

The seeond system of nerves, that of the viseera, is formed of neuroblasts which have migrated towards the organ from the neural eanal. They all pass through at least one ganglion or a plexus which aets like a loeal headquarters or exchange. 
Some nerves have a sheath or coat composed of unsaturated fatty acids and lecithin (and allied lipoids). The function of this medullary sheath has not been discovercd. It is formed from scparate cells, but it must retain some connection with the nerve cell, as it dies and disintegrates when dissociated from it.

1. Structure. The neuron, like any other cell, is a colloidal fluid mass. This may be demonstrated by examination of the living nerve by means of the ultra-microscope, when particles in Brownian movement will readily be seen. Some of these particles, at times, chump together to form local large aggrcgates which again dissociate. Further, Carkon has shown that nerves may be stretched without altering their efficiency, judged by rate of conduction of an impulse. Macallum states that alterations in surface tension can be detected especially in the growing nerve. It has been urged by Gothlin that, as a nerve is doubly refracting to a slight extent just like muscle it must have a similar composition. These facts all go to prove that nerve is of a liquid nature.

2. Its function is to conduct. One cannot lay too much stress on the fact that it does not conduct an impulse originating outside, as a telephonc wire conducts current from a battery. The battery is an integral part of the neuron.

3. The nature of the stimulus scems immaterial. Mechanical, electrical or chemical stimuli all cause the nerve to propagate the same kind of impulse. Furthermore, the excitatory result of the propagated impulse depends not on the nature of the "trigger" stimulus but on the nature of the effector mechanism to which the nerve goes. That is, stimulation of the sciatic nerve by elcetrical, mechanical, thermal or chemical means always causes contraction of the gastrocnemius muscle; stimulation of the vagus nerve by any means always slows the heart, stimulation of the chorda tympani causes the salivary glands to secrete, no matter how the stimulation is effected. Miuller's law of the specific energies of the scnses states that, by whatever manner a sensory nerve is stimulated, the resulting sensation is always that produced by this nerve when stimulated by its specific "trigger." That is, the receptor organ of a sensation-carrying nerve controls the sensation received. To be concrete, stimulation of a taste nerve (chorda tympani), by pinching, sudden heating or cooling, electrical shock or chemical reagents, produccs the sensation of taste and nothing else. Similarly, stimulation of the cye nerves by any means makes onc see light. Keith Lucas 
states that thcre is no evidenee to show that the nerve impulse is in any way modified by the nature of the stimulation. Each nerve has however a rhythm of its own-an optimal rate of stimulation known as Waller's "eharaeteristie," whieh is similar to the natural rate of incidenee of energy.

No diffieulty should be experieneed in grasping this idea, especially if an eleetrieal model be kept in mind.

Consider an electrieal eireuit such as shown in Fig. 331s. $C$ is a galvanie eell or eleetrieal unit where ehemical energy is eonverted into eleetrieal energy. $F_{1}$ and $F_{2}$ are wires eonneeting $C$ to $M$, an eleetric machinc, and a key eloses the eireuit. (a) It does not matter how the key is elosed, the eurrent passing along $F$ will be the same, and $(b)$ the manifestation of the eurrent will depend

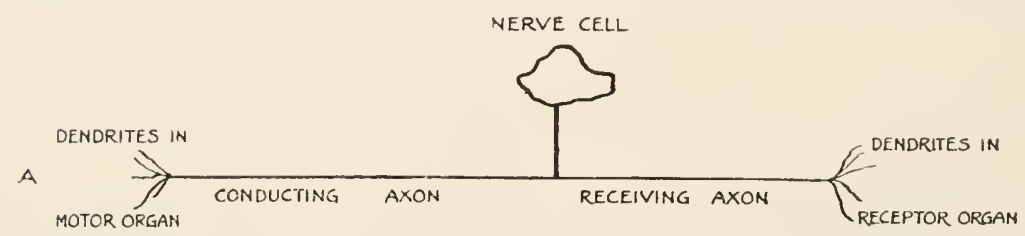

B

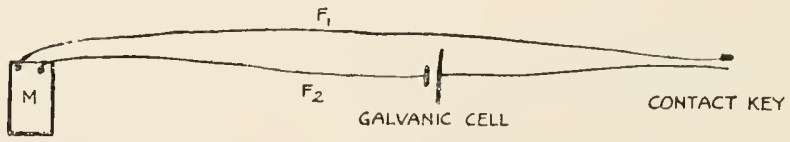

FIf. 33.-A. Diagram of a unit of the nervous system compared with $\mathrm{B}$.

B. Electrical Model to illustrate Müller's Law and the "All or Nothing" hypothesis as explained in the text.

on the nature of $\boldsymbol{M}$. If $\boldsymbol{M}$ is a telephone reeeiver, the elosing of the key will eause a sound to be heard, if $M$ is an ineandeseent globe, light will be seen, if $\boldsymbol{M}$ is a motor, motion will result, and so on. The eleetrieal energy of $C$ ean thus be eonverted into any form of energy by an appropriate $\boldsymbol{M}$. Further, the magnitude of the foree applied to the key makes no differenee to the magnitude of the resulting manifestation at $\boldsymbol{M}$. That depends on the energy set free by the eell and on the resistanee of the eireuit.

Of eourse the reeeptor must be modified to suit different kinds of stimuli. A telegraph key or a bell push is a eonvenient kind of meehanism for elosing a eireuit meehanieally, but it would not answer for eleetrieal, thermal, sound or light vibrations. Speeial means for elosing the eireuit have to be devised to suit different kinds of stimuli. For example, sound waves may be eaused to elose an eleetrieal eireuit by mierophone, e.g. telephone transmitter. 
The neuron may be likened to this elcetrieal model (Fig. 3:3A). $C$ is then the nerve cell, $F$ the process or nerve fibre, the key the receptor mechanism and $M$ the effector mechanism. A seeond cireuit of the nature of a telephone relay could be added to the first, $S$ being an clectro-magnet which closes the second circuit when the key of the first is depressed (Fig. 34).

$S$ may be termed the synapse joining an effector and receptor neuron. The student will notice that there is no material continuity between the two neurons and that no cnergy passes from one to the other.

4. "All or nothing." It is obvious in the clectrical model that connection is cither made or not made. The cnergy available

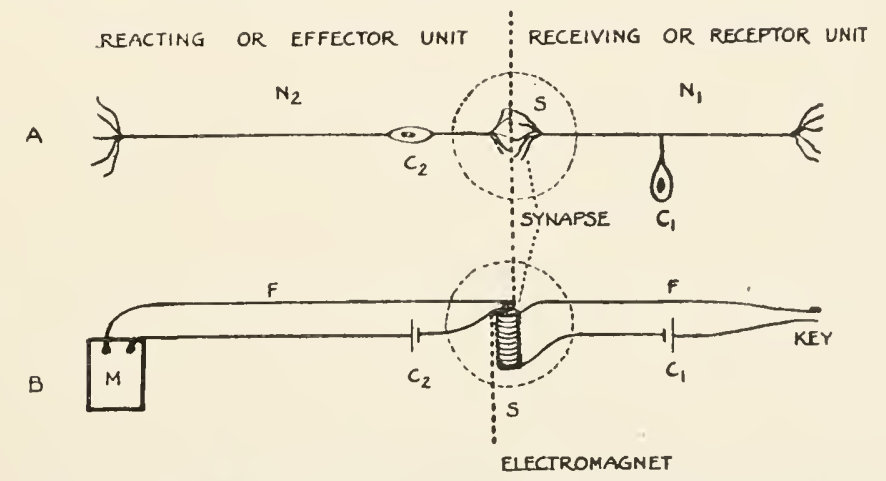

\footnotetext{
FIo. 34-A. Diagram showing a receiving $\left(N_{1}\right)$ and a reacting Neuron $\left(X_{2}\right)$, each with dendrites at its extremities, and their connection to one another through a Synapsis $\left(x^{\prime}\right)$.

B. Filectrical Model to illustrate the functlonal continuity of two neurons. see text.
}

from $C_{1}$ is a fixed quantity independent of the energy used to close the eireuit, and similarly the energy in the system of which $C_{2}$ is the cell is independent of the energy used in the electromagnet $S$.

It is truc also for the nervous system that the maximum motor effect is produced, if any effect is produced at all. It is a case of " all or nothing." Nerves are, however, made up of several more or less parallel neurons, and some of these may be stimulated and some may not. As each nerve fibre activates one muscle fibre and as each muscle fibre responds to the activation by a maximal contraction, the result is that the extent of contraction depends on the number of muscle fibres which shorten and which, in turn, depends on the number of nerve fibres implicated.

5. Temperature coefficient of the nervous impulse. When a length of nerve is cooled its power to conduct an impulsc is 
decreased ; that is, ncrve-conduction has a positive tempcrature cocflicient. It was pointed out by Van't Hoff that the vclocity of chemical reactions is inercased twofold or more for each ten degrees in tempcrature, i.e. the tempcrature cocfficient for chemical reactions is greatcr than 2 . On the other hand, the tempcrature coefficient for physical processes is less than 2 . The temperature cocflicient (i.e. ratio of velocity of propagation of nervous impulse at $(T+10)^{\circ}$ to its ratc at $\left.T^{\circ}=\frac{v \text { at } T+10^{\circ}}{v \text { at } T^{\circ}}\right)$ has been estimated by Lucas as approximately 1-8. This value has been proved to be right by later workers. Thereforc, physical factors are involved in the propagation of a nervous impulse. This does not exclude chemical reactions but tends to show that the process is not purely chemical.

6. Decrement of the nervous impulse. If a length of ncrve is cooled, not only does the velocity of the propagation of the impulse suffer diminution but there seems to be a diminution in the intensity of the impulse as well. If the degree of cold is sufficient, or if the length cooled is extcnsive, the impulse may be stopped entirely. If, however, any of the impulse is propagated through the cooked region into a normal piece of nerve it secms to recover its full intensity and vclocity. Lucas eompares this phenomenon to the transmission of fire along a fuse of gunpowder. If a section of the fuse is slightly damp, the rate of burning as well as the heat evolved will be decreased but will recover as soon as combustion starts on a dry section. Narcotisation of a nerve by ether, alcohol, cocaine or other drug has a similar effect to cooling.

7. Refractory period. The passage of a nervous impulse produces some change in the physico-chemical state of the nerve, so that it is followed by a statc during which its funetion is depressed. A certain time must elapse between each ncrvous impulsc. This spare time is called the refractory period, during which a stimulus will not receive normal treatment. The length of the pcriod varies inversely as the temperaturc. The refractory period may be divided into three stages: (a) The absolutely refractory period when no strength of stimulus is effective. (b) During the relative refractory period the nerve is recovering and will respond to stimulus stronger than usual. (c) The supernormal stage follows during which subnormal stimuli are effective. Two factors at lcast come into play to cause the refractory pcriod, viz. alterations in excitability and alterations 
in conductivity. These two factors go hand-in-hand, i.e. the nerve is non-irritable and offers a resistance to the passage of the impulse sufficient to swamp it during the absolute refractory period; during the relative refractory period the nerve steadily reeovers its irritability and its conducting power; while the last period is one of supernormal irritability and eonduetivity.

8. Summation. If a second stimulus be applied to the nerve during the third refractory period, it will give rise to an impulse which will meet with less resistance in its passage along the nerve. Now, if the first impulse be subminimal, i.e. insufficient to cause a manifestation of energy in the motor mechanism which the nerve supplies, then the seeond impulse if it be propagated along a nerve during the supernormal period may cause the motor endorgan to act. Such a phenomenon is ealled summation.

9. Fatigue. Nerve fibres can apparently act as conductors of the nervous impulses for very long periods without showing any signs of fatigue. It is generally said that nerves eannot be fatigued. While this is true of the eondueting power of the fibre it is not applicable to the neuron as a whole. (1) The nerve eell loses something in the process. Granules which are apparent while the cell is at rest diminish slowly during activity. Then (2) ehanges take place at the synapses, the junction between neuron and neuron, and also at the "end plate" or junction between nerve fibre and organ. These potential junctions lose their power to eause the impulse of one neuron to aet as stimulus to the next neuron or to the end organ. They become fatigued.

10. Metabolism. This leads one to infer that the energy exchanges during the conduction of impulses are small. The amount of oxygen used is negligible and it is doubtful whether a measurable amount of $\mathrm{CO}_{2}$ is produced. There is no doubt of the need for oxygen for the metabolic changes of the nerve cell, but the extra amount necessitated by the passage of a nervous impulse has not been estimated. It must be very small indeed. Ingenious methods have been devised by Waller and by Tashiro for the measurement of the $\mathrm{CO}_{2}$ evolved during activity, but so many uncontrolled sources of error enter into the experiment that many physiologists hesitate to aceept their figures as representing the actual amount of oxidation undergone. One nust bear in mind that an increased output of $\mathrm{CO}_{2}$ docs not necessarily mean a simultaneous absorption of oxygen or a corresponding liberation of energy. The $\mathrm{CO}_{2}$ may be due to liberation of $\mathrm{CO}_{2}$ from solution in the surrounding tissue by the heat of the stimulus 
or from earbonates from the action of acids set free electrolytically by either the impulse or the stimulus.

Hill has found that when a nerve is placed in a carefully shielded thermopile, the registering galvanometer shows unaccountable fluctuations corresponding to temperature changes of the order of $\tau \times 10^{-6}$ of a degree $C$. The passage of some 600 impulses does not produce any larger variation. Therefore, the amount of heat produced must be less than this figure.

11. Electrical changes during conduction. Just as in muscle, so in nerve, an electrical wave aceompanies the nervous impulse. The part excited becomes electro-negative to the rest (see Musele, p. 143), and this negative wave passes along the nerve in the direction of and at the same rate as the nervous impulse. It is followed by an electro-positive wave of greater potential. The combined electrical changes are thus said to be diphasic. The electrical wave complex must not be confused with the nervous impulse. In other words the nervous impulse is not electrical in nature but produces localised differenees of potential in nerve as it passes. The rate of conduction of an clectrical impulse along frog's nerve is about 300 metres per second, while the nervous impulse travels at about 30 metres per second.

12. Electrical changes during stimulation. This wave of negativity is the current of action (or of injury) of the nerve. It may be made manifest as indicated.in Fig. 35, by rapidly

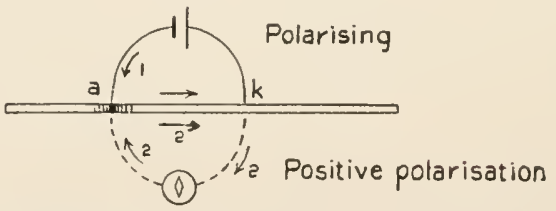

Fig. 35.- Diagram to show direction of the positive polarisation current, due to a break excitation at the anode.

connecting anodal and eathodal parts of a nerve through a galvanometer. If a stimulating current is passed through a section of a nerve so that $a$ is the positive electrode and $k$ is the negative electrode, then on breaking the eircuit and connecting $a$ and $k$ through a galvanometer (circuit 2), it will be obvious that a current flows momentarily along the nerve from $a$ to $k$, i.e. in the same direction as the previous stimulating current. This is sometimes termed a positive polarisation current.

Under certain conditions it is possible to observe an electrical change in the opposite direction after cessation of the stimulus 
(Fig. 36). Nerve consists of a eondueting core of electrolytes and colloids surrounded by a sheath enelosing electrolytes and colloids. The passage of a constant eurrent through this mass gives rise to certain physico-ehemieal ehanges in eore and in

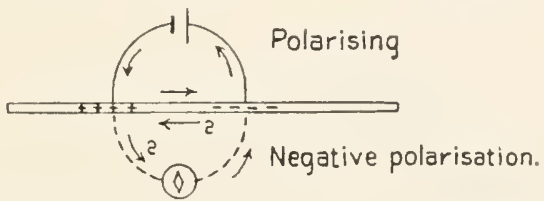

FIG 36.-Diagram to show direction of the negative polarisation current.

sheath. These electrolytic and polarisation changes set up a eurrent which tends to restore equilibrium (back E.M.F.). 'This is negative polarisation.

The changes that take place may be studied eonveniently by means of a model (Fig. 37). A platinum wire, forming a con-

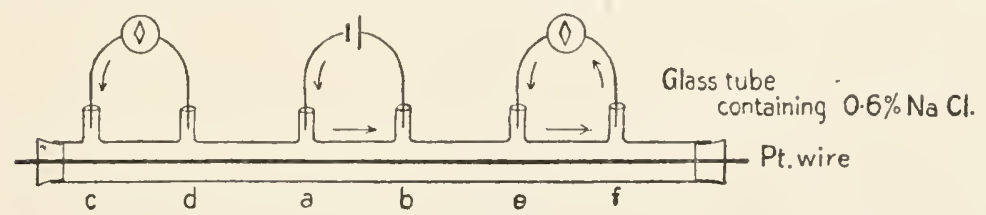

FiG. 37.-Apparatus for initating the polarisation phenomena in medullated nerve.

dueting core, runs inside a glass tube filled with eotton wool soaked in 0.6 per cent. sodium chloride solution.

The points $a$ and $b$ are eonnected to a battery and the extrapolar points $c$ and $d, c$ and $f$ are led off to galvanometers. On the passage of a current from $a$ to $b$ it is found that an extra-polar

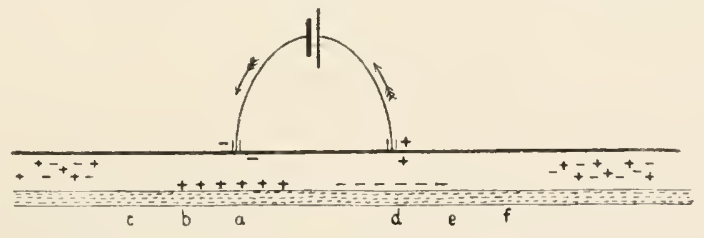

FIG. 38.-Diagram to show polarisation at the surface between conducting core and electrolyte sheath.

eurrent is flowing from $c$ to $d$ and from $e$ to $f$ (ef. Fig. 40). The cause of these extra-polar or, as Du Bois-Reymond ealled them. electrotonic currents, is to be sought in the movements of the dissociated salts in the sheath. Opposite the anode (Fig. 38), the positive ions are conecntrated on the surface of the eore. This causes opposition to the passage of the primary current and 
also sets up eurrents in the electrolytic fluid (Fig. 39) from $a$ to $b$, $b$ to $c$, ete. These currents are indicated by the galvanometers.

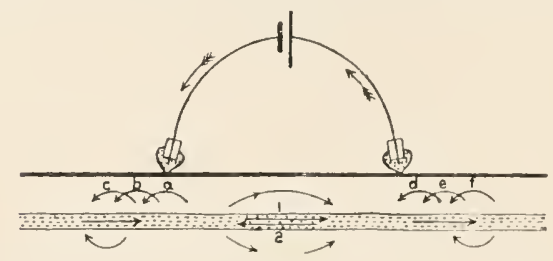

FIG. 39.-Diagram_to ${ }^{-}$show polarisation currents in a medullated nerve or in a polarisation model.

Emphasis must be placed on the fact that these electrotonie eurrents are absolutely distinet from the nerve impulse as well as from the wave of negativity or eurrent of action and the enrrent of injury. (a) 'The former have a mueh greater velocity than the nerve impulse, as indieated by the wave of negativity

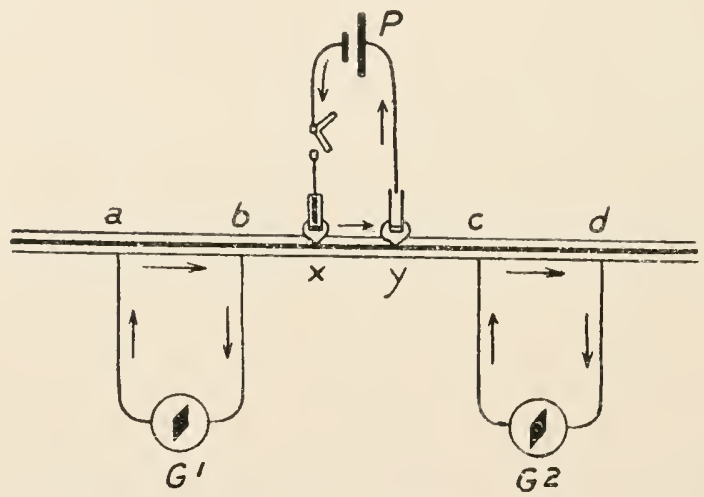

VIt. 40.-1)iagram showing electrotonic currents. $P$, polarising circuit; $G^{1}, G^{2}$, galvanometers.

(see 11 above). ( $\beta$ ) Their E.M.F. may attain a value twenty-five times that of the eurrent of injury. $(\gamma)$ 'The direction in which electrotonic currents flow depends entirely on the direction in which the primary eurrent is flowing, reversion of the latter leading to reversion of the former. Action and injury eurrents ahways maintain a flow in the nere from a stimulated or injured part to a resting or uninjured portion of the nerve. 


\title{
CHAP'TER XVIII
}

\section{OU'TPOS'TS OF THE IN'TELLIGENCE SERVICE}

(a) GENERAL AND INTRA-COMMUNAL RECEPTORS

\begin{abstract}
"By mine eye, I do not know that I see, or by mine ear that I hear, but by my common sense who judgeth of sound and colours."

BurToN.
\end{abstract}

TuE Cabinet which eontrols a nation has to set up maehinery to provide itself with two different kinds of intelligence. First it necds to know how its orders are being earried out by the eivilian population as well as by the military. The internal or interoceptive intelligence staff is distributed among the factory workers, along lines of transport and in the various effeetive units of the army. Their duty is to report on the conditions in their sector. Before a shortage of raw material has become so marked as to eause an outery from, or mayhap, a strike of some part of the population, the outposts of the intelligence staff should have their report "on the wires." Very little is known of how this work is carried out. It is mere guesswork to say that slight alterations in the physico-chemical condition of the material surrounding a nerve-ending is sufficient to cause stimulation of the nerve. The other intelligence staff operates on matters outside the organism. They are exteroceptors.

Sherrington divides interoceptors into two groups:

1. General, which have to do with sensations of hunger or thirst, nausea, respiratory and circulatory scnsations, scxual sensations, visecral pain, ete.

2. Special consists of end organs for taste and smell. These are distinctly ehemieal in their aetions and are the chief exteroceptors in many animals (see later).

To these fall to be added a group with a double function :

3. The somatie proprioceptors, which are situated in the museles, tcndons and joints, and are concerned with the production of the muscle scnse. To this group also belong the organs which have to do with the sensations of equilibrium. Not only have 
the proprioceptors to report on work done but it is obvious that they have to form some opinion of the relation of the organ to its environment. 'They thus have a function closely allicd to that of the truc exteroceptors which are stimulated under ordinary conditions by forces outside the organism.

It is a good thing to bring in the aid of comparative physiology when about to study a fresh group of organs. One may then see how various modifications arise and how the simple undifferentiated cell becomes specialised and fitted to act as a receptor for one particular form of external energy. 'Time and space do not permit such a digression here, but the sturdent would do well before reading further to revise his knowledge of the comparative zoology of the sense organs.

The sense organs or receptors may be considered as points of least resistance, gateways through which the manifestations of external forces may reach the internal struetures. They are much more than that. They are specialised outposts of an intelligence serviee which pick up minute alterations in the energycomplex of the environment, make a rapid but incomplete analysis of these changes, and send in a report to departmental headquarters for complete analysis and transmission to headquarters.

Only by specialisation can efficiency be obtained. The organism is subject to stimulation from various forms of energy which may be classified into vibratory and chemical.

\section{A. Vibratory Energy.}

1. Mechanical impacts received by the tactile corpuscles of the skin. They may be pereeived as separate stimuli even when they arrive as rapidly as $\mathbf{1 5 5 2}$ per second.

2. Slow vibrations especially in air are received by the ear. The human ear may be stimulated by vibrations ranging from 16 to 10,000 per seeond. Practice may extend this range.

3. Rapid vibrations in ether.

(a) Radiant heat. Vibrations with a frequency of between 3 billions and 400 billions per second stimulate the temperature receptors of the skin.

(b) Light. 'The retina is capable of receiving as light, ether waves, the frequency of which varies between about 400 billions and 800 billions per second.

\section{B. Chemical Energy.}

'The various chemical stimuli to which the organ is exposed, have receptors in the skin, giving rise to sensations of pain or 
discomfort, and in the special end organs to those of taste and smell.

The function of the receptors is to receive that form of energy for which they are fitted and to transform that energy into nervous energy. We have previously shown that any one form of cnergy can be transformed into any other form. It has been found convenient, for instance, to calculate all forms of energy manifestations found in the body in heat units-calories. Nervous energy may be electrical encrgy. It can readily be demonstrated that any form of encrgy can be converted into the electrical form.

As receptors for these various manifestations of energy we have the so-called five senses. 'That is, five different means are employed for the purpose of oricntation, viz. touch, hearing, sight, smell and taste. These senses come into contact with the cxternal forces through the skin, ear, eye, nose and tongue. But some of these are composite end-organs. The skin, for instance, includes not only touch corpuscles but the end-organs for pain and temperature. The ear not only analyses sounds but contains organs for the static and dynamic senses. In all there are over twenty different kinds of receptors and sense-organs in the body.

Specific irritability. In the preceding chapter we have alluded to Müller's law of specific irritability, and an elcetrical model was discussed as illustrative of this idea. A very little consideration suffices to show $(a)$ that the same physical stimulus applied to various receptors will give rise to absolutely different sensations and $(\beta)$ that different physical stimuli applied to the same end-organ, if they arouse any response at all, give rise to the specific sensation of that organ or to pain.

Stimulus and Sensation. Each receptor has a certain functional inertia and will not respond to stimulation until the energy of the stimulus has reached a minimal valuc which is specific for each receptor and for each form of stimulus. 'This threshold value is lowest, as has been said above, for the form of stimulation specific for that organ. Once this value is gained, the resulting sensation bears a definite relationship to the incident stimulus until an upper limiting value has been reached, after which increase of stimulation is of no avail. In fact, fatigue rapidly sets in, and the resulting scnsation is sub-maximal (Fig. 41).

Touch is the sense by which mechanical force is appreciated Mere contact is gentle pressure, a greater amount of applicd force causes a fecling of resistance referred to the skin, a still greater 
amount evokes a response from reeptors in the musele, while pain results from great pressure. The total number of tactile eorpuseles (exeluding those on the head) has been estimated as 500,000 . These are not evenly distributed over the skin but are more numerous and more sensitive on certain of the more mobile parts of the body, e.g. tongue and fingers. The degree of sensitiveness of the skin may be determined by some form of aesthesiometer

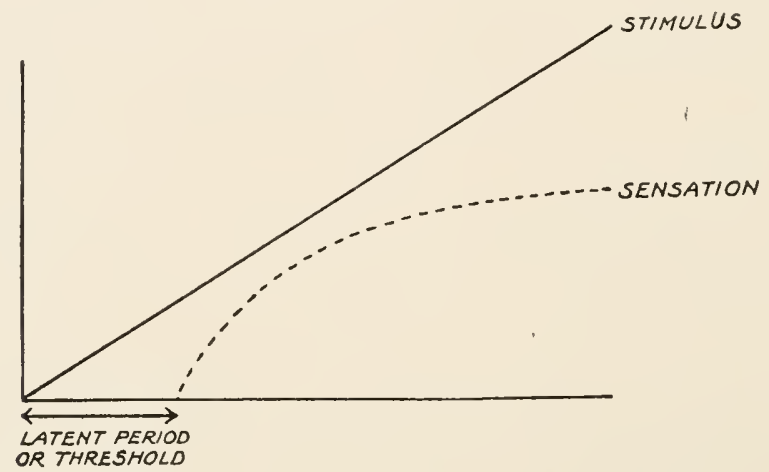

FIG. 41.-Diagram to show relationship between stimulus and sensation.

(say a pair of eompasses) by means of which one may measure the smallest distance at which impress of the two points may be pereeived as two distinet sensations. The following table gives the activity of the diseriminating sense for different parts of the skin :

\section{TABLE XXIX.}

Tip of the tongue

Nillimetres.

Third phalanx of finger, volar surface -

Red part of the lip

of finger, volar surface

finger, volar surface -

First phalanx of finger, volar surface - $\quad-\quad-5-5 \%$ )

Third phalanx of finger, dorsal surface $\quad$ - $6 \cdot 8$

Tip of nose - $\quad$ - $\quad$ - $\quad$ - $\quad$ - $\quad$ - $\quad$ - 6.8

Head of metacarpal bone, volar surface $\quad-\quad$ - $5-6 \cdot 8$

Ball of thumb - $\quad$ - $\quad$ - $\quad$ - $\quad$ - $\quad$ - $\quad$ - $6-5 \cdot 7$

Ball of little finger $\quad$ - $\quad$ - $\quad$ - $\quad$ - $\quad$ - $5 \cdot 5-6$

Centre of palm - $\quad$ - $\quad$ - $\quad$ - $\quad$ - $\quad$ - 8-9

Dorsum and side of tongue ; white of lips ; metacarpal part of the thumb - $\quad-\quad-\quad-9$

Third phalanx of the great toe, plantar surface - $11 \cdot 3$

Second phalanx of the fingers, dorsal surface - $11 \cdot 3$

Back - - $\quad$ - $\quad$ - $\quad$ - $\quad$ - $\quad$ - $\quad$ - 11.3

Eyelid - $\quad$ - $\quad$ - $\quad$ - $\quad$ - $\quad$ - $\quad$ - $11 \cdot 3$

Centre of hard palate - $\quad$ - $\quad$ - $\quad$ - $\quad$ - $\quad$ - 13.5 


Lower third of the forearm, volar surface
In front of the zygoma -

'The intensity of the eontact sensation is inereased in a meehanieal way by the presence of hairs, beeause they aet as levers on the tactile eorpuseles. The whiskers of the eat render the touch points of the jaw very sensitive in this way, being able to detect even slight air eurrents.

Absolute sensitiveness as indieated by a sense of pressure is generally determined by finding a minimum pressure neeessary to evoke a minimal sensation. Below is given the weight in grams which could just be detected when placed on various parts of the skin. The values given are normal values ('Table XXX.). Praetiee may inerease the discriminating point. Every one knows how a blind man "sees" with his fingers.

\section{TABLE XXY.}

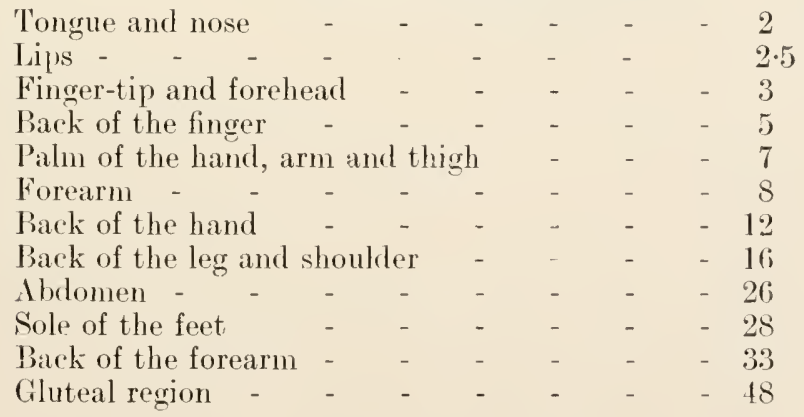

In a similar way one eould map out the hot and cold spots and the pain spots in the skin. 'They vary in distribution but not in 
the sanc order as the pressure spots. For example, the minimum pereeptible difference of temperature in degrees centigrade is given in the sueceeding list for various regions :

\section{TABLE XXYI.}

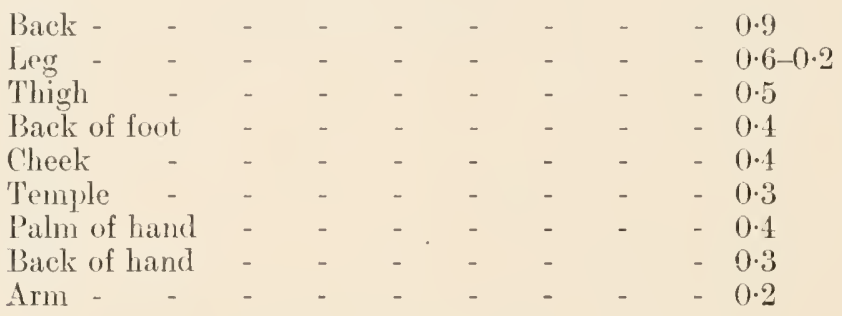

Taste and smell are the ehemieal senses (partly ehemical and partly physieal) and are closely allied to touch. 'To stimulate the end organs of ehemieal sense, the substance must be in a fine state of division and eapable of going into solution in the fluid on the superficies of the sense organ. In spite of mueh research, little more ean be added to this brief statement. Of the two senses, taste is the more limited as well as the less useful. Four kinds of taste nay be diseriminated, viz. sweet, salt, aeid and bitter. Flavours are odours and really give rise to an olfactory sensation. Smell is the aneestral ehemical sense and may be elassed, especially in the lower animals, as a distance reeeptor. In eivilised man, this sense, unless rendered acute by training, is merely vestigial.

The areas of nasal mueosa assoeiated with this pereeptive meehanism, are small rectangular strips in the upper part of eaeh nasal cavity, just above the superior turbinate bone. In ordinary respiration, air does not pass directly over the olfactory mueous membrane, but some air diffuses baekways through the posterior nares (Fig. 42). This is important for the preservation of the sense. 'The receptor neurons have retained their primitive eondition of eell body in the epithelium itself (Parker). They are rapidly fatigued and readily destroyed. Now, by their situation in a backwater they do not come direetly into eontact with ligh concentrations of odoriferous substanees and, furthermore, air attains body temperature and moisture and is freed from suspended particles (dust, baeteria, ete.) before reaching the sensory surfaee. 'T'he physical details of the meehanism for the pereeption of smell, that is, for the eonversion of ehemical into nervous energy, have not yet been brought to light. The sense is extraordinarily delieate. Mereaptan, in as low a eoncentration as 0.0000000004 
gram per litre of air, can be detected. Training renders the sense more acute. The working chemist relies on his sense of smell to a great extent to help him in the identification of compounds. The tea blender and the wine expert can detect very slight differences in "flavour."

It is worth while noticing that receptors all depend for stimulation on the cxistence of an alteration in external energy. This

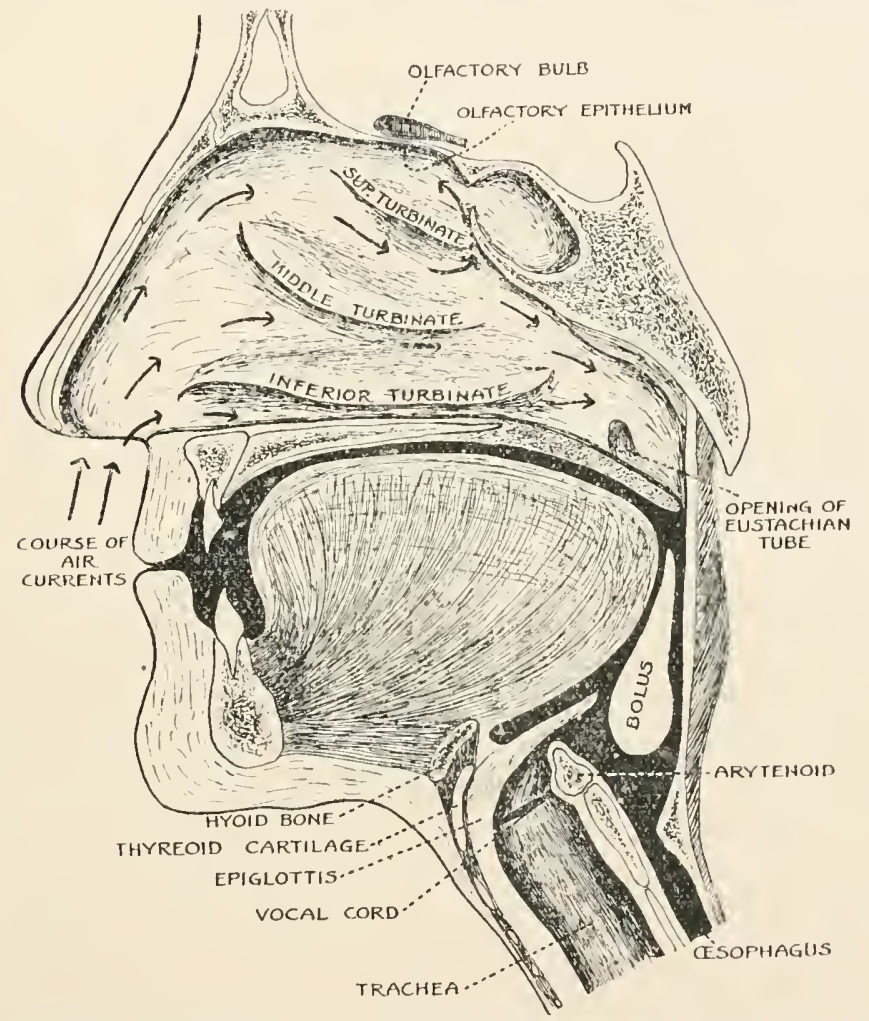

Fit. 42.-Antero-posterior section throngh nasal fossae, mouth and neek. The arrows show the direetion of the air rurrents during inspiration.

is specially marked in the case of this aneestral chemical sense. Our accustomed environment presents no stimulus. Air has no smell and water no taste. The introduction of a trace of foreign body alters the energy content of the environment and stimulation follows. It is a common experience to find that people do not experience sensations that have, for the time being, become permanent in their environment. A room may be stuffy to an incomer but quite comfortable to the tenants. The physiological 
chemist works in an atmosphere which causes his visitor to choke and splutter, but the introduction of a new odour, say ammonia. is at once perceived and produees instant aetion.

Hunger is a sensation which must be regarded as primitive and basal. It is not our business to analyse the feelings of hunger. but to consider the mechanism by which the lack of nourishment is signalled to consciousness. The evolution of knowledge of this sensation is largely due to Prof. Cannon, whose book on the subjeet should be read by every student. There ean be no doubt that the feeling of hunger is elosely allied to pain.

"The sensation of hunger is diffieult to deseribe, but almost everyone from childhood has felt that dull ache or gnawing referred to the lower mid-ehest region or epigastrium, which takes imperious control of human actions. As Sternberg has pointed out, hunger may be sufficiently insistent to force the taking of food which is so distasteful that it not only fails to rouse appetite but may even produce nausea. The hungry being gulps his food with a rush. The pleasures of appetite are not for him-he wants quantity rather than quality, and he wants it at once

Hunger may be described as having a eentral eore and eertain more or less variable accessonies. The peculiar dull ache of hungriness referred to the epigastrium is usually the organism's first strong demand for food; and when the initial order is not obcyed, the sensation is likely to grow into a highly uncomfortable pain or gnawing, less definitely loealised as it becomes more intense. This may be regarded as the essential feature of hunger. Besides the dull aehe, however, lassitude and drowsiness may appear, or faintness, or violent headache, or irritability and restlessness such that continuous effort in ordinary affairs beeomes increasingly diffieult. That these states differ mueh with individuals-headache in one and faintness in another, for, example-indicates that they do not indieate the central fact of hunger, but are more or Jesis inconstant accompaniments. 'The 'feeling of emptiness,' which has been mentioned as an important element of the experience, is an inference rather than a distinct datum of conseiousness and ean likewise be climinated from further consideration. The dull pressing sensation is left, therefore, as the constant characteristie, the central fact to be examined in detail" (Cannon).

Camnon and his eolleagues have definitely proved that the sensation of lumger is caused by strong contractions of parts of the alimentary canal. As we shall see later when dealing with 
transport (Chap. XXVII.), there are certain definite movements of the alimentary canal designated as peristaltic associated with the forward transference of the contents of the canal. In the absence of any content other than gaseous, the cavities of the stomach, lower oesophagus and upper intestinal region, at least, are almost obliterated. This wave of contraction precedes the sensation of hunger and may be regarded as the cause of it. Cartson and his students, who were fortunatc in having a subject with a permancnt gastric fistula, have confirmed Cannon's work and carried it further. They have shown that the local contraction is a sign of a gencral state. According to Carlson and Luckhardt the blood of a fasting animal, if injected into the vein of a normal animal, is capable of producing in the latter, contraction of the gastric muscles, an effect which does not occur when the blood of a well-fed animal is injected.

'The significance of this phenomenon is plain. In Cannon's words :

"The very condition which causes hunger and leads to the taking of food is the condition, when the swallowed food stretches the shortence muscles, for immediate starting of gastric peristalsis. In this connection, the observations of Haudck and Stigler are probably significant. They found that the stomach discharges its contents more rapidly if food is eaten in hunger than if not so eaten. Hunger, in other words, is normally the signal that the stomach is contracted for action; the unpleasantness of hunger lcads to cating, eating starts gastric digestion and abolishes the sensation. Meanwhile the pancreatic and intestinal juices as well as bilc have been prepared in the duodenum to receive the oncoming chymc. The periodic activity of the alimentary canal in fasting, therefore, is not solely the source of hunger pangs, but is at the same time an exhibition in the digestive organs of readiness for prompt attack on the food swallowed by the hungry animal." 


\title{
CIAPTER XIX
}

\section{OU'TPOS'TS OF THE IN'TELLIGENCE SERVICE}

\author{
(b) DISTANCE RECEPTOR FOR SOUND
}

THE: EAR

\begin{abstract}
"A clue to the structure of a machine lics in the diseovery of the purpose for which it was designerl and the manner in which its various parts are co-ordinated to sccure that cnd. That is eminently true of the car." KEITI.
\end{abstract}

Tine ear is a modified touch receptor. In the lower invertebrates it consists of hair-like appendages, either on the free surface or in a depression, more or less protected. In the higher vertebrates it is a much more complieated structure. The human ear may be considered as composed of three structural elements, viz. :

External ear-collector and conductor of sound to the middle ear.

Middle ear-converter of air vibrations to a to-and-fro movement of a piston-like lever and the accentuation of these movements.

Part of internal ear-transformer of mechanieal pressure, via hydraulic pressure, into nervous energy.

1. External ear. 'The structure of this presents no outstanding points of physical interest. It consists of the pinna and the external acoustic meatus at the end of whieh is the membrana tympani or eardrum (Fig. 43).

(a) The pinna is a flattcned horn presenting irregularities of surface. If these undulations are filled in with wax or if the pinna is awanting, the quality of sounds is altered and difficulty in localising sound is increased. This may be due to a differential reflection of tones by the pinna, $e$.g. it may reflect a fundamental tone more strongly than the partial or vice-versa.

(b) The external acoustic meatus is a curved tube about 21-26 $\mathrm{mm}$. long. Its function is two-fold. (i) On account of its shape, secretion, and hairs (at orifice) it protects the delicate tympanie membrane from draughts and dust, and from the incursion of 
insects. This is its main function. (ii) The sound waves are condueted by reflection from the walls without loss of intensity, and directed almost perpendicularly on to the drum which lies at an angle of $150^{\circ}$ to the axis of the canal.

2. Middle ear. The meehanism found in the middle car eonverts vibrations in air into vibrations in fluid by means of membrancs and a series of levers. It consists of an air-filled eavity hollowed out of the petrous part of the temporal bone. It is scparated from the external ear by the tympanic membranc, and

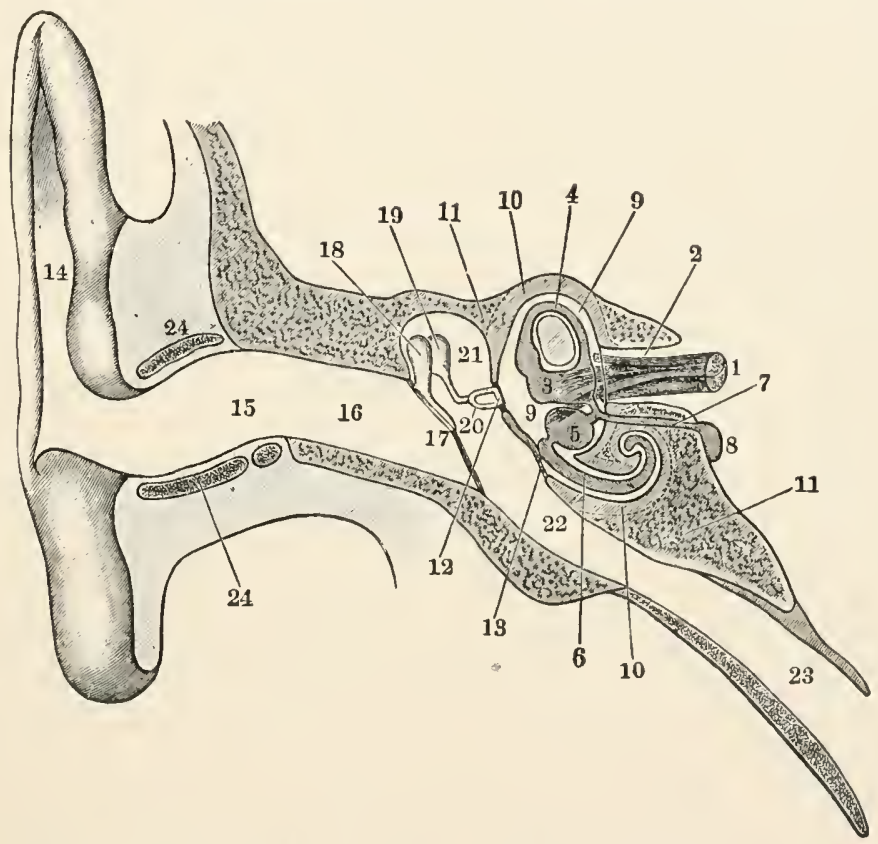

FIg. 43.-Diagrammatic view of anditory organ. (After Schafer.)

1 , Aconstic nerve; 2 internal acoustic meatus: 6 , canalis media of cochlea ; 9 , vestibule containing iymph; 12, stapes; 13 , fenestra cochleae (rotunda); 19 , incus; 18, malleus; 17 , membrana tympani; 16 , external acoust ic meatus ; 14 , auricle or pinna ; 23 , Eustachian or auditory tube.

from the internal ear by the membrane elosing the round window and by a dise of bone- the foot of the stapes, which along with the membranous collar surrounding this bone makes a fluid-tight packing or gland filling the fenestra ozalis, the oval opening into the internal ear. Between the drum and the stapes lie two bony levers-the malleus and the incus.

(a) Membrana tympani. This structure is fixed in a frame of bone which is almost circular (vertical diameter $10 \mathrm{~mm}$. ; horizontal diameter $8.5 \mathrm{~mm}$.). Although it is not more than $0.1 \mathrm{~mm}$. 
thick, it is constructed of three layers. On the outer surface there is a layer of epithelium proteeting the membrane proper whieh is of fibrous tissue and is covered on the inner side by a layer of mucous membrane. The fibres of the fibrous layer are arranged partly eircularly and partly radially- the cireular fibres being most marked near the rim. To the inner surface is attaehed the handle of the malleus, the first of the ehain of three auditory ossieles. This attaehment to the malleus, whieh is pulled inwards by the tensor tympani muscle, gives the tympanie membrane the form of an eceentrie funnel opening outwards. The membrane is highly elastie and responds very readily to very slight variations in the pressure of the air waves entering the cxternal ear. The peculiar form of the membrane eontributes to its value as a sound transmitter. In the first plaee it aets synkinetically, i.e. moves passively with the vibrations of the sound-waves. It begins and ends its vibrations synehronously with the impact of the sound vibrations. There is no latent period, no waiting for a summation of impulses before it can get into its swing, having no swing to get into. It does not continue to vibrate after the sound vibrations have ccased. It is dead-beat. Further, it does not vibrate sympathetically to any special overtone present in a compound tone reaching the car. This is brought about by (i) the damping effect of attachment to the ossieles and (ii) by the dragging inwards at the point of attachment (umbilieus). On this aeeount the fibres vary in tension as well as in length, so endowing each bit of the menbrane with a different pcriod of vibration resulting, in toto, in an aperiodic membrane. It is obvious that sueh a property is valuable in rendering hearing distinct. In the seeond place the arched sides of the membranc act as a lever of the 1st elass.

"As the outward curvature of the radial fibres is slight, each fibre may be regarded as the long arm of a lever, while the handle of the hammer is the short arm. This mechanism seeures that a slight pressure of the air eorresponding to a sound wave, excrts a considerable force upon the malleus. To aid in understanding the mechanism, it will be easier to consider, first, the cffeet of pressure upon a single radial fibre. The fibre may be regarded as inextensible and slightly curved outwards; hence variations in pressure on the convexity of the eurve will cause the degree of eurvature to change, while the length of the are will remain the same.

In other words, the radius of the are and the ehord of the are will ehange, while the length of the arc remains eonstant. But 
the length of the are may be regarded as the length of a radial fibre; henee

$$
l=2 r \sin ^{-1}\left(\frac{\lambda}{2 r}\right)
$$

where $l=$ length of fibre, $r$ = radius of the eirele of curvature, and $\lambda$ ehord of the are $l$, beeause ${ }_{2 r} r$ is the sine of half the angle at the eentre belonging to the are $l$. This equation may also be written

$$
\lambda=2 r \sin \left(\frac{l}{2 r}\right) \text {. }
$$

Now, if we subtraet the (each side) from $l$, we have

$$
l-\lambda=2 r\left\{\frac{l}{2 r}-\sin \left(\frac{l}{2 r}\right)\right\},
$$

which gives the differenee between the ehord of the are and the eurve. But as the eurve is very slight, $r$ is large in eomparison with $l$ and the divisions beeome rapidly very small as the sine in the formula is developed by the involution of its are. Henee

$$
\sin \frac{l}{2 r}=\frac{l}{2 r}-\frac{1}{6}\left(\frac{l}{2 r}\right)^{3}
$$

and from this the preeeding equation beeomes

$$
l-\lambda=\frac{1 l^{3}}{24 r^{2}}
$$

Again, let $s$ be the distanee of the eentre of the are from the eentre of the ehord. Then the degree of eurvature is found by the equation

$$
\begin{gathered}
r-s \\
r
\end{gathered}=\operatorname{eos} \begin{aligned}
& l \\
& 2 r
\end{aligned}
$$

so that

$$
\begin{aligned}
s & =r-r \cos \frac{l}{2 r} \\
& =r\left(1-\operatorname{eos} \frac{l}{2 r}\right) .
\end{aligned}
$$

Sinee

$$
\operatorname{eos} \frac{l}{2 r}=1-\frac{1}{2}\left(\frac{l}{2 r}\right)^{2} \text { approx. }
$$

we have

$$
s=r\left[1-\left\{1-\frac{1}{2}\left(\frac{l}{2 r}\right)^{2}\right\}\right],
$$

that is

$$
s=\frac{1}{8} \frac{l^{2}}{r} \text {. }
$$


Now, eliminate $r$ from equations (1) and (2), and we obtain

$$
l-\lambda=\begin{aligned}
& 8 s^{2} \\
& 3 \quad l
\end{aligned}
$$

This equation gives the amount of shortening of the ehord whieh occurs when the curve of the are is inereased; that is to say, it gives the extent to which the two ends of the fibre are drawn together. Now, if $s$, the displacement of the middle of the fibre, be very small in eomparison with $l$, then $l-\lambda$ obviously beeomes very small in eomparison with $s$. Conversely, the very small inerease in the magnitude of $l-\lambda$ must eause a relatively great inerease of $s$; that is to say, it must cause a relatively great displaeement of the centre of the fibre.

Again, if $t=$ the tension of the fibre, $p=$ the pressure on eaeh unit of its length, and $r=$ the radius of eurvature, then

$$
t=p r
$$

and the forees whieh aet upon both ends of the fibre must be equal to the pressure whieh aets upon the diameter of the semieirele through a width cqual to that of the fibre (Hehmholtz). Therefore

$$
2 t=2 p r .
$$

Henee the greater the radius of curvature, the greater will be the alterations in tension of the fibre eaused by alterations in the pressure of the air. Further, as the radial fibres are those whieh are attached to the malleus, it is evident that the variations in the tension of the fibres cause movements of the bones when sound-waves strike the drum-head. Thus a very small ehange of pressure in the air eauses a eonsiderable ehange in the tension of the fibres; and further, in aeeordanee with the laws regulating the action of the lever, as the force whieh fibres exert upon the handle of the malleus inereases, amplitude of movement of that bone diminishes. In this way, the speeial form of the drum-head secures a maximum of effieieney for tones of the fecblest intensity" (M'Kendriek).

Briefly, encrgy applied to the membrane is passed on to the handle of the malkeus diminished in amplitude but with inereased intensity.

(b) Ossicles. The three bones of the middle ear,--the malleus, the incus and the stapes, - streteh aeross the tympanie eavity forming an artieulated ehain of levers, so that every normal movement of the tympanie membrane is transmitted by the stapes to 
the fluid of the internal ear. The Malleus, or hammer, is about $18-19 \mathrm{~mm}$. long, and has an average weight of $23 \mathrm{mgms}$. It eonsists of a thickened rounded head and a long handle-the mambrium, whieh is attached to the tympanie membrane, the tip of the handle reaching the umbilieus. Near the insertion of the head and handle rises a bony process-the processus gracilis or processus Folianus, which projeets forward and is eontinued by a ligament, the anterior ligament by means of which the hammer is anehored to the wall of the tympanum. There is also a shorter protuberanee, the processus brevis, which presses against the edge of the upper surface of the drum. Three other ligaments are attached to the malleus, the external ligament, binding it to the

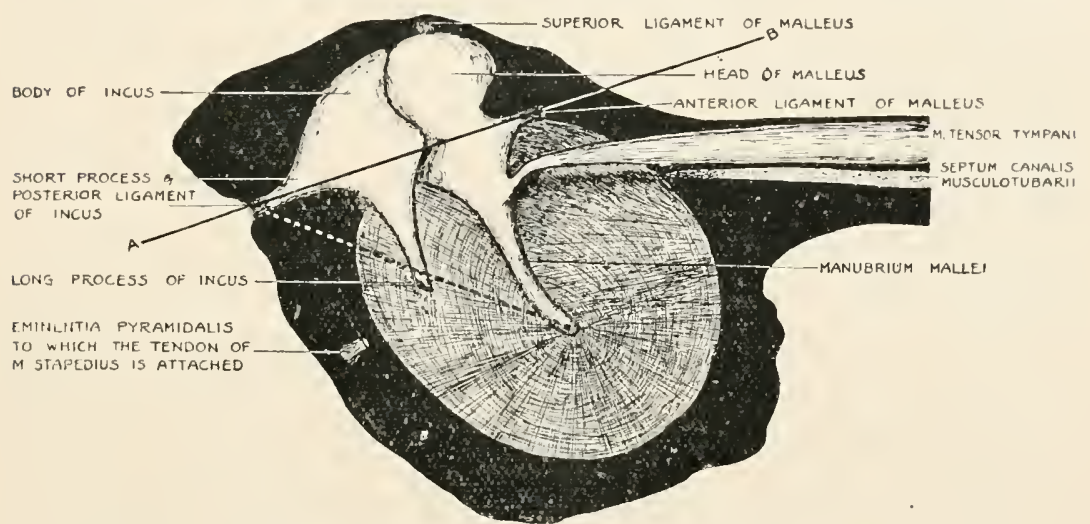

Fig. 44-Diagram of the left Membrana Tympani and Chain of Tympanic Ossicles seen from the medial aspect.

The line $A-b$ is the axis of rotation of the malleus and incus. The dotted line represents the line of leverage anplied from the handle of the malleus to the posterior ligament of the incus. The stapes lies almost at right angles to the plane of the paper.

external face of the tympanie eavity, the superior or suspensory ligament, attaching the top of the head to the roof of the eavity, and the posterior ligament. These ligaments prevent the malleus from rotating in any other axis than a horizontal one whose line passes through the head of the malleus and the anterior ligament (Fig. 44). The posterior surfaee of the head of the hammer fits into the saddle-like hollow in the anterior surfaee of the body of the anvil-bone or incus. This is a larger bone than the malleus, weighing on the average 25 mgms. The body of the incus is drawn out on its posterior side to a proeess-the short proeess, which is attached by a ligament to the posterior wall of the tympanie eavity, forming one end of the malleo-ineal axis mentioned above. Almost at right angles to the short process, the inferior surface of 
the incus tapers down to the knob-like os orbiculare, forming the long process.

The os orbiculare articulates with the knob on the top of the stirrup bone or stapes. This bone, a flattened stirrup arch, weighing only about $3 \mathrm{mgs}$, is set almost at right angles to the long process of the incus. Its oval footplate is attached to the margin of the fenestra ovalis by a short stiff membrane, the annular ligament.

\section{Muscles of middle ear.}

Two slender museles are attached to the ossicles:

(i) The stapedius is inserted into the knob at the head of the stapes and is attached to the posterior wall of the tympanie eavity.

(ii) 'The tensor tympani arises from the inner wall of the eavity, passes outwards and upwards above the Eustachian tube, to be inserted in the upper part of the handle of the malleus.

\section{Function of the muscles.}

The tensor, on contraction, draws the handle of the malleus inwards, and so, as its name implies, increases the tension on the tympanie membrane. This decreases the natural period of vibration of the drum, and this makes it more sensitive to high tones, and better fitted to adjust its vibrations to rapid ehanges of phase. Paralysis of this musele impairs hearing.

The stapedius prevents the footplate of the stapes from having purely a piston-like action in the fenestra ovalis. Its line of traction (Fig. 44), which is almost parallel to the long axis of the oval window, eauses the footplate to move on the posterior annular ligament as on a hinge. Contraction of this muscle thus draws the anterior end of the footplate outwards.

These two museles are therefore antagonistic; simultaneous contraction balances the ossieles and regulates the degree to which the perilymph of the internal ear is displaced. Further, the tension of the two museles prevents a slack engagement between the ossieles. If the bearings were not kept together with sufficient foree, slipping, knocking and loss of power would ensue. This state of equilibrium is absolutely necessary if the system of membranes and ossieles is to move in immediate response to the slightest alteration in air pressure.

Before going into the mode of aetion of the ear bones, a pressure equalising device comes up for consideration. As has just been said, perfect equilibrium of vibrating parts is necessary for perfeet 
transmission of energy. One can therefore realise how important it is for there to be some open communieation between the tympanie eavity and the atmosphere. By means of the Eustachian tube, communication is established between the middle ear and the pharynx and through the latter with the exterior, and so both sides of the tympanie membrane are kept at atmospherie pressure. Normally, it is closed by an areh of eartilage which surrounds the lower end. The tensor palati muscle is inserted in one side of this areh, and when this muscle contracts during the act of swallowing (Chap. XXVII.), it draws down and flattens the eartilage and so opens the tube. Ocelusion of the tube by mucus or by inflammation of the throat, isolates the air in the middle ear. 'The air is gradually absorbed by the tissues, pressure is thus redueed and the drum is sucked inwards. This increased tension in the membrane makes it less responsive to sound. Temporary deafness eaused by a rapid alteration in external air pressure (e.g. rising in an aeroplane; deseending in a submarine, or diving in a bell or suit, cntering a caisson, ete.) is immediately rchieved by movements of swallowing. The Eustachian tube is also the drainage tube to the middle ear, preventing the aecumulation of mueus (Figs. 42 and 43).

\section{Mechanism of the middle ear.}

The function of the mechanism is to transform the alternate condensations and rarefactions of air, which we call sound, into a series of hydraulic movements of the fluid in the internal ear. Direct observation has shown that the ear-bones form a chain of levers which together eonduet the vibrations ineident on the drum to the foot of the stapes.

A. Let us look first at the mechanism of the levers. In Fig. 44 is given a sehematic sketch of the ossieles illustrating their lever action. 'The axis on which the malleus and incus together turn is represented by the line $A-B$ passing from the tip of the short process of the malleus to the tip of the short process of the incus. A movement inwards of the mamubrium will eause the head of the malleus to swing outwards, earrying with it the upper part of the incus and so moving the long process of the incus in the same direction as the manubrium. This movement is directly transmitted to the stapes. The ehain of bones, therefore, acts as a bent lever whose fulcrum is at $a,{ }^{*}$ the power arm being represented by the dotted line and the load arm by the line $\mathbf{i}-\mathbf{a}$. Aceording to

* $\mathbf{a}=$ junction of dotted line with $A-B ; \mathbf{i}=$ tip of long process of ineus ; $\mathbf{p}=$ proint of application of power, i.e. tip of manubrium mallei. 
Helmholtz, the distance $\mathrm{p}-\mathrm{a}$ is $9.5 \mathrm{mms}$, and $\mathrm{i}-\mathrm{a}$ is $6.3 \mathrm{~mm}$. The movement at $\mathrm{i}$ therefore will be only $\frac{2}{; 3}$ of the movement at $\mathrm{p}$, but will have $1 \frac{1}{2}$ times the intensity. We have now to eonsider the transmission of this power to the foot of the stapes. If $x-y$ represents the range of the tip of the incus, $c-d$ the distanee from $c$, the hinge (lower annular ligament) to $d$ the eentre of the foot of the stapes, and $c-r$, the distanee from the tip of the incus to the lower end of the stapes, then the range of motion of the ecntre of the foot of the stapes will be $\frac{(x-y) \times(c-d)}{(c-r)}$ which, aecording to the seale of a drawing given by IIelmholtz, would give a leverage of about $2-1$.

So that, on the whole system of bones there is a leverage of about 3-1. This theoretieal value is, however, reduced by the frietion of the levers and by the damping effeet of the air filling the intcrnal ear. It has been estimated that half the foree is thus dissipated.

Three further points about the chain of ossieles claim our attention. Firstly, by the position of the axis, $a-b$, the mass of the heads of the hammer- and anvil-bones are above the line, while the lever arms are below the line on which the bones rotate. This keeps these two bones suspended in equilibrium. Sceondly, there are tooth-like proeesses on the surface of the hammer which cngage with the body of the anvil, enabling each to move the other in the to-and-fro movements of the drum. In the ease of unusually sudden alterations in air-pressure, $e . g$. a blow on the ear, these proeesses slip over eaeh other and prevent damage to the internal car. Thirdly, by the way in which they are hung on opposing ligaments, and eontrolled by opposing muscles, they form a kind of balance wheel whieh is very sensitive to the transmission of power in small vibrations. Its efficiency in this respeet is derived from the faet that the elastie forees balance one another in the meehanieal eentre of the system, and so praetieally the whole power applied to the drum is transnitted to the foot of the stapes.

B. The pressure in the internal ear is reinforeed not only by the system of lever transmission but by the relative sizes of the membranes at either end of the chain of ossicles. The area of the tympanie membrane is about twenty times the area of the fenestra ovalis. 'This means that, keeping the total power eonstant, the power per unit area is inereased twenty times. This is augmented by the intermediate leverage (correcting for airdamping, frietion, ete.), whieh we have seen has been estimated 
as not less than $1 \frac{1}{2}-1$. This would give a total inerease of effective pressure of at least $30-1$. (Wrightson puts the value as high as $60-1$ on the assumption that no slip oeeurs at the malleo-ineal joint, ete.)

3. Internal ear. The internal ear is a somewhat eomplex eavity in the petrous part of the temporal bone. Two separate organs are housed in this cavity, viz. the labyrinth by which equilibrium is maintained, and the eochlea.

The Cochlea is a tube, $20-30 \mathrm{~mm}$. long, which takes two and a half spiral turns round a conical bone, the modiolus through the eentre of which the auditory nerve passes. The eochlea is divided into three portions by means of $(a)$ a spiral lamina of bone extending from the modiolus about $\because$ aeross the tube, and $(b)$ joined to the walls of the tube by two membranes, Reissner's and the basilar membrane. The former is a thin layer of eells and separates the vestibular duct from the intramembranous middle duet. The part below the basilar membrane is ealled the tympanie duet. The fenestra oralis eloses the vestibule-the swelling at the wide end of the seala zestibuli-while the membrane of the fenestra rotunda does similar serviee to the lower duet, the seala tympani. 'The two duets are united at the apex of the eoehlea by an irregular eresecntie aperture ealled the helicotrema. This opening has an average area of $0 \cdot 15$ sq. $\mathrm{mm}$.--markedly less than the seetional area of the terminal part of either seala. These sealae are filled with a fluid, perilymph, which obviously, beeause of the fenestra rotunda, is normally under atmospheric pressure.

Chicf interest in the internal ear lies in the strueture of the scala media and its contents (Fig. 45). It is triangular in seetion, having for base the basilar membrane which separates it from the tympanie duet; the long side is eomposed of Reissner's membrane, whieh divides it from the vestibular duet. The short side is separated from the outer wall of the osseous eochlea by a vaseular layer (stria vascularis), laid on and in a eontinuation of Reissner's membrane, whieh in turn is plaeed on the spiral ligament, or pad. Roughly, the eubie eapaeity of this duet is about a quarter of that of the scala tympani and about a third of that of the scala vestibuli. It is filled with endolymph, a fluid similar to the perilymph of the rest of the eoehlea. No eommunieation exists between the seala media and any other part of the cochlea. There is a narrow tube, the camalis reuniens, which runs from this duet to the saeeule-part of the organ for maintaining equilibrium.

The reason for the attention that has been directed to the seala B. B. 
media is that the auditory nerve, which runs down the modiolus, cnters only this scala, passing along the basilar membrane and ending in dendrites among the hair-cells of the organ of Corti. This structure is a devclopment of the cpithclium lining the tube. It is set on the basilar membranc at its junction with the limbus laminae spiralis, and consists of four esscntial clements. (1) Certain columnar cells with short stiff hair-like processes projecting from their frec border, the hair cells, to which pass, as we

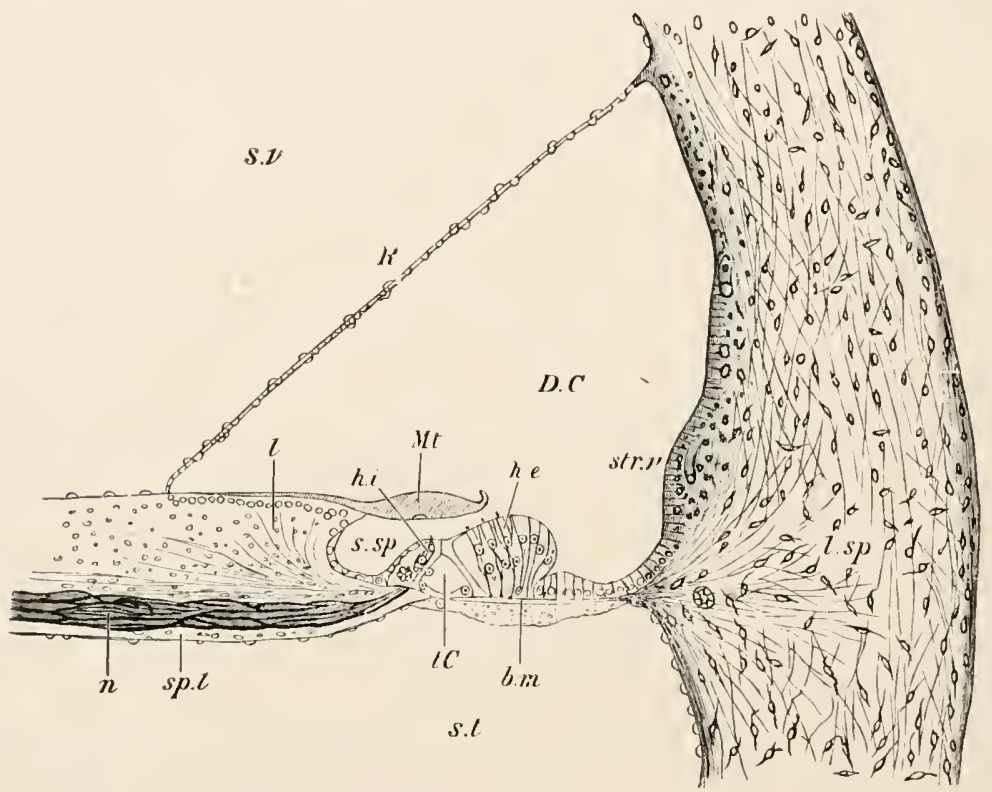

FIG. 45.-Vertical section of the first turn of the human cochlea ( $G$, Retzius).

$s . v$, scala vestibuli; s.t, scala tympani; D.C, scala media ; sp.l, spiral lamina ; $n$, nerve fibres; $l . s p$, spiral ligament ; str. $v$, stria vascularis ; m.t, membrana tectoria ; $b . m$, busilar membrane; $h . i$, and $h . e$, internal and external hair cells; $R$, section of Reissner's membrane; $t$. $C$, tunnel of Corti ; $l$, limbus laminae spiralis.

have just said, branches of the cochlear nerve; (2) elongated strengthening cells betwecn the hair cclls, cells of Deiters, the peripheral processes of which join together to form a network through which the hair-cells project (membrana reticularis); (3) stiff short fibres sct one against another in the form of an arch; and (4) an cxcecdingly delicate membranc attached to the upper surface of the spiral lamina, and lying over or fixed to both the outer and the inner walls of Corti's organ.

The arch of Corti, which lies just outside the single row of inncr hair cells, is composed of a row of inner " rods," shaped like ulnar bones, attached by their terminal end to the basilar membranc, and 
fitting on to the heads of the outer " rods." The latter resemble swans' heads and necks, the backs of the heads fitting into the hollows of the inner " rods."

\section{The mechanism of the internal ear.}

It is obvious that every movement of the stapes is eommunicated by the perilymph to the membranes of the scala media, from them to the endolymph, and so to the organ of Corti. There is also no doubt about the hair eells as being the final instruments for the transmission of the impulses to the nerve. 'Two main theories are held as to the mechanism of the cochlea, viz. the resonance theory and the displacement thcory.

\section{Resonance Theory.}

Helmholtz considered that the only mechanism capable of analysing compound vibrations was a system of resonators. In his own words, "Suppose we werc able to connect every string of a piano with a nerve fibre in such a way that this fibre would be excited and experience a sensation every time the string vibrated. 'Then every musical tone which impinged on the instrument would excite in the ear, as we know to be really the easc, a series of sensations corresponding to the pendular vibrations into which the original motion of the air had to be resolved. By this means, then, the existence of each tone would be exactly so pereeived, as it is really pereeived by the ear. The sensations excited by the higher partieles under the supposed conditions, would fall to the lot of different nerve fibres, and hence be produced perfeetly, separately and independently. Now, as a matter of fact, later mieroscopic discoveries respecting the internal construction of the car, lead to the hypothesis that arrangements exist in the car similar to those which we have imagined. The end of every fibre of the auditory nerve is connected with small clastie parts which we eannot but assume to be set in sympathetic vibration of the waves of sound."

He considered that the fibres of the basilar menubane constituted this system of resonators. 'This membrane increases its width (about three times) as it passes from its beginning in the base of the cochlea to its termination in the apex and contains somewhere about 10,000 of these fibres within its substanec. He considers that "damping arrangements exist in the ear so as to quickly cxtinguish movements of the vibrators" (M'Kendrick). 
'This theory receives confirmation from the following facts:

(1) Birds and other animals whose ealls have a short range of pitch have short basilar membranes.

(2) Prolonged subjection to a definite note produces degeneration in a definite part of the membrane - e.g. in boiler makers' disease there is inability to hear high notes with degeneration of the short fibres; animals give evidence of deafness to low notes when the long fibres of the membrane have been destroyed.

A gainst this theory are arrayed most psychologists and not a few physiologists and anatomists. They find in it no adequate explanation of ecrtain phenomena.

(1) The parrot has only half a whorl of cochlea, but is able to imitate speceh and to whistle musical notes over a fair range, while the guinea pig, with one and a half whorls more than man, produces only squeaks and grunts.

(2) The bird has a short basilar membrane, about $\frac{1}{5}$ that of the mammal, but has numerous hair cells. These eclls are set in the bird in rows of 30 or 40 , and in the mammal in rows of 4 . If equal lengths of membrane vibrate sympathetically to the same note, then as the bird has ten times the number of hair cells stimulated as the mammal, it ought to hear the sound correspondingly louder. 'This does not appear to be so.

(3) It is rather difficult to see how, even taking differenees in tension into account, sufficient resonators could be obtained to receive the wide range of notes that it is known we do receive.

\section{Displacement Theory.}

The latest form of this theory is put forward by Sir Thomas Wrightson, an engineer. He is supported by Professor Arthur Keith, the eminent anatomist. He considers that the ear is not a physiological piano played upon by the sound waves, but a delieate spring weighing every phase of a sound wave, simple or compound, and transmitting to the brain a record of every fluctuation of pressure in the endolymph of the scala media. Every variation of pressure transmitted by the stapes to the perilymph is in tum transmitted to the membrane closing the fenestra rotunda. The cochlear system is a elosed one, in shape rather like a long drawn out, doubled over hour glass, with the stapes operating at one end. 'The only relief for the motion of displacement is at the fenestra rotunda, at the opposite cnd, whose membrane moves to and fro simultaneously with the stapes. These movenents are transmitted to the endolymph enclosed in the tube, the scala media, which ends blindly at the 
helicotrema. He believes that the hair cells and not the hasilar membrane are the sensitive organ. They pass through the meshes of the reticulate menbrane, and, aceording to Wrightson and Keith, have their upper ends fixed in the tectoria. The tectorial membrane, it will be remembered, is attached to the spiral lamina, as a nail grows out of the finger. Now, displacement of the fluid causes movement of the whole reticulate membranc. This latter produces a to-and-fro movement of the base of all the hairs, and as these hairs are fixed in the tectorial membrane, they will bend. "It would only be the simple pure tones which would give to the hairlet a pure symmetrieal harmonic motion, but by the displacement of liquid under pressure, every conecivable suceession of bendings of the innumerable hairlets ean be obtained to eonvey to the auditory nerve every impulse required to produce the pitch of each resultant and component tone" (Wrightson).

Thus, the eubic displacement of fluid is eonverted, by means of the arch of Corti, into a lincar movement of the reticulate membrane, ete. By means of the resistance of the tectoria, the linear movement is converted into the bending of the hairlets.

Such an explanation fails to account for the ability of the trained musical car to pereeive as separate entities the different sounds from an orchestra reaching it simultancously, and it does not give a very clear explanation of "tone-gaps."

To eonelude in the words of Hchmholtz: "On reviewing the whole arrangement there can be no doubt that C'orti's organ is an apparatus for receiving the vibrations of the basilar menbrane and for vibrating of itself, but our present knowledge is not sufficient to determine with accuracy the manner in which these vibrations take place."

There remains one very important matter which shoukd be considered because of its diagnostic value to the physician, viz. conduetion of sound waves by the bones of the head. It is common knowledge that sound vibrations travel more readily through a solid than through a liquid or a gascous medium. A watch. placed sufficiently far away to be inaudible, can be heard ticking if touched by a lath held between the teeth. If soncthing goes wrong with the mechanism of the ear, one wants in the first place to locate the fault. Is the external ear, the middle car or the internal ear the scat of the trouble? 'The test is usually made by placing a vibrating body, such as a tuning fork, on one of the cranial bones. If the sound is not appreciated, then the fault lies within the internal ear. Either the organ of Corti (or 
its nervous attachments) have broken down or the membrane of the fenestra rotunda is not normal. Provided the organ of Corti and its nervous attachments are intact and the round membrane is flaceid, sounds may be heard by bone eonduetion, and ordinary hearing is not impossible. The vibrations are transmitted direetly through the thiek, exeeedingly dense but elastie bony walls of the aural eavity, and produee a novement of the basilar membrane, ete. This ean only take place if the membrane of the round window is functioning properly, or if the stapes moves normally in its oval window. If the openings were to lose their elastie windows and not move to and fro with every eondensation and rarefaetion, then the eochlea would be, to all intents, a sealed eavity filled with fluid. Sueh fluid eould not oseillate; it eould be alternately eompressed and released from this extra pressure, but this slight moleeular movement eould not stimulate the hairlets.

Further, if both the stapes and round membrane were free to move, hearing in the ease of a diseased middle ear would not be so good as when only one of the pair were free. This is beeause part of the displacement of the eochlear fluid eaused by the vibrations of the surrounding bone is dissipated by moving the stapes outwards. People may hear fairly well after the stapes has beeome inmovably fixed in the fenestra ovalis. In eases where the drum of the ear has been punetured, hearing may be improved by fixation of the stapes, e.g. by applieation of a phig of eotton wool.

When sounds are eondueted to the inner ear by means of the bones of the skull, in people with normal hearing, the intensity of the sound is markedly inereased if the movement of the stapes is hindered. For example, on p. 423 of Part II. is given an experiment where a vibrating tuning-fork is plaeed on the region of the interparietal suture. When both ears are unobstrueted and normal, sound is heard equally by both. If the drum of one ear and appended ossieles are hindered from taking a full exeursion by bloeking the meatus with a finger, the sound appears most distinetly at this ear. When both ears are treated in this way, loealisation is again median. A eommon entotie phenomenon is the audibility of the pulse in an obstrueted ear. It may be due to the transmission of the pulse-ivave oseillation to the air of the middle ear-which aets as a resonator-reinforeing the vibrations and then transmitting them to the internal ear. It is more probable, however, that the beat of the earotid artery is transmitted through the parietal bone direet to the fluid of the eochlea. 


\section{CHAP'TER XX}

\section{OUTPOSTS OF THE INTELLIGENCE SERVICE}

\section{(c) DISTANCE RECEPTOR FOR LIGITT}

TIIE EYE

By W. F. Sianks, B.Se., M.B., Lecturer on Experimental Physiology in the Iniversity of Glasgow.

TuE following points in eonneetion with light are reealled to the student's memory.

(1) Refraction.

When a ray of light passes from a rare to a dense medium (or vice versa) it undergoes refraetion, i.e. it is bent towards

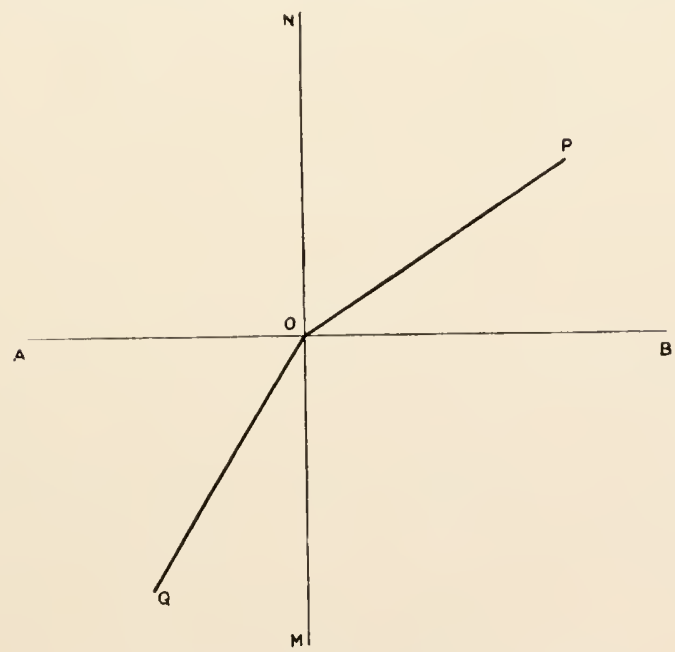

FIG. 46.--Refraction of incident ray $P O$ at interface $A B$.

(or away from) the perpendieular to the surface at the point of ineidenee. This perpendieular is ealled the normal. Snell's Law 
states that for any two media, the sine of the angle of ineidenee bears a eonstant ratio to the sine of the angle of refraction.

In Fig. $46 P O$ is the incident ray, $O Q$ the refracted ray, NOM the normal to the interfaee $A B$ between the media (the upper being the less dense). Then $\frac{\sin \hat{P O N}}{\sin \hat{Q O O M}}=$ constant. This constant is ealled the refraetive index, and is usually denoted by the letter $\mu$. The refractive index of air is taken as unity, and other refractive indices are expressed as numerical values eompared with it.

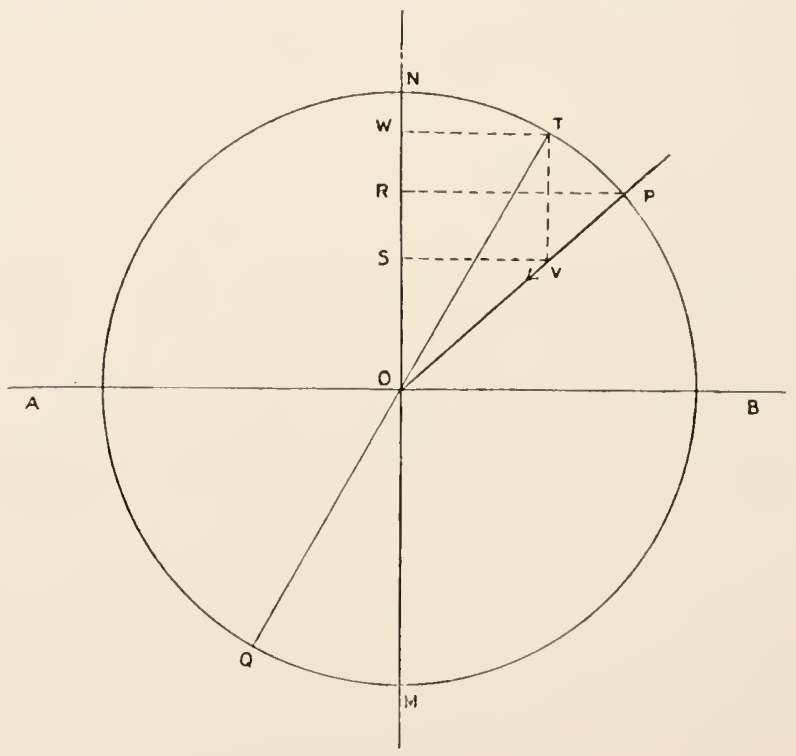

FIG. 47 .

If we are given the angle of incidenee and $\mu$, we ean easily find the direetion of the refracted ray. Let $P O$ be the incident ray. Measure $O V^{\prime}=$ unity and $O P=\mu$ (stated in the same units). With eentre $O$ and radius $O P$ deseribe a eirele. Draw $I S, P R$ perpendieular to normal NOM. Draw $I T$ parallel to $O N$. Join $T O$ and produce it to eut eirele at $Q$. Then $O Q$ is the refraeted ray.

Proof : $\quad$ Sin $P \hat{O N}=\frac{P R}{P O} . \quad \sin T \hat{O} W($ or $Q \hat{O} M)=\frac{T W}{T O}$,

that is,

$\frac{\operatorname{Sin} P \hat{O N}}{\operatorname{Sin} \hat{Q O M}}=\frac{P R}{P O} . \quad T O=\frac{P R}{T W}=\frac{P R}{V S}$.




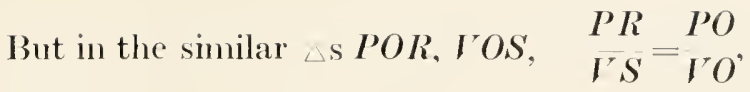
and $\frac{P O}{\Gamma O}=\mu$ by construction.

$\operatorname{Sin} P \hat{O N}$ $\therefore \quad \operatorname{Sin} Q \hat{O} M=\mu$. Henee $O Q$ is the refracted ray.

If $P O$ is perpendieular to $A B, \sin P \hat{O N}=O$. Henee $\sin Q \hat{O} M=O$, i.e. the ray is unrefracted in its passage.

But, in addition to this refraction, a part of the ineident light is reflected. The amount refleeted varies with (i) the obliquity of ineidenee, (ii) the differenee in refraetive index.

When a souree of light, e.g. a eandle, is placed near a bieonvex lens, we see very elearly two images produeed by reflection. The first is formed by the anterior convex surface and is upright, the second is formed at the posterior surface, which is concave in respeet of rays passing out of the lens into the atmosphere, and is inverted. The size of the image decreases as the eonvexity of the lens inereases. Its brightness inereases, the more obliquely the rays from the eandle strike the surface and also with increase of the refraetive index of the medium eomposing the lens.

(2) Images formed by a Convex Lens. (a) When the objeet is between $\infty$ and $2 f$ ( $f$ being the focal length), the image lies between $-f$ and $-2 f$, and is real, inverted and diminished.

(b) When the object is between $2 f$ and $f$, the image lies between $-2 f$ and $-\infty$, and is real, inverted and magnified.

(c) When the object is between $f$ and the optical eentre of the lens, the image lies between $+\infty$ and the optical eentre of the lens, and is virtual, ereet and magnified.

(3) Chromatic Aberration. When white light passes through a lens its eomponent rays are unequally refracted, the violet being

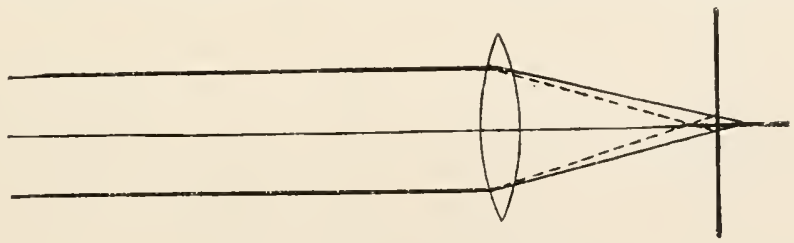

FiG. 48. Chromatic Aberration.

brought to a foeus nearer the lens than the red. If the image is reeeived on a sereen midway between these points it will appear to be surrounded by a red and violet halo. 
(4) Spherical Aberration. Rays of light passing through the peripheral part of a lens are refraeted more than those passing through the eentral part. This tends to produee distortion of the image at the periphery.

We will point out the application of these facts to the eye in due eourse.

\section{Anatomy.}

To understand the meehanism of the eye even from the purely physical standpoint, i.e. as an optieal instrument, it is neeessary to have a elear eoneeption of its strueture.

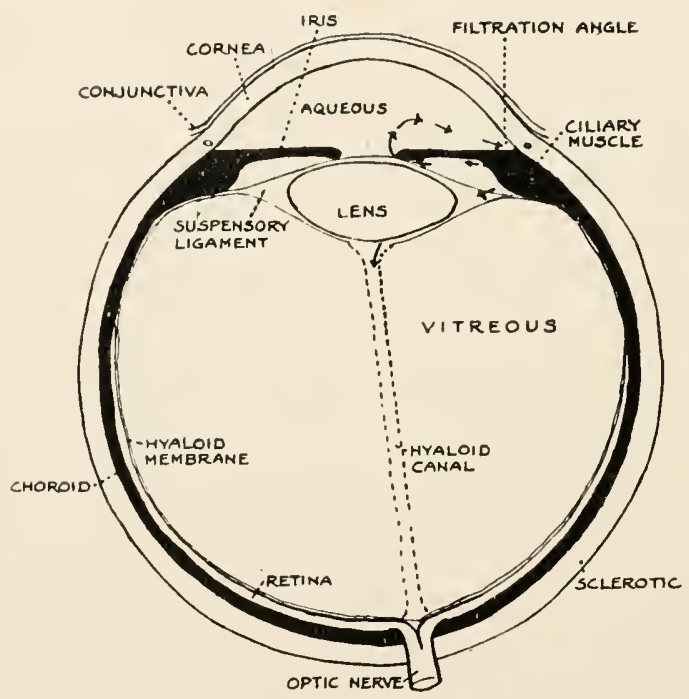

Fig. 49.-Diagrammatic section of eye.

The eyeball is a hollow sphere of dense fibrous tissue- the sclerotic. In front there is a window, the cornea, formed also of fibrous tissue, but so modified as to be transparent. Its radius of curvature is much smaller than that of the selerotie. Inside the eyeball is a seeond layer, the choroid, eonstituting the vaseular portion of the eye, and loaded with pigment. 'This last performs the funetion of the blaek lining of optieal instruments, preventing the reflection of rays in the interior. At the eorneo-selerotie junction the ehoroid eeases to be in eontaet with the wall of the eyeball, and hangs free as a eurtain-the iris. In this eurtain there is a eentral aperture, the pupil, whieh in the human subjeet is eireular. In the iris are museular fibres, a well-marked eireular set serving to diminish, and a feebly marked radial set serving 
to enlarge the pupillary opening. Thus the amount of light entering the eye ean be regulated. At the baek of the eyeball, slightly internal to and just below the antero-posterior axis, the optie nerve pierees the selerotie and ehoroid, and its fibres spread out on the inner surface of the latter to form the retina which extends forwarl almost to the eiliary body (sce below). Where the antero-posterior axis meets the retina is a small yellow area, the macula lutea, in the eentre of whieh is a depression, the fovea centralis. The maeula eonstitutes the area of distinet vision. The retina is a sensitive sereen, on which a pieture of external objects is brought to a foeus, and eorresponds to the plate of a photographie eamera. Along with the optie nerve the arteria centralis retinae enters, and its branehes radiate outwards on the inner surface of the retina. Internal to the retina is a delieate layer, the hyaloid membrane, whieh, like the ehoroid, beeomes free near the corneo-selerotic junction and splits to enelose the crystalline lens. The latter is a laminated biconvex strueture placed just behind the iris, and eentred with the pupil. Between the wall of the eyeball and the lens the hyaloid membrane is eonsiderably thiekened, and forms the suspensory ligament or Zonule of Zinn. Close to the eorneo-sclerotie junetion the ehoroid is thickened and raised in radiating ridges, the eiliary processes. To these the hyaloid membrane is firmly attached, and into them are inserted fibres of the ciliary muscle. The eiliary musele arises from the eorneo-selerotic junetion and its fibres are arranged in two sets - a radial passing baek into the eiliary proeesses and a cireular. The eiliary proeesses, plus the ciliary musele fibres, eonstitute the eiliary body. The lens, with its attaehments, separates the eyeball into an anterior ehamber filled with elear fluid, the aqueous humour, and a posterior containing a rather more jelly-like substanee, the vitreous humour. Thie anterior ehamber is divided into two eompartments by the iris, but there is free eonmunieation between them through the pupil.

\section{Refraction in the Eye.}

Let us now eonsider the passage of a ray of light through the instrument we have deseribed. We must first know the indiees of refraetion of the various media. They have been determined experimentally, and may be given approximately as follows :

$\begin{array}{lllllllll}\text { Cornea } & - & - & - & - & - & - & - & - \\ \text { Aqueous } & - & - & - & - & - & - & - & - \\ \text { Lens - } & - & - & - & - & - & - & - & - \\ \text { Vitreous - } & - & - & - & - & - & - & -133 \\ \text { - } & & -33\end{array}$


Remembering that refraction takes place only at the plane of junetion of media of different densities, we see that it will oceur at (i) the anterior surface of the cornea, (ii) the anterior surface of the lens, (iii) the posterior surfaee of the lens. At each of these surfaces the incident ray will be bent towards the central axis, and in the normal eye the result is to bring all incident rays to a foeus exactly on the retina. Thus a picture is produced.

Wc have seen that refraction is always accompanied by a certain amount of reflection, and this is the eause of the phenomenon known as Sanson's Images. If a candle is held at a short distance from one side of the eye, the observer ean distinguish the images formed by each of the refraeting surfaces. The image produeed by the eornea where the change in refractive index is from 1 to 1.33 is much brighter than the images from the lens, where the ehange is from 1.33 to 1.43 and from $1 \cdot 43$ to 1.33 . In the case of the two latter also there is a certain amount of absorption of light by the media. The images from the cornea and the anterior surfaee of lens are upright, that from the posterior surface of lens is inverted. The radii of curvature of the refraeting surfaces are respectively, 8,10 and $6 \mathrm{~mm}$. Consequently the images differ eorrespondingly in size.

The combination of the three refracting surfaces constitutes the physiological lens of the eye.

\section{Accommodation.}

Every one knows that in a photographie eamera it is neeessary to adjust the distance between plate and lens in order to focus sharply objects at varying distanees. The eye, regarded as an optieal instrument, must suffer from this disadvantage, and it is a matter of daily experience with us that near and far objects eannot be seen clearly at the same time. How does the eye overcome this diffeulty? The eycball is rigid and the lens praetically fixed. No change in the relative positions of the latter and the retina is possible. The adjustment, called accommodation, is brought about by ehanges in the lens, so that the eyeball har virtually a series of lenses of varying strength, from which it selects the one most suited to the requirements of the moment.

The lens suspended in the resting eye has not its natural shape; it is kept somewhat flattened by the tension of the capsule. If this tension can be relaxed, the lens will become more convex on account of its inherent elasticity. A mechanism for bringing this about is present. The ciliary muscle is fixed 
at the corneo-sclerotic junction, when its radial fibres eontract they drag the ciliary processes, with the adherent hyaloid membrane, forward, simultaneously the circular fibres by their contraction constrict the circle round which the suspensory liganent is attached. The result is to relax the ligament and lens capsule, and the clasticity of the lens eomes into play. The maximum alteration in radial curvature, which affects the anterior surface almost exclusively, is from $10 \mathrm{~mm}$. resting to $6 \mathrm{~mm}$. fully accom-

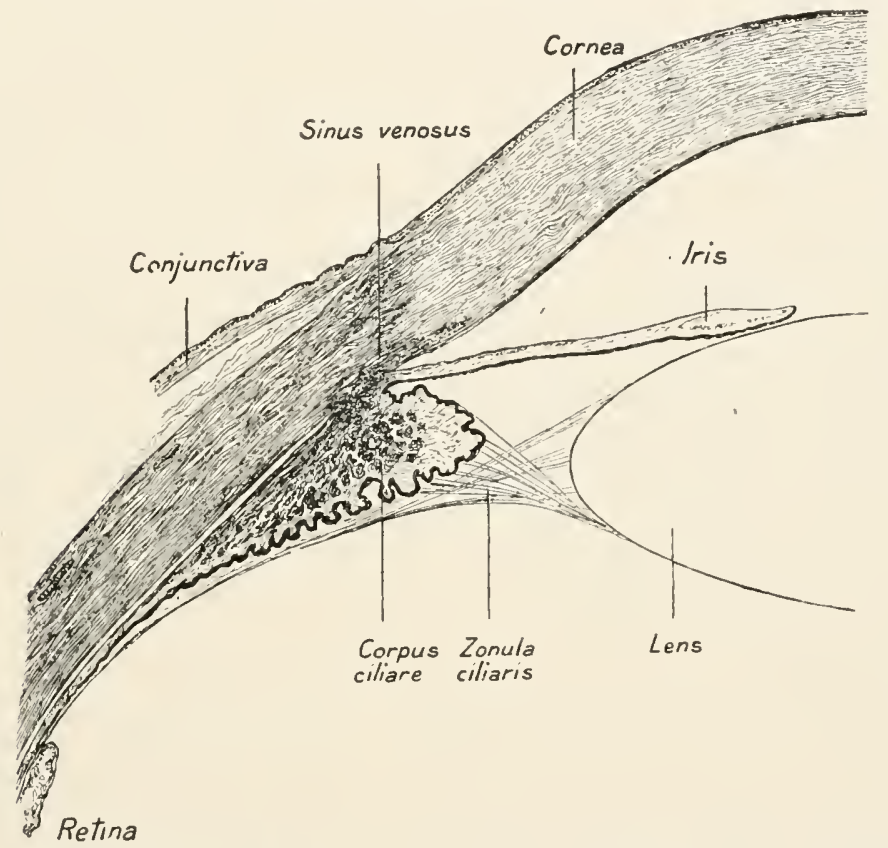

FIG. 50.- Section of anterior mart of eveball, showing structures concerned in accommodation. (After Merkel and Kallius.)

modated. The normal adult is thus enabled to see objects distinctly to within 10 or 15 cms. distance. (Note. This is the theory of accommodation at present almost universally accepted.)

\section{The Abnormal Eye.}

In the normal or emmetropic eye, parallel rays, which in practice arc those coming from a distance greater than 6 metres, are focused in the resting state. Within 6 metres accommodation begins, and it increases as the object approaches, reaching its maximum at about 10 or $15 \mathrm{cms}$. This is called the near point of vision, and the point at which accommodation begins is ealled the far point. 
The eyes of a considerable proportion of persons do not produce sharply foeused pietures within normal limits. The defect consists most eommonly in the sereen being (i) too far from the lens, or (ii) too near the lens. In the first ease the pieture in the resting eye falls in front of the retina. This is the eondition of Myopia or short sight. Divergent rays from near objeets are foeussed with little or no aeeommodation, and images are sharply defined when objeets are well within the normal near point. But parallel rays eannot be foeused unless they are artificially rendered divergent before entering the eye. This is effeeted by the use of eoneave lenses. In the seeond ease, parallel rays are foeussed behind the retina in the resting eye. This is Hypermetropia or long sight. Sueh rays ean be eonverged and brought to a focus by using aceommodation, but the near point is reached while the objeet is still eomparatively distant. To enable the eye to foeus objects near at hand we strengthen its eonverging powers by interposing a convex lens.

Presbyopia is the result of a gradual diminution of the power of aceommodation through loss of elastieity of the lens as age advanees, the retina retaining its normal position relative to the lens.

Astigmatism is the variation of the radius of eurvature of the eornea in different planes.

\section{The Dioptre.}

'The measurement of the refraction of the eye is made in terms of lenses which have their focal lengths expressed in metres. A lens of $\mathbf{1}$ metre focal length is a lens of $\mathbf{1}$ dioptre, of $\cdot \mathbf{5}$ metre, 2 dioptres, ete. Errors of refraction are thus measured by the elinieian, e.g. a hypermetropie patient who requires a lens of $\cdot 3$ metre foeal length in order to render his eye emmetropie is said to have 3 dioptres of hypermetropia.

\section{Movements of the Eyeball.}

The eycball lies at the front of the bony orbit, a eone-shaped eanal with its apex direeted backwards and piereed by the optie foramen. 'The antero-posterior or visual axis of the eye, i.e. the line passing through the eentre of the eornea and the fovea makes an angle of about $20^{\circ}$ with the long axis of the orbit. The movements of the eyeball are earried out by the extrinsie museles, which are six in number. Of these, four (ealled the reeti) originate in a eommon tendon surrounding the optie foramen, 
and pass forward to be inserted a short distance in front of the equator of the eyeball. One is placed above (R. superior), one below (R. inferior), one on the outside (R. externus) and one on the inside (R. internus). The remaining two muscles are the superior and the inferior oblique. 'The former arises from the same tendon as the reeti, and follows a eourse similar to but above the internal reetus. At the front of the orbit its tendon passes through a fibrous loop or pulley, and bends sharply baek to be inserted in the eyeball about the equator. Its line of aetion makes an angle of about $60^{\circ}$ with the visual axis. The inferior oblique arises from the inner anterior part of the orbital floor, and passes outwards and backwards to its insertion rather beyond the equator. It aets on the same line as the superior oblique.

All the movements of the eyeball are rotations round axes passing praetically through the eentre of the sphere, but it ean be proved experimentally that rotation never oecurs round the visual axis.

'The internal and external reeti rotate the eye round a vertical axis, and

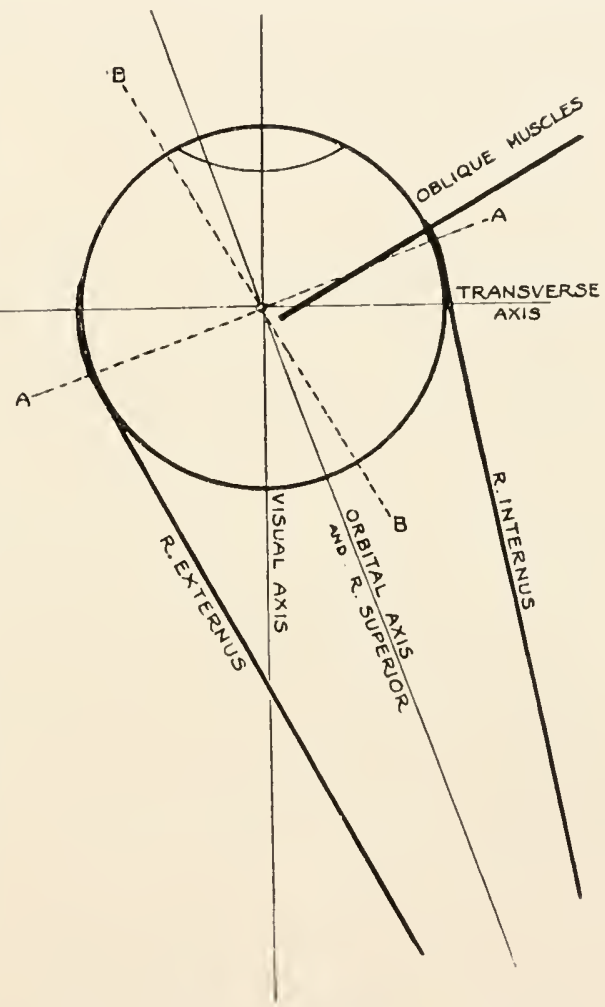

Fig. 51.-Diagram of extrinsic muscles of eye. their aetion is unaffected by the relative obliquity of the visual and orbital axes.

The reetus superior aets along the line of the orbital axis, and its foree ean be resolved into two eomponents, the one tending to rotation round a horizontal axis at right angles to the visual axis, the other tending to rotation round the visual axis itself in a countereloekwise direction (viewed from the front). In order to overeome the latter tendeney, the inferior oblique acts simultaneously. Its foree can likewise be resolved, one 
eomponent tending to rotation round the horizontal axis at right angles to the visual axis, the second component tending to rotation round the visual axis, eloekwise. The two rotations round the visual axis eounteraet each other, the remaining two aet as a eouple, and reinforce eaeh other. The result of the eombined aetion is to move the eornea vertieally upwards. For movement upwards and inwards, for instanee, the co-operation of a third musele, the internal reetus, is required. The reetus inferior and the obliquus superior eombine in an exaetly similar manner to move the eyeball downwards.

\section{Ophthalmoscopy.}

When we look at a person's eye the pupil appears perfeetly black. Nothing ean be seen of the interior beeause it is fecbly illuminated eompared with the outside world. If we eould light up the interior it would beeome visible, just as we ean see into a lighted room at night if the window is not eovered with a blind. When we try to illuminate the interior of the eye, we find that we must always interpose our head between it and the souree of light in our attempts to peer into it. 'This diffieulty is overeome by refleeting light from a mirror provided with a small eentral aperture, through which the observer ean look. This instrument is ealled an ophthalmoscope. It may be used in two ways :

A. In direct ophthalmoscopy, the mirror and the observer's eye are brought elose to the observed eye, and the refraeting media of the latter produee a virtual image, ereet and magnified, of the retina. The lens, ete., of the observer cye aet in exaetly the same way as a magnifying glass, the object being just inside the foeus.

B. In indirect ophthalmoscopy the observer holds a eonvex lens in front of the observed eye, and plaees himself farther away. The interposed lens brings the rays leaving the observed eye to a foeus between itself and the observer, who consequently sees an inverted image of the retina. This is real and magnified, the magnifieation depending on the lens used.

\section{Defects of the normal eye as an optical instrument.}

(i) 'The eye is not perfeetly eentred, i.e. the axis of the lens does not eoineide with the axis of the eornea.

(ii) The optieal axis passing through the ecntre of the eomea and the centre of the lens does not eoineide exaetly with the visual axis passing through the eentre of the eornea and the fovea eentralis. 
Ncither of these defeets interferes appreeiably with the aeeuracy of vision.

(iii) Slight degrees of astigmatism are ahmost always present.

(iv) Chromatie aberration is uneompensated optieally. The retina, however, is less sensitive to the extremes of the speetrum, consequently the slight halo of red rays foeussed behind and of violct foeused in front produces no sensation.

(v) Spherieal aberration is provided for by the iris whieh cuts off the peripheral rays. This is partieularly noticeable in aeeommodation where in order to exelude the more divergent rays the pupil contracts.

\section{Binocular Vision.}

1. The Visual Field. When one cyc is closed and the other fixed on a eertain point the whole range of objeets which ean be seen without moving the eye or the head is ealled the visual field. The angle subtended by thesc objeets is ealled the visual angle. With both eyes open and fixed we eommand a greater range. (For the mapping out of the visual field and measurement of the visual angle see pages 425 and 426 .)

2. Focusing of objects within the far point. We have seen that in order to foeus near objeets we employ aeeommodation. This is always aeeompanied by a movement of the eyeballs, causing the visual axes to eonverge from their parallel resting position towards the middle line. Sueh a movement is neeessary in order that the images in both cyes may fall on the fovea eentralis (Fig. 52). If this meehanism is defeetive, strabismus or squint results. The amount of eonvergenee varies inversely as the distance of the objeet. This may be proved as follows (Fig. 52) :

$$
\begin{gathered}
\operatorname{Sin} O \hat{O E P}=\frac{O P}{O E} \quad \sin O^{\prime} \hat{E} P^{\prime}=\begin{array}{c}
O^{\prime} P^{\prime} \\
O^{\prime} E
\end{array}=\begin{array}{c}
O P \\
O^{\prime} E
\end{array} \\
\operatorname{Sin} O \hat{E P} \quad O P \quad O^{\prime} E \\
\operatorname{Sin} O^{\prime} \hat{E} P^{\prime}
\end{gathered}=\frac{O E}{O E} \quad \begin{aligned}
& O P \\
& O O^{\prime} E
\end{aligned}
$$

Since $O \hat{E} P$ and $O^{\prime} \hat{E} P^{\prime}$ are small, $\sin O \hat{E} P=O \hat{E} P$ and $\sin O^{\prime} \hat{E} P^{\prime}$ $=O^{\prime} \hat{E} P^{\prime}$.

Henec

$$
\frac{\widehat{O E P}}{O^{\prime} \hat{E} P^{\prime}}=\frac{O^{\prime} E}{O E}
$$

'The power of eonvergence is rather less than that of accommodation, for we ean foeus an object with one cye at a slightly shorter distanee than when we use both eyes. 
It is only in the emmetropic eye that convergence and aeeommodation eorrespond exaetly in amount. A hypermetropie person viewing a near object may require to use, say 4 dioptres of aecommodation, whereas an emmetropie person uses only 2 dioptres, but both employ the same amount of eonvergenee. Similarly an emmetrope may foeus a near objeet, and if eoneave lenses are plaeed in front of his eyes he ean eontinue to see the objeet plainly by inereasing his aceommodation suffieiently to neutralise their effeet. The objeet still remains at the same distance, i.e. the eonvergenee does not alter. Henee we see that aeeommodation and eonvergence are to some extent independent.

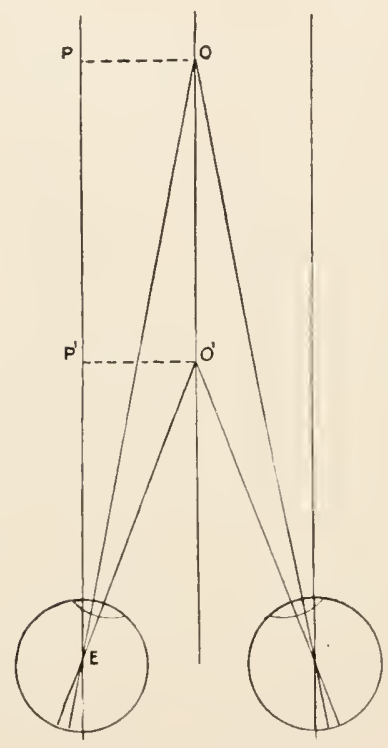

FIG. 52.-Convergence.

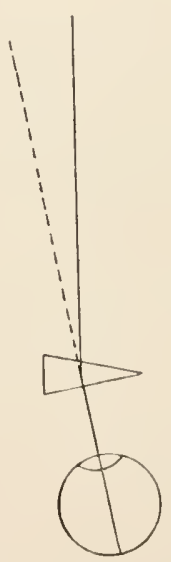

FIG. 53.-Artificial divergence of visual axes.

3. Divergence. In normal eireumstanees the visual axes never diverge, for they are in parallel adjustment for objeets at infinity. Divergenee ean however be brought about artifieially. Thus if we interpose prisms to render the rays divergent we ean produce a eorresponding divergenee of the visual axes.

4. Visual Judgments. On aceount of the distance between the eyes, objeets are viewed from a slightly different angle by eaeh eye. This is readily demonstrated by looking at an objeet first with one eye and then with the other. It is partieularly well brought out by two objeets almost or completely in alignment, and the phenomenon persists at long distances. Each retina thus 
receives a slightly different picture, and we are furnished with a most important means of judging solidity and distance. Objects scen with one cyc only have a very flat appcarance. Shadows hclp matcrially in conveying impressions of solidity, and thcir significance may be illustrated in the interpretation of acroplane photographs. In such photographs taken during the War there were numerous marks which might have either a positive or a negative solidity, i.e. they might have been either projections above the ground, such as machinc-gun emplacements, or depressions, such as shell holes. This could only be determined by the shadows cast, and the direction of the sun's rays was always marked on such photographs. Thus $A$ is a projection and $B$ a depression.

In judging very short distances, two eyes are an enormous advantagc. 'Try to thread a needle with one cyc closed. At rather longer distances this may be demonstrated by looking at a wall between which and the observer an object, such as the wirc of an electric

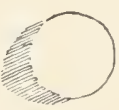

A FIG, 5t. -Shadows. lamp, is suspended. Using one cyc only and avoiding looking at the point of attachment to the ceiling we will judge its distance from the wall very imperfectly, but with both cyes we can make an accurate estimation.

At long distances numerous extcrnal factors come into play. Perspective, light and shade and atmospheric conditions are of importance. Thus "visibility" may be good or bad, and will influence our judgments. At sca, where the surface is perfectly flat and the gradations of illumination change uniformly with distance, the untrained eye commits the grossest errors. The proximity of an object of known size frequently supplies a scale against which to measure the size and consequently the distance of unknown distant objects. 'The faculty of judging distances is poorly developed in the avcrage man. A trained soldicr or a big game shot can make incomparably more accurate estimations of distances for rifle fire than the novice. The same thing occurs with the cxpert golfer for certain distances.

5. The Stereoscope. The combination of two slightly dissimilar picturcs to form an apparently solid object is illustrated by the stereoscope. This instrument consists of two prisms or half lenses placed, with the thin edgc inwards, about the samc distance apart as the eycs. The dissimilar pictures $P_{1}$ and $P_{2}$ are fixed one in front of each lens, and a median screen cuts off each 
opposite pieture. By means of this apparatus we obtain a single picture in the most pronounced relief, and situated apparently at $P$.

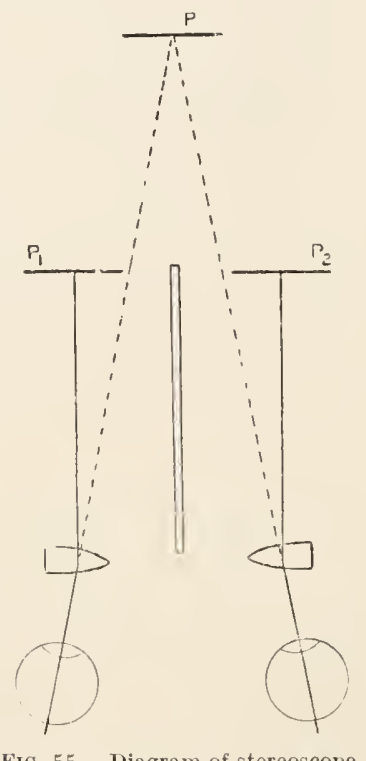

FIG. 55.-Diagram of stereoscope.

We may summarise the advantages of binoeular vision as follows :

(i) The visual field is inereased.

(ii) We reecive impressions of solidity.

(iii) We have a most important means of judging distances

(iv) The loss of one eye does not reduee us to blindness 


\section{SECTION IV.: TRANSPORT.}

\section{CHAP'TER XXI}

\section{THE BLOOD}

\section{INLAND TRANSPORT SERVICE}

\footnotetext{
"If they flourish not, a kingdom may have good limmes, but will have empty veines and nourish little."

BACON.
}

WE have seen reason to consider the animal body as a country eontaining numerous towns or cell-eommunities, each busily engaged on its speeifie staple industry and conneeted with one another and with the seat of government by an extremely effieient means of communication - the nervous system. Sueh a country, on aecount of its complex nature, must have a system of transport. Raw materials from outside must be brought into the eountry and some means must exist for sorting out the imports and forwarding the suitable ones to the appropriate cell-communities, ete. It is eonvenient to earry still further this simile of a country.

It is obvious that some imports may arrive from overseas ready for use and have only to be handed to the distributors for transmission to the eonsumer. Others again have to undergo some change before they ean be transported inland. That is, there are two classes of raw material arriving at the same port, viz. : gas and liquid-solid food. These are handled by different gangs of labourers. The oxygen is sent direetly to the inland transport serviee, while the food material is sent to a series of factories where it undergoes partial manufacture and is repacked in smaller containers, before being handed to the same inland transport serviee as the oxygen. Just so, iron ore may be shipped to the Clyde, from whieh it passes through a series of factories, in whieh it is partially purified, smelted, ete., and then sent as pig-iron, say to Sheffield, for final treatment, before being distri- 
buted in a useful form over the eountry. There are, therefore, two forms of transport which we may term external and internal. As all material has finally to be carried by the inland transport service and as the amount of traffic on this system to some extent controls the rate of importation, it will be convenient to direct attention to it in the first place.

\section{Inland Transport-The Blood.}

The blood has been called the liquid tissue of the body. On two counts this is a misnomer. Firstly, it tends to detract from the liquidity of the tissues in general. Further, blood cannot rightly be considered a tissue at all. No doubt a very pretty picture could be drawn of blood and its containing membranes as a tissue, clotting, as other tissues clot, on death, but when the facts are examincd they do not bear out such an idea. The evidence too, culled from comparative studies of the development of a circulatory system, is all at variance with the liquid tissue theory.

\section{Development.}

Much may be learned from a study of the evolution of any system. Matcrial exists for such a study in Comparative Physiology.

(a) Uniccllular organisms require no circulatory system. Their imports go direct to the sole factory of the place. They may be landed at any part of the coast and are at once aeted on. What is suitable is accepted, the residue is rejected or left untouched. Examination of a unicellular animal leads to the conclusion that the cell contents are in a state of constant motion. Water, every now and then, is engulfed, passes more or less directly through the organism, and is excreted, carrying with it the by-products of cell activity.

(b) Some invertebrates have an open coelomic system. Their more complex structure neeessitates the production of a current of fluid so that material may reach the inner cells. That is, some of the water in which the animal lives is passed by means of eanals to the different parts of the body. The fluid is kept in circulation by the rhythmic contractions of whip-like processes ealled cilia. The ciliary waves force the water through the tubes into the laeunae of the tissues. Such a system is difficult to control. It is dependent on the nature of the bathing medium. It carries the possibility of constant ehanges in the salt content of the cells of the animal. Any change in the environment will be passed on 
to the coclomic fluid and at once reflected in the ecll. It demands constant adaptation on the part of the organism, and thus it is not economical (cf. our systcm of canals).

(c) Higher invertebrates and the vertcbrate amphioxus have a closed system in which the fluid passes through tubes capable of rhythmic contractions.

(d) The vertebrates have a closed vascular system with the advantages of ease of control and freedom from constant adaptation. It is the most economic system of transport known.

When the sea animals crawled on to land and became breathers of air, they included a certain proportion of the sea-water in their vessels. By the alteration in surface tension caused by the exchange of a protoplasm-water interface for a protoplasm-air interface their open coelomic systcm automatically closed (cf. camcls' hair brush expcriment, p. 403).

'The vertebrate has, therefore, a fluid in its vessels having a composition similar to that of the sea from which originally it came (sec salts of plasma, p. 239). Some arose from a tropical sea and therefore this included fluid was warm. Others again did not attain to this. We have, therefore, warm and cold blooded animals (Regulation of temperature, Chap. XXXI.). This is a very pretty theory. It cannot be considered as proved any more than the hypothesis of evolution, but in the same sense both fit in with certain facts.

\section{Function.}

(a) The blood-stream conveys food including oxygen to all parts of the organism.

(b) It removes the wastc products of activity including carbondioxide, which would paralyse function if allowed to accumulate.

(c) The carriage of chemical substances (hormones) from the organs in which they are produced in order to influence the activity of other organs may be considered as the co-ordinative action of the circulation.

(d) The movement of blood aids in the regulation of the temperature of the body (Chap. XXXI.).

(e) It plays a very important part in the defence of the organism against parasites, etc.

( $f)$ The preservation of the $\mathrm{H}$-ion concentration of the body is principally a function of the circulating fluid (Chap. XXX.).

(g) It maintains the water and salt content of the body at a certain level. 


\section{Composition.}

Sinee the function of the blood is to aet as eommon nutritive medium to all the parts of the body, it has to eonvey food material from the digestive organs and oxygen from the lungs to the tissues. From these, it reeeives in exehange their waste products, viz., results of nitrogenous metabolism, $\mathrm{CO}_{2}$ and $\mathrm{H}_{2} \mathrm{O}$, and earries them away to the exeretory organs, kidneys, lungs, skin, ete., by whieh they are eliminated. It is therefore evident that the composition of the blood must vary from time to time and from place to place, aceording to the activity and the function of the organ whieh it is traversing. The eells of the body are adjusted to respond to very minute ehanges in the composition of the blood and, therefore, changes are kept within infinitesimal limits.

The term blood or whole blood is usually applied to the fluid content of the vaseular system, i.e. to the fluid plus formed elements.

\section{Fluid or Plasma.}

\section{(a) Physical Characters.}

(i) Colour, light straw.

(ii) Opacity, practically transparent.

(iii) Specific Gravity, about 1030. The speeifie gravity is lowered after a meal beeause of the dilution of the plasma by ingested water. Conversely, exereise and profuse perspiration eause a slight inerease in the speeifie gravity on aeeount of the loss of water (see specifie gravity of blood, p. 277). Variation in activity will therefore produce a diurnal variation - a deerease during the day and an inerease during rest at night. The night worker, of eourse, has this reversed. It varies greatly in individuals so that a figure whieh is normal for one person may be pathologieal for another.

(iv) Viscosity. At body témperature $\left(37^{\circ} \mathrm{C}\right.$.) plasma has a viseosity about twice that of distilled water, i.e. 1·7-2.09. Salt solutions have almost the same viseosity as water. This faetor is due to the emulsoid eolloids present (q.v.), one of whieh by forming a gel under certain eonditions may produee so great an inerease in viseosity that the flow of plasma may be entirely stopped. The plasma is then said to clot (see fibrinogen and also viseosity of blood).

(v) Reaction. Plasma turns red litmus blue and therefore has an $\mathrm{H}$-ion coneentration under $\mathbf{1 0}^{-7}$. It is aeid to phenolphthalein and therefore has an $\mathbf{H}$-ion eoneentration greater than $10^{-8}$. Exaet 
determinations have shown that the $p H$ of plasma is $\boldsymbol{7} \cdot 4$, i.e. just on the alkaline side of neutral. This alkalinity is due to the presenee of sodium biearbonate (see below).

(vi) Osmotic Pressure. The osmotie pressure of plasma as taken by an ordinary osmometer with a semi-permeable membrane or by the depression of the freezing point is almost the same as that exhibited by a 0.9 per eent. solution of sodium ehloride. It varies with the diet and with the amount of fluid ingested. If the kidneys are not funetioning properly so that the produets of metabolism are not eliminated with suffieient rapidity the osmotie pressure will rise.

The student eannot guard too earefully against the errors of eonsidering that $(a)$ the osmotie pressure of plasma is due to the presenee of 0.9 per eent. $\mathrm{NaCl}$ in it and $(b)$ that the figure given even approximates to the proper value of the osmotie pressure in the blood vessels. These vessels are permeable to salts in solution, and, therefore, the true osmotie pressure of plasma must be due not to eleetrolytes but to eolloids (see below).

(vii) Refractive Index (see p. 216). The refraetive index of plasma depends primarily on the amount and nature of the proteins present. Its variations are governed by praetieally the same faetors as are responsible for the variations in speeifie gravity.

\section{(b) Components. (i) Colloids.}

The major eolloidal eonstituents of plasma are protein in ehemieal nature. These proteins are :
(a). Albumin
$(\beta)$. Globulin
- $2.5 \%$ circa.
$(\gamma)$. Fibrillogen
$-\quad 3 \cdot 8 \%, \%$
$-\quad 0 \cdot 15-0 \cdot 6 \%$

(a) Albumin, probably a mixture of three albumins. At least it is possible by eareful heating to diseover three separate eoagulation temperatures.

$(\beta)$ Globulin is similarly a mixture of two or more globulins. Globulins are insoluble in distilled water but soluble in dilute salt solutions. They therefore require to have a eertain eoneentration of eleetrolytes present if they are to remain in solution. They may be partially separated from albumin by dialysis. When the salt eontents of plasma is foreed below a eoneentration of about 0.2 per eent., the globulins are almost eompletely preeipitated. In the blood stream they funetion to a great extent as regulators of the amount of $\mathrm{NaCl}$ present. It is of importanee that this fact 
be thoroughly grasped. Where the amount of globulin in the blood is increased, the chloride content increases, e.g. in pneumonia. In patients with this infection, as well as in cases of chronic nephritis and syphilis, the total protcin content of plasma is decreased and the globulin content increased both absolutely and rclatively. In mild infections and in chronic septic conditions the total amount of protein prescnt remains normal while the amount of globulin and of chlorides shows a marked increasc. $\mathrm{NaCl}$ held by globulin acts as if adsorbed, i.e. cxerts no osmotic pressure. Globulin is precipitated by an increase in hydrogen ions. It is specially sensitive to $\mathrm{CO}_{2}$.

$(\gamma)$ Fibrinogen, a globulin.

The osmotic pressure in the vessels is due to proteins. They are also responsible for the viscosity of blood. The defibrination of blood lowers its viscosity to very little greater than that of water. After cxtensive bleeding, water pours into the vessels from the tissues through the lymph, and the specific gravity, viscosity, etc., drop. The blood ceases to be an efficient carrier. Bayliss found that the injection of a non-toxic emulsoid colloid would restore normal conditions for sufficiently long a time as would enable the cell-factories, especially the liver, to manufacture new blood proteins from the amino acids in the blood. The most efficient sol, he found, was a.solution of gum arabic in Ringer's solution. The story of this discovery as told in his monograph is one of the most interesting side-lights on the medicoscientific work of the War.

\section{Clotting.}

The main use of fibrinogen lies, not in its viscosity or in its osmotic pressure, but in its property of changing from a sol into a gel. The clotting of plasma prevents the loss of blood and keeps the blood channel free from any angularities. The evolution of the knowledge of the process of clot formation has been very slow and even now the physico-chemical reactions involved are anything but well understood.

Mammalian plasma, if left standing in a tube exposed to the air, clots to a jelly in two to ten minutes. The gel has the same volume as the sol, and no heat is evolved in the process. This is a process common to most cmulsoid colloids. In about half an hour the clot contracts and expresses a clear straw-yellow liquid, the serum.

$$
\text { i.e. } \text { Plasma }=\text { Clot }+ \text { Serum. }
$$


This proeess whereby the fluid eontent of the gel is deereased is common to gels and is ealled symeresis.

\section{Historical.}

Observers at first thought that living tissue had a restraining influenee. They noticed that in the living tissue the blood did not clot. Lister formed a living test-tube by ligature of the aorta and showed that the blood did not elot until a foreign body sueh as glass was introdueed.

This demonstrated that elotting was not due to (1) removal from living vessels, (2) stoppage of the cireulation, (3) eooling or (4) to eontaet with air. This latter faet has been eonfirmed by the observation that blood elots as readily in a vacuum as in air. Further, air embolism and eaisson disease do not lead to intravaseular elotting. Nor is elot formation due to cooling. As a matter of faet reduetion of temperature lengthens the time taken to produee a clot and, if the plasma is eooled suffieiently, may prevent it altogether.

The elassieal work on blood elotting was performed by Andrew Buehanan, Professor of Physiology at Glasgow, who gave explanations of the proeess to the Glasgow Philosophieal Soeiety, in Mareh, 1844, and February, 1845. Using hydroeele fluid from the tuniea vaginalis of a horse he showed that it would elot if to it were added a drop or two of blood, of elot washings, of serum or of tissue juiee. He eompared the proeess to the eurdling of milk by remnin and eonsidered that the white eorpuseles or leueoeytes were the aetive agent.

In 1861, Sehmidt, who had devoted some thirty years to the work, proved that :

(i) Fibrinogen, the precursor of the elot, was a globulin in the plasma.

(ii) There was a fibrin-former in plasma, in serum and in elot washings.

He also showed that this fibrin-former (now ealled thrombin) did not exist as such in the blood but only appeared after treatment with a fibrin-ferment or -kinase. That is, the elotting seheme as lie left it appears as follows (modern names):

$$
\begin{gathered}
\text { Fibrinogen + Thrombin }=\text { Fibrin (or Clot) } \\
\uparrow \\
\text { Pro-thrombin + "Thrombokinase." }
\end{gathered}
$$

Arthus and Pagès in 1890 showed the need of ealeium in the elotting proeess. 
Hammersten eonfirmed this, and found that the caleium ions aet on the pro-thrombin produeing aetive thrombin. Later work explains the aetion of ealeium ions here and in milk eurdling as being due to the non-hydrophilie property of ealeium eompounds.

This still does not explain why blood does not elot in the vessels, so physiologists had to postulate the presenee of some substanee in the blood whieh would prevent the ealeium ions from aetivating the pro-thrombin. This hypothetieal substanee they ealled antipro-thrombin. In all cells there is a large or small quantity of thrombokinase, whieh is the trigger setting off the whole elotting proeess. When a vessel is ruptured and blood eomes into eontaet with the tissues or into eontaet with disintegrating blood-eells, it takes from them thrombokinase whieh neutralises the inhibitory aetion of the anti-pro-thrombin and so allows the caleium to aet. It is now known that this substanee from the tissues is not a ferment or kinase. Some people, therefore, prefer to eall it thromboplastin.

The seheme now stands as follows :

(2) (Clot) Fibrin (synerised gel) + Serum

(Clot) Fibrin enmeshing serum
Fibrinogen (sol) + Thrombin (a proteose).

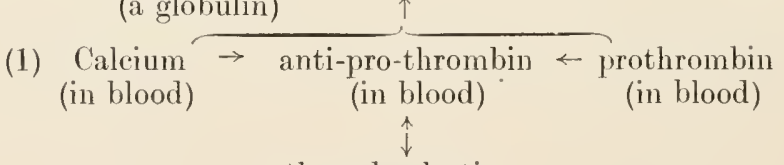

thromboplastin

(from tissues, etc.).

Free ealeium ions are neeessary for the first step, but apparently not for the seeond.

It has been known for long that thromboplastin is a phosphatide, a body like leeithin, eontaining nitrogen, phosphorus and a fatty aeid. That this substanee is kephalin has been proved by Howell. Pure kephalin has not been prepared in suffieient quantity to allow of eomplete analysis but its moleeule probably eonsists of :

$$
\begin{array}{cl}
\text { Two fatty acids } & \begin{array}{l}
\text { Stearic (saturated) } \\
\text { Linolic (unsaturated) }
\end{array} \\
+ & \begin{array}{ll}
\mathrm{NH}_{2}-\mathrm{CH}_{2}-\mathrm{CH}_{2}-\mathrm{OH} \\
\text { an amino alcohol }
\end{array} \\
+ & \text { amino ethyl alcohol) }, \\
\text { a glycero-phosphoric acid. }
\end{array}
$$


It is optically active, rotating the plane of polariscd light to the right.

The main point of interest for us apart from its presence in all tissues is its colloidal character. It is an extremely hydrophilic emulsoid with a strong negative eharge. On exposurc to air it readily absorbs oxygen (a property dependent on its unsaturated fatty acid) and undergoes partial deeomposition.

The addition of calcium ions to a solution of kephalin causes it to form a calcium soap with vcry little water-holding power (see p. 82). Calcium seems also to combine readily with the products of decomposition mentioned above.

One must not consider for a moment that the last word on clotting has been spoken. The subject has reently been investigated from the standpoint of colloidal physics. 'The scheme given above does not aceount for the experiment of Lord Lister already quoted. Kephalin does not seem to be necessary. Freund noted that blood would not clot if it came into contact with a vaselined surfaee. Placed with due precautions on a nasturtium leaf, which is not wetted by water, blood does not clot. Clotting is induced by contaet with a water- (i.e. plasma) wettable surface. This is normally afforded by colloidal kephalin, but may be produced artificially by the introduction of powdered glass, etc., or even by bubbling $\mathrm{CO}_{2}$ gas through the plasma.

Tait and his colleagues have shown that the precursors of thrombin are the thigmocytes of the blood. These thigmoeytes or platelets are spindle-shaped cells which have a strong phagocytic aetion. In place of prothrombin we may write thigmocyte. Now in ealeium-free plasma the thigmocytes may come in contact with a surface, but will not stick. The introduction of an ionisable calcium salt causes them to adhere to the surface, and, on account of the extrcme lowering of surface tension, the covering membrane of the thigmocyte is ruptured, i.e. it undergoes eytolysis and the cytoplasm is sent into the blood stream. Thrombin comes from this cytoplasm.

To summarise: (a) Shedding of blood sets free kephalin from the cells of the blood or of the tissues, $(b)$ this forms a surface on which, in the presence of ionised calcium, the thigmoeytes may spread themselves and rupture, setting free thrombin, which eauses the formation of fibrin-gel from fibrinogen sol.

It is worthy of note that kcphalin partieles of a size just visible under an oil-immersion mieroscope are eapable of producing intravascular clotting when injected into the blood stream, while 
powdered glass or quartz particles of apparently the same size are without effect. Coarser glass suspensions are necessary to produce the effect. Some other factor in addition to surface must come into play or kephalin particles must have a wrinkled surface.

Birds' blood is peculiar in that, if drawn with due care to prevent contact with the tissues it may be kept liquid for a long time. The avian thigmocytes even under normal conditions will not adhere to glass surfaces. The addition of the slightest trace of tissue extract (kephalin) causes immediate and extensive clotting.

This gel formation has been studicd ultramicroscopically. 'The first sign of clotting is the appearance of blood platelets or thigmocytes, and from them as centres liquid crystals of fibrin crystallise out, forming a feltwork of long elastic threads.

Anti-coagulants. Certain substances by preventing the calcium from acting on the thigmocytes, i.e. on pro-thrombin, prevent clotting. One of these, called heparin by Howell, arises in the liver. Other substances are really anti-thrombins. Hirudin, a proteose prepared from the buceal glands of the medicinal leech bclongs to this class and is injected in blood-pressure and similar expcriments to prevent the formation of clots in the cannulae. Certain salts act on the calcium. For example, oxalates, fluorides, ctc., form insoluble calcium salts, citrates form a double salt in which $\mathbf{C a}$ is not a free ion. Differing from all the above anticoagulants which act whether injected into the blood stream or added to shed blood, are those which prevent elotting only when injected. Snake venom in amounts as small as $\mathbf{0} 00001$ gram per Kg. suffices. Commercial peptone (mixture of proteoses and peptones) injected into the circulation in the proportion of $0 \cdot 3$ gram per $\mathrm{kg}$. produces a non-coagulable blood for an hour or so. This class of coagulant seems to act by stimulating the liver to -manufacture heparin. Peptonisation and the injection of venom may cause some alteration in the state of the thigmocytes. This has not bcen investigated. Of course, plasma or blood from which the fibrinogen or fibrin has been removed will not clot.

Coagulants. Extracts of organs rich in kephalin, e.g. thymus, testes, lymph glands, produce intravascular clotting.

Similarly, certain snake venoms which contain large quantitics of thrombin causc clotting of the blood in the vessels and rapid death.

\section{Components. (ii) Crystalloids.}

There is nothing more remarkable than the maintenance of a fairly constant concentration of crystalloids in plasma, under 
the most varied conditions. As we have seen, this is duc in great part to the salt- and water-holding power of the colloidal constituents, especially of the globulins. Bunge, in his handbook of physiological and pathological chemistry (1889), suggested that as the notochord and branchial clefts were legaeies from forcbears who had lived in the sea, the high sodium chloride content of mammalian blood might also be an heirloom from marine ancestors. No doubt the circulation fluid of marinc animals with an open coelomie system is sea water. It is held by many observers, that when the ancestral form of vertebrates acquired a closed form of circulatory systen, the fluid shut in was sea water. Analysis shows that while the coneentrations of erystalloids in plasma and in sea water arc not similar, yet there is a remarkable rescmblance in the proportions of the main salts present in both.

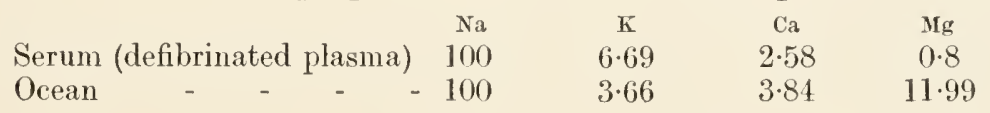

TABLE XXXII.

Non-clotting Blood.

\begin{tabular}{|c|c|c|}
\hline Nature of Plasma. & Reason. & To cause Clotting. \\
\hline $\begin{array}{l}\text { Whipped } \\
\text { (Defibrinated) }\end{array}$ & $\begin{array}{l}\text { Fibrin removed as soon as } \\
\text { formed by whipping with } \\
\text { a bunch of twigs. }\end{array}$ & $\begin{array}{l}\text { Add fibrinogen to whip- } \\
\text { ped plasma (or } \\
\text { blood). }\end{array}$ \\
\hline $\begin{array}{l}\text { Salted. } \\
\frac{1}{2} \text { sat. with } \\
(\mathrm{NH})_{2} \mathrm{SO}_{4} \text {. }\end{array}$ & Fibrinogen precipitated. & $\begin{array}{l}\text { Dilute with water and } \\
\text { so reduce concentra- } \\
\text { tion of electrolytes. }\end{array}$ \\
\hline Cooled to $0^{\circ} \mathrm{C}$. & $\begin{array}{l}\text { Cooling slows the physico- } \\
\text { chemical changes which } \\
\text { are optimum at about } \\
40^{\circ} \mathrm{C} \text {. }\end{array}$ & Warm. \\
\hline $\begin{array}{l}\text { Oxalated. } \\
\text { Addition of } \\
\text { soluble oxalate. }\end{array}$ & Ppts. calcium. & $\begin{array}{l}\text { Add soluble calcium } \\
\text { salt. }\end{array}$ \\
\hline Citrated. & De-ionises Ca. & Add soluble calcium salt. \\
\hline Hirudinised. & Combines with thrombin. & Add thrombin. \\
\hline Peptonised. & $\begin{array}{l}\text { Stimulates production of } \\
\text { anti-prothrombin. }\end{array}$ & $\begin{array}{l}\text { Dilute to decrease con- } \\
\text { centration of anti-pro- } \\
\text { thrombin, or add tis- } \\
\text { sue extract or kephalin } \\
\text { or pass in } \mathrm{CO}_{2} \text { gas. }\end{array}$ \\
\hline
\end{tabular}

The similarity in proportion is not very striking because the figures given are from analysis of the ocean as it is to-day. What 
we should have is the analysis of the occan in prevertebrate days. Not only has the concentration of the salts of the sea undergone change, but alterations have taken place in the proportion of its constituents. Sodium and magnesium have increased in concentration and are still increasing. Material lixiviated from river beds, etc., is rich in those salts.

On the other hand, potassium and calcium have decreased. The formation of soil leads to the abstraction of potassium from the river water. Water cvaporated from the ocean contains potassium in not ineonsiderable amounts. 'The rain falling in the region of Caen is responsible for an annual increment to the land of 1.23 tons of potassium per square mile. Rivers discharge more calcium into the occan than they do of sodium, magnesium or potassium and yet the concentration of this element appears to be fairly steady. The cause for this lies in the formation of rock-beds of gypsum $\left(\mathrm{CaSO}_{4}\right)$ and limestone $\left(\mathrm{CaCO}_{3}\right)$ and in the formation of calcareous skcleta $\left(\mathrm{CaHPO}_{4}\right)$. From the study of fossil seas and of lakes surrounded by pre-Cambrian formations as well as from other geological considerations it has been decided that the ocean of Cambrian days had a ratio of salts somewhat as follows.

\begin{tabular}{|c|c|c|c|c|c|c|c|}
\hline & & & & $\mathrm{Na}$ & $\mathbf{K}$ & $\mathrm{Ca}$ & $\mathrm{Mg}$ \\
\hline Present day & - & - & - & 100 & $3 \cdot 6$ & $3 \cdot 9$ & $11 \cdot 9$ \\
\hline Cambrian & - & - & - & 100 & $6 \cdot 0$ & $3 \cdot 0$ & $2 \cdot 0$ \\
\hline Serum - & - & - & - & 100 & $6 \cdot 6$ & $2 \cdot 5$ & $0 \cdot 8$ \\
\hline
\end{tabular}

'The following table (from Macallum) shows the evolution of plasma through a series of animals.

\section{TABLE XXXIII.}

A. Marine Invertebrates.

\begin{tabular}{lccccc} 
& \multicolumn{2}{c}{ Na } & K & Ca & Mg \\
Ocean - - - & - & 100 & $3 \cdot 61$ & $3 \cdot 84$ & $11 \cdot 99$ \\
Limulus polyphemus & - & 100 & $5 \cdot 30$ & $3 \cdot 83$ & $11 \cdot 67$ \\
Aurelia flairdula - & - & 100 & $5 \cdot 18$ & $4 \cdot 13$ & $11 \cdot 43$
\end{tabular}

B. Elasmobranchs, Teleosts, Mammals.

\begin{tabular}{|c|c|c|c|c|c|c|c|c|}
\hline Dog-fish & - & - & - & - & 100 & $4 \cdot 61$ & $2 \cdot 71$ & $2 \cdot 46$ \\
\hline Pollock & - & - & - & - & 100 & $4 \cdot 33$ & $3 \cdot 10$ & $1 \cdot 46$ \\
\hline Dog - & - & - & - & - & 100 & $6 \cdot 86$ & $2 \cdot 52$ & 0.81 \\
\hline Man & - & - & - & . & 100 & $9 \cdot 22$ & $3 \cdot 37$ & 0.76 \\
\hline
\end{tabular}

The salt content of the plasma is regulated by the kidneys. It is interesting to note that while the blood is Cambrian the tissues are decidedly pre-Cambrian in their salt content, e.g. Muscle. $\mathrm{Na}=100, \mathrm{~K}=400, \mathrm{Ca}=9 \cdot 3, \mathrm{Mg}=\mathbf{2 6} \cdot 4$. This may be in part 
aecounted for by the adsorption of salts by the protoplasmic eolloids. Of these salts one of the most important is sodium biearbonate on aeeount of its power of neutralising acid. 'This has been termed its "buffer" value - a term which, although faulty, has erept into the writings of physiologists and clinicians and seems firmly ensconeed there beeause it is handy. As Prof. Bayliss points out, a railway buffer absorbs shock but not the engine, while $\mathrm{NaHCO}_{3}$ absorbs the aeid.

The amount of $\mathrm{NaHCO}_{3}$ present in plasma has been ealled the alkali reserve of the body. How does it act? The addition of aeid to biearbonate may be represented by the equation

$$
\mathrm{NaHCO}_{3}+\mathrm{HA}=\mathrm{NaA}+\mathrm{H}_{2} \mathrm{O}+\mathrm{CO}_{2} \text {. }
$$

Until nearly all the biearbonate has becn acted on by the acid, no increase in aeidity ean be deteeted. This is a meehanism of great value to the organism. Aeids are eonstantly being produeed in the tissues, especially in musele. Unless the organism had an alkali reserve, the eoneentration of hydrogen ions woukd so increase after museular exereise, for instance, that a serious derangement of metabolism would ensue (see Preservation of Neutrality, (hap. XXX.).

\section{Formed Elements.}

The formed elements borne by the plasma have a volume of half the plasma and weigh about the same amount.

$\begin{array}{llccc} & & & \text { Plasma. } & \text { corpuseles. } \\ \text { Volume } & - & - & 2 & 1 \\ \text { Weight } & - & - & 3 & 2\end{array}$

This may be determined by the haematocrite (see p. 422) or by an ingenious method due to Stewart. He made use of the fact that the presenee of corpuscles reduees the eleetrical conduetivity of plasma in proportion to their number.

They are of two kinds, viz. : the leueoeytes and erythroeytes. The former have been discussed in Chaps. XII. and XV. They play a further part in stopping bleeding from a wound. As we saw (p. 237) the thigmoeytes (altered leueoeytes) on undergoing eytolysis set free thrombin. The blood eontributes in a seeond way towards the arrest of haemorrhage, viz. : by the agglutination of certain eells to form a plug elosing the opening. The primary event is the loeal adhesion of the thigmoeytes to the edge of the wound. These altered eells aequire stiekiness and any other formed element coming into contaet with them adheres. In this way a plug is formed. 
The erythrocytes are the carriers, submerged barges into whieh are paeked the oxygen for the tissues and the carbon dioxide from the tissues.

Number. In health, a man has about $5,000,000$ of these corpuseles per eubic millimetre of blood.

Shape. Mammals (exeept Camelidae) have eircular biconcave discoids. The eamels have elliptieal biconvex eorpuscles.

Size. Human eorpuseles have a fairly eonstant diameter of about 7 to 8 miero-millimetres.

Colour. Individual eorpuscles appear pale yellow, but in bulk they appear red.

Structure. The pigment is enclosed in a fine sponge-work of lipoid nature which also forms the covering membrane of the corpuscle. 'This membrane is elastie, allowing the corpusckes to elongatc in passing along capillary vessels.

History. Erythroeytes are born in the red bone marrow. The young corpuscle is ealled an erythroblast and has a nucleus. It may live and dic in its place of origin. In that casc the valuable constituent of the pigment, the iron, is retained by the marrow and used in the construetion of other cells. Most of the eells, however, do not remain in the bone marrow. Their nuclei atrophy and the enueleated eorpuscles are shot into the blood stream on their way to the liver, the erematorium of the body, where they are alleged to be destroyed after 10 to 14 days. Those which die by the way are taken out of the circulation by the spleen. Eeonomical Nature in this way makes use of the dying erythrocyte as a beast of burden.

\section{Viscosity of whole blood.}

The presenee of corpuscles prolongs the time taken by whole blood to traverse a viseosimeter as eompared with plasma. The following figures show this. Serum was used instead of plasma, to prevent eomplications by clot formation.

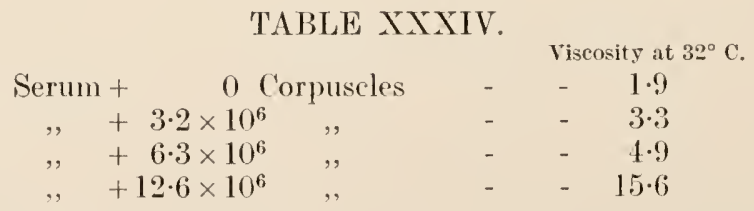

The last high value was due to the mechanical blocking of the capillary tube by the corpuscles which tend to agglutinate when so coneentrated. 
'The stroma (and capsule) are colloidal in character. 'The emmeshed fluid is also colloidal and, therefore, the corpusele as a whole will act as a colloid. Acids increase the power of colloids to imbibe water and, therefore, one would expect that $\mathrm{CO}_{2}$ would eause an increased imbibition of water by the corpuseles and, consequently, incrcase the viscosity of blood, due (a) principally to the absorption of water from the plasma rendering it more viscous and $(b)$ the swelling of the corpuscle itself. The experimental proof of this has not been very satisfactory, but some workers have observed increased viscosity in venous blood, especially in cases where the unsaturation of haemoglobin is low (pneumonia, gas poisoning).

Viscosimetric measurcments afford a means of determining the volume of blood corpuseles. Viscosity depends principally on the total volume of corpuscles per unit volume of fluid. Having determined (i) the viscosity of whole blood $=p c$, and (ii) that of the plasma $=p$, the total corpuscular volume $K$ may be derived from the formula

$$
1-K=\frac{p}{p c} .
$$

If the total number of corpuscles per unit volume be $N$, then the average volume of each will be $K / N$.

The results obtained from such an indirect method are fairly regular but cannot be considered as absolutely accurate, as viscosity does not depend, in prineiple, on either the number or the volume of corpuscles, but on the effective surface, i.e. on the area liable to friction (sec relation between viscosity and bloodpressure).

The sponge-work, which is a colloidal complex of protein, lecithin, kephalin, cholesterol, etc., with adsorbed electrolytes, encloses water and electrolytes in solution and the pigment haemoglobin. This pignent is an elcetropositive protein containing 0.399 per cent. iron. It is not in true solution in the corpuscles. 'The corpusele contains 32 per cent. IIb in 63 per cent. water, while the solubility in water is 18 per eent. It may be set free by rupturing the corpuscle. This is known as haemolysis and haemolysed blood, because it is similar in colour to crimsonlac-resin (a gum extruded from tropical trees after puncture by the lac insect), is said to be laked.

Blood may be laked by various methods :

1. Mcchanical, grinding corpuscles with sand or powdered glass and taking up with salt solution. 
2. Physical, frecking and thawing, heat, condenser diseharges, ete.

3. Endosmosis, dropping blood into water or into a hypo-tonic solution.

4. Exosmosis (see erenation), dropping blood into a hypertonie solution.

5. Action on Lipoid constituents of capsule.

i. Anaesthetics are lipoid solvents.

ii. Bile salts and pigments affect permcability of lipoid membranes.

iii. Glueosides, e.g. saponin are adsorbed by the membrane (Willard Gibbs' Law), because they lower surface tension. They then insert thenselves into the texture of the membrane and inerease its pernneability (sce p. 111).

6. Biological Agents.

i. 'Toxins of certain bacteria produce hacmolysis, e.g. tetanolysin of 13. Tetani; megatheris Iysin of $\mathbf{B}$. Ifegatherium; toxie lysins of staphyloeoceus and 13. pyoeyaneus.

ii. Cobra and rattlesnake venom eause laking both in vivo and in vitro.

iii. The serum of one animal is often haemolytie for the blood of a different species.

iv. Certain phyto-albumins, e.g. abrin, ricin, and robin produce haemolysis.

\section{Chemical Agents.}

IIacmolysis may be eaused by the ingestion or injection of certain drugs, e.g. ehlorates, nitrites, nitrobenzene, aniline derivatives (c.g. acetanilide and phenacetin) quinine. 'These, generally, partially convert the haemoglobin into methaemoglobin (q.v.).

The laking of blood thus depends on altering the permeability of the stroma or eapsule of the erythroeyte. Normally this membrane is impermeable to colloids and to most erystalloids. This has been determined by estimating the electrieal eonduetivity of blood before and after laking. 'The eorpuseles hinder the passage of small eleetrical eharges beeause their walls are impermeable to ions earrying the eharge. On rupturing the membranes these ions get a free passage and the eonduetivity of the blood inereases. That this inerease is not due to the liberation of hacmoglobin may be shown by fixing the corpuseles with formalin which prevents the egress of the pigment but not of the salts. 
Laked blood has a lower viscosity than whole blood due to the pscudo-viscosity caused by the eorpuscles.

\section{Haemolysis by freezing and thawing.}

It has been noticed that blood could be repeatedly frozen and thawed as in the determination of the osmotic pressure (freezing point method) with little or no laking. If, however, the blood was suddenly cooled to below the freezing point of water, was kept at that temperature for a long time, or was rapidly thawed, pronouneed haemolysis was produecd. Burton-Opitz prepared completely laked blood by eight times freczing it solid, and thawing it rapidly. The mechanism of this laking is not clearly understood. Possibly the withdrawal of water from the membrane to form ice might be adduced as sufficient reason (Guthric). (Cf. Test for frozen meat.)

\section{Endosmotic laking.}

Normally, the corpusele has within it a concentration of colloids and of crystalloids isotonic with 0.9 per cent. sodium chloride. A similar state prevails, as we have secn, in the plasma in which the corpuscle is immersed. The corpuscular membrane is almost scmipermeable. That is, water may pass through it but not certain salts in solution and not colloids. If the concentration of salts and colloids inside and out of the membrane were not exactly balaneed, water would pass from the place of low eonecntration to that of high concentration (sce Osmotic pressure, Chap. V.). That means that blood dropped into water or into a solution of lower conecntration than $0.9 \mathrm{NaCl}$ would gain watcr. Water would pass into the corpuscle, cause it to swell, and when the limit of elasticity had been passed, the corpuscle would burst and scatter its contents into the fluid.

\section{Crenation.}

Loss of water by evaporation or by immersion in a solution more conecntrated than 0.9 per cent. NaCl causes the corpuscles to shrink and shrivel. They then break up into fragments, due to inequalities in the tensile strength of the eorpusele. Most peculiarly the first stage in exosmotic laking is a swelling of the corpuscle. Some change in the physico-chemical state of the protein moiety in the envelope is indicated. It has been shown that the power of colloids to imbibe water may be altered by alterations in their crystalloid content. 


\title{
CHAP'TER XXII
}

\section{RESPIRATORY FUNC'IION OF THE BLOOD}

\begin{abstract}
"There is no instance in which it can be proved that an organ increases its activity under physiological conditions without also increasing its demand for oxygen."

BARCROFT.
\end{abstract}

The erythroeyte assumes importanee as the earrier of the respiratory gases, oxygen and earbon dioxide. Air has an average eomposition of about 79 volumes per eent. of nitrogen and 21 of oxygen. The amount of carbon dioxide present is so small ( 0.03 per eent.), that it may for the present be negleeted. The partial pressure of oxygen, therefore, at normal pressure would be $2010 \times 760=159 \cdot 6 \mathrm{~mm}$. of mereury. The partial pressure of oxygen in the lung is, on account of the earbon dioxide and aqueous vapour present, mueh less than this. Alveolar air eontains in 100 e.c. about $5 \cdot 5$ vols. of $\mathrm{CO}_{2}, 13$ vols. of $\mathrm{O}_{2}$ and $79 \cdot 5$ vols. of $\mathrm{N}$. Their partial pressures will be (at normal barometrie pressure)

$$
\begin{aligned}
\mathrm{O}_{2} & =13.3 \times 760=98.8 \mathrm{~mm} . \mathrm{Hg} . \\
\mathrm{CO}_{2} & =10.0 \times 760=41.8 \mathrm{~mm} . \mathrm{Hg} . \\
\mathrm{N} & =7.5 .5 \times 760=604.2 \mathrm{~mm} . \mathrm{Hg} .
\end{aligned}
$$

The partial pressure of the oxygen in the lung is thus about $2 / 3$ of its partial pressure in the atmosphere. The pereentage of nitrogen shows an apparent inerease beeause the total air is decreased in the ratio 300 by the absorption of oxygen without a eorresponding produetion of earbon-dioxide. Then, too, the tension of aqueous vapour at body temperature is by no means negligible. It amounts to about $50 \mathrm{~mm}$. of $\mathrm{Hg}$. That is, dry air at $760 \mathrm{~mm}$. $\mathrm{Hg}$. when taken into the body has its pressure redueed to $760-50=710 \mathrm{~mm}$. $\mathrm{Hg}$. This eauses the actual oxygen pressure to fall to $92 \cdot 3$, and earbon-dioxide to $39 \mathrm{~mm}$. $\mathrm{Hg}$.

The quantity of gas by weight (or by volume redueed to N.T.P.) dissolved in a liquid is proportional to its partial pressure provided chemical and physical conditions remain constant. If, for 
instanee, the pressure of the gas be doubled, twice as much of it will go into solution. The appended table eontains experimental verifieations of this Law of Henry.

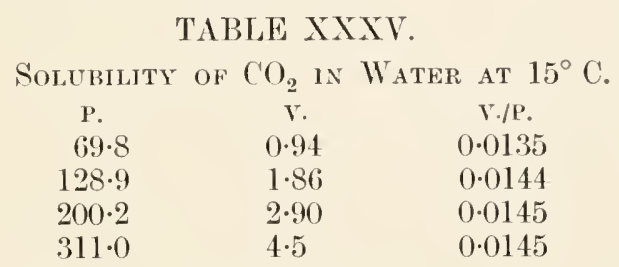

where $\mathrm{P}=$ pressure in $\mathrm{mm}$. of $\mathrm{Hg}$. of $\mathrm{CO}_{2}$,

$\mathrm{V}=$ volume of $\mathrm{CO}_{2}$ (measured at N.T.P.) absorbed by 1 c.c. of water at $15^{\circ} \mathrm{C}$.

('The same volume of gas at eonstant temperature is absorbed by the fluid, no matter what the pressure is. Inerease of pressure proportionally inereases the weight of unit volume. 'Thus, if one volume of water dissolves one volume of gas weighing 1 gram at 1 atmosphere pressure, then, if the pressure be raised to two atmospheres, 1 volume of water would dissolve 1 volume of the gas weighing 2 grams, or if redueed to normal pressure, 1 volume of water would dissolve 2 volumes of the gas weighing 2 grams.)

Absorption coefficient (usually denoted by the Greek letter a).

Different gases, just like different solids, vary in their solubilities. The volume of gas (at N.T.P.) which dissolves in 1 e.e. of water under a pressure of one atmosphere is termed its absorption eoefficient, e.g. 1 e.e. of water will dissolve at N.T.P. $0 \cdot 0489$ c.c. of oxygen, 0.0239 c.e. of nitrogen, and 1.713 e.e. of earbon dioxide. The volume of gas absorbed by 1 c.c. of water under any pressure may be found by the following equation :

$$
L=\text { ap, }
$$

where $L=$ amount of gas dissolved,

$a=$ absorption coefficient,

$p=$ pressure in atmospheres.

Increase of temperature causes the solubility of gases to deerease.

TABLE XXXVI.

$\begin{array}{cccc}\text { Absorption Coffacients } & \text { at } & \text { Various } & \text { Temperatures. } \\ \text { Temperature. } & \text { Oxygen. } & \text { Nitrogen. } & \text { Carbon-dioxide. } \\ 0^{\circ} \mathrm{C} \text {. } & 0.0489 & 0.0239 & 1.713 \\ 10^{\circ} \mathrm{C} . & 0.0380 & 0.0196 & 1.194 \\ 20^{\circ} \mathrm{C} . & 0.0310 & 0.0164 & 0.878 \\ 30^{\circ} \mathrm{C} & 0.0262 & 0.0138 & 0.665 \\ 40^{\circ} \mathrm{C} . & 0.0231 & 0.0118 & 0.530\end{array}$




\section{Effect of solutes.}

Plasma eontains erystalloids and eolloids. 'The erystalloids are all more or less hydrated. They eombine loosely with a eertain amount of water and, therefore, reduee the effeetive absorption volume. Similarly, the emulsoid eolloids present reduee the effective eoneentration of water by imbibition. They, however. are able to adsorb a quantity of gas (see p. 66).

It has been found that at the pressure of about $90 \mathrm{~mm}$. $\mathrm{Hg}$., which we saw oxygen had in the lung, 100 c.e. of plasma will dissolve 0.273 e.e. of oxygen (measured at N.T.P.). The tension of oxygen in the tissues eannot be less than zero, and, therefore, one has as a maximum amount 0.273 e.e. of oxygen for every 100 c.e. of plasma passing through the tissue. A eat's gastroenemius musele weighing 20 grams uses about $0 \cdot 24$ e.e. of oxygen per minute and, therefore, would need to have at least 100 e.e. of plasma passing through it per minute. A warm-blooded animal would need to have about twice as mueh plasma by volume as the present volume of its body. 'The body would be unable to eope with the wieght of its own eireulating fluid. For example, the average man weighing $66 \mathrm{~kg}$. would have to earry, in addition. at least $140 \mathrm{kgs}$. of plasma, thus inereasing his total weight to 206 kilos. As Barcroft puts it, "man would never have attained any aetivity which the lobster does not possess, or had he done so it would have been with a body as minute as the fly's." In the experiment quoted above the aetual amount of blood passing through the eat's muscle was 4.5 e.c. per min.-just under a twentieth of the amount neeessary when plasma alone was eonsidered. 'This is due to the speeifie oxygen eapacity of the haemoglobin in the blood.

The following table gives the volume (in e.e. at N.T.P.) of oxygen, nitrogen and earbon dioxide whieh will dissolve in 100 e.e. of fluid at $38^{\circ} \mathrm{C}$. and $760 \mathrm{~mm}$. pressure.

\section{TABLE XXXVII.}

\begin{tabular}{|c|c|c|c|c|c|}
\hline $\mathrm{Wa}$ & - & - & $\begin{array}{c}\text { Oxygen. } \\
2 \cdot 37\end{array}$ & $\begin{array}{c}\text { Nitrogen } \\
1 \cdot 2\end{array}$ & $\begin{array}{c}\text { Carbon-dioxide. } \\
5.55\end{array}$ \\
\hline Plasma & - & - & $2 \cdot 3$ & $1 \cdot 2$ & $5 \cdot 41$ \\
\hline Blood & - & - & $2 \cdot 2$ & $1 \cdot 1$ & $5 \cdot 11$ \\
\hline
\end{tabular}

In addition to the amount dissolved one has to eonsider the amount held by the haemoglobin. The table given below eontains the results of a series of experiments on the blood of a horse, 
where the amount of oxygen in the blood was determined at various pressures.

TABLE XXXVIII.

\begin{tabular}{|c|c|c|c|c|}
\hline \multirow{2}{*}{$\begin{array}{l}\text { Oxygen tension } \\
\text { in mm. of } \mathbf{H g} \text {. } \\
\text { (1) }\end{array}$} & \multicolumn{2}{|c|}{$\begin{array}{l}\text { Oxygen in c.c. (at N.T.P.) } \\
\text { per } 100 \text { c.c. of blood. }\end{array}$} & \multirow{2}{*}{$\begin{array}{l}\text { Degree of } \\
\text { Saturation } \\
\text { of } \mathrm{Hb} . \% \% \\
(1)\end{array}$} & \multirow{2}{*}{$\begin{array}{c}\text { Degree of } \\
\text { Dissociation \% } \\
\text { (unsaturation). } \\
{[100-(4)]}\end{array}$} \\
\hline & $\begin{array}{l}\text { Bound by } \\
\text { Itaemoglobin. } \\
\text { (2) }\end{array}$ & $\begin{array}{l}\text { Dissolved in } \\
\text { Plasma. } \\
\text { (3) }\end{array}$ & & \\
\hline 10 & $6 \cdot 0$ & $0 \cdot(020$ & $30 \cdot 0$ & $70 \cdot 0$ \\
\hline 20 & $12 \cdot 9$ & $0 \cdot 0+1$ & 64.7 & $35 \cdot 3$ \\
\hline 30 & $16 \cdot 3$ & 0.061 & $81 \cdot 6$ & $18 \cdot 4$ \\
\hline 40 & $18 \cdot 1$ & $0 \cdot 081$ & $90 \cdot 4$ & $9 \cdot 6$ \\
\hline 50 & $19 \cdot 1$ & $0 \cdot 101$ & $95 \cdot 4$ & $4 \cdot 6$ \\
\hline 60 & 19.5 & $0 \cdot 121$ & $97 \cdot 6$ & $2 \cdot 4$ \\
\hline 70 & $19 \cdot 8$ & $0 \cdot 141$ & $98 \cdot 8$ & $1 \cdot 2$ \\
\hline 80 & $19 \cdot 9$ & $0 \cdot 162$ & $99 \cdot 5$ & 0.5 \\
\hline 90 & 19.95 & 0.182 & $99 \cdot 8$ & 0.2 \\
\hline 150 & 20 & $0 \cdot 303$ & 100 & $0 \cdot 0$ \\
\hline
\end{tabular}

If the tensions (1) are taken as abseissae and the degree of saturation (4) as ordinates, a curve (Fig. 56, heavy line) is obtained called the dissoeiation curve of blood. This eurve is compound and may be resolved into its component faetors :

(a) Pure Haemoglobin. The dissociation eurve for pure haemoglobin will be found in Fig. 56, dotted line. It differs from that of whole blood in that its eontour is that of a reetangular hyperbola.

(b) Solutes. The materials in solution in the blood corpuseles and in the plasma are the eause of the differenee between the dissociation eurve of pure haemoglobin and haemoglobin in blood. If the pure haemoglobin is dissolved in the actual salts whieh are present in the red blood corpuscles, the curve of the haemoglobinsalt solution will be found to lie, point for point, on that of whole blood. Examination of sueh eurves will demonstrate the value of these salts in the unloading of oxygen from the corpusele.

From the curves it will be seen that at the pressure of oxvgen in the lung-i.e. $90 \mathrm{~mm}$. Hg.--both whole blood and pure haemoglobin solution are saturated to about the same extent with oxygen. (To say that they are 92 per cent. saturated is equivalent to saying that 92 per cent. of the haemoglobin has got its full cargo of oxygen, and 8 per cent. has no oxygen at all. This must not be considered as admitting the correctness of such a supposition. It may be that each molecule of haemoglobin has got 92 per cent. of its maximum load.) That is, the presence of solutes does not materially modify the oxygen capacity of the blood at high tensions of oxygen. In the tissues, the tension of oxygen is low, say $15 \mathrm{~mm}$. Hg. 
At this tension, whole blood can only be 15 per cent. saturated. Therefore the oxygen carried by 77 per cent. $(92-15)$ of the haemoglobin, is discharged. On the other hand, pure haemoglobin is still 65 per cent. saturated at $15 \mathrm{~mm}$. Hg. It will only be able to discharge the oxygen borne by 27 per cent. of its haemoglobin. In other words, because of the presence of solutes, whole blood is able to set free in the tissues the full amount of oxygen that could be obtained from pure haemoglobin, with, in addition, the amount that would be carried by the haemoglobin represented by the space between the heavy curve and the dotted curve in Fig. 56. That is, salts so aid in the unloading of oxygen that 50 per cent. of the haemoglobin

DISSOCIATION CURVE OF HAEMOGLOBIN AT $37^{\circ} \mathrm{C}$.

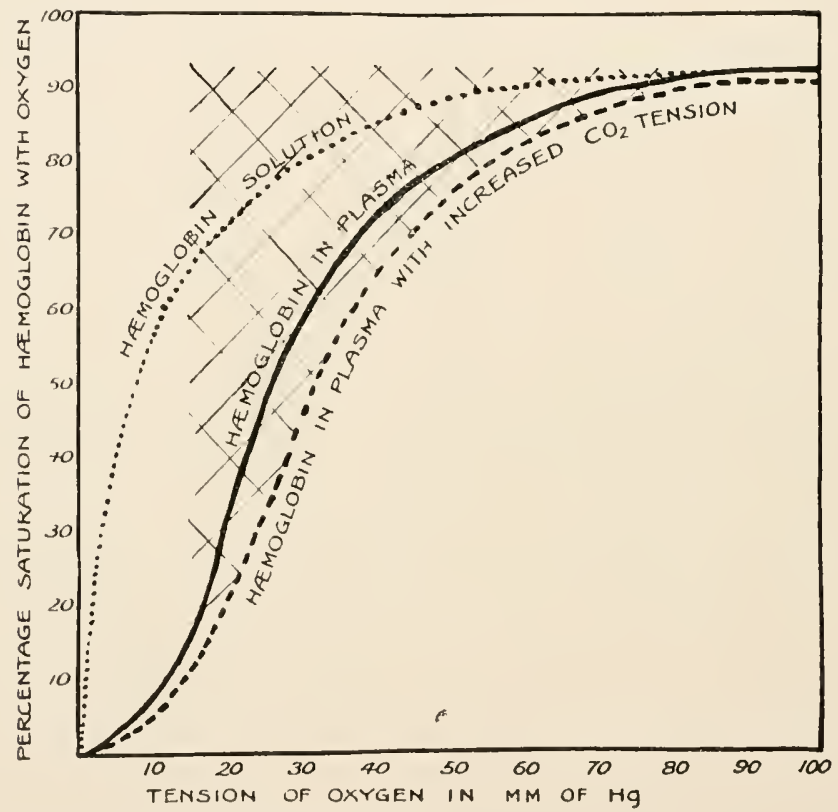

FIG. 56.-1)issociation curve representing the equilibrium between oxygen tension, oxy-haemoglobin and reduced haemoglobin :

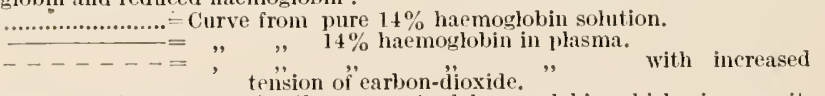

The hatched portion represents the anount of haemoglobin which gives up its oxygen when the oxygen tension is reduced from 100 to $15 \mathrm{~mm}$. $\mathrm{Hg}$.

that would otherwise have retained its oxygen, is induced to give it up to the tissues. Because of the solutes, whole blood becomes an effective carrier of oxygen, and the total volume of fluid (and mass of haemoglobin) is liept within reasonable limits.

\section{Nature of union.}

The average normal man has about 5 litres of blood, $2 \cdot 5$ litres of this is oceupied by $25 \times 10^{12}$ red corpuscles with a total surface of about 3000 sq. metres. When fully saturated with oxygen at 
atmosphcric pressure $(160 \mathrm{~mm}$. $\mathbf{H g}$.) cach litre of blood will take up 200 c.c. of oxygen. Leaving out of account the relatively small amounts of oxygen carricd in solution in the plasma and adsorbed by the plasma proteins, we may calculate that each corpuscle will carry oxygen to the extent of

$$
\frac{\text { Total oxygen capacity of blood }}{\text { 'Total number of corpuscles }}=\frac{1000}{25 \times 10^{12}}=4 \times 10^{-11} \text { e.c. }
$$

Each cubic centimetre of oxygen will need $25 \times 10^{7}$ corpuscles to carry it.

Further, the total iron content of human blood is about $\mathbf{2 \cdot 5}$ grams (Schmidt).

That is, each gram of iron is associated with $1000 / 2 \cdot 5=400$ c.c. of oxygen - a figure closely approximating to Barcroft's experimental finding of 401 e.c. Normal blood contains 14 grams per cent. of haemoglobin. It follows that each corpuscle carries $140 \times 5$ $25 \times 10^{12}=28 \times 10^{-12}$ grams of haemoglobin. In other words, each cubic centimetre of oxygen postulates the presence of

$$
\frac{28 \times 25 \times 10^{9}}{10^{12}}=0.7 \text { gram. of } \mathrm{Hb} .
$$

The iron content of Hb. must therefore be $\frac{10}{7 \times 400}=\frac{1}{280}$ gram per gram of $\mathrm{Hb}$. Putting this in molecular terms, one molecular proportion of iron (56 grams) cnters into the composition of 15,680 grams of $\mathrm{Hb}$. The molecular weight generally given for $\mathrm{Hb}$ is 16,660 .

Evidence has been produced which shows that when haemoglobin is fully saturated with oxygen there are 401 c.c. of oxygen for every gram of iron. That is, each combining proportion of iron (56 grams) co-cxists with two combining proportions (32 grams) of oxygen. From this, some deduce the presence of a compound $\mathrm{FeO}_{2}$ in haemoglobin. That may be. On the other hand, the idea of a chemical combination between haemoglobin and oxygen raises hosts of difficulties which would not arise on the hypothesis of adsorption of gas on a colloidal surface. However, no reliable direct experimental evidence bearing on this has come to hand. If analogies could be taken as a proof instcad of analysis, the adsorption theory would hold the field undisputed. 


\section{How the tissues unload the oxygen.}

These little barges $7 \cdot 6 \mu$ in diameter squeeze along the capillary vessels in the tissues. During their passage along a tube with a diameter less than their own the eorpuscles naturally undergo distortion. This distortion has at least one effeet on the loading and unloading of the oxygen from the eorpuseles. It puts on the brake, slows down the corpuseles and gives the dock-labourers and others opportunity to earry out their work.

Another physieal faetor eomes into play, viz. : alterations of temperature, and that has a profound effect on both the amount of gas liberated and the speed at whieh it is handled. The temperature in the lung where oxygen is taken on board is usually less than $37^{\circ} \mathrm{C}$. while the temperature of active tissue may be greater (see Chap. XXXI.).

Inerease in temperature inereases the desaturation of hacmoglobin. The amount of desaturation brought about by an inerease in temperature may be ealeulated from the laws of van't IIoff and Arrhenius. The process of saturation and desaturation may be represented by the reaetion formula

$$
\mathrm{IIb}+\mathrm{O}_{2} \rightleftharpoons \mathrm{HbO}_{2} \text {. }
$$

The veloeity of this reaction depends, other things being equal, on the aetive masses of oxygen $-C_{0}$ and of haemoglobin $C_{\mathrm{R}}$. i.e. $v=k\left(C_{0} \times C_{\mathrm{R}}\right)$.

Now $k_{1}$, the velocity constant of the saturation proeess, and $k_{2}$. the eorresponding eonstant for desaturation, vary with the temperature. We have seen (p. 247) that a, the absorption coeffieient of oxygen in blood, varies inversely with the temperature.

$$
C_{\mathrm{r}}=C_{\mathrm{k}} \times\left(\frac{k_{1}}{k_{2}} \times \frac{a}{760}\right) \times p=C_{\mathrm{R}} \cdot \boldsymbol{K} \cdot p,
$$

where $C_{\mathrm{H}}=$ eoneentration of oxyhaemoglobin and $p=$ oxygen pressure.

This value, $\boldsymbol{K}$, is eonstant for cach temperature, and by the law of van't Hoff the values of $K$ for any two temperatures $T_{1}$ and $T_{2}$ are related by the equation

$$
K_{2}=K_{1} \epsilon^{\frac{-a}{2} \cdot \frac{T_{2}-T_{1}}{T_{2} T_{1}}}
$$

( $\epsilon=$ base of Napicrian logs, $q=$ heat evolved when 1 gram molecule of $\mathrm{Hb}$ unites with 1 gram moleeule of oxygen). 
For example, let us try to determine what desaturation would arise from raising the temperature from $36^{\circ} \mathrm{C}$. to $39^{\circ} \mathrm{C}$.

Here

$$
\begin{aligned}
& T_{1}=273+36=309 \text { absolute, } \\
& T_{2}=273+39=312,
\end{aligned}
$$

and

$$
q=28,000 \text { eals., }
$$

$$
K_{39}=K_{36} \epsilon^{\frac{-280009}{2} \cdot 309 \times 312}=K_{366}^{*} \epsilon^{-04356} .
$$

If $K_{36}$ be 30 per eent., then $K_{39}$ is equal to $30 \epsilon^{-04356}=\mathbf{1 9 \cdot 4}$, we find that haemoglobin which was 30 per eent. saturated at $36^{\circ}$ beeomes only $19 \cdot 4$ per eent. saturated at $39^{\circ}$.

An inerease in $3^{\circ} \mathrm{C}$. between the values of 36 and 39 eauses the $\mathrm{HbO}_{2}$ to lose oxygen to the extent of about 10 per cent. of full saturation.

A physico-chemieal factor, however, is mueh more potent than temperature in producing desaturation. Aetive tissues tend to beeome acid. In dealing with musele, we have seen how laetie acid is set free as the result of aetivity and how oxygen is required before it ean be replaced in the musele complex. This free laetie acid performs another serviee. Either directly by partially diffusing into the surrominding lymph or indirectly by produeing alterations in the Helmholtz (polarising) electrie eharge, it eauses a potential alteration in the hydrogen ion eoneentration of the tissue fluid. By a series of ehanges which we have already briefly eonsidered, and to which we shall return, the net effect is to inerease the tension of $\mathrm{CO}_{2}$ in the eapillaries. The molecules of $\mathrm{CO}_{2}$ are to be the new passengers on the erythroeytes, and because of their aeidity they eause an aggregation of the eolloidal particles of haemoglobin and a marked desaturation. Carbon-dioxide aets as if the tension of oxygen in the tissues were redueed to $10 / 24$ ths of its real value. That is, hacmoglobin parts with as mueh oxygen at a tissue tension of oxygen of $24 \mathrm{~mm}$. $\mathrm{Hg}$. as if the tension of oxygen were only $10 \mathrm{~mm}$. For example, blood which, in the absence of $\mathrm{CO}_{2}$ would be 30 per eent. desaturated is aetually desaturated to the extent of 78 per eent. by the presenee of a $\mathrm{CO}_{2}$ tension of $40 \mathrm{~mm}$. Hg. The blood beeomes now a earrier of $\mathrm{CO}_{2}$ from the tissues to the lungs (Fig. 56, dash line eurve).

Handling of Oxygen. Consider an inland village supplied by a eanal eoming as elose as possible to the eommunity. Internal communication is effeeted by waterways fed from the canal. The by-produets of manufacture (sent elsewhere for elaboration) are transported along these waterways to the eanal and the same 
gangs of labourers unload the raw material from the barges and float it up to the factories.

To take a speeifie instance, muscle, as a result of its aetivity. produces carbon dioxide. This weak aeid aets on the sodium hydrogen phosphate of the tissue fluid aeeording to the following equation :

$$
\mathrm{H}_{2} \mathrm{CO}_{3}+\mathrm{Na}_{2} \mathrm{HPO}_{4} \rightleftharpoons \mathrm{NaIH}_{2} \mathrm{PO}_{4}+\mathrm{NaHCO}_{3} \text {. }
$$

'The sodium biearbonate so formed finds its way into the blood stream. Now in plasma, biearbonate is in equilibrium with free dissolved earbon dioxide when the volume of $\mathrm{CO}_{2}$ in solution is $1 / 20$ of the volume of $\mathrm{CO}_{2}$ eombined

The result of the influx of $\mathrm{NaHCO}_{3}$ is to inerease the volume of free $\mathrm{CO}_{2}$ in order to preserve the ratio $\underset{\mathrm{CO}_{2} \text { eombined }}{\mathrm{CO}_{2} \text { free }}=\frac{1}{20^{\circ}}$. Briefly, the $\mathrm{CO}_{2}$ tension in the musele capillaries tends to increase. As stated above, inerease of $\mathrm{CO}_{2}$ tension eauses inereased unloading of oxygen from haemoglobin.

That is to say--inereased activity postulates inereased energy usage, which renders necessary an immediately inereased supply of oxygen. The amount of oxygen required is liberated by the desaturating aetion of $\mathrm{CO}_{2}$ - the main ehemical produet of the aetivity.

The amount of oxygen in the blood does not control oxidation in the tissues, but the eall for oxygen by the tissues eontrols the rate of unloading of oxygen.

\section{Transport of carbon dioxide.}

The principle underlying the transport of earbon dioxide is identieal with that enunciated for oxygen. In the tissues, the tension of earbon dioxide is relatively high and the gas passes to the blood, is earried to the lungs and is there eliminated. Haemoglobin, onee freed from its load of oxygen, takes on a eargo of earbon dioxide. But haemoglobin is not the sole means of transport. Carbon dioxide is about twenty-five times as soluble as oxygen under similar eonditions. Relatively more $\mathrm{CO}_{2}$ will, therefore, be earried in true solution in the plasma. In addition to this amount (which we have just seen is earefully regulated) a eonsiderable quantity of the gas is adsorbed to the various eolloids of the plasma. (i) Each gram of fibrinogen ean carry 1/30 gram of $\mathrm{CO}_{2}$. (ii) Serum proteins may adsorb a measurable quantity of earbon dioxide-at the lowest estimate, over 5 per eent. It is 
obvious that while these factors may almost be neglected in the consideration of the transport of oxygen, they have to be reckoned with in the case of carbon dioxide.

\section{TABLE XXXIX.}

Partition of $\mathrm{CO}_{2}$ in 100 c.c. of Defibrinated Blood (Haematocrite Value $=51$ ).

$\begin{array}{lccccc}\mathrm{CO}_{2} \text { tension. } & \begin{array}{c}\text { Vol. of } \mathrm{CO}_{2} \\ \text { in blool. }\end{array} & \begin{array}{c}\text { Vol. of } \mathrm{CO}_{2} \\ \text { in serum. }\end{array} & \begin{array}{c}\text { Vol. of } \mathrm{CO}_{2} \\ \text { in corpuscles. }\end{array} \\ \text { Oxygenated } & - & 40 & 15 \cdot 0 & 25 \cdot 9 & 19 \cdot 1 \\ \text { Reduced - } & 40 & 50 \cdot 4 & 28.0 & 22.4\end{array}$

That is, in arterial (whole) blood, there is about 50 e.c. of $\mathrm{CO}_{2}$, of which amount the fibrinogen earries about 5 c.c., the serum (proteins, water and erystalloid bases) about 26 c.e. and the corpuseles about 19 e.e.

\section{TABLE XL.}

100 c.c. of Artertal Blood ( $\mathrm{CO}_{2}$ tension $40 \mathrm{~mm}$., $\mathrm{O}_{2}$ tension $100 \mathrm{~mm}$.).

Corpuscles $\quad$ in solution - - 0.85 c.c. $51 \%$ by volume $\}$ carry $\%$ of total $\mathrm{CO}_{2}\left\{\begin{array}{l}\text { bound }\left(e . g . \mathrm{NaHCO}_{3}\right) 8.45 \text { c.c. } \\ \text { adsorbed by } \mathrm{Hb} \text {, etc. } 9.7 \text { c.c. }\end{array}\right.$

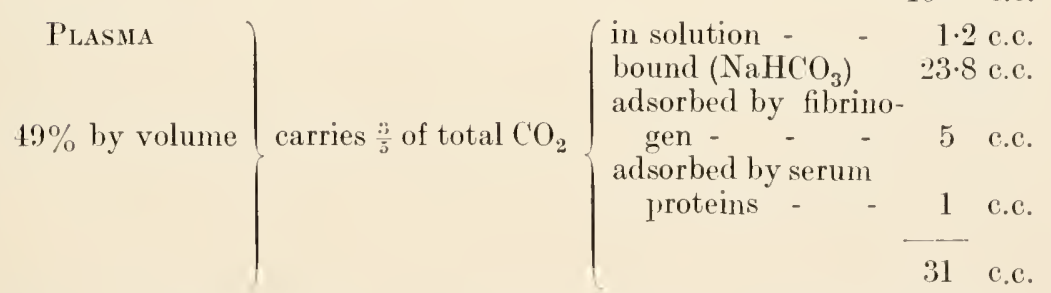

100 c.c. of Venous Blood ( $\mathrm{CO}_{2}$ tension $=45 \mathrm{~mm}$., $\mathrm{O}_{2}$ tension $=40 \mathrm{~mm}$.).

$\begin{aligned} \text { Corpuscles carry - } & 22 \text { c.c. }=+3 \text { c.c. } \\ \text { Plasma carries }- & 34 \text { c.c. }=+3 \text { c.c. } \\ & 56 \text { c.c }+6 \text { c.c. }\end{aligned}$

For all practical purposes there is very little difference between the corpuseles and plasma as transporters of earbon dioxide. But, in times of stress when the $\mathrm{CO}_{2}$ tension tends to be abnormally high or when the desaturation of oxyhacmoglobin beemes abnormally great (e.g. over 40 per eent.) the eorpuseles will play the major part in the transport of $\mathrm{CO}_{2}$.

Plasma must be considered as a fluid separated from other fluids (with which it is in equilibrium) by membranes permeable to ecrtain solutes. 'The whole transport system is a multi-phase fluid in equilibrium. Alterations in any phase produee regulatory 
changes in every other phase. Bricfly, blood has an integrative action.

To come back to the simile of a community : suppose Cottonopolis failed to funetion normally. This eould be manifested by the seareity of eotton goods in the hands of the distributors. The cause of the failure might be found by a proeess of elimination. In general, (1) either the supply of raw material was inadequate (bad harvest or transport strike), (2) or the supply of fuel was restrieted (eoal strike), (3) or the workers were on strike, or (4) the means of distributing the finished produet had broken down (transport strike). It might even happen that (5) over-produetion had " drugged" the market, produeing the invariable reaction on the faetory. Similar mishaps might overtake that collection of cell-eommmities ealled the aninal organism. (1) If the various raw materials are not available even when ample fuel supplies exist, eell life becomes narrowed and inefficient. Certain matter must be imported-it eannot be manufactured. If the raw material is imported but does not reach the cell, then the transport system is at fault. (2) A similar statement could be made about the supply of energy. (3) 'The ecll itself may be at fault-e.g. after HCN poisoning, in spite of adequate supplies of energy and material, metabolism is at a low ebb. (4) The transport trouble might be due to the searcity of barges, $e$.g. anaemia, or to want of foree in the driving mechanism, e.g. heart failure. (5) In certain pathologieal conditions a cell-community may take the bit between its teeth and overproduee. The immediate result is to hamper its own activities by the presence of the products of its aetivity.

To take a speeifie instanee - suppose we find that an organ seems to suffer from a lack of oxygen. This may be due (i) to a seareity of oxygen in the air breathed-analysis will show that. (ii) The lung meehanism may be out of order (Chap. XXVI.). (iii) The membrane separating lungirair from blood may have lost its permeability. Comparison of the oxygen eapacity of arterial blood with its actual oxygen content will indieate whether or not this is the fault. (iv) This will also show if the erythroeytes are taking on their full load. (v) If the blood suffers little or no desaturation on passing through the organ, then one may presume either that the haemoglobin has lost its power of unloading oxygen (methaemoglobin) or that the organ has lost the power of using oxygen. Examination of the blood pigment by means of the speetroseope may help us to ehoose which of these alternatives is eorreet. 
No matter what organ or tissuc it is that fails to function normally - it must remain in dynamic equilibrium with the blood, and through the blood with every other tissuc and organ in the body. Every change occurring anywhere in the body sets in motion a series of far-reaching alterations tending to restore equilibrium. It is this constant adjustment of physical and chemical forec and matter brought about mainly via the inland transport system that goes to make up the metabolism of the organism.

Other materials are carried by the plasma, viz. :

I. Substances to be Used by the Tissues.

$\begin{array}{llllll}\text { Glucose } & - & - & - & - & \text { From alimentary canal and from } \\ \text { Amino Acids } & - & - & - & - & \text { I }\end{array}$ \begin{tabular}{lllll|l} 
Fats & - & - & - & - & From thoracic duct and from depots. \\
Hormones & - & - & - & - & From
\end{tabular}

II. Substances Excreted by the Tissues.

Urea

Ammonia - - - -

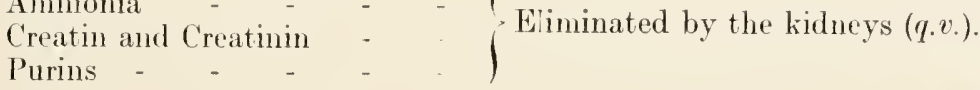




\title{
CHAP'TER XXIII
}

\author{
LOADING UP
}

\footnotetext{
"I send it through the rivers of your blood

Even to the eourt, the heart, the seat o' the brain,

And through the cranks and ofliees of man,

The strongest nerves and small inferior veins

Fron me reeeive that natural eompetency

Whereby they live."

SIIAKESPEARF.
}

WE have now come to one of the most interesting parts of our study, namely the handling of the imports in their eourse between the external and the internal transport systems. As we have seen, the material brought to the body may be divided into two elasses. One of these consists of the gas, oxygen, which eomes to the port of arrival ahmost ready for use, and which is passed direetly to the inland transport system for transmission to the various cell-eommunities.

The foodstuffs form the other elass. They are "raw material" and have, as a rule, to undergo some proeess of manufacture before they ean be distributed to the eonsumer. 'They are handled by a special mechanieal transport service and are taken through the various factories and then handed to the inland transport.

In this ehapter, we are to deal with the importation of oxygen and the mechanism by which it is reecived at the port, earried overland and loaded on the submersed barges on their way inland. Indissolubly assoeiated with any system of importation is the provision of exports. Any barge travelling empty on the blood stream as on any external industrial eanal is a distinet loss to the whole community. Every ship that leaves our shores without a full eargo tells a tale of industrial inefficieney. In the body the output of earbon-dioxide and the intake of oxygen are nicely balaneed. As a matter of faet, the regulation of the rate of importation by the rate of exportation is as much a law here as in the realm of Politieal Eeonomy. 
A separate ehapter has been devoted to the mechanism whereby the oxygen is brought from outside into the port. Bricfly, by museular movenents air is drawn through filtering and warming appliances into the harbour, and after a very short interval is expelled from the harbour into the outer air.

In the average resting man, somewhat over 500 e.e. of air come into the respiratory chambers at each ordinary quict inspiration and somewhat less than this amount is expelled at each expiration. One may say, in round numbers, that the tidal air of the average adult is about 500 c.e. The tidal air at various ages and weights has been determined and is given below :

TABLE XLI.

\begin{tabular}{|c|c|c|}
\hline Age. & Weight in kilos. & Tidal air in c.c.s \\
\hline $0-6$ months. & $3 \cdot 77$ & 48 \\
$6-12$ months. & $7 \cdot 7-12$ & $85-129$ \\
$3-7$ years. & $14 \cdot 3-19$ & $124-221$ \\
S-14 years. & $22-29$ & $221-395$ \\
Adult. & $60-70$ & $440-550$ \\
\hline
\end{tabular}

If a very deep inspiration is taken, more than 500 c.e. can be sucked into the lungs. This extra quantity, which varies with the "build" and expertness of the subject but which usually is about three times the tidal volume, is ealled the complemental air. By a foreed expiration after a normal inspiration the reserve air may be expelled from the lungs. The volume so expelled varies very much witl practice. Some people ean only breathe out an additional 500 to 700 e.e., while singers, physieal training experts and others who practise abdomino-thoracic breathing, may register a volume of 1500 to 2500 c.e. These three quantities together give the vital capacity of an individual, i.c. the amount of air that a person ean expire after a deep inspiration. It is not possible completely to empty the lungs. As we shall see later, a mechanism exists in the air vesieles which prevents their total collapse. They retain about a litre of air-the residual air.

To summarise, taking average figures :

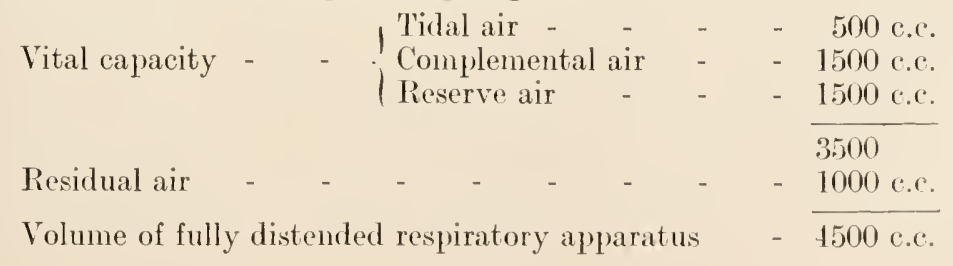


'This volume of 4500 ('.c. includes not only the volume of the lungs but of the approaches to the lungs the nasal eavity, the trachea, the bronchi and the bronchioles. These constitute the outer harbour or "dead space." which has a capacity of about 140 c.c. That is, in ordinary quict breathing each respiration brings about 360 c.c. of air into the inner harbours (air sacs, alveolar saes, or infundibula). These fumnel-like chambers to which the air passages lead are the most expansile structures in the lung, and they are largest where the expansion of the lung is greatest. All round their walls open myriads of small thin-walled air-cells or alveoli-the true wharves of the port. There and there alone takes place the interchange of exported $\mathrm{CO}_{2}$ and imported $\mathrm{O}_{2}$.

Let us look first at the area of wharfage. The interior of the air saes and their alveoli is lined by a thin transparent layer of endothelium. If the lining could be stripped from all the saes of both lungs and inflated, it would form a spherical balloon about 17 feet in diameter. If it were spread as a continuous flat sheet it would cover a square floor of 30 feet by 30 feet. In other words, the area of wharfage is, at least, over fifty times the surface area of the body. The average diameter of an air eell is $0.2 \mathrm{~mm}$., with a volume of 0.004 cub. $\mathrm{mm}$., and an area of $0 \cdot 125 \mathrm{sq} . \mathrm{mm}$. suppose these air cells to be spherical and closely packed together, then the maximum number contained in a eubie millimetre of lung substance would be 250 cells of total surface $31.2 \mathrm{sq}$. $\mathrm{mm}$. Now the average value for the total volume of lung substance is $1 \cdot 617$ e.c. This provides for the possible presence of 404,500,000 air cells with a surface of 50.56 square metres. Of course this is a maximum value for the number. From the volume of lung substanee has to be dedueted the volume of the supporting cells of the lung and of the air passages. On the other hand a minimal value is given for area, sinee no aceount is taken of the increase of surfaee caused by the projeetion of the blood capillaries into the lumen of the alveoli. Various estimates have been made of the surface area of the alveoli ranging from that of von Husehke of $2000 \mathrm{sq}$. metres to that of Aeby given above. Hufner's value is gencrally taken as a mean, viz. 140 sq. metres. Of this area, about three-fourths consists of thin-walled capillary blood vessels. That is, the effective absorptive surface is about $100 \mathrm{sq}$. metres.

Over a surface of about $100 \mathrm{sq}$. metres, intcrchange between alveolar air and blood is possible. Just behind this surfaeeepithelium lie capillary blood vessels of sueh small bore that the 
red blood eorpuseles are distorted in their passage through them. This naturally produces a decrease in the rate of blood flow. The rate is further decreased by the increase in the total sectional area of this eapillary system which is at least seven times greater than that of the aorta (Chap. XXIV.). The sudden increase in the area over which the blood has to spread itself in a layer less than one corpusele thick eauses a marked decrease in the velocity of the stream. These two conditions, $(a)$ narrow bore and $(b)$ increased area of distribution, of course facilitate the processes of unloading and reloading the erythrocytes. The structure is, in principle, just the same as that of the kidney.

The next problem before us is that of the transference of carbon dioxide from the blood to the air and of the oxygen from the alveolar air to the blood. About the first proeess there seems to be no difficulty. Everyone is agreed that, as the tension of earbon dioxide in the blood of the pulmonary artery just as it enters the eapillary system is greater than its tension in expired air, a simple process of diffusion through a wet membrane is all that is required. The tension of $\mathrm{CO}_{2}$ in alveolar air and in the blood is 40 and $46 \mathrm{~mm}$. Hg. respeetively. There is, therefore, a difference of $6 \mathrm{~mm}$. $\mathrm{Hg}$. in the $\mathrm{CO}_{2}$ pressure tending to eause a flow of $\mathrm{CO}_{2}$ from blood to air. Is this gradient of pressure suffieient to account for the 250 e.c. of gas normally expired per minute?

The passage of gas through a membrane depends $(a)$ on the nature of the membrane, $(b)$ on the structure of the membrane, $(c)$ on the physical state of the membrane, $(d)$ on the nature of the gas, and $(e)$ on the gradient of pressure.

(a) The layer of flattened eells separating blood from alveolar airdiffers little in chemieal nature from any other similar structure. One may note, however, its richness in lipoids. (b) It is eonstructed of large irregular flattened cells forming an extremely delicate layer as thin as the film of a soap bubble. The average thiekness of this membranous layer is $0.004 \mathrm{~mm}$. (c) Not only does the protoplasm forming the membrane eontain about 90 per cent. of water, but it is kept moist on both sides. (d) Carbon dioxide is very soluble in water. Water at body temperature and atmospheric pressure will absorb over half its volume of carbon dioxide. (e) Experiments by Krogh and others seem to have proved beyond question that the differences in tension existing on the two sides of the lung tissue are quite sufficient to aceount for the passage of the neeessary volume of gas. 
It is worth while to look a little more elosely at this problem. In Chap. XXII., p. 247, is given a table of absorption coefficients of the respiratory gases. These values of " indicate the volumes of gas at N.T.P. which will dissolve in 1 c.c. of water. Later in the same chapter, figures which hardly differ from a were given for the solubility of these gases in plasma, ete. The velocity of diffusion depends not merely on the pressure gradient and on the absorption coefficient of the gas, but also on a factor $\mathbf{k}$-the diffusion coefficient. $\mathbf{k}$ is a constant for each gas and each temperature. The appended table (from Locwy) will amplify this.

TABLE XLII.

Diffusion Coefficinnts.

$\begin{array}{llccc}\text { Temperature - } & - & 16^{\circ} \mathrm{C} & 37^{\circ} \mathrm{C} \\ \text { Oxygen - } & - & - & 1.62 & 1.68 \\ \text { Carbon dioxide - } & - & 1.38 & 1.43 \\ \text { Nitrogen - } & - & 1.73 & 1.79\end{array}$

The product of a and $\mathbf{k}$ gives the diffusion rate in $\mathrm{em}$. per 24 hours through a layer of water, $1 \mathrm{~cm} . \times 1 \mathrm{sq}$. $\mathrm{cm}$. with a pressure gradient of 1 atmos. For example, at $37^{\circ} \mathrm{C}$. earbon dioxide has a diffusion rate of $1.43 \times 0 \cdot 57=0.815 \mathrm{~cm}$. per 24 hours.

It has been found that $\mathrm{k}$ bears a definite inverse relationship to the square root of the molecular weight of the gas. The result of multiplying the diffusion coeffieient by the square root of the molecular weight of the gas is thus a constant for all gases. This diffusion factor $k \sqrt{m}$ has a value, for water, of 0.0649 .

The diffusion rate through lung substanee, because of its large eontent of lipoids and lipins must be greater than that through water. Experiments with soap bubbles and with frogs' lungs have confirmed this deduction. It has also been found that the velocity of diffusion is absolutely unaltered by slight alterations in the $p \mathrm{II}$ of the lung tissue. Loewy maintains that the rate of diffusion is the same in dead and in living lung tissue. The diffusion factor through lung has been estimated as 0-139. Experiment has shown definitely that $\mathrm{CO}_{2}$ passes just as readily in cither direction through the lung wall. This has been amply eonfirmed by Krogh, who found that the direction of diffusion depended entirely on the direction of the gradient of pressure, and the rate of diffusion was regulated by the steepness of this gradient.

The volume of gas diffusing per minute through one sq. em. of alveolar wall may be calculated from this formula:

$$
v=\frac{a\left(p_{1}-p_{2}\right) C}{760-\sqrt{ } m \cdot d}
$$


Dealing with earbon dioxide we may evaluate as follows: a at $37^{\circ}=0 \cdot 57$,

$p_{1}=\mathrm{CO}_{2}$ tension in the blood of the pulmonary artery $=$ about $46 \mathrm{~mm}$. $\mathrm{Hg}$.

$p_{2}=\mathrm{CO}_{2}$ tension in alveolar air $=$ about $40 \mathrm{~mm} . \mathrm{Hg}$, $p_{1}-p_{2}=46-40=6 \mathrm{~mm}$. $\mathrm{Hg}$.

This difference of pressure, of course, only exists at the beginning of the experiment. The blood loses carbon dioxide, i.e. $p_{1}$ decreases; ${ }^{\circ} \mathrm{O}_{2}$ passes into the alveolar air, i.e. $p_{2}$ increases, and $p_{1}-p_{2}$ tends towards zero. It is, therefore, necessary to take a mean value between 6 and 0 , i.e. $3 \mathrm{~mm}$. $11 \mathrm{~g}$.

$$
\begin{aligned}
& C=\text { diffusion faetor }=\mathbf{0} \cdot \mathbf{1 3 9} \text {, } \\
& \sqrt{m}=\sqrt{44}=6 \cdot 63 \text {, } \\
& d=\text { thiekness of alveolar wall }=0.004 \mathrm{~mm} \text {., } \\
& \text { i.e. } \quad v=\frac{0.57 \times 3 \times 0.139}{760 \times 6.63 \times 0.004} \\
& =0.01 \text { e.em. per minute. }
\end{aligned}
$$

As the effeetive absorptive surface of the lung is about $100 \mathrm{sq}$. metres, there ean pass through it eaeh minute

$$
100 \times 10,000 \times 0 \cdot 01=10,000 \text { e.em. }
$$

of earbon dioxide by simple diffusion.

One may eonsider the problem from another aspeet and determine the gradient of pressure neeessary to furmish the 250 e.e. of earbon dioxide normally expired per minute. Transposing the formula one gets

$$
p_{1}-p_{2}=\frac{v \times 760-\sqrt{m} \times d}{a \times c} .
$$

Evaluating this,

$$
\begin{aligned}
p_{1}-p_{2} & =\frac{250 \times 760 \times 6.63 \times 0.004}{0.57 \times 0.139 \times 100 \times 10,000} \\
& =0.063 \mathrm{~mm} . \mathrm{Hg} .
\end{aligned}
$$

That is, a differenee of $\mathrm{CO}_{2}$ tension between blood and alveolar air of only $2 \times 0 \cdot 063=0.12 \mathrm{~mm}$. $\mathrm{Hg}$. would be quite suffieient to eause 250 e.e. of $\mathrm{CO}_{2}$ to pass through the lung wall per minute. During work the amount of earbon dioxide eliminated by the lungs may be increased tenfold. The above figures show that there is ample wharf-spaee for this exportation.

The transferenee of oxygen from alveolar air to blood has been the eause of mueh eontroversy. Two eonflieting views both baeked by experimental faets are held. 
(1) The lungs may be considered as secretory glands. Fish have a swim bladder which is, like the lungs, an outgrowth from the alimentary eanal. Oxygen is seereted by it so as to equalise the speeific gravities of fish and water. The fish may secrete oxygen against the pressure produced in the bladder by immersion to a great depth, e.g. against the pressure of hundreds of atmospheres. Against this view may be opposed the histologieal fact that cells eomposing the walls of the swim-bladder structurally do not resemble those of the lung. The former are deep granular cells typieal of seeretory tissue, while the latter, like the eapsule of Bowman in the kidney, are thin and flat. Moreover birds, which have of all animals the most rapid and effieient respiratory exchange and so should have a lung epithelium exhibiting marked seeretory qualities, have no epithelial eovering at all, so that the capillaries appear to be almost completely free and surrounded by alveolar air.

(2) Most modern workers maintain that just as $\mathrm{CO}_{2}$ diffuses outwards so does oxygen diffuse from air to blood. The whole controversy turns on the existence of a pressure gradient for oxygen. The earlier investigators got results which indicated that the oxygen tension of the blood frequently exceeded that of the alveolar air. Later workers like Douglas and Haldane disagree with the earlier findings, and by the employment of finer technique have proved definitely that normally the tension of oxygen is always less in the blood than in the alveolar air. They still maintain, however, that under eertain more or less abnormal conditions - say, acelimatisation to high altitudes - there is an active absorption and transference of oxygen to the blood on the part of the pulmonary epithelium.

A man at rest requires about 300 c.e. of oxygen per kilo of body weight per hour. The average man weighs about 66 kilos, i.e. 330 e.e. of oxygen must pass into his blood every minute. During violent exercise the necessary intake of oxygen may be as great as 3000 e.e. per minute. In order to produee this transference from air to blood a eertain pressure difference is necessary.

Krogh has shown by an ingenious tonometric method, that the oxygen tension of the blood is always lower than the alveolar oxygen tension, and the difference is generally 1 to 2 -even 3 to 4 - per cent. of an atmosphere. One must now eonsider whether 1 per cent., i.e. $7 \cdot 6 \mathrm{~mm}$. $\mathrm{Hg}$, is a sufficient pressure gradient for respiratory purposes. 
Employing the same formula as for $\mathrm{CO}_{2}$ one finds with a differenee of pressure of $7 \cdot 6 \mathrm{~mm}$. Hg that

$$
v=\frac{0.0239 \times 3.8 \times 0 \cdot 139}{760 \times 5 \cdot 66 \times 0.004}=0.0006 \mathrm{c.cm} .
$$

per minute per sq. $\mathrm{cm}$. 'This gives a value of

$$
100 \times 10.000 \times 0 \cdot 0006=600 \mathrm{e.cm} .
$$

passing through the total effective absorptive surfaee of the lung. Thus we see that the physical conditions allow for an ample supply of oxygen for ordinary purposes. As a matter of fact a difference in pressure of less than four millimetres would be quite suffieient to ensure the supply of the 330 e.e. per minute required by the average man resting but awake.

How is the rate of transference increased to meet the needs of the man doing hard museular work who uses up 3000 e.e. of oxygen per minute? One very obvious point of differenee between a resting and a working man lies in the volume of air passing into the lungs per unit of time. The following table shows that the ventilation of the lungs is markedly inereased by the performance of work.

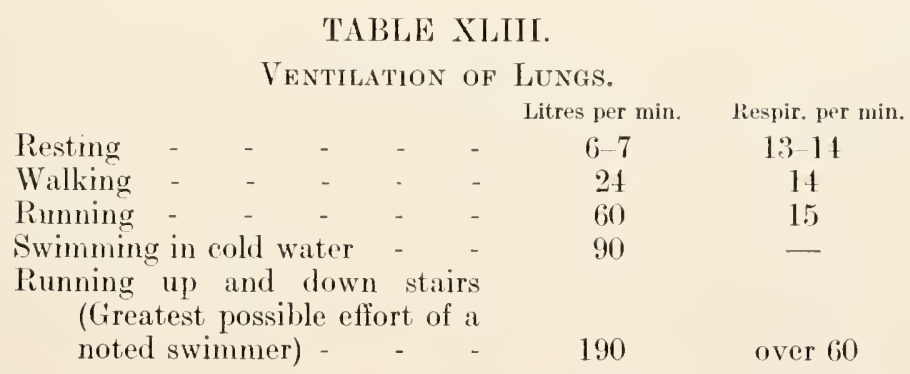

That is, by the eonstant addition of fresh air to the lungs the tension of oxygen in the alveoli is kept from falling. A tenfold inerease in ventilation provides an ample margin for even the most strenuous work.

Those who hold to the secretory hypothesis maintain that while diffusion is capable of providing a suffieient oxygen supply for a normal existence even with hard museular work, yet when the pressure of oxygen in the hung is brought much below normal, active secretion by the lung epithelium must be brought into play. Aviators, for instance, rise to great heights, and so eome under a low barometric pressure. 
It is well known that ballooning, for instanee, eauses respiratory distress ; so, too, does mountaincering. Mountain siekness frequently begins at altitudes of 2000 to 3000 metres, partieularly if the ascent has been fairly rapid by railway. Airmen usually suffer after ascending 5000 to 6000 metres. The partial pressure of oxygen in the blood as determined by the earbon monoxide method has been found to be $35 \mathrm{~mm}$. $\mathrm{Hg}$ above the oxygen pressure of alveolar air. Considerable doubt exists, however, as to the validity of this method. It depends on the eareful matehing of a earboxylated blood with a blood-earmine mixture, and minute quantities of blood are used.

TABLE XLIV.

$\begin{array}{ccc}\begin{array}{c}\text { EfFect of Heigit } \\ \text { Height above sea level } \\ \text { in metres. }\end{array} & \begin{array}{c}\text { Barometer. } \\ \text { mm. Ilg. }\end{array} & \begin{array}{c}\text { Pressure. } \\ \text { Per cent. of an } \\ \text { atmosphere. }\end{array} \\ 0 & 760 & 100 \\ 1000 & 670 & 88 \\ 2000 & 593 & 78 \\ 3000 & 524 & 69 \\ 4000 & 463 & 61 \\ 5000 & 410 & 54 \\ 6000 & 357 & 47 \\ 7000 & 320 & 42\end{array}$

TABLE XLV.

Effect of Atmospheric Pressure on Alveolar Oxygen Tension.

$\begin{array}{lcccc} & & \begin{array}{c}\text { Height above sea } \\ \text { level in metres. }\end{array} & \begin{array}{c}\mathrm{O}_{2} \text { tension of } \\ \text { air. } \mathrm{mm} . \mathrm{Hg} .\end{array} & \begin{array}{c}\text { Alveolar } \mathrm{O}_{2} \text { tension. } \\ \mathbf{m m} . \mathrm{Hg} .\end{array} \\ \text { Berlin } & - & 54 & 157 & 105 \\ \text { Brienz } & - & 500 & 148 & 88 \\ \text { Brienzer Rothorn } & 2130 & 121 & 62 \\ \text { Col d'Olen - } & - & 2900 & 110 & 60 \\ \text { Monte Rosa } & - & 4560 & 89 & 61\end{array}$

One fact in the data given by those investigators is a little strange although it may have no signifieanee. Notwithstanding that the arterial oxygen tension was always higher than that given for the alveolar air, it was never higher than that of the atmosphere at the time, although oeeasionally not mueh below it. Why should the seeretory power fail just at this level and not raise the oxygen tension above that of the atmosphere? Is it possible that the blood had come into equilibrium with an oxygen tension which was not given correetly by the measurement of that of the alveolar air? Might it not also be possible that the carbon monoxide method gives different values when the 
hacmoglobin content of the blood is increased, as in the ease of acclimatisation to high altitudes ?

TABLE XLVI.

Atmospheric Pressure and Number of Erythrocytes.

$\begin{array}{lccc} & & \begin{array}{c}\text { Height alove sea } \\ \text { level in metres. }\end{array} & \begin{array}{c}\text { Red } \\ \text { corpuscles. }\end{array} \\ \text { Christiania - } & 0 & 4,970,000 \\ \text { Zurich - } & - & 412 & 5,752,000 \\ \text { Davos - - } & 1560 & 6,551,000 \\ \text { Arosa - - } & 1800 & 7,000,000 \\ \text { Cordilleras - } & 4392 & 8,000,000\end{array}$

Hasselbalch shows that the liydrogen ion concentration is inereased under those eireminstanees.

"This question of secretion by the lungs is instructive from the point of view of 'vitalism.' When first proposed, it was held to apply to the ordinary state of affairs ; but as improvements were made in experimental methods, the absorption was shown to follow physical lines; it was then held to apply to cases of muscular exercise, and now only to acclimatisation to high altitudes. One might venture to say that the more accurate the methods of investigation the better is it found that chemical and physical laws are capable of explaining physiological phenomena." - Bayliss, Principles of General Physiology.

Let us now consider what happens to the inland transport service when the port becomes congested with incoming traffic. Compressed air is used in all the great sub-aqueous works of to-day, in diving, in preparing foundations for bridges, in pier building, and in the construction of tunncls or shafts through water-bearing strata. It is well known that a large percentage of the men working under those eonditions suffer illness and many die. In the eonstruction of the Adour bridge 90 per cent. of the workers suffered from " eompressed air" disease, and in the boring of the Hudson Tumel 2 per cent. of the caisson workers dicd each month. Compressed air sickness is characterised by its protean symptoms - loss of speech, blindness, deafness, transitory madness, vertigo, loss of eonsciousness, emphysema, spinal paralysis, ete. None of the symptoms, with the exeeption of some slight ear trouble, ever oecurs while the men are under pressure. "Mules lived about a year in the Hudson tumnel and were healthy enough to kick and bite at all "comers." The illness secmed to eome on during or after decompression and is now known to be due to the appearance of bubbles of nitrogen in the tissues. Boyle, in the seventeenth century, showed that bubbles of gas appeared in the humours of a viper's eye when submitted to rapid decrease of air pressure under 
an air pump. Paul Bert in a remarkable series of experiments (1870-1880) proved that these bubbles were nitrogen and that they might bloek up the eapillaries in some part of the body and, by eutting off that part from the blood supply, produee one or other of the symptoms mentioned above.

If merely the pressure of the surrounding air is increased, why should nitrogen alone be set free on deeompression? When a person is plaeed in eompressed air, the blood passing through the lungs dissolves the same volume of the atmospherie gases as it does under normal eonditions, but the weight of gas absorbed will be inereased above normal in proportion to the inerease in partial pressure of each gas in the alveolar air. Now we have seen that the partial pressure of earbon dioxide in alveolar air is a eonstant, henee there ean be no inerease in the amount of earbon dioxide present in the blood during exposure to eompressed air. Oxygen is earried in two ways, $(a)$ by haemoglobin, and $(b)$ in simple solution in the plasma. (a) At atmospherie pressure the haemoglobin is almost saturated with oxygen,- the little erythroeyte barges are eomfortably filled. Inerease of alveolar tension may produee a slightly better oxygenation of the haemoglobin, but it requires a very marked inerease of pressure to make an appreeiable inerease in the amount of oxygen earried by this means (Fig. 56). (b) Aecording to Dalton's Law, the amount of gas dissolved is direetly proportional to its partial pressure.

At body temperature and normal pressure, arterial blood holds 3 e.c. of oxygen in solution in every litre of fluid. If the pressure is inereased $x$ times, then eaeh litre will still dissolve 3 e.e. of oxygen, but this oxygen will weigh $x$ times as mueh as normally. On being earried to the tissues, the blood will share its dissolved oxygen with them in proportion to its partial pressure and to its solubility in the various tissues. These tissues will use up the dissolved oxygen in preference to that earried by the eorpuseles, and as the amount in solution, exeept after exposure to enormous pressures, is only a small pereentage of the total available oxygen in the arterial blood, it will soon be used up. We again draw attention to the fact that increase in the available oxygen does not cause increase in its utilisation by the cell. A eandle burns more brightly in oxygen and soon ends its light-giving eareer. The eell " ea's eanny" - holds on the even tenor of its way, takes up the oxygen it requires for its immediate needs and keeps no store but the tiny quantity dissolved in its protoplasm.

To take a eonerete example. At $38^{\circ} \mathrm{C}$. and atmospherie 
pressure 1 litre of blood contains 200 c.c. of oxygen carricd by haemoglobin and only 3 e.e. in simple solution (measuredat N.T.P.). Sixfold inerease of pressure makes no appreciable difference to the value of the corpuseular oxygen but increases the dissolved oxygen to about 18 c.c. That is, the ratio of dissolved to " bound" oxygen is inereased from about $1 / 70$ to $6 / 70$. The cntire result would be that as there are about $3 \frac{1}{2}$ litres of blood in the average man the venous blood would carry not more than 20 per eent. more oxygen than normally. In other words, the desaturation of haemoglobin would take place to quite the same extent as under atmospheric pressure. This eliminates oxygen as the gas causing "eompression illness" and leaves nitrogen alone to be dealt with.

Let us first consider how the nitrogen taken up by the blood from the alvcolar air is distributed to the various tissues of the body. In view of what we have seen as to the ease and completeness with which the blood becomes saturated with oxygen in its passage through the pulmonary capillaries, we may take for granted that saturation with nitrogen under the same conditions is just as eomplete. It is also reasonable to suppose that Dalton's Law of partial pressures is just as applieable to blood exposed to compressed air as to any ordinary solution. This supposition is supported by experimental facts. When blood is exposed to compressed air it will absorb a volume of nitrogen commensurate with the absorption eoeffieicnt of this gas in blood. During its passage through the tissues it will share its load of nitrogen with them in proportion $(a)$ to the absorption eoeffieient of the gas in blood and tissues and $(b)$ to the partial pressure of the gas in blood and tissues. (a) With regard to the first point, the solubility of nitrogen per unit mass of tissue varies greatly. For example, fat can absorb about six times as much nitrogen gas as blood, while the carthy eonstituents of bone probably absorb only an infinitesimal amount. With these two tissues excepted we may consider that, as the others differ but slightly in chemical and physieal eonstitution from plasma, they also take up approximately the same quantities of gas. (b) Normally the tissues are saturated with nitrogen at its partial pressure in the atmosphereevery gram of tissue contains approximately 0.0145 e.c. of nitrogen. If the external pressure is increased, this volume will immediately be diminished eorrespondingly, and the deficit will be made good at the expense of the eireulating blood. Take for example the sudden inerease in pressure to three atmospheres brought about by a rapid descent through $60 \mathrm{ft}$. of water to the 
bed of the sea. The volume of gas in solution in the body is at onee reduced to $1 / 3$, viz.: $0 \cdot 005$ e.e. per gram. At the same time the blood in the lungs lias its content of nitrogen redueed from its normal value of 0.87 e.e. per 100 e.e. of blood to 0.29 with almost immediate restoration to the normal figure. The litre of blood in the eapillaries of the lungs would now have in solution three times the weight of nitrogen as under normal pressure. When the blood arrives at the tissues, partition of its load will take plaee. Eaeh gram of tissue has a defieit of 0.01 e.e. of nitrogen, and nitrogen will pass from blood to tissue till eaeh gram of tissue eontains the normal value of 0.015 e.e. per gram. This value will not be reaehed at onee, because the very aequisition of nitrogen by the tissue implies the loss of nitrogen by the blood. The blood then returns to the lungs for a fresh eharge, whieh it again shares with the tissues, and so on. Haldane ealeulates that somewhere about five hours are required before the body is eompletely saturated with nitrogen after any ehange of pressure, i.e. till the partial pressure of nitrogen in the tissues eorresponds with its partial pressure in the blood and so to its partial pressure in the alveolar air.

If we eonsider the amounts taken up by the various tissues we may arrive at some eonelusion as to the meehanies of the proeesses of saturation and desaturation. The average working man weighs $70 \mathrm{~kg}$., of this amount 15 per eent. or $10.5 \mathrm{~kg}$. is fat or fatty material; 5 per eent. or $3.5 \mathrm{~kg}$. represents the amount of blood; while the earthy eonstituents of bone (about 3 per eent.) may be negleeted.

TABLE XLVII.

Distribution of Nitrogen in the Tissues of Men Weighing 70 Ka.

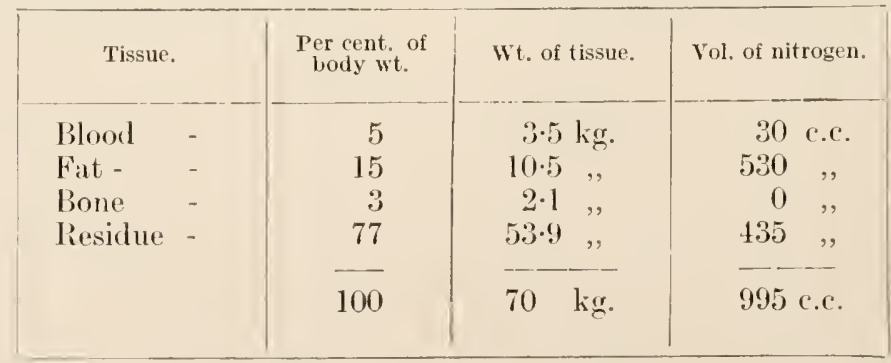

Blood, as we have seen, ean take up in simple solution about 0.87 e.e. of nitrogen for every 100 e.e. Taking the speeific gravity of blood as 1.06 we may eonsider that about 30 e.e. of 
nitrogen are constantly in solution in the blood. Fat is capable of absorbing six times as much nitrogen as an equal weight of blood, i.e. we may write down 500 e.e. as the volume of the gas held by the fatty matter of the body. Leaving out the earthy part of bone the remaining tissues account for about 435 c.c.

Taking round figures we see that the average man has, dissolved in his blood, about a litre of nitrogen. 'The weight of this litre is a funetion of the pressure under which it has been absorbed. Looked at from another point of view, the weight of nitrogen held in solution by the tissues is 32 times as great as that present in the blood. If, therefore, the blood is, for the purpose of this calculation, considered as spread uniformly and at a uniform rate throughout the body, the tissues would receive at the end of one complete eircuit of the blood after exposure to a sudden increase in air pressure, $1 / 32$ of the exeess of nitrogen corresponding to complete saturation at the new pressure. The seeond round of the circulation would add $1 / 32$ of the remaining deficit in saturation, and so on. Haldane finds that it takes 23 rounds of the cireulation to half saturate the tissues at the new partial pressure of nitrogen. The progress of the saturation of the body with nitrogen may be represented by a logarithmie eurve (Fig. 57). As about 3.5 litres of blood pass through the lungs every minute and as the total blood volume is also 3.5 litres, we may substitute mimutes for rounds of the circulation and state that it requires 23 minutes to render the tissues half saturated to a new pressure of nitrogen.

The proeess of desaturation, provided physiological eonditions are kept eonstant, follows the same curve. If the tissues are exposed to blood earrying nitrogen in excess of the normal amount, for suffieiently long to be in gaseous equilibrium with that bloodi.e. to be saturated-then in order to prevent the formation of bubbles, the process of desaturation would need to be earried out at the same rate as the saturation. If the desaturation rate were too rapid, then gas would be released from the tissues more rapidly than it was being passed from blood to alveolar air. 'This would entail a very slow and uniform rate of deeompression. A diver's aseent from the sea bed might have to be spread over hours. Paul Bert, from his experiments on animals, eoneluded that the decompression period should be 30 minutes for under 3 atmospheres, and 60 minutes for 3 to 4 atmospheres. This ruling of the famous French seientist has never been carried out in industrial praetice, the usual period for "leaking out" being 
about 15 minutes altogether. As a result of this haste to get into "free air," constructional engineers are afraid to put their men under more than +3.5 atmospheres. Bullion has been salved from ships lying $\mathbf{1 7 1}$ feet below the surfaee. 'The divers in this ease stayed below for only 20 minutes at a time and took 20 minutes to ascend. Even then some of them were strieken with paralysis. Greenwood endured eompression to 7 atmospheres $(=210$ feet of sea water), but took over 2 hours to deeompress. 'These long

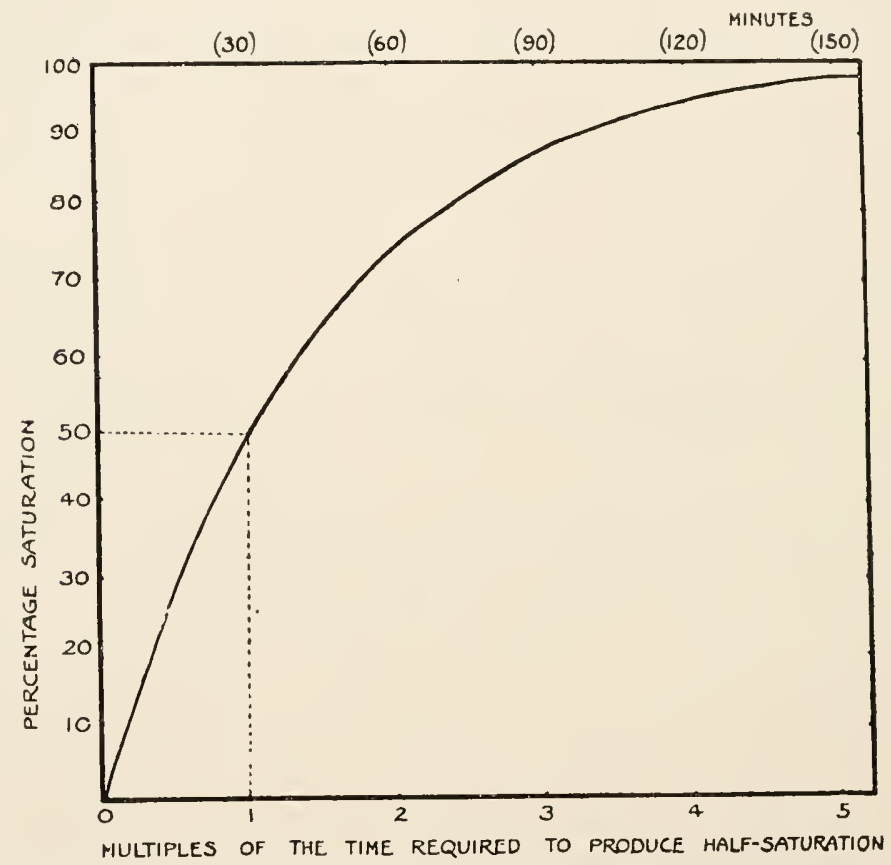

Fig, 57-Curve showing the progress of saturation of any part of the body with nitrogen after any given sudden rise of air pressure (after ilalane).

periods of deeompression which seem neeessary for safety, put the men in eharge in an awkward dilemma when, on aeeount of some mishap, it is neeessary to bring men at once to the surfaee.

From table XLVIII. it will be seen that the diver is brought to the surfaee from the bottom in stages. These stages are three metres apart and the time spent at each one depends on the duration of his stay on the bottom. This method of decompression by stages depends on the empirieal faet that no untoward results arise from even a rapid decompression of one atmosphere or less. 
An atmosphere or $760 \mathrm{~mm}$. of mereury is equal to a pressure of $1 \mathrm{~kg}$. per sq. em. or to about 3 metres of sea water. Even with this more rapid means of attaining normal pressure, the diver is limited either to a very short stay under water or to a tedious waiting at various levels.

\section{TABLE XLVIII,}

A Portion of a Diving Table used by Naval Divers.

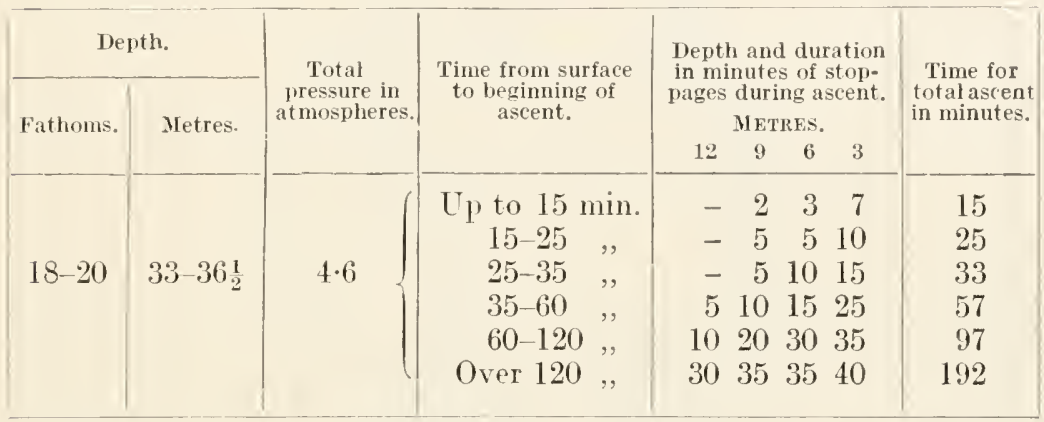

Haldane and his collaborators have very fully investigated this question. They argue that, as the volume of gas in solution is constant no matter what is the pressure, and as it has been proved to be perfeetly safe to decompress rapidly from a plus pressure of one atmosphere $(\mathbf{1} \cdot \mathbf{2 5}$ atmospheres to be exact) to normal, then it must be equally safe to deeompress rapidly to half pressure for any value. For example, if the total pressure were eight atmospheres, these workers advise a rapid decompression to four atmospheres, and after a pause to two atmospheres, and, after a pause, more slowly to normal pressure. The principle underlying this plan is that the diseharge of nitrogen from the start of decompression is at the maximum rate consistent with safety. The rate of diseharge, of eourse, depends on the gradient of pressure between venous blood and alveolar air. This gradient is kept as steep as possible, and there is, therefore, a maximum elimination by the lungs. 


\title{
CHAP'TER XXIV
}

\author{
CIRCULATION
}

" The circling streams, once thought but pools of blood, (Whether life's fuel or the body's food)

From dark oblivion Harvey's name shall save."

DRYDEN.

The inland transport system that we have had under consideration differs materially from our eanal system. Not only are the barges submersed in the plasma but the forec which earries them along is the force which eauses the plasma itself to move. The waterways are a scries of elastic-walled tubes forming a closed circuit.

- In this circuit is a central pumping station, the heart which keeps the blood in motion. The accompanying figure (Fig. 58) is a diagranmatical view of a vertical-mesial section through the heart. From it we learn that the heart is not a simple structure. In the diagram four distinct eavities ean be seen, viz. : right and left ventricles, left auricle and aortic space-the right auricle is not shown. The heart is really a double pump consisting of a main pump or systemic heart (left auricle and ventricle) and a subsidiary pump or pulmonary heart. In Fig. 59 is given a scheme of the eirculation. By contraction of the left ventricle the blood is foreed along a series of eonducting tubes or arteries (Art.) which lead to every part of the body and end in the substance of the tissues in a network of innumerable hair-like eanals, the eapillaries (Cap). 'These eapillary vessels are the wharves of the tissues. Through their walls takes place the exehange of imports and exports by which we measure the metabolism of the tissues. Consequently it is found when the eapillaries join together to form the wider conducting canals, vemules and veins, that the blood has lost some of its eargo of oxygen and nutrient matter, and has gaincd a certain amount of waste matter. 'This withdrawal of nutrient material is made good by the diversion of some of the blood from an arterial eanal to the eapillaries in the 
walls of the intestine (Al.C.). The waste matter is climinated, as we have seen, by a capillary mechanism in the kidney. Chemical

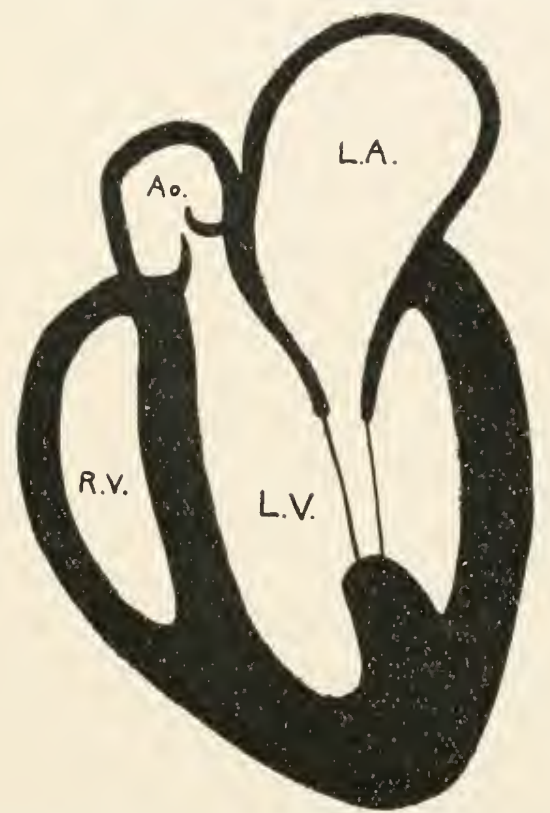

Fra. 58.-Vertical Vesial Section through Heart to show Aortie and Mitral Valves. $R$.V., right ventricle; $L . V$., left ventricle with papillary muscle; $L . A$., left auriele with the mitral valve extending into the left ventricle: Ao., aorta with anterior eusp on top of septum.

(Noël Paton's Essentials of II uman Physiology.)

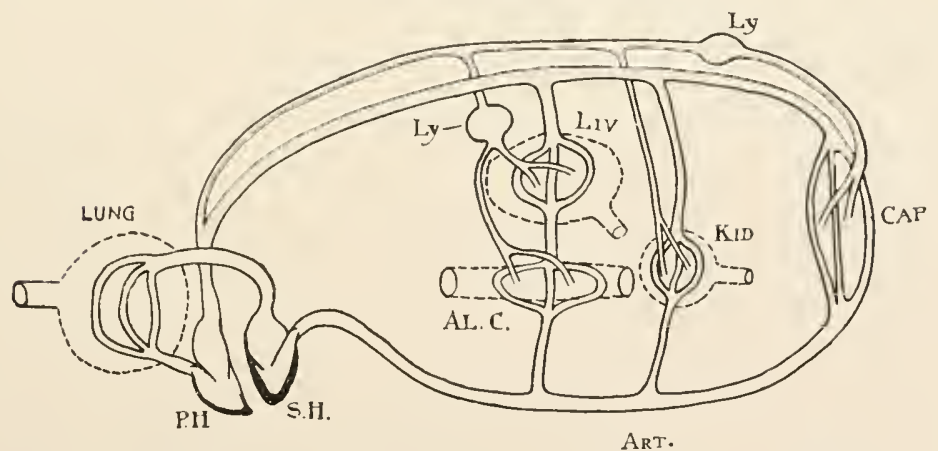

Fit. 59.-Scheme of the Circulation. S.H., systemie heart sending blood to the capillaries in the tissues, Cap. The blood brought back by veins, and the exuded lymph by lymphatics, $L y$. passing through glands ; blood sent to the alimentary canal, $A l C$. and from that to the liver, $L i v$; blood also sent to the kidneys, Kid.; the blood before again being sent to the body is passed through the lungs by the pulmonie heart, $I$..II. (Noël Paton's Essentials of II uman Physiology.)

changes oceur on the passage of the blood through the eapillaries of certain factories, e.g. liver and spleen. The loss of oxygen is 
not made good until the blood has been earried by the veins into the right auricle, passed from this reeeption house into the body of the pump, the right ventriele $(P . I I$.$) and foreed by the aetion$ of this subsidiary pump into the lung eapillaries. There, as we saw in the last ehapter, it gets rid of the exeess of earbon dioxide and makes up its deficit of oxygen. Finally the blood, with its fresh supply of nourishing substanees from the alimentary eanal and of oxygen from the lungs, is poured into the reeeiving ehamber of the main pump-again to pass into the left ventriele and so to the tissues.

From the eapillaries some of the eonstituents of the plasma are foreed into the spaees between the cells as lymph. From these spaees the fluid either passes baek into the eapillaries or flows away in a series of lymph vessels whieh earry it through lymph glands (Ly.) from whieh it gains eertain neeessary eonstituents and finally bring it baek to the eentral pump.

This, in brief, is the cireulation as we know it to-day, and this knowledge is due in great part to the labours of Harvey. Before his time little was known of how the blood was distributed in the body. Of one point the old physiologists were sure, and that was that there was no eireulation of the blood, only an ebb and flow. Harvey's work is a perfeet example of how seientifie work should be earried out. First of all, he eleared his mind of all preeoneeived ideas and got down to bedroek. Then he stated his method. The method employed was that now made famous by the author of Sherloek Holmes, viz., induetion, based on eareful investigation. He examined the valves of the veins, and using them as sign posts, traeed the eourse of the blood. Similarly, the valves of the heart permit a eurrent to flow in one direetion only. There never was a more eomplete argument than the one that Harvey pressed for the eireulation of the blood. There eould be no ebb and flow where all the valves were "one way." No scientifie work is complete without a referenee to quantities. The test of truth must rest with the balanee or measuring meehanism. Harvey found that the left ventriele of a man's heart held two ozs. of blood without being distended. If only half the load were diseharged at eaeh systole and the heart beat 70 times per minute, then 700 ozs. or 44 pints of blood would be diseharged into the aorta every 10 minutes. The total blood volume is under 9 pints. From this he urged the neeessity of some eommunieation between the arteries and veins. That is, after experiment, observation, analysis and argument come 
reasoned hypotheses. Four years after Harvey's death the great Italian anatomist Malpighi saw under the microseope these eapillaries which the physieian had seen with the eye of faith. The demonstration of the aetual passage of blood from arteries to veins through eapillary ehannels was given in 1688 by Leeuwenloek, the illiterate janitor of the aldermen of Delft.

Dynamically eonsidered, the blood aets in mueh the same way as any other equally viseous fluid driven through a series of tubes. In order to understand many of the problems which one meets in the study of physiologieal phenomena, it is necessary to obtain some insight into the movement of fluid under an external driving force. As Servetus says, "In order to learn how the blood is formed it is necessary to ascertain how it moves." First of all, let us consider the flow of liquid from a reservoir through a series of tubes. In a liquid the moleeular forces are in equilibrium; the kinetic forees characteristic of matter in the gascous state are exactly balaneed by the Newtonian forees predominant in solids. As Soddy would put it, the processes of pellation and tractation would not be manifest. Gravitation alone lias to be reckoned with. In common parlanee, liquids seek their own level and so always tend to flow to the lowest possible position. It is a wellknown fact that the speed attained by a body falling in vacuo through the distance $(\mathrm{h})$ equals $\sqrt{2 \mathrm{gh}}, \mathrm{g}$ being the aceeleration produeed by gravity. This formula eannot be used to estimate the velocity of fluid eseaping from a reservoir. As every boy knows, when the waste water is being run out from the bottom of a wash-hand basin, the fluid tends to rotate round the orifice and to assume a conical form. This is due to the attempt of the water particles to rush the exit (so to speak). Only a limited number of them lie in the eolumn vertically above the opening. The majority, occupying more lateral positions, tend to escape along with the minority in the queue and so exert a foree applied at an angle to the line of exit. Consequently, the total energy eannot be used to produce velocity. Some of it has to be spent in overeoning the resistance at the outlet.

Still further modification of the formula is required if the orifice is fitted with an exit tube. It must be evident that the presence of this passage imposes a greater resistance to outflow and materially reduces the rate. Let us consider the effect produced on rate of flow by attaching a rigid eylindrical tube of uniform bore to the lower orifice of the reservoir. In order to simplify matters, we will place this pipe horizontally. Two eauses 
tend to rednee the kinctie energy of fluid flowing through a tube, viseosity or internal friction and external friction on the walls of the tube. On aecount of the latter, the outermost layers of the fluid adhere to the walls of the tube and beeome more or less stationary. 'The moleeules of the layers of fluid next to the outermost tend to eohere to the stationary layer on one hand and are pulled along by their eohesion to the next inner layer. As a result, their veloeity is deereased. The net result is that a whole series of eylindrieal layers is produeed eaeh with a different rate of flow-ranging from the almost stationary outer layer to the central axial eolumn, which is retarded least of all and, therefore, possesses the greatest kinetie energy. In a straight tube of uniform bore, such as is under eonsideration, this retarding influence reduees the average rate of flow to half that of the axial stream. It is obvious, therefore, that a eonsiderable amount of the potential energy of the liquid in the reservoir is absorbed in overeoming the peripheral resistance eaused by cohesion and adhesion. Resistance to flow also depends on the area of eross-seetion of the tubethe wider the tube the larger the number of eylindrieal layers over whieh the adhesive resistance spends itself and, therefore, the less the resistance met by the axial stream. A tube so narrow that only an outer layer and a eentral eolumn eould pass along would move with infinite slowness. Exeept in instanees in whieh the eondueting tube has a very large or a very small diameter, the rate of flow is proportional to the area of eross-seetion. Furthermore, sinee the resistance in a tube of uniform diameter is proportional to its length, the energy of the fluid must deerease gradually from the reservoir to the outlet of the tube. 'The energy of the fluid is shown by the pressure it exerts. Pressure may be measured by some form of manometer. It is suffieient to insert a number of vertical glass tubes, of uniform bore and open to the air, at various points of the eondueting tube to see the fall of pressure with distanee from the souree of power. The fluid rises in these eollateral tubes or piezometers to a height proportional to the pressure in the main conduit. In other words, the level of the liquid in those pressure-gauges is aeeurately adjusted to the peripheral resistanee eneountered by the liquid as it passes their points of insertion. Sueh a system is represented in Fig. 60. 'The power furnished by the liquid, in the eonstant-level reservoir (R), is the downward pressure of gravity. The pressure at various points is manifested by the height of the fluid in the branch tubes $(A) \mathbf{1}, 2,3$, ete. If the levels of the eolumn of 
liquid in each of these piezometers be joined by a straight line which is produced to the reservoir wall at $(\mathbf{y})$ the mass of liquid will be divided into two portions. 'The lower portion ( $\mathbf{r}$ ) represents the portion of the encrgy of the total spent in overeoming the resistance and is consequently known as resistance-pressure. Of the remainder, a certain amount (o) is spent in forcing the fluid through the orifice into the tube. The aetual driving force or velocity pressure eomes from the mass (v).

FALL OF PRESSURE

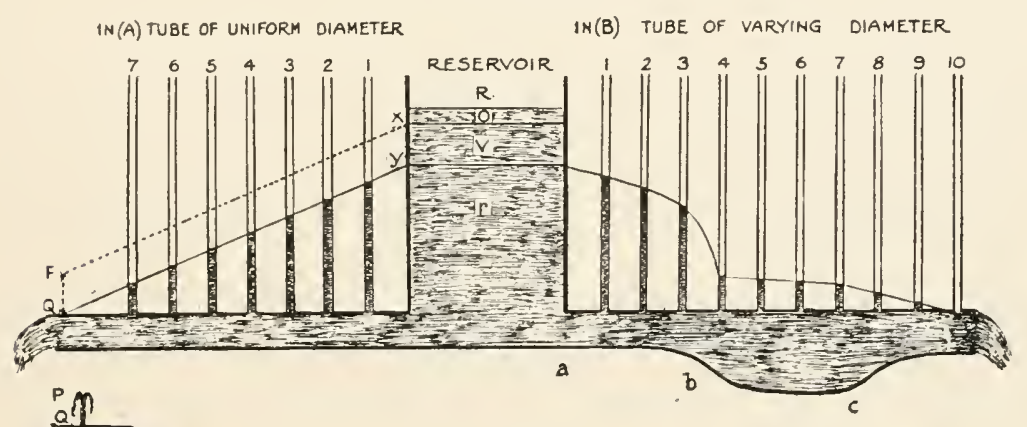

FIG. 60.

If the main tube is not of uniform bore-suppose $(B)$ it inereases in sectional area, at first gradually ( $a$ to $b$ ) and then somewhat suddenly ( $a t \mathbf{b}$ ) - corresponding alterations in pressure may be seen in the manometers. Increase in width means smaller resistance, and therefore a smaller resistance-pressure is required to drive the fluid along the tube. As the total mass in the reservoir is kept eonstant, the amount not required in $\mathbf{r}$ goes to increase $\mathbf{v}$. There being relatively a greater head of pressure, the levels shown by the manometers will tend to decrease progressively at a slower rate than before. If, on the contrary, the bore of the tube is diminished as at $\mathbf{c}$, the fall of pressure will become more rapid. Further, if at b a constriction is produced, resistance to flow is augmented, and therefore there is a heaping up of the fluid in the earlier tubes 1, 2 and 3, a rapid fall to tube 4, and thereafter a fall of pressure at the same rate as in the earlier part of the system. All the above is stated in terms of pressure. Putting the same matter in terms of velocity of flow, one may say that if a tube be used, the second segment of which is wider than the first and third, the speed of flow will be decreased in the central one.

In the preeeding expcriment, the head pressure has always been kept constant by making provision for a steady influx of 
water to the reservoir to eompensate for the outflow. If, however, the head of pressure is produeed by the aetion of a piston in a eylinder, it will not cause a continuous but an intermittcnt flow in the main eonduit. The pressures shown in the piczometers will vary from a maximum to a minimum as the wave of pressurc passes down the system after cach stroke. Such conditions entail great loss of power. In order to reduee this loss to a minimum, it is neeessary to replaee the rigid conduit by an elastic tube. Such a tube would, of eourse, if rigid, permit a certain flow of fluid per unit of time per unit of pressure, say with a constant veloeity of $(\mathbf{v})$. Now on the descent of the piston more water tends to be forced into the eonduit than ean be passed out with this velocity (v). The elastic walls distend till their clastie power exaetly eounterbalanees the extra energy, and the fluid has an outflow veloeity of (v). 'The influx of water having eeased, the steady pressure of the distended walls of the tube as they reeoil kecps the fluid flowing at the eonstant velocity (v). In this way the fluid is held under a continuous pressure and, provided the pump has the proper frequeney, the outflow remains praetieally eonstant. That is, the elastic tube really converts an intermittent inflow into a constant outflow, the property of elasticity preserving normal conditions of flow even during periods when the piston is not descending.

Such a system of single stroke pump and elastie regulator does not differ in essentials from the one eontrived by nature to provide a perfeet transport serviee to every unit of a eomplex organism like the human body. In Fig. 61 a simple foree pump and its eireulating system is compared with the left ventricle, aorta. etc.

The manner in which the contents are foreed out from the ventriele differs in some details from that obtaining in the water pump. In the latter, a rigid piston deseends within a rigid cylinder and thus obliterates the space of the main ehamber and forces the water through the outflow pipe. The power neeessary to drive the plunger home is derived from an engine of some sort, external to and independent of the pump itself. In the heart, the elastic museular walls of the ventrieles contraet as a whole, deriving their force just as any other museular strueture does, from the potential energy of materials brought to them by the blood and liberated in their protoplasm.

The value of the work done by a pump may be ealculated approximately by the formula

$$
W=Q R+\frac{w v^{2}}{2 g}+O,
$$


where $\mathbf{W}$ (gram-metres) is the work done at cach stroke, $\mathbf{w}$ is the weight in grams and $\mathbf{Q}$ the quantity of fluid in c.c. expelled at each stroke; $\mathbf{R}$ is the average resistance of the circuit, $\mathbf{v}$ (metres per sec.) is the velocity of cxpulsion, and $\mathrm{g}$ is the acceleration due to gravity $=9.8$ metres per sec. per sec. That is, $Q R$ represents the resistance pressure ( $\mathrm{r}$ in Fig. 60) and $\frac{z \omega v^{2}}{2 g}(\mathrm{v}$ in Fig. 60) the velocity pressure while $\mathbf{O}$ is the cnergy expended in overcoming the resistance to outflow at the orifice of the pump.

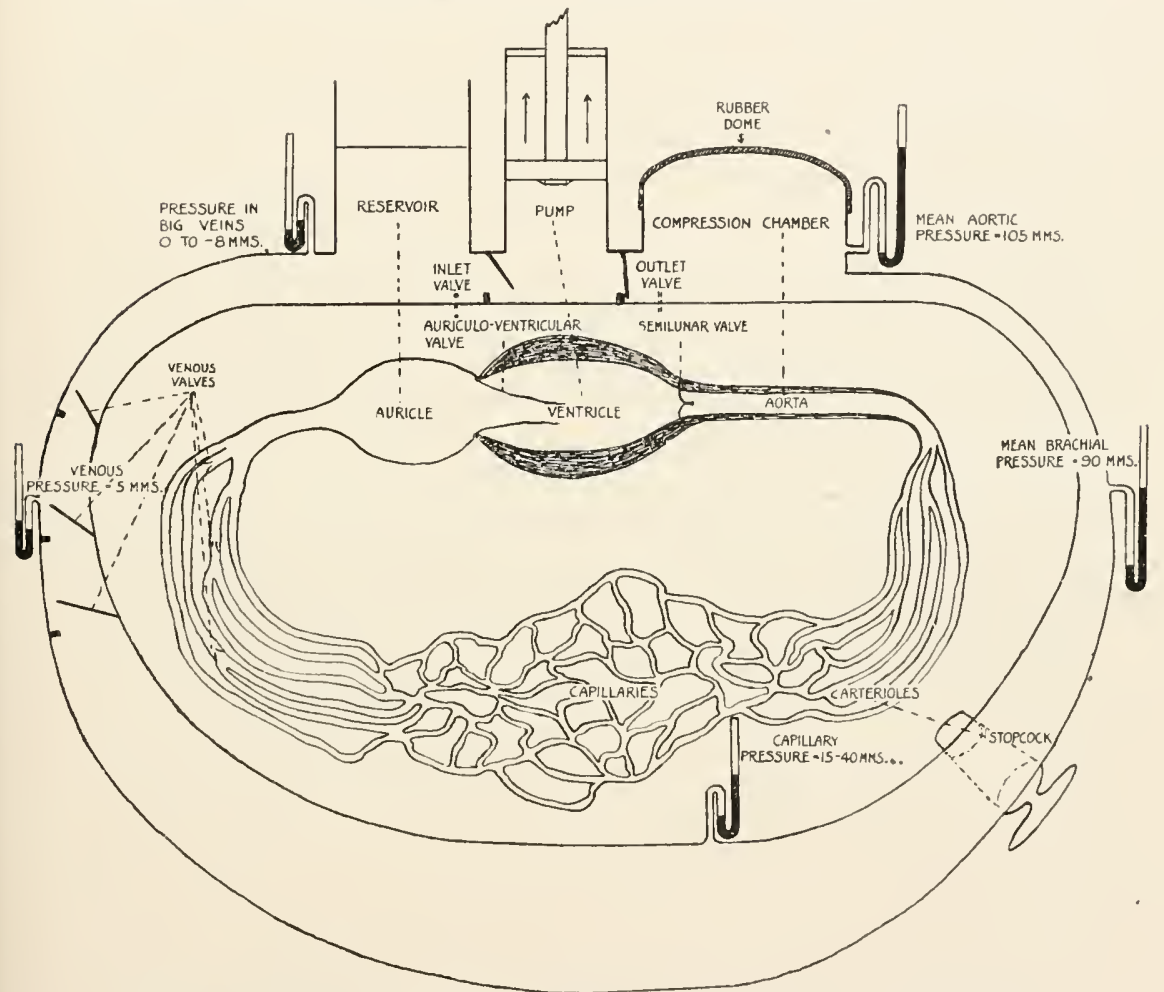

Frg. 61.-Diagram of a simple force pump (outer eireuit) to compare with diagram of eirculation from left side of heart (imer circuit).

If we take average figures for the left heart as follows :

$$
\begin{aligned}
Q= & 60 \text { c.c., } \\
R= & 100 \mathrm{~mm} . \mathrm{Hg} \text { pressure in aorta } \\
= & 0.1 \times 13.6 \text { gram-metres }(1 \mathrm{c.c} \text {. of } \mathrm{Hg} \text { weighs } \\
& 13.6 \text { grams), }
\end{aligned}
$$

the expression $Q R$ may be evaluated as

$$
60 \times 0 \cdot 1 \mathrm{~m}, \times 13 \cdot 6=81 \cdot 6 \text { gram-metres. }
$$


That is, about 80 gram-metres of work is done in overcoming the resistance of the conducting tubes. This value is only approximate, as the work done in forcing a fluid along an elastic tube in which the pressure falls steadily, say from $150 \mathrm{~mm}$. $\mathrm{Hg}$ to $50 \mathrm{~mm}$. $\mathrm{IIg}$ is not strietly proportional to the average pressure, but would need to be determined by integration. The error is, however, less than 10 per eent. If the blood is expelled at a veloeity of 0.5 metre per second, the velocity pressure will have a value

$$
\frac{70 v^{2}}{2 g}=\frac{60 \times(0.5)^{2}}{2 \times 9.8}=0.7 \text { gram-metre. }
$$

This quantity is so small compared with the former that for all practieal purposes the work of the heart may be taken as proportional to the output multiplied by the average arterial pressure, i.e. $W=Q$. R.

Similarly the work of the right heart may be estimated from the average pressure of the pulmonary artery $(20 \mathrm{~mm}$. $\mathrm{Hg}$ ) as $60 \times 0.02 \times 13.6=16.1$ say, 16 gram-metres per beat. The average heart beats seventy times per minute and, therefore, in 24 hours the work done by the heart (of a man at rest) will be about 10,000 kilogram-metres.

Muscular work, of course, augments this figure not only by increasing the volume of blood per beat and inereasing the number of beats but by raising the value of the velocity factor. During a short sprint, an athlete may have a pulse rate of 180 per minute with an output of 180 c.c. at each beat and an average arterial pressure of $120 \mathrm{~mm}$. $\mathrm{Hg}$. Then for the systemic heart :

$$
Q R=180 \times 0 \cdot 12 \times 13 \cdot 6=294 \text { gram-metres, }
$$

and $Q R$ (pulmonary) $=180 \times 0.025 \times 13 \cdot 6=61$ gram-metres.

If the time of outflow is considered as $3 / 8$ of each cardiac eyele, of which there are 180 per minute, then the contents of the ventricle, 180 c.c., are shot into the aorta at the rate of 1440 e.e. per second (say 1500 e.c.). If the cross-section of the root of the aorta be taken as $625 \mathrm{sq}$. mm., then the veloeity of expulsion will be $\frac{1500}{625}=\mathbf{2} \cdot 48$ metres per sec. (say 2.5 metres). Therefore :

$$
\frac{2 v v^{2}}{2 g}=\frac{180 \times(2 \cdot 5)^{2}}{2 \times 9 \cdot 8}=57 \text { gram-metres. }
$$

The total work on both sides of the heart will be :

$$
\begin{gathered}
\left.\begin{array}{c}
294+50 \\
\text { Left side }
\end{array}\right\}+\left\{\begin{array}{c}
61+57 \\
\text { Right side }
\end{array}\right\}=462 \text { gram-metres per beat } \\
=83 \cdot 2 \text { kilogram-metres per minute. }
\end{gathered}
$$


The main fault to be found with this ealculation is that the various quantities required are almost impossible to obtain. For instance, the only methods by which the output of the heart in situ can be determined are indirect. 'Zuntz, by finding the pereentage amount of oxygen whieh the blood gains per unit of time in passing through the lungs, and the actual amount of oxygen taken from the lungs per unit of time, calculated the amount of blood that had passed through the lungs during that period. For example, if the blood gains 5 per cent. of oxygen and the lungs part with 30 c.c. of oxygen to the blood, then, in order to have a 5 per cent. mixture, 600 e.c. of blood must have passed through the lung in unit time. Now if the heart beats 70 times per minute, and the unit of time ehosen was $1 / 5$ of a minute, then the volume of the right ventricle would be

$$
5 \times 600 / 70=\text { almost } 43 \text { c.c. }
$$

Since, of course, the lcft and right ventricle must discharge equal amounts of blood, the output of the left ventricle is found.

Muscular work causes an inerease in the output per beat. Under resting conditions, it is probable that the amount of blood entering the heart during the diastole is not sufficient to fill the ventricle up to the limits set by the fibrous inextensible bag surrounding the organ (pericardium). The first effect of the call for more oxygen set up by the muscles is to incrcase the output of the heart per beat. The powcr of the heart to thus increase its capacity is limited. By a reflex mechanism the heart rate is increased and so the output per minute is augmented. The following table shows approximatcly the share of the burden of increasing the output borne by increased distension of the ventricular walls and by increased pulse rate.

\section{TABLE XLIX.}

Effect of Work on Cardiac Output.

\begin{tabular}{|c|c|c|c|}
\hline $\begin{array}{l}\text { Muscular work per min. } \\
\text { in } \mathrm{h} \text { gms. }\end{array}$ & $\begin{array}{l}\text { Pulse rate } \\
\text { per min. }\end{array}$ & $\begin{array}{l}\text { Output per } \\
\text { beat in c.c. }\end{array}$ & $\begin{array}{l}\text { Output per } \\
\text { min. in c.c. }\end{array}$ \\
\hline At rest - - 0 & 70 & 45 & 3,150 \\
\hline Moderate exercise 270 & 100 & 75 & 7,500 \\
\hline & 110 & 120 & 13,200 \\
\hline Light labour $\quad-735$ & 130 & 115 & 14,950 \\
\hline Very hard work - 1000 & 180 & 117 & 21,060 \\
\hline
\end{tabular}

It will be secn that at first the pulse rate is practically unaltered although the amount of work done has been increased from 270 to 
735 kilogram-metres while the output per beat has increased from 75 to 120 c.e. After this, the output per beat is not materially changed, if anything it tends to decrease while there is a marked increase in the pulse rate. It is interesting to note the increase in the rhythm of the heart when work has just been started, viz. from 70 to 100 . This is assoeiated with the initial changes originated by the acts of volition and attention. The mere caution, "Are you ready ?" is sufficient to cause a rise in the pulse rate due, in part, to the increase of muscular tone in the act of attention, and, in part, to psychological causes.

A fair day's muscular work may be taken at 100,000 kilogram-metres. We have seen that the work done by the heart is, at least, 10,000 kilogram-metres per day. Hence the work done by the heart is always more than $1 / 10$ of that done by the skeletal musceles.

The efficiency of the heart may be taken as the percentage amount of the energy taken in as fuel that is converted into work. Workers in this field are agreed that it is extremely probable that the sole normal source of cardiac energy is the glucose taken to the heart by the blood and in part stored as glycogen in the heart substance. This storage of glycogen renders difficult the interpretation of the results of estimations of the amount of glucose in the blood before and after passing through the coronary vessels. More accurate calculations of the cnergy generated during the cardiac cycle can be marle from the oxygen consumption and earbon dioxide production during bodily rest and during measured work. The appended table from a paper by Evans and Matsuoka demonstrates this method for obtaining a value for the efficiency of the heart The total output of blood from the ventricle is fairly constant-averaging about 16 litres per

TABLE L.

EfFiciency of the Heart under various Conditions.

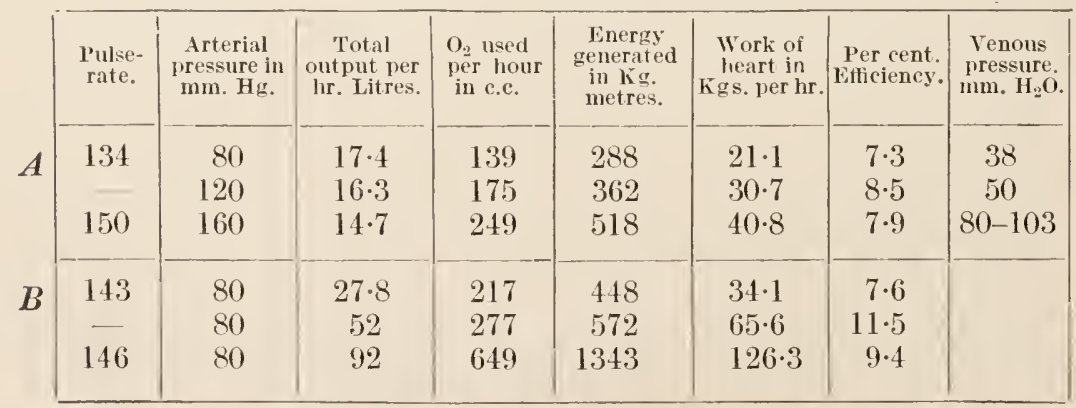


hour. The resistance to outflow was increased by steps of $40 \mathrm{~nm}$. $\mathrm{Hg}$ from 80 to $160 \mathrm{~mm}$. $\mathrm{Hg}$, corresponding to an increase in cardiac work of about 10 kilogram-metres a time.

To free the energy necessary for this increased work the heart uses up more oxygen. The amount of oxygen (in c.c.) so used multiplied by 2.07 gives, in kilogram-metres, the energy developed. It is clcar that, with a moderate increase in arterial resistance, the mechanical efficiency of the heart improves but tends to decrease when the resistance is doubled. In other words, when the arterial pressure is raised, the oxygen intake is increased, and more tension developed in the cardiac muscle. The mechanical efficiency is raised to a certain limit, beyond which it again diminishes. The venous pressure in the experiment quoted, and in most others, runs parallel with the oxygen usage. In the series of observations tabulated as $B$, the arterial pressure was kept constant at about $80 \mathrm{~mm}$. Hg, while the output per hour was increased roughly as $1: 2: 3$. This was donc by varying the inflow of blood to the heart. The increase in oxygen usage is not quite proportional to the increase in work done, but is if anything, less. 'The efficiency values therefore tend to increase with increasing outputs up to a certain limit. Beyond this point, the amount of oxygen used increases very suddenly. In the example given, for a little less than double the output, almost two and a half times as much oxygen is required. As this involves the liberation of enough energy to lift 1343 kilograms to the height of a metre, and as only 126.3 kilogram-metres of work are done, the increased work is not done so economically and therefore the efficiency value falls. How can this primary increase in efficiency and subsequent decrease be explained and what factors are brought into play to settle the critical point at which maximal efficiency will be found ? If output is to be increased, intake must first be increased and the ventricle must be distended to hold the extra amount of blood. That is, the musele fibres of the ventricular wall will be stretched. We have already mentioned, in connection with skeletal muscle, that a stretched muscle develops more tension during the isometric phase. The heart responds to increased work by such a lengthening of its fibres. If the lengthening process is carried too far. the muscle fibres per unit of area will become fewer, so that the larger the ventricular volume, the more strongly will each fibre have to contract in order to produce a given tension. At this greater length they also use up more potential energy just as skeletal muscle does. 
The maximal mechanical efficiency was obtained by moderate increase of both pressurc and output and reaehed 26 per cent.

It has been suggested that a term Energy Index should be used to denote the total foree developed by the heart per minute. If the systolic blood pressure be $120 \mathrm{~mm}$. $\mathrm{Hg}$ and the diastolie $80 \mathrm{~mm}$., then the foree of each beat would be $120+80=200 \mathrm{~mm}$. Hg. This figure multiplied by the number of beats indicates the total force per minute. From an examination of about 26,500 recruits for the American army the normal index was found to be about $20,000 \mathrm{~mm} . \mathrm{Hg}$ per minute. This Systolic-Diastolic-Rate index designates the amount of effort which the heart is putting forth. A high S.D.R. index indicates increased eardiac effort due either to inability of the heart to carry on its normal work at a normal rate or to the presence of some resistanee to flow in the circulation.

For example, adrenalin causes an increased blood pressure by constricting the peripheral vessels. A man who had S.P. $=108$, D.P. $=70$, P.R. $=84$, giving an index of 19,852 , had a small injection of adrenalin. His S.D.R. index then rose to 23,520 , made up from S.P. $=140$, D.P. $=70$, P.R. $=112$.

The diagrammatic section of the heart (Fig. 58) demonstrates that the walls of the left ventricle are much thiekcr than those of the right. The mean of a large number of determinations furnishes the ratio of $6 \cdot 8: 1$. This may be interpreted as indicating that the left ventricle develops about seven times as much pressure as the right ventricle. Proof confirmatory of this deduction is obtained by determining the hydrostatic pressures necessary completely and symmetrically to fill these two chambers. The right ventricle is dilated by a seventh of the pressure cmployed in equally dilating the other ventricle.

A dog weighing 10 kilos with an average aortic pressure of $100 \mathrm{~mm}$. Hg, and an output of 2,000 c.c. of blood per minute, develops pressure in right and left ventricles of 25 and $150 \mathrm{~mm}$. $\mathrm{Hg}$ respectively-a ratio of $25: 150=1: 6$.

The pressure developed in a distended hollow clastic vessel depends on (i) the elasticity of the walls, (ii) the degree of distension and (iii) inversely, the radius of curvature of the walls. The volume output from both ventricles is the same and their radii of curvature are similar. There remains only a marked difference in elastieity. As both are formed from the same material, altcration in elasticity must be brought about by alteration in wall thiekness. 
Sections of the ventricles at different points show that the ventricular walls vary in thickness at different parts. For instance in the left ventricle the apex, in the fully dilated ventricle, has, by far, the thinnest wall. As presumably the pressure in the chamber is constant over the whole wall area at any moment, some other factor must be found to account for this diminution in thickness. From the purely physical study of the shape assumed by clastic-walled cavities the conclusion has been drawn that where an elastie membrane is subjected to internal pressure, its shape will be determined by the law of distribution of radial pressure. With a given shape and size of body, equilibrium is maintained by altering the thickness (resistanec to pressure) of the wall so that where curvature is least the wall is thickest and vice versa. The apex of the heart is the portion with the greatest curvature.

To take a very simple example : if an elastic band is stretched between two points on a flat surface it will exert no pressure on any part of the underlying surface. But if it is stretched over a curved surface, e.g. a cylinder, it will exercise a downward pressure depending on the radius of the cylinder. A flat surface may be considered as equivalent to a curved surface of infinite radius. As the numerical value of the radius is decreased, i.e. as the curvature is increased, the pressure exerted by the band will increase. In mathematical form $p=T / R$, i.e. Pressure per unit of surface $=$ Tension of band divided by Radius of curvature.

Where there are curvatures in two dimensions, e.g. a sphere, the two pressure effeets are additive, i.e. $p=\frac{2 T}{R}$.

The ventricles are roughly egg-shaped, i.e. they have radii in two dimensions and of unequal length. The pressurc will therefore be equal to the sum of these, i.e. $p=T / R+T / R_{1}$.

We have seen rcason to corrclate thickness with pressure.

We may therefore say that thickness of wall varies inversely with the radius of curvaturc. This gives the formula

$$
t\left(\mathrm{l} / R+\mathbf{1} / R_{1}\right)=C,
$$

where $t=$ thickness of the walls and $C$ a constant.

The wall of the apex of the heart has the largest mean curvature ( $\boldsymbol{R}$ is least and, therefore, $t$ is least).

Similar reasoning may be applied to the consideration of the thickness of the walls of the blood vessels. The pressurc $(P)$ within the vessel is balanced by (1) the elastic tension of the wall $(T)$ divided by the radius of curvature $(R)$, and (2) by the pressure 
brought to bear on the external surface of the wall by the resistance to distortion of the surrounding tissues $(p)$.

'Thus

$$
T=R(P-p)
$$

or putting $t=$ thickness and $C=$ a constant, we may write

$$
t=C R(P-p) \text {. }
$$

That is, if $(P-p)$ be kept constant the thickness of the walls will vary as the radius of curvaturc.

\section{TABLE LI.}

\begin{tabular}{|c|c|c|c|c|c|}
\hline Artery. & Intima. & Media. & Adventitia. & Total. & Lumen. \\
\hline Brachial (human) & $0 \cdot 03$ & $0 \cdot 5$ & $0 \cdot 25$ & $0 \cdot 78$ & $4 \cdot 17$ \\
\hline Carotid (ox) - & $0 \cdot 84$ & $1 \cdot 176$ & 0.484 & 1.744 & $6 \cdot 0$ \\
\hline ,, (sheep) - & $0 \cdot 028$ & $0 \cdot 420$ & $0 \cdot 168$ & $0 \cdot 616$ & $3 \cdot 0$ \\
\hline Metacarpal (horse) & 0.03 & $0 \cdot 513$ & $0 \cdot 31$ & 0.853 & $2 \cdot 7$ \\
\hline
\end{tabular}

Thickness of Walls and Diameter of Lumen of Arteries in ma.

(MacWilliam and Kesson.)

According to measurements made on cxcised vessels the carotid artery of the ox has a lumen of $6 \mathrm{~mm}$. while that of the shecp is $3 \mathrm{~mm}$. The maximal pressure devcloped in these vessels at body temperature amounted to 60 and $40 \mathrm{~mm}$. $\mathrm{Hg}$ respectively.

That is $R / R_{1}=2 / 1$ and $p / p_{1}=3 / 2$.

Now $t / t_{1}=R / R_{1}$ and as $p / p_{1}=6 / 2=3 / 1$.

The actual thickness of the carotids as measured by MacWilliam and Kesson are 1.74 and $0.61 \mathrm{~mm}$. respectively. Of course, the main clastic resistance to distortion is met with in the muscular tunica media which in the ox is $1.12 \mathrm{~mm}$. and in the sheep 0.42 widc. Either pair of figures gives a close approximation to the ratio 3 to 1 .

The valves of the heart and veins are interesting mechanical structures. During the two years that Harvey studied at the University of Padua, Fabricius, the renowned Professor of Anatomy there, was investigating the valves of the veins. He demonstrated their presence in the veins of the arms and legs and also in the vessels at the root of the neck. These sluice-gates arc very simple contrivances-just little pockets set in pairs opposite each other in the vein. ' Fabricius noted that the openings of the pockets were always directed toward the central part of the body. He interpreted this as indicating a mechanism to prevent the blood 
from gathering, under the influcnee of gravity, in the lower parts of the body. Harvey saw that this explanation did not account for the setting of the valves in the veins of the neek, and we saw how, by noting the dircetion in which the valves would allow fluid to pass, he discovered the cireulation of the blood.

It is elear that the pockets offer practically no resistance to the passage of blood towards the heart. If, however, the pressure on the heart (or central) side of a valve becomes greater than the pressure in the preeeding seginent, the pockets will fill with blood, become distended and effectively prevent a back-flow. That this is so ean be proved by repeating one of Harvey's experiments. IIc ticd a ligature round the upper part of his arm and so dammed up the blood in the lower part of the arm. When he milked these swollen veins towards the hand he noticed that the blood could not pass certain points where he knew valves were placed. No valves are necessary in the arteries as there is always a positive driving pressure. The type of two of the valves of the heart is indicated in Figs. 58 and 61.

(1) The auriculo-ventricular valves are triangular sheets of fibrous tissue-tough but flexible-fixed by one side to the auriclo-ventricular ring and hanging apex downwards into the ventricular eavity. The pointed part of each flap or cusp is tied to the ventricular wall by a number of cords, chordae tendineae. The main eords are, however, not inserted directly into the ventricular wall but are attached to the finger-like papillary muscles. These muscles regulate the tension of the valve-flaps. When the ventricles contract so do the papillary muselespulling on the chordae and thus bringing the eusps eloser together. The increasing pressure of the blood in the ventricle causes the flaps to bellow out and block the passage-way so that the blood cannot pass back into the auricles. The greater the pressure devcloped in the ventriele, the more tightly is the valve shut. The cusps may even bulge up into the auricles. Valves constructed on this principle are obviously fitted to oeclude openings which vary in size and shape during the various phases of the eardiae cycle.

The right and left sides of the heart differ in the number of cusps in their valves and in the details of their movements. The mitral valve on the left side of the heart has only two triangular flaps like a bishop's mitre, while on the other hand the passage way from right auricle to right ventricle is guarded by the three cusps of the tricuspid valve. 
During systole, the strong anterior cusp of the mitral valve does not materially shift its position. 'The other cusp is pulled forward against it.

On the right side, one of the cusps hangs down on the scptum and is practically immovable. 'The other two cusps by the aetion of their papillary museles are pulled over towards the septal cusp. The mass of blood pressing on the sides of the cusps completes the closing of the orifice.

When this mass of blood, under the pressure induced by the eontraction of the ventricles, strctches the auriculo-ventricular valves it eauses them to emit a sound which is a eomponent of
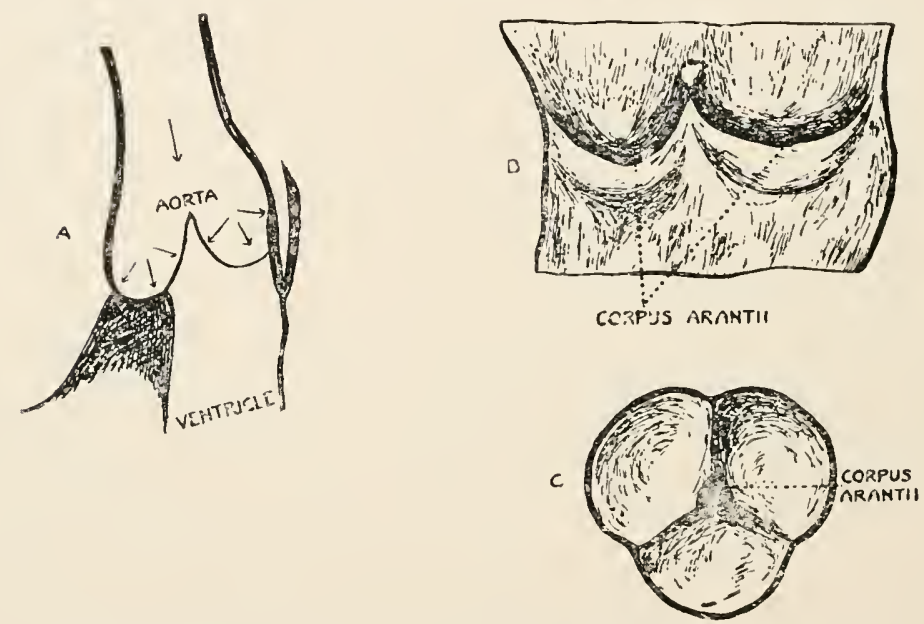

FIG. 62.- Gemilunar valves, $A$, in longitudinal-mesial section. $B$, Artery laid open and exposed, and $r$, elosed valves from the arterial aspect.

the first sound of the heart. The other component is the sound produced at the same time by the contraction of the ventricular walls. It is said that a trained car can piek out the notes due to closure of the valves from those due to stretching of the museular walls.

(2) The valves situated at the openings of the ventricies into the arteries are similar in shape and in aetion to the poeket valves of the veins (Fig. 62). Each is eomposed of three poekets or half eups attached along their eurved margins to the walls of the artery and upper part of the ventrielc and with their openings set away from the ventrielc.

The cusps are not plaecd all exactly on the same plane. One (usp lies somewhat deeper in the heart than the others. 'This eusp is mounted on a muscular septum which acts as a cushion, 
absorbing the shoek when the pressure falls on the valve and the other two cusps shut down on it.

The sudden stretching of these semilunar valves by the inpact of the high arterial pressure sets the valves in vibration like the blow of a drum-stiek on a drum-head. It produces a clear sharp high-pitehed sound, the so-called second sound of the heart.

A third sound has been deseribed. It has been attributed to the rebound of the semilunar valves when the ventricle relaxes and the ventrieular exit again becomes patent.

When the valves are diseased certain more or less continuous sounds or murmurs are heard. They are in the main due to either of two eauses.

(1) Stenosis. When a fluid flows along a tube of uniform bore or a tube where the bore alters gradually no vibrations are set up. On the other hand, if the cross-seetion is altered suddenly and appreeiably, the fluid is set into vibrations. These vibrations are transmitted to the solid tube and to the material in which it is set and a sound is produeed. Most people have heard the rather irritating purr enitted by the domestic water supply when there is "air in the pipe." The vibrations may not only be heard but they may be felt at the tap and seen in the water issuing. Something similar takes place when, by disease, the opening from auricle to ventriele is narrowed. During the whole period when the ventricle is filling up from its auricular reservoir, the blood flowing through the narrowed opening is set into vibrations which are transmitted through the more solid tissues to the inner earthis is the murmur of mitral or of tricuspid stenosis, aceording to whether the fault lies on the systemic or pulmonary side respectively. The narrowing does not need to be absolute. If the previous part is dilated, the orifice will beeome relatively narrower and will produce the result.

Similarly the murmur eaused by stenosis of the aortic or of the pulmonary valves will be heard during the expulsion of blood from the ventrieles.

(2) Incompetence. The failure of any of the valves to close completely, allows blood to trickle baek into the empty cxpelling chamber. This regurgitation throws the tightly stretched eusps into vibration and produees a murmur. If this sound is heard during ventricular systole it may be aseribed to incompetence of either of the auriculo-ventricular valves-if during ventrieular diastole, the aortic or pulmonary valves are at fault. 
In aortic ineompetenee the sound will be best heard where the aorta comes nearest to the surface, viz. at the sceond right costal cartilage; in pulmonary incompetenee the stethoscope will be placed over the seeond left interspaee just external to the margin of the sternum.

The sound of the mitral valve is heard at its best just over the apex of the heart; that of the tricuspid valve at the junction of the fourth right costal cartilage with the sternum.

By means of a recording mierophone, a tracing may be obtained representing the values of these sound waves. Such a phonocardiogram (Figs. 66 and 67), if taken simultaneously with a tracing of the mcchanical or clectrical ehanges of the heart, is of great use to the physieian as an indication of cardiae effieieney.

If any of the large arteries be compressed, say by the imposition on the overlying skin of the stethoscope, murmurs will be heard. These sounds are eaused by the sudden narrowing of the lumen of the artery by the pressure of the instrument. The blood rushes through the narrowed part into the eomparatively wide part of the vessel beyond the point of pressure and so sets up eddies. The vibratory movement of the fluid is transmitted to the arterial walls and passed on to the internal car (Part II.).

Considering the eireulatory mechanism as a whole one is struek by the extraordinary efficieney of this method of transport. Comparatively little energy is wasted. Fluid leaves the ventricle under a pressure of over $100 \mathrm{~mm}$. $\mathrm{Hg}$, passes through a system of large and small tubes and returns to the reservoir of the ecntral pump with no surplus pressure. Just enough blood is provided to earry the fluid within range of the auricular suction and no more. It has been stated that by the rhythmic contraetions (peristaltic waves) of the muscular coat of the vesscls, the blood is helped along its course. The meehanies of peristalsis will be eonsidered shortly (Chap. XXVII.).

One further point making for the ceonomical working of the inland transport serviee, owes its enunciation to John Hunter. He wrote, "To kecp up a cireulation sufficient for the part and no more, Nature has varied the angle of the origin of the arteries aecordingly." Suppose a point $C$ is $h$ units vertically distant from an artery $A B$, the problem is to find out the route by which the blood could be eonveyed from $A$ to $C$ with the least possible loss of energy. This is not neessarily by the shortest route or by the route using the shortest piece of branch tubing. The shortest route would be $h$ units long and would arise from $A B$ at 
right angles (say at $D$ ). For the purposes of this ealculation let us eonsider that the least loss of power oeeurs when the branch originates at $X$ which is $x$ units from $D$, making an angle of $\theta$ with the main trunk. Then the distanee from $X$ to $C$ would be $\sqrt{x^{2}+h^{2}}$ (hypotenuse of right-angled triangle).

Assuming that loss of pressure is due to frietion on the walls of the vessels, then it will be directly proportional to their lengths and indirectly proportional to their radii (e.g. main trunk $=\boldsymbol{R}$. braneh $=r)$;

i.e. loss is proportional to $\frac{X C}{r}+\frac{A X}{R}$.

If the whole distanee from $A$ to $D$ be put $=b$, then $A X=b-x$.

Substituting, we have $\frac{\sqrt{x^{2}+h^{2}}}{r}+\frac{b-x}{R}$,

multiplying by $R r$ gives us the value

$$
S=R \sqrt{x^{2}+h^{2}}+(b-x) r .
$$

Differentiating and equating to zero we obtain a value for $x$ which makes $S$ a minimum.

Thus

$$
\begin{aligned}
& \frac{d \cdot S}{d \cdot x}=\frac{2 R x}{2 \sqrt{x^{2}+h^{2}}}-r=0 ; \\
& \frac{r}{R}=\frac{x}{\sqrt{x^{2}+h^{2}}}=\frac{X D}{X C}=\cos \theta .
\end{aligned}
$$

That is, the angle of origin required is such that its cosine is numerically equal to the radius of the branch divided by the radius of the main trunk.

The size of the angle of origin is governed neither by the radius of the branch vessel nor by the radius of the main vessel but by the ratio of these two quantities. For any partieular value of the ratio $r / R$, we have therefore a eonstant value of $\theta$; that is, all branches of equal radius will be equally inclined to the main artery.

(1) In partieular, if the artery bifureates into two equal branches, the angles of bifurcation will be equal.

(2) If $r$ is so small eompared with $R$ that the amount of blood going to the branch is almost negligible, then $\cos \theta=\frac{r}{R}$, tends to be infinitely small, i.e. angle $\theta$ will be elose to $90^{\circ}$. 
(3) If $r$ differs but slightly from $R$ it is obvious that $\cos \theta$ tends towards the limiting value $=1$, i.e. $\theta$ will be very small.

While these statements are true as they stand they are not the whole truth. Other factors eome to bear on the angle of origin and produce modifieations not comprehended in Hess's Law. 


\section{CIAPTER XXV}

\section{THE ELEC'TROCARDIOGRAM}

"Providence ... can make a harmony
In things that are most strange to human reason."

MIDDLETON.

'THE electrical changes that occur during each cardiac cycle have, of late, become rather important to the clinician, as a rapid and reliable indication of the state of the heart. Cardiac muscle, just like any other musele, or, in fact, like any other living tissue, is the scat of electrical differences in potential. Ordinary skeletal muscle on contracting develops potential in such a way that the contracting part becomes electro-negative or zincative to the rest. This causes a current to pass through the external or galvanometric circuit to the contracting part, from the rest of the muscle. Heart muscle acts in a similar way. It has been found that the wave of contraction starts in the auricles. Therefore the auricles will become electro-negative to the rest of the heart. The auricles contract as a whole, passing on the excitation through a piece of primitive tissue (Bundle of His) to the ventricle. This will then become negative to the rest of the heart and so on.

(1) The existence of this change in the sign of the potential devcloped may be demonstrated, as it was in muscle, by the use of a fresh nerve-muscle preparation. The nerve is laid across the beating ventricke and produces two muscle twitches per beat.

(2) Earlier cxperimenters used the eapillary electrometer (p. 404) as the instrument wherewith to measure the potential differences. They found (Fig. 63), on leading one electrode from the auricular sinus and one from the ventricular apex, that on the initiation of the contraction of the auricle, the mercury ran up the capillary away from the tip, indicating the presence of a negative difference of potential. This was followed immediately by a tiny positive movement constituting the second part of the auricular diphasic response. Similarly, a large upward excursion of the 
mereury followed by a smaller downward movement demonstrated a similar but greater ventricular diphasic response. It is not neeessary to expose the heart and lay non-polarisable electrodes on it in order to see this diphasie response by the elcetrometer. The right arm may be considered as electrically continuous with the base and the left leg (or arm) with the apex of the heart. Connection of the arms by non-polarisable elcetrodes to the clectrometer gives results similar to those obtained from animals by direct "leading."

Clinieians seem to prefer the more sensitive string galvanometer as an instrument for electrocardiographic work, in spite of its great expense and the difficulty of analysing its reeords. The

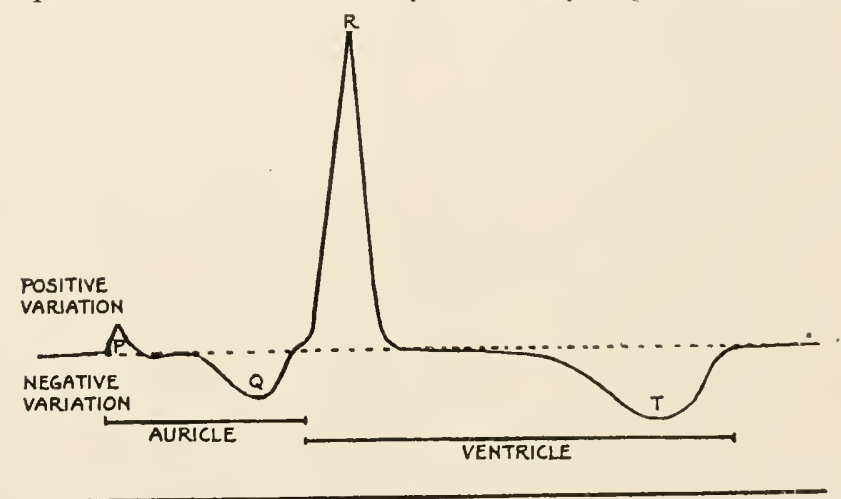

Fig. 63.- Record of the electrical variations in the beating heart of a tortoise, taken by a capillary electrometer (after Gotch).

instrument at present generally employed is substantially that invented by Ader and modified by Einthoven. The earlier forms of string galvanometer were almost uscless as a means of registering the rapid alterations in the clectrieal state of the heart. Any recording apparatus for such work must be as "dead beat" as possible-moving in exact aceordance with the exact potcntial differenee developed and having no period of vibration of its own. As its name implies the moving part of the string galvanometer is a string or fibre. The string $(C$, Fig. 64) which is an extremely light fibre of silvered glass, quartz, or platinum is stretehed between the poles $(N, S)$ of a powerful clectromagnet. When a eurrent passes along a fibre, the fibre is defleeted at right angles to the magnetie ficld, the amplitude of the exeursion depending on the magnitude of the potential differenee eausing the eurrent; and the direction of the deflection (observer's left or right) depending on the direction in which the eurrent is passing. If the eurrent 
passes in the direction of the arrow, from top to bottom of the diagram, the fibre will bend outwards, i.e. in the direetion of the arrow a. Reversal of the direction of the eurrent of eourse eauses reversal of the movement of the fibre. The excursions of the string can be observed by means of the reading mieroseope $A E$, which passes through a loole in the magnet, or reeords may be made by placing an are lamp at $G$, eoneentrating the light on the

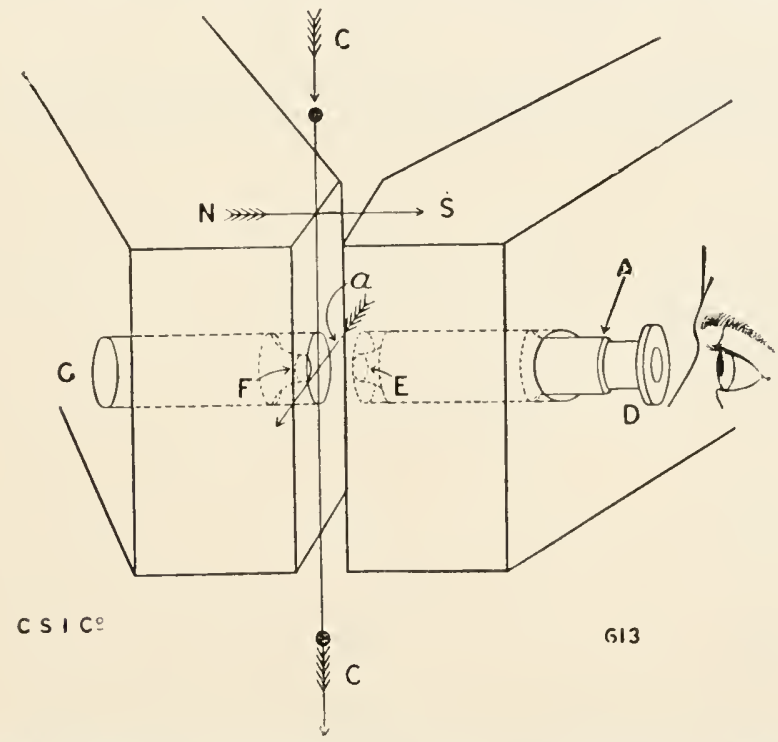

Fig. 64.-Diagram of the essential parts of the string galvanoneter. $N$ and S are the poles of a powerful electromagnet, between which is stretched the fibre $C$.

fibre by a lens $F$ and throwing the shadow on to a moving photosensitive surface. Fig. 65 shows diagrammatically the arrangements of galvanometer and aecessories for photographing the fibre movements. The distances are given in millimetres.

The optieal mechanism for producing the eleetrocardiograms needs some mention. The eamera is a light-tight box fitted with a eylindrical lens and an arrangement whereby a sensitive photographie plate or film (or bromide paper) is made to travel at a uniform speed past the narrow lens. The field of the objective is projected by an eyepieee on to the lens which foeuses it as a spot of light on the part of the sensitive surface exposed by the slit. The shadow of the fibre appears as a dark spot in this band of light. Thus if the plate or paper be moved downwards normal to the eylindrieal lens, the whole surface will be exposed to the action of the light exeept that portion protected by the shadow 
of the fibre. The movements of the fibre are, as we have seen, parallel to the plane in which the lens is set, and therefore when the fibre moves towards the reader (in the diagram) the result

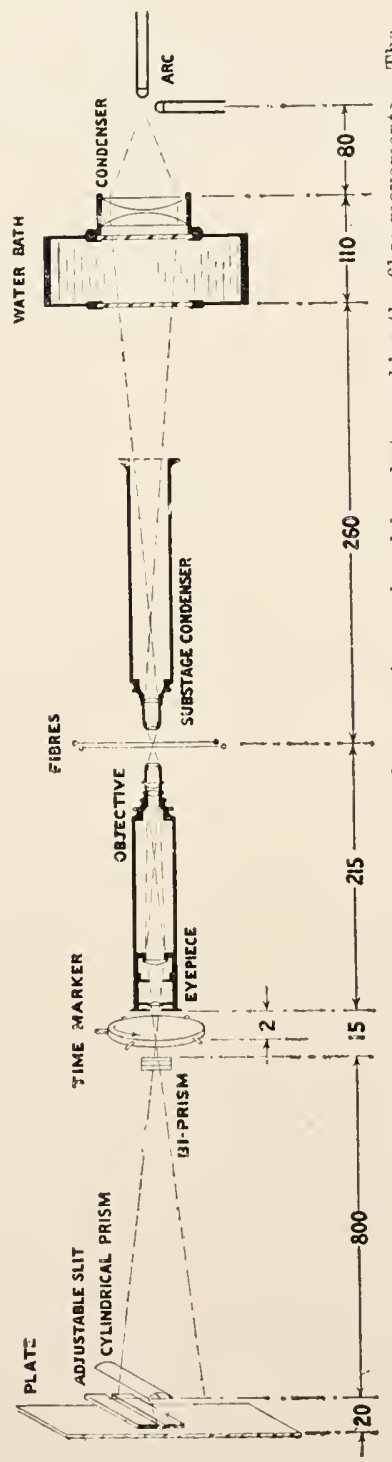
will be a eorresponding alteration in $\cong$ the position of the shadow spot. A continuous record of these positions is formed on the moving sensitised surfaee.

The reeords (Figs. 66 and 67) show vertieal and horizontal markings as well as the electrocardiogram itself. The horizontal markings enable one to find by inspection the potential differenee generated at different phases of the eardiae eyele. The spaee between eaeh line is generally $1 \mathrm{~mm}$.= 1/10,000 volt (Einthoven's standard). The lines are engraved aeross the width of the eylindrieal lens. When illuminated they produce shadows forming lines along the length of the reeord. The vertieal lines, shortened to tieks at the foot of the reeords illustrated, are a measure of timein the eases given $=1 / 30$ of a seeond.

They are produeed by the interruption of the focused beam of light by a serrated wheel (Fig. 65) so that for a short interval no light falls on the whole (or on part of the sensitised surface) as it is travelling past the slit. In consequenee, a sharp line falls on the reeord.

Before a reeord ean be taken, it is neeessary to know the resistanee of the subjeet's body and the magnitude of the "skin-eurrent." The latter faetor is a relatively large and fairly constant potential difference eaused by the glandular aetivities of the skin. It has to be eounterbalaneed by sending an equal eurrent through the fibre in the opposite direetion. The resistanee of the body to the passage of 
a eurrent is very rarely considered in routine elinical electroeardiography.

The analysis of electroeardiograms is by no means simple.

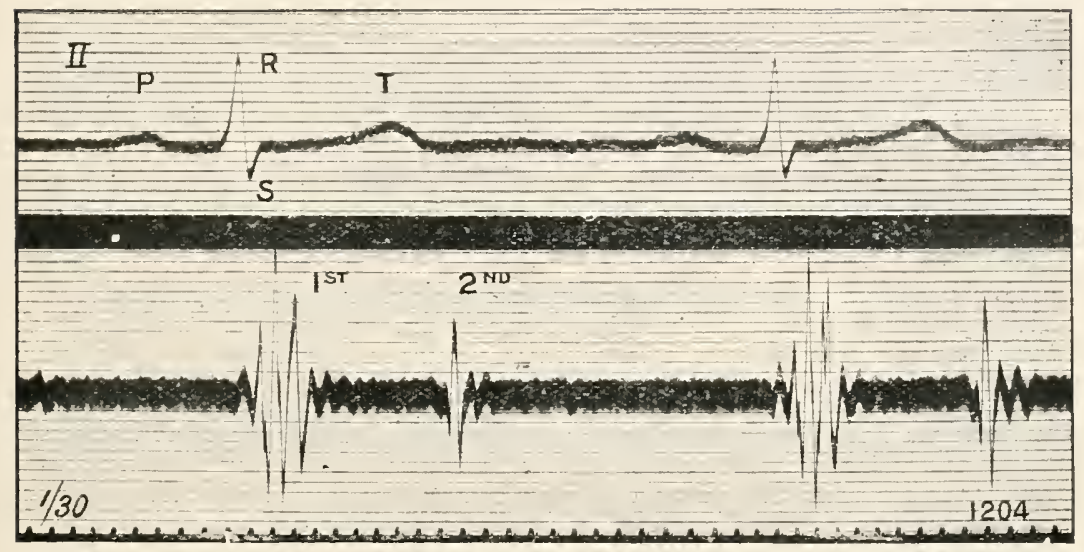

FIG. 66.-Electrocardiogram from lead 11. and Phono-cardiogram taken simultaneously from a normal subject.

Considerable uneertainty exists as to the exact interpretation of eertain units in the trace. If Finthoven's symbols PQRST are

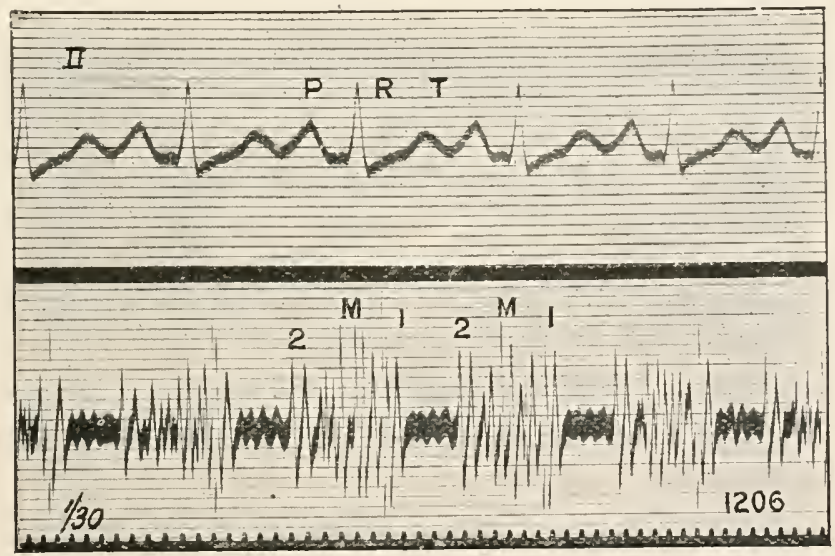

Fif, 67.-Similar recorls to above, hut taken from a subject suffering from mitral stenosis. The space between the first and second sound is filled by a coarse, Inud, diastolic murmur ( $M)$.

used it is generally agreed that $\mathbf{P}$ is pre-systolie and that $\mathbf{Q}$ (positive E.M.F.) indieates that the wave of eontraetion does not start at the base of the ventriele but a short distance from it. $\mathbf{R}$ is no 
doubt the wave of negativity produeed by the eontraction of the ventrieles and $\mathbf{S}$ is the seeond phase or positive reaction. The space between $\mathbf{S}$ and $\mathbf{T}$ represents the time during which the whole ventriele is excited, and $\mathrm{T}$ probably indicates the arrival of the wave of negativity at the apex. Other interpretations have been given.

It has been suggested for ease in analysis, that it is advisable to compound the reeords from all three leads into one diagram. This so-ealled monoeardiogram represents the algebraie sum of all the potential differenees at every point of the eardiae eyele. 


\section{CHAP'TER XNVI}

\section{ENTERNAL RESPIRATION}

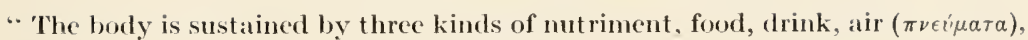
of which the last is by far the most important."

HIPPOCRATES.

FEw of the mechanieal arrangements of the body lend themselves better to popular deseriptive writing than the lungs, and fewer still have given rise to more misconeeption of the actual means employed in the performance of their function. From the earliest times of which written reeords exist, one of the most inportant and yet most mysterious problems of physiology has been the part played by the lungs. 'The regular inhalation of air and its regular exhalation was reeognised by all as essential to life. Prolonged stoppage of either eaused death, and death was accompanied by eessation of breathing. Hippoerates, following Hindu philosophers, maintained that "aerial nutriment" was "the ehief support of animal life" (Cicero). Aristotle denied this and considered that the function of respiration was to eool the heart. The followers of Hippoerates, notieing that the arteries and veins differed in strueture, suggested that they might differ also in function. It was further observed that the arteries of a dead man were empty although the veins were full. Henee they argued that the arteries were channels for air and not for blood (Erasistratus, circa 294 B.c.). That these philosophers had a glimmering of the truth may be addueed from Galen's writings, e.g. "The air which is drawn outwards from the rough arteries (trachea and bronehial tubes) reeeives its first elaboration in the flesh of the lungs but afterwards in the heart and arteries." It is our business at present to consider the first step in this sequenee, viz., the passage of the respiratory gases between lungs and atmosphere.

\section{Principle of Mechanism.}

The lung mechanism may be eonsidered as an elastic bag with one opening, the whole suspended in an air-tight box with movable 
sides. When the sides are pulled outwards the box increases in eapacity and the air is sucked into the bag to keep the pressure eonstant. When, however, the foree which drew the sides out-

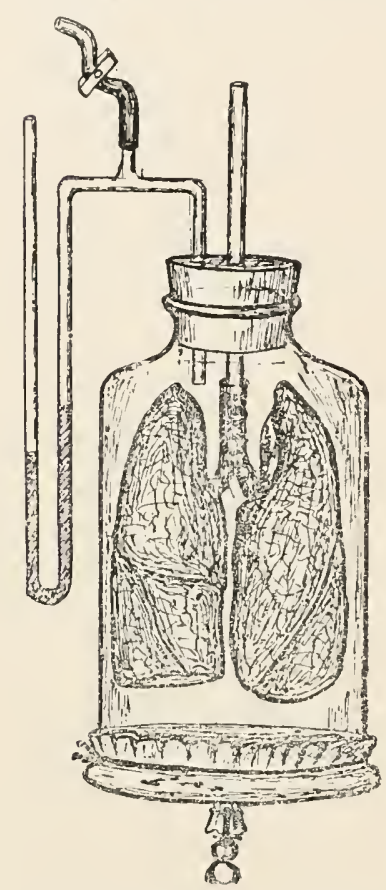

Fia. 68.-Model to demonstrate action of diaphragm. On pulling the rubber sheet downwards, air enters the lungs and they expand. wards is released, the box and bag resume their former volumes, and air is expelled. In short the lungs are a form of suction pump or bellows (Fig. 68).

\section{Structure of Mechanism.}

While the foregoing aceount of the principle underlying the respiratory meehanism may be taken as substantially correct, it is apt to eonvey a wrong impression of the details of the meehanism.

(a) The lungs are not simple clastie hags but are composed of thousands of little distensible air saes-a spongework.

(b) 'These eomplex bags are suspended in and almost fill the thoracic eavity. Each organ is enelosed in a membranous sae-the pleura, which bends back from the bronehi and lines the entire internal surface of the ehest wall. That is, the pleura eonsists of two layers-an outer, parietal or ehest wall layer, and an inner, viseeral or lung layer. These surfaees are kept moist with lymph. It is important to note that as long as the chest reall is kept intact the pleural cavity is only a cavity in name. The layers of the pleura are always normally in elose eontact with one another and with the underlying and overlying surfaces. In other words, the ehest wall, the two layers of the pleura and the outer surface of the lungs move almost as one strueture. 'The elastieity of the lungs has been determined as about $30 \mathrm{~mm}$. $\mathrm{Hg}$. If this inwards pull of the pulmonary tissue be subtraeted from the atmospherie pressure $(760 \mathrm{~mm}$.) in the lung, the resulting figure $(7: 30 \mathrm{~mm}$.) represents the foree tending to keep the lungs expanded. If, now, eommunieation be established between the outer air and the intra-pleural eavity, there will be a pressure of $760 \mathrm{~mm}$. tending to cause the lungs to collapse. As these outwards and inwards pressures (760 as against $730 \mathrm{~mm}$.) do not balanee, one 
would expect to find that the lungs eollapse. This is not always so. A further foree eomes into play. Moistening the various surfaces is the lymphatic secretion already referred to and, by the force of surface tension, the lungs are held to the ehest wall, just as firmly as a boy's leather "sueker" is held to the pavement and for the same reason.

\section{Mechanics of Respiration.}

During inspiration the capaeity of the thorax is increased in all directions. That expansion oeeurs laterally and in an anteroposterior direetion may be made manifest by measurement or by moulding strips of lead (eyrtometers) to the eireumference of the chest. The movements in a vertical plane have been studied by means of the $\mathrm{X}$-rays and by pereussion. If the intereostal spaces are tapped with the finger, a elear resonant note will be emitted when the pereussion has been performed on a part overlying inflated lung. Otherwise a dull sound will be produeed. Horizontal expansion is obtained by movements of the ribs while the vertieal movements are eaused by contraetion of the diaphragm.

I. Structure of the diaphragm. This is a vaulted nuseulofibrous sheet separating the thorax from the abdomen. It eonsists of a eentral tendon like a double-arehed cupola whieh is attached on its thoraeie surfaee to the perieardium and marginally to the thoraeic walls by museles. These diaphragmatie museles may be divided into two sets, (i) crural and (ii) costal. The former have their origin in the three or four lumbar vertebrae and in the areuate ligaments and are inserted into the posterior margin of the ecntral tendon, while the latter arise from the eartilages and lower six ribs and from the back of the ensiform process. Such a division of the musele into erural and sterno-eostal portions is supported not only (1) by their different origins, but (2) by their development from different museular sheets in the embryo; (3) by their different blood supply-the former direetly from the aorta and the latter from the intereostal and intemal mammary arteries; and (4) by their different nerve supply, the erus being served by the posterior branch of the phrenie nerve and the eostal by the anterior braneh. Moreover, the two portions aet somewhat differently, and further, people may be elassed as having respiration of a erural or of a parietal type depending on whether the erural or the eostal portions of the diaphragm are employed during quiet breathing. The majority of individuals employ both parts of the muscle in varying degrees. 
II. Mechanics of diaphragm. The crural portion, when it contraets, aets as power to a lever of the third elass. That is, the fixed point or fulcrum is the point of origin of the shect of musele in the posterior wall of the thorax-on the vertebral column. 'The resistanee to be overeome is mainly the pressure of the contents of the abdomen, the perieardial fixture and the point of insertion of the vena cara and other vessels. They may, on the whole, be considered as a weight applied at the central tendon. The power is thus between weight and fulcrum-giving speed at the expense of strength. The sterno-costal part of the muscle eonnects the lower ribs with the eentral dome and acts as a lever of the same elass as the crura. In this ease, however, the fulcrum is movable and is moved outwards by other museles. This results in a forward as well as a downward movement of the dome.

On the whole, the final result of the eontraction of the diaphragm is similar to the descent of a piston-increasing the eapacity of the thorax vertically. The average descent is equivalent to a drop of about half an inch all over. For ease in ealculation, say that the distance through which the diaphragm moved in an ordinary quiet respiration were $10 \mathrm{~mm}$. and that the mean area of the piston were $250 \mathrm{sq}$. em., then the volume of air sucked in would be 250 c.c. (eomplemental pleura). Now as the tidal air in quiet breathing is under 400 c.e., it will be elcar that the part played by the diaphragm in ordinary respiration is of major importance.

Acting along with the diaphragm there are those museles which abduct the lower ribs, viz.: the quadratus lumborum and the decp costal muscles. These are synergic-eontracting synchronously with the diaphragm, and preventing the lower ribs from being pulled inwards. In children where the musculature is poorly developed one sometimes observes a distinet depression of the lower chest wall at cvery inspiration.

The antagonistic muscles together with the viscera form the resistance against which the diaphragm moves. These are the muscles of the abdominal wall, viz. : external oblique, internal oblique, tranversalis and rectus abdominis on cach side.

(a) External Oblique (Descendens). This is the outermost and largest of the paircd abdominal museles. It is muscular laterally and tendinous in front. Above, it is attached to the lower eight ribs by eight fleshy digitations from which the muscular fibres pass obliquely downwards and forwards. The muscle fibres of 
the lower rib are attached dorsally to the anterior half of the erest of the ileum. The middle and upper parts of each musele terminate in aponeuroses which, eovering the whole of the front of the abdomen, are joined together at the mid line (linea alba).

(b) Internal Oblique (Ascendens). 'This pair of museles lies between the external oblique and the transversalis and is attaehed below to the outer half of Poupart's ligament and to the anterior two-thirds of the erest of the ileum. Dorsally it is attaehed to the lumbar faseia. From this origin, the fibres spread in a fanshape passing behind to the lower three ribs and in front forming an aponeurosis.

(c) Transversalis. A pair of flat muscles lying behind the other pairs. The fibres arise from the outer third of Poupart's ligament and from the anterior two-thirds of the iliae crest. They are attaehed behind to the lumbar fascia and above to the inner surfaces of the eartilages of the lower six ribs. The fibres run transversely and horizontally, being inserted into the aponeurosis of the linea alba.

(d) Rectus. This musele extends along the front of the abdomen on each side of the linea alba from the stermum to the pubes.

The floating ribs (and in 40 per cent. of people, the tenth rib also) are funetionally part of the abdominal wall. Their movements are eontrolled by the quadratus lumborum and erector spinae museles. The twelfth rib, in addition, is anchored to the transverse processes of the first and seeond lumbar vertebrae by a strong ligamentous membrane, an extension of the middle layer of the lumbar faseia. In this way the upward movement of the rib especially in its spiral segment is restricted. The anterior and lateral segments have a freer movement, so permitting of a movement of the floating ribs (and the tenth) round an axis eorresponding to their spinal segments. It has been notieed that during inspiration, the spaces between those ribs widen and that during expiration the reverse takes plaee.

Function of Abdominal Muscles. The four pairs of abdominal museles and their fibrous attaehments aet antagonistically to the diaphragm. When the latter contracts the former have to yield to aecommodate the displaced viseera. That is, during diaphragmatic breathing, inspiration is aceompanied by a relaxation of the abdominal wall which will move forwards. Correspondingly, expiration will be aided by the tendency of the viseera to return to their normal positions and by the return of the abdominal museles to the position of rest. 
This museulature has also an important part to play in the maintenance of an adequate cireulation. There is no doubt that the diaphragm, with its synergic and antagonistic museles, was evolved not in connection with respiration but with circulation. Amphibians, for instance, earry on their interchanges of air between lungs and atmosphere by the action of museles under the jaw. Without the eonstant tension of the abdominal museles applied to the abdominal viseera, the larger veins would beeome distended with blood. These veins are capable of holding the entire amount of blood in the body. If for any reason the muscles of the abdominal wall lose tone, considerable fall in arterial blood pressure is the result. It may even fall to zero and death ensue. This may be determined experimentally, either by dividing the spinal eord at the level of the first dorsal vertebra, or by using an animal with poorly developed abdominal museles such as the tame rabbit. In the first ease, the influence of the bulbar centres on the part below the seetion is removed, and the tone of the abdoninal wall is abolished. If the animal is now placed vertieally creet, the abdominal veins distend under the hacmostatie pressure. In them the whole of the blood colleets and there is no blood to fill the heart.

III. Thoracic Respiration. The upper and lower regions of the thorax should be considered separately. The museles and movements of the upper series of ribs are quite different from the lower series.

(a) Lower costal scrics (6th to 9th or 10th rib).

This segment moves along with the diaphragm and leads to the expansion downwards of the lower lobes of the lungs. The ribs are articulated to the spinal eolumn so that during inspiration the lateral and anterior part of each moves outward more than the one above it. Two movements may be noted:

(i) The 50 to $7 \mathrm{~mm}$. of each rib next the spine to which is attached the erector spinae musele moves forward at each respiration. The tuberele of the rib shides forward on the flat upper facet of the transverse process.

(ii) The non-spinal portion of a pair of ribs moves with a buekethandle action, rising and coming forward with each inspiration. It the eentre of each pair is the sternum-eartilage eomplex which is raised and foreed forwards during inspiration. The museles eoncerned in this increase of the volume of the lower thorax, transversely and antero-posteriorly, are the external intereostals.

(b) Upper costal series (2nd-5th rib). 
'These ribs differ from the lower series in shape, articulation, ligamentation, musculature and, eonsequently, in their movements.

(i) Shape. The upper ribs have a concave upper margin and do not have such a marked twist as those in the lower costal series. 'The second rib as a matter of fact may be laid flat on a table.

(ii) Articulation. The spinal artieulation differs from the lower scries mainly in that the convex ovoid facet of the tubercle fits into a eorresponding cavity in the transverse process instead of gliding on a flat facet. Each transverse proeess from above downwards is tilted a little more backwards so that the angle of articulation beeomes more oblique as one passes down the series (Fig. 69).

Further, the upper ribs not only artienlate with the vertebral eolumn by their tubereles but also the facets on the head of each rib work against the eorresponding facets on the head of the vertebra.

(iii) Ligamentation. Each of the upper series of ribs is joined direetly to the sternum by a band of cartilage. The following are the lengths of these attaehments in a wellbuilt man : seeond, $37 \mathrm{~mm}$. ; third, $50 \mathrm{~mm}$. ; fourth, $62 \mathrm{~mm}$.; fifth, $75 \mathrm{~mm}$. The angle of attachment increases as the length in. creases, e.g. the second costal eartilage joins the sternum at right angles while the third aseends to the sternum.

(iv) Musculature. The museulature of these ribs is the intercostal interchondràl.

(v) Movements. Beeause of the double articulation of each rib to the vertebral

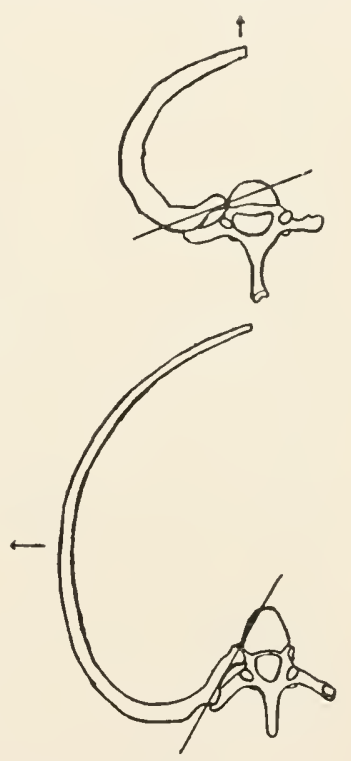

FIG. 69.-Rib and vertebra! column in upper and in lower costal series to show the differ ence in the obliquity of articulation and the resulting differ ence in the expansion of the chest.

(From Noël Paton's Essentials of Iluman Physiology.j column by tubercle and head, rotation round a spino-stemal axis is limited. Very little bucket-lıandle action can take place. As the artieulations are practically transverse, movement must occur at the manubrio-sternal articulation, i.e. chiefly forwards.

(e) The first rib provides the necessary fulerum for the intercostal muscles. Along with the manubrium sterni, to which they are firmly bound by their broad but short costal cartilages, the first pair of ribs form the operculum or lid of the thorax. 'This 
lid is articulated anteriorly with the thoracic wall, at the manubriosternal joint, forming a synchondrosis. That is, the opposing surfaces of bone eovered with a layer of hyaline eartilage and united by fibro-cartilage are bound together firmly by longitudinal fibres developed from the strong and thick periosteum. The eartilages of the first ribs are implanted upon the side of the manubrium forming a synehondrosis with the sterno-manubrial joint and there is no synovial eavity.

Great importanee has been attached to the movements of this joint. Its amplitude varies, of eourse, with the type of respiration, being greatest with those who make least use of the museles of the abdominal wall and vice versa. In other words, if the sternum moves freely then the excursions of the sterno-manubrial joint will be small. On the other hand, in eases where the lower part of the sternum moves but little during inspiration (thoracic breathing), there will be a correspondingly large rotation of the upper end of the sternum on the end of the manubrium. Some physicians declare that in phthisical subjects this joint does not move freely. Whether phthisis eauses an anchylosis or whether want of free movement leading to incomplete expansion of the apiees of the lungs is a factor favouring the development of the disease, is as yet an unsolved problem. On the whole the evidence tends to show that ossification of the costal eartilages in question is a consequenee rather than a cause of a limited expansion of the apices of the lungs.

Posteriorly the lid is artieulated to the vertebral column by a joint which is set more transversely and is wider in the extent of its attachment than any other of the eostal ares.

IV. Mechanics of Thorax. The ribs are a series of bent levers.

(1) The fulcra or hinges on which the levers work have been mentioned when dealing with the ribs of the various thoracic segments.

(2) The power differs aceording to whether inspiration or expiration is being performed ( 1.320 ).

(a) Inspiration.

(i) 'The lid or operculum is raised by the action of a flat triangular musele (scalcni). The scalcms anticus is inserted in the upper surface of the first rib just dorsal to the cartilage and passes almost vertically to the transverse processes of the third, fourth, fifth and sixth cervical vertebrae. The scalemes medius lies dorsally to the anticus and passes to the transverse processes of the lower six eervical vertebrae. 
(ii) The external intereostal muscles may be regarded as a triangular sheet of muscle having its origin in the dorsal part of the lid and being inserted into the upper surfaees of the ribs. It pulls upwards.

(b) Expiration.

(i) The power eausing eollapse of the ehest wall is mainly the clastie reeoil of the lungs together with the weight and elasticity of the chest wall.

(ii) The abdominal museles, espceially the external oblique, play a part in expiration in pulling down the ribs. The fixed basis from which they aet is the pelvis, and they aet as if attaehed to the lower margin of the ribs exaetly opposite the external intereostals.

(3) Load. This too is different in inspiration and expiration.

(a) Inspiration.

The resistanee to be overeome is :

(i) 'The elastieity of the lungs-a variable load, as the greater the expansion of an elastie body, the greater is the resistanee that it offers to further expansion. This factor, thercfore, is numerieally greater towards the end of inspiration than at the beginning.

(ii) The elastieity of the ehest wall-the eostal eartilages have to be twisted and the muscles overlying the ehest wall have to be stretehed.

(iii) The elastieity of the abdominal wall.

(iv) The clastieity of the vertebral eolumn. During inspiration the spinal eolumn is lengthened by a stretehing of the ligaments, eartilages and artieular proeesses.

(v) Gravity - weight of ehest wall, ete.

These loads may be resolved into one applied to the upper surface of the ribs at their frontal tips. That is, we are dealing with levers of the third order where power is applied between load and fulerum-giving speed at the expense of strength.

(b) Expiration.

The main resistanee to expiration is the resistanec to the outflow of air from the lungs. We have scen that the prineipal force causing expiration is the inspiratory load. Here then we have a lever of the seeond elass with the load between the power and the fulerum. During foreed expiration, when every musele that ean reduee the size of the thorax is brought into play, we have a simple bellows aetion. The front of the thorax aets like the movable side of a pair of bellows and is depressed towards the 
other side by the abdominal museles. This is also a lever action of the seeond order.

V. Elasticity of the lungs. The work done by the respiratory musculature eannot be treated as a simple problem in hydraulies. The dynamies of the ordinary foree pump eannot be applied to this question. Not only are the walls of the pump clastie and complex but (a) they are not equally extensible throughout and (b) their elastie foree varies with the degree of extension. Further, (c) the fluid enmeshed in the pulmonary eapillaries has to change its position to be aecommodated at every alteration in the extension of the lungs.

(a) Examination of the strueture of the lungs shows that they eannot be equally extensile throughout. Anatomists divide each lung into three zones.

(1) Root zone eontaining bronchus, artery, vein, lymphatic vessels, ete. This apieal part eontains mueh fibrous tissue and, therefore, offers eonsiderable resistanee to distortion. Using physieal terms one may say that its clasticity is strong but far from perfect (p. 168).

(2) Outer zone, estimated as extending for about $30 \mathrm{~mm}$. from the pleura containing very little fibrous tissue and made up mostly of small eapillaries and pumonary tissue. Of these the pulmonary tissue is perfectly but feebly clastie and the capillaries (empty) have a modulus of about $0.04 \times 10^{6}$-not quite so perfeet as the lung substanee but offering a greater resistanee to distortion. Even within this zone extensibility is not uniform. The stratum lying immediately below the pleura is much more extensible than the inner stratum. Inflation of a lung reently removed from the body elcarly demonstrates that certain parts of the surface are inflated first and that the inflation of ecrtain parts of the subpleural stratum spreads from these points.

(3) The middle zone, lying between the apieal and surface zones, is intermediate to them in its clastie propertics, containing as it does highly elastie pulmonary tissue interspersed between the rays of the bronchial and vaseular systems.

(b) That the elastic foree of a material alters with the degree of distension is a physical fact that has already been eonsidered in dealing with the foree of the heart. Sinee the pressure of a gas aets equally in all direetions, the pressure eaused by any given tension of the walls of the hollow (spherieal) vessel containing air will increase with the diameter of the vessel. If we eonsider that the diameter of each air sae is doubled during inspiration, then the 
total pressure excrted by the walls will be increased four times, i.e. distending foree $=$ resistance to distension $=$ pressure of gas multiplied by area of ressel. Morcover with increasing distension, the lung substance will become more attenuated.

(c) The blood and lymph enmeshed in the pulmonary system has to adjust its position to suit every alteration in the shape of the lungs. These fluids are highly viscous and as such resist distortion roughly in proportion to thcir pressure and to the area of the cross-section of their ressels. Further, the capillary vessels are so narrow that the corpuscular component of the blood viscosity becomes predominant.

(d) In addition to these factors which may be deduced from a study of hungs removed from the thorax one must take into consideration the position of the lungs in the thorax. Certain parts of the thoracic wall are stationary and the surfaces of the lungs in contact with these parts cannot directly expand.

(i) The mediastinal surface is in contact with the pericardium and with the structures of the mediastinum. (ii) The dorsal surface lies close against the vertebral column and spinal portions of the ribs. (iii) The dorsal part of the apical surface is bounded by Sibson's fascia at the root of the neck.

On the other hand the parts of the hungs in contact with (iv) the diaphragm, (v) the lower ribs (ventro-lateral aspect) and (vi) upper ribs (sternal aspect) undergo direct expansion at cach inspiration.

VI. The efficiency of the lung mechanism. If figures could bc obtained denoting the work done by the respiratory mechanism and its efficiency, they would be invahuable. One may arrive at an approximate value by measuring the oxygen consumed by an animal under standard conditions with normal and with increased respiration. With man, it was found that during muscular rest, 1 to 3 per cent. of the total basal oxygen intake is utilised by the respiratory mechanism. This amounts to from $0 \cdot 3$ to 0.7 c.c. of oxygen per litre of ventilation. Assuming that all the energy used is obtained from glucose, these figures indicate that from 0.0017 to 0.005 calories are expended for each litre of air breathed. This amount of cnergy is liberated from $0.004-0.0012$ grams of glucose. During quiet breathing each breath (400 c.c.) costs at most 0.002 calorie obtained from just about 0.0007 of a gram of ghucose and 0.28 of a cubic centimetre of oxygen. If it is assumed that the lung mechanism is at least 20 per cent. efficient, then at each quiet complete respiration, $0 \cdot 00016-0 \cdot 0004$ calories are converted into work $=1 / 3$ to $1 / 2$ kilogram-metre. 
This work is almost entirely performed by the diaphragm. The other muscles eoneerned, whether synergie or antagonistic, seem to play an ahmost passive part. This may be inferred from the faet that although they are skeletal in strueture yet they undergo constant slow contraction without showing fatigue. When the respirations are forced the subsidiary museulature has to perform work and the $\mathrm{CO}_{2}$ output increases. The effort sooner or later brings on fatigue. Foreed respirations are earried out uneeonomieally, i.e. at a relativcly higher cost per litre than ordinary quiet ventilation.

Regulation of Respiratory Rate. The aetivity of the respiratory centre, which lies in the medulla near the root of the ragus, is normally governed by the tension of the $\mathrm{CO}_{2}$ in the blood going to it. The rate of breathing is increased by any increase in the $\mathrm{CO}_{2}$ tension ; and, conversely, dininution of the $\mathrm{CO}_{2}$ tension leads to a decreased respiratory rhythm.

The $\mathrm{CO}_{2}$ tension of the blood and the partial pressure of the $\mathrm{CO}_{2}$ in the alveolar air are, as we have explained (Chap. XXIII.), always in dynamic equilibrium, and, therefore, any change in the one will lead to corresponding changes in the other. It has been found that an increase of $0 \cdot 2$ per eent. in the $\mathrm{CO}_{2}$ of the alveolar air, i.e. a rise of tension of from to to $41.6 \mathrm{~mm}$. Hg. is sufficient to double the rate of respirations. The increased ventilation leads to a "washing out" of $\mathrm{CO}_{2}$ from the blood and from the lung, thus rapidly restoring a normal eondition. The power of adjustment is so extraordinarily effective that under wide variations of metabolic and atmospherie conditions, the tension of $\mathrm{CO}_{2}$ in alveolar air is maintained at an ahmost eonstant level of about $40 \mathrm{~mm}$. IIg (sec p. 333t).

Regulation of Depth. Impulses are constantly passing from the lungs, through the vagi, to the respiratory centre and, by a reflex aet, inspiration is ehecked when a ecrtain tension is set up in the lung substanee, i.e. the respiratory mechanism earries out the inspiratory phase of its function till this streteh-reflex inhibits it. In eases where the ragi are hyper-irritable, the stop mechanism acts too soon and breathing beeomes shallow and rapid. 


\title{
CHAPTER XXVII
}

\author{
MLIMENTARY CANAL
}

\footnotetext{
"I receive the general food at first, Which you do live upon; and fit it is, Beeause I an the store-house, and the shop of the whole borly :

. . . . Though all at once eannot See what I deliver out to cach :

Yet I can make my audit up, that all From me do back receive the flour of all, And leave me but the bran."
}

SHAKESPEARE.

As has been indicated (Chap. XXI.) the non-gaseous imports are submitted to a certain amount of manufacture before being handed over to the inland transport service for transportation to the cells of the body. For instance, proteins have to be split into their constituent amino-acids, carbohydrates are broken down into monosaccharides and fats undergo some change. In addition to these changes in molecular complexity and preceding them come, in many cases, changes of physical state. Most of our foodstuffs are solid or semi-solid and in such a state are useless to the organism. Before they can be split into their constituent units they must be rendered sohuble.

General. In brief, the function of the alimentary canal is to provide (1) a series of mills and factories where food may be comminuted and dissolved in water, (2) a series of factories for breaking down the dissolved foods into units which the organism is capable of absorbing, (3) a mechanism for absorbing these units, (4) a mechanism for eliminating the waste material, (5) a means of transport from one factory to another and (6) an adequate control over these various processes so that all may be co-ordinated.

In structure, the alimentary canal is a tube passing longitudinally through the body having anteriorly a voluntary mechanism for receiving and grinding food; intermediately, stations, not controlled by the will. for complctely breaking down the food 
mass to eonvenient units and for absorbing the same, and posteriorly, a semi-voluntary meehanism for ejeetion of waste.

I. The mouth is the port of the alimentary transport system. First, by nose and eye the eargo is sighted and its nature estimated. Messages are sent inland, faetories get busy and all is ready when the ship reaches port. By means of the taste buds on the tongue, the nature of the eargo is further aseertained and appropriate seeretions from the salivary glands take plaee. Bitter or saline substanees provoke a profuse seeretion of watery saliva. Flesh is met by a seeretion eontaining a large proportion of the lubrieating material-muein. Dry matter eauses the flow of a thinner and more watery saliva than moist matter.

(a) The functions of saliva in the mouth are purely mechanical. It aets as a lubrieant: moistening the surfaees of the mouth and the passage from it : infiltering the food mass and so neeessitating the expenditure of less energy in milling the food; and finally eovering the outside of the bolus with muein, thus rendering deglutition easy. Normally, saliva has no chemical action in the mouth. It eontains a diastatie enzyme, ptyalin, which, however, earries out its aetion on polysaeeharides during the earlier period of gastric digestion (q.v.).

(b) The tongue is a mobile organ lying on the floor of the mouth. It eonsists mainly of a mass of museles which are paired. Some of these museles lie wholly within the tongue (intrinsie), and for the most part, by their eontraetion, give rise only to alterations in shape. The extrinsie museles have their point of attachment outside the organ, and so are eapable of eausing alterations in position as well as in form.

\section{Intrinsic Muscles.}

1. Superior longitudinal, pulls tip upwards and decreases length of dorsum.

2. Inferior longitudinal, pulls tip downwards and inwards, i.e. curves dorsum.

3. Vertical, working in conjunction with the transverse they produce a concave surface on the dorsum. Acting alone a convex surface is producer.

4. Transverse.

\section{Extrinsic Muscles.}

1. Genio-glossus-downwards.

2. Hyo-glossus-backwards.

3. Chondro-glossus (not always present) - backwards and downwards.

4. Stylo-glossus-backwards and towards palate.

5. Palato-glossus - side to side-continuous with intrinsic transverse. 
The tongue has a threefold duty to perform as a unit of this transport system-(a) working in conjunction with the lipsphincter-orbicularis oris, and with the triangular and other muscles it acts as a suction-plunger; $(\beta)$ during deglutition it functions as a force plunger and $(\gamma)$ it forms with the cheeks an effective hopper during the mastication of food.

(c) The lower jaw is a horse-shoe shaped lever of the third order. The load is placed on the teeth, the fulcra are at the cnds of the horse-shoe, where they articulate with the fixed upper jaw while the power is applicd at a point on either side between the teeth and the fulcrum. The jaw is pressed against the upper jaw by the action of the temporal, masseter and internal pterygoid museles which act antagonistically to the mylo- and genio-hyoids, to the platysma and to the anterior belly of the digastric musele. Nuts having a crushing point of about 400 kilograms may be crinshed by a direct thrust of the front teeth. The molars, lying as they do nearer the fulcra and further from the application of the power, may exert a direct pressure of about $550 \mathrm{~kg}$. The employment of such pressures is rarely necessary on account of the previous treatment of the food (milling, cooking, etc.), and of the influence of saliva. Soft bread, for instance, is merely compressed by a pressure of $100 \mathrm{kgs}$. but, after moistening with saliva, only a twentieth of this pressure is necessary to obtain a clean bitc through.

The grinding operations of the molars (and of the incisors at times) are a compound motion made up of a side-to-side and a forwards-backwards motion. The former is produced by the action of the external pterygoids working in conjunction with the posterior fibres of the corresponding temporal muscle. The latter movement may be aseribed to the forcards pull of the external pterygoids and the backicards pull of the posterior fibres of the temporals.

This mill-like motion tears the food with a smaller exhibition of pressure than direct crushing. Cooked meat which could be crushed by the application of from 30 to $100 \mathrm{~kg}$. pressure can be torn by a grinding movement when the pressure is only 2 to $5 \mathrm{~kg}$.

In Chap. XVI., we saw how bone was formed in accordance with the stresses and strains upon it. It is, therefore, interesting to note that in proportion as the food is prepared by factory milling and cooking, in proportion in fact, to the avoidance of the stimuli to growth furnished by incident stresses and strains. so the jaws of civilised men tend to become weak. In consequence 
faees are elongated and narrow instead of short and round like those of primitive men.

II. The act of swallowing. 'The food, after being ehewed, is eollected on the surface of the tongue by the action of the buecinator and other voluntary museles. The tip and sides of the tongue are pressed against the hard palate and teeth. A rapid eontraetion of the mylo-hyoid museles, which form a floor for the front portion of the mouth (diaphragma oris), pushes the tongue up against the hard palate. At the same time the hyoglossus pulls the tongue backwards and the bolus is shot towards the gullet. 'This eloses the voluntary stage of deghutition.

Several other museles eome into play at this point. As will be seen from Fig. 42, just above the larynx is a busy erossing common to two routes. Gaseous food and gaseous exereta pass to and fro right aeross the track of the descending bolus. At the moment of swallowing, the nose-to-lung and lung-to-nose traffie is reflexly held up. Further, the eseape of the food mass by either of these ineorrect routes is prevented as follows :

(a) The naso-pharynx is elosed by the action of the pharyngopalatini museles, which form the posterior pillars of the fauces. 'The pharynx is thus drawn to a narrow eleft. Against this narrow opening the soft palate is pressed by the aetion of the levator and tensor veli palatini museles. (b) The laryngeal aperture is kept elosed by the action of the erieo-arytaenoideus lateralis, arytaenoidei, and the thyreoarytaenoidei museles, which pull the arytaenoid cartilages forwards against the back of the epiglottis. Acempanied by a quick downward motion of the tip of the epiglottis, the bolus is pushed over the back of this strueture and is impelled into the gullet.

III. The stomach. By the impulse imparted to it at its entry into the gullet, aided generally by gravity and to a questionable extent by peristalsis, the bolus is foreed down to the gateway to the stomach. This aperture, in eommon with the exit from the stomach, is guarded by a thick ring of viseeral musele. When eontracted, i.e. during the normal state of tonus, these sphineters prevent the too hurried passage of material along the alimentary canal and also prevent its regurgitation. 'They are not eontrolled by the will but by loeal nerve centres. By its weight, the bolus usually exerts sufficient pressure to eause the opening of the eardiae sphineter and gain admission to the stomach, in which it is loeked by the operation of a local automatie arrangement.

The proeesses of digestion or splitting of the foodstuffs by 
enzymes now eommenee (Chap. IX.). Polysaecharides are broken down to maltose by ptyalin and the native proteins first eonverted to metaprotein by the aetion of the hydrochloric acid of the gastric juiec and reduced in size and eomplexity to the proteose stage by the aetion of pepsin.

Even a casual examination of the stomach will show that it is divided into two parts, each with a distinct function. The upper or eardiac portion is a reservoir or hopper where the food pulp is stored for a short time without mixing. It is during its stay here that salivary digestion reaches its maximum. By the steady pressure of the walls in the eardia, the mushy mass is fed little by little through the throat of the hopper (prepylorie sphineter) into the lower or pyloric part of the stomach. By peristaltie eontractions of its walls, this pyloric section of the stomach mixes food and gastric juiee most thoroughly. 'The aeid of the juiee aids peptic while inhibiting diastatic action. Catheart showed that the prepylorie sphineter was eontrolled by the hydrogen ion coneentration of the duodenum and of the pylorie part of the stomach. Aeid entering the intestine undoubtedly causes eonstriction of the sphineter. While the $C_{\mathrm{H}}$ of the pylorie portion of the stomach does not seem to effeet the closure of the sphineter, the above worker demonstrated that a sufficient reduction of the $C_{\mathrm{H}}$ brought about a rapid opening of the sphineter. The introduction of an extra alkaline juice, e.g. by regurgitation from the intestine, leads to a smart flow of acid chyme into the antrum pylori.

The rate of exit from the antrum is eontrolled by the hydrogen ion concentration of the duodenum. As long as the duodenal contents are markedly acid, the pyloric sphincter remains firmly closed and only opens to admit more aeid ehyme when its reeptors are no longer stimulated by acid.

IV. The intestines have three functions to perform : (a) transporting, (b) mixing and digesting, $(c)$ absorbing.

(a) Transporting. This is carried on by means of a series of peristaltic waves, i.e. a seetion of the museular wall adjacent to the anterior end of the food-mass undergoes relaxation while a eorresponding posterior seetion contraets. 'This double wave of relaxation and eontraction passes along the tube and acts as a piston with a eentral orifice. In this way, the ehyne is passed along at the rate of about 1 inch a minutc, and ehurned meanwhile.

(b) These driving peristaltic waves are not the only movements 
of the intestinal musculature. The chyme is kncaded and its surface broken by the rhythmic segmented eontraetions of the cireular muscles of the bowel. By this neans (i) the various digestive juices of the intestine are thoroughly mixed with the chyme, (ii) fresh surfaecs are exposed to the absorbing surfaces of the wall and (iii) the capillary blood-vessels of the lining menbrane are compressed rhythmieally, so helping to drive the blood laden with the produets of digestive aetivity on to the liver, etc.

The work of digestion, begun in the mouth and stomach, is completed in the intestinc. Carbohydrates are redueed to single sugars and proteins are broken down to anino acids, ete. In addition to this, the fats are attaeked by lipase, which resolves them into their eomponent fatty acids and glycerol (or other alcohol). In this proeess, the bile salts, by lowering the surlace tension at the fat-lipase interface, play an important part.

(c) Absorption seems to be a ease of passage of material through a nembrane (q.v.).

V. Fæces. 'The materials not absorbed by the intestine are climinated by the reetum as the facees. One suggestive physicochemical fact about these excreta is the proportion of soap to mass in their make up. It has been found that, nornally, lat forms approximately $\frac{1}{3}$ of the freal mass (dry). About 10 per cent. of this fat is in the form of soap. This may be eorrelated with the water-loolding power of soaps and with their lubrieating properties. Somewhere about 80 per eent. of their eontents is water. This is somewhat remarkable, as both water, fatty aeids and soaps are readily absorbed from the gut. If one desires to reduee the water eontent, caleium is exhibited. As we have already seen (p. 82) ealeium soaps are hard "dry" soaps. On the other hand, the addition of easily dissoeiated sodium and potassium salts leads to the formation of "softer" soaps and a marked increase in the water eontent of the feees. It is noteworthy that the fat content (as soap) renains eonstant. 'That unabsorbed fat is an excellent frecal lubrieant is an axion in present-day preseribing when mineral oil (liquid paraflin), which eannot be absorbed, is given to produce easy deficeation.

For the final diseharge of the waste alimentary eontents a simple kind of "toueh button" mechanism is provided. The aet is initiated by a voluntary response (removal of inhibition) to the stimulus produeed by the stretehing of the muscular wall 
of the rectum by the freces. When the pressure of the freces in the rectum reaches a value of about $30-40 \mathrm{~nm}$. Hg, there is a eall to defreeate. If no response be made, the call is not repeated immediately, as the reetal walls relax and so lose their irritability to pressure. While the initiation is voluntary the act itself is purely reflex like the other movements of the intestine. 'The reflex eontractions and relaxations are generally aided by voluntary contraction of all the museles, which will increase abdominal pressure.

From a physico-chemical standpoint practically nothing can be said of the mechanism of alimentary transport. While the movements, ete., are apparent the underlying causes are completely hidden. No help so far is given by attempting to trace the development of the highly complex system of the vertebrate from the apparently simple physico-chemieal response of the amocba to contact with food. 


\section{CHAP'TER XXVIII}

\section{MOVEMENTS OF THE LIMIBS}

"If the mountain will not eome to Mohammed,
Mohammed must go to the mountain."

IN order to get food, prepare food, and preserve its life and that of its race, the higher animal makes use of a series of levers to move its body in whole or in part. These levers are gencrally, but not always, made of bone, and gencrally but not always they work against a bony fulerum.

In general, a lever is a rigid bar either straight or eurved which is eapable of a rotatory motion round a fixed point-the fulerum. It is usual to divide levers into three elasses depending on the relative positions of power, fulcrum and load.

Class I. The fulcrum lies between the power and the load. In this elass of lever, if the power arm is equal to the load arm, we have a balance. The applieation of one $\mathrm{kg}$. of power will lift one $\mathrm{kg}$. of load. If the power arm is lengthened by shifting the fulcrum nearer to the load, then power will be increased proportionally as speed is decreased. For example, dealing with a straight lever and putting $P=$ point of application of power, $F=$ fulcrum and $L=$ point of application of load, then $P F$ represents the length of the power arm, and $L F=$ length of the load arm of the lever. If $P F=10$ times $L F$, then $1 \mathrm{~kg}$. at $P$ would balanee $10 \mathrm{~kg}$. at $L$, i.e. the load of $10 \mathrm{~kg}$. would be lifted by the exertion of a little over $1 \mathrm{~kg}$. weight. This is the crowbar lever and is very little employed in the body. The most notable example of it is the forwards and downwards movement of the head when one is overtaken by unconseiousness, $e$.g. s'eep. The fulcrum on which the head moves is the atlas, and the weight of the prefuleral part of the head (long power-arm) outbalances the postfulcral portion (short load-arm).

Generally, speed is the desideratum. The fulerum is plaeed 
ncar the power. The power-arm $P F$ is short and the load-arm $L F$ is long. The relative spceds of the points will be as $L F / P F$. The catapults employed by the ancients to cast stones are examples of this kind of lever. The arm is used as a lever of the first elass with a short power member when a cricket ball is thrown.

Normally, the head is a lever of this order, the power being applied very close to the fulcrum. The quick nod of assent is caused by the contraction of the anterior straight muscles which are yoked close to the fulcrum, while the slower backward movement is duc to the placing of the effective muscles (splenii and complexi) somewhat further away from the occipito-atlantal joint. 'The feature of this arrangement is stability. Another good example is when the foot is lifted off the ground and the ground pressed on by the toes on contraction of the gastrocnemius.

Class II. The fulcrum is at one end of the lever and the load lies between it and the power. That is, the power-arm is always of the same length while the load-arm may vary in length with the position of the load, e.g. nut crackers. The outstanding example of this lever in the body is the foot. On rising on the toes, the base of the metatarsals is the fulcrum, the body-weight, borne by the tibia to the ankle, is the load, while the power is applied to the os caleis by the gastrocncmius. A foot with a long load-arm, i.e. with the load near the power, is designed for speed not power,well adapted for rumning. On the other hand, the further the load is from the point of application of power, in this case, the longer the heel, the smaller will be the force necessary to lift the body. That this is so, may be inferred from a study of the development of the gastrocnemius muscle compared with the length of the heel bone. Europeans have short heel-bones and well-developed, bulky calves, while Africans have long heels and ill-developed calf muscles.

Class III. The point of application of the power is between fulcrum and load. This power must always be greater than the load. It is the commonest class of lever in the body, and this is to be cxpected as its use results in the most rapid action possible. Speed is obtained, as beforc, by shortening the power-arm. In the arm, the brachial muscle is inscrted about one centimetre beyond the fulcrum (elbow) whilc the total length of the load-arm (forearm) is about 30 cms. The result of this arrangement is that the load (hand) moves with about 30 times the speed of the bone at the point of the application of the power" "Speed is gained at the cxpense of power." It follows that while a long- 
armed man may be able to give a quick blow he will be quite unable, unless his brachial muscles are abnormally developed, to give a heavy one.

This introduces a point to which the author of the "Tarzan" stories paid little attention. Tarzan was able to hold his own among the tree tops. Now; man has a fore-arm considerably shorter than the upper arm while the anthropoid ape has a forearm only a little short of twice as long as its humerus. This gives it a long and quick reach. In swinging and elimbing, the upper arm is the lever employed to lift the body, mainly by the contraction of the anterior brachial muscle, and the insertion of the brachial over half-way up the humerus from the clbow (fulerum) gives a power-arm with rather more power than speed. 'That is, a short humerus is a necessity for climbing animalsto furnish strength, just as the long forearm is neeessary to give agility. To have equal elimbing power, man would need to have extraordinarily bulky biceps, etc., and this would not aid him when he desired to swing and seize distant branches surely and rapidly.

So far, we have dealt with the levers of the body in a general sense, as if they were straight bars. As a matter of fact, none of the bones of the body can be considered as straight levers, and none of the muscles aet absolutely at right angles to the length of the bone. The lengths of the effective power and load arms may be obtained by dropping perpendieulars from the fulerum to the lines of application of power and load. The ratio of these perpendiculars gives the ratio of the distribution of power and speed by the lever.

The value of the bone-muscle mechanism depends on the mass of active muscular fibres, their degree of contraction and the angle which they make with the bone to be moved. The very movement of the bone will alter the angle of pull of the muscle. For each of its positions, the lever will have a moment of rotation determined by the size of the angle made by the line of traction (axis) of the muscle and the axis of the bone. By resolving the foree of the muscle into two components, one of which acts along the axis of the bone and the other at right angles to it, one can readily perceive that the latter, the effective component, varies in value directly with the sine of the angle of pull. The incffective or parallel component varies as the cosine of the angle of pull and represents the pressure exerted by the muscle on the fulcrum. As the moment of rotation is equal to the tension developed $(F)$, 
and the perpendicular distance $(d)$ of the axis of the muscle from the fulerum, one may write $M=F d$. Then the effective component is equal to $F$ sin " where $"$ is the angle of pull. and the parallel component to $F \cos \alpha$. Hence, as the bony lever gets pulled up, the effective component will become greater and the parallel eomponent will beeome less. In other words, the more parallel the axis of a muscle is to the axis of the bone which it is to move, the weaker will be its action-the maximum value is obtained when the line of action is at right angles to the bone.

Pulleys. By means of a single fixed pulley the direction of a force is altered, but not its magnitude. In the body, instead of reducing friction by means of a rotating pulley the tendon operates in a synovial sheath (q. $\tau_{\text {. }}$. Good examples of the pulley may be found in the eartilaginous loop (trochlea) for the superior oblique on its way to the eycball: and the peroneus longus looping round the outer malleolus on its passage to the inner side of the foot.

Opponents. All the muscles attached to levers in the body are set in opposing pairs or antagonistic groups. As one group eontracts, the opposing group will relax to exactly the same degree. The ulna, for instance, is pulled up towards the humerus by the aetion of the anterior braehial and it is pulled downwards by gravity and the action of the posterior braehial muscle. Both sets of muscles act together and hamoniously, so that in any position of the ulna relative to the humerus, the opposing (muscular and gravity) forees exactly balance one another. That is, the arm may come to any position and remain there without the expenditure of any extra energy (not taking into account gravity).

Synergists. Movement does not usually take plaee merely by the contraction of a muscle and the relaxation of its opponent. There are numerous other muscles brought into play, synergistswhose aetion, though seeondary, helps the primary movements, generally by altering the pose of the body as a whole, but sometimes by immobilising the bone to which the muscle is fixed. As an example of the former, may be eited the action of the trunk muscles holding the body erect while a weight is being held above the head. The latter synergetical complex may be illustrated by the various muscles brought into action in opening a table drawer. "One hooks his fingers into the handle of the drawer and if it opens casily cough, the contraction of the flexors of the fingers is suffieicnt. If it works a little harder the flexors at the elbow eontraet to hold the bones of the forearm up so that the 
flexors of the fingers may have a firm origin. If still more foree be needed the latissimus and teres major spring into aetion to support the humerus and rhomboid to hold the seapula. To make a strong pull one pushes against the table with the other arm and brings the extensors of the trunk into aetion, and finally if this does not suffiee, the legs are braeed and the whole body is eonverted by museular action into a single solid pieee in order that the flexors of the fingers may exert all their power to open the drawer." This deseription by Bowen shows elearly the eomplexity of an apparently simple aetion. The student will note too that as more muscles are ealled upon, the lever is lengthened and the position of the fulerum altered. 


\section{CHAP'TER XXIX}

\section{THE VOICE}

"As the power of the vital soul is situated in the substance of the heart, and the power of the natural soul in the proper substanee of the liver,... so also does the brain, in appropriate structures and in organs properly subserving its work, manufacture the animal spirit, which is by far the brightest and most delieate, and indecd is a quality rather than an aetual thing. And while on the one hand it employs this spirit for the operations of the ehief soul, on the other hand it is eontinually distributing it to the instruments of the senses and of movement...."

(1543) Vesalius quoted by Foster.

Articulate speech may be considered as the resultant of essentially two component factors, $(a)$ the production of sound, and $(b)$ the modification of the sound to produce speech.

I. The latter factor is the simpler and may be dealt with first. Speech sound-units may be classed as vowels and consonants.

The vowels, $\mathbf{U}, \mathbf{O}, \mathbf{A}, \mathbf{E}$ and $\mathbf{I}$ are produced by the continuous issue of a blast of air through the mouth. $\mathbf{U}, \mathbf{O}$ and $\mathbf{A}$, pronounced $\bar{o} \bar{o}$ (cook), oh and ah, respectively, are simple tones. They are produced by a regular series of vibrations emitted by a singlc cavity formed by lips, chceks, palate and tongue (Fig. 42).

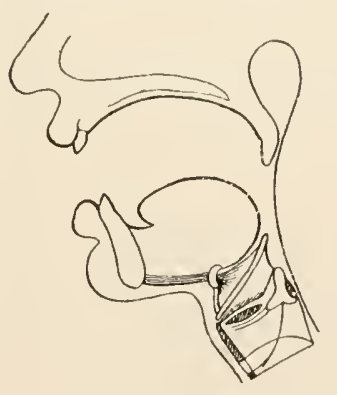

A $(a h)$

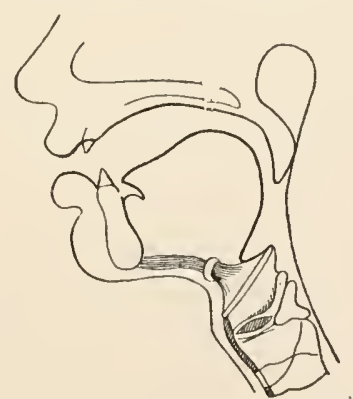

$\mathbf{U}(\bar{o} \overline{0})$

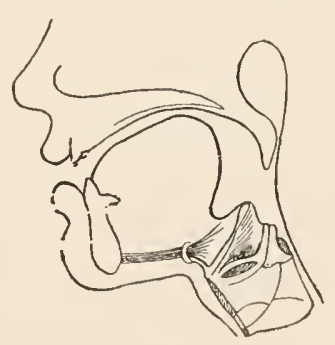

$\mathbf{I}(\bar{e} \bar{e})$

Fra. 70.-Changes in the Shape of the Mouth in Sounding the Vowels, A, U, and I. (Grätzner.)

This cavity is widest and shortest with $\mathbf{A}$, longest and narrowest with $\mathbf{U}$, while $\mathbf{O}$ is intermediate. On the other hand, $\mathbf{E}$ (as in 
pet) and I (=ee) are double-toned. 'The back of the tongue is brought up against the front part of the soft palate so that the mouth is divided into two resonating eavities each with a charaeteristic note (Fig. 70).

By whispering the vowels one may readily determine the resonance-piteh eharacteristic of each. $U$ has the lowest piteh, followed by $\mathbf{O}$ and $\mathbf{A}$. It is thus easicr to $\operatorname{sing} \mathbf{U}$ and $\mathbf{O}$ on low than on high notes. An attempt to go up the seale by sounding " oos" will eause a tendeney to elip the full vowel and sound a short "ee." The characteristic notes of each of these vowels (by pereussion, Expt. 51, p. 422) is given by Helmholtz as follows (Fig. 71) :

$\mathrm{U}=F$

$\mathrm{O}=B^{\mathrm{I}}$

$\mathrm{A}=B^{1 \mathrm{I}}$

$\mathrm{E}=F^{\mathrm{L}}, B^{\mathrm{III}}$

$\mathrm{I}=F, D^{\mathrm{IV}}$.

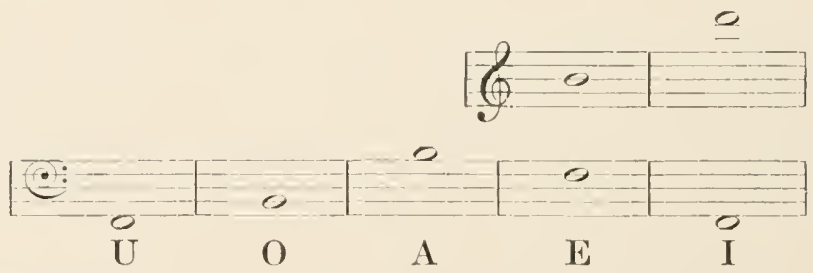

Fig. 71 (Starling).- Talues obtained by pereussing mouth cavity while shaped for the pronunciation of the vowels.

The English I is really a diphthong and is pronouneed by rapidly uttering the component unit sounds, e.g. I (as in fight) $=\mathbf{A I}=$ ahl-ce.

Consonants are not eontinuous but are sharply interrupted sounds. The issuing air is suddenly shut off by the lips to give the labials; by the teeth to produce dentals; by the tongue to give rise to gutturals. If the eheck oecurs before the sound is produeed, and the air is suddenly released, explosives are the result. The eharacteristic sounds of some consonants, e.g. M and $\mathbf{N}$ (which are meehanieally the same as $\mathbf{B}$ and $\mathbf{D}$ ), are produeed by keeping patent the posterior opening of the nares. In this way some of the air comes eontinuously through the resonant nasal passages.

TABLE LII.

Consonants.

\begin{tabular}{|c|c|c|c|c|}
\hline Class. & & Labial. & Jental. & Guttural. \\
\hline Explosives & - & P. B. V. & T. D. & K. G. \\
\hline Aspirates & - & $\mathrm{F}$ & S. L. Th. & Ch. (Scots) \\
\hline Vibratives & - & - & - & R. (Scots) \\
\hline Nasals - & - & M. & N. & $\mathrm{Ng}$. \\
\hline
\end{tabular}


All these with the exception of the hard consonants (e.g. B and $\mathbf{D}$ ) can be pronounced quite well without the use of the larynx. The hard consonants are aecompanied by phonation. Thus, although in pronouncing $\mathbf{D}$ there is a chcek at the teeth, the produetion of the laryngeal sound goes on.

II. Phonation, or the production of sound, is not so simple as articulation. At least two essential factors are concerned. The mechanism for producing sounds consists of a bellows or blowerthe lungs; a vibrating structure-the vocal chords; a cyclone chamber-the ventricle or space between true and false vocal eords; the wind pipe or trachea; and resonating chambersthe cavities of pharynx, mouth and nose. Musical notes can be produced without the intermediation of the vocal cords. It has been shown that the sudden expansion in bore of the windpipe at the ventricle is quite sufficient to produce a cyclonic disturbanee of the air, and sound is the result. Most people are of opinion, however, that the vocal cords play the major part in sound production.

Loudness is due to amplitude of vibration and depends, in part, on the force and volume of the blast of air cmitted.

In part, it depends on the size of the larynx and of the resonating chambers, and on the tension of the vocal cords. "A truc crescendo is obtained by relaxing the tension of the vocal cords.

Pitch, or tonc-height, is a function of the rate of vibrations. This may be proved by running a gramophone record at various speeds. When running at its slowest the plate of the sound-box is reeeiving and transmitting vibrations at the rate of about 100 per sec., and one hears a bass voice. As the speed is increased the voice rises in pitch till it may be a distinctly light tenor with 500 vibrations per second.

The limits for the human voice are given in Table LIII.

TABLE LIII.

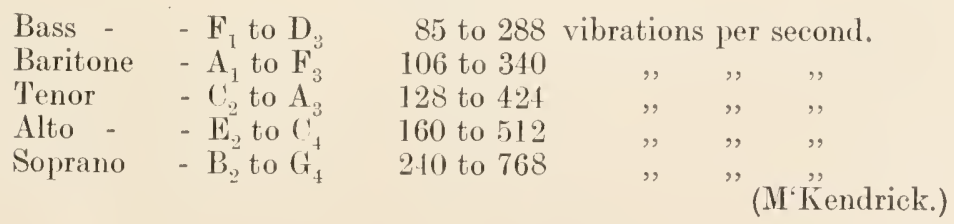

We derive the musical notion of high and low pitch from the rise and fall of the larynx in the production of sounds-an entirely subjective phenomenon. The pitch of a tone, from a physical 
point of viero, is absolutely defined by its vibration number. High pitehed notes have a higher rate of vibration than low pitehed notes. Alterations in the piteh of a note are probably brought about in the larynx by altering the tension of the voeal eords, by the action of the erieo-thyreoid muscle-the greater the tension of the vibrating membrane, the higher the piteh of the note produeed. The part of the eords free to vibrate may be varied by the approximation of the arytenoid eartilages to one another. A long eord vibrates more slowly than a short one. This aeeounts for the high pitehed voices of ehildren.

In addition to this, it is eommon knowledge that when the foree of the blast of air is inereased, the piteh of the voiee rises. There is thus a tendeney to sing sharp when foreing the voiee, say in a large badly built hall.

In one and the same larynx, different parts or regions of the seale are produeed in different ways. 'Those notes of the seale which are produeed by the same means are said to be produced in the same register. 'Thus, we produee deep notes in the ehest-, or thiek-register, while high notes eome from the high-, head-, or small-register. The thin or middle register is used normally by tenors and when the male voiee sings falsetto.

Laryngoscopical investigation has shown that, when produeing notes from the chest register, the glottis forms an elongated slit and the voeal cords, stretehed as tightly as possible, are vibrating as thick masses over their whole extent. In taking the lowest notes the posterior portion of the arytenoid eartilages are close together with a wide elliptieal ehink between the cords. As the piteh of the note rises the arytenoid cartilages are brought eloser together and so shortening of the vibrating portion of the eords is produeed. The thyreoid eartilage approximates to the erieoid and the voeal eords are stretehed and brought elose. The epiglottis rises as the piteh rises.

When the upper limit of this register has been reached the tension on the various parts is extreme and onc passes with relief to the middle register-the normal meehanism in the female (and tenors) for the produetion of notes between $\mathbf{F}_{3}$ and $\mathbf{F}_{4}$. The thyreoid eartilage returns to its normal position, the tension on the eords is deereased and they vibrate at their thin membranous edges only. As the piteh rises the thyreoid and the ericoid cartilages are again pulled together by the aetion of the erieo-thyreoid musele, and this state of tension lasts in tenors, sopranos and eontraltos alike from $\mathbf{F}_{3}$ to $\mathbf{C}_{4}$. Higher notes than 
this are attained by a shortening of the voeal ehink. In the small or head register the notes are produeed by vibrations of only the inner margins of the eords, and the voeal ehink is redueed to a small anterior aperture whieh beeomes smaller as the piteh rises. These different meehanisms produee tones of pereeptibly different quality.

Timbre or quality of the voiee depends largely on the aeeessory resonating ehambers. These eavities pick out and aeeentuate the overtones produeed by the vibrations of the segments of the eords. Trained singers conseiously or instinetively adapt the shape of the mouth so as to seeure for each tone the most suitable overtones.

The work done in speaking and in singing is eomplex. Many museles are brought into play and the energy expended by them varies with the rate of speeeh and the intensity of the sound produeed. The pressure of air employed in ordinary quiet eonversation amounts to between 140 and $240 \mathrm{~mm}$. of $\mathrm{H}_{2} \mathrm{O}$, while nearly $1000 \mathrm{~mm}$. are required when shouting is indulged in.

If work (phonation only) is taken as equal to the produet of the pressure and volume of air expelled, i.e. $\mathbf{W}=\mathrm{VH}$, we may make a rough assessment of the amount of work done. During ordinary eonversation, a man with a tracheal eannula developed an air pressure of $100 \mathrm{~mm}$. $\left(\mathrm{H}_{2} \mathrm{O}\right)$ and expired 300 litres of air per hour i.e.

$$
V H=\frac{300 \times 100}{1000}=30 \mathrm{kgm} \text {. per hour. }
$$

Speaking in a large hall the same man expired 1440 litres of air per hour and developed a mean pressure of $150 \mathrm{~mm}$. $\left(\mathrm{H}_{2} \mathrm{O}\right)$,

$$
W=1440 \times 0 \cdot 15=216 \text { kilogrammetres. }
$$

One may arrive at an estimate of the work of speaking by measuring the oxygen used during rest and during speeeh. Delivering an oration at the rate of $\mathbf{1 5 0}$ syllables a minute eaused the eonsumption of 28.78 litres of oxygen. Subtraeting from this the amount used during a similar period of rest, viz. $\mathbf{1 6 . 9 6}$ litres, we find that $\mathbf{1 1} \cdot 82$ litres were used by the orator. In large Calories this amounts to $11.82 \times 4.9=57.9$ Cals. per $\mathrm{hr}$. In $\mathrm{kgm}$. this gives $\frac{57 \cdot 92}{4} \times 425=6154$ kilogrammetres.

The value just obtained is about 15 times as great as that of mere phonation. We must remember that the orator, and the subjeet of the experiment was a Frenehman too, uses many 
additional museles in gestieulation, ete. A speech of an hour's duration may tax his entire powers. 'To add to his troubles he has to make himself heard in a large hall. 'Table LIV. gives the relative values of the expenditure of energy in the utteranee of a single pereeptible note in various sizes of halls. The notes were produeed by an artifieial larynx (syren).

TABLE LIV.

\begin{tabular}{|c|c|c|c|c|c|c|c|}
\hline \multicolumn{5}{|c|}{ Nature of Hall. } & \multirow{2}{*}{$\frac{\text { Tenor. }}{1 \cdot 0}$} & \multirow{2}{*}{$\frac{\text { Baritone. }}{3}$} & \multirow{2}{*}{$\begin{array}{c}\text { Bass. } \\
7\end{array}$} \\
\hline Theatre & - & - & - & - & & & \\
\hline Church & - & - & - & - & 4 & 6 & 42 \\
\hline Lecture room & $1-$ & - & - & - & $1 \cdot 4$ & 4 & 12 \\
\hline Dining hall (l & bad & $\operatorname{cou}$ & es) & - & 4 & 6 & 66 \\
\hline
\end{tabular}

These figures, multiplied by $2 \times 10^{-5}$, give, in kgms. per sec., the minimum expenditure of energy necessary to make the sound perceptible in ten different parts of the hall.

In every ease the possessor of a bass voice has to expend more energy than the baritone or tenor. Generally speaking, the tenor has least trouble in making himself audible, but instanees may oeeur where on aeeount of its resonating qualities, a building may prove more suitable for a baritone than for the former. 


\section{SECTION Y.: THE ANIMAL AS A WHOLE}

\section{CHAPTER XXX}

\section{THE PRESERVATION OF NEU'TRALITY}

\footnotetext{
"To test a principle by its consequences is allowed by good logic and enjoined by sound reason."

Joubert.
}

Frour a physieo-ehemieal standpoint, the animal body may be considered as a polyphase liquid, the various phases being separated from one another by a series of membranes of varying and variable permeability. From the moment of origin of the organism as an entity, that is, from the time when the eonjugation of spermatozoön and ovum produeed a mass of protoplasm which was not in equilibrimm with its environment, the various external forees brought to bear on the organism still further aeeentuate this disturbanee. The sum of the ehanges termed life may be looked on as the response of this polyphase-multimembrane-enelosed liquid to these impaets. Briefly, all ehanges tend to restore balanee - whieh, when attained, is death. It is diffieult to make statements on this subjeet without using terms implying purpose, for example we speak of water reaching its own level--eell adjusting itself to its environment, ete. To nse other terminology would be eumbrous if eorreet.

IVe dealt (Chap. XVI.) with the effeet produeed, on the internal and external structure of bone, of altering the incidence of a load. Not only are the nearby bones altered but even distant and apparently unaffeeted bones undergo ehanges. In our study of the transport system we saw how an alteration prodneed in one part of an organism spread throughout the whole animal.

One of the main funetions of blood is to maintain eonstant the eoneentration of hydrogen ions throughout the organism. A slight potential inerease in the aeidity or alkalinity of the system 
acts as a trigger, setting off a scries of reactions resulting, finally, in the restoration of neutrality. Acid is set free, say in muscle, and before it can be rebuilt into the muscle complex, oxidation of glucose has to take place. The introduction of this acid in a minute amount has three profound effects. Firstly, it increases the dissociation of oxyhaemoglobin (p. 253) setting frec the needed quota of oxygen, secondly, by stimulating the respiratory centre (Chap. XXVI.), it specds up the intake of oxygen, and lastly, the blood flow is increased, both locally by vasodilatation, and generally by increased cardiac action.

In the work of prescrving the neutrality of the organism, the blood is aided by the eliminating organs, - the lungs and the kidneys.

Factors tending to preserve neutrality.

I. In the plasma we have $(a)$ colloids, and $(b)$ crystalloids.

(a) The colloids of blood plasma are mainly serum albumin and serum globulin and they are amphotcric in character, i.e. they may act either as acids or as bases. Expcriments carried out in the laboratory show definitely that, although the proteins of the plasma readily combine with mineral acids, they are unable to react with the weakly dissociated acids found in the body. Both albumin and globulin form hydrochlorides for instance, but protein lactates or carbonates are unknown. Apart from the amount of $\mathrm{CO}_{2}$ adsorbed by the colloidal particles, the blood colloids can play but a small part in reducing the carbonic acid, etc., produced in the organism.

(b) Of the crystalloids in solution in the plasma, sodium bicarbonate has a marked "buffer" effect. In this salt a strong base is united with a weak acid and, therefore, any acid stronger than $\mathrm{H}_{2} \mathrm{CO}_{3}$ will take the place of the $\mathrm{HCO}_{3}$ ion in its combination with Na.

For instance,

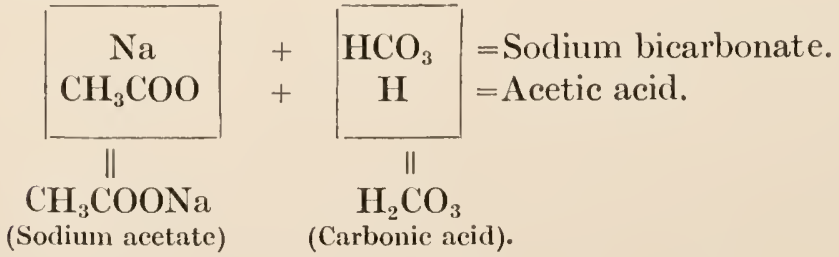

This reaction appears just to postpone matters because carbonic acid is set frec and, although this acid is only slightly dissociated, yet, as an acid, it must be reckoned with. But the equation 
of the dissociation of $\mathrm{NaHCO}_{3}$ shows that it is a reversible reaction :

e.g.

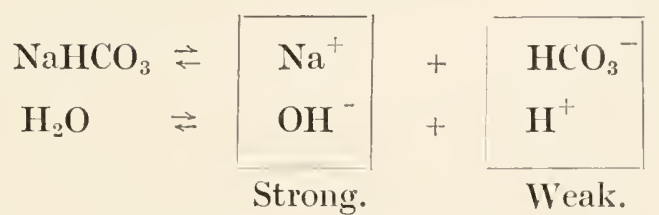

This means that the direetion of the reaetion will, in the main, depend on the relative amount of $\mathrm{CO}_{2}\left(\mathrm{H}_{2} \mathrm{O}\right)$ present eompared with the amount of $\mathrm{NaHCO}_{3}$. This ratio has been determined experimentally. 'To give the normal $p \boldsymbol{I I}$ of $\boldsymbol{7 \cdot 4}$, plasma must have 3.75 grams of $\mathrm{CO}_{2}$ bound in $\mathrm{NaHCO}_{3}$ present for every gram of uneombined $\mathrm{CO}_{2}$ : or, by volume, one volume of $\mathrm{CO}_{2}$ remains constant when assoeiated with 20 volumes eombined as earbonate. In tabular form this reads :

$$
\frac{\text { Free } \mathrm{CO}_{2}}{\text { Bound } \mathrm{CO}_{2}}=\frac{1}{3 \cdot 75} \text { by weight, } \frac{1}{20} \text { by volume. }
$$

If exeess of $\mathrm{NaHCO}_{3}$ over this ratio is present, some will dissoeiate to balance the dissoeiation pressure. If too mueh $\mathrm{CO}_{2}$ is present it will in the first instance eombine with any free base to form a bicarbonate; if no free base offers, the exeess $\mathrm{CO}_{2}$ will be eliminated by the lungs.

The bicarbonate of the plasma represents the excess of base which is left over after all the non-volatile acids have been neutralised. It is the alkali reserve of the body which ean be drawn upon to neutralise any free aeid stronger than $\mathrm{CO}_{2}$ which may find its way into the blood stream (Demonstration, Part Ir.). Not until praetically all the alkali reserve has been used up, will the blood show any ehange in hydrogen ion eoneentration. Long before that point ean be reaehed, other mechanisms will be brought into aetion to preserve neutrality. The biearbonate is a nest egg of potential base whieh may be drawn upon when required, but the inroad must be made good at the first opportunity. It is really an emergeney measure useful to tide one over the diffieulties that oeeur suddenly and frequently. It is not a widow's cruse of oilalways magically replete. If the ratio of $\mathrm{H}_{2} \mathrm{CO}_{3}$ to $\mathrm{NaIICO}_{3}$ is kept within normal limits even though the reserve is permanently lowered, the acidosis necessitating the draft on the reserve is ealled compensated. If on the other hand: the amount of $\mathrm{H}_{2} \mathrm{CO}_{3}$ inereases to a value greater than 1,20 of the alkali reserve in arterial blood, the aeidosis is said to be uncompensated. 
II. 'The lungs eliminate $\mathrm{CO}_{2}$. The amount eliminated per' unit of time is a function of the eapaeity of the lungs and the rhythm of respiration. The rate and depth of respiration are eontrolled by the amount of $\mathrm{CO}_{2}$ in the blood perfusing the respiratory eentre in the medulla oblongata. Any inerease in the $\mathrm{CO}_{2}$ of the blood eauses an increase in the rate of respiration. Similarly, the process of respiration may be slowed down, till it stops, by decreasing the amount of $\mathrm{CO}_{2}$ in the blood. It has becn stated that this regulatory aetion of the medulla is caused not by $\mathrm{CO}_{2}$ but by the hydrogen ion conecntration of the blood, i.e. any acid perfusate will quicken respiration. But, as is obvious from the eontext, no free acid but $\mathrm{CO}_{2}$ can oeenr in the blood of a living animal. Further, eareful researeh has shown that the $p H$ of blood does not alter, the regulation is so nice.

III. Excess of base, and acids in combination with bases arc eliminated by the kidney. The eells of this organ have a low threshold for such salts.

IV. The red eorpuseles of the blood play an ill-defined part in the preservation of ncutrality. In eommon with other tissue elcments, the erthrocytes have a phosphatebuffer system. Sodium dihydrogen phosphatc, $\mathrm{NaH}_{2} \mathrm{PO}_{4}$, is an acid salt and reacts with biearbonate, for instanee, to form the basic salt $\mathrm{Na}_{2} \mathrm{HPO}_{4}$,

viz. : $\quad \mathrm{NaH}_{2} \mathrm{PO}_{4}+\mathrm{Na}_{2} \mathrm{HCO}_{3} \underset{\longrightarrow}{\longrightarrow} \mathrm{Na}_{2} \mathrm{HPO}_{4}+\mathrm{H}_{2} \mathrm{O}+\mathrm{CO}_{2}$ acid phosphate. basic phosphate.

A mixture of these two phosphates such as is found in all tissues obviously will not inerease in aeidity till nearly all the disodium phosphate has been converted into dihydrogen phosphate, nor will the $[\mathbf{H}] \cdot$ markedly deercase till all the dihydrogen phosphate has been converted into the basie salt.

In addition to this it secms as if the pigment, haemoglobin, took some part in the reaetion. Some evidenee has been produeed whieh indicates that $\mathrm{Hb}$ adsorbs or eombines with $\mathrm{CO}_{2}$ at high $\mathrm{CO}_{2}$ tensions and parts with it at low tensions, i.e. in the lungs. Be that as it may, the haemoglobin aets as a buffer to a degree of which the plasma protcins are incapable, and promotes the dissoeiation of bicarbonate during diminishing tensions of $\mathrm{CO}_{2}$. This property is due to the clectrieal charge of haemoglobin. In an alkaline medium, haemoglobin carries a positive eharge; the more alkaline the medium, the more aeidie is hacmoglobin, and conversely, when the blood is taking up $\mathrm{CO}_{2}$ from the tissues, haemoglobin is least aeidie. 
V. The tissues themselves exert a neutralising effect on the blood. As mentioned above they are endowed with a phosphate buffer system.

To summarise :

Blood and tissuc fluids normally ncutral $p \mathrm{I}=\boldsymbol{\gamma} \cdot 4$.

Alterations caused.

1. Tending towards alkalinity-Alkaline tide after digestion.

2. Tending towards acidity.
A. Normal.
(1) Muscular activity. $\quad \mathrm{CO}_{2}$.

Lactic acid.

(2) Protein disintegration. food $\mathrm{H}_{2} \mathrm{SO}_{4}$ muscle $\mathrm{P}_{2} \mathrm{O}_{5}$

B. Abnormal. Mal-oxidation acidosis.

Alterations checked.

1. Tissue compensation-Phosphates.

2. Alkali rescrve- $\mathrm{NaHCO}_{3}$.

3. $\left\{\right.$ Respiration $\left\{\begin{array}{l}\mathrm{CO}_{2} \text { stimulates respiratory centrc. } \\ \text { Lack of free } \mathrm{CO}_{2} \text { depresses centre. }\end{array}\right.$

4. Kidncy $\left\{\begin{array}{l}(a) \text { increased climination of }<\text { acid } \\ (b) \mathrm{NH}_{3} \text { salts. (Liver action.) }\end{array}\right\}$ as salts.

An apology is necessary for the use of the word "buffer "to denote the power of phosphates and bicarbonates to maintain a steady $p \mathrm{H}$ in spite of additions of acid or alkali. Prof. Bayliss has pointed out the misleading nature of this expression and has shown how it crept into use. Nondescriptive as the word undoubtedly is, it has found a place in current physiological and physico-chemical literature, dislodgment from which will be a difficult task. 


\section{CHAP'TER XXXI}

\section{THE REGULA'TION OF' TEMIPERA'TURE}

" Where hot and eold, and dry and wet Strive each the other's place to get."

Prior.

ONE of the most striking phenomena in the life of man and of the hot-blooded animals generally is the remarkable constancy of the temperature maintained in spite of the variations of temperature to which they may be subjected. This is a fact whieh did not escape the attention of the ancients, who tlought out many weird and wonderful explanations. Even well on in the ninetecnth eentury, text-books echocd the idea of Haller (1757) that animal heat arose mainly from the friction of tlre blood in the vessels.

The manmal or the bird may travel from the arctic regions where the external temperature may be at $-53^{\circ} \mathrm{C}$. to the tropies at $53^{\circ} \mathrm{C}$. without much increase in body tempcrature. Contrast this freedom from variation with the continuously changing temperature of the cold-blooded animal as the tempcrature of its environment changes.

TABLE LV.

\begin{tabular}{c|c}
\hline Temp. of Water. & Temp. of Frog's Stomach. \\
\hline $2 \cdot 8^{\circ} \mathrm{C}$. & $5 \cdot 8^{\circ} \mathrm{C}$. \\
$20 \cdot 6^{\circ} \mathrm{C}$. & $20 \cdot 7^{\circ} \mathrm{C}$. \\
$41^{\circ} \mathrm{C}$. & $38^{\circ} \mathrm{C}$. \\
\hline
\end{tabular}

Within natural limits, the temperature of the eold-blooded animal is usually about $1^{\circ} \mathrm{C}$. above that of its environment. It is interesting to note that those animals which hibernate become for the time as if cold-blooded. The evolutionists postulate that, as all animals were once marine eold-blooded organisms, the ancestors of the warm-blooded animals must have crawled out 
of a tropieal sea and ever sinee have had to maintain this initial high temperature. The advantages that they possess by reason of thcir higher temperature arc due $(a)$ to the well-known faet that most chemieal and some physical reactions are inereased in rate by heat, and $(b)$ to their freedom from constant fluctuations of temperature. Against this must be plaeed the faet that they have to maintain a temperature greater than their environment by about $20^{\circ} \mathrm{C}$.

Of all animals, birds have the highest tempcrature, For example, that of the chicken is about $43 \cdot 8^{\circ} \mathrm{C}$ : : of mammals, the rabbit and the fox have a temperature as high as $40^{\circ} \mathrm{C}$, whilc the horse and the elephant come low on the scale with $37 \cdot 6^{\circ} \mathrm{C}$.

In health, the temperature of the human body varies so little from the normal value of $37^{\circ} \mathrm{C}$. $\left(98 \cdot 4^{\circ} \mathrm{F}\right.$.) that temperature is regularly taken as a elinical indieator and any fluctuation from the normal points to the employment of remedial measures.

Homoiothermic Animals maintain a constant temperature.

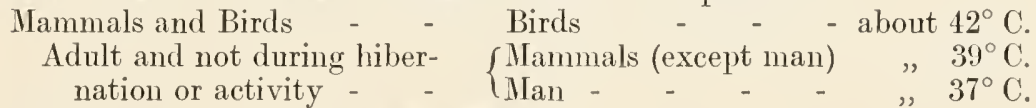

Heterothermic or Poikilothermic Animals.

(a) Lethal temperature, New born Homoiothermes. about $20^{\circ} \mathrm{C}$.

(b) Hibernation starts when Hibernating animals. temperature falls to about $20^{\circ} \mathrm{C}$.

(c) Still active below $20^{\circ} \mathrm{C}$ Reptiles, Batracia, Fish, Molluses, Insects, etc.

Instruments used.

(a) Mercury thermometer.

(b) Electrical resistance thermometers.

(c) Thermo-electric couple (Thermopile).

(a) The thermometer was probably invented by Galileo (1603), and was first used clinically by Sanctorius (1626), who reported the temperature of a fevered man.

The clinical thermometer is an adapted form of the common mercurial thermometer having, (1) a long cylindrical reservoir to admit of rapid attainment of equilibrium between body and mercury. (2) A small bulbous part just above the mercury reservoir to catch the mercury driven out of the reservoir by the expansion due to the increase in temperature to $34^{\circ} \mathrm{C}$. (3) $\mathrm{A}$ small bore capillary graduated from $35^{\circ} \mathrm{C}$. to $45^{\circ} \mathrm{C}$. to admit of reading to a tenth of a degree, and finally, (4) another bulbous part to catch any mercury that might be driven over by accidental hcating beyond $46^{\circ} \mathrm{C}$. Usually the thermometer is made self-registering by having a small detached thread of mercury which is pushed up by the expanding fluid and remains at the highest temperature reached. 
Where a continuous record has to be made, or where great accuracy is desired, one of the electrical methods is employed.

(b) This method depends on the alteration of the electrical resistance of a platinum (or other metal) wire caused by a slight increase in its temperature. The alteration in conductivity may be measured by a Wheatstone's bridge or may be recorded photographically as in the study of the electrical changes in tissues (p. 297). This is by far the more sensitive of the two electrical methods, but great care must be exercised in its use. It has, however, some disadvantages. For example, the current flowing through the thermometer tends to heat the fine coil of wire. The heating is proportional to the square of the current, and to the resistance of the wire.

(c) The thermopile is based on the principle that, if the junction of two dissimilar metals (e.g. constantan and iron) be warmed, a difference of potential between the two will be produced. In order that small fluctuations of temperature may be measured, a second thermopile is arranged in the circuit in series with but opposed to the first. This second thermoelectric junction is kept at a certain known temperature differing but little from the temperature to be measured. By this means the bulk of the electromotive force resulting from thermopile 1 will be neutralised by the E.M.F. produced by thermopile 2, and thus the E.M.F. produced by a small change of temperature becomes a relatively large proportion of the net E.M.F. The current changes are read from a potentiometer.

\section{Location of Thermometer.}

(a) Natural Cavities.

(i) Mouth. The cavity underneath the tongue is generally chosen by the physician as suitable for the taking of temperature. The thermometer should remain at least 7 mins. in situ. If the mouth is kept open, low readings will be obtained due to the inrush of cold air and the vaporisation of moisture.

(ii) Rectum. Practically all physiologists are agreed that the most favourable position for the thermometer for the indication of the true temperature of the interior of the body is the rectum (or vagina in females). The instrument should be inserted sufficiently deeply $(7 \mathrm{~cm}$.$) , to make$ sure of the maximum temperature, and, in the case of the rectum, it should not be imbedded in faecal matter.

(b) Artificial Cavities.

(iii) Axilla. In the private practice of a physician, temperatures are generally taken from the armpit. Care has to be taken to free the skin from moisture and sweat and to close the cavity on the thermometer for a time sufficiently long to enable the surface of the skin to attain the temperature of the interior of the body.

(iv) Groin. In young children the thermometer is usually placed in the fold of the groin.

While the temperature of the body is so constant that it is taken as a clinical sign, yet it does vary regularly during the 24 hour day. From the chart (Fig. 72), it will be seen that between 3 and 4 in the morning body temperature is at its lowest 
and between 3 and 4 in the afternoon it is at its highest. This rhythm or periodieity is shown by night workers as well as by those who live a normal average life. Benediet tells of a night

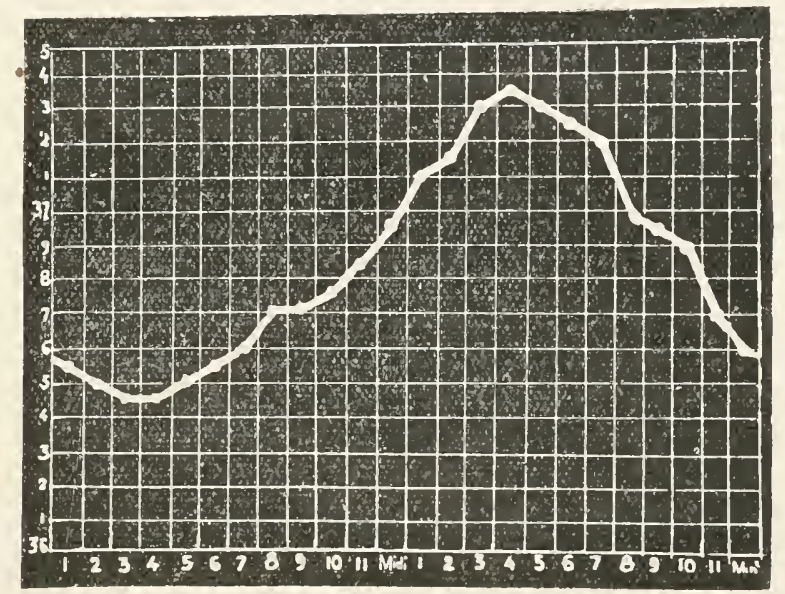

FIG. 72.-Chart of the Daily Variation of Temperature in the Normal Human Subject, in degrees Centigrade. The hours are marked irom midnight. (Richet.)

watehman who for seven years had been working during the night and sleeping during the day, and had his maximum temperature about 4 o'elock in the afternoon when sound asleep and his minimum about 4 o'eloek in the morning when he was awake and active.

It is common knowledge that certain means may be taken to bring about alterations in the body temperature :

1. Muscular exercise causes heat.

2. Want of muscular exercise is followed by cooling, e.g. cold has to be guarded against during sleep.

3. Heat or work causes sweating.

4. Heat produces lassitude. Compare the day's work of a man in Spain with that of a man in Scotland.

5. Still air has the same effect as that of heat on the feeling of lassitude. The production of a movement of the air removes the tired feeling.

6. A higher temperature can be endured in a Turkish than in a plunge bath. Further, a hot dry climate is comfortably endured, while air at the same temperature, but saturated with moisture, oppresses.

7. Cold air does not chill one to the same extent as water at the same temperature. Cold much more severe than is experienced in Britain may be enjoyed in the dry, Canadian climate.

For example, a temperature of $-40^{\circ}$ may be borne if the air be dry and still, while a much warmer but damp and windy atmosphere may "cut to the bone."

8. Ingestion of hot or cold food or of heat-producing food normally produces an almost negligible increase in rectal temperature. 
What we want to get at is the mechanism whereby the body tenperature of the higher mammal is kept fairly constant despite variations of outside and "inside" temperaturc. In this respect, they obey the ordinary laws of cooling-surface phenomena. Heat may be lost by :

I. Conduction and eonvection.

Ia. Ingestion and excretion. Inspiration and expiration.

II. Radiation.

III. Evaporation of moisture.

\section{Conduction.}

By conduetion is meant the loss of heat from a body at a higher temperature to one at a lower temperature by passage from particle to particle, for cxample, the passing of heat along a poker, one end of which is in the fire. The amount of heat lost by the body in this way depends on several factors.

(i) Surface exposed. (a) The loss of heat varies directly with the area of the surface exposed. For example, the flow across two square metres is double that across one squarc metre. The area of surface of a child of 2 ycars weighing $10 \mathrm{~kg}$. is $5120 \mathrm{sq}$. em., and of a man of $60 \mathrm{~kg}$. is $14,079 \mathrm{sq}$. cm. That is, the area per $\mathrm{kg}$. for a ehild of 2 ycars is $512 \mathrm{sq}$. cm., and for a man is $234 \mathrm{sq}$. $\mathrm{cm}$. It is obvious that weight for weight the ehild will lose more heat than the man.

(b) The loss of heat depends on the moistness of the surface. The thermal conductivity of all liquids cxcept mereury is very low. Water may be boiled in the top portion of a test tube without affecting a pieec of ice at the bottom.

TABLE LVI.

Thermal Conductivity.

\begin{tabular}{|c|c|c|c|c|c|c|c|}
\hline \multicolumn{3}{|c|}{ Substance. } & Conductivity $(c)$. & \multicolumn{3}{|l|}{ Substance. } & Conductivity (c) \\
\hline ilver & - & & 1.52 & Cotton flock & - & & $4 \times 10^{-5}$ \\
\hline Platinum & - & & $1.14 \times 10^{-1}$ & Water at $37^{\circ} \mathrm{C}$ & C. & & $135 \times 10^{-5}$ \\
\hline Marble & - & & $180 \times 10^{-5}$ & Sea water & - & & $108 \times 10^{-5}$ \\
\hline Wood & - & & $10 \times 10^{-5}$ & Olive oil - & - & & $39 \times 10^{-5}$ \\
\hline Paper & - & & $30 \times 10^{-5}$ & Human skin & - & & $60 \times 10^{-5}$ \\
\hline Vulcanisec & d rubber & & $8.9 \times 10^{-5}$ & Lard - & - & & $48 \times 10^{-5}$ \\
\hline Wool & $-\quad-$ & & $5 \times 10^{-5}$ & Leather - & - & & $42 \times 10^{-5}$ \\
\hline Compresse & ed cotton & & $3 \times 10^{-5}$ & Air (dry) & - & - & $5 \times 10^{-5}$ \\
\hline
\end{tabular}

(c) The loss of heat depends on the nature of the surface and of the subeutaneous tissue. A good layer of subeutaneous fat 
which has a low thermal eonduetivity will deerease the rate at which heat arrives at the surface and retard heat loss.

Every one knows that certain substances do not readily conduct heat. In the hot room of a Turkish bath, where all the objects are at the same temperature, metallic objects feel much hotter than those of wood, bone, rubber, etc. A familiar example of the retention of heat by a body surrounded by some bad conductor is found in the hay box or Norwegian cooker, which consists of a wooden box having a thick lining of felt. The partially cooked meal while still hot is placed in the box and the intervening space firmly packed with hay or paper. The felt-lined lid is closed and the meal left to cook itself. After several hours the temperature will have fallen only a few degrees. The Dewar or thermos flask depends on a vacuum as non-conductor.

Animals which have a good layer of subeutaneous fat lose heat much more slowly than lean ones.

Fat aets as a heat insulator and retards loss by eonduetion. On a moderately warm day, the obese person beeomes uneomfortably warm. $\mathrm{He}$ is unable to eliminate heat with sufficient rapidity, and, as a eonsequenee, his temperature rises, and may eause an inerease in general metabolism amounting to 50 per eent. over that of a thin person. Aquatie mammals rely on their adipose tissue to protect them from a too rapid loss of heat.

Several measurements of the temperature inside the body have been made. The natural eavities, e.g. the reetum, and vagina, are generally used, both being deep eavities into which the thermometer or thermal elements ean be inserted for a considerable distanee. Measurements have been made of the temperature in the inside of the stomaeh in patients with gastrie fistulae. 'The temperature of freshly voided urine was suggested by Stephen Hales in 1731 as representing that of the interior of the body. It has been found that, while the temperature of the surfaee of the body is about $32^{\circ} \mathrm{C}$, as the depth from the surface inereases, the temperature rapidly rises till the depth of about $5 \mathrm{em}$. is reached. It continues to rise mueh more slowly for the next two em. or so. Apparently the temperature after this is fairly uniform, i.e. $37^{\circ} \mathrm{C}$. That is, the subeutaneous tissues cause a temperature lag or thermal gradient of about $5^{\circ} \mathrm{C}$. This is due to the large proportion of water which enters into the eomposition of the tissues, giving the body the high speeifie heat of about $0 \cdot 83$. A man weighing $60 \mathrm{~kg}$. would consequently have a water equivalent of $50 \cdot 4 \mathrm{~kg}$. of water, so that a rise of $0 \cdot 1^{\circ} \mathrm{C}$. would only be registered after $5 \cdot 04$ eals. of heat had been rendered latent. 
(d) The loss of heat varies directly with the time of exposure of the surface. In actual practice, this can be determined for nonliving systems only, beeause, as we shall see, in the living body secondary reactions take place; alterations in the state of the surface and also of the deep-lying tissues are produced, rendering difficult the application of this law to living beings. If the student uses his eommon sense, however, he will readily see that, if all eonditions are kept constant except time, the amount of heat lost by eonduction must vary directly with the time of exposure.

(ii) Temperature gradient. Newton's law states that the amount of heat lost by a body in unit time is proportional to the difference in its temperature from that of the surrounding medium. The warm body loses heat and becomes colder, while the environment becomes warmer. This loss and gain goes on till the body and its environment are at the sanie temperature. Inspired air or cold food is warmed to body temperature at the expense of body heat. The drinking of cold water may cause a temporary reduction of rectal temperature. Conversely, hot food and drink tend to increase the temperature of the body.

The heat lost by excretion depends not so much on this factor as on the amount and nature of the excreta. Compared with the total heat lost, the amount lost by the heating of inspired air, cold ingesta, and by the excreta is trivial.

(iii) Force of wind. In still air, the loss by eonduction is very slight. Air is not a very good thermal conductor. A layer of warmed air soon forms an envelope round the cooling body and prevents rapid conduction. A very slight movement of the air may produce a very appreciable effect by driving off the warm particles and bringing eool ones into contact with the body. This may arise naturally by the formation of convection eurrents. The heated air expands and becomes lighter and so rises and allows the colder air to flow in.

An air current may be felt when it moves at the rate of about $0 \cdot 4$ to 0.5 metre per second. A non-perceptible draught with a velocity of 0.2 metre per second playing on the naked arm may increase the heat loss over that experienced in still air by 19 to 75 per eent. depending on the temperature of the air. A moderate breeze at 8 metres per second $(15$ miles per hour) with a temperature of $20^{\circ} \mathrm{C}$. causes more rapid chilling of a naked man than exposure to still air at $2^{\circ} \mathrm{C}$. (see also p. 346 ).

(iv) Humidity of atmosphere. Water is a better conductor 
of heat than air. A moment's consideration of the fecling of cold before entering cold water and during the process will convinee one of this. We have already mentioned the difference in the eold sensation caused by a dry cold wind compared with that produced by a wind of even a much higher temperature but laden with moisture.

\section{Radiation.}

The transmission of heat by radiation differs essentially from conduction and convection. The particles of a body have a vibratory movement depending on their kinetic energy. Increase of temperature will therefore cause increase in the velocity of these movements. In conduction some portion of another body is heated by eontaet with the warm body. This sceond body passes the heat on. There is molecular continuity. By radiation, on the other hand, one body can affect the thermal state of another body not in eontact with it without sensibly affecting that of the intervening medium. Radiation is not dependent upon the presence of air. It takes place quite readily in a vacuum. This is manifest when we consider how we derive heat from the sun whose radiant heat is transmitted through the ether at a very high velocity (about 186,000 niles per second) by means of transverse wave motion.

Radiant heat may be detected and measured by means of a suitable thermopile provided with a eollecting horn or by means of Leslie's differential air themometer. The amount of heat lost by radiation depends on :

(i) The area and colour of the surface. It has been proved experimentally as well as dedueed mathematically that the cmissive and absorptive powers of a body are equal. A perfectly black body absorbs all the heat energy that falls on it, and therefore, since a body cannot absorb more than is incident on it, the absorptive power of such a body is unity. The emissive power of a body is the ratio of the quantity of heat radiated per sq. $\mathrm{cm}$. of surface to the quantity radiated per $\mathrm{cm}^{2}$. of a "perfectly" black body under the same conditions. (Expt. 53, p. 424.)

TABLE LVII.

Radiating and Absorbing Powers of Bodies.

Lamp black - $\quad$ - $\quad$ - $\quad$ -

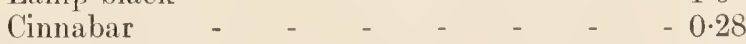

White paper - $\quad-\quad-\quad-\quad-\quad-\quad-0.9$

White lead - $\quad-\quad-\quad-\quad-\quad-\quad-0.21$

Polished silver $\quad-\quad \ldots \quad-\quad \ldots \quad-\quad-0.03$ 
(ii) There is a eonnection between the amount of radiation from, and the temperature of, a body. The total heat-loss by radiation is proportional to the differenee between the fourth powers of the absolute temperatures of the body and its environment as well as to the area and nature of the surface. If body and environment differ little in temperature, the heat lost by radiation will thus be comparatively small. For example, if the temperature of the air were $17^{\circ} \mathrm{C}$., the heat radiated from a "perfectly" blaek man at $37^{\circ} \mathrm{C}$. would be $(273+37)^{4}-(273+17)^{4}$ $=310^{4}-290^{4}=216 \times 10^{6}$ per unit surfaee.

Of eourse a perfectly blaek man does not exist nor yet a perfectly white man. If black skin has a radiation-eoeffieient of 0.98 and white skin of 0.7 , then the differenee in radiating power would be expressed by $\frac{0.98}{0 \cdot 7}=\mathbf{1} \cdot \mathbf{4}$, a trivial advantage to blaek-skimned animals. This has been eonfirmed experimentally by Leslie, who used a differential air thermometer as a very delicate method for the detection of very small differenees in temperaturc.

\section{Evaporation of Moisture.}

As the temperature of the air and of the body approaeh the same value, the heat lost by the body by radiation and eonduetion will be exactly balaneed by the heat absorbed from the environment by the body. If the atmosphere attain a higher temperature than the body, then these means of heat elimination will become inadequate, and the body temperature should increase synehronously with that of its surroundings. That this is normally not so is common knowledge. Many interesting instances have been known of persons submitted to high temperatures, and an examination of some of these eases may lead us to a knowledge of the

TABLE LVIII.

Time to kill Spores of Hay Bacilli at Various

Temperatures.

\begin{tabular}{l|c}
\hline Temperature. & Time. \\
\hline $100^{\circ} \mathrm{C}$. & over 16 hours \\
$105-110^{\circ}$ & $2-4$ hours \\
$115^{\circ}$ & $30-60$ minutes \\
$125-130^{\circ}$ & $5-6$ minutes \\
$135^{\circ}$ & $1-5$ minutes \\
$140^{\circ}$ & about 1 minute \\
\hline
\end{tabular}


mechanism called into play to prevent untoward results. On one point preliminary emphasis must be laid, viz. the times during which these extreme temperatures were endured were of very short duration. That the time factor is of immense importance may be adduced from the preceding experiment (Table LVIII.) by Christen.

In warm-blooded animals, $45^{\circ} \mathrm{C}$. is generally eonsidered a lethal temperature, but death may oceur at a lower temperature $\left(42^{\circ}\right)$, provided the time of exposure is sufficiently prolonged.

Bakers' assistants are known regularly to have entered ovens heated to over $126^{\circ} \mathrm{C}$. When the temperature approached $160^{\circ}$, they experienced extreme superficial vasodilatation. Young girl labourers are said to experience no inconvenience from a stay of $5-10$ minutes in a kiln heated to about $130^{\circ} \mathrm{C}$. Chaubert, the "Fire King," is reported as having withstood a temperature of between $226^{\circ}$ and $315.5^{\circ} \mathrm{C}$. Yet immersion in a bath of water at $45^{\circ} \mathrm{C}$. is unbearable. It is a matter of common knowledge that those who habitually work in abnormally overheated places consume large quantities of fluid, and sweat profusely. The latent heat of water is the greatest of all substances known. Every gram of water which is vaporised entails the use of 536 calories. This is in accordance with the principle of energetics laid down by Le Chatelier (p. 9). In general, if any change is brought about by the incidence of energy, then alteration will take place in the substance acted on to nullify these changes, i.e. a reaction of opposite direction occurs.

Substances which expand on heating will be cooled by mechanical expansion. Water increases its volume in passing from the liquid to the gaseous state, and therefore, as the result of such an expansion, the parent fluid is cooled. The evaporation of moisture from the surface thus causes cooling of the body (see also clothes, p. 351).

The quantity of heat lost by the evaporation of moisture $(a)$ in the bronchial passages, ete., $(b)$ in the form of sensible and insensible perspiration, depends mainly on five factors, viz. :

1. Area of moist surface exposed.

2. Colour ,", , ,

3. Gradient of temperature between body and environment.

4. Foree of wind (partial pressure equilibrium).

5. Humidity of the air.

(1) The effective area of surface exposed to cooling depends in great measure on the state of the superficial blood vessels. Dilatation of these enormously increases the area.

(2) The effect of colour is merely a matter of the differential absorption of radiant energy producing local heating in proportion to the amount of energy absorbed and so causing a more or less rapid evaporation. The black moist muzzle of the bull-dog is much cooler than its white, comparatively dry skin. 
(3) The gradient of temperature has mueh to do with the amount of heat lost by evaporation. 'This is an indireet effeet. It has been suggested that the pigmented skin of tropical raees, by absorbing radiant energy and so beeoming unduly warm, stimulates epidermal nerve-endings and produees rasodilatation and profuse sweating. The evaporation of this water then eools the body in a similar way to the Indian chatti or water eooler. Aceording to G. F. Hearne, exhaustion of the sweat meehanism always preceded heat-stroke in Mesopotamia.

(t) The presenee of a eurrent of dry air removes the gaseous water from the surface, and so brings dry air in eontaet with the body. In other words, the partial pressure of the gaseous water in the layer next to the body is kept at a minimum. This drying effeet of wind is operative irrespeetive of the temperature of the wind, as witness the drying of shallow pools of water and of wet elothes by eold and by warm breezes.

(5) Humidity of Air. The presenee of moisture in the air affeets its eooling powers in two ways. ( $a$ ) Obviously, if the air is already saturated with moisture it is unable to absorb more, and evaporation from the body even when played upon by a draught will be at a minimum. ( $\beta$ ) On the other hand, as we have already mentioned, moist air is a mueh better eonduetor of heat than dry air, and therefore, the heat lost by conduction tends towards a maximum in a humid atmosphere. The former of these faetors plays a major part when the surroundings are warm, the latter operates maximally in cold climates.

In the assessment of the conditions of the atmosphere making for ideal heat-loss, two instruments are in common use, viz., the wet and dry bulb thermometer and Hill's "Kata " thermometer (or its popular modification - the Comfimeter). The first of these instruments consists of two similar mercury thermometers fastened side by side on a stand. The reservoir of one is covered by a close fitting muslin bag which is kept moist by connection to a wick dipping in water. The water evaporates from the bulb at a rate depending principally on the degree of saturation of the atmosphere with aqueous vapour. It is obvious that, if the air is already saturated with moisture and no evaporation is taking place from the wet bulb, both thermometers will register the same temperature. On the other hand, if the difference in the temperatures recorded is great, one may consider that the air is dry.

Example. The degree of humidity of the air may be calculated from the formulae,

$$
\text { degree of humidity }=\frac{f}{m} \text { and } f=F-A H^{\prime}(t-0) \text {, }
$$


where $A=$ the constant of the instrument,

$F=$ the tension corresponding to $\theta^{\circ}$, the reading on the wet bulb thermometer,

$H=$ atmospheric pressure,

$t=$ reading on dry bulb thermometer,

and $\quad m=$ maximal vapour tension at $t^{\circ} \mathrm{C}$.

If $A=0.00082, t=20^{\circ} \mathrm{C} ., \theta=16^{\circ} \mathrm{C}$, $H=758 \mathrm{~mm}$. $\mathrm{Hg}$.,

$F$ (from a table of vapour tensions) $=13 \cdot 63 \mathrm{~mm}$. $\mathrm{Hg}$.

Then $f=13 \cdot 63-0.00082 \times 758 \times 4=11.16 \mathrm{~mm}$. $\mathrm{Hg}$.

The maximal vapour tension at $20^{\circ} \mathrm{C}$. (from a table $)=17.52 \mathrm{~mm}$. $\mathrm{Hg}$.

Therefore, the degree of humidity $=\frac{f}{m}=\frac{11 \cdot 16}{17 \cdot 52}=0 \cdot 637$.

The "Kata" thermometer is a large bulbed spirit thermometer. It may be warmed to say $38^{\circ} \mathrm{C}$. The time is then taken while it cools to $35^{\circ} \mathrm{C}$. It may be surrounded by wet muslin and the experiment repeated. The dry bulb instrument gives an indication of the possibilities of heat-loss by radiation and conduction, while the wet bulb indicates, in addition, the possibility of heat-loss by evaporation of moisture.

The Comfimeter is a form of kata-thermometer designed to give an immediate indication of the cooling property of the air in rooms. It consists of a cylindrical metal box in which is inserted an electric incandescent lamp.

On the top of the box is fixed an inverted metal funnel having a long stem. An ordinary thermometer is humg from inside the upper part of this stem so that about $2 / 3$ of its length remains outside the instrument. When the lamp is lit, air enters the comfimeter by means of holes in the cylindrical box and the heated air rises and leaves by the orifice in which the thermometer is hung. The whole apparatus is cooled by radiation, convection and by conduction. When the comfimeter gives a reading of $30^{\circ} \mathrm{C}$, this indicates a cooling power of about 7 millicalories per square centimetre of effective cooling surface per second-an ideal condition. If, now, the box be screened from draughts, the comfimeter thermometer will rise to $45^{\circ}$ or maybe $50^{\circ} \mathrm{C}$. On permitting free ventilation, the instrument will again record a temperature of about $30^{\circ} \mathrm{C}$. A lower temperature than this is a sign of too rapid cooling. The designer, Prof. L. Hill, says that as long as schools, factories, ete., are kept with the comfimeter indicating somewhere about $30^{\circ} \mathrm{C}$, conditions suitable for work will be maintained.

Work of itself, as is well known, eauses produetion of heat in the body. Some 75 per eent. of the energy generated in musenlar eontraetion is dissipated as heat. In spite of the large quantity of heat thus liberated, the body temperature does not inerease to any great extent. It may rise by about $2^{\circ} \mathrm{C}$, depending on the eooling value of the environment as well as on the severity of the work. The following figures from Pembrey (Table LIX.) illus- 
trate the influence of the rate of eooling on the body temperature after severe work :

TABLE LIX.

Soldiers on Completing a March of Seven Miles.

\begin{tabular}{c|c|c|c}
\multicolumn{2}{c|}{ External Temp. } & Increase of pulse rate. & Increase of temp. \\
\hline Dry bulb. & Wet bulb. & & \\
\hline 79 & $67 \cdot 5^{\circ} \mathrm{F}$ & 62 & $1 \cdot 4^{\circ} \mathrm{F}$. \\
45 & $38^{\circ} \mathrm{F}$. & 14 & $0 \cdot 8^{\circ} \mathrm{F}$. \\
\hline
\end{tabular}

On the eold day with a percentage differenee of about 15 between dry and wet bulb temperatures, i.e. under good cooling eonditions, the temperature and heart rate of the soldiers showed only a slight inerease, while on the hot day with almost the same humidity, the men beeame uneomfortably hot, and the heart rate was increased. Under these conditions work is ineffieiently done.

The effeet of the temperature and the humidity of the external air on the loss of heat from the body is very well marked in those people endowed with a good layer of adipose tissue. As has already been mentioned, this dense non-condueting material is a very effective heat insulator, thus preventing rapid heat loss. In hot weather and during exereise, fat subjeets beeome unduly heated. If, in addition, they have poorly funetioning sweat glands, then severe or prolonged work beeomes impossible.

The following table gives a rough indieation of the amount of heat lost per day through the various ehannels :

TABLE LX.

\begin{tabular}{|c|c|c|c|}
\hline & & Per cent. & Calories per day. \\
\hline 1. Radiation and conduction & - & 73 & 1792 \\
\hline 2. Evaporation $(a)$ lungs, etc. & - & $7 \cdot 2$ & 182 \\
\hline (b) skin - & - & $14 \cdot 5$ & 364 \\
\hline \multirow{2}{*}{$\begin{array}{l}\text { 3. Excreta }(a) \mathrm{CO}_{2}- \\
(b) \text { urine and faeces }\end{array}$} & - & $3 \cdot 5$ & 84 \\
\hline & - & $1 \cdot 8$ & 48 \\
\hline Total heat loss per day & - & - & 2470 \\
\hline
\end{tabular}

The question now under eonsideration is, provided some 2500 ealories of heat are lost per day, $(a)$ how is exeessive heat loss prevented and $(b)$ how is the amount lost made good? 
A. Physical Regulation-Preventative. (Usually effective between $40^{\circ}$ and $20^{\circ} \mathrm{C}$.)

This is obtained by deereasing the effective eooling surfaee, a result which may be produced in three ways:

1. By wearing clothes (or fur), a layer of still air is established between the body and the outer air. Heat will then be lost from the eovered area by radiation only (sce elothes).

2. A good layer of subeutaneous fat prevents a rapid diffusion of heat from the interior to the exterior of the body.

3. Constriction of the eutaneous blood vessels, a reflex aet, results $(a)$ in a decrease in the amount of blood earried to the surfaee, i.e. decrease in cooling surfaee and $(b)$ in a decreased output from the sweat glands.

Paralysis of the vasomotor nerves leads to vasodilatation. This is given as the reason for the death of animals whose skins have been eovered with a layer of impenetrable varnish. It is alleged that, at the enthronement of Pope Leo X., a boy was gilded to represent an angel. Before the ecremony was finished the boy, despite the efforts of Leonardo da Vinei and other physicians, had died. That exeessive heat loss was the cause of this aceident is proved by the experiments of Valentin. He showed that, under similar eircumstanees, the earbon-dioxide output of the subjeet was redueed to about $1 / 6$ of the normal, i.e. metabolism was at a low ebb. If the animal were kept normally warm, the earbon-dioxide output returned to a normal figure. On the other hand, Senator states that the human body ean be eovered for 8-10 days with an impenetrable layer without produeing any disturbanee of metabolism. He avers that, in those eases where vasodilatation oceurred, some toxie substance must be, absorbed from the varnish.

Alcohol produces vasodilatation-an increased cooling surface. That is, this drug, because it causes more warm blood to come to the surface, gives rise to a sensation of cutaneous warmth while at the same time materially aiding in the depletion of the body's store of heat.

B. Chemical Regulation--Curative. (Usually predominant below $20^{\circ} \mathrm{C}$.)

These mechanisms come into play to replace heat which has been lost.

(a) Voluntary or involuntary work. We have already seen that work eauses the liberation of heat and we have diseussed the reason for this. Shivering, or involuntary work is a reflex aet which oecurs in any person of normal museular tone when the 
skin temperature is allowed to drop below a ccrtain value. Anything which will prevent muscle from responding to this stimulus will do away with this curative heat production, e.g. curari, aleohol, etc. Young animals which have little museular development arc, obviously, unable to keep themselves warm by exercise and have to be carefully protected against undue heat loss.

(b) Increased muscular work ultimately learls to increased catabolism of food material and so, indirectly, to an increase in the quantity of heat liberated. Over and above this amount, however, the result of exposure to excessive cold may be combated by the ingestion of foods having a high energy value. Natives of the colder climates introduce much fatty matter into their diets.

One may just glance at a problem connected with the above. If the action of any tissue-complex, muscle, liver, etc., results in the liberation of "waste" heat, is heat then liberated during cerebral activity? At present, careful investigation has failed to show the production of heat by the brain. It is admittedly true that the head becomes heated during prolonged mental work, but this is accounted for by the increased cranial blood supply-blood flowing away from the extremities and from the viscera to the brain.

Centre. Since the means adopted for the maintenance of an unfluctuating temperature involve the bringing into play of so many structures and of such a variety of nerves,--vasomotor, muscular, secretory and so on,-it is plain that a co-ordinating centre is a necessity. Expcrinental evidence leads one to the conclusion that such a centre exists in the corpus striatum. Vasoconstriction, shivering, and a rise in rectal temperature result from the stimulation of this structure with a cold object. On the other hand, the application of a warm stimulating point leads to vasodilatation, muscular relaxation, and a fall in body temperature. Such results are generally interpreted as indications of the sensitiveness of the corpus striatum to alterations of the tcmperature of the blood flowing through its capillary system.

Clothes. The question of the maintenance of the human body in comfort is so closely associated with the nature of clothing that a few physical facts bearing on the nature and value of artificial protective and decorative coverings are not out of place here. Liebig made clear one aspect of the function of clothing, saying, "Our clothing is, in reference to the temperature of the body, nierely an equivalent for a certain amount of food." In other words, if we were to do without the protection afforded by clothing we would have to make good the heat thus lost by cating more food. 
The proteetive value of clothing mainly depends (1) inversely on the thermal conduetivity of the material, (2) on its powcr of absorbing water, and (3) on the arrangement of the fibres of the material in the eloth. The eonductivity of various materials is given in Tables LVI. and LXI.

TABLE Lxi. (From Rutser).

\begin{tabular}{lll|l}
\hline \multicolumn{2}{c|}{ Substance. } & Coefficient of Conductivity. \\
\hline Air - - - & - & $53 \times 10^{-6}$ \\
Brown human hair - & - & $76 \times 10^{-6}$ \\
Grey hmman hair - & - & $74 \times 10^{-6}$ \\
Feathers (eiderdown) & - & $57 \times 10^{-6}$ \\
Horse hair - & - & $57 \times 10^{-6}$ \\
Cotton cloth (smooth) & - & $81 \times 10^{-6}$ \\
Woollens - - - & - & $68 \times 10^{-6}$ \\
Silk - - & - & - & $68 \times 10^{-6}$ \\
Cashmere wool- & - & - & $68 \times 10^{-6}$ \\
Cambric - - & - & - & $81 \times 10^{-6}$ \\
Flannel - - & - & - & $72 \times 10^{-6}$ \\
Flannelette - & - & - & $75 \times 10^{-6}$
\end{tabular}

In order to ealeulate the eocffieient of protection of elothing one must know the thickness of the material. Table LXII. compiled by Rubner gives further information regarding the density of the material and of the anount of air enmeshed in the structure. This layer of imprisoned air, as we have already mentioned, has a greater protective value than mere thickness of material.

\section{TABLE LXII.}

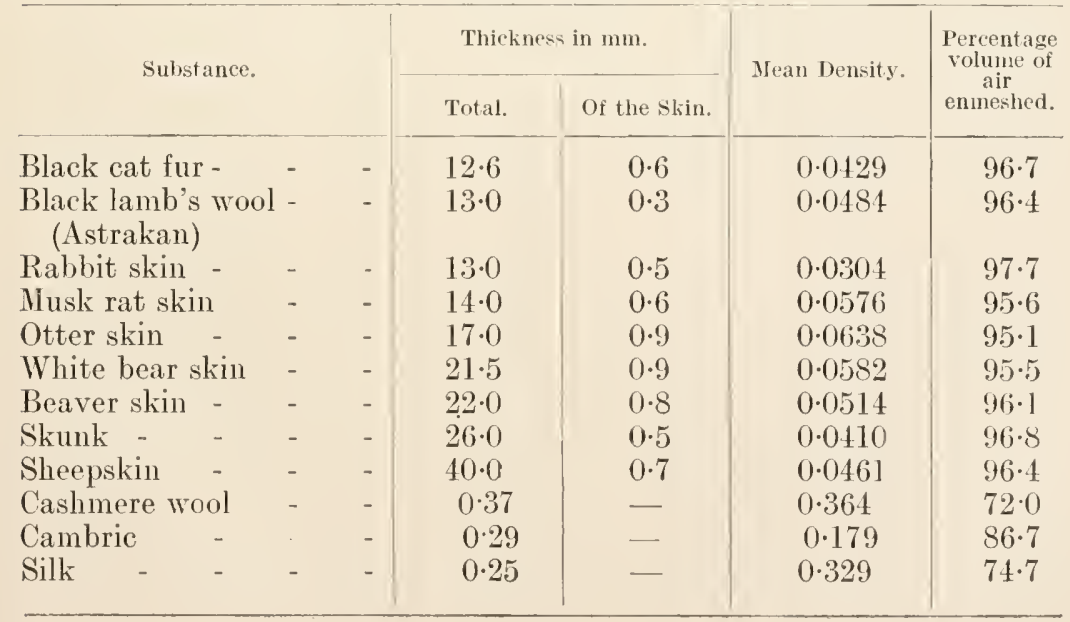


A man entirely elothed in a garment of a total surface $(s)$ of $19 \times 10^{3} \mathrm{sq}$. cm., of a thiekness $(t)$ of $75 \times 10^{-2} \mathrm{em}$. and having a differenee of temperature $(d)$ on the two sides of $10^{\circ} \mathrm{C}$., loses heat $(Q)$ as shown by the following formula:

$$
Q=\frac{c \times s \times d}{t} \text { calories per minute, }
$$

where $\quad c=$ crefficient of conductivity,

i.e. $Q=\frac{c \times s \times d \times 3600 \times 24}{t \times 1000}$ calories per day.

If the garment were of wool, $c=68 \times 10^{-6}$, we have

$$
=\frac{68 \times 19 \times 36 \times 24 \times 10^{-6} \times 10^{3} \times 10^{2} \times 10}{75 \times 10^{-2} \times 10^{3}}
$$

$=\mathbf{1 8 8 8} \cdot 3$ ealories per day.

The coefficient of utility of clothing matcrials may be determined by eovering with them a number of similar copper spheres filled with warm water and finding how long they take to cool through $10^{\circ} \mathrm{C}$. If the time taken to eool $10^{\circ} \mathrm{C}$. by an unclothed sphere with an external temperature of $12^{\circ} \mathrm{C}$. be taken as $\theta$, and the time neeessary for the same sphere (elothed) to cool to the same extent be $t$, then $t / \theta=U$ (Coefficient of utility).

\begin{tabular}{|c|c|}
\hline Clothing. & Values of $U$. \\
\hline Cycling vest (tight fitting) & $1 \cdot 1$ \\
\hline Woollen shirt - - - & 1.5 \\
\hline Black leather waistcoat - & $1 \cdot 6$ \\
\hline Flannel shirt - - - & $1 \cdot 75$ \\
\hline Rough tweed coat - & $1 \cdot 9$ \\
\hline Weatherproof cloak - & $2 \cdot 1$ \\
\hline Woollen undervest - & $2 \cdot 5$ \\
\hline Heavy greatcoat - & $4 \cdot 5$ \\
\hline
\end{tabular}

TABLE LXIII. (From Bergonié).

The efficieney of clothing depends in great measure on the arrangement of the fibres of the eloth so as to enmesh air and thus form a stationary layer between the body surface and the outer air. The following table (Table LXIV.) from Lefèvre gives an idea of the protective value of elothing. His subjeets were placed in a rectangular box through whieh a measured amount of air was passed. The temperature of the air just before it reached the body and immediately after leaving the body was taken. If $\boldsymbol{M}$, 
the mass of air passing in $t$ mins., is heated by $\theta^{\circ}$, then the heat lost per minute $=\frac{0.237 \times \theta \times M}{t}$ calories, where 0.237 is the specific heat of air.

\section{TABLE LXIV.}

\begin{tabular}{|c|c|c|c|c|c|}
\hline \multirow{2}{*}{$\begin{array}{l}\text { Rate of } \\
\text { wind. } \\
\text { Metres per } \\
\text { sec. }\end{array}$} & \multirow{2}{*}{$\begin{array}{l}\text { Tempera- } \\
\text { ture of air } \\
\text { entering. }\end{array}$} & \multicolumn{2}{|c|}{ Loss per hour in calories. } & \multicolumn{2}{|c|}{ Ratios. } \\
\hline & & Naked. & rlothed. & Fast/slow. & Naked/clothed. \\
\hline $1 \cdot 2$ & $9^{\circ} \mathrm{C}$. & 134 & 98 & $\frac{201}{134}=1.5$ & $\frac{134}{98}=1 \cdot 36$ \\
\hline $3 \cdot 8$ & $9^{\circ} \mathrm{C}$. & 201 & 130 & $\frac{130}{98}=1.32$ & $\frac{201}{130}=1 \cdot 45$ \\
\hline $1 \cdot 5$ & $5^{\circ} \mathrm{C}$. & 185 & 143 & $\frac{277 \cdot 5}{185}=1 \cdot 5$ & $\frac{185}{148}=1 \cdot 3$ \\
\hline $3 \cdot 8$ & $5^{\circ} \mathrm{C}$. & $277 \cdot 5$ & 172 & - & $\frac{277 \cdot 5}{172}=1 \cdot 61$ \\
\hline $4 \cdot 0$ & $4^{\circ} \mathrm{C}$ & 313 & 170 & $\frac{17 \cdot 2}{143}=1 \cdot 2$ & $\frac{313}{170}=1.84$ \\
\hline
\end{tabular}

It will be noticed that heat production increases with the lowering of the tempcrature of the wind and also with increasing the speed of the wind. It is obvious that, under similar conditions, the heat lost (and the heat produced) by the clothed is less than that of the naked subject.

The colour of clothes has also something to do with their protective action. Quite apart from psychological effects, certain colours conduce to warmth and others to coolness. This is a problem that exercised the minds of those responsible for the hcalth of white troops in tropical countries. The final result of one series of investigations was to recommend the wearing of white clothes with a black lining. The student may find it an interesting exercise to furnish a reason for this. 


\section{CHAP'TER XXXII}

\section{TROPISHS-'THE SLAVES OF' 'THE LAMP}

\footnotetext{
"Beloold the child, by Nature's kindly law, Pleased with a rattle, tiekled with a straw : Some livelier plaything gives his youth delight, A little louder but as empty quite ;

Scarfs, garters, gold, amuse his riper stage, And beads and prayer-books are the toys of age, Pleas'd with this bauble still, as that before, 'Till tir'd he sleeps, and life's poor play is o'er."
}

Pope.

IT may be laid down as axiomatic that onee an object has eome into equilibrium with its environment, it will remain so until some change in the environment disturbs the harmony. In other words, matter has inertia-moves when it is moved, stops when it is stopped, and alters only in so far as it is altered. All inorganie substances are not in equilibrium with their environment. Radioaetive minerals, as we have seen, are eharaeterised by undergoing eonsiderable ehange-seemingly independent of the nature of their surroundings. It is a moot point whether living things may be brought under this general statement. That they have inertia both in the ordinary physical sense and funetionally is undoubted. Moreover, that alterations in the distribution of energy in the enviromment do lead to apparently eorresponding alterations in the organism will be granted by most workers in this field, but all are not agreed as to how far the interpretation ean be applied to animals high in the seale.

I. One of the best investigated phenomena in this line of study is that of heliotropism or phototaxis. It is well known that radiant energy is eapable of influeneing the rate of some ehemieal reaetions-in proportion to the intensity of the light. This is known as the Bunsen-Roscoe Law, whieh may be formulated as :

$$
i t=\text { eonstant, }
$$

where $i$ is the intensity of the light and $t$ the time of exposure. 
(1) Certain animals and free-swimming plant-organisms move towards or away from the souree of light. These are said to be positively or negatively heliotropie respeetively. Caterpillars of Porthesia chrysorrhoea are of the former elass. They move towards the light and may starve, with abundance of food just behind them.

(2) If positively and negatively heliotropie animals are placed in a trough eovered half with red and half with blue glass, those that are positively heliotropie eollect at the blue end and the others at the red end of the trough. Red glass is praetically opaque, as every photographer knows, to the photo-ehemical rays of light. The most effieient rays for heliotropic reactions are (a) the blue between 460 and $490 \mu \mu$ and $(b)$ the yellow-green between 520 and $530 \mu \mu$. Now, most blue glass permits not only the passage of the blue rays but of the yellow-green rays also (ef. Fig. 1).

(3) That the heliotropie animal is oriented in relation to the source of light is shown by a simple experiment due to Loeb. Direet sunlight is allowed to fall from the upper half of a window on to a table and diffused daylight from the lower half on to the same table on which is placed a test-tube in such a way that it lies at right angles to the window and is illuminated over one-half of its length (room half) by direet sunlight and over the remainder by diffused daylight. Positively heliotropie animals are introdueed into the sunny end of the tube. They promptly and invariably move towards the window, i.e. out of the sunlight into the shade torcards the source of light.

(4) To explain these facts (and others) Loeb has put forward an interesting theory. "Animals possess photosensitive elements on the surface of their bodies, in the eyes or oceasionally also in the epithelial eells of their skin. These photosensitive elements are arranged symmetrieally in the body and through nerves are eonneeted with symmetrieal groups of museles. The light eauses photochemieal ehanges in the eyes (or photosensitive elements of the skin). The mass of photoehemieal reaetion produets" so formed "influenees the eentral nervous system and through this the tension or energy produetion of the museles. If the rate of photoehemieal reaction is equal in both eyes, this effect on the symmetrieal museles is equal and the museles on both sides of the body work with equal energy ; as a consequence the animal will not be deviated from the direction in which it is moving. This happens when the axis or plane of symmetry of the animal goes 
through the souree of light, provided only one source of light be present. If, however, the light falls sideways on the animal the rate of photoehemieal reaetion will be unequal in both eyes and the rate at whieh the symmetrieal museles on both sides of the body work will no longer be equal; as a eonsequenee, the direetion in which the animal moves will ehange. This change will take place in one of two ways, aeeording as the animal is either positively or negatively heliotropie."

(5) If this is true, it follows that the animal will obey the BunsenRoscoe Law. This is rather troublesome to prove for free-moving animals. 'The following table shows the applieability of the law to regenerating polyps of Eudendrium. The intensity of the light was altered by varying the distanee between the souree of light and the polyps.

\section{TABLE LXV.}

\begin{tabular}{|c|c|c|}
\hline \multirow{2}{*}{$\begin{array}{l}\text { Distance between Polyps } \\
\text { and source of light } \\
\text { (metres). }\end{array}$} & \multicolumn{2}{|c|}{$\begin{array}{l}\text { Time in minutes required to cause } 50 \text { per cent. of Polyps to } \\
\text { bend towards the source of liglit. }\end{array}$} \\
\hline & Observed. & Calculated. \\
\hline $\begin{array}{l}0.25 \\
0.50 \\
1 \cdot 00 \\
1.50\end{array}$ & $\begin{array}{l}10 \\
35-40 \\
150 \\
360-420\end{array}$ & $\begin{array}{r}- \\
40 \\
160 \\
360\end{array}$ \\
\hline
\end{tabular}

The eakculated values of $t$ tend to be somewhat larger than the observed results. Sehwarzsehild observed that when development followed exposure to light the formula should be modified to

$$
i t^{p}=\text { eonstant. }
$$

For silver bromide gelatine plates, the value of the exponent $p$ varies between 0.8 and 1 aecording to the brand of the plate.

Talbot's Law is the Bunsen-Roseoe Law modified to make it applieable to intermittent light. Intermittent light is as effeetive as eonstant light of the same intensity provided that the total duration of the intermittent light is equal to that of the eonstant light.

(6) What is going to be the result when the organism is subjeeted to two sourees of light ? One might prediet that, if Loeb's hypothesis is correet, the organism will be oriented so that it eomes to rest in a position where it is symmetrically stimulated. (a) If the two sourees of light are of cqual intensity and duration and 
are set at an equal distanee from the organism it should be oriented with its plane of symmetry at right angles to the line joining the sourees of light. (b) If the lights are of unequal intensity, the animal should move so that its photosensitive elements are in a position to absorb equal amounts of light energy. Further, the absolute intensities of light should have no effect on the deviation of the path of the organism from the perpendicular path outlined at first. The relative intensities should be the governing factor. These three predietions have been amply proved experimentally. The following results (Table LXVI.) from Patten's investigations illustrate the nature of the findings.

\section{TABLE LXVI.}

\begin{tabular}{|c|c|c|c|}
\hline \multirow{2}{*}{$\begin{array}{l}\text { No. of lamps } \\
\text { used. }\end{array}$} & \multicolumn{3}{|c|}{$\begin{array}{c}\text { Difference of intensity between the two lights in } \\
\text { percentages. }\end{array}$} \\
\hline & 0 & 25 & 50 \\
\hline & \multicolumn{3}{|c|}{ Jeflection in degrees. } \\
\hline 1 & 0.55 & $9 \cdot 04$ & $19 \cdot 46$ \\
\hline 2 & $0 \cdot 1$ & $8 \cdot 55$ & $22 \cdot 28$ \\
\hline 3 & $0 \cdot 45$ & $8 \cdot 73$ & $20 \cdot 52$ \\
\hline 4 & $0 \cdot 025$ & $9 \cdot 66$ & $19 \cdot 88$ \\
\hline 5 & 0.225 & $8 \cdot 30$ & $19 \cdot 28$ \\
\hline
\end{tabular}

This table shows elearly that (eol. 1) when the intensity of the two lights was equal, the animal varied on the average only 0.09 degree from the perpendieular. It also demonstrates that when the one light was reduced to three-quarters (eol. 2) the intensity of the other, the angle of deviation was about $8 \cdot 86$, and that when a further reduetion to a half was made, the angle of deviation was more than doubled. Finally, the figures show that the angle of deviation depends on the relative differences of light intensity and is independent of absolute intensity (provided suffieient light is present to overeome inertia (cf. stimulation, p. 193).

(7) A model with a heliotropie meehanism has been construeted by Hays Hammond, the inventor of the dirigible torpedo. The prineiple on which the machine depends is the alteration in the electrical resistance of metallic selenium when exposed to light. The " eyes" are lenses separated from each other by a projecting "nose" which permits the shading of one eye while the other is illuminated. The lenses are each focused on separate selenium 
eells. The heliotropie machine consists of a reetangular box about $3 \mathrm{ft}$. long, $1 \frac{1}{2} \mathrm{ft}$. wide and $1 \mathrm{ft}$. high mounted on three wheels, two of which are geared to a driving motor. The third wheel, mounted at the rear-cnd, eontrols the steering. It may be turned right or left by the differential action of two solenoid electromagnets. The selenium cells are in circuit both with the driving motors and with the stecring magnets. In the former ease, the selenium cells control a scries of very sensitive relays (cf. nervous system) in such a way that the amount of energy sent through the driving motors and hence their speed is determined by the intensity of the light falling on the lenses. The steering magnets are opposed, i.e. if both selenium cells are illuminated equally, both magnets will receive the same current and the stecring wheel will lie parallel to the driving wheels. If more light falls on one selenium "retina" than on the other, the former has its power to conduct electricity increased in proportion to the relative increase in intensity; eonsequently the magnets controlling the position of the rear wheel are activated asymmetrically. The wheel is pulled over to make an angle with the previous line of traction of the " dog." The mechanism is so arranged that this steering movement turns the machine towards the light. It will continue to turn till both lenses are equally illuminated. As soon and as long as both "eyes" are equally illuminated in sufficient intensity, the machine moves in a straight line towards the source of the light. The apparatus is fitted with a reversing switch which will convert it from a positively to a negatively heliotropic maehine.

If, say, a portable electric light be turned on in front of the machine it will immediatcly start to follow (or run from) the light at a speed which may attain to 100 yds. per min. On reducing the intensity of the light, the " $\log "$ will slow down, and on switching off, it will stop. In this way, the machine follows a lantern in a dark room just like a positively heliotropic animal. By reversing the direetion of the current one may make the machine negatively heliotropic.

II. Stereotropism is the term applied to the tendency of certain organisms to bring their bodies as much as possible on all sides in contact with solid bodies. "The butterfly Amphipyra, which is a fast rumner, will eome to rest under a glass plate when the plate is put high enough above the ground so that it touches the back of the butterfly." Man orients himself partly by appreciation of the taetile influenees on the soles of the feet. When these are weakened as in locomotor ataxia, and when the orienting 
influence of the eyes is removed, the patient finds difficulty in standing and in walking (Romberg's sign).

III. Chemotropism plays an important part in the life of the lower organisms. By it, the animal is drawn towards or draws away from certain chemical substances. The organ stimulated. asymmetrically is oriented so that the stimulating impacts on it are symmetrical.

IV. Orientation in space is determined mainly by three factors, light, tactile scnse and gravitation. Normal equilibrium or normal geotropic orientation is defined as that position in which the plane of symmetry of the animal passes through the centre of the earth. Any deviation from that position causes unilateral stimulation and corrective movements are instituted. The tight-rope walker perceives that his centre of gravity is tending towards unstable equilibrium and voluntary (though generally sub-consciously) corrects his balance. In the labyrinths, we have a delicate mechanism for detecting alterations in our orientation in space.

Sufficient has been said to show the nature and indicate the mechanism of those actions termed tropisms. In principle they depend on unilateral stimulation of a symmetrical animal. How far they can be accepted as explanations of all the instinctive actions of the lower organisms or of any of the actions of the higher animals remains an open and debatable question. 


\section{CHAP'TER XXXIII}

\section{ADAPTATION}

"The free use of final causes to explain what seems obscure was temptingly easy .... Hence the finalist was often the man who made a liberal use of the ignava ratio, or lazy argument : when you failed to explain a thing by the ordinary process of causality, you could 'explain' it by reference to some purpose of nature or of its Creator."

Principal Galloway quoted by D'Arcy Tirompson.

IF the environment exerts such an all-powerful effect on the organism, can the organism alter itself according to the principle of Le Chatelier so that it may live with the least possible expenditure of energy? That is, has the animal the power of adaptation? There is no doubt whatever as to the adaptation of growing bone or growing tissue of any sort to the stresses and strains ineident upon it. Various organs are known to adapt themsclves to meet alterations in the conditions under which they work.

When one eomes to consider the organism as a whole, the evidence for adaptation is not so conelusive. The arctic fox and the polar bear are not white beeause thcy have adapted themselves to a white background, but because their coloured relatives, not having their invisibility, have paid the penalty. It has becn said that trypanosomes may be obtained which are almost unaffected by treatment with arsenic. The proeess for producing them is to give their host a high but non-lcthal dose of arsenic, infect another host with the survivors and so on. This is elearly a case of the survival and propagation of the most resistant strains.

Animals which live in dark or semi-dark places have generally defective eyesight. Is this duc to atrophy from want of use or might one not argue that the cnvironment of the cave was the fittest for the blind or semi-blind animal ? Not only would they be at a manifest disadvantage in the struggle for existence outside, but they have a distinct advantage in the cave over any sccing animal that may stray in. 
To be brief, one must eonsider that, as anything but a rapid response to the distribution of forees in the environment is ineompatible with life, the animal eapable of adapting itself to eireumstances will live and propagate. Man, beeause of his highly organised nerrous and museular systems, is able to adapt himself readily and, therefore, reigns supreme.

No case is known where acquired characters have been transmitted to offspring.

On the other hand the environment may have profound effeets, not in the nature of adaptation, but on the development of the organism.

Temperature. In Chap. XXXI. the effeet of alterations in temperature on physical, ehemical and physiological phenomena was considered. 'Temperature influences all life phenomena.

(a) Development. One of the simplest experiments of this nature is to determine the temperature coeffieient of the development of an cgg. Usually the egg of the sea-urehin is ehosen for this purpose. 'Table LXVII. (Loeb and Chamberlain) gives the time in minutes required from insemination to the first celldivision for various temperatures.

\section{TABLE LXVII.}

Effect of Increase of Temperature on Cell-division.

\begin{tabular}{ll|c|c|c|c|c}
\hline Temperature $\left({ }^{\circ} \mathrm{C}.\right)$ & - & 8 & 10 & 15 & 20 & 25 \\
\hline Time (minutes) & - & 411 & 208 & 100 & 56 & $39 \cdot 5$ \\
\hline
\end{tabular}

Inerease of temperature thus eauses a more rapid development of the egg.

(b) Rate of Metabolism. Inerease of temperature, within limits, as we have seen, eauses an inerease in general metabolism. More oxygen is used, more earbon dioxide is exereted, ete. Organs work at a greater rate, $e$.g. the heart beats more rapidly. The alterations of the rate of the heart of Fundulus (embryo) keeps sueh regular paee with alterations in external temperature that it could form the basis for a rough thermometer as Table LXVIII. shows. From the figures we are also justified in inferring that the influenee of tempcrature in this reaction is a funetion of this partieular temperature and does not depend on whether the organism is gaining or losing heat. 


\section{TABLE LXVIII.}

Relation between Temperature and Rate of Heart Beat in findulus Embryo.

\begin{tabular}{|c|c|c|c|c|c|c|c|}
\hline Temperature $\left({ }^{\circ} \mathrm{C}.\right)$ & 20 & 15 & 10 & 5 & 10 & 15 & 20 \\
\hline Time for 19 beats (minutes) & 11.5 & $19 \cdot 0$ & 32.5 & 61 & 33.5 & 18.8 & 12 \\
\hline
\end{tabular}

(c) The time necessary to reach sexual maturity is detreased by increase of temperature. Stefansson reports that the Eskimo girl usually has offspring by her twelfth year. This early maturity, he states, may be attributed to the faet that the Eskimo keeps his body at a temperature as high if not higher than that of dwellers in Southern Europe. Be that as it may, other observers have notieed that growth in licight and in weight is increased during periods of inereased temperature, e.g. summer (see Growth). 


\section{CHAP'TER XXXIV}

\section{GROW'TH}

"The living organism is so constituted that each disturbing influence stimulates it to put in action a compensatory mechanism which will neutralise and render innocuous the disturbing agency."

Growti may be considered as an attempt of a system to get into equilibrium with its enviromment. Generally, but not invariably, inerease in size is aecompanied by ehanges in external form and in internal strueture. Development is, in most eases, a neeessary result of growth. This ehapter will deal with inerease in size quite apart from any coneomitant alterations in eomplexity.

\section{Nature of the Phenomenon.}

At first sight it seems easy to distinguish between a mere aceretion of material like erystal growth, snowball inerease or aceumulation of interest on eapital, and organie growth. A more careful examination of the eause and resultant velocity of growth shows that in both inorganie and organie worlds similar prineiples are involved, and that similar factors operate towards similar ends.

A series of interesting and illuminating experiments emanating from Ledue's laboratory are suggestive. If a little seed compounded of copper sulphate and glueose be planted in a gelatine (1-5 per eent.) gel, through which a little potassium ferrocyanide has been dispersed, growth will take plaee. In the first plaee, by the interaction of copper- and ferrocyanide-ions, a membrane of copper ferroeyanide will be formed round the seed. 'This membrane is semi-permeable, allowing free passage of water but preventing the egress of the erystalloid ions. As a result, the seed, thus gaining water by endosmosis, will swell up and, when the elastie limit of the membrane has been reached, will burst. Immediately this happens, a new membrane will form round the copper-glueose 
solution and the proeess will be repeated. By this means remarkable life-like growths are obtained. (Details of preparation are given in Part II., p. 399.)

Botanists are agreed that osmosis plays an important part in plant growth. An experiment is given in Part II., p. 399, to illustrate the production of turgeseenee and eonsequent rigidity as the result of endosmosis. Plant growth is conspicuously associated with turgor, and depends in great measure on the amount of water taken up. Another and more plausible explanation may be given of the swelling of plant tissues. In Chap. VIII., p. 66 (3), we mentioned the power of eolloids to imbibe and eompress water. It is extremely probable that plant turgor may be due to this imbibition, initiated by some alteration in the hydrogen ion eoneentration of the tissue.

It has been definitely proved that animal growth is accompanied by inerease in water eontent as shown in Tables LXIX. and LXX.

\section{TABLE LXIX.}

Water Content of Human Embryo. (Fehling.)

\begin{tabular}{c|c|c|c|c}
\hline Age (weeks). & Weight (grams). & Inerement. & $\begin{array}{c}\text { Increment } \\
\text { per week. }\end{array}$ & Water per cent. \\
\hline 6 & 0.975 & - & & - \\
17 & $36 \cdot 5$ & $35 \cdot 525$ & 3.23 & $97 \cdot 5$ \\
22 & $100 \cdot 0$ & $63 \cdot 5$ & $12 \cdot 7$ & $92 \cdot 0$ \\
24 & $242 \cdot 0$ & $142 \cdot 0$ & $71 \cdot 0$ & $89 \cdot 9$ \\
26 & $569 \cdot 0$ & $327 \cdot 0$ & 163.5 & $86 \cdot 4$ \\
30 & $942 \cdot 0$ & $355 \cdot 0$ & $88 \cdot 75$ & $83 \cdot 7$ \\
39 & $1640 \cdot 0$ & $716 \cdot 0$ & $79 \cdot 56$ & $74 \cdot 2$ \\
\hline
\end{tabular}

TABLE LXX.

Water Content of Frog Embryo. (Davenport.)

\begin{tabular}{c|c|c|c|c|c|c|c|c}
\hline Age (weeks) - & 1 & 2 & 5 & 7 & 9 & 14 & 41 & 84 \\
\hline Water per cent. & $56 \cdot 3$ & $58 \cdot 5$ & $76 \cdot 7$ & $89 \cdot 3$ & $93 \cdot 1$ & $95 \cdot 0$ & $90 \cdot 2$ & $87 \cdot 5$ \\
\hline
\end{tabular}

In the later stages of growth and especially in the higher mammals the ratio of water to solids tends to diminish. Inhibition of growth oeeurs when means are taken to prevent the entrance of water. For example, Loeb put Tubularia and Cerianthus, which live and grow in sea-water having about $3-3 \cdot 5$ per eent. salts, into a more eoneentrated mixture. He found, when the concentration of salts in the water was 5.4 per eent., that 
these organisms ecased to grow. The water-holding power of the salt solution, i.e. the exosmotic property of the artificial scawater, balanced the inwards pull of the protoplasm.

\section{Normal Rate of Growth.}

(a) Weight. Brailsford Robertson has shown that the rate of increase in weight follows a curve characteristic of autocatalytic reactions, i.e. of reactions in which one of the resultant products acts as a catalyst for the whole reaction. A simple cxample of a reaction of this type may be found in the inversion of an aqucous solution of cane sugar at $100^{\circ} \mathrm{C}$. Part of the product of the reaction (ghucosc and fructose) appears to undergo further decomposition, giving rise to an unknown acid which accelerates the rate of inversion.

If $x$ denote the amount of invert sugar formed during hydrolysis. $x$ will also be proportional to the amount of acid produced. Now, by the ordinary compound interest law in which a function varies at a rate proportional to itsclf-an exponential function-we have:

$$
\frac{\delta x}{\delta f}=k x(a-x)
$$

or, on integrating,

$$
k=\frac{1}{a t} \log \frac{a x}{a-x},
$$

where $k$ is a constant.

As the result of a series of experiments on auto-inversion at $100^{\circ} \mathrm{C}$, the value of $k$ for this reaction has been put $=122 \times 10^{-6}$. With this value we can tell at any time after the inception of the reaction just how much sugar has been inverted. Further, it is obvious, that as the action proceeds, the velocity due to the concentration of the original substance gradually decreases (i.e. the ordinary mass action without the catalyst), while that due to the concentration of the newly formed substance keeps steadily increasing. Hence, there must, at a certain timc, be a maximum velocity duc to definite concentrations of $a$ and $x$. In an autocatalytic reaction this maximum vclocity is reached when the concentration of the newly formed substance is half the concentration of the original substance, i.e. when $x=a / 2$.

Do statistical results bear out the statement that growth is an autocatalytic reaction? In the following table (LXXI.) is given for comparison, the weight of the human body at various ages, as found and as calculated from the assumption that the rate of growth is autocatalytic. 
TABIE LXXI

\begin{tabular}{|c|c|c|c|}
\hline \multirow{2}{*}{ Age (years). } & \multicolumn{2}{|c|}{ Body weight (Kg.). } & \multirow{2}{*}{ Number of cases. } \\
\hline & Found. & Calculated. & \\
\hline $0 \cdot 5$ & $3 \cdot 4$ & $3 \cdot 4$ & 100 \\
\hline $5 \cdot 5$ & $22 \cdot 7$ & $16 \cdot 5$ & 176 \\
\hline $6 \cdot 5$ & $24 \cdot 6$ & $20 \cdot 1$ & 327 \\
\hline $7 \cdot 5$ & $25 \cdot 9$ & $23 \cdot 4$ & 631 \\
\hline 8.5 & $27 \cdot 0$ & $26 \cdot 2$ & 1038 \\
\hline $9 \cdot 5$ & $28 \cdot 3$ & $28 \cdot 4$ & 1262 \\
\hline $10 \cdot 5$ & $30 \cdot 4$ & $30 \cdot 4$ & 1200 \\
\hline $11 \cdot 5$ & $32 \cdot 3$ & $32 \cdot 2$ & 1129 \\
\hline $12 \cdot 5$ & $35 \cdot 0$ & $34 \cdot 0$ & 863 \\
\hline $15 \cdot 5$ & $47 \cdot 1$ & $44 \cdot 8$ & 1451 \\
\hline $20 \cdot 5$ & $66 \cdot 1$ & $65 \cdot 4$ & 459 \\
\hline
\end{tabular}

From these results we see that the agreement between observed and ealeulated results is exeellent in all eases where a suffieiently large number of subjeets have been weighed, exeept at age $15 \frac{1}{2}$, where weight inereases more rapidly than theory demands.

A simple but empirieal formula for obtaining "expected" weight is $\begin{gathered}A \\ 4.75 m\end{gathered}$, where $A=$ eoneeptional age in years and $m$ is a eonstant for eaeh age (see Table LXXII. for values of $m$ and for results).

(b) Length. It was at first believed that the length eurve was of parabolie form of the equation $y^{2}=a(x+b)$, but later and more eomplete investigation has shown that this is untenable. There is for eaeh type of body a definite relationship between length and weight, viz. : $l=\sqrt[3]{m w}$, where $l=$ length in metres, $w=$ weight in kilograms, and $m$ is a eonstant for eaeh age (and each type). As $w=\frac{A}{4 \cdot 75 m}$, therefore $A=4 \cdot 75 l^{3}$ or $l=\sqrt[3]{\frac{A}{4 \cdot 75}}$. (Pfaundler.)

Pfaundler gives the following examples :

(i) A boy aged 1 year has a conceptional age $A=1.75 \mathrm{yr}$.

Hence length $=\sqrt[3]{\frac{1 \cdot 75}{4 \cdot 75}}=\sqrt{0 \cdot 36}=0 \cdot 72$ metre, which compares favourably with the value given in Table LXXII.

(ii) A boy aged 8 yrs. has $A=8 \cdot 75$.

Hence length $=\sqrt[3]{\frac{8.75}{4 \cdot 75}}=\sqrt{1 \cdot 74}=1 \cdot 23$ metres.

(Average length of boy of 8 yrs. $=1.20$ metres.) 
TABLE LXXII.

\begin{tabular}{|c|c|c|c|c|c|c|c|c|}
\hline \multirow{2}{*}{\multicolumn{2}{|c|}{$\begin{array}{c}\text { Age from } \\
\text { birth. }\end{array}$}} & \multirow{2}{*}{$\begin{array}{l}\text { Concep- } \\
\text { tional } \\
\text { age A } \\
\text { (yrs.). }\end{array}$} & \multicolumn{2}{|c|}{ Length (metres). } & \multirow{2}{*}{$\begin{array}{c}\text { Constant } \\
m \text {. }\end{array}$} & \multicolumn{2}{|c|}{ Weight ( $\mathrm{kg}$.). } & \multirow{2}{*}{$\frac{\text { Weight }}{\text { Height }} \times 100$} \\
\hline & & & Found. & Cale. & & Found. & Calc. & \\
\hline \multicolumn{2}{|c|}{3 months) } & $0 \cdot 225$ & 0.08 & - & $25 \cdot 6$ & $20 \times 10^{-3}$ & - & $0 \cdot 025$ \\
\hline &,$\quad$ I & $0 \cdot 150$ & $0 \cdot 31$ & $0 \cdot 15$ & 46.91 & $635 \times 10^{-3}$ & - & 2 \\
\hline 8 & , & $0 \cdot 600$ & $0 \cdot+2$ & $0 \cdot 50$ & $36 \cdot 1$ & $2100 \times 10^{-3}$ & - & 5 \\
\hline 10 &,,$\quad 1$ & 0.750 & 0.50 & 0.53 & $39 \cdot 73$ & $3300 \times 10^{-3}$ & $3975 \times 10^{-3}$ & 6 \\
\hline & month & 0.83 .3 & 0.54 & 0.5 .5 & $38 \cdot 72$ & $4 \cdot 25$ & 4.53 & 8 \\
\hline & months & $0 \cdot 916$ & 0.58 & 0.58 & $40 \cdot 24$ & $4 \cdot 95$ & $4 \cdot 79$ & $8 \cdot 5$ \\
\hline 3 & , & 1.008 & $0 \cdot 61$ & $0 \cdot 60$ & $41 \cdot 33$ & $5 \cdot 6$ & $5 \cdot 09$ & 9 \\
\hline 6 & , & $1 \cdot 25$ & $0 \cdot 66$ & $0 \cdot 64$ & $40 \cdot 56$ & $7 \cdot 2$ & $6 \cdot 50$ & 10 \\
\hline 9 & , & $1 \cdot 50$ & $0 \cdot 70$ & $0 \cdot 69$ & $40 \cdot 74$ & $8 \cdot 6$ & $7 \cdot 75$ & 12 \\
\hline & year & $1 \cdot 75$ & 0.74 & $0 \cdot 72$ & $42 \cdot 88$ & $9 \cdot 4$ & $8 \cdot 59$ & $12 \cdot 6$ \\
\hline 2 & years & $2 \cdot 75$ & $0 \cdot 84$ & $0 \cdot 83$ & $48 \cdot 98$ & $12 \cdot 1$ & $11 \cdot 82$ & 14 \\
\hline 3 & , & $3 \cdot 75$ & $0 \cdot 90$ & 0.92 & $55 \cdot 06$ & $13 \cdot 2$ & $14 \cdot 34$ & $14 \cdot 6$ \\
\hline 6 & 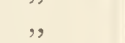 & $6 \cdot 75$ & $1 \cdot 11$ & $1 \cdot 12$ & $68 \cdot 17$ & $18 \cdot 1$ & $17 \cdot 76$ & $16 \cdot 3$ \\
\hline 9 & , & $9 \cdot 75$ & $1 \cdot 24$ & $1 \cdot 27$ & $78 \cdot 41$ & $24 \cdot 9$ & $26 \cdot 15$ & 20 \\
\hline 12 & , & $12 \cdot 75$ & $1 \cdot 38$ & $1 \cdot 39$ & $84 \cdot 94$ & $30 \cdot 9$ & $31 \cdot 60$ & 22 \\
\hline
\end{tabular}

Table LXXII. is from Pfaundler's data. It gives the ealeulated and observed weights for eaeh age as well as his values for $m$ and the eentimetre index.

The ratio, weight in $\mathrm{Kg}$./length in $\mathrm{cm}$., is called the centimetre index. Sometimes the ratio is modified as in Levi's ratio, which is

$$
\frac{100 \sqrt[3]{w t . ~ i n ~ g r a m s ~}}{\text { length in } \mathrm{cm} .} \text {. }
$$

This ratio diminishes as age increases up to puberty.

Dreyer suggests that instead of the total length of the body it would be better to deal with the sitting height.

He has established the following ratios:

$$
\begin{array}{ll}
\text { Iales, } \quad W=0 \cdot 38025^{0 \cdot 319} / l & \\
\text { Females, } \quad W=0 \cdot 36093^{0.313} / l & \\
\text { where } & W=\text { weight of the body in grams }
\end{array}
$$$$
\text { and } \quad l=\text { length of trunk in } \mathrm{cm} \text {. }
$$

Some organisms when their size reaches a eertain limiting value tend to divide into two equal portions (Saeh's Rule). Therefore, one has to deal with an inerease in number quite apart from inerease in individual size or weight. It has been proved by numerous experiments that the inerease in the number of cells follows the compound interest law, i.e. is an autoeatalytie reaction.

To summarise: When it is said that growth is an autoeatalytie reaction it is inferred that (i) superimposed on the veloeity of 
reaetion, which may be elassed as ehemieal and is governed by the law of mass aetion, (ii) there is a variation in rate due to the presenee of a eatalyst in one of the produets of the main aetion. 'The phases of sueh a reaction are, at least, four:

(1) Ordinary veloeity, proportional to the mass of the reaeting bodies.

(2) After a short period the eatalyst makes its appearanee, and the total rate gradually and steadily inereases.

(3) Certain limiting faetors probably eaused by the presenee in the blood (or in the sap of plants) of endoerinetes inhibit too rapid a growth.

(4) The aceumulation of the produets of the reaetion produees a tendeney to eause a reaetion in the reverse direetion. That is, arrest of growth and even negative grozcth may be produeed.

Quetelet, who was the pioneer of the statistieal study of growth, found that the rate of growth alters with age in a definite orderly way, and the veloeity eurve may be divided into fairly well-defined regions, eaeh having a definite and eharaeteristie slope, e.g.

(1) From eoneeption to about 3 lunar months the veloeity is low, about $2 \mathrm{em}$. per month.

(2) Period of rapid growth from 3-9 lunar months $=9 \mathrm{em}$. per month.

(3) Rate almost equal to (1), i.e. $2 \mathrm{em}$. per month from birth to 3 years or so.

(4) Slower but still rapid growth in early boyhood. (Marked quiekening in teens (growing age).)

(5) Period of arrest-full stature has been reaehed.

(6) Somewhere about fifty years of age the period of negative grozeth sets in. That is, the curve of growth and picture of velocity followes point by point the velocity curve of a typical antocatalytic reaction.

\section{Factors modifying Growth.}

Chemieal reaetions may be profoundly altered by alterations in external eonditions, and therefore, we may expeet to find eertain variations in the rate of growth whieh may be eorrelated with alterations in the eonditions to whieh the subjeets are subjeeted.

\section{Phase Differences.}

(a) Individual. Quetelet found that under normal eonditions the variations in the rate of growth of man were just what might 
be predicted from the application of the mathematical law of probability. This law is represented by the equation

$$
y=\frac{h}{\sqrt{\pi}} \cdot \epsilon^{-h^{2} x^{2}}
$$

where $x$ and $y$ are rectangular coordinates and $h=$ parameter of the curve. Riedel tabulated the heights of nearly 4000 schoolboys of various ages, and found that the variations in height observed for each age were, for all intents and purposes, just what the mathematician predicted. Other investigators have confirmed this and have cxtended the scope of the equation, applying it to variations in weight, chest mcasurcment, ctc.

The index of variability, or standard deviation denoted by the letter $\sigma$, is equivalent to a determination of the point on the actual frequency curve, where it changes its curvature on either side of the mean. For cxample, if the curve showing the number of individuals of a ccrtain age having a certain height, for instance, be plotted it will cut the theoretical curve at various points. $\sigma$ is a measure of this divergence.

The coefficient of variability is obtained by dividing $\sigma$ by the mean and, for convenience, multiplying by 100 ,

$$
\text { i.e. } C=\frac{\sigma}{M} \times 100 .
$$

\section{TABLE LXXIII.}

Coefficient of Variability in Man at Various Ages.

\begin{tabular}{c|c|c}
\hline Age (yrs.). & Height $C$. & Weight $C$. \\
\hline 0 & $6 \cdot 5$ & $15 \cdot 66$ \\
5 & $4 \cdot 1$ & $11 \cdot 5$ \\
10 & $4 \cdot 3$ & $11 \cdot 6$ \\
15 & $5 \cdot 5$ & $15 \cdot 3$ \\
20 & $3 \cdot 6$ & $10 \cdot 8$ \\
\hline
\end{tabular}

From this, we see that the coefficient of variability tends to decrease when the rate of growth decreases and tends to increase again when rapid growth restarts in the "teens."

(b) Sex introduces a phase difference in the rate of growth. Girls run through the various phenomena of growth at a more rapid rate than boys.

(c) Difference in race, even under similar climatic conditions, has a profound effect on the final result of growth-i.e. on total stature, weight, form, etc.-but seems to have little or no effect 
on the rate of growth. 'The little Jap increases in size year by year at the same rate as the tall Norwegian. The rate of growth is a spccific phenomenon gozerned by factors deep rooted in the composition of the organism.

\section{External Factors.}

Quite apart from these more or less normal variations due mainly to hereditary influences, there are various external factors which have a modifying effect on the rate and amount of growth.

(d) Temperature. As we have seen previously, all ehcmical and physical reactions respond to alterations in temperature by an alteration in velocity. In the terminology of van't Hoff, it may be said that if $x$ is the temperature coefficient of a reaction, and the temperature of the reacting mass is raised $n$ degrees, the consequent alteration in velocity will be as $x^{n}$. Usually the interval taken (i.e. $n$ ) is $10^{\circ} \mathrm{C}$. and $x$ is written as $Q_{10}$. For most chemical reactions $Q_{10}$ is $=2$. 'This may be taken to mean that for an increase of temperature of $10^{\circ} \mathrm{C}$. the velocity of the reaction will be doubled. Van't Hoff noticed that, at low temperatures, very high temperature coefficients were obtained-in some cases $Q_{10}$ reached the value of 5 or 6 . Most physical reactions, as we have seen, differ from most chemical reactions in having a negative temperature cocfficient, i.e. their rate is decreased by an increase of tempcrature. The various reactions which are manifested as growth are some chemical and some physical, and it is, therefore, somewhat difficult to apply the van't Hoff law to this phenomenon. Moreover, as pointed out in the earlier pages, Errera extended the principle of Le Chatelier by stating thatevery physiological process causing change, by its very action, set in being other reactions to inhibit change. It is, therefore, a difficult matter to interpret the figures obtained for the influence of temperature on the velocity of growth in animals.

Hertwig's classical work on the rate of growth of the tadpole illustrates the type of result got in this line of research. He found, for instance, that at $10^{\circ} \mathrm{C}$. the tadpole took 6.5 days to reach the same stage of development that at $20^{\circ}$ would have taken two days, i.e. the two rates are as $6 \cdot 5 / 2=3 \cdot 25$. Using the equation given above and putting $n=10$,

i.e.

Therefore and

$$
\begin{aligned}
x^{10} & =3 \cdot 25, \\
10 \log x & =\log 3 \cdot 25=0 \cdot 5119 .
\end{aligned}
$$$$
\log x=0 \cdot 05119 \text {, }
$$$$
x=1 \cdot 125 \text {. }
$$ 
The temperature eoeffieient for the development of the tadpole is thus $\left(Q_{10}\right)=1 \cdot 12$. That is to say, if it takes $t$ days at a certain temperature $\theta^{\circ}$ (between $10^{\circ}$ and $20^{\circ}$ ), for a eertain amount of growth to take place, then it will take $t \times 1 \cdot 12^{n}$ days when the temperature has fallen to $\theta-n^{\circ} \mathrm{C}$.

(e) Climate. The various meteorologieal eonditions temperature, relative humidity, nature of soil, ete., which are all included under the term elimate-undoubtedly exereise an influence on animal and regetable growth. The effeet of relative humidity on plant growth has been exhaustively studied and eonelusions have been drawn as to the eoneentration of moisture at eaeh temperature which best promotes the growth of speeified plants. It is more difficult to get statisties eorrelating animal growth with the various elimatic factors. In order to study biologieal problems like this experimentally, one must have the power of altering the component factors one at a time and noting the results.

(f) Seasonal variation. Indubitable evidence is available to show that the growth-rate of the lower animals is subject to seasonal alterations. There are indications that positive and negative variations oecur in man in summer and winter respeetively.

TABLE LXXIV.

Growth in Height of German Military Cadets in Half Yearly Periods. (Daffner.)

\begin{tabular}{c|c|c|c}
\hline \multirow{2}{*}{ Number observed. } & Age. & \multicolumn{2}{|c}{ Increment in cm. } \\
\cline { 2 - 3 } & & Winter, 6 months. & Summer, 6 months. \\
\hline 12 & $11-12$ & $1 \cdot 6$ & $2 \cdot 3$ \\
80 & $12-13$ & $1 \cdot 5$ & $2 \cdot 9$ \\
146 & $13-14$ & $2 \cdot 0$ & $3 \cdot 0$ \\
162 & $11-15$ & $2 \cdot 5$ & $3 \cdot 5$ \\
162 & $15-16$ & $2 \cdot 3$ & $3 \cdot 0$ \\
150 & $16-17$ & $1 \cdot 9$ & $2 \cdot 3$ \\
82 & $17-18$ & $1 \cdot 2$ & $1 \cdot 5$ \\
22 & $18-19$ & $0 \cdot 8$ & $0 \cdot 9$ \\
6 & $19-20$ & $0 \cdot 4$ & $0 \cdot 4$ \\
\hline
\end{tabular}

Other investigations (West Point, Sing-Sing, ete.) do not yield such a marked seasonal variation.

(g) Diurnal variations. Both weight and height vary in the course of 24 hours. The weight is lowest in the morning before 
breakfast, and is highest after supper in the evening. This may be accounted for by the fact that the weight of food eaten is greater than the weight of excreta. On the other hand, stature decreases during the day by from 1 to $3 \mathrm{em}$. This trifling shortening is attributed to eompression of the intervertebral dises, curving of the spine and depression of the areh of the foot. Measurements for eomparative purposes should, therefore, always be taken at the same time of the day-e.g. before breakfast.

(h) Nutrition. It is obvious that, if the animal does not get an adequate supply of the material to be built into tissue, and of the energy neeessary for these proeesses, the work will be done slowly and badly. In man at least, this only applies to increase in girth and weight. Growth in stature seems to be specifie and is almost independent of the quality and quantity of the food available. In the lower animals, while deerease in growth is conspicuous in underfed animals, one may also deteet a elear falling off in the rate of increase of length (ef. Table LXXV.).

TABLE LXXV.

Comparative Weights and Lengties of Full Fed and Underfed Rats.

\begin{tabular}{c|c|c|c|c}
\hline \multirow{2}{*}{ Age (weeks). } & \multicolumn{2}{|c|}{ Length of body. } & \multicolumn{2}{c}{ Weight. } \\
\cline { 2 - 5 } \cline { 4 - 5 } & Full fed. & Underfed. & Full fed. & Underfed. \\
\hline 0 & $48 \mathrm{mim}$. & 48 & $5 \cdot 4 \mathrm{gm}$. & $5 \cdot 4 \mathrm{gm}$. \\
6 & 128 & 98 & 42 & 24 \\
10 & 173 & 100 & 150 & 25 \\
\hline
\end{tabular}

The underfed rats were given food of just sufficient energy content to provide for their maintenance.

It is well known that quite apart from its energy content, food for growing animals must have eertain of the amino aeids in its make up. These are the building stones or units of whieh the complete organism is eonstrueted. It has been shown that if animals are deprived, say, of the amino aeid lysin, their growth is inhibited. On the addition of this amino aeid to their diet, not only is growth restarted but leeway is made up and a normal growth is produced.

Certain mueh studied but little known accessory factors are absolutely essential eonstitucnts of the diet of the growing elild. Of their chemistry a little is known- of their physies or of the mechanism of their aetion, nothing positive can be said. 
(i) Social position. The children of the well-to-do are generally markedly heavier and slightly taller than those of the working classes. Quite apart from any possible underfeeding of the latter, one must take into account the more or less shcltered life of the former and their freedom from those influences which tend to put the burdens and responsibilities of the adult on the child of the lower classes at a comparatively early age.

(j) Endocrinetes. Considering the factors which influence the rate of growth, and keeping wcll in mind the unthinkable complexity of the polyphase solution of colloids and crystalloids composing the animal body, one can hardly be surprised that so little is known of the mechanism of growth. In some way, the various alterations in size and shape are interrelated and regulated through the blood and through the ncrvous system, by various secretions from endocrine organs. Growth in length is associated with the secretion of the pituitary gland. Any alteration in this gland causes alteration in the performance of other endocrine organs, e.g. the gonads and thyreoid. The growth of cartilage and bone are profoundly modificd by alterations in the output of the thyreoid gland, while the gonads, and in early life, the thymus, control both growth and development, again by processes of which the mechanism, from a physico-chemical standpoint, is quite unknown.

\section{The Energy of Growth.}

It is generally believed that young animals require much food because they are growing. That this is not quite correct has been shown in Chap. XXXI., where we saw that the young animal, because of its large surface compared to its mass, lost heat most rapidly. To prove this we need only examine the metabolic balance sheet of the child. Camerer gives the following composition of a new born child (in grams) :

Total weight.

2820
Protein.

320
Fat.

348

Now, as we have seen, in 180 days the child doubles its weight. It does not, however, do so by adding equal quantities of the matcrial already present. In a child 180 days old, weighing 5600 grams, there are 790 grams of protein and 733 grams of fat. Thus $\mathbf{4 7 0}$ grams of protein and $\mathbf{3 8 5}$ grams of fat are added. In calories that gives $470 \times 5 \cdot 3=2491$ cals. $+385 \times 9 \cdot 3=3580 \cdot 5$ cals. $=$ a total of 6071.5 calories for the period, or about 35 calories 
per day. A child of that age has an intake on the average of about 500 cals. per day. That is, the encrgy used for growth amounts to about 7 per eent. of the total energy intake.

It has been caleulated that each gram of infant's body substance has a value of 1.87 cals. 'Thus, if the child adds 20 grams a day, it "fixes" $20 \times 1 \cdot 87=37 \cdot 4$ calories per day, a result closely approximating to that just given.

Rubncr has formulated the following law regarding the energy of growth.

Law of constant energy consumption. "The number of ealories required to double the weight of a new born animal of all species (except man) is practieally the samc in spite of the enormous differenees in time taken in attaining the double weight." Analysis has shown that each kilogram of body substanee contains about 113 grams of protein and 120 grams of fat having an energy value of 1726 calorics. Experiment has shown that in building this up the animal uses about 4800 ealories. Man is an cxeeption and requires six times the amount.

The growth quotient is the pcrcentage of the energy intake which is "fixed" in the animal tissues. It is about $36\left(\begin{array}{c}1726 \\ 48\end{array}\right)$ for" all animals cxeept man, who is able to "fix" only 6 per cent. of his energy intake.

The question now arises as to why growth stops. If it is an autocatalytic reaction, growth should stop when the proeess is balanced, i.e. when anabolism and catabolism mathematieally eanecl one another. Aecording to Loeb, this happens when the organism has reaehed a eertain size, or a certain number of cells have been formed. Rubner's seeond law, that of length of life, is suggestive rather of the cessation of positive growth after the cell had expended a eertain amount of energy. It is eertain that if growth is inhibited during a eertain pcriod, i.e. if energy which would normally have been expended on building up tissue is not used for this purpose, the whole "growing time" may be prolonged.

The healing of a wound, the regencration of tissues and the growth of tumours, ete., bear a elose resemblance to animal growth as a whole. They may be modificd by the same factors, and investigation of the various processes involved has shed eonsiderable light on the meehanies of growth.

Leo Loeb and his eo-workers have made an extensive study of the healing of a skin wound. They found that if the skin is 
removed from any spot, epidermal eells from the edge of the wound ereep upon the lenuded spot and form a eovering layera surface-tension phenomenon. The stretehing of the eontents of the surrounding eells so produeed, eauses a rapid series of eell divisions, i.e. growth under stimulation of stress takes plaee (Chap. XVI.). That the eause of the inereased eell division is the stretehing of the eells is borne out by the fact that the larger the area to be eovered (within limits) the greater is the tension and the more rapid the proeess of forming a new skin. When the skin is formed and the internal pressure is altered from one of stretehing to one of eompression due to the erowding of the proliferating eells, growth slows down to normal. It is noteworthy that, before this return to a normal rate of cell division ean take plaee, distinet pressure must be exerted by the epithelial eells on one another, i.e. exeessive formation of epithelial eells oceurs. Is it possible, from this and similar experiments, to consider that cell pressure is one of the limiting factors in growth?

There are, as we have seen, two main epoehs of growth, eaeh followed by a slowing down of veloeity. In the first ease, in early life, the slowing down is temporary, This may be correlated with (a) the fact that the increase in weight during this period is due in great part to a deposition of fat whieh is absorbed during the subsequent period of slower growth, and $(b)$ to the ehanges in glandular functions, ete., which usher in the seeond period of very rapid growth. This final period is followed by a eomplete arrest of positive growth. The inereased weight is due to musele and organ building - protein is laid on and the pereentage of water deereases. No further ehange resulting in inereased metabolie aetivity takes plaee after this. Cell pressure now developed is not relieved.

The physical chemistry of negative growth will be considered in a later chapter.

\section{Growth and Form.}

One eannot leave this subjeet without a brief referenee to the relationship existing between growth and form. Form is determined by the specific rate of growth in various directions, i.e. as D'Arey 'Thompson puts it, form is a funetion of time. If a spherieal organism grew symmetrieally its form would not alter, but beeause of its eomplexity, growth is not uniform in all direetions. There are struetural differenees in protoplasm which set up unequal resistanees to growth. One part may be more viscous 
than another, or may have a higher surface tension and so on. Although it has been pointed out that the presence of extemal resistance acts as a stimulus to growth, it has also been said that internal resistance arrests growth.

Bohn propounds the following four laws relating growth and form in plants, and they may be applied to animals with some measure of justification :

(1) Law of Vectors. A vector in distinction from a scalar phenomenon is one representable graphically by a line of known direction and definite length, i.e. a conception of a change of magnitude with time. "The principal forces of growth are directed along axes offering a geomctrical disposition."

(2) Law of Depolarisation. "When growth becomes exaggerated in a certain dircetion, a force is developed in the living organism which tends to oppose the growth, "i.e. Frrera's Rule, $q . v$., or the ordinary law of balanced reaction.

(3) Laze of Axial Repulsions. "When secondary axes are borne on the principal axis of a plant or animal, a reciprocal repulsive force is developed between the principal axis and each secondary axis."

(4) Law of Compensation. When an axis branches in onc plane there is a tendency for the re-establishment of the destroyed bilateral symmetry."

'To summarise :

1. Growth is a balanced reaction having the mature organism for an end point.

2. The organism grows at a definite rate which is, at any moment, proportional to the amount of growth yet to be made.

3. The rate of growth is not uniform throughout but is specific for each cpoch of life.

4. The growth in each epoch procecds at a rate corresponding to an autocatalytie reaction.

5. Various factors which influence chemical and physieochemical reactions, influence the rate of growth.

6. If the rate of growth is arrested in any epoch, the length of time spent in that eycle is prolonged-so that the amount of growth characteristic of that epoch is accomplished.

7. Form is a function of growth. 


\section{CHAPTER XXXV}

\section{DEVELOPMEN'T}

"... I compared the cell-growth, by which Nature builds up a plant or an animal, to the glass-blower's similar mode of beginning,--always with a hollow sphere, or vesicle, whatever he is going to make."

Oliver Wendell Holmes.

OccurRing simultaneously with increase in size, are changes in extcrnal form and internal structure-the organism develops. Mainly through the brilliant researches of J. Locb and his school, some light has been thrown on this scemingly mysterious and apparently inexplicable process. The changes taking place are most readily perceived when the transparent eggs of the cchinoderms are used as the material on which to experiment, and consequently, our ideas of the processes involved in mammalian development are largely derived from the study of processes in the lower aquatic animals which may or may not be quite analogous.

The unfertilised ovum is a moribund body which disintegrates more or less rapidly. If, before disintegrative processes have become apparent, the egg undergoes fertilisation, destruction is stayed. The fertilised egg develops, grows and becomes differentiated into various structures. This process of differentiation of protoplasm is an orderly one, taking place always in the same manner and being modified always by the same conditions.

On the entry of the spermatozoön, some change in the free cncrgy of the egg must take place. The egg is no longer static but becomes endowed with dynamic force. In order to discover the underlying physico-chemical change, Loeb attempted to induce development of unfertilised eggs by alteration of the environmental conditions. No change in a system in equilibrium ean take place unless the relative amount or incidence of the free energy of the cnvironment is first altered. The two series of 
ehanges-external and internal-are eause and effeet. This is merely a restatement of the Law of Inertia. 'The entry of the spermatozoön alters the balanee of free energy between egg and environment. Loeb attempted to bring about the same result by altering the free energy balanee between environment and egg. He found that two separate and distinet ehanges took place after fertilisation, viz., membrane formation and development. These involve totally different physico-chemical reaetions. Membrane formation is not followed neeessarily by development.

\section{Membrane Formation.}

Loeb found that all those substanees or ageneies which ean bring about haemolysis (Chap. XXI., p. 244) also induce membrane formation. The best agent for this purpose is dilute butyrie aeid. Immersion of sea-urehins' eggs (unfertilised) in sea-water containing about 5 per cent. of $N / 10$ butyrie aeid for two to four minutes brings about typieal membrane formation. This membrane is tough and is separated from the egg-substanee by a layer of more fluid material.

Examination of the performanee of the other eytolytic substances makes manifest the meehanism of the change brought about by their ageney, and its similarity to that eaused by butyrie acid or other fatty aeid. The former all lead to the abnormal production of acids in living protoplasm, and these aeids produee, as a seeondary effeet, the physieo-ehemical change now under consideration. These eytolytic substanees are, as we saw in Chap. VIII., just those substanees whieh break emulsions. Egg protoplasm is an emulsion very rich in fat, and it is obvious that the breaking of such an emulsion would lead to the setting free of protein and would probably change the nature of the eomplex from a water-(and protein)-in-oil type to an oil-in-water(and protein) type. The protein and lipoids carried to the surface and coming in contact with sea-water would readily be adsorbed and form a membrane (Chap. X.).

Eggs undergoing artificial parthenogenesis quickly show disintegrative changes unless means are taken to confine the eytolytic effect to the surface. This is provided for in some eases (e.g. starfish and eertain annelids) by the speeifie nature of the proteins in the cortical layer. The diffusion of the acid eauses them to alter in electrical state. They imbibe water, swell up and develop normally. 


\section{Exosmosis.}

In most cases, however, unless a second alteration is made in the bathing medium, the egg will either not develop at all, or will die at some intermediate stage. It is known that after fertilisation, the eleetrieal eonduetivity of the egg is inereased for fifteen minutes or so. 'This may be interpreted as a sign of increased permeability of the membrane to surrounding salts, or it may, with equal justiee, be aeeounted for by a withdrawal of water with a consequent inerease in the eoneentration of eleetrolytes. During this period of inereased electrical eonduetivity, the eggs readily undergo plasmolysis if placed in a solution of eane sugar. Unfertilised eggs, of eourse, do not show alterations at this early stage in electrical eonduetivity nor are they easily plasmolysed. This may be taken as a confirmation of the second hypothesis, viz, that water is removed by exosmosis and, eonsequently, the coneentration of electrolytes in the egg is inereased. Whatever be the aetual physico-ehemieal proecss brought about by the entrance of the spermatozoön, the result has been imitated by simple physico-chenical means.

If, after removal from the butyrie aeid bath (or other cytolytic ageney), the egg is plaeed in hypertonie sea-water for about halfan-hour and then returned to its normal environment, it will, in all likelihood, reaeh maturity. That is, not only does artificial membrane formation initiate the processes of development but it starts, at the same time, processes which nltimately lead to the dissolution of the organism.

'These latter activities may be, for a time, suspended, by a short exposure to a hypertonic solution.

Loeb has proved that the withdrawal of water is merely the trigger setting off a series of chemieal as well as physical changes. Attention has been repeatedly drawn in previous pages to the fact that while most physieal proeesses have a low or even a negative temperature eoeffieient. most chemical reactions have a high $\left(Q_{10}=2\right.$ or more) temperature cocfficient. This worker found that, at a temperature of $5^{\circ} \mathrm{C}$., the eggs had to remain in the hypertonie solution for at least 210 minutes. The time of exposure was deereased to 40 minutes when the temperature of the solution was raised to $15^{\circ}$. Therefore, the temperature eoefficient for this proeess is

$$
210, \text { i.e. } \quad Q_{10}=5 \text {. }
$$

Hence, superimposed on the physical process of exosmosis are secondary chemical reactions initiated by it. 
Attempts have been made to determine what part the spermatozoön plays in the process of fertilisation. Brailsford Robcrtson has extracted a substance oocytin from the testicles of the scaurchin which produces membrane formation. The question then arises - "Is this substance a catalyst speeding up some slow change or does it counteract some obstacle to development ?" 'To the first part of the question a negative answer ean be given The velocity of the process of development is not catalytic. It does not follow Schuitz's law and vary in velocity with the square root of the concentration. If two spermatozoa are caused to cnter an ovum, the rate of segmentation should increase by $1 \cdot 4$ (i.e. $\sqrt{2}$ ) times, if the process werc catalytic. The ratc, as a matter of fact, is unaltered by the introduction of additional spermatozoa. Thercfore, the spermatozoön does not contain a catalyst for developmental processes.

Loeb is inclined to belicve that the spermatozoön removes from the egg a substance or condition which inhibits or prevents the process of development.

On the other hand, it is conceivable that the entry of the spermatozoön increases the free energy of the now fertilised ovum. The potential energy of the system cannot be utilised without the employment of a small quantity of frce encrgy. This quantity of free energy may be extraordinarily small as long as it is sufficient to start the series of reactions which once started are autocatalytic.

One result of the entrance of an effective spermatozoön into an ovum is an accelcration of the processes of oxidation, i.e. metabolism begins, and the various phases of development can be followed by the same calorimetric methods (direct and indirect) adopted in the study of the cnergy exchanges of the mature organism (see over, p. 386).

\section{Differentiation.}

Cell division is the most general of the specific functions of living protoplasm and it is the basis underlying the differentiation of the comparatively simple structure of the egg into a more complex organism. The division of a cell is a necessary consequence of its increase in volume. The metabolic activity of the cell is a function of its effective surface, i.e. its surface must bc of such a size compared with its volume that an adequate supply of oxygen can reach the centre of the cell and that all the byproducts of cellular activity can be eliminated with sufficient rapidity. A freely suspended unicellular animal is spherical. 
Its surface-volume ratio is $3 / 1$. 1)oubling the radius inereases the surface four times while increasing the volume cight times, i.c. $S / I^{r}=\frac{3}{2}$, i.e. the effective surfaec has been halved. The immediate result of decreasing the specific surface to a valne below the minimal effeetive value is to deerease the supply of oxygen to the centre of the cell and to eause a heaping up of earbon-dioxidc and other produets of metabolie activity. This has, at least, two effects(a) The process of development is retarded (Law of balanecd reactions), (b) The protoplasm becomes acid. The effect of acid on an alkaline gel-emulsion has ahready becn considered and may possibly be the cause of cell division. We have, however, to inquire into the reason for the symmetrical division of the ceil.

Some cells divide directly without showing mitotic figures. After a change in the distribution of free energy manifested by a division of the nucleolus into two separate nucleoli, the whole nucleus is divided equally into two daughter nuclei. This separation is followed by the formation of a cell membrane between the two nuclei dividing the entire cell into two equal and similar portions.

Usually, however, cell division is aecompanied by a complex but regular scrics of changes in the distribution of the nuclear chromatin. 'These mitotie or karyokinetic changes are dependent on the bipolarity of the cell. Morphologically the polarity of a cell refers to a symmetry of visible structurc about a particular axis. For instance, a line, drawn through the centres of nucleus and centrosome, symmetrically divides a typical resting cell and may be considered as its axis of polarity. This symmetry of form is an indication or expression of a symmetry of free energy.

In a bipolar eell there are two "poles" or centres of force, and the axis of symmetry must divide the field of force equally about these poles.

Typical fields of force may be plotted by scattering iron filings on a sheet of glass resting on the pole (monopolar field) or poles (bipolar field) of a magnet. The filings set themselves along the lines of force, each little filing becoming polarised and exerting an influence on adjacent filings. (This "carding out" under the influence of stress was dealt with in Chap. XVI.) In addition to the strength of the field and the direction of the force, the movement of particles under its influence depends on the friction of the contiguous matter and on the chemical nature of the particles themselves. Friction prevents the filings from collecting in mass round the poles while the specific inductive capacity (p. 52) or " permeability" of the particles is a measure of the influence exerted by the "force" on the particle. In the case of magnetic force, the specific inductive capacity of iron is high while that of bismuth is low. Iron filings will, therefore, be 
attracted towards the poles and will tend to lie on the lines of stress. On the other hand, bismuth filings are polarised in a sense opposite to that of the adjacent field. They are forced by the incidence of stress to move (or because of friction, to tend to move) from the stronger to the weaker parts of the field and thus take up positions as far from the poles as possible. In general, a body placed in a field of force will tend to move towarls regions of greater or less intensity of stress aceording as its "pormeability" to the particular form of energy in question is yreater or less than that of the surrounding medium.

The introduction of an aggregate of high permeability into the field of force makes considerable changes in its configuration. Suppose a small heap of filings were placed in the magnetic field alrearly referred to, so that it lay somewhat out of the interpolar axis but on the equatorial axis, the result would be to provide an "easier path" for the lines of force. It is obvious that, within certain limits, a longer path through a more permeable mass would be more advantageous than a shorter path through a less permeable medium, and so many of the lines of force would be "shortcircuited " through the heap of filings. If, moreover, the heap of filings were free to move, they would be drawn en masse into the field of force until a point of equilibrium was reached. This resting place would depend for its position on the relative " permeability" of the filings in heap and the filings distributed over the field.

We have dealt with a magnetic field of force because it is easy to demonstrate and may be readily modified experimentally, but our remarks are applicable to any field of force. A simple experiment, due to Leduc, shows that the lines of stress set up by diffusion may be made manifest. A layer of salt solution is spread over a flat sheet of clean smooth glass, and on top of this is placed a small drop of indian ink or blood. A drop of a hypertonic solution of common salt is placed on either side of this central drop. In a short time the pigment seems drawn out into threads (piros) stretching between the centres of the two salt drops, so making a figure exactly the same as that formed by iron filings under bipolar magnetic influence.

The Bjerknes phenomenon demonstrates the applicability of this treatment to the stresses and strains set up in a fluid as the result of movement in it. Bodies synchronously vibrating or pulsating in a liquid mediun attract or repel one another according as their oscillations a re identical or opposite in phase. That is, a bipolar field exists which may have, like a magnetic field, similar or dissimilar poles. In such a field of force currents are set up in the fluid (hydrodynamic lines of force) and any particles in suspension, if lighter than the fluid, act like the iron filings, if heavier like the bismuth filings above. Moreover, the lines of force set up by identically pulsating (attractive) bodies are exactly similar to those produced by similar (repulsive) magnetic poles, and vice versâ.

The first stage in the development of a cell eonsists in the division of the centrosome into two equal parts whieh draw away from onc another. A field of foree is set up between the two centrosomes and threads of those ecll constituents which arc more "permeable" to the form of energy cxisting, are carded by the incident stress into a figure closely resembling those 
mentioned above. On the "outer" side of the eentrosomes ean be seen starlike radiations (astral rays) recognisable as indieations of ineomplete lines of foree which run externally to those stronger interpolar lines whieh eonstitute the spindle.

The nucleus is eomposed of material of fairly high " permeability" and, therefore, may be expeeted to travel towards the equatorial axis. This is found to be so. In some cases the nueleus is wholly, and in other instanees it is only partially drawn into the field between the eentrosomes. Differenees, too, exist in the relative development of asters and spindle whieh are eapable of explanation by analogy to the magnetie model. If, in the experiment with iron filings, the field were surrounded by an iron ring, the majority of the lines of foree would pass round by the ring. That is, the interpolar lines would be slight and the extra-polar rays would be heavy. Similarly, we may eorrelate a mitotie figure having good astral rays and a poor spindle with a marked "permeability" of the surface of the eell.

One would be entering the realms of pure hypothesis if physicoehemieal interpretations were attempted of the various stages of karyokinesis. The eonstitution of protoplasm-vaguely stated as an emulsion of various lipoids in a eomplex protein-water emulsoid with various crystalloids in solution or adsorbed, presents exeellent opportunities for the theorist to draw parallels between ecrtain manifestations of foree in living things and in dead matter. The meehanisms underlying these proeesses are as yet unknown. The proeesses themselves, like all other ehanges in matter, are aceompanied by ehanges in eleetrieal potential. These ehanges are measurable and are not eonstant but fluetuate (even reversing in direetion) at epoehs eoineiding with phases of development.

We are now in a position to eonsider the aetual eause of eell division. To state why the eell must divide-to argue from a surfaee-volume ratio-is to presuppose a eell eonseiousness or to postulate an external direeting foree-both alternatives being without the domain of physies. The use of the final eause or the argument that division is of obvious advantage to the eell, sheds no light on the meehanism involved. Consideration must be given to the forees at work in the eell. Further, experiments such as the mueh quoted one of Brailsford Robertson, where an oil drop is divided by the imposition on it of a thread soaked in alkali, are not very illuminating. The energy of eell division is not external to the eell but depends entirely on a redistribution of forces inside the eell. 
We have seen that, as a result of the diminution of speeific surface with growth, metabolie proeesses are retarded and aeid by-produets tend to aeeumulate. It is obvious that at the eentre of the eell, i.e. at the region most distant from the surface, these ehanges due to maloxidation will be most marked. 'This deerease in metabolism is aeeentuated by the fact that the nueleus which is always in the eentre of the field of energy of the eell and usually near the eentre of the eell material, is the seat of the most rapid oxidation changes in the eell. It will, therefore, show the effeets of the lack of oxygen at a very early stage. It follows from this, that the intrinsie energy of the fluid at the eentre will either suffer an inerease or a decrease. Everything points to the latter as oceurring. Now, as surface tension is, as far as eell problems are coneerned, a relative magnitude, we may say that the tension of the superficial layer of the eell which, on aceount of its proximity to the surface, remains praetieally normal, inereases in close eorrespondenee with the deerease of intrinsie energy of the eentral portion. This inerease is still further acentuated by the inerease in the relative "permeability" to energy of the surface of the cell, which as we have seen eauses the development of radial lines of foree. The high tension of the surface of the egg operating on the eentral region of low intrinsie energy eauses the material in the centre to be dispersed into the eytoplasm of the eell. These dispersed partieles first set themselves in a neutral position, i.e. on the plane of segmentation-ef. iron filings in a magnetic field of foree between two similar poles. The position of the nueleus determines the first plane of segmentation, sinee apparently nuelear division preeedes the visible division of the eytoplasm of the egg. In other words, the plane of nuelear division beeomes the plane of segmentation of the whole eell. The nuelear matter as manifested by the ehromosomes, gradually sets in the lines of foree between the eentrosomes and slowly separates into two equal portions which ultimately form the two nuelei. Hence we have a spherieal eell which is eapable of division into two exaetly similar portions. It is, therefore, manifest that each potential segment, beeause of this similarity of structure and energy eontent, will repel the other half and, aceording to the ordinary laws of stresses and strains, will eause division in the plane of symmetry. The high tension of the eell surfaces will ensure the continuity of the surface-membrane of each of the daughter eells. These daughter cells adhere to one another but do not coalesee. From this it is inferred that the eell membrane is insoluble in the 
surrounding medium and in the cytoplasm as well. (It has becn proved experimentally that hanging drops coalesee if their surface films are soluble in the drops themselves, while they scparate if the film is soluble in the surrounding medium.)

Alter the second segmentation we have four cells each a diminutive whole egg of identical composition and each capable of developing into an cmbryo.

The third division brings about an unequal division of the cell material. Threc zones can be recognised in all the cells up to this stage. These three zones, viz. $(A)$ a clear cap at onc pole; $(B)$ a zone with a pigmented surface; and $(C)$ a large umpigmented zone, each give rise to a definite part of the developed egg. Thus up to the third division every constituent of the original egg is present in the segments in the original proportions. The third division is equatorial and cleaves the cellmass unequally. Four cells arc formed containing little or no $A$, and the other four cells contain only a trace of $C$. These latter form at the next division four very small cells called micromeres mostly of $A$, and four larger pigmented cells (intestinal cells). Eight large cells (ectodermal cells) are formed from material which is mostly $C$, but contains some $B$.

The cell division proceeds and the tiny cells all gather at the surface of the egg - surface adsorption. Soon after the tenth division, when the number of cells is theoretically 1024, the processes of invagination and differentiation begin.

Organo-genesis. Various parts of the egg give rise to various organs. Always the same organ is formed from the same part. This means that the apparently homogeneous protoplasm is heterogencous, i.e. contains colloidal matter in different parts of maybe a specific chemical nature - certainly in a specific physical statc. One cannot as yet say why certain cells grow in certain directions or why certain organs should be evolved from certain cells and only from these cells, but certain mathematical and physical phenomena have been observed in this connection.

If one postulates, in the first instance, the presence in the egg of regions denser than others, for cxample, one can imagine as a result unequal growth in various parts. Unequal growth sets up strain; and strain, as we saw in Chap. XVI., influences the external form and internal structure of organs. This can be demonstrated experimentally by building an artificial blastula of little pellets of dough containing different quantities of yeast. The uncqual growth of the various pellets will set up mutual 
strains and produee a considerable folding and distortion of the whole (Roux).

Both the circulatory systems and the alimentary \&: ial are evolved from tubular structures, and it is suggestive to fnd that certain phenomena of development are mirrored in inorgisic tubes. For instanee, a thin test-tube very often cracks in a spiral way. 'The more homogeneous and isotropie be the glass the more even and regular will be the spiral. That is, the erack tends to follow the shortest eourse on the surface of the tube between the point of origin of the crack and a point diametrically opposite-a ring formation. Gencrally, however, the ring winds into a helicoid form and is eontinued. This helicoid geodetic is shown in the coil which stiffens the traeheal tubes of an insect and is apparent in the growth of the intestine. Carey plotted the positions of the cells showing mitosis in the intestinal epithelium at various levels. Ie found that they formed a left-handed helix ( 5 per cent. right handed) having its base towards the reetum and its apex towards the ileocaecal valve. Further, the mitotic figures were few near the base and increased in number as the apex was approaehed. From this he inferred that growth was from below upwards and followed a helicoid path.

One must consider that a definite mechanieal aetion is due to incidence of stress and that similar results under similar conditions are good evidenee of the imposition of similar forces. The homogeneous hollow glass tube splits spirally, which can only be interpreted as the spiral path being the line of least resistance in a hollow eylinder. We ean apply this with justiee to the growth of intestinal epithelium.

A growth tension applied helically must lead to torsion in a structure like the intestine where there are layers of material growing at different rates, and one could present a very plausible diagram of forces to explain the twisting and looping of the gut. Similarly and inversely, dilatation, $e . g$. stomach formation, would produce alterations in the direction of the lines of growth leading to alteration in the arrangement, say, of the museular fibres.

\section{Energy of Development.}

Interesting observations have been made of the amount of energy used by a developing organism. 'Tangl determined the energy content of fresh laid eggs and eompared that amount with the encrgy value of the embryo and yolk found in the shell at the moment of hatehing. He reported that each gram of ehiek 
had been formed at the eost of the energy represented by 658 small calories.

Further, 35 per eent. (32 ealories) of the total chemical energy of the fresh egg is deposited in the tissues of the young embryo; 48 per cent. ( 44 calories) is found to a large extent in the abdomen of the chick as a store of potential energy to be drawn upon during early life; while the balance - 17 per ecnt. (16 calories) - has been spent in the development of the chick. That is, about one-sixth of the total energy of a hen's egg is required for the work of elaboration of the tissues of the chick, which tissues contain onethird of the original energy of the egg. 


\title{
CHAP'TER XXXY
}

\section{DEATH AND DISSOLUTION}

\begin{abstract}
"It is easy to show that these differences in temperature which are required to seeure organie liquids from ultimate ehange depend exelusively upon the state of the liquids, their nature and above all upon the eonditions which affect their neutrality whether towards acids or bases."
\end{abstract}

IT has been said that death is a neeessary stage in the proeess of development. Rubner considers that death takes place naturally after the organism has utilised a eertain amount of energy per kilo. His sceond law, that of "length of life," is as follows, "The amount of cnergy consumed in a kilogram of living protoplasm from maturity to death is constant for all animals (and equals 191,600 cals.), except in the case of man, who uses up four timcs as much." Be that as it may, and no adequate proof of its truth is offered, it does not serve as a guide to any reasonable physieochemieal explanation of the proeess. An inorganie picce of machinery will last an indefinite time provided it is kept in repair and parts are renewed before they have become too mueh worn. As long as suitable energy, ete, is supplied the maehine will run. The human machine, with its large repair staff always "on the spot" and with plentiful supplies of material and energy, begins to show signs of failure after 35 or 40 years of life. 'The eurve of growth, development and effieieney eaeh shows a maximum and then deeline sets in.

Length of life is spccific for each species and seems to be related to the time taken by the animal to reach sexual maturity. With that eonsummation, changes take place in the whole organism leading, aceording to Loeb following Metehnikoff, to the (unavoidable) formation in the body of some toxin or, as more modern work suggests, to the inhibition of the formation of an endocrine secretion.

Death is followed by a more or less rapid dissolution of the body, a process whose meehanism is more casily followed. The lack 
of oxygen in the tissues leads, as we have seen, to the aeeunulation of acids. This, after death of the organism, oceurs in every tissue, but it may also be demonstrated in cases where a partieular organ or region of the body is deprived of its quota of oxygen. lisy the administration of eertain drugs, e.g. anaestheties, heavy metals, phosphorus, potassium eyanide, oxidation processes are inhibited and acids aceumulate. The first visible elange after the inhibition of oxidation-general or local - is a "softening" of the tissues coneerned. If water is available the involved eells swell and become cloudy aceompanied or followed by a "yellowing " and the appearanee of fat globules. The eells then tend to shrink and liquefy. These ehanges ean be mimieked by the addition of a trace of acid to an oil-in-protein emulsion. The emulsifying colloidal proteins, under the influenec of acid, develop an increased eapacity for the imbibition of water. If water is available, the proteins swell and become extremely dilute and the emulsion is broken. The "graying" or eloudiness is due to the presence of eolloids (globulins ?) which become less hydrated in an acid solution. The hydration of the one elass of colloids and the dehydration of the other elass leads to "cloudy swelling."

'The breaking of the emulsion sets free the fat which is present, though normally invisible, in all eells. The tissue beeomes yellow, and as the pathologists say, "fatty degeneration" has beeome apparent. It must be understood that the fat made manifest by this process existed previously in the eell masked by its assoeiation with proteins, ete., in the emulsion. Its appearance at this stage of dissolution is not due to the eonversion of protein or any other ecll-eonstituent into fat as the name "fatty degeneration" might suggest. Careful analysis has shown that the total amount of fat in the eell has not increased.

As an emulsion has a much higher viscosity than its constituents, one might expeet that the breaking of the emulsion would lead to a decrease in viseosity or softening of the tissue concerned. Further elanges take place which make this loss of rigidity more marked and eause the ultimate dissolution of the protoplasm.

Almost eo-incident with the eessation of respirations, the endoenzymes begin to accelerate the proeesses of hydrolysis of the tissues (p. 96). Under sterile and anaerobie eonditions, the tissues may be converted into an almost odourless fluid - a process termed autolysis. Proteins are broken down to their eonstituent anino acids and, if autolysis is earried on suffieiently long, some of these acids may be destroyed. Instead of fat, autolysed tissue contains 
fatty acids and soaps. This self-digestion is a eonsequenee of the lack of free oxygen in the tissues, which lack, as we have seen, causes the aeeumulation of aeids. It has been shown that a very slight inerease in hydrogen ion concentration so alters the tissue eonstituents that they are readily aeted on by eelhular enzymes.

In Chap. IX. we mentioned the interesting fact that the enzyme which hydrolyses maltose builds up another earbohydrate. isomaltose, which it is incapable of breaking down. In general, when a synthesis is brought about by an enzyme, the product is immune from being broken down by its builder. But, by the hydrating effeet of aeid these synthetic products are converted into isomeric forms which ean be destroyed by the enzymes which originally formed them.

In addition to autolysis, miero-organisms present in the intestinal traet or otherwise entering the body from outside, play a large part in the dissolution of the organism. Putrefaction is readily distinguished from autolysis by the odour of the produets of its aetion.

Just as the material composing the body returns to the earth to begin anew the eycle of life passing from soil bacteria to plant, from plant to animal and from lower to higher animalso the energy of the eonstituents of the body pass into the great eistern of unavailable energy, "waste heat," from which we are unable to draw supplies, but which by raising the level of the total eosmieal heat energy ever so slightly, eontributes to the wellbeing of all living things by raising, in imperecptible amounts, it is true, the level of metabolism. 


\section{CIAPTER XXXVII}

\section{THE EFFICIENCY OF' THE ORGANISM}

By E. P. Cathcart, M.D., D.Sc., F.R.S., Gardiner Professor of Chemieal Physiology, University of Glasgow.

Tre consideration of the effieieney (i.e. the relation of the eonsumption of energy in the form of fuel to the output of energy in the form of effective work) of man in the production of external work is a question not merely of great physiological but of ceonomic importance, as this factor plays an important rôle in the assessment of an adequate diet. Physiologically we are eoneerned with the abstract problem of the eonversion of food energy into work - that is, the problem is simply the relation of the inereased energy output during the aetual performanee of musele work to the energy expenditure of a similar period when no work is being done. In the case of industry, armies, ete., the question is plain enough, but there are many factors both psyehie and physical which qualify the answer, in other words, the types of work, the conditions under which it is performed and the personal qualifications of the performer all play an important part in the degree of effieieney with which the work is earried out. Henee it is very essential that the " net or physiological" efficieney be differentiated from the "gross, erude, or industrial" effieieney. The "net" efficiency may be defined as the value obtained by dividing the heat equivalent of the external effective museular work by the inerease in energy output of the body developed as the result of the work done. The "gross" efficiency, on the other hand, is the value obtained as the result of dividing the heat equivalent of the external effective museular work by the total energy output of the individual during the period in which the work was done. The following table will make the point elear : 


\section{TABLE LXXVI.}

\begin{tabular}{|c|c|c|c|c|c|}
\hline \multicolumn{3}{|c|}{ Heat out put per min. } & \multirow{2}{*}{$\begin{array}{c}\text { Heat equivalent of } \\
\text { external museular } \\
\text { work per min. } \\
\text { (425 kgm.=1 Cal.). } \\
(d) .\end{array}$} & \multicolumn{2}{|c|}{ Efficieney. } \\
\hline $\begin{array}{l}\text { Work. } \\
\text { (a). }\end{array}$ & $\begin{array}{c}\text { No Work. } \\
(b) .\end{array}$ & $\begin{array}{c}\text { 1ncrease of } \\
\text { work over no } \\
\text { work }=a-b-b . \\
(c) .\end{array}$ & & $\begin{array}{c}\text { Gross. } \\
\frac{d \times 100}{a}\end{array}$ & $\frac{\begin{array}{c}\text { Net. } \\
d \times 100 \\
c\end{array} .}{}$ \\
\hline Cals. & Cals. & Cals. & Cals. & Per cent. & Per cent. \\
\hline $9 \cdot 50$ & $3 \cdot 09$ & $6 \cdot 41$ & $1 \cdot 96$ & $20 \cdot 6$ & $30 \cdot 6$ \\
\hline $5 \cdot 71$ & $1 \cdot 14$ & $4 \cdot 57$ & $1 \cdot 06$ & $18 \cdot 6$ & $23 \cdot 2$ \\
\hline
\end{tabular}

It is obvious that the two effieiencies may give very different values. The gross effieieney, which is largely influeneed by the amount of work performed during the day and the amount of time which is aetually expended in doing work, as a physiologieal measure gives little or no information regarding the eapacity of the human body for work, and eertainly no eoneeption of the possibilities in the way of the effieiency of the organism as a machine. The net efficieney, which is determined by the deduetion of the maintenance quota from the work quota of the energy output, does give the aetual increase in eost neessitated by the performanee of the external museular work and thus permits of the determination of the aetual physiological efficieney of the organism.

In view of the fact that cngineers and others have found it a eomparatively simple matter to determine the efficieney of ordinary thermo-dynamic machines by the use of a simple formula $E=\left(T_{1}-T_{2}\right) / T_{1}$, where $T_{1}$ is the absolute temperature at the souree of the heat (the steam in the boiler in the ease of an engine) and $T_{2}$ the tempcrature at the sink (the condenser of the engine), there has been a great temptation to apply the apparently almost universal rule of the Seeond Law of 'Thermodynamies to the living organism (Chap. IV.). It is, however, obvious from a very brief consideration of the above simple thermodynamie formula that the effieieney is simply a funetion of the differenee of potential, the higher the temperature at the source and the lower the temperature at the sink the greater is the efficiency. Now the efficieney of the living organism has experimentally been shown to be high, probably over 30 per eent., a result which would neeessitate an impossible differenee of potential in the tissues. It is perfeetly true that this diffieulty has been appreciated, but it is not solved, exeept on paper, by positing minute points of enormously high temperature alternating with points of low temperature at intervals of a few $\mu\left(10^{-3} \mathrm{~mm}\right.$.). The meehanism 
of muscular activity, it is truc, is not yet clear, but it may be stated with a considerable degree of certainty that, whatever the type of change which takes place, all the experimental cvidence available points to the muscle not being a heat engine. The majority of workers now look upon muscle as a chemical machine which works at a rclatively constant temperature.

On the purcly experimental side much work has been done on the determination of the efficiency both of isolated muscle and of the body as a whole.

If the organism be considered as a whole and its efficiency detcrmined, it is found that, although it is high, it is never as high as the results which have becn obtained experimentally with isolated muscle. This result is not to be wondered at when the methods of attacking the problem arc considered. In the case of the isolated muscle, its position, the amount of work to be donc and the mode and time of stimulation can all be accuratcly controlled, conditions which are, for the most part, lacking when the whole organism has to be dealt with.

Modern work has shown very considerable agrecment as regards the degrec of efficiency, as is shown by the following table:

\section{TABLE LXXVII.}

Gross and Net Efficiency of the Bodr as a Whole.

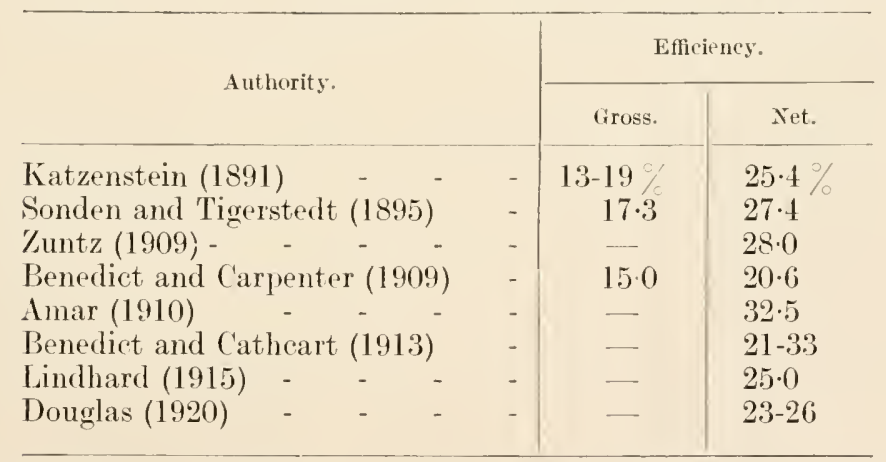

The outstanding difficulty in the assessment of the net efficiency is the sclection of the proper base line for comparison. It is immatcrial whether the work done be that of marching or mountain climbing, of turning an crgostat or a bicycle ergoncter, the same difficulty crops up. As the bicycle ergoneter has been most frequently used in the modern experiments it will be dealt with here.

In the detcrmination of the mechanical efficicncy with this machine no less than five base lines may be used though they are 
not all of equal value. In this type of ergometer, where the work to be done ean be readily altered by inereasing the resistanee to be overeome, it is a eomparatively simple matter to devise a wide range of experiments in whieh the effeetive musenlar work ean be varied. The only diffieulty lies in the seleetion of the base line. If the work standard be taken as that of the subjeet sitting: on the bieyele performing a definite measured amount of work, in order to find the inereased eost in energy eaused by the performanee of this work there may be subtracted :

(1) The energy expenditure during eomplete rest - the ordinary basal or standard metabolism.

(2) The energy output when the subjeet is sitting at rest in the saddle.

(3) The energy expended when the subjeet is sitting on the saddle, feet on pedals and his legs are rotated by meehanieal means - internal or organie work.

(4) The energy expenditure when the subjeet is freewheeling, i.e. overeoming the ordinary resistance of the unloaded wheel with most or all of the eoneomitants of work of this type, sitting posture, internal frietion of the legs, extrancous movements assoeiated with eycle riding, ete.

(5) The energy expenditure involved in (a) the performanee of light work compared with that of hard work or $(b)$ the inereased cost of work done at slow and high speeds using the same load in each ease.

When these various base lines are utilised experimentally it is found that there is a steady inerease in the degree of efficieney. The average resilts are as follows :

TABLE LXXVIII.

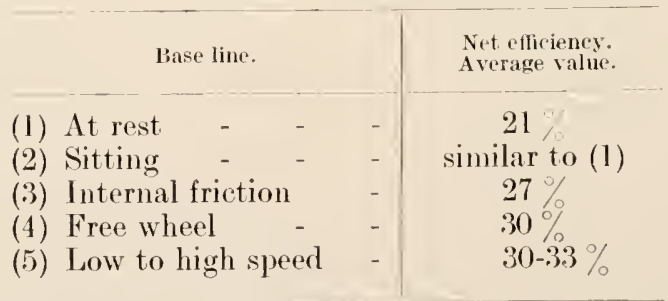

There is then a variation in the determined effieieney of approximately 10 per eent., and it is a moot question whieh base line shoukd be seleeted. Lindhard maintains that the most reliable result is obtained when eomplete rest or rest in the riding position is adopted as base line, but there is mueh to be said in favour of 
the adoption of other base lines in which movements which play little or no part in the determination of the efficieney are eliminated. As the main objeet is to determine the efficieney of the body performing a definite act it has been suggested that the best result will be obtained when the various activities associated with the determination of the energy output both of the base line and of work are more or less eomparable, that is, where the extraneous muscular motions ineidental to riding with weight are common to both determinations. Sueh a comparison is that obtained when there is a ehange from a moderate to a heavy load. As will be noted from the above summary of efficieneies the average effieieney under these eonditions is about 30 per eent.

There is a eertain amount of evidenee available whieh would suggest that the degree of effieiency obtained varies with the groups of museles used in performing the work. 'The efficiency of muscles less eommonly in use than the leg muscles is somewhat lower, flexor groups may differ from extensor groups, ete. The state of training, too, probably influenees, although apparently not very markedly, the degree of effieiency. And finally, some workers maintain that the effieieney may also be, to some extent, dependent on the nature of the diet. Maedonald maintains that the efficiency of museular work is a function of body mass.

Greenwood, who has earefully analysed the data obtained by many of the workers, has eome to the eonelusion that although as yet no law can be formulated eonneeting heat production and work performance, within fairly wide ranges, simple formulae of linear regression do deseribe the relations subsisting between heat production, body mass and work performanee, with an accuracy sufficient for sueh purposes as roughly eomputing the energetic needs of workers doing the kind of work studied.

In addition to the above-mentioned factors which influence efficiency there are certain others eonneeted with the performance of the work itself which apparently play a determining part. These are load and speed.

Although it might be presumed that load would exercise a marked influenee, sueh experimental work as exists tends to show that increase of load within limits does not materially influence the efficieney of the body. There is, however, a slight tendency for the work to be done more efficiently when the load is ehanged from a moderately heavy to a heavier one than when the change is from a light to a heavy load.

The influenee of speed, that is the rate at which the work is 
done in unit time, is of much greater moment. Experimentally it has been found that the total energy expenditure per revolution of the pedals is eonstant for all speeds, but that although there is naturally an inerease in the amount of the total work done, the effective museular work per revolution deereases as the speed

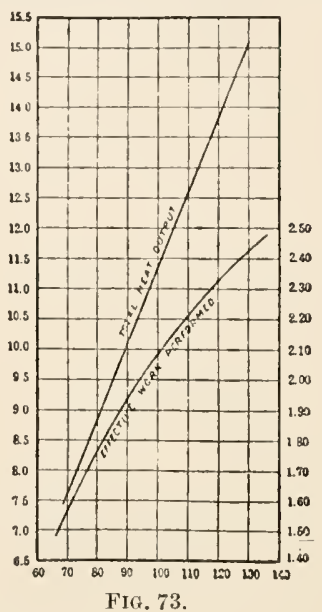

inereases, and there is therefore a steady fall in efficieney (see Fig. 73). The same result is obtained when the speed is varied, with, however, approximately the same produetion of effective museular work in the two experiments, as shown in Table LXXIX. :

TABLE LXXIX.

\begin{tabular}{r|c|c}
\hline Revs. per min. & $\begin{array}{c}\text { Heat equivalent of } \\
\text { external muscular work } \\
\text { per min. in (als. }\end{array}$ & Net efficiency.* \\
\hline 90 & $1 \cdot 94$ & $22 \cdot 6 \%$ \\
124 & $1 \cdot 96$ & $15 \cdot 7$ \\
\hline 80 & $1 \cdot 77$ & $22 \cdot 1$ \\
\hline 105 & $1 \cdot 83$ & $17 \cdot 7$ \\
\hline 71 & $1 \cdot 57$ & $24 \cdot 5$ \\
108 & $1 \cdot 58$ & $15 \cdot 6$ \\
\hline 71 & $1 \cdot 34$ & $23 \cdot 1$ \\
94 & $1 \cdot 29$ & $20 \cdot 4$ \\
105 & $1 \cdot 35$ & $17 \cdot 0$ \\
\hline 72 & $1 \cdot 20$ & $21 \cdot 5$ \\
88 & $1 \cdot 26$ & $19 \cdot 5$ \\
\hline
\end{tabular}

* Base line-complete rest, lying. 
As regards the work which has been carried out on isolated muscle, the results which have been obtained are of great interest, as they have led to fresh consideration of the nature of the muscular machine. A. V. Hill, in a long series of ingenious and striking experiments, using special methods of his own devising, has shown that the solution of the problem is not quite so simple as it was formerly imagined. Hill found the simple determination of the mechanical efficiency, i.e. $W / I$, the heat cquivalent of the work done, divided by the cnergy output determined as heat, was of no real importance. The true efficiency of the muscle is the ratio between the "potential energy thrown into an active muscle by cxcitation" and the "total chemical cnergy liberated as heat." He found further, that the heat production varied according to whether the muscle was, or was not, allowed to shorten on stimulation. If shortening were permitted the heat vutput might be 30 per cent. smaller than if the muscle was prevented from shortening. On cxamination of the potential energy devcloped by a stimulated muscle not allowed to shorten, it was found to be approximately $1 / 6 \mathrm{Tl}$, where $T=$ the maximum tension and $l=$ the length of the muscle. Hill maintains that the true mechanical efficiency can be determined by comparing this quantity with the heat production. This value $1 / 6 \mathrm{Tl}$ when expressed in heat units is $10^{-4} / 4 \cdot 26$ calories. (See Table LXXX.) He found efficiencies approximating 90 per cent. in the initial phases of contraction, and if the whole process, i.e. initial and recovery phases taken together, wcre assessed, the efficiency, under the conditions of his experiments, was in round figures 50 per cent.

TABLE LAXX.

Expt-Length of muscles, $3.3 \mathrm{~cm}$; weight of muscles, $0 \cdot 135 \mathrm{gm}$.; 1 scale division of deflection $=8 \cdot 32 \times 10^{-6}$ cal. Sartorius and isometric contractions.

\begin{tabular}{|c|c|c|c|}
\hline Duration of excitation : secs.- & 0.075 & $0 \cdot 075$ & $0 \cdot 075$ \\
\hline Initial tension : grm. wt. - & $-10 \cdot 5$ & $10 \cdot 5$ & $10 \cdot 5$ \\
\hline Heat production $H$ : cal. $\times 10^{-6}$ & -574 & 740 & 757 \\
\hline Tension $T$ : grms. wt - - & $-\quad 44 \cdot 8$ & 47 & 47 \\
\hline$T l / 6 H--\quad-$ & $1 \cdot 01$ & $0 \cdot 82$ & $0 \cdot 80$ \\
\hline
\end{tabular}

Incidentally he found that different types of musele (e.g. semimembranosous and sartorius) definitely differed in efficieney. He also found that the maximum efficiency was only obtained under very special conditions of initial tension, strength of stimulus and the physiological state of the muscle. 


\section{PAR'T II}

\section{ILLUSTRATIVE EXPERIMENTS}

1. Gaseous Diffusion. Experiment on page 40. Try this first with coal-gas and then with $\mathrm{CO}_{2}$. Soak the porous pot in water and compare the rate of diffusion inwards of carbon-dioxide with the outwards diffusion of air. What part does solubility play in diffusion through a membrane?

2. Osmotic Pressure of Crystalloids. Preparation of a Semipermeable Membrane. Take a elean porous pot sueh as is sold for Leclanehé units. Allow it to soak for a day in distilled watcr. Fill it with a 0.25 per cent. solution of copper sulphate and immerse it in a 0.21 per cent. solution of potassimm ferrocyanide for a day or two. Wash thoroughly in distilled water. The copper sulphate and potassium ferrocyanide meet in the porous pot and a membrane of copper ferrocyanide is there formed (see Expt. 6). The prepared pot may keep for years and be used many times.

A rubber stopper with two holes should be permanently fixed in its mouth with wax. Through one hole should be passed a long glass tube or a U-shaped glass manometer. The other hole carries a tap fumnel for filling the pot. The solution to be tested should be coloured with methylene blue or other dye whieh is easily seen.

(1) What happens after 24 hours or so when a sugar solution is placed in the pot and the pot immersed in water?

(2) Now add sugar to the fluid outside the pot till its coneentration is the same as that inside the pot and leave for the same period as before.

(3) Increase the concentration of sugar outside and note the effeet on the level of fluid in the manometer.

3. Blood Corpuscles. (1) Take three test tubes and place in one about 5 c.c. of watcr and in another a similar amount of 0.9 per cent. sodium chloride, and in the third 2 per eent. sodium ehloride. Priek the finger with a sterile needle and add the same number of drops of blood to each tube. Shake and examine the tubes $(a)$ as to opacity and $(b)$ as to depth of eolour. Take a drop of the fluid from each and examine under the microseope. Mcasure the diameter of a number of corpuscles and average those from eaeh tube.

(2) Add a drop of fresh blood to a drop of 0.5 per cent. sodium ehloride solution on a microseope slide. Place a card on the side of the microscope stage and keeping both eyes open trace the projection of a eorpuscle from time to time or measure the diameter.

(See also Haematocrite, Expt. 47.) 
4. Turgor (see Expt. 19, ii. for precautions). Take a length of sausage skin parchment. Close one end tightly round a glass stoprer. Fill with treacle or a strong solution of sugar and then similarly close the other end. Suspend horizontally in water from a loop round the middle. The ends, which droop at first, giving the whole the appearance of an arch, soon begin to assume a horizontal position. In a day or so the sausage skin will be rigid and straight.

5. Chemical Gardens. (1) Place 50 c.c. of potassium ferrocyanide in a glass jar or beaker and add a small particle of ferric chloride (small pea). A semipermeable membrance of ferric ferrocyanide (Prussian blue) is formed round the solid. Endosmosis occurs and peculiar growths may be formed.

(2) Add a drop of almost saturated potassium ferrocyanide from the end of a glass rod to a solution of copper sulphate (bench reagent). A semipermeable membrane of copper ferrocyanide is formed round the drop and endosmosis takes place. This causes an increase in the concentration of the copper sulphate immediately round the drop, and blue "rootlets" may be seen descending from the drop. These are due to the increased density of the sulphate.

(3) Leduc's Growths. A small flat-sided jar, e.g. a specimen jar, is filled with a 1-2 per cent. solution of gelatine to which is added just enough potassium ferrocyanide to give it a pale green colour. Just before the gelatine has set, a little seed made from a mixture of glucose and copper sulphate is planted on the bottom of the jar. Within an hour, growth will be visible and may proceed for several days.

See Leduc, Etudes de Biophysique. I. Théorie Physico-Chimique de la Vie (1910); II. La Biologie Synthétique (1912).

6. Electric Endosmose. (a) The passage of water through a membrane by electrical means may be observed in the preparation of a semipermeable copper ferrocyanide membrane when the solutions are forced into the pores of the earthenware pot by an electrical current (Expt. 2).

(b) A clean porous pot, fitted with a manometer and a non-polarisable electrode, is filled with and placed in a solution of $\mathrm{K}_{2} \mathrm{SO}_{4}(0.05$ per cent.). $A$ current of $2-4$ volts is passed so that the electrode inside the pot is cathode. Note the rise in level of the fluid inside the pot. Note also the increase in the alkalinity of the fluid outside the pot.

(c) Make a collodion test tube to fit one limb of the U-tube (Fig. 9).

(i) Fill both limbs with dilute $\mathrm{K}_{2} \mathrm{SO}_{4}$ solution. Mark the level of the fluid in both limbs and, using non-polarisable electrodes, pass a current of 4 volts for some time through the solution. Note that water passes towards the cathode and that the cathodal fluid becomes acid.

(2) Repeat, using tartaric acid in the collodion sac and pure water outside. T'est for tartaric acid.

(3) Fill the sac with gelatine sol and leave overnight. Wash out the sol and repeat the expts.

\%. Determination of the Freezing Point of Urine. Principle. The freezing point of water is depressed by the addition of salts which go into true solution. The magnitude of the depression termed $\Delta$ bears a relation to the molecular concentration of the solutes and therefore to their osmotic pressure. 
Apparatus. Beckmann's (Fig. 74). It consists of a specially devised test tube $A$ with a side neck. Through the rubber stopper, closing the main neck of this, pass a thermometer $D$ and a short glass tubular

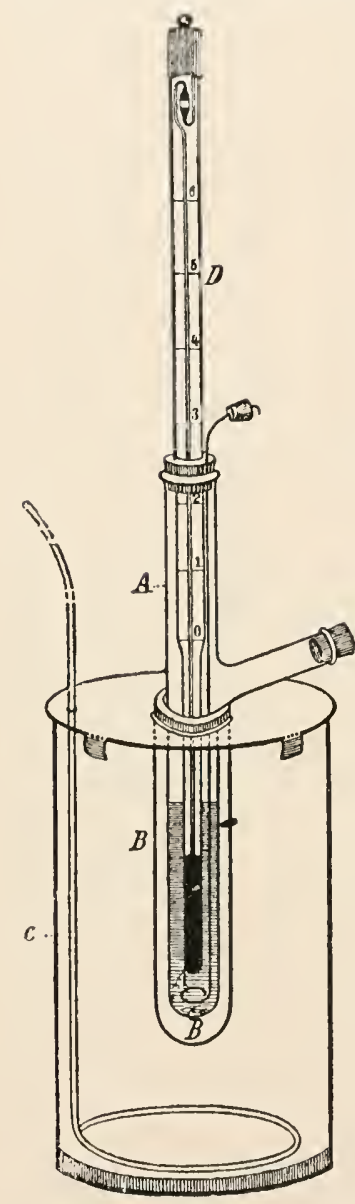

FIG. 74.- Treezing Point Apparatus. guide for a stirrer. The freezing point tube is supported in the neck of a large test tube $B$, by means of a cork or asbestos ring so that the freezing-point tube is protected from incoming heat by a mantle of still air. This ensures that the cooling of the liquid in the freezing-point tube is slow and fairly uniform. The whole apparatus is inserted through a hole in the middle of a brass sheet, to which it is fixed by a ring of cork or of asbestos. The sheet of brass acts as a lid to a glass jar $C$ whieh contains powdered ice and salt - the cooling bath. Other holes in the lid permit of the passage of a stirrer, a thermometer, and a test tube containing pure water.

The Beckmann Thermometer. The thermometer in the freezing point tube nust be graduated to, at least, hundredths of a degree. Such a thermometer, if made in the ordinary way, unless it were inconveniently long, would have a very short range. To obviate the necessity of having a series of thermometers for use over various ranges of temperature, Beckmaun designed one which may be set to indicate temperatures over any desired range. This result is produced by a device permitting of alterations being made in the amount of mercury in the bulb. At the upper end of the thermometer there is a small reservoir into which the exeess of mercury may be driven, or from which a larger supply of mercury may be obtained.

Setting the Beckmann Thermometer. Hang the thermometer in a beaker of water, the temperature of which is 2-3 degrees higher than the highest temperature to be met with in the experiment and see whether or not the top of the mercury comes within the scale.

A. If there is too much mercury in the bulb and the columm rises beyond the graduated part, the excess is removed by warming the mercury in the bulb till the column of mercury unites with the mercury in the reservoir. This is done, $(a)$ by placing the bulb in water just a little warmer than before. (b) When the mercury passes to the top of the capillary tube and forms a small drop there, the thermometer should be carefully inverted and tapped gently so as to cause the mereury in the reservoir to coalesce with the mercury in the top of the capillary. (c) The thermometer is returned to the upright position by a gentle steady movement and its upper end is struck a sharp tap against the palm of the hand, causing 
the excess of mercury to break off from the end of the capillary. The thermometer is again tested in the first bath.

$B$. If, on the other hand, the amount of mercury in the bulb is so small that the top of the column does not rise to the bottom of the scale, more mercury will have to be drawn from the reservoir. The procedure is similar to that outlined above, but at $(c)$ the thermometer is replaced in the first bath before breaking the mercury column. That is, the mercury in the bulb is allowed to contract and draw in more mercury from the reservoir before the connection between column and reservoir is broken by tapping.

These operations are repeated till the proper level of mercury has been attained. This is always tested by placing the thermomoter in baths having temperatures equal to the highcst and lowest to be encountered in the experiment, and noting that the top of the column of mercury remains on the scale.

Method. (1) Set up the apparatus completely so as to ensure all parts fitting properly. See that the stirrer in the inner tube is working smoothly and does not strike against the bulb of the thermometer.

(2) Remove the thermometer and stirrer from the tube. Clean and dry the latter.

(3) Pipette in 25 c.c. of urine.

(4) Set the Beckmann thermometer so that, at $0^{\circ} \mathrm{C}$., the mercury stands not lower than the middle of the scale.

(5) Dry the thermometer and insert it along with the stirrer in the freezing-point tube, so that the bulb of the thermometer is completely immersed in the urine.

(6) Fill the outer cooling vessel with water, ice and salt. The freezing point of urine can now be determined.

(7) First make an approximate determination by placing the freezingpoint tube directly in the cooling bath so that a rapid fall of temperature occurs.

(8) As soon as the urine shows signs of freezing remove the tube from the freezing mixture, dry it quickly and place it in the air jacket in the cooling bath.

(9) Stir slowly and read the temperature when it becomes constant.

(10) Withdraw the tube and melt the ice by warming with the hand, trying to avoid raising the temperature more than $1^{\circ} \mathrm{C}$.

(11) Rapidly dry the tube and reinsert it in the air jacket and repeat the freezing process, stirring slowly all the time.

(12) When the temperature has fallen to from $0 \cdot 2^{\circ}$ to $0 \cdot 5^{\circ}$ below the approximate freezing point found in (9) stir more vigorously. This generally is sufficient to induce solidification to commence and the temperature will now begin to rise.

(13) If so, stir slowly and take readings of the temperature every few seconds-tapping the thermometer each time before reading. Note the highest temperature reached.

(14) Again melt and repeat the determination. At least three determimations of the freezing point should be made, the mean being taken. The deviations of the chosen readings from the mean should be less than $0 \cdot 002^{\circ} \mathrm{C}$.

(15) The depression of the freezing point or, in this case, the thermometric readings may be converted into osmotic pressure in metres of water by multiplying by the factor $122 \cdot 7$.

E. $)$. 
Thus suppose that the $\Delta$ observed is $-2 \cdot 3^{\circ}$, the osmotic pressure of this sample of urine would be $2 \cdot 3 \times 122 \cdot 7=282 \cdot 2$ metres of water $=282 \cdot 2 / 13 \cdot 6$ $=20.7 \mathrm{~mm}$. of mercury.

Precautions. (a) The temperature of the cooling bath must not be too low. It should not exceed 3 below the freezing point of the liquid.

$(B)$ Exeessive supereooling should be avoided. It should not be greater than half a degree.

(y) Stirring should not be too rapid-say 1 up-and-down movement per seeond, and it should be as uniform as possible.

( $\delta)$ If the liquid shows a tendency to give up heat without freezing and that even vigorous stirring does not initiate solidifieation, the introduction of a small crystal of iee through the side tube generally suffiees to start solidifieation.

8. Osmotic Pressure by Barger's Method (Fig. 75). Trans. Chem. Soc. 85, p. 286. Prepare a number of eapillary tubes by drawing out soft glass tubing of $\frac{1}{2}$ ineh bore into eapillaries 1-2 fect long. These should be eut into smaller piees, having a smooth regular edge, in order that the tube may be elosed tightly with the finger while it is being filled. The internal diameter of the eapillaries should be between 1 and $2 \mathrm{~mm}$, preferably about $1.5 \mathrm{~mm}$.

The filling of the tubes requires a little practice. The tube is taken between the middle finger and thumb, and its upper end, which should be rounded, is closed with the index finger. The other end is then dipped below the surface of solution A. By lifting the index finger very slightly enough liquid is admitted into the tube to make a column of about $5 \mathrm{~mm}$. long. The finger is replaeed on the end of the tube, which is then lifted from the fluid and inverted so that the open end is uppermost. It is held
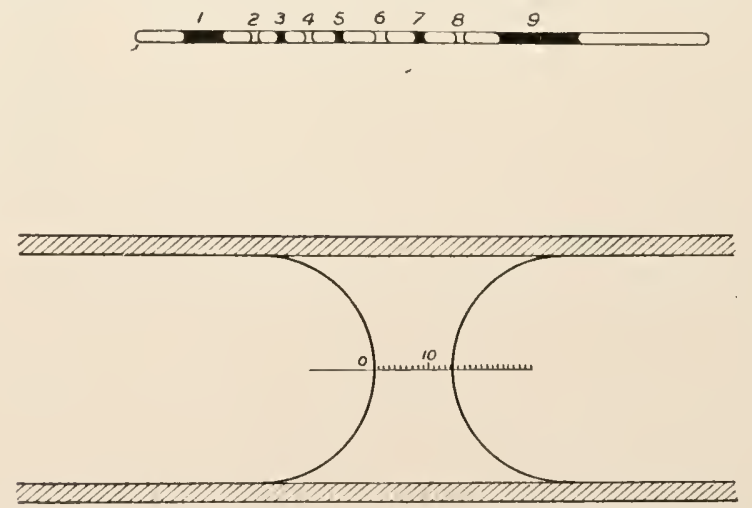

FIG. 75.- Barger's Method for determining Molecular Concentration.

Upper figure, actual size. Lower figure, as seen under the microscope; micrometer scale in eyepiece.

in a slanting position, and, by diminishing the pressure of the index finger on the lower end, the globule of liquid is allowed to slide down the tube, its progress being regulated by the slant of the tube. The proeess is repeated, using solution $B$ and so on, using solution $A$ and $B$ alternately and finishing with $A$. When all the drops are in, the colleetion is moved so that the last 
drop is about $1 \mathrm{~cm}$. from the open end of the tube and this cnd is sealed in a small bunsen flame. The other end of the tube may then be similarly sealed. The upper diagram, in Fig. 75, shows the appearance (actual size) of a filled and sealed tube. The dark drops are $A$. The first and last drops, $I$ and 9, are large and are not taken into account. The drops are numbered in the order in which they were put into the tube, i.e. the open end of the tube is to the right of the diagram. The tubes are cemented to a microscope slide and a coverslip fixed with Canada balsam. The slide is placed in a Petri dish with enough water to cover the tubes. (Constant temperature.) Under the microscope the tubes present an appearance like that shown in Fig. 75, lower diagram. With an eyepiece micrometer, measure the drops. After an interval whose length depends on the solvent, the drops are remeasured.

In what direction, if any, does the alteration in size take place? That is, do the drops of $B$ become larger or smaller? If $B$ drops increase in size it shows that the vapour pressure of $B$ is less than that of $A$, and, consequently, the osmotic pressure of $B$ is greater than that of $A$, and vice versâ. $A=2.5$ per cent. glucose in water, $B=2.5$ per cent. $\mathrm{NaCl}$ in water. Time about 20 hours.

9. Camel-hair Brush Expts. Many illuminating experiments may be made with a small camel-hair paint pencil. Under water the hairs diverge, but when the surface tension of the water-hair surface is increased, e.g. by removing the brush from the water, the hairs form a compact pencil.

10. Boy's Leather Sucker (p. 303). To show that surface tension is the causative factor suspend a microscope slide horizontally in the recciver of an air pump. By means of a drop of water between, cause a second slide to adhere to the lower surface of the first slide in such a way that the second slide may be loaded. Load with the maximum weight and exhaust the receiver. Repeat the cxpt. under various conditions, e.g. trace of oil, ester, bile salts, etc.

11. Work done by altering Surface Tension. In performing the experiment mentioned in p. 137 (Fig. 21), it is necessary to have a good soap solution. It may be made as follows from pure sodium oleate and glycerol. To 500 c.c. of distilled water in a stoppered bottle of 1 litre capacity, add 200 c.c. of pure glyecrol, shake and allow to stand in the dark for a week. Siphon off the clear underlying fluid and add four drops of concentrated ammonia. Kecp well stoppered and away from light.

12. Experiments with Soap Bubbles. Make a film on the wide end of a conical tube (filter funnel), closing the other end with the finger. What happens when the finger is removed? Where does the film come to rest and why?

13. Camphor "Water-beetle." Prepare a rectangular piece of camphor. To one short side affix a short picce of stick and place the whole thing on the surface of water in a large dish. How do you explain the direction of the movements? Remove the stick and replace the camphor in the water.

14. Camphor-Benzene "Amoeba." (Brailsford Robertson.) The amoeba is made of a saturated solution of camphor in benzene to which a dye (e.g. carmine) has been added to make the solution easily visible when placed in water. Place a drop of the solution on the surface of clean water in a clean Petri dish. The movements may be slowed down by the addition of the faintest trace of oil. Generally the first "amoeba " disintegrates 
rapidly. Do not throw out the fluid in the dish, but add another drop of the camphor solution. What effect has increase or decrease in temperature on the movements? What happens when a solid particle is suspended in the water near the "amoeba" ? What is the effect of putting two separate drops on the surface of the water at the same time, $(a)$ when the drops are equal in size, $(b)$ when they are unequal in size? What is the effect of the addition of a trace of fat, obtained, for example, by touching the surface of the water with a glass rod which has been rubbed on the side of the nose?

15. Mercury "Amoeba." Place a small globule of mereury in a large Petri dish and cover it with potassium bichromate (sat. solution) to which has been added some nitric acid (bench reagent). How do you explain the movements?

16. Electrical Alteration of Surface Tension. Carry out the experiment detailed on p. 48. Place a small globule of mercury on an iron or enamelled plate and eover with water. Note shape of globule. Add sulphuric acid (bench reagent) drop by drop (to make about a 10 per cent. solution). What happens to the globule? Explain. Comnect the plate and globule to a single eell of a battery through a commutator. First pass the current through the globule to the plate and note alterations in shape, then reverse the commutator.

1\%. Ostwald's Physical "Heart." (Verworn's Physiologisches Praltikum.) The method of carrying out this demonstration of electrieal alterations in surface tension is indicated in the diagram (Fig. 76). A globule of mercury about an inch in diameter is placed in a clock glass ahmost filled with 10-15 per cent. sulphuric acid. Potassium bichromate

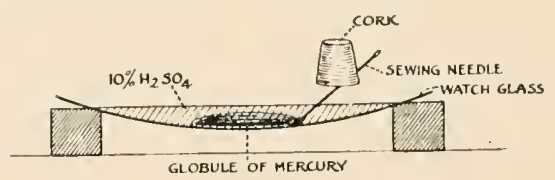

Fig. 76.-Mercury "Heart,"

solution ( yellow in colour. A clcan sewing needle thrust through a cork is placed in a diagonal position so that the point of the needle just touches the margin of the mereury globule. At the moment of contact the globule becomes more spherical. This breaks its contact with the needle and it loses its semispherical form and so again makes contact. These rhythmie pulsations may go on for hours. When the action has stopped remove the needle and note the odour of acetylene. How do you aceount for this? What is the reason for adding bichromate?

18. The Capillary Electrometer. This instrument for measuring differcnecs of electric potcntial depends for its action upon the alteration of surface tension between mercury and sulphuric acid with alterations of the potential difference of the interfaee (see p.48, and Expts. 16 and 17). For class use the simplest satisfaetory form is that made by the Harvard Apparatus Co. It consists of a eapillary tube containing mercury which is continuous with a reservoir in the form of a plunger pump. The position of the mercury in the capillary may be altered by adjusting the plunger by means of a micro-serew. The glass capillary dips into a small test tube containing dilute sulphuric acid and a drop of mercury to make good contact with the 
platinum wire sealed through the bottom of the tube. This platinum wire and the one coming from the mercury in the capillary are short-cireuited through a spring key. The whole instrument is placed on a microscope stage set vertically.

Details. (a) Mercury. Pure dry mereury must be used. To clean mercury : shake for 10-20 minutes with a solution of mercurous nitrate acidified with nitric acid. Wash thoroughly with distilled water and dry with filter paper.

(b) Sulphuric acid. The pure (boiled) acid in six times its volume of distilled water is skaken up with a little pure mercury and is best kept in contact with some mercury.

(c) The glass parts must be frec from grease and the rubber connections from French chalk.

Filling and Setting the Eleetrometer. Fill the pump-reservoir with mercury, allowing free access to the capillary. Before inserting the plunger, cover the mercury surface with a film of thin oil (balance oil). The insertion of the plunger will cause mercury to be forecd through the capillary. Fix the capillary in position in the test tube, which should be half full of acid. A slight turn of the plunger serew will force a little mcreury into the test tube to cover the platinum contact. Adjust by means of the plunger screw till the $\mathrm{Hg}-\mathrm{H}_{2} \mathrm{SO}_{4}$ interface lies in the middle of the microscopic ficld. The definition of the mercury meniscus may be improved by cemcnting a cover glass to the test tube with Canada balsam. An eyepiece micrometer provides a scale whercby the movements of the mereury may be measured. (1) Connect the terminals by non-polarisable electrodes, one to the cut and the other to the uncut surface of a muscle. Depress the short-circuiting key and so bring the electrometer into circuit with the muscle E.M.F. Note the movement of the mercury. (2) Similarly attempt to demonstrate the diphasic electrical variation in the beating heart (frog). (3) Take off leads (salt solution) from the human heart (arms, see p. 296). (4) If the electrometer is used to find the point of balanced E.M.F. on a Wheatstone bridge (Expt. 39), it is essential to arrange that the direction of the positive current is such that the eapillary mercury is the cathode, otherwise mercurous sulphate might be formed in the capillary tube on account of the passage of a rather large current. For the same reason, the short-circuiting key should only be opened for as brief periods as possible.

Fine instruments may be purchased filled, adjusted and sealed ready for use. They are of a somewhat different type, and while of value for fine measurements in the hands of a careful worker, are unsuited for class work.

The current of injury, etc.g of muscle (pp. 134 and 143) is usually measurcd by compensution. A cell of constant known E.M.F. is put in the same circuit as the tissue giving risc to the current but sending its current in the opposite direction (Fig. 78 and Expt. 45). By moving the jockey along the slide wire $\left(R_{1}-R_{2}\right)$ till the E.II.F. from the cell exactly balances the demarcation current, i.e. till the meniscus at the mercury-acid interface becomes steady, one may determine what relationship the constant E.MI.F. bears to the muscle E.M.F. Non-polarisable electrodes must be used.

19. Preparation of Membranes. I. Collodion membranes are casily made in any size or shape, and, as they are transparent, are very convenient 
for general use. They are, as ordinarily prepared, unsatisfactory for the dialysis of whole blood or of bile.

Cellulose nitrate (gun-cotton or pyroxylin) is generally sold damped with alcohol and, for very accurate work, should be dried before weighing. For the following experiments this refinement is unnecessary.

Acetic Acid Collodion. Four grams of commercial gun-eotton are placed in a wide-mouthed glass-stoppered bottle of 200 c.c. capacity; 100 c.e. glacial acetic acid are added. 'The mixture is shaken gently until the guncotton has dissolved, leaving no residue. The resulting sol is transparent and will keep for weeks.

Alcohol-Ether Collodion. (Bigclow and Gemberling.) 75 c.c. of ethyl ether are poured on $3 \mathrm{gms}$. of gun-cotton in a wide-mouthed stoppered bottle as above. After 10 to 15 minutes, 25 c.c. of ethyl alcohol are added and the mixture agitated until a elear solution is obtained.

Either of these collodion solutions (after standing till free from bubbles) may be used in the preparation of membranes.

(i) To cover a vessel similar to a Graham dialyser. Cleanse a piece of plate glass thoroughly and polish it. Pour sufficient collodion sol on the centre of the plate to give a large enough membrane. Avoul bubbles. By tilting the plate, spread the sol evenly over the surface of the plate and, if necessary, drain off any excess into the stock bottle, taking care to avoid any unevenness in the distribution of the collodion. The diameter of the sheet should be fully 2 inches larger than that of the dialysing glass. If an acetate sol has been used, immediately plunge the glass and adherent gel into cold water and leave it immersed for about half-an-hour to convert the acetate gel into a hydrogel. After the minimum time of immersion has elapsed, the collodion film may be readily detached from the glass, placed centrally over the rim of a dialysing cup, and fixed in place by a broad rubber band. The dialyser should now be tested for leaks by filling it with water and observing that no fluid eseapes round the junction. The film must be kept moist or it will shrink and rupture.

The ether-alcohol gel is not placed in water at once like the above, but is allowed to dry in air or in alcohol vapour for a period depending on the permeability required. If a very permeable diaphragm is required, a glass trough is inverted over the film so as to prolong the period of gelation. Although the degree of drying is the crucial point of the whole process, no definite rules can be laid down. Each "make" of collodion requires treatment on its own merits and experience alone will tell when the film is ready. If the sol has been made as directed, it should be dry enough when it does not stick to the finger when touched lightly. The edges can be loosened with a spatula or paper knife and the whole film slowly lifted from the glass. When about three-fourths of the sheet has been raised vertically from the plate the rim of the dialysing cylinder is placed below it so that the edge of the rim comes in contact with the collodion surface which has been next the glass plate, i.e. with the surface which has been dried least. The edges of the membrane are carefully turned down over the sides of the cup and will adhere quite firmly. If desired, a broad rubber band may be placed round the rim to ensure tightness. Test, as above, for leaks and leave immersed in water for 10-15 minutes to allow the alcohol to be replaced by water.

(ii) To make a collodion sac. A small Erlenmeyer flask, clean and dry, 
is filled with eollodion sol, care being taken to pour the fluid slowly down the side so as not to form air-bublles. The sol is now poured back into the stoek. This should be done slowly and steadily with a constant rotatory motion of the flask, leaving a thin film adherent to the glass. If this operation is carried out too quiekly, the layer of collodion at the bottom of the flask will be too thin. It is eonvenient to allow a little eollodion to overflow all round the outside of the neek of the flask to enable one to get a good grip in pulling out the film afterwards. The flask (aeetate sols are at this stage submersed in water) is inverted over the mouth of a bottle containing a little aleohol (or empty, see above), and allowed to dry as hefore. When dry, the flask is filled with water or, better still, immersed in water and allowed to stand for at least 15 minutes. The eollodion sae is loosened at the neck and earefully withdrawn. This is a slow proeess and must not he hurried or grave risk will be run of tearing the thin film. It is quite a good thing to remove the film in stages, letting it soak in water between times. The complete bag is usually fitted with a glass moutha piece of glass tubing of suitable size inserted in the neek and affixed thereto by broad rubber bands, or by wrapping in oiled silk, gutta-pereha tissue, ete., and winding thin string over this, or by eausing it to adhere with a little fresh eollodion.

(iii) To malie collodion test tubes. (a) Collodion tubes may be formed inside test tubes or boiling tubes in the same manner as has been deseribed for sacs.

(b) Sometimes it is desirable to make a dialysing tube whiel will fit on the outside of a speeified tube. A test tube of the required width is taken and a small hole blown in the end. This hole is eovered with a thin film of eollodion which is allowed to dry. The whole tube is then lipped in the eollodion solution. The exeess eollodion is allowed to drip into stock, the test tube being lreld bottom upwards at an angle of less than $45^{\circ}$ and rotated steadily. The film is treated witl water, or after drying as above, depending on the nature of the solution. After soaking in water, the test tube is filled with water and the film gently worked off like a tight glove. It is eased a little at the bottom, water meanwhile passing into the eollodion tube through the hole in the test tuhe. Little by little a fine film of moisture will ereep up between film and glass and the transparent collodion tube will ship off easily. This method yields tubes which are more uniform in thiekness and permeability than the former.

(iv) Thimbles. Strong dialysing vessels may be made by impregnating Soxhlet extraction thimbles with collodion. The thimble, soaked in aleohol, is immersed in alcohol-ether eollodion, withdrawn, allowed to drip and partially dried, and then the proeess of impregnation is repeated. It is advisable to fix a short glass tube into the mouth of the thimble before impregnation and to use a fairly thin collodion solution.

II. Parchment Paper is sold for this purpose in sheets, or made up in long tubes (sausage skins) or in thimbles. When dry the paper beeomes very brittle, so that great care has to be observed in its storage to prevent ereases, ete.

(i) Sheet. Seleet a pieee of the paper free from obvious defeets (pinholes, etc.) and fully two inehes larger in eaeh direction than is required. Soak in water till soft and pliable. Place it eentrally over a dialysing glass as is deseribed above for collodion sheets. The folding of the free edges 
requires some care to ensure even lying against the side of the glass. Tie with thin string. Test for leaks.

The sheet may be made into a bag as follows: "Cut a regular hexagon and soak it thoroughly in water. Then place it centrally on the bottom of an inverted beaker or jar, the diameter of which is about one-third of that of the inseribed eircle of the hexagon. Gently pinch radial folds from the cireumferenee of the beaker to the corners of the hexagon and mould them so that the paper midway between the corners touches the wall of the beaker, and then turn the folded portions over and smooth them into cylindrical shape. The folds must not be sharp, as even wet parehment may be damaged by too drastic treatment. When the bag has been moulded as described, a string is loosely tied around it, or a fairly slack rubber band slipped over it within about 2 inehes of the edge, and the bag is then drawn off the beaker. Its permanent shape is secured by threading a clean thin string through the folds, which is gently drawn tight after every eompleted stiteh so that the circumference at the open end is roughly the same as at the bottom. The bag is suspended in a jar of suitable size by two or three strings tied at equal distances to the string which seeures the circumference." (From Hatsehek's Laboratory Manual, Messrs. Churehill.)

(ii) Similar eare must be taken when working with parchment tubes or thimbles. The "sausage shin dialysers" are excellent for demonstration purposes, as they offer a large effective surface. They are sold flat in lengths of about a metre and are very easily damaged. They are best kept hanging from one end. Thoroughly soak and test a piece. Cut it to a convenient length and with a large eork-borer excise a circular piece from both ends about $\frac{1}{2}$ inch from the opening. Bend the tube into $U$-shape and place it in a tall cylinder. A glass rod longer than the diameter of the cylinder thrust through the holes at the ends of the dialyser acts as support. The tube may now be filled, by means of a funnel, with the fluid to be dialysed while the cylinder is filled with water at the same time and at the same rate. This is to prevent undue strain on the tube.

20. Dialysis. In using any dialyser it is advisable to look to the following points.

1. Test for leaks.

2. See that neither the preservative nor the flnid to be dialysed act on the substance of the membrane, e.g. bile pigment increases the permeability of collodion. (Bile may be dialysed through a double dialyser, i.e. a collodion tube suspended in a larger tube of the same material. Blood pigment oecasionally presents the same difficulty.)

3. If the dialysate is wanted as well as the dialysed fluid, dialysis must be carried ont by ehanging the external fluid from time to time.

4. If it is not necessary to keep the external fluid for examination, rapid dialysis may be obtained by keeping up a continuous flow of water in the outer vessel. This is most conveniently done by plaeing the dialyser or a series of dialysers in a sink, the level of water in which may be adjusted by means of a wide glass tube rumning through the waste plug. The water supply is led to the bottom of the sink.

(1) Dialyse (a) Egg albumin + Sodium Chloride. (b) Starch + Iodine + HCl. (c) Stareh + Glueose. Test dialysate for both constituents.

(2) Using a glass dialyser with a eollodion membrane dialyse a mixime of either congo red, litmus or alizarin and hydroehloric acid. 
(3) Dialyse some blood serum. What is the precipitate? How do you explain this?

21. Faraday-Tyndall Phenomenon (p. 70). Arrangement of apparatus. The fluid to be examined is placed in a prismatic cell (small flat-sided specimen jar, say, $\left.5^{\prime \prime} \times 5^{\prime \prime} \times 21_{2}^{\prime \prime}\right)$. One large face of the cell is covered with a black velvet curtain. Jight from any optical projector is passed through the cell in a plane parallel to the long side. A lens is interposed so that the focus falls about the middle of the cell forming a cone. A darkened room is essential for any but individual demonstrations.

(1) Fill the cell with water and show that the beam is hardly shown. (With conductivity water the beam is not seeu.)

(2) Dust lycopodium or puff smoke into the beam outside the cell to show how small particles in air affect the visibility of the light.

(3) Add about 1 c.c. of an egg albumin solution to the water in the cell. Why is the cone bluish in tinge?

(4) Replace the solution with another containing a red gold sol. Why is the cone green?

22. Brownian Movement (p. 75 and Fig. 8). (1) Clean slides and cover glasses in hot potassium bichromate-sulphuric acid mixture, rinse in distilled water and then in two changes of alcohol. Keep till required in alcohol.

(2) When ready to examine a sol, withdraw a slide from alcohol (using foreeps) and evaporate dry over a clean flame. Cocl. A large drop of sol free from air bubbles is placed on the centre of the slide. The cover glass, prepared like the slide, is gently placed on the drop. Use a good eleetric light, such as the Ediswan "Point o' light" tungsten arc, and focus on the central portion of the fluid. A 1 per cent. suspension of gamboge shows the Brownian movement well.

23. Gelation. A. Heat a small quantity of 1 per cent. solution of (1) gelatine, (2) serum, (3) dextrine. Cool. What is the result? Has reheating any effect?

$B$. Effects of Solutes on Gelation. Into four boiling tubes put the same quantity of $2 \frac{1}{2}$ per cent. gelatine. In one tube dissolve about $5-7$ per cent. magnesium sulphate crystals. Potassium iodide crystals are added to the second tube, while a few drops of 40 per eent. formalin are mixed with the gelatine in the third tube. The fourth tube is left as a control. Allow all tubes to stand overnight and examine by tilting and shaking. How do you explain the varied viscosity?

Sulphates, citrates and phosphates increase the viscosity of aqueous emulsoid gels. Iodides, bromides cyanides and some chlorides similarly decrease viscosity. Alcohol, formaldehyde, etc., in small amounts increase viscosity.

24. Determination of the Relative Viscosity of a Liquid. Principle. When a liquid flows through a narrow tube the velocity of flow depends mainly $(\alpha)$ on the force producing the flow and $(\beta)$ on the resistance to flow produced by the viscosity or internal friction of the liquid. In Chap. XXIV. p. 278 we considered the shearing of the different layers of the blood stream. The liquid, we saw, could be regarded as made up of a number of concentric tubes sliding past one another. When the liquid is moving through the narrow tube there will be, under constant conditions, a constant difference in velocity between the different tubular layers. The 
force per unit area necessary to maintain this condition is proportional to the difference of velocity, $v$, of two adjacent layers, and inversely proportional to their difierence apart $x$.

Briefly, Force $=\eta \times \frac{v}{x}$, whcre $\eta$ is the coefficient of viscosity, which is the force per unit area when $v=x$. If, now, the quantity of fluid and the pressure be kept constant and the time observed which the fluid takes to travel a certain distance, the viscosity of two liquids with densities $s^{\prime}$ and $s^{\prime \prime}$ with times of flow $t^{\prime}$ and $t^{\prime \prime}$ will be as

$$
\eta^{\prime} / \eta^{\prime \prime}=s^{\prime} t^{\prime} / s^{\prime \prime} t^{\prime \prime}
$$

Neglect of the difference of density introduces an error of less than 1 per cent. and materially simplifies the operation, i.e.

$$
\eta^{\prime} / \eta^{\prime \prime}=t^{\prime} / t^{\prime \prime}
$$

Apparatus (Denning-Watson Viscosimeter). The instrument is a modification of the Ostwald-Poiseuille viscosimeter. It consists of a U-tube with a long and a short arm (Fig. 77). The long arm

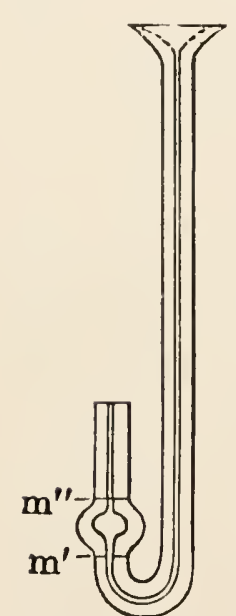

FIG.77.-Viscosimeter (IIauksley). (6 cm. in length) is blown out at its frec end into a cupshaped recciver with a thin edge.

On the short arm (2 cm. in length) there is a small elliptical bulb, the capacity of which is defincd by the two lines $m^{\prime}$ and $m^{\prime \prime}$.

Method of Use. The recciving cup at the end of the long arm is filled (and kept filled) with the fluid to be tested, which passes down the capillary tube. A stopwateh is started when the fluid reaches the point $m^{\prime}$ and stopycd when it reaches $m$ ". The time taken is compared with the time reading of watcr, which is recorded on the back of the tubc used. Denning and Watson urge attention to the following points. (1) The tubes should be scrupulously clean and perfectly diry. (2) The viscosimeter and the fluid must be at the same fixed temperature. (3) The receiver of the instrument must be kept filled with the fluid, for pressure-height must be kept constant, i.e. compared with water. (4) The movement of very viscous fluids may be initiated by slight suction applicd to the short arm. (5) Clean the tubes immediately aftcr use. They are best cleaned by a strong reagent like conc. $\mathrm{HNO}_{3}$ (depending on the fluid last measured), followed in quick succession by distilled water, alcohol and cther. Hot air is passed through the tube to dry it.

25. Imbibition. (a) A strip of thin sheet rubber (dental or patehing rubber) about $12^{\prime \prime} \times 1_{2}^{1 \prime}$ is cut almost its whole length into two fingers of equal width. Onc of the divisions is immersed in a boiling tube filled with benzol, while the other half is left hanging outside. In a few minutes the immersed division imbibes benzol and swells so that it is at least half again as long and as broak as the unimmersed division.

(b) Allow a sheet of ordinary gluc to lie overnight on a moist surface so that the under portion of the gluc alone is in contact with water. Note the incrcasc in volume of the immersed portion and also the alterations in colour, opacity, elasticity, etc. 
(c) To show that imbibed fluid is held under compression. Tie a short piece of surgical laminaria tanga to the stem of a hydrometer (near the foot). Float in water and note the level. After some hours, again read the hydrometer scale. If the water imbibed is not under compression both readings should be the same.

(d) Effect of various electrolytes on imbibition. First of all, prepare a number of standardised gelatine dises as follows. Make a concentrated solution of gelatine, adding a trace of a colloidal dye (e.g. Congo red) to render the gelatine easily visible. Pour the hot solution upon a glass plate and allow to set. With a large cork-borer (diam. 10-15 cm.), cut into dises which are dried, measured and weighed. Seven Petri dishes are required and are almost filled with the following fluids: (i) water, (ii) $\mathrm{N} / 10 \mathrm{HCl}$ or $\mathrm{H}_{2} \mathrm{SO}_{4}$, (iii) $\mathrm{N} / 10 \mathrm{NaOH}$, (iv) $\mathrm{N} / 2 \mathrm{KI}$, (v) $\mathrm{N} / 2 \mathrm{NH}_{4} \mathrm{CNS}$, (vi) $\mathrm{N} / 5 \mathrm{CaCl}_{2}$, (vii) Sat. $\mathrm{IgSO}_{4}$.

Put a few gelatine dises (not touching one another) into each dish, immersing them quickly and completely to avoid the adherence of air bubbles. After an hour's immersion some of the dises will have visibly swelled. Leave for 24 hours and examine against a black background. Measure and weigh. Which dise has swelled most? Arrange the electrolytes in a descending order as they have favoured imbibition. This is the so-called lytropic series. Instead of gelatine, 1 per cent. agar may be used. The lytropic series will be in the same order.

(e) Effect of Acid on Imbibition. Stretch a piece of catgut vertically between a weight and a weighted frog-heart lever so that weight and catgut lie in a tall cylinder. The lever may be made to mark a smoked rotating drum. Set the drum going very slowly and almost fill the cylinder with water. Note the changes. Now add sufficient hydrochloric acid to make the whole fluid 1-2 per cent. acid and note the result.

26. Shell Formation (Rhumbler). (1) Mix a little powdered glass with chloroform and set a drop of the mixture in water. The glass particles gather rapidly round the surface of the drop.

(2) Repeat the experiment, using fine silver sand dispersed through oil and finally dropped into 70 per cent. alcohol. The movements take place more slowly and the drop requires about three hours to attain equilibrium.

2\%. Adsorption. (1) Adsorption of Colloids to a Surface. Into a number of flasks place a spoonful or two $(2-3 \mathrm{gm}$.) of bone chareoal and pour into each, one of the following fluids. Shake vigorously and then pour into a large filter paper in a fumnel.

Liquids to try : Berlin blue, congo red, acid fuchsin (2-3 mg. per 100 c.c.).

To show that lowering S.T. sets free the colloid, add methylated spirit to funnel mixture and collect filtrate.

(2) Adsorption of Colloid to Colloid. Capillary Analysis. Cut a number of strips $2 \times 15 \mathrm{~cm}$. from a good filter paper. (Do not take the slip from too near the edge of the sheet.) Hang two or three of these strips so that each one dips its edge into a narrow-necked vessel (Erlenmeyer flask) containing a fluid to be tested, taking care that the papers are immersed to the same and to a sufficient depth (about $2 \mathrm{~cm}$.), and that glass and paper do not come in contact. Filter paper becomes negatively charged in contact with water, and therefore positively charged colloids will become " fixed " electrostatically at the liquid-paper interface. while negatively charged colloids will ascend with their dispersion inedia. (i) Flask i. Water. 
ii. Aqueous night blue or Prussian blue. iii. Aqueous alkali blue. In 10 to 15 minutes examine the height of water and cach dye on the strips.

(ii) Flask iv. Mixture of 20 c.c. 2 per cent. aqueous alizarin red and 0.5 c.c. sat. aqueous picric acid. Leave paper hanging in this mixture for 20-30 minutes. Remove and examine. Hold over strong ammonia for a moment to make alkaline (i.e. to redden the alizarin). How do you account for the extremely dark band at the junction of the stains of picric acid and picric-alizarin mixture.

(3) Adsorption of Salts to Colloids. Cut a series of dises 3-4 mm. thick from a fairly concentrated gelatine gel and place them in a Petri dish containing a 2 per cent. aqueous solution of commercial aluminium sulphate (contains iron) and leave for some days. In three days or so the gelatine becomes tinged reddish brown (ferric salts). Now test the original solution, the solution after standing with gelatine, and the gelatine itself for iron by adding a few drops of ammonium thiocyanate to each. Note the depth of colour.

28. An Acid Perfusate from an Alkaline Solution. Prepare some colloidal ferric hydrate either by dialysing 5 per cent. ferric chloride or by gradually adding 1 c.c."of 30 per cent. ferric chloride to 25 c.c. of boiling water. Put 10 to 15 c.c. of this sol into a dialysing thimble suspended in an Erlenmeyer flask, containing distilled water and some indicator (litmus or methyl red). Estimate the concentration of iron in the wash-water by abstracting, at each change of water, 10 c.c. of the fluid and adding $\mathrm{K}_{4} \mathrm{FeCy}_{6}$ solution. When the iron content becomes very small (after 48 hours) add some HCl to the colloid. Note the increase in the diffusibility of the Fe. How can you explain this? Why does an acid perfusate come from an electro-negative sol ?

29. Preparation of Colloidal Gold. (1) Protected Solution (Ostwald). To 100 c.c. of ordinary distilled water add a few drops of 1 per cent. neutral gold chloride. Mix and add a few drops of $0 \cdot 1$ per cent. tannic acid sol. Heat over a free flame till boiling, shaking it constantly. If the red colour does not appear on boiling add a little more tannic acid and a little more gold chloride alternately. Divide into two parts.

$A$. To one part, while still hot, add about an equal volume of water.

$B$. Cool the other part before diluting. $A$ is violet in colour while $B$ is cherry red. Blue gold sol. may be prepared from neutral $0 \cdot 05$ gold chloride. Take three portions of the gold chloride solution and add (i) 5-10 drops, (ii) 10-15 drops, and (iii) 15-20 drops respectively of a hydrazine hydrochloride solution prepared by adding a tiny crystal to about 20 c.c. of water. If (ii) does not turn blue add more hydrazine. If it is greenish, too much hydrazine has been added.

(2) Gold Sol for Colloidal Gold Test (p. 80). Heat 150 c.c. of triply distilled water (from a resistance glass still). Add 1 c.c. of 1 per cent. gold chloride solution and then 2.5 to 3 c.c. $\mathrm{N} / 5$ pure $\mathrm{K}_{2} \mathrm{CO}_{3}$. Bring to the boil, stirring vigorously. Add gradually but not too slowly, 2-3 c.c. of 1 per cent. commercial formaline (1 c.c. 40 per cent. formaline in 99 c.c. of water) and remove the flame. See that the sol (which should be ruby red without any purple tinge) is neutral to alizarin red and that a 5 c.c. sample of it is completely reduced in one hour by adding $1 \cdot 7$ c.c. of 1 per cent. $\mathrm{NaCl}$.

(3) Determination of the $C_{1 \mathrm{t}}$ of Colloidal Gold. Take a series of small test tubes of equal bore, etc., and range them in two equal rows. Into each 
tube put 1 c.c. of triply distilled water. To the first tube of one row add 1 c.c. of $\mathrm{N} / 50 \mathrm{HCl}$. Mix. Remove 1 c.c. of the mixture and add this to the second tube, and so on down the row. This will give a series of acid solutions as follows : $\mathrm{N} / 100, \mathrm{~N} / 200$, etc. The other series of tubes is treated in exactly the same way with $\mathrm{N} / 50 \mathrm{NaOH}$. The final 1 c.c. of each series is discarded. Two drops of alizarin red and 1 c.c. of the gold sol are added to each tube and the contents mixed. The tube showing the neutral alizarin colour is picked out and its value determined. The whole gold sol is now neutralised by the addition of the exact amount of $\mathrm{NaOH}$ or $\mathrm{HCl}$ as the case may be.

30. Protective Action of Emulsoids (p. 80). Two equal portions (9 c.c.) of neutral gold sol are treated (1) with 1 c.c. of a $0 \cdot 1$ per cent. gelatine sol and (2) with 1 c.c. of distilled water. To both are added 1 c.c. of $\mathrm{N} / 1 \mathrm{NaCl}$ solution. Examine by pure transmitted light, i.e. by looking through the tubes at a uniformly illuminated screen of white paper.

31. Diffusion of Electrolytes and Colloids into Gels. Two-thirds fill four test tubes with 3 per cent. gelatine and allow to gel. Add 1 per cent. solution of (1) $\mathrm{CuSO}_{4}$, (2) picric acid, (3) colloidal iron, (4) Congo red, one to each tube, and put aside for some days.

32. Electrical Diffusion (p. 79). Fit up a U-tube with an electrode of platinum- or silver-foil rolled cylindrically at the top of each tube. Fill the tube two-thirds full with 3 per cent. gelatine containing a trace of citric acid, and allow to stand overnight to form a gel. Fill one limb with coloured electrolyte (e.g. $\mathrm{CuSO}_{4}$ ), the other with acidulated water. Determine roughly the rate of diffusion ( 2 hours). Then pass a current through the tube (lighting supply with a lamp in circuit) and note rate of diffusion (2 hours). Reverse the direction of the current for 2 hours or more and note changes. Try various clectrolytes and find which are forced into the gel at the cathode and which at the anode.

33. Adsorptive Stratification. (Liesgang Phenomenon, p. 79). " 4 grams of gelatine are dispersed in 100 c.c. of water and 2 c.c. sat. potassium bichromate are added to the sol. The mixture is poured on clean glass plates to form a thin layer, about 0.45 c.c. per sq. ineh of surface being allowed. The plate is supported on a horizontal surface and the sol allowed to set; 10-15 minutes will be required. A large drop of 20-30 per cent. silver nitrate is placed in the centre of the plate, preferably by allowing five successive drops of about 0.1 c.c. each to fall on the same spot from a small pipette.

The drop should have a clean circular outline. The plate is kept in the dark for 24-48 hours. At the end of this period any traces of the original drop may be removed with a pointed strip of filter paper, and the gel is then allowed to dry. (1) Use commercial gelatine. (2) Do not disturb the plate after adding $\mathrm{AgNO}_{3}$, till excess has bcen removed. (3) $\mathrm{A}$ trace of citric acid (5-10 drops of 5 pér cent. solution to 100 c.c. of sol.) gives wider rings.

34. Electrophoresis (Fig. 10, p. 77, and letterpress, p. 78). The electrodes (Fig. 10) are two strips of platinum- or silver-foil fastened parallel to one another about $16 \mathrm{~mm}$. apart (Chatterton's compound is an excellent fixative). The slide is placed on a microscope with a paraboloid condenser (or with a small stop) and the lighting, etc., arranged to suit the particular type of condenser used. A large drop of the sol under examination is placed in 
the eentre of the space between the electrodes, making contact with them and covered with a $\frac{7}{8} \mathrm{in}$. glass. After 10 minutes the microseope is focussed on the central layer of liquid (partieles not in contaet with glass and free to move) and a current of 4-5 volts (keep amperage low) passed between the eleetrodes. Determine the sign of the electrie charge on chialysed iron sol, gold sol, night blue, alkali blue, ete. Fit an eyepiece micrometer and with a stop-watch determine the velocity of the particles in em. per volt per see.

35. Model to Illustrate some Phases of Urine Formation. (Fiseher and MacLaughlin.) Prepare some cups of sodium stearate by pouring the hot stearate solution (1/10 molar) into a mould consisting of one beaker (120 c.c.) suspended within another similarly shaped (350 c.e.). A cup is supported on a filtration disc in a filter funnel whose stem enters the mouth of a graduated cylinder. Another cylinder (gas jar) or bottle inverted may be used as a constant level device. Fill the eup and the gas jar with the solution. Invert the full jar and suspend it vertieally so that its mouth just dips below the surface of the fluid in the eup. From time to time measure the fluid in the lower graduated eylinder, say every hour.

Try the following solutions: (a) water (3-6 hrs.), (b) molar sodium oleate (24 hrs.), (c) $\mathrm{NaCl} 1 / 8 \mathrm{~m} ., 1 / 4 \mathrm{~m}$., and 1/1 m. (3-6 hrs.), (d) 1/8 m. $\mathrm{CaCl}_{2}$ (1-4 hrs.), (e) $1 / 8 \mathrm{~m} . \mathrm{NH}_{4} \mathrm{Cl}$ (7 hrs.).

Note increased flow with $(c)$ and $(d)$; initial increase and final deerease of flow with $(e)$ and total inhibition with $(b)$. Test, in each ease, the perfusion fluid, the perfusate and the cup, with phenolphthalein. How do you aeeount for your results? Test the perfusates for fatty acids. Why does pure water dissolve out more of the aeid than do the salt solutions?

36. Mimicry of Cell Structure (Herrera after Harting). A erystallising dish $18 \mathrm{em}$. in diameter is filled with eolloidal siliea. This may readily be prepared by dissolving freshly precipitated gelatinous siliea in a solution of ammonia (density $26^{\circ}$ ). Siliea is added till all the ammonia has been driven off and the eolloid has a density of over 1.032 (i.e. $3-5$ per eent. solid siliea). (A solution of sodium silicate of a density of 1.020 may be used instead of colloidal silica.) At one edge of the erystallising dish plaee 10-20 mgrms. of rcerystallised potassium bifluoride. At the diametrieally opposite side of the dish plaee 5 gms. pure powdered anhydrous ealeium ehloride. Cover and keep at $20^{\circ} \mathrm{C}$. for 24 hours. Various structures which may be stained by any of the dyes used by histologists may be seen, e.g. nueleated amoebae, eells undergoing division, nuelear spiremes, granular and honeyeomb struetures, ete.

The figures are due to the strains produeed in the silieate by the simultaneous formation of a colloid, calcium silicate and a crystalloid, caleium fluoride. Silica, eoagulated by a crystalloid, gives rise to a semipermeable membrane, whieh, if it forms a sae round a erystalloid, may set up endosmosis. Slow amoeboid movements may be shown by some of the eomplexes lying near the point of insertion of the $\mathrm{CaCl}_{2}$. Add a trace of aleohol over the $\mathrm{CaCl}_{2}$, and more rapid diffusion ensues.

3\%. Emulsions. 1. Take four test tubes and place in each 10 e.e. of olive oil. In addition add to $(a)$ a few drops of oleic aeid and a drop of aleoholic $\mathrm{NaOH}$; to $(b)$ some (soft) soap solution; to $(c)$ a few drops of oleic acid and about the same quantity of eonc. $\mathrm{Ca}(\mathrm{OH})_{2}$ solution and allow to stand. Which gives the best emulsions? 
2. To determine the optimum concentration of colloid for the stabilisation of an emulsion. Into each of three mortars introduce 20 c.c. of water, (a) containing 1.25 per cent. of commercial soft soap, (b) 1.875 per cent. and (c) 2.5 per cent. To each slowly add 120 c.c. of, say, cottonseed oil, stirring regularly but not too vigorously meanwhile. If possible, put on a mechanical shaker for $\frac{1}{2}$ hour. Pour into tall cylinders and allow to stand for some days.

3. Effect of concentration of oil on rigulity. Stir into four lots of 25 c.c. of 25 per cent. soft soap in mortars, (a) 50 c.c., (b) 100 c.c., (c) 200 c.c., (d) 400-500 c.c. of cottonseed oil. Place in shallow dishes. Note rigidity. What happens when the optimum concentration of oil has been prassed.

4. Divide an emulsion of oil in water (soap), (i.e. 120 c.c. oil in 20 c.c. 7 per cent. soft soap) into nine portions. No. (1) will serve as control. To the others add a few drops of one of the following $\mathrm{N}$ solutions, (ii) $\mathrm{HCl}$, (iii) $\mathrm{NaOH}$, (iv) $\mathrm{Ca}(\mathrm{OH})_{2}$, (v) $\mathrm{CaCl}_{2}$, (vi) $\mathrm{NaCl}$, (vii) Alcohol, (viii) $\mathrm{CHCl}_{3}$, (ix) Ether.

5. Instead of soap any hydrophilic colloid nna be nsed, e.g. albumin, casein, acacia, dextrin, starch. The carbohydrate-stabilised emulsions are the hardest to break.

6. To 5 grams of dry easein in each of three mortars add slowly (a) 50 c.c. $\mathrm{N} / 20 \mathrm{NaOH},(b) 50$ c.c. water and to $(c) 50$ c.c. $\mathrm{N} / 20 \mathrm{HCl}$. Allow to stand overnight and then slowly stir 75 c.c. of cottonseed oil into each. Pour into clear jars and allow to stand. Why does $(b)$ separate out?

38. Model of Mucoid Secretion. (Fischer.) Grind up in a mortar a small quantity of gum acacia and one or two c.c. of cottonseed oil. Put a drop of this mixture on a microscope slide with cover glass and cxamine. Place a drop of water at the edge of the cover slip and note what happens when it touches the oil layer.

39. Comparison of the Electrical Conductivity of Equimolecular Solutions of Mineral and Organic Acids. Conductivity being the reciprocal of resistance, obviously can be measured by a resistance method, e.g. by the

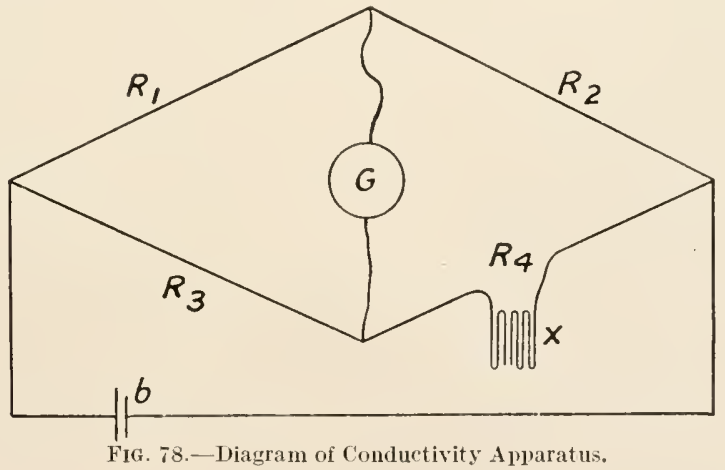

Wheatstone bridge (Fig. 78). The current from $b$ is divided between two circuits (1) by $R_{1}$ and $R_{2}$ and (2) by $R_{3}$ and $R_{4}$ (where $R=$ resistance in ohms). The amount of current travelling by these circuits is such that the drop of potential in both is the same. If then a lead be taken from the junction between $R_{1}$ and $R_{2}$ and connection made with the $R_{3}, R_{4}$ route 
so that $R_{1} / R_{2}=R_{3} / R_{4}$, then no eurrent will flow through the lead as shown by the indicator $(G)$, a galvanometer, lamp, telephone reeeiver, etc. Thus $R_{1}, R_{2}$ and $R_{3}$ being known, $R_{4}$ can be found. In praetice, the lead fixed between $R_{3}$ and $R_{4}$ terminates in a joekey-piece which slides along a platinum, iridium, or nickelin wire of uniform resistance and a metre long, eonstituting $R_{1}, R_{2}$. The length of $R_{1}$ is read from an underlying scale when $G$ indicates that no eurrent is passing.

Owing to polarisation oeeurring at the electrodes when a steady current is passed through an electrolyte, it is neeessary to employ an alternating eurrent which renders a galvanometer useless as an indicator. The alternating eurrent is usually got from the secondary terminals of an induction coil. As an indieator, one may use a telephone receiver or a small A.C. pea lamp.

Expt. (a). Rough Demonstration. Fit up a Wheatstone bridge, using a 4-volt aceumulator with switch as $b$, and a pea lamp as $G . \quad R_{3}$ is a resistance box and $R_{4}$ or $x$ is a simple type of conductivity eell, $e . g$. a beaker containing the solution to be tested with two sheet-silver electrodes. Find the point on the metre wire when the light from the lamp is at its minimum $=x$. Then eonduetanee

$$
c=\frac{x}{P_{3}(100-x)},
$$

and the moleeular eonductivity is equal to $C \phi$, where $\phi$ is the volume in e.e. in which 1 mole is dissolved. Suitable solutions $=1 / 16$ molar hydrochloric, aeetic, and benzoie aeids ; $1 / 8$ molar $\mathrm{NaCl}$ and glueose. (N.B.Keep the switch from $b$ open as much as possible to prevent polarisation of the eleetrodes of $x$.)

(b) With the same apparatus the neutral point of a titration may be determined. Plaee 20 e.e. of $\mathrm{N} / 50 \mathrm{NaOH}$ in the eonductivity cell and arrange the resistance box $\left(R_{\mathrm{n}}\right)$ so that the bridge reading is about $50 \mathrm{~cm}$. From a burette run in a standard $(\mathrm{N} / 50)$ solution of $\mathrm{H}_{2} \mathrm{SO}_{4}$ and mix as in titration, determining the point of balance on the wire after eaeh addition. It will be found that the balance point will first tend towards the zero end of the scale and later will move in the reverse direction. The point at whieh it changes direction is the eleetrotitrametrie neutral.

For any but very rough readings, many precautions have to be observed. These will be found in any book on practical physical ehemistry. Instead of a lamp, the eapillary electrometer may be used as an indicator.

40. (i) Buffer Solution. Sørensen. (a) $\mathrm{M} / 15$ solution of $\mathrm{KH}_{2} \mathrm{PO}_{4}$ (9.078 grams per litre). The salt should be ehemieally pure, and its solution should be water clear and free from even traees of ehloride and sulphate.

(b) $\mathrm{M} / 15$ solution of $\mathrm{Na}_{2} \mathrm{HPO}_{4} \cdot 2 \mathrm{H}_{2} \mathrm{O}$ (11-876 grams per litre). The salt is prepared by exposing to the air the recrystallised $\mathrm{Na}_{2} \mathrm{HPO}_{4} \cdot 12 \mathrm{H}_{2} \mathrm{O}$. Ifter two weeks' exposure on a porous plate, dissolve the salt in water and test for chloride and sulphate. 8 c.e. of $(a) \mathrm{KH}_{2} \mathrm{PO}_{4}+2$ e.e. of $(b) \mathrm{Na}_{2} \mathrm{HPO}_{4}$ $2 \mathrm{H}_{2} \mathrm{O}$ gives a solution of $p \mathrm{H} 7 \cdot 381$.

(i) To demonstrate the acid-combining power of a "buffered" solution. Take 50 e.e. of the above mixture or prepare a solution containing about 0.25 per cent. sodium bicarbonate. Place this in a tall cylinder and in another similar vessel place the same quantity of water. Add about 20 drops of neutral red (0.05 per cent. in alcohol) to each. Add N/10 NaOH 
to the water till it has approximately the same $p \mathrm{H}$ as the bicarbonate. Titrate both with $\mathrm{N} / 50 \mathrm{HCl}$ to the same end point.

(ii) To demonstrate the effect of the tension of $\mathrm{CO}_{2}$ on the $p \mathrm{H}$ of a solution of bicarbonate. Put 5 c.c. of a 0.25 per cent. solution of $\mathrm{NaHCO}_{3}$ in each of three tall stoppered cylinders. To each add 2 drops of neutral red. Fill $(a)$ with air expired after a deep inspiration, $(b)$ with alveolar air (Expt. $43)$ and $(c)$ with $\mathrm{CO}_{2}$ from a generator or cylinder. Stopper and shake. Note colours. Remove the $\mathrm{CO}_{2}$ in $(c)$ by repeated changes of atmospheric air. Note that the colour goes back from crimson through the red of $(b)$ to the orange of $(a)$ or even to the yellow seen before any $\mathrm{CO}_{2}$ was added.

41. An Approximate Determination of the Alkali Reserve of Blood. (Rieger.) Principle. Erythrocytes are easily damaged by acid. This will lead to agglutination and haemolysis on the addition of acid as soon as the reserve of base has been used up.

Method. Twelve test tubes $\left(8^{\prime \prime} \times 1^{\prime \prime}\right.$ or thereabout) cleansed thoroughly and dried are set in a rack. The first or stock tube is charged with 18 c.c. of a 0.85 per cent. solution of $\mathrm{NaCl}$ (pure salt in distilled water) and 2 c.c. of whole blood (oxalated with 0.2 per cent. pure sodium oxalate). Mix thoroughly by drawing up into the pipette several times, keeping the tip of the pipette always below the surface of the liquid.

One c.c. of the diluted blood is placed in the bottom of each tube, avoiding the sides, and then, starting on the left, $\mathrm{N} / 100 \mathrm{HCl}$ is added from a graduated pipette. The first is given 0.7 c.c. acid, the next 0.75 and so on, increasing the amount by 0.05 c.c. with each tube, the last tube thus receiving 1.20 c.c. In about an hour examine the tubes. Those on the left should show no haemolysis and the corpuscles should be settled in a sharply defined clump in the centre of the foot of the tube. The tube on the right may show haemolysis and have corpuscles scattered over the bottom in an irregular manner, giving a speckled appearance. The tube with the greatest anount of acid which shows no haemolysis or scattering of corpuscles gives an indication of the alkali reserve of the blood.

For example: Normal blood-the first seven tubes (i.e. 0.7-1 c.c.) are clear, tube 8 shows scattering and slight haemolysis. Therefore $0 \cdot 1$ c.c. of blood can neutralise 1 c.c. of N/100 acid, or 100 c.c. of blood contains base equivalent to 0.42 grams $\mathrm{NaHCO}_{3}$. This would, in Van Slyke's apparatus, give rise to 112 c.c. of " bound " $\mathrm{CO}_{2}-\mathrm{a}$ somewhat high result (see 42 and 43), probably due to interaction of acid and protein.

42. Alkali Reserve. (C. J. Martin.) Principle. Dilution of a wellbuffered solution such as plasma does not alter its $C_{\mathrm{H}}$. If an indicator is used which has a low protein error the plasma may be titrated with acid. The titration value indicates the acid-combining power of the plasma.

Apparatus. A small wooden stand to hold three "non-sol" glass test tubes $(8 \times 0.8 \mathrm{~cm}$.) vertically in a row and close together. The central tube at its upper end runs through the rubber stopper of an inverted "non-sol" flask (100-150 c.c.).

Method. The flask is removed from the central tube and 0.5 c.c. of plasma or serum and 2 c.c. of neutral 0.9 per cent. sodium chloride added. The side tubes are almost filled with a phosphate buffer mixture of $p H=7 \cdot 4$. These standard tubes are coloured by the addition of a drop of two aqueous solutions of burnt sugar and flavine $(1 / 100,000)$ till they match the fluid in the central tube. To all of the tubes are then added 2 drops of 0.05 per 
cent. (alcoholic) neutral red. The optical effect of the turbidity of the plasma may be counteracted by placing a sheet of white tissue paper behind the tubes. The plasma mixture is titrated with $\mathrm{N} / 50 \mathrm{HCl}$ ( 2 c.c. burette with fine nose) till its colour matches the standards. This is done by running the plasma into the flask, adding a few drops of acid and rotating gently but steadily for 1 minute, the flask meanwhile being in communication with the air. This readily allows the thin film of plasma to give up the liberated $\mathrm{CO}_{2}$. The fluid is run back into the tube and compared with the standards. The process is repeated as often as necessary. Rotation for at least 1 minute is necessary after each addition of acid.

Titration value for 0.5 c.c. plasma $=0.77$ c.c. $\mathrm{N} / 50 \mathrm{HCl}$, i.e. Alkali reserve of $, \quad, \quad=0.77$ c.c. $\mathrm{N} / 50 \mathrm{NaHCO}$

$$
\begin{aligned}
& \text { " " } 100 \text { c.c. , } \quad \begin{aligned}
& =154 \text { c.c. , " } \\
& =3.08 \mathrm{~N}
\end{aligned} \\
& \begin{array}{l}
=3.08 \mathrm{~N} \\
=3.08 \times 22.4 \text { " c.c. } \mathrm{CO}_{2},
\end{array}
\end{aligned}
$$

i.e. 68.99 volumes per cent. of $\mathrm{CO}_{2}$ are bound as bicarbonate in the plasma.

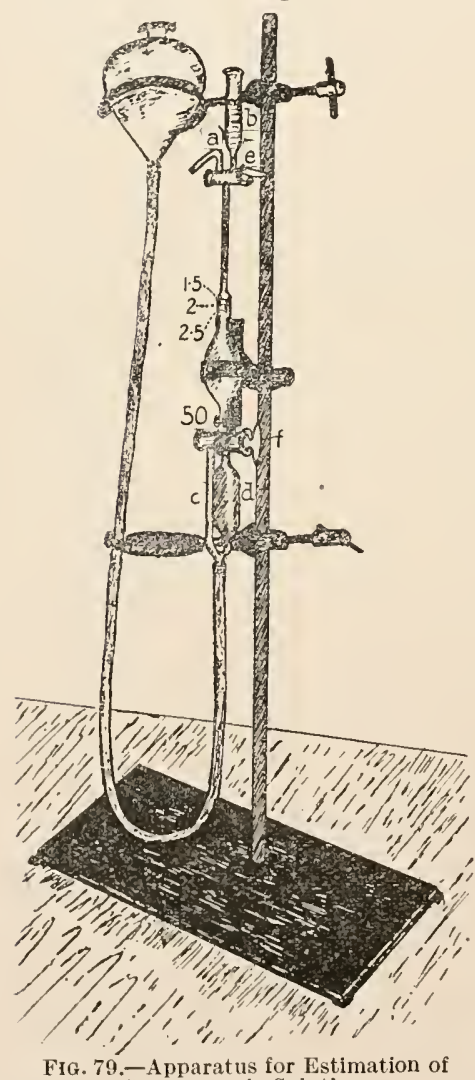

Fig. 79.-Apparatus for Estimatic

A sharper end-point is obtained by the use of phenol sulphonephthalein as indicator. In this case the standard phosphate solutions are made of $\mathrm{pH} 7 \cdot 2$ to correct the protein error.

43. Alkali Reserve by Van Slyke's Method. The Van Slyke apparatus is illustrated in Fig. 79. It consists essentially of a 50 c.c. pipette with three-way stopcocks ( $e$ and $f$ ) at top and bottom, and a 1 c.c. scale on the upper stem, divided into 0.02 c.c. divisions. The body of the apparatus is connected through heavy walled rubber tubing with a levelling bulb filled with mercury. The whole apparatus is supported on a stand so that, without unclamping, the pipette may be rotated round a central axis. The stopcocks are lubricated with a rubber-vaseline mixture and may be held in place by strong rubber bands.

Preliminary preparation. Open taps $e$ and $f$ and fill the entire apparatus with mercury by raising the levelling bulb, allowing some mercury to run into $a$ and into $b$. Shut $e$, and lower the levelling bulb till the mercury falls half-way down $c$ and $d$. The bulb is then slowly raised. If the apparatus is gas-free, a sharp click will be heard when the mercury strikes the upper stopcock. If a gas cushion is present, open $e$, and force the gas out, and repeat the evacuation process, opening $f$ alternately to $c$ and $d$.

Determination. (1) Solutions required. It is convenient to have four 
dropping bottles with ground in pipettes and rubber teats containing (a) 5 per cent. $\mathrm{H}_{2} \mathrm{SO}_{4},(b) 1$ per cent. carbonate-free $\mathrm{NH}_{3}$ water, (c) caprylic alcohol and $(d)$ distilled water. The carbonate-free ammonia is prepared by adding a small amount of sat. barium hydrate solution to ordinary ammonia solution. The barium carbonate is filtered off, and the excess of barium remaining is precipitated with a little $\left(\mathrm{NH}_{4}\right)_{2} \mathrm{SO}_{4}$.

(2) Plasma. An ordinary centrifuge tube is fitted out with rubber cork and glass tubes just like a wash-bottle. The longer tube bears at its upper end a hypodermic needle. The whole apparatus - glass, tubes and needleis washed out with a saturated solution of neutral potassium oxalate. (Van Slyke and Cullen point out that it is desirable that the subject should avoid vigorous muscular exertion for at least an hour before the blood is drawn. It is also best to avoid stasis, or when stasis is unavoidable the ligature should be released as soon as the vein is entered. In this case, the first sample of blood should be neglected.) The blood should run into the tube without suction. By a gentle rotary motion, mix the blood with the finely crystallised oxalate left adhering to the walls of the vessel, and centrifuge at once. The plasma is then transferred to sampling tubes (Fig. 80),

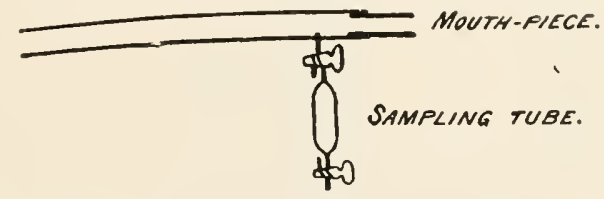

Fig. 80.-Alveolar Air Collecting 'Tube.

3-4 c.c. of plasma to each tube. These tubes (300 c.c.), or separating funnels of the same capacity, are filled with alveolar air (of the subject, if possible). This may be done by holding the tube horizontally, opening both taps and, without inspiring more deeply than normal, expire as quickly and as completely as possible through the tube, closing the further tap just before the expiration is finished. A bottle containing large glass beads must be interposed between mouth and funnel in order to prevent dilution of the plasma by condensation of vapour from the breath. With both taps closed, the funnel is rotated (not shaken) so that the plasma forms a thin layer over the walls, and so readily comes into equilibrium as regards $\mathrm{CO}_{2}$ tension with the alveolar air.

(3) Procedure. The apparatus is entirely filled with mercury, including the two capillaries ( $a$ and stem of $b$ ) at the top. The cup $b$ is washed with $\mathrm{CO}_{2}$-free $\mathrm{NH}_{3}$. 1 c.c. of plasma is run into the cup from an Ostwald-Folin pipette, keeping the tip of the pipette immersed in the fluid. Placing the mercury reservoir in the second ring (Fig. 79) and with cock $f$ open to $d$, open $e$ and admit the plasma to the pipette, leaving sufficient in $b$ to fill the capillary. Wash the cup twice into the pipette using about 0.5 c.c. of water each time, adding a very small quantity of caprylic acid to the second wash water. Finally run in 0.5 c.c. of 5 per cent. $\mathrm{H}_{2} \mathrm{SO}_{4}$ and seal the capillary with mercury. The fluid must come to the 2.5 c.c. mark. Wash out the cup with water and then with carbonate-free ammonia till acid-free. The mercury bulb is now taken to a position (about $80 \mathrm{~cm}$. below the second ring) so that a Torricellian vacuum is formed in the gas pipette. Allow the mercury to run down almost to (but not below) the 
50 c.c. mark. Close $f$ and replace the bulb on the upper ring. Slacken the milled head of the serew that controls the central swivel. Holding the pipette at the bulb with the right hand and gathering up the loose rubber tubing with the left, rotate the bulb through $180^{\circ}$ some 15 times. Set vertically and tighten the milled head. Lower reservoir and, with $f$ open to $d$, rapidly empty the water solution into $d$ without however allowing any of the gas to follow it. Now open $f$ to $c$ and, by raising the reservoir, fill the body of the pipette with clean mercury. Hold the reservoir in such a position that pressure inside the reservoir is atmospheric and rapidly take a reading. If thought desirable, re-extraction may be carried out.

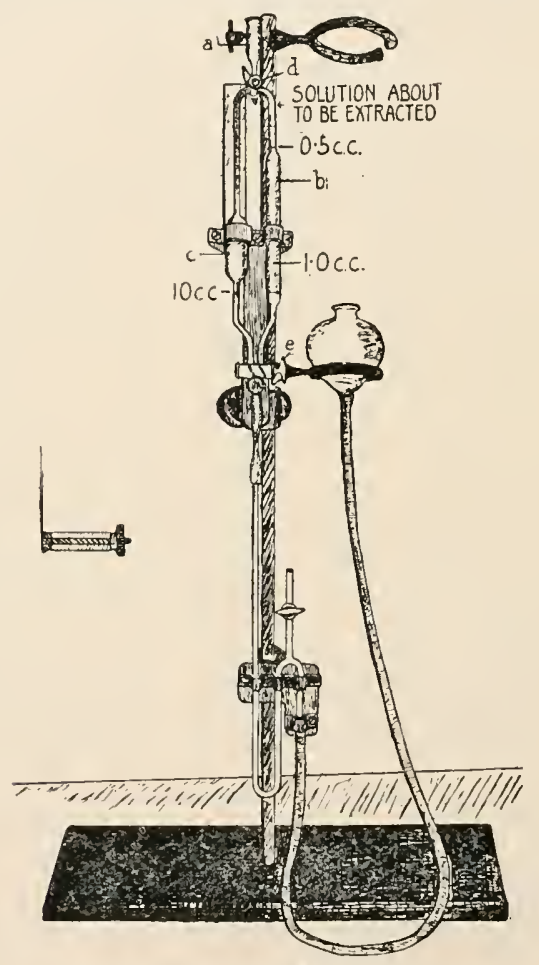

FIG. 81.-Van Slyke Micro Apparatus.

Cleaning. Lower the reservoir and run most of the mereury back through $c$. Open $f$ to $d$ and, by raising the reservoir, run the water back into the pipette. Open $e$ to $a$ and force the fluid out into a collecting jar. The apparatus is now ready for another determination.

Micro apparatus (Fig. 81). This apparatus is easier to manipulate, and as water, etc., never cnters the gas pipette, it is easily kcpt clean. The different parts are in the same relative proportions as the corresponding parts of the larger apparatus. Each division of 0.002 c.c. on the smaller corresponds to 0.01 c.c. on the larger.

(1) It is advisable to mark the course of the canals with pencil on the butt end of the tap $d$. 
(2) No froth preventer is necessary or advisable. It merely acts on the tap lubricant.

(3) All quantities are reduced to $1 / 5$ of those given above, e.g. 0.2 c.c. plasma, $0 \cdot 1$ c.c. water, and 0.1 c.c. acid. In all, exactly 0.5 c.c. of fluid is used.

Calculation of Results.

TABLE LXXXI.

Table for Calculation of $\mathrm{CO}_{2}$-Combining Power of Plasma (from Van Slyke and Cullen).

\begin{tabular}{|c|c|c|}
\hline \multirow{2}{*}{ Observed Vol. $\times \frac{B}{760}$. } & \multicolumn{2}{|c|}{$\begin{array}{l}\text { C.c. of } \mathrm{CO}_{2} \text { Reduced to N.T.P. bound as } \\
\text { Bicarbonate by } 100 \text { c.c. of plasma. }\end{array}$} \\
\hline & $15^{\circ} \mathrm{C}$ & $20^{\circ} \mathrm{C}$ \\
\hline $0 \cdot 2$ & $9 \cdot 1$ & $9 \cdot 9$ \\
\hline $0 \cdot 3$ & $18 \cdot 8$ & $19 \cdot 5$ \\
\hline $0 \cdot 4$ & $28 \cdot 4$ & $29 \cdot 0$ \\
\hline 0.5 & $38 \cdot 1$ & $38 \cdot 5$ \\
\hline $0 \cdot 6$ & $47 \cdot 6$ & $48 \cdot 1$ \\
\hline $0 \cdot 7$ & $57 \cdot 4$ & $57 \cdot 6$ \\
\hline $0 \cdot 8$ & $67 \cdot 1$ & $67 \cdot 2$ \\
\hline $0 \cdot 9$ & $76 \cdot 8$ & $76 \cdot 7$ \\
\hline $1 \cdot 0$ & 86.5 & $86 \cdot 2$ \\
\hline
\end{tabular}

Intermediate values may be obtained by interpolation.

$B=$ observed barometric pressure.

Normal range-adult 53-77 c.c., infants about 10 per cent. lower.

44. Alterations of the Surface Tensions of Oil-Water Interface by Alterations in Hydrogen Ion Concentration (Hartridge and Peters, Jour. Physiol. LIV., Proc. XLI.). Oil free from fatty acids or soaps is essential. Pure olive oil, castor oil, or cod-liver oil may be freed from these bodies by boiling for a number of hours with frequent changes of a considerable excess of tap water. A series of test tubes $6 \times 5 / 8^{\prime \prime}$ each receives 5 -10 c.c. of the treated oil. Into each is put a capillary tube 4 " long, open at both ends. The test tube is almost filled with the fluid to be tested. Try solutiong having a $p \mathrm{H}$ of $9,8,7,6$. Measure the height to which the oil rises in the capillary.

45. Principle of Measurement of $\mathbf{H}$-ion Concentration by Potentiometer. The principle is much the same as that of the conductivity measurements (Fig. 78), only instead of having a single source of potential and an unknown resistance, one has known resistances and two sources of E.M.F., one of which is of unknown value.

In Fig. 78, $b$ may be taken as a cell of standard E.M.F. sending its current through the wire bridge $R_{1}-R_{2}$. If we lead into $R_{1}-R_{2}$ the wires from another battery $x$, taking care that the direction of the difference of potential is the same, e.g. both negative poles leading to $R_{1}$, as the fall of potential along $R_{1}-R_{2}$ is regular, we can readily divide the wire so that the difference of potential between the point of entrance and exit of the current from $x$ is equal and opposite to the difference of potential betwcen the same points caused by the standard cell, i.e. the galvanometer or electrometer will 
indicate no E.P.D. The cell $x$ is of interest. It consists of two half cells or electrodes. One of these is the ordinary standard calomel clectrode, i.e. an electrode of mercury covered with $\mathrm{HgCl}$ in the presence of a definite concentration of $\mathrm{KCl}$. The other half cell is a hydrogen electrode, i.e. platinum black laden with hydrogen and immersed in a solution containing H-ions. The difference of E.M.F. between electrode and solution depends on the concentration of $\mathrm{H}$-ions in the latter.

The difference of potential between the calomel and normal hydrogen electrode can be ascertained. This value is subtracted from the total E.M.F. of the cell to give a value from which the $p \mathrm{H}$ may be calculated.

46. Determination of the Relative Viscosity of Blood (see expt. 24). Blood may be taken from the lobe of the car or from the finger. The skin is thoroughly cleansed with ether and pricked with a fine pointed lancet.

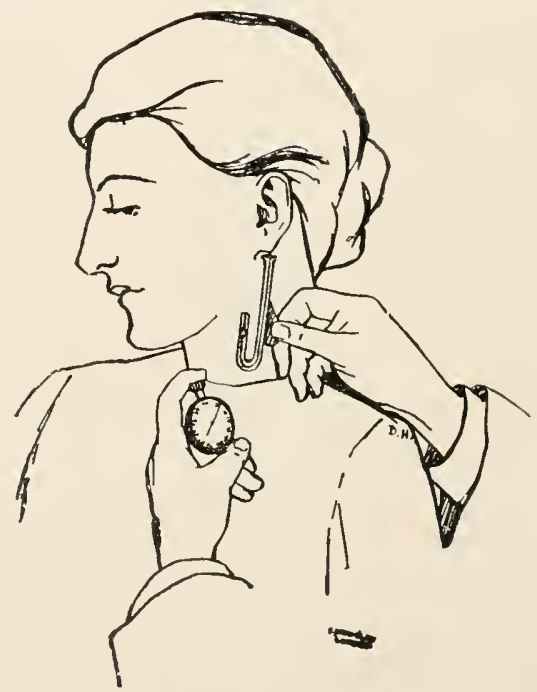

Fit. 82.-Denning-Watson Clinical Viscosimeter (Hawtsley).

The viscosimeter (at body temperature) is held vertically under the bleeding spot and the receiver filled (Fig. 82). Measure as in expt. 24.

Immediately after an observation, the blood should be driven out by a blast from an inflator attached by rubber tubing to the short arm of the capillary.

It is advisable to make a blood count at the same time (p. 242).

4\%. Haematocrite. This apparatus consists of two similar graduated capillary tubes, which, after clipping in a holder, may be spun horizontally by a centrifuge. A small measured quantity of Müller's fluid ( $\mathrm{Na}_{2} \mathrm{SO}_{4}-1 \mathrm{gm}$. ; $\mathrm{K}_{2} \mathrm{Cr}_{2} \mathrm{O}_{7}-2 \mathrm{gm}$. ; distilled water, $100 \mathrm{gm}$.) is placed in a test glass. The same quantity of blood is added. Mix thoroughly with a glass rod. Fix a short length of rubber tubing furnished with a mouthpiece to cach of the graduated tubes and suck up sufficient of the mixture to fill the tubes. Place them in a holder and spin for 5-7 minutes with a velocity of 8000 revs. per minute. Read off the relative length of the column of corpuscles. As the glass walls of the 
tubes are thick, it is advisable to aid the eye by looking along a glass plate held at right angles to the tube. The tubes have a bore of one square $\mathrm{mm}$. and are divided into 100 equal parts. The reading multiplied by 2 will give the volume of corpuscles in 100 parts of blood. The function of the Müller's fluid is to retard clotting and to fix the red corpuscles in their natural size.

48. Blood Pressure Model. (a) General distribution. Examine the schema (Fig. 83) of the circulation given you and identify the parts representing arteries, capillaries and veins. Disconnect the rubber ball $I I$ and the two Bunsen valves $V, V$. Attach the arterial tube $A$ to the water supply and lead the tube from $G$ to the sink. Cautiously turn on the water and measure the pressure in the arteries (at $B$ ), and in the veins (at $E$ ). ( $\mathrm{It}$ is more economical to have single vertical tubes at $B$ and $E$, the pressures read off in $\mathrm{mm}$. of water may be calculated in $\mathrm{mm}$. of mercury.)

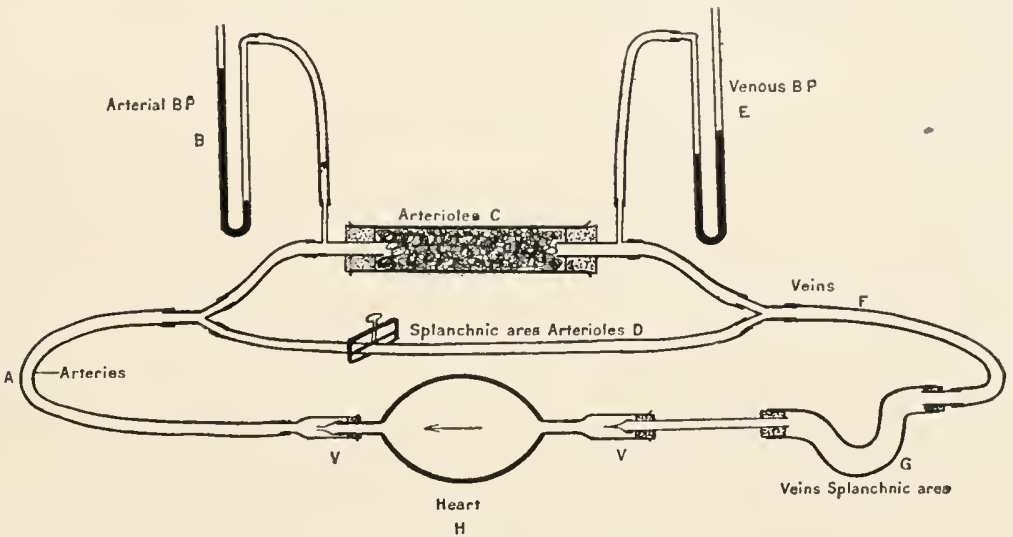

Fig. 83.--Schema of the Circulation.

Note the effect of $(a)$ varying the force of inflow by manipulation of the water tap, (b) varying the resistance to flow by tightening the chip at $D$. With a steady pressure over its whole length, compress $G$ and note alteration in manometer levels.

(b) Pulse. Fill with water and replace $H$ and $V-V$ in circuit. Gently compress and relax $H$ at regular rhythmic intervals of about a second. Note the effect of this upon the arterial and venous pressures. Study the further effect of constricting $D$.

(c) Place a finger on $A$ and note the expansion with each contraction of $H$. Study the same thing on $D$ and on $F$.

49. (a) Conduction of Sound Waves by the Cranial Bones. Place a vibrating tuning fork in the region of the interparietal suture. From where does the sound apparently come? Place the tip of the finger into the auditory meatus of one ear and then block both ears. Explain.

(b) Binaural Localisation of Sound. With the eyes closed listen to the ticking of a watch through a binaural stethoscope. Pinch one of the tubes to prevent transmission of sound to one ear. Release and repeat with other tube.

50. Vowel Sounds by Percussion. Place the mouth in the position necessary for the pronunciation of the various vowels and then percuss 
over the eheek (Fig. 70). Now shift the point of pereussion to a position over the pharynx just behind the angle of the jaw and percuss again. Note that the "cheek notes" rise as one passes from $\mathrm{U}-\mathrm{O}-\mathrm{A}-\mathrm{E}-\mathrm{I}$, while the "pharynx notes" rise $\mathrm{U}-\mathrm{O}-\mathrm{A}$ and fall to $\mathrm{E}$ and $\mathrm{I}$. This demonstrates the double nature of the mouth eavity in producing $\mathbf{E}$ and I.

51. Prepare a series of bladders filled completely with $(a)$ air, $(b)$ water and $(c)$ some viscous fluid like syrup and $(d)$ lard. Pereuss and palpate eaeh.

52. Demonstration of the effect of colour on the absorption of radiant energy (L. Hill). Two similar pieees of cotton tape, one white and the other black, are suspended so that the end of each dips in a graduated eylinder filled with water. Place first in the shade and measure the amount of water evaporated from each cylinder during a period of 30 minutes. Refill with water to the same level and repeat the experiment in direct sunlight.

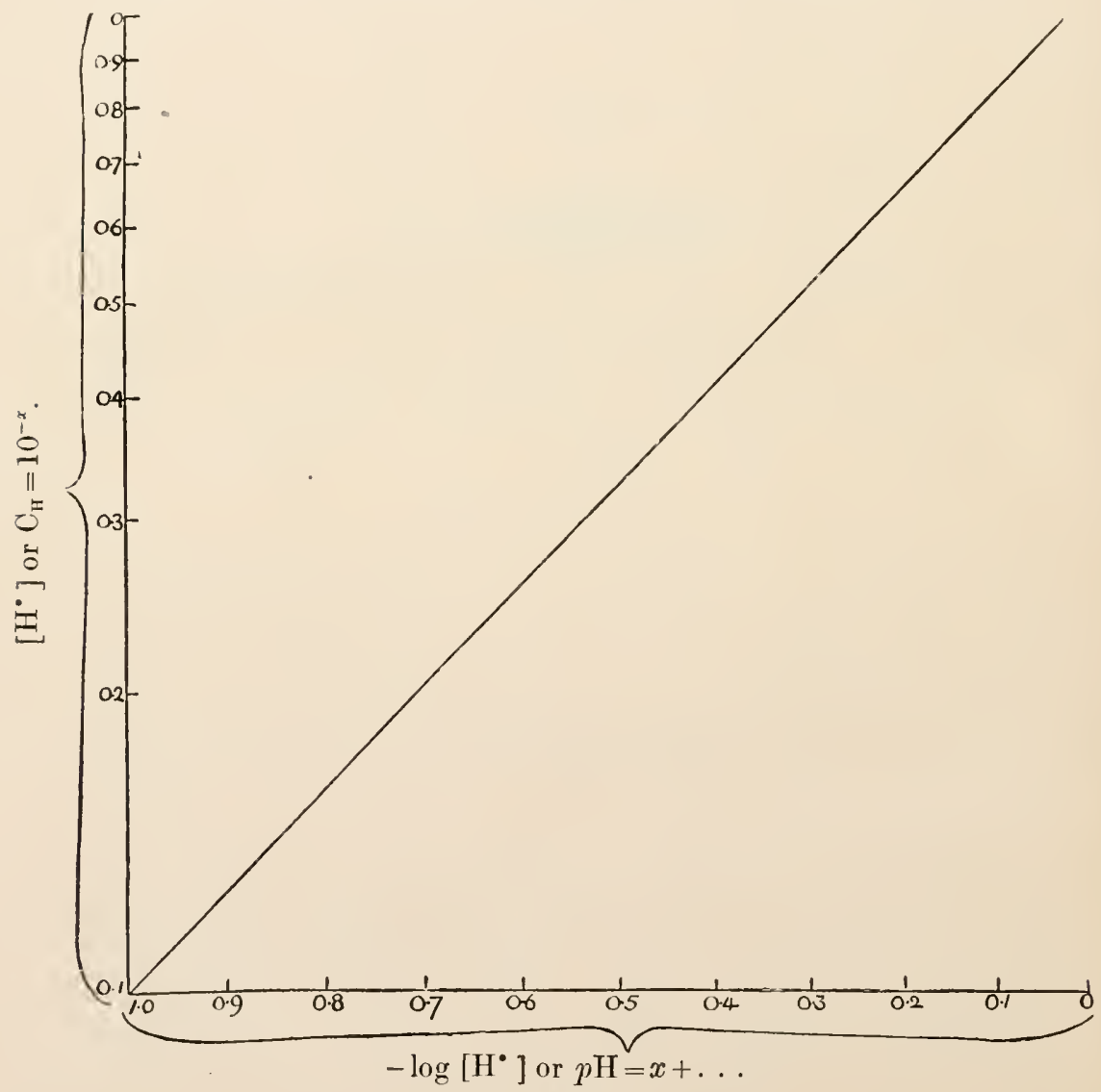

Fia. 84.-Graph for Conversion of $p \mathrm{H}$ to $\mathrm{C}_{\mathrm{H}}$.

Graphic Conversion of S $\varnothing$ rensen's $p \mathrm{H}\left(-\log \left(\mathrm{H}^{\circ}\right)\right)$ into Concentrations of Hydrogen Ions and the reverse (Roaf, Journ. of Physiol.). Fig. 84 is a graph 
whereby the logarithmic notation of Surensen can be converted at sight into true concentrations. It would be advisable to redraw the figure on semi-logarithmic paper and so enable the reading to be taken to two places of decimals. For example, to convert $p \mathrm{H} 6.7$ into $\mathrm{C}_{\mathrm{H}}, p \mathrm{H}=6$ is $\mathrm{C}_{\mathrm{II}}=10^{-6} ; 0.7$ cuts the diagonal line opposite 0.2 ; therefore

$$
p \mathrm{H} \text { of } 6 \cdot 7=\mathrm{C}_{\mathrm{H}} \text { of } 0 \cdot 2 \times 10^{-6} \text {. }
$$

Estimation of the Surface Area of the Body. Rubner announced that the amount of heat produced by an animal is proportional to its superficial area. This law of surface area has rendered necessary the accurate determination of the skin surface in most metabolism experiments.

Since the surface of a figure varies as the square, and that of volume as the cube of its linear dimensions, it follows that

$$
S=K \sqrt[3]{V^{2}}
$$

where $S=$ surface, $V=$ volume and $K=$ constant, or, as weight $(W$ ) varies directly as volume,

$$
S=K \sqrt[3]{W^{2}}
$$

Meeh, from sixteen experiments, suggested that $K$ should adults; and Lissauer used the value $10 \cdot 3$ for children. The average error of this calculation is about 16 per cent.

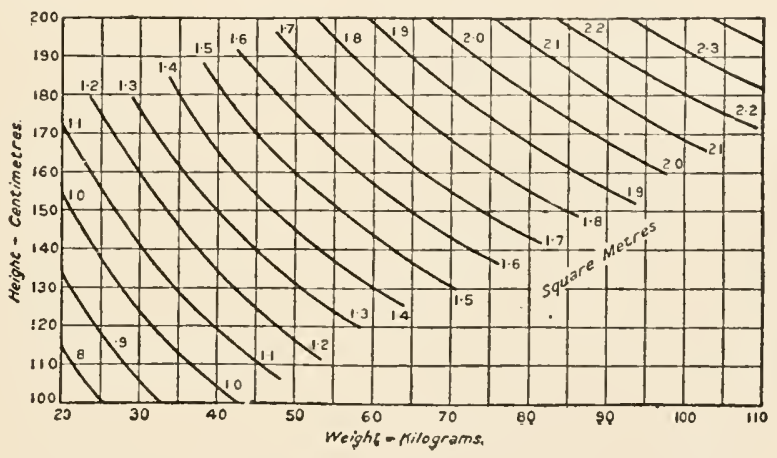

Fit. 85.--Du Bois Graphs for Estimating the Area of Body-Surface.

The brothers Du Bois covered the body-surface of their subjects with "tights" and applied melted paraffin. Paper strips were affixed to prevent change of area during the process of removing the "shell." The model of the surface, cut into pieces sufficiently small to be flat, was photographed upon squared paper of uniform thickness. The weight of each square on the paper was known. The darkened portions of the paper were carefully cut and weighed, and from this was calculated the area of body surface. The formula resulting from this work involved nineteen measurements. From this they have evolved a two-measurement formula on which the appended chart is based (Fig. 85).

Tile Field of Vision (see p. 225). The extent of the field of vision may be measured approximately as follows:

Describe a semi-circle on a blackboard with the free ends of the line finishing at one side. Mark the centre of the circle at the edge of the board, 
and the middle point of the rireumference with an $X$. This forms a rough "Perimeter."

The subject of the experiment closes one eye and places the other at the centre of the semi-circle, directing his gaze at the middle point of the circumference. The observer slowly draws a small object, say a piee of chalk, along the circumference from below. The subject states when it becomes visible and the other marks this point. The process is repeated, starting from above, and the point when the object comes into view is again marked. The angle formed by joining these points to the centre of the circle subtends the vertical field of vision.

By turning the blackboard into the horizontal plane, or by using the top of a table, the horizontal field of vision may be mapled out.

Movements of the Eyeball. The movements of the eyeball may be studied by means of a ball of wool. Make some mark on it to represent the pupil, and thrust three knitting needles through the ball to represent the axes round which the eyeball rotates (Fig. 51, p.223). The movements can then be reproduced with a fair degree of accuracy. 


\title{
INDEX
}

\author{
(References to Part II. are in italics.)
}

Absorption coefficient of gases in liquids, 247 ; from almentary canal, 317,318 ; of light, 15, 18, 71, 72; of heat, 343 . $345,4 \% t$; of solutes by renal tubules, 163 ; spectrum of chlorophyll, 14.

Accessory factors of diet, 372 .

Aeclimatisation, 267.

Accommodation in cye, 220 .

Acid, action of, on emulsions, 86, 378, 381,389 ; on fats, 421 ; on soaps, 82 ; on tissues, $381,389$.

Acid, effect of, on dissoeiation curve of $\mathrm{HbO}_{2}, 253$; on imbibition of water by colloids, $378,389,411$.

Acidity, numerical expression of, 57 , $58,4 \% 4$.

Aequired characters, transmission of, 361 .

Adaptation, 360.

Adipose tissue, 17:3.

Adsorbed material, state of, $66,153$.

Adsorption, 66, 98, 111, 378 .

Adsorption and osmosis, 66, 153.

Adsorption by enzymes, 94,98 ; cause of, 48 ; demonstrations, 111 ; effect of temperature on, 94, 109; of gases by colloids, 248, 332 ; of carbon dioxide by haemoglubin, 254,334 ; of oxygen by haemoglobin, 248, 251; specific surface for, 66,94 .

Adsorptive stratification (Liesgang phenomenon), 79, 413.

Agar-agar, 82 .

Agglutination, 79.

Alimentary canal, general plan of, 313 .

Alkali reserve of blood, $241,333,41 \%$, $418,419$.

"All or nothing," in nerve, 185.

Alveoli, 260.

Amicron, 74.

Amoeboid movement, $130,403,404$.

Amphoteric colloids, 332 ; electrolytes, 59.

Anabolism, 2, 374 .
Anaestheties, aetion on colloids of, 83, 86.

Analyser, 102, 104.

Angle of origin of blood vessels, 292 .

Angstrom units, 14, 127.

Anion and cation, 49, 52 .

Anode, 50.

Anti-enzyme, 97.

Anti-pro-thrombin, 236, 238.

Anti-thrombin, 236, 238.

Antrum pylori, 317.

Aortic valves, 289, 290.

Arrhenius' theory, 44 .

Arteries, pressure in, 281.

Arterioles, pressure in, 281.

Artificial laccase, 94; membranes, 41, 109 , 399, 399, 405, 407; parthenogenesis, 378 .

a rays, 120 .

Astral rays, 383.

Asymmetric carbon atom, 105, 106.

Autocatalysis and growth, 365 .

Autolysis, 389 .

Available energy, 9 ; of cell, 36 .

Avogadro's hypothesis, 38.

Axial repulsions, law of, 376 .

Bacon, Instances of Magic (quoted), 91. Balanced chemical reactions, 99, 376, 381. Barger's vapour pressure method for determination of asmotic pressure, $f(0)$.

Barotaxis, 131 .

Basilar membrane, 209.

Beckmann thermometer, 400.

Benzol, imbibition of, 410 .

Bicarbonate systen, $241,332,416$.

Bile, function of, 318 .

Binocular vision, 225.

Bio-electric phenomena, 133.

Bjerknes' phenomenon, 382.

Blood, alkali reserve of, $241,333,41 \tau$; coagulation of, 235 ; colloids of, 233 , 243 ; composition, 232 ; corpuscles, 241 et seq., 398, 422; crystalloids, 238 ; 
development of. 230 ; flow, 163, 277 ; function of, 229, 231; hydrogen ion eoneentration of, $232,4: 1,4: 4$; in. tegrative action of, 256 ; osmotie pressure of, 157, 233, 244; plasma, q.v., 232; pressure, $162,279,423$; viseosity of, 242,422 .

Bone, 174; adaptation of, 176,179 ; eonduction of sound by, 213, 4.2 ; development of, 174 ; internal strueture of, 176 ; strength of, 175 ; stress lines in, 175.

Bowman's eapsule, 156.

Boyle's law, 38 .

$\beta$ rays, 120.

Brownian movement, 73, 75, 409; in neuron, 183.

"Buffers," 241, 416.

Bunsen-Roseve, law of, 354, 356.

Caisson disease, 267.

Caleium, action of, in eoagulation of blood, 235; in breaking emulsions, 86, 87, 113, 415; on water-holding eapaeity of soap, 82, 236, 237.

Calorie, 3,21 ; value from oxygen usage, 31 ; value of diet, 26 .

Calorie, value of diet (physiologieal), 27. Calorimeter, bomb, 24.

Calorimetry of animals, direet, 27 ; indireet, 29.

Cambrian period, sea water in, 240.

Capacity of a eonduetor, 53.

Capillary analysis, 411.

Capillary circulation, 252, 279, 423.

Capillary eleetrometer, 47, 259, 104.

Carbohydrate, formation of, 15.18; oxidation of, 19, 29, 136, 139, 150.

Carbon dioxide, effect of, on dissociation of $\mathrm{HbO}_{2}, 253$; excration of, 261 ; production of, 22,28 ; speeifie function of, 253 ; tension in blood and alveoli, 255 ; transport of, 254.

Carnot's prineiple, 32 .

Cartilage, 174.

Catabolism, 2, 350.

Catalase, 96.

Catalysis, 92, 380.

Cataphoresis, 78, 413.

Cathode, 50.

Cathode rays, 119.

Cation and anion, 49.

Cell as factory, 91 .

Cell division, cause of, 375 .

Cell pressure and growth, 375 .

Centimetre index, 367.

Charles' law, 38.

Chemieal energy, receptors for, 192, 196.
Chemieal gardens, 399.

Chemiotaxis (Chemotropism), 131, 15.5, 359.

Chloroform : effeet of, on dispersoids, 83, 86 ; on membranes, 244.

Chlorophyll, absorption speetrum of, 1 t; funetion of, 19 ; effieiency of, 18.

Chromatie aberration, 217.

Cireulation of blood, general plan of, 274, $281,423$.

Coagulation of eolloids, 79, 234.

Coeffieient of variability, 369 .

Co-enzyme, 97.

Cold, reaction to, 349,350 .

Collagen, 172.

Colligative properties of solntions, 43 .

Collodion nembranes, 405

Colloidal aggregates, dimensions of, 65, 74.

Colloidal gold, 72, 412.

Colloidal solutions, eoagulation of, 79, 409 ; osmotie pressure of, 66, 233, 234; viscosity of, $232,234,409$.

Colloidal state, 67.

Colloids, elastieity of, I69; hydrophilie, 173.

Colour, of colloidal solutions, 71,72 ; of iris, 71 ; of sky, 70 .

Compensation, law of, 376.

Complemental air, 259.

Compound interest law, 365, 367.

Condensation in surfaee layer, 48, 109, $151,189$.

Conduction of nerve impulse, 185; of heat, 340 ; of sound, 423 .

Connective tissues, 168 .

Conservation of energy, 4,32 .

Continuous phase, 67.

Cooking, 89.

Copper ferroeyanide membranes, 41,110 , 398,399

Corti, organ of, 210.

Crenation, 245.

Crooke's tube, 119.

Crystalloids, 66.

Current, eleetrotonie, 189 ; demarcation, $134,143,145$; of aetion, $134,144,145$, 190 ; of injury, $134,143,145,190,405$; polarisation, 133, 188 .

Dalton's law of partial pressures, 40.

Dark ground illumination, 74, 409.

Dead spaee, 260.

Deerement in nervous impulse, 186.

Degeneration, fatty, 389 .

Degraded energy, 5,8 .

Dehydration of fertilised eggs, 379 ; of tissues, 364. 
Demarcation current, $134,143,145$.

Dendrites, 182, 184.

Depolarisation, law of, 376 .

Dermatoptic funetion, 174.

Destruction of enzyme, 94, 95.

Dialysis, 67 ; experiments on, 408 .

Diaphragm, mechanies of, 304 : structure of, 303 .

Dielectric constant, 52,53 .

Diffusiometer, 40,398 .

Diffusion, coefficient, 262 ; factor, 262 ; field of force of, 382 ; of colloids, 67 , 113; of electrolytes, 113 ; of gases, $40,39 \mathrm{~S}$; of gases through membranes, 40,41 ; potential, 52 .

Dimension of colloidal particles, 65, 74 .

Dioptric system of eye, 222 .

Diphasic electrical response, 144, 188, 296.

Dispersant, 68 .

Dispersed phase, 67.

Dispersion, degrec of, 68 .

Dispersoid, 68.

Displacement theory of hearing, 212.

Dissociation constant of water, $\mathbf{5 5}$.

Dissociation curve of oxyhaemoglobin, 249 ; effect of acid on, 253 ; effect of earbon dioxide on, 253; effeet of clectrolytes on, 248; effect of oxygen tension on, 249,250 ; effect of heat on, 252.

Dissociation, temperature coeffieient of, 63 ; theory of solutions, 44.

Distance receptors, 191, 200, 215.

Diuresis and oxygen consumption, 160. Diuretics, model to imitate action of, 111.

Dynamic equilibrium, $163,257$.

Far, 200.

Eeto-enzymes, 97.

Effective surface of blood corpuscles, 243 ; of solvents, 65 .

Efficiency, factors influencing, 395 ; "gross" (physiological), 391, 393; "net" (industrial), 391.

Effieiency of an engine, 6,392 ; of animal as a machine, 34 ; of heart, 284 ; of lung mechanism, 311 ; of muscle, 138 , $141,142,143,397$; of organism as a whole, 391 ; of secretory glands, 154 ; of tympanic membrane, 203.

Elasticity, 168; of tissues, 169, 310 .

Elastin, 172.

Electric charge on colloids, 78,79 ; on inns, 50, 52; on surfaees, 47, 48, 51.

Electric endosinose, 115, 399.
Electric phenomena of cell, 132; of muscle, 143, 405 ; of nerve, 1SS; of seeretion, 153,154 .

Electrical conductivity, 50, 379, 415.

Electrocarliogram, 29.5.

Electrorles (anode and cathode), 50.

Eleetrolytes, 44, 49; aetion of, on colloids, 79 ; effect of, un dissociation of $\mathrm{HbO}_{2}, 249$.

Electromagnetic theory of light, 53 .

Electrometer, capillary, 47, 259, 404.

Electromotive force, 52.

Eleetron, 117.

Eleetron theory, 53.

Electroscope, gold leaf, 121.

Electrostatic attraction of ions, 52, 189.

Electrotonic currents, 189.

Emulsifying agents, 85 .

Enulsions, $83,173,414$; effects of acid on, $86,378,389,415$; effects of anaesthetics on, 86 ; cxperiments in, 411, 115 ; fatty degeneration in, 389 ; types of, 84 .

Eumlsoids, 68 ; protective action of, 80 , 413.

Endoerinetes, $368,373,388$.

Endo-enzymes, 97, 389.

Endosmosis, 399.

Enduthelium, 173.

Endothermic reactions, 18.

Energetics of karyokinesis, 383.

Energy, absorbed by chlorophyll, 17 ; available, 9 ; available, of cell, 36 ; bound, 7 ; chemical receptors for, 192 ; conservation of, 4 ; consump)tion of, by glands, 150 ; by kidney, 156 ; by muscle, 143 ; by nerve, 187 ; by organism, 388 ; by respiratory musculature, 311 ; degradation of, 5,8 ; free, 3,8 ; index of heart, 286 ; kinetic, $6,7,8$; laws of, 3 ; neeessary for dissociation, 54; of food, 26 ; of growth, 373 ; of radiation from sun, 14; potential, 6,5 ; vibratory, receptors for, 192, 193, 194, 200, 215.

Enterokinase, 97.

Fintropy, 6.

Fnzyme aetion, 92: effect of anaesthetics on, 95 ; effect of hydrogen ion concentration on, 95, 101; cffect of solutes on, 95 ; effect of temperature on, 94 ; inlibition of, 100 ; reversal of, 99 .

Enzyme activators, 97.

Enzymes as catalysts, 93 ; ehemical nature of, 93 ; physical nature of, 93 . Epithelium, 166, 375 . 
Equilibrium, 97, 99, 164, 363; is death, $2,331,377$.

Erepsin, 101.

Ergometer, 393.

Errera's rule, $370,376$.

Erythroeyte, 164, 241, 242, 267, 398 .

Eustachian tube, 206, 207.

Evolution of alimentary eanal, 132, 313 ; of nervous system, 131, 182; of temperature regulation, 337 .

Exeitation of eell, 131, 134; of musele, 137, 138; of nerve, 183, 192; of seeretion, $149,153$.

Exeretion, 132, 156, 164, 318.

Exosmosis and development, 379.

Exothermie reaetions, 19.

Exteroecptors, 191.

Eye, 215.

Faraday-Tyndall phenomenon, 70, 409.

Fat, energy value of, 22 ; funetion of, 173,311 ; formation of, 18 ; invisible in eells, 173, 389 ; visible in cells, 173 , 389.

Fatigue, in muscle, 141, 147; (foreed respirations), 312 ; in nerve eells, 187 ; in nerve fibres, 187.

Fatty degeneration, 87, 173, 389; rôle of aeids in, 86,389 .

Ferroeyanide nembranes, $398,399$.

Fertilisation, inereased permeability in, 384 ; spermatozoön and, 380.

Fibrin, 235 .

Fibrinogen, 234.

Fibrons tissue, 17!.

Flow through tubes, 277.

Food, ehanges of, in digestion, 316 ; eomposition of, 87 ; energy value of, 26 ; requirements for growth, 372 .

Foree, fields of, 381 .

Form, symmetry of, 381.

Formaldehyde in photosynthesis, 17.

Free energy, 7, 138, 377, 380, 381 .

Freezing point, determination of, 399 ; of urine, 157.

Friction, 243,336 .

Galvanometer, string, 296.

Gas eonstant, $R$, value of, 39 .

Gas dispersions, 68.

Gus laws, 38, 39.

Gas, pressure of, eause of, 39 .

Gay Lussae's law, 38.

(iel, 69.

Gelatine, imbibition by, $\$ 11$.

Gelation, 79, 409 .

Gibbs-Tliomson prineiple, 48, 152, 175.

Glands, mode of stimulation of, 153.
Glomerulus of kidney, 162.

Gold number, 80 .

Gold, preparation of eolloidal, 11 ?

Graham, 40, 41, 69.

$\gamma$ rays, 120 .

Growth, 132, 315, 363; and form, 375.

Guanidin salts, dissoeiation of, 49 .

Ciuldeberg \& Waage, Mass aetion, 55. $61,368$.

Haematoerite, 241, 42\%.

Haemodynamies, $278,423$.

Haemoglobin, 242, 248, 334 .

Haemolysis, 108, 243, 378.

Harvey's work on cireulation of bloorl, 276.

Hearing, 211.

Heart, effieieney of, 284; physieal (Ostwalel's), 404; strueture of, 275 , 286; sounds, 290 ; thiekness of walls of, 286 ; valves of, 288 ; work done by, 280 .

Heat, aetion of, on ehemieal reactions, 370 ; on effieieney, 141 ; on emulsoids, 81; on enzymes, 94; on physieal phenomena, 370 .

Heat eentre, 350 .

Heat, of eombination, 54 ; of eornbustion, 22; of dilution, 22, 54; of liylration, 54 ;

Heat produetion, $34,347,349$; in glands, 154 ; in musele, 138,145 ; in nerve, 188.

Helieotrema, 209.

Heliotropie maehine, 357.

Heliotropism (phototaxis), 131, 354.

Helmholtz-Jippmann, double layer, 47, $51,151,152$.

Helmholtz on ear, 211, 213.

Henry's law, 247.

Hess's law, 293.

Hibernation, temperature regulation luring, 337.

Hirudin, 238.

Hoff, J. H. van't, $37,43,111,186$.

Hoffmeister series, see Lyotropie series.

Homoiothermie animals, 337.

Hormone, 231.

Hunger, sensation of, 198 .

Hyilration of eolloids, $66,69,82$; ions, 50.110.

Hydrogen electrode, $42: 2$.

Hydrogen ion coneentration, 56 ; measurement of, 421; of blood, 232.

Hydrol, 55.

Hydrolysis, by enzymes, 96, 389.

Hydrophilie eolloids, 173.

Hydrosol and hydrogel, 69. 
Hypertonie and hypotonic solutions, 107 , 398.

Illumination, dark baekground, 74, 409.

Imbibition by colloids, 66, 153, 172, 245, $110,411$.

Incus, 204.

Index of variability, 369 .

Inertia, 9, 354, 357, 378.

Infundibula, 260 .

Injury, current of, 134, 143, 145, 190, 405 .

Integrative action of blood, 206,231 .

Interface, 47, 151.

Interoeeptors, 191.

Intrinsie pressure, 47.

Ion, definition of, 44.

Innic mieelle, 4.5.

Ionisation, 49 .

Ionisation constant of water, 56 .

Ions, eleetrical eharge of, 50 ; hydration of, $45,50,51$; relative speed of, 50 .

Iris, 218.

Iron eontent of haemoglobin, 251.

Irritability of matter, 131, 193, 319.

Isoelectric point, 79 .

Isomeric compounds, 106,390 .

Isometrie eontraetion, 136.

Isotonic solutions, 43, 233.

Joints, 180 ; lubrieation of, 179.

Joule's heat, 147.

Karyokinesis, 381.

Kathode, see eathode.

Kephalin and blood elotting, 236, 237.

Kidney, model of, 414 ; structure of, 156 , 161.

Kinetic energy, 6, 7, 8, 138 ; of substanees in solution, 36,46 .

Kinetie theory, 37,75 .

Laecase, artifieial, 94.

Laetic aeid, of musele, origin of, 138.

Latent heat, 341,345 .

Latent period of tympanic membrane, 202.

Law, natural, 1.

Law of Avogadro, 38 ; Boyle, 38 ; Bunsen and Roseoe, 3.54, 356 ; Charles, 38 ; Dalton, 40 ; Gay Lussac, 38 ; Guldbery and Waage, 55, 61, 368; Henry, 217 ; Hess, 293; Müller, 183, 184, 193; Newton (cooling), 342; (energetics), 37 ; Sehütz, 380 ; Snell, 103 ; Talbot, 356 ; von Weimarn, 69.

Law of autoeatalysis, 365 ; eatalysis, 380 ; eooling, 340 ; corresponding states, 69 ; least action, 9 ; length of life (Rubner), 388 ; mass action, 5.5, 61, 368; probability, 369 .

Laws of energeties, 3,37 ; growth, 374, 376.

Le ('hatelier, prineiple of, 9, 128, 345, $360,370$.

Ieduc's diffusion experiment, 382 ; osmotic growths, 109, 399.

Length of inuscle fibre, energy proportional to, $136,142$.

I.ens of eye, 219.

Leucocytes, 130, 155, 241.

Levers, 202, 207, 308, 315, 320.

Liesgang phenomenon, 79, 413 .

Light, absorption of, by ehlorophyll, 14 ; by eolloids, 70,72 .

Light, electromagnetic theory of, 53; energy of, 14 ; polarised, 70 ; reeptors, $215,355$.

Lippmann's capillary elcetrometer, 47 , 101.

Load, influence of, on effieieney, 395 .

Loconotion, movements of, 320 .

Lubrieation of joints, 179.

Lung, meehanism of, 302 ; structure, 260, 301 .

Lungs, oxygen eonsumption of, 311 .

l.ymph, 276.

Lyotropic series, 78, 409, 411.

Maintenanee of metabolic level, 150.

Malignant growths and radiation, 126.

Malleus, 202, 204.

Malpighian eorpuscle, $156,162$.

Mannitol, 19.

Mass aetion, law of, $55,61,368$.

Mastication, 314.

Maximum energy of solar spectrum, 14.

Mean free path of moleeules, 47.

Measurement of, alkaline reserve of blood, 417; eleetrieal eonduetivity, 415 ; electrie potential differences, 404; energy values, 22 ; hydrogen ion concentration, 421 ; lowering of vapour pressure by solutes, 402; osmotie pressure, $39 S, 399,40 \%$; surface area of body, 425 ; viseosity, 109.

Mechanical equivalents of licat, 3,4 : heart (Ostwald), 101.

Mechanies of, bone formation, 175, 331 ; locomotion, 320; mastieation, 315 ; respiration, 303 ; specch, 325 .

Mechanism of ear, 211 ; kidney, 163.

Membrana tympani, 201.

Membrane, basilar, 209 ; Reissner's, 209. 
Membranes, adsorption, 109 ; cell, 107, 108,378 ; for dialysis, $67,40.5$; lipoirl, 242,243 ; of variable permeability, 111 , 132; polarised, 116 ; selective permability of, 116 ; semi-permealsle, +1, $110,395,399$.

Merenry, anncha, 101 .

Mercury leart (Ostwald's), 104.

Metabolism, definition of, 2 ; effect of intensity of temperature on, 337,341 , 361 ; of nerve centres, 187.

Metabolites, function of, 381 .

Micelle, ionic, 45.

Micron, 74 .

Nlilk, 87 .

Mimicry, of amoeboid movements, 131, 403,404 ; of cell structure, 114 ; of mueoid secretions, $153,115$.

Mirror images (optical activity), 101, 10., 106.

Mitosis, 381, 382.

Model of kidney, 111 ; nerve cell, to illustrate Müller's law, 184; polarimeter, 102 ; receiving and reacting neuron, 185.

Müller's law, 183, 184, 193.

Muscle, efficiency of, 143; electrical changes in, 143 ; cnergy of, a surface phenomenon, 137 ; excitatory process in, 146; heat production in, 145; oxygen consumption of, 138; plrases of action, 136,145 .

Nareotics, action of, on nervous impulse, 186 ; on soaps, 83.

Narcotics and stability of emulsione, 86 , 389.

Negative osmosis, 113, 115.

Negative polarisation, 189.

Nerve, carbon dioxide production in, 187.

Nerve cclls, 182.

Nerve, eonductivity of, 183 ; clasticity of. 169; electrical change in, 188; fatigne of, 187 ; heat production in, 185; mechanical stimulation of, 183 .

Nervous impulse, decrement of, 186 ; nature of, 188 ; refractory period in conduetion of, 186 ; temperature coefficient of, 185.

Neuron, 182; Brownian movement in, 183.

Neutrality, definition of, 57 ; preserva. tion of, 241, 252, 331.

Newton's laws of eooling, 342 ; of thermodynamies, $37,46,49$.

Nicol's prism, 102 .

Nitrogen eycle, 390 .

Normal solutions, 60 .
Nucleus, 129.

Nucleus and mitosis, 381 ; and oxidative changes, 384 .

()il in water dispersions, 84,414 .

Olfactory nerve, 196.

Oöcytin, 380 .

Ophthalmoscopy, 224.

Opsonins, 155.

Uptical activity, 101 ; due to asymmetric forces, 105 ; factors modifying, 102 ; mcasurement of, 104.

Optical isomers, 105, 106; and cnzyme action, $98,106$.

Optical resonance, 73 .

Optimal, incidence of encrgy to merve, 1S4; rate of work, 396 ; tcmperature for enzyme action, 94.

Organ of Corti, 210.

Organogenesis, 385 .

Osmometer, preparation of, 41,398 .

Osmosis, clectrical, 112, 115, 399.

Osmosis in cclls, 107, 108.

Osmosis, negative, $113,115$.

Osmotic growths, 399.

Osmotic pressure, and lowering of freezing point, 43; and growth, 379 ; and secretion, 153 ; and turgor, 364,399 ; and vapour pressure, 43 ; cause of, 37 ; definition of, 42 ; demonstrations of, 398 , 399 ; mcasurcment of, $399,40 \%$; of blood, 157, 39S; of colloids, 45 ; of electrolytes, 44,398 ; of urine, 157 , 399.

Ossicles, auditory, 202, 204.

Ostwald, Wo., 66, 72; (physical heart), 40.4 .

Oxidase, 96.

Oxidative removal of lactic acid, 138 , 140.

Uxygen, calorie equivalent of, 31 .

Oxygen, eonsumption of, glands, 150 ; lreart, 284 ; kidneys, 156, 160 ; lungs, 311 ; muscle, 142 ; organism, 380.

Oxygen, effects of want of, 381,389 ; solubility of, 247 ;

Oxygen tension and barometric pressure, 266.

Oxygen tension in air, 246 ; in alveoli of lung, 249 ; in arterial blood, 249 ; in tissues, 249 ; in renous blood, 249.

Oxygen transport by blood, 246.

Oxylhaemoglobin, 249.

Pacinian corpuscles, 194.

Parchment paper for dialysis, $40 \%$.

Parthenogenesis, 377 ; artificial, 378 ; stages of, 378 . 
Partial pressure of gases, 40 .

Perilymph, 209.

Peripheral resistance in vascular system, 281.

Peristalsis, 317.

Permeability as affected by ealcium, 113.

I'ermeability, differential, 133 ; selective, 111.

Peruxidase, 96.

Plragocytes, 155.

Phases of action, of gland, 148; of inusele, $136,145,147$.

Phases of growtlı, 368 .

Phosphate buffer system, $334, \pm 16$.

Photosynthesis, 15, 355.

Phototaxis, see Heliot ropism.

I'hysiological availability of energy, 9, 27.

P'igment, 174; cells stimulated by light, 174 ; of iris, colour of, 71 .

Plasma, blood, coagulation of, 234 ; colloids of, 233 ; eomposition of, 233 ; crystalloids of, $238 ; \mathrm{C}_{\mathrm{H}}$ of, 232 ; function of, 234, 241 ; osmotic pressurc of, 233; oxygen carrying power of, 248 ; refractive index of, 233 ; specific gravity of, 232 ; viscosity of, 232 .

Plasmolysis, 107.

Poikilothermic organisms, 337.

Polarimeter, 104; model to explain, 102.

Polarisation, 116 ; at electrodes, 116 ; currents, 133, 188, 189 ; of membranes, 116.

Pole-finding paper, 116.

Positive polarisation eurent, 188.

Potassium, in Helmholtz double layer, 152: radioactivity of, 122, 124; soaps, 82.

Potential energy, 6,8 .

Potentiometer, $4: 1$.

Preparation of artificial amoeba, 403. 40.1 ; chemical gardens, 399 ; colloidal solutions, 412 , 113 ; dialysing vessels, 405, 407; diffusioneter, 39S; osmometer, 398 .

Prepyloric sphincter, 317.

Preservation of neutrality, 2.11, 252, 331, 116.

Pressure and growth, 374, 386 .

l'ressure of gas, 39.

Principle of Avogadro, 38 ; Carnot, 32 ; Gibbs, 48, 152, 175 ; least action, 9, 11 ; Le Chatelier, 9, 128, 345, 360, 370.

Production of heat, $34,347,349$.

Proprioceptors, 191.

Proteetive action of emulsoids, 80.

Protein, energy of, 19, 26; encrgy value of (physiological), 27.
Proteins as colloids, 80; digestion of, 317,318 ; function of, in preserving neutrality, 332 .

Proteins of blood, 233 ; function of, 2399 : osmotic pressure of, 233 ; viscosity of, $2: 32$.

Protoplasm, 2, 130; as an emulsion, 87, 378; Brownian movement in, 183; colloidal nature of, 34,130 ; liquid nature of, 34,130 ; structure of, 130 .

Proximate prineiples of food, 19, 26.

Pseudo-activation of enzymes, 97.

Pseudo-arlsorption, 109.

Pulleys, 323.

P'ulsc wave, $280,283$.

Putrefaction and anaerobic action, 390.

Pyloric sphincter, 317.

Quantum of energy as stimulus, 194.

Quinine, action on haemoglobin, 244 .

Radio-active phenomena, 117.

Radio-activity of potassium, 122 ; effect on lieart, 124.

Radium, effect on colloids, 81 .

Rate of adsorption, demonstration on, $\$ 11$.

Rate of conduction in nerve, 185.

Rate of growth, 365.

Rate of respiration, $26.5,311$.

Reaction, 58.

Receptors, 191.

Refraction, 103, 215, 219.

Refractive index, 53, 103, 216.

Refractory period of nerve, 186 .

Regulation of rate of growth, 375 ; respiration, 312, 334; temperature, 336.

Reissner's nembrane, 209.

Reserve air, 259.

Residual air, 259.

Resonance, optical, 73 ; theory, 211.

Respiration, 258.

Respiratory centre, 312,334 ; reaction to $\mathrm{C}_{\mathrm{H}}, 312,334$.

Respiratory quotient, 30.

Retina, $218,358$.

Reversibility of enzyme action, 100, 390 .

Peversible reactions, $99,376,381$.

Rheoscopic frog, 145 .

Phythnic movement, model producing, io.4.

Rigidity of tissues, 87,389 ; experiments to demonstrate, 399,415 .

Rivers, dissolved matter and colour of . 71.

Röentgen rays, 119 .

Roux's.experiment on growth, 385. 
Rubber, an emulsion, 84 ; imbibition of benzol by, 410 .

Rubner's law of constant cnergy consumption, 374 ; length of life, 388.

Sach's rulc, 367 .

Saliva, function of, 314 .

"Salting out" of colloids, 79 ; of soaps, 83.

Salts, effect on $p_{\mathrm{H}}, 61,62$.

Saponin haemolysis, 244.

Scala media, tympani vestibuli, 209.

Scheme of circulation, 281, 423.

Schütz's law, 380 .

Secretion and osmosis, 151, 153; and permeability, 154; by renal tubules, 163 ; electrical change in, 154; mechanism of, 151; mucoid, 153, 415 ; phases of, 148 ; source of energy for, 150; work done in, 1554 .

Secretory hypothesis of respiration, 265, 267.

Selective permeability of membranes, 116.

Semipermeable membranes, 41 ; preparation of, .39s.

Sensation and stimulus, 194.

Sense organs, 192.

Sensitiveness, absolute, 195.

Serum, blood, 234.

Shell formation, 411 .

Simpson light, 126.

Slyke, van, alkali reserve, $241,333,418$.

Smell, sense of, 196.

Sncll's law, 103.

Soap, 82 ; calcium, $82,318,415$; films, 137, 403; in faeces, 318; loss of hydrophilic properties of, $82,318,415$; potassium, 82, 415 ; sodium, 82,415 ; soft, 82 .

Soap solution, effect of acids on, 82,415 ; effect of anaesthetics on, 83 ; preparation of, 403.

Sodium bicarbonate and $\mathrm{CO}_{2}$ tension, 241,332 .

Sodium bicarbonate system, $62,332,416$.

Sorlium soap, 82,415 .

Sol and gel, 69, 234.

Solutions normal, 60 .

Solution tension, 163 .

Soma, 135.

Sounds of the heart, $290,299$.

Source of cnergy, for food formation, 17 ; muscular contraction, 140 ; secretion, 150.

Speeific action of enzymes, 98 .

Specific inductive capacity, 52, 381 ; irritability, 193 ; nerve energy, 183 ; surface, $66,93,381,384$.
Spectrum, I4.

Speech, 325.

Spermatozoön, function of, 380 .

Sphincter muscles, 316.

Splcen, 164.

Stabilisation of colloids, 78; emulsions, 85.

Stapedius, 206.

Stapes, 204.

Stereoscope, 227.

Stereotropism, 358.

Stimulus for growth, $315,376$.

Stomach, 316.

Streaming of protoplasm, 131.

Stress and strain, 168, 381 ; lines of, in bone, 176.

String galvanometer, 296.

Stroma of blood corpuscles, 243 .

Structure of bone, 175 ; cell, 129 ; ear, $200,205,209$; erythrocyte, 243; eye, 218 ; lung, 260.

Struts and ties, 169, 170, 17 l.

Submicron, 74 .

Substrate, 93.

Summation of stimuli, 187.

Surface area of body and heat loss, 340 , 343.

Surface area of body and mass, 65, 381 .

Surface area of body measurement, 425 .

Surfaee condensation, 151, 158, 175.

Surface energy in cell mechanies, 131 ; source of, 46 ; temperature coefficient of, $47,109,137$.

Surface, extent of, in colloidal suspensions, 65, 237.

Surface tension, 46.48; and electrical charge, 47, 153; and growth, 375; and $\mathrm{C}_{\mathrm{H}}, 421$; effect of solutes on, 48, 237; experiments on, 403, 404; in muscle processes, 137 ; in nerve, 183 ; in urine formation, $158,163$.

Survival of fittest, 360 .

Synapse, 182, 185.

Syneresis of gels, 235.

Syncrgetical muscles, 323 .

Synkinetic movement, 202 .

Synovial fluid, 180 ; sheath, 323.

Synthesis by enzymes, 100, 390 .

Taste, 196.

Temperature cocfficient, 47, 370; of absorption of gas by a liquicl, 247 ; of development, $36 \mathrm{I}, 379$; of dissoeiation, 51, 63; of growth, 370 ; of muscular contraction, 137 ; of nervous conduction, 185; of surface tension, $47,109,137$.

Temperature regulation, 336,349 . 
Tendon, 172 ; sheaths, 180.

Tension and rate of growth, 374 .

Tension of gases, 246 .

Tension, see surface tension.

Tetanus, 145 .

Thermal conductivity, table of, 340 .

Thermal efficiency, 33.

Thermodynamies, laws of, 3,5 .

Thermometer, Beckmann's, 400 ; clinical, 337.

Thermopile, 145, 338 .

Thigmocytes, 237, 241.

Thorium, 123, 124.

Threshold values, 163, 193.

Thrombin, 235, 236, 237.

Thrombokinase, 235.

Thromboplastin, 236.

Thymus, 238, 373.

Thyreoid, 373.

Tidal air, 259.

Tissue, connective, 168 ; elasticity of, 169 ; fibrous, 171 ; strength of, 170 ; vegetative, 166.

Tone of muscle, 142.

Tongue, 196, 314, 325.

Touch, 193.

Touch-button mechanisms, 312, 318.

Transinission of acquired characters, 361 .

Trigger action, 183.

Trigger energy, 7, 8, 138, 146.

Trophic and secretory nerves, 153.

Tropisms, 131, 354 .

Trypsin, 96, 97, 101 .

Turgor, 364, 399.

Tympanic inembrane, 201.

'Tyndall phenomenon, 70, 409.

Types of colloids, 69 ; dispersoids, 68 ; emulsions, 84 .

Ultra-filtration, 75 .

Ultra-microscope, 74.

Ultra-violet light, 14, 20, 126 ; action of, on organisms, 126, 127, 132 .

Uranium, 120, 121.
Urine, formation of, 162 ; work done in formation of, 157 .

Valves of heart, 288 ; veins, 288.

Vapour pressure, of a liquid, 38 ; and osmotic pressure, 43; Barger's de. termination of, $10 \%$.

Variations in growth, factors causing, 368.

Vectors, law of, 376.

Vegetative tissues, 166.

Velocity of growth, 368 .

Vibratory energy, receptors for, 192 , 193, 194, 200, 215.

Viscosity, measurement of, 409,422 ; of blood, 242, 243, 42: ; of cmulsoids, 389 ; of plasma, 232 .

Visual judgments, $226,227$.

Vital capacity of lungs, 259.

Volition, 11.

Volume of blood, 250.

Volume of blood corpuscles, 243.

Waller's characteristic, 184.

"Waste" heat, 6, 12, 390.

Water, chemical formula of, 54; dielectrie constant of, 53; dissociation of, 55; electric conductivity of, 53, 55.

Water equivalent of calorimetric bomb, 25 ; of human body, 341.

Water, heat conductivity of, 340,345 .

Weimarn, von, law of, 69.

Work, done in formation of urine, 155 ; done in secretion, 150, 15t; of heart, 280 ; of lungs, 310 ; of muscle, 136 , 142 ; of phonation, 329.

X-rays, 119, 120.

Young's inodulus, 168, 169.

Zymase, 97.

Zymogen, 97. 




H.

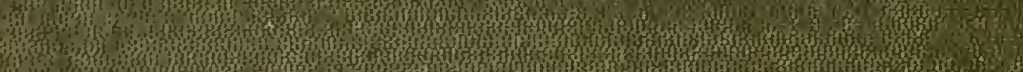

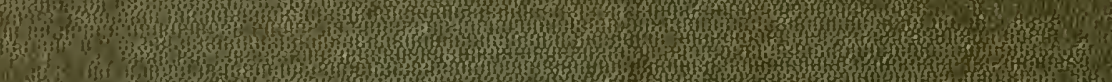

\section{(1)}

4 (1)

(1)

4.

3.1.

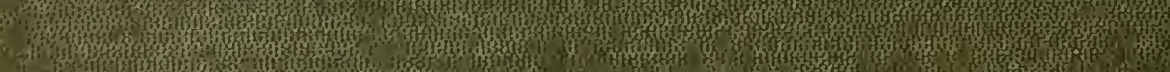

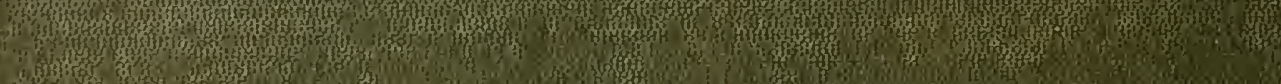
(1)

(3)

(4) H.t.

(1)

How

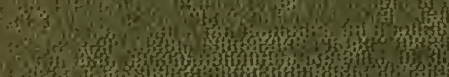

and

1.7.

H.m.

ind

3.



m.

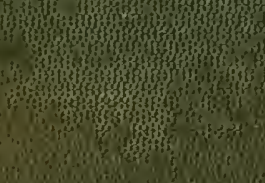

H.t.m.

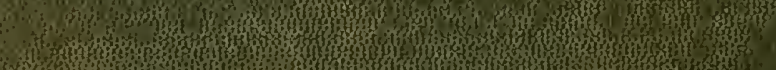

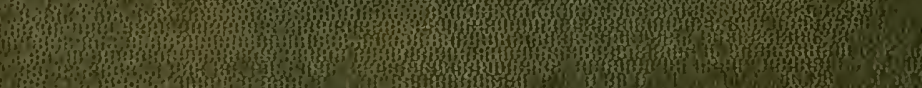

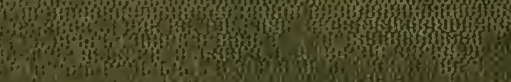

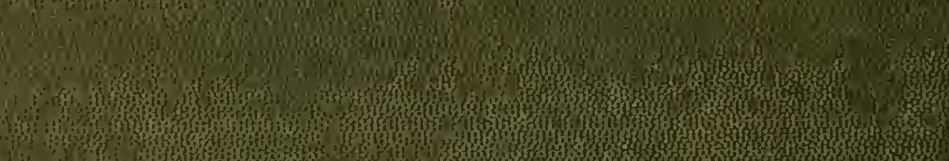

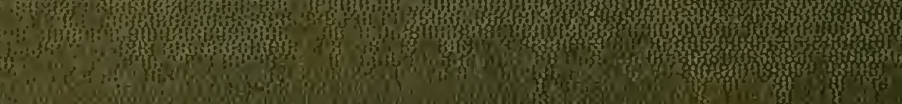

wisters

W.

6. 